\title{
Contribution to the environmental impact assessment of biodiesel in the context of spain
}

NEUS ESCOBAR LANZUELA 

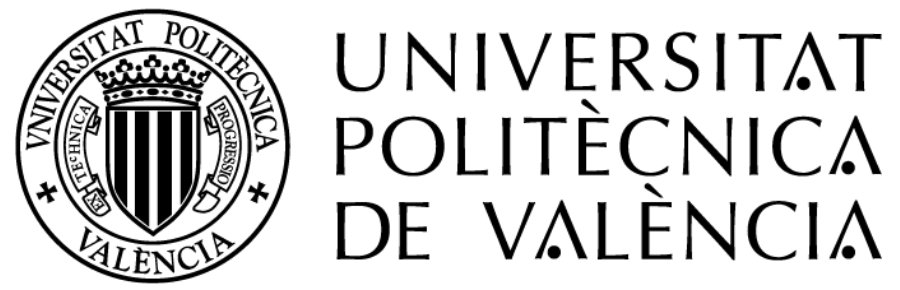

Departamento de Tecnología de Alimentos

\title{
CONTRIBUTION TO THE ENVIRONMENTAL IMPACT ASSESSMENT OF BIODIESEL IN THE CONTEXT OF SPAIN
}

DOCTORAL THESIS International PhD Mention

\author{
Presented by: \\ Neus Escobar Lanzuela \\ and \\ Supervised by: \\ Prof. Neus Sanjuán Pellicer \\ Prof. Gabriela Clemente Polo
}

Valencia, May 2015 
Collection doctoral thesis

(c) Neus Escobar Lanzuela

(c) 2015, of the present edition: Editorial Universitat Politècnica de València Telf.: 963877012 / www.lalibreria.upv.es

ISBN: 978-84-9048-389-3 (printed version)

Any unauthorized copying, distribution, marketing, editing, and in general any other exploitation, for whatever reason, of this piece of work or any part thereof, is strictly prohibited without the authors' expressed and written permission. 
Departament de Tecnologia d'Aliments

NEUS SANJUÁN PELLICER I GABRIELA CLEMENTE POLO, AMBDUES CATEDRÀTIQUES D'UNIVERSITAT DEL DEPARTAMENT DE TECNOLOGIA D'ALIMENTS DE LA UNIVERSITAT POLITĖCNICA DE VALÈNCIA

\begin{tabular}{|l|l|}
\hline CERTIFIQUEN: & $\begin{array}{l}\text { Que la memòria que porta per títol "CONTRIBUTION TO THE } \\
\text { ENVIRONMENTAL IMPACT ASSESSMENT OF BIODIESEL IN THE } \\
\text { CONTEXT OF SPAIN", presentada por NEUS ESCOBAR LANZUELA } \\
\text { per a optar al grau de Doctora per la Universitat Politècnica de } \\
\text { València, compleix les condicions adequades per a la seua } \\
\text { acceptació com a Tesi Doctoral, pel que }\end{array}$ \\
\hline AUTORITZEN: & $\begin{array}{l}\text { A la interessada a la seua presentació en la Universitat } \\
\text { Politècnica de València. } \\
\text { I per deixar-ne constància als efectes oportuns, presentem } \\
\text { l'esmentada memòria mitjançant la firma del present certificat a } \\
\text { València a 14 de maig de 2015. }\end{array}$ \\
\hline
\end{tabular}

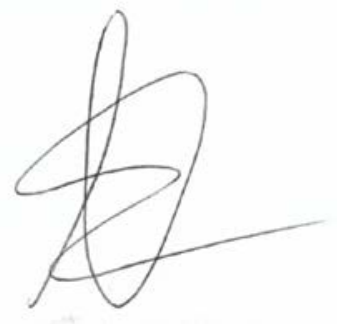

Firmat Dra. Neus Sanjuán Pellicer

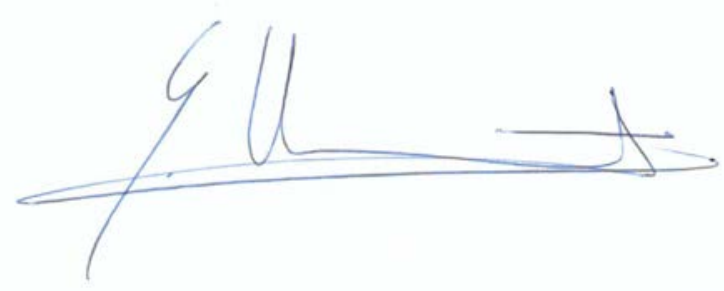

Firmat Dra. Gabriela Clemente Polo 



\section{Table of contents:}

Abstract

i

Resumen

xi

Resum

$x x i$

Acknowledgments

$x x x i$

Preface

xxxiii

Figures

xxxvii

Tables

Xliii

List of acronyms, abbreviations and equivalences

XIvii

\section{Chapter I. Introduction}

1.1. The biofuel sector

1.1.1. Leading biofuel countries

1.1.1.1. Ethanol-producing countries

1.1.1.2. Biodiesel-producing countries $\quad 7$

$\begin{array}{ll}\text { 1.1.2. The European biofuel sector } & 10\end{array}$

1.2. Biofuel policies 15

$\begin{array}{ll}\text { 1.2.1. European biofuel policies } & 17\end{array}$

1.2.1.1. Renewable Energy Directive 17

1.2.1.2. Fuel Quality Directive 19

1.2.1.3. Draft Directive on Indirect Land Use Change $\quad 19$

1.2.2. Main biofuel policies across the world 21

1.2.2.1. The United States 21

1.2.2.2. Brazil 23

1.2.2.3. Argentina 24

1.2.2.4. Southeast Asia 24

1.3. The biodiesel sector in Spain 25

1.3.1. Regulatory framework 25

1.3.2. Sector overview 26

1.4. The problem of glycerol glut 28

1.5. Life cycle perspective in the environmental assessment of biofuels $\quad 30$

1.5.1. Life Cycle Assessment of biofuels 30

1.5.2. Field-to-wheel analysis 32

1.5.3. Consequential Life Cycle Assessment 33

1.5.4. Discrepancies between GHG calculations in biofuel studies $\quad 34$

1.6. Motivation of the dissertation 37

1.7. Objectives of the dissertation 38 
Chapter II. Methodological overview

2.1. General outline and working plan

2.2. Attributional Life Cycle Assessment

2.2.1. Multi-functional systems 48

2.3. Consequential Life Cycle Assessment 51

2.3.1. System expansion 52

2.3.2. Partial Equilibrium approach 53

2.3.3. Computable General Equilibrium approach

2.3.3.1. The Global Trade Analysis Project 59

2.4. Life Cycle Costing

62

2.5. Uncertainty analysis

64

2.5.1. Scenario analysis 66

2.5.2. Sensitivity analysis 68

2.5.3. Monte Carlo analysis 69

\section{Chapter III. Results}

3.1. Uncertainty analysis in the environmental assessment of an integrated management system for restaurants and catering waste in Spain

Abstract

Keywords

3.1.1. Introduction

3.1.2. Methods 80

3.1.2.1. Functional Unit 80

3.1.2.2. System description and scenario formulations

3.1.2.3. Life Cycle Inventory 86

3.1.2.4. Environmental assessment 90

3.1.2.5. Sensitivity and uncertainty analyses 90

3.1.3. Results

3.1.3.1. Impact assessment of the base scenarios

91

3.1.3.2. Results from the uncertainty analysis

95

3.1.4. Discussion 99

3.1.5. Conclusions 102

3.2. Uncertainty analysis in the financial assessment of an integrated management system for restaurants and catering waste in Spain 
$\begin{array}{ll}\text { Keywords } & 107\end{array}$

$\begin{array}{ll}\text { 3.2.1. Introduction } & 108\end{array}$

3.2.2. Methods 111

3.2.2.1. Functional Unit 111

3.2.2.2. System description and scenario formulations 112

3.2.2.3. Inventory data 115

3.2.2.4. Financial assessment 117

3.2.2.5. Uncertainty analysis 118

3.2.3. Results 121

3.2.3.1. Financial results from the base scenarios 121

3.2.3.2. Results from the uncertainty analysis 123

3.2.4. Discussion 128

3.2.4.1. Discussion of the LCC results 128

3.2.4.2. Comparison of the LCA and LCC results 130

3.2.5. Conclusions 134

3.3. Consequential LCA of two alternative systems for biodiesel 137 consumption in Spain, considering uncertainty

$\begin{array}{ll}\text { Abstract } & 139\end{array}$

Keywords 139

3.3.1. Introduction 140

3.3.2. Materials and methods 142

3.3.2.1. Functional Unit 142

3.3.2.2. System description and system boundaries 142

3.3.2.3. Inventory data 145

3.3.2.4. Impact assessment 147

3.3.2.5. Sensitivity and uncertainty analyses 147

$\begin{array}{ll}\text { 3.3.3. Results } & 151\end{array}$

3.3.3.1. Impact assessment of the base scenarios 151

3.3.3.2. Sensitivity and uncertainty analyses 156

3.3.4. Discussion 158

$\begin{array}{ll}\text { 3.3.5. Conclusions } & 160\end{array}$

3.4. Optimization of the biodiesel supply chain in Spain to meet the 163 European GHG reduction targets

$\begin{array}{ll}\text { Abstract } & 165\end{array}$

Keywords 165

3.4.1. Introduction 166 
3.4.1.1. Biofuel policy landscape in the EU 166

3.4.1.2. Environmental implications of biofuels $\quad 168$

3.4.2. Materials and methods $\quad 170$

3.4.2.1. Industrial module 171

3.4.2.2. Agricultural module 173

3.4.2.3. Agri-model calibration 177

3.4.2.4. Emissions module 178

3.4.2.4.1. Biodiesel pathways from domestic 179 virgin oils

3.4.2.4.2. Biodiesel pathways from imported 181 virgin oils

3.4.2.4.3. Biodiesel pathways from UCO 182

3.4.2.4.4. Partitioning 182

3.4.2.5. Policy and land use scenarios 183

3.4.3. Results 185

3.4.3.1. Optimal mix, emission factors and GHG savings 185

3.4.3.2. LCA results 190

3.4.3.3. Shifts in land use in the Spanish agriculture $\quad 194$

3.4.4. Discussion 196

3.4.4.1. ILUC impacts from domestic oilseeds 196

3.4.4.2. Policy recommendations 199

3.4.5. Conclusions 201

3.5. Global land use change and greenhouse gas emissions due to 203 recent European biofuel policies

Abstract 205

Keywords 205

3.5.1. Introduction 206

3.5.2. Methodology 211

3.5.2.1. The GTAP-BIO version 211

3.5.2.2. Intensive and extensive margins 214

3.5.2.3. Calculation 215

3.5.3. Results 217

3.5.3.1. Market responses 218

3.5.3.2. Land use change effects and GHG emissions 221

3.5.4. Discussion 225

3.5.5. Conclusions 228 
4.2. Emission factors for other critical impact categories

\section{Chapter V. Conclusions}

5.1. Conclusions about the Integral-b project assessment

5.2. Conclusions about the consequential LCA

5.3. General conclusions and policy recommendations

\section{Chapter VI. References}

\section{Annexes}

Annex A. Supplementary material for section 3.1

A1. Life Cycle Inventory

A2. Description of the sensitivity analysis

A3. Impact assessment results

A4. Probability distributions and Monte Carlo simulation results

A5. References

Annex B. Supplementary material for section 3.4

B1. Model validation and calibration

B2. Mathematical specification of the agro-industrial model

$\mathrm{C} 1$. Regions, industries and commodities in the GTAP-BIO model 



\section{Abstract}

In the transport sector of many countries, there has been an increase in demand for biofuels, fostered by public policies on the promotion of renewable energy. The most widespread biofuels are ethanol (made from the biological fermentation of starch or sugar-rich biomass) and biodiesel (made from the transesterification of oils or fats). The political motivation to support these alternative fuels arises from two main drivers, climate change and energy security. In the European Union (EU), Directive 2009/28/EC or Renewable Energy Directive (RED), establishes a 10\% target for renewable energy use in the transport sector by 2020, in order to reduce overall greenhouse gas (GHG) emissions. This has led to a sharp expansion of the biofuel sector since 2000, especially that of biodiesel. However, in recent years, increased imports of both biofuels and biofuel feedstocks have been compromising the energy independence of the EU. Furthermore, concerns have been raised as to the suitability of biofuels to meet climate goals. Coinciding with the boom in biofuels, dedicated energy crops have expanded worldwide, leading to land use change (LUC) in regions with great carbon stocks and/or of high biological value. In view of this evidence, environmental considerations are more frequently incorporated into biofuel policies. In the EU, these are based on increasing GHG reduction thresholds from 2013 onwards, in combination with ineligible land use categories for biofuel expansion. Their ultimate goal is to promote only the use of biofuels delivering substantial GHG savings, by calculating overall emissions from the production of the raw material to the final use of the fuel based on the Life Cycle Assessment (LCA) methodology.

Public policies usually distinguish between first-generation biofuels (FGBs), and second and third-generation biofuels, also known as advanced biofuels. While the first are produced from arable crops, the second are made from waste, residues, non-food cellulosic and ligno-cellulosic material, or derived from aquatic autotrophic organisms (e.g. algae), respectively. FGBs are generally related to greater environmental impacts, since they imply agricultural production. Additionally, they can also require land conversion in order to grow bioenergy feedstock, with the associated changes in soil and biomass carbon stocks (known as direct LUC). On this basis, the RED proposes a double-counting scheme for second-generation biofuels. In addition, it is now agreed that there are indirect effects, inasmuch as FGBs generally come from edible biomass competing for available cropland with other commodities. When previous land uses are displaced, the affected crops are likely to be produced elsewhere to keep up with global demand. This ultimately generates indirect land use change (ILUC), with the associated GHG emissions. The European Commission (EC) has made a new biofuel proposal in order to take ILUC emissions into consideration. This proposal has generated intense debate on the default calculation factors provided, since there is no consensus on the 
methodology to be used in the quantification of ILUC. This phenomenon is the result of global shifts in land cover and crop patterns in response to price changes; thus, it is subject to market forces and difficult to predict.

The aim of the present thesis has been to analyze the environmental effects of biodiesel consumption in the Spanish transport sector, in fulfillment of the most recent European policies on biofuels and climate change. To this end, different systems for biodiesel production have been analyzed in the Spanish context. The available methodologies have been applied under a life cycle perspective, yielding different case studies. In order to provide additional insights into the evaluation of controversial issues that affect the environmental performance of biofuel systems, such as uncertainty, multi-functionality and indirect effects, not only have environmental considerations been taken into account but also economic ones.

First of all, the environmental and economic benefits brought about by an integrated process for biodiesel production from used cooking oil (UCO) have been evaluated. The system, developed by a European LIFE initiative known as the Integral-b project, proposes the joint management of the solid organic waste (SOW) and UCO from restaurants and catering in Spain by anaerobic digestion and transesterification, respectively. Although it may improve the viability of biodiesel plants, the Integral-b has been addressed as a waste management system. Thereof, its main goal is to provide a proper treatment for the organic waste from the hospitality sector, rather than only producing biodiesel. Specifically, the Integral-b system consists of implementing an anaerobic digester (AD) and a combined heat and power (CHP) engine in the same biodiesel facility. Thermal energy and electricity are thus obtained, improving the energy efficiency of the process. The $\mathrm{CHP}$ engine, specially adapted to use glycerin as a fuel together with the biogas from the $A D$, allows the glycerin surplus from transesterification to be valorized; this co-product is increasingly becoming a waste to be treated (with the subsequent cost) as biodiesel production expands on a global scale. The electricity is sold to the grid while the digester sludge from the $A D$ is sold for agronomic purposes. These co-products are expected to increase revenues for biodiesel plants.

In order to discuss the results of the environmental and financial analysis jointly, it is required that both share the same Functional Unit (FU). The FU has been defined as the management of the amount of UCO and SOW from restaurants and catering, both produced per person during a year in Spain. The analysis of the environmental performance has been carried out in section 3.1, by using attributional LCA. Since the Integral-b system is, by definition, multi-functional, the environmental burdens from additional co-products must be taken into account. Hence, the system expansion approach has been chosen to compare the system proposed (scenario A) with a reference system consisting of the prevailing 
management options in Spain for the same kind of waste (scenario B). As a result, the indirect functions have been subtracted in each scenario following the substitution method, causing avoided burdens. Specifically, it has been considered that the cogeneration electricity sold to the grid in scenario $A$ avoids the production of electricity, while the glycerin surplus from biodiesel production in scenario $B$ is in demand for industrial purposes. Choosing between these avoided processes may have a great influence on the environmental results and, thus, uncertainty due to these methodological assumptions has been assessed. Hence, two options have been considered for the purposes of estimating glycerin credits in scenario B: displacing synthetic glycerin or propylene glycol, with two different substitution ratios. Similarly, it has been considered that electricity from the CHP engine in scenario A can replace electricity from the average mix in Spain or wind-generated electricity. Finally, in order to define the FU, two levels of UCO collection have been addressed: the current and potential availability in Spain. These options led to eight different scenario formulations with which to study the differential impacts of scenario B-scenario A.

It has been found that scenario A performs better than scenario $B$ in most of the impact categories and scenario formulations when the FU represents the current UCO collection levels (80,000 t/a). This is mainly due to the avoided burdens from digester sludge and electricity from cogeneration, especially when this replaces electricity from the Spanish mix. When considering potential levels of UCO collection $(300,000 \mathrm{t} / \mathrm{a})$, scenario $A$ does not markedly improve the relative environmental performance. In fact, scenario B appears to be better in half of the cases. This is due to the greater production of glycerin from transesterification, which clearly benefits scenario $B$ under these scenario assumptions, since it implies larger avoided burdens. In general, avoided propylene glycol entails larger environmental benefits despite the lower substitution ratio. Global warming (GW) and photochemical ozone creation are the only categories in which the results from all the scenario formulations entirely favor the Integral-b system. Data uncertainty has been assessed by means of the Monte Carlo simulation, showing that parameter variability is only relevant in those scenario formulations for which the probability distribution of the differential impact, scenario B-scenario A, has positive and negative values. A discernibility analysis has been carried out for these cases. It can be concluded that parameter uncertainty is not as critical as uncertainty due to scenario assumptions. By analyzing parameter uncertainty, we are more certain that the impacts are within the range obtained, although it cannot be concluded that scenario $A$ is always better than scenario $B$ because this depends on scenario choices. These choices regarding co-product credits are not, in themselves, opportunities for decision-makers to reduce the impact of the Integral-b system, since they arise from the LCA methodology and are not certain, but likely, to happen depending on the context. However, a scenario analysis which captures 
possible outcomes of the LCA, depending on which choices are made, eases the interpretation of the results and is useful for decision-making.

The combined study of the economic viability and the environmental impact of the Integral-b process is a pre-requisite for a more thorough understanding of its sustainability. Hence, the profits generated by the FU under the two scenarios defined in section $\mathbf{3 . 1}$ have been subsequently calculated in section 3.2, from a financial point of view. To this end, Life Cycle Costing (LCC) has been applied, by considering that co-products deliver revenues to the system in which they are produced, consistent with the system expansion (substitution) approach in attributional LCA. However, co-product prices are subject to great uncertainty, since they are determined by the market and companies are price-takers. In addition, the sale price of the electricity from waste management, cogeneration and renewable sources is determined by market regulations, which have recently changed in Spain. Four different scenario formulations have also been defined for the purposes of assessing the differential profits of scenario B-scenario A, by considering two electricity rate systems (2012 and 2014) and two UCO functional inflows (current and potential). The profits in all the $A$ and $B$ scenarios are negative (between -2.27 and $-6.29 € / F U$ ). Scenario $A$ yields lower profits in all the scenario formulations, despite the fact that it generates greater income; this comes at the cost of higher expenses, mainly due to the SOW collection. The new electricity rates are detrimental to the economic performance of the Integral-b, since sale prices are less subsidized and the overall profits are highly dependent on the sale of electricity in scenario $A$; this is why the scenario considering the lowest UCO collection levels and the 2014 electricity rates delivers the lowest profits. Readier UCO availability benefits both scenarios to a similar extent but changes in electricity rates are not neutral, since they affect the scenario profits in a different way depending on both the amount of electricity produced and the source (e.g. cogeneration or incineration). An uncertainty analysis has been performed by using the Monte Carlo simulation, including both technical parameters and prices. The results reinforce the robustness of the comparative analysis, although there is some probability of scenario A generating greater profits. The highest probability (19.5\%) has been found for those scenarios considering readier UCO availability and the 2012 electricity rates. The sensitivity analysis allows for the key parameters (e.g. SOW collection, CHP performance, etc) to be identified in order to optimize the process further.

Possible trade-offs between the environmental and economic results have been identified, measuring the change in profits needed to decrease environmental impacts by choosing one waste treatment option or another. It can be concluded that the environmental impacts could be substantially reduced when switching to the Integral-b system on a municipal scale, despite the new electricity rates, but 
this comes at the expense of the profits generated. It must be noted that, from the perspective of a biodiesel producer who is not responsible for the costs of collecting the SOW, the Integral-b process could deliver positive profits, in addition to lower impacts relative to a reference scenario. However, uncertainty in the electricity regulations becomes an obstacle if projects such as these are to be implemented.

In the following sections, the LCA procedure has been applied on different systems whose main function is that of producing biodiesel. In view of the fact that the attributional LCA has limitations when it comes to measuring indirect effects, consequential LCA has been identified as the methodology to apply in order to measure ILUC from biofuels. There are different approaches to performing a consequential LCA, and all of them require the application of economic concepts; the methodologies subsequently employed differ in their ability to capture marketmediated responses. These methodologies allow for the main environmental impacts associated with different biodiesel production pathways to be estimated and compared.

Section 3.3 compares two possible biodiesel pathways for the Spanish transport sector in environmental terms -including that of ILUC- by performing the system expansion approach for consequential LCA. Two scenarios have been considered: scenario 1, in which $1 \mathrm{MJ}$ of soybean biodiesel is imported from Argentina, the prevailing option in the period 2010-2013; and scenario 2, in which $1 \mathrm{MJ}$ of biodiesel from UCO is manufactured in Spain. System expansion consists of including the additional function(s) provided by the co-product(s), since it is founded on the assumption that indirect effects arise from co-product interactions with other life cycles in the international market, ceteris paribus. Based on the observation of the markets involved, the marginal suppliers of the main co-products have been identified, which are those most likely to be affected by a change in demand for the FU. Marginal amounts of each co-product (protein meals and vegetable oils) have been estimated by an iterative calculation. In scenario 1 , it is assumed that expanding the production of soybean biodiesel in Argentina causes a reduction in the soybean oil available in the international market, which must be compensated by an increase in the production of palm oil in Malaysia as the marginal supplier $(25.27 \mathrm{~g})$. This implies, in turn, a decrease in the production of soybean meal in Brazil $(3.44 \mathrm{~g})$. In scenario 2, interactions in the global oil market lead to changes in the opposite direction: collecting UCO in Spain reduces the need to import oil from the marginal supplier; thus, palm oil production falls in Malaysia (26.31 g), whereas soybean meal production rises in Brazil $(3.58 \mathrm{~g})$.

When emissions from LUC are not taken into account, the Spanish UCO biodiesel performs better than the imported biodiesel from Argentina in every analyzed impact category, except GW. In this case, the impact is $138.9 \%$ lower in scenario 
1, mainly due to the carbon uptake by soybeans in Argentina and palm trees in Malaysia. Since these results may underestimate negative environmental consequences, the GHG emissions from LUC in each country have been included, too, following the IPCC guidelines. As a result, scenario 2 causes a reduction of between $49.0 \%$ and $112.9 \%$ in all the impact categories with respect to scenario 1 . As for the LUC effects, apart from the land transformation in Argentina $\left(+8.75 \cdot 10^{-2}\right.$ $\left.\mathrm{m}^{2}\right)$, scenario 1 leads to deforestation in Malaysia $\left(+1.86 \cdot 10^{-3} \mathrm{~m}^{2}\right)$ and area contraction in Brazil $\left(-1.73 \cdot 10^{-2} \mathrm{~m}^{2}\right)$, due to market-mediated responses. As side effects, some carbon stock is lost: direct LUC in Argentina releases $1137.5 \mathrm{~g}$ of $\mathrm{CO}_{2}$ into the atmosphere, whereas overall ILUC is responsible for $87.3 \mathrm{~g}$ of the additional $\mathrm{CO}_{2}$. In scenario 2, net LUC is estimated at $1.61 \cdot 10^{-2} \mathrm{~m}^{2}$ (more than 5 times lower than in scenario 1 ), which comes entirely from ILUC in Malaysia ($\left.1.94 \cdot 10^{-3} \mathrm{~m}^{2}\right)$ and Brazil $\left(+1.80 \cdot 10^{-2} \mathrm{~m}^{2}\right)$. As a consequence, $230.6 \mathrm{~g}$ of $\mathrm{CO}_{2}$ are absorbed and $139.4 \mathrm{~g}$ of $\mathrm{CO}_{2}$ are released into the atmosphere, respectively. In this case, the market-mediated responses even improve the environmental profile of the UCO biodiesel system, and scenario 2 generates an overall uptake of $28.6 \mathrm{~g}$ of $\mathrm{CO}_{2}$-eq., $1092.3 \mathrm{~g}$ of $\mathrm{GHG}$ emissions less than scenario 1 . The results show that there are clear environmental benefits arising from the use of UCO biodiesel in Spain to meet the EU targets, as compared with the use of imported soybean biodiesel from Argentina. The Monte Carlo simulation for both scenarios also reinforces confidence in the comparative assessment.

In view of the long and lasting crisis in the Spanish biodiesel sector, section $\mathbf{3 . 4}$ provides an operational framework for the purposes of optimizing the entire supply chain, allowing for the optimal feedstock mix to be determined, in accordance with both environmental and economic criteria. A mathematical programming model has been proposed based on the sector's nameplate capacity, today underused, so as to protect current investments. It is built on the assumption that the entire target demand for 2020 is met by the domestic biodiesel supply. The model allows for an LCA to be simultaneously carried out, including emissions from direct LUC, with the aim of detecting if the GHG reduction targets in the RED are compatible with other environmental gains, together with the surplus maximization of the actors involved. The FU is $2.58 \mathrm{Mt}$ of biodiesel, produced from both imported and domestic feedstocks. The model couples the biodiesel industry to the arable sector in Spain in a multi-sectorial setting, and is written in General Algebraic Modeling System (GAMS). The joint optimization of the agricultural and industrial module yields the optimal oil input combination given the sector configuration, together with the optimal biomass supply, given the farming sector in Spain. In industry, the supply is defined by a step-function, based on capacity and cost information. The agricultural module is built on resource, rotation, policy and quota constraints in order to capture regional differences. A detailed representation of the country's biomass 
supply is necessary in order to measure direct (and indirect) GHG emissions as a result of an expansion in the industrial demand for domestic oilseeds.

Four different scenarios have been considered, allowing for different policy issues to be analyzed, in terms of overall welfare and environmental impacts. The proposed scenarios depict increasing levels of GHG reduction thresholds and two different prices of biodiesel from UCO, one representing the current market price in Spain, and another representing a double-counting scheme. In addition, when the emission constraint holds, different $\mathrm{CO}_{2}$ emission factors for direct LUC per ton of oil have been considered for the imported virgin feedstock; each of them corresponds to an ecosystem that can be potentially converted into oil crops in Argentina, Brazil and Southeast Asia. The optimal oil mix for the sector is highly dependent on these assumptions regarding LUC in the oil-exporting countries. As could be expected, increasing the GHG savings thresholds enhances the use of UCO and domestic oilseeds, which may even account for $97.1 \%$, while preventing the deforestation of carbon-rich ecosystems. The only exception is the Cerrado savannah in Brazil, which could still provide $7.3 \%$ of the oil needed under the $60 \%$ reduction requirement. A double-counting scheme is necessary to make plants with second-generation technology work at full capacity, increasing the profitability of the sector. All this delivers further environmental benefits. Specifically, those scenario formulations capturing the RED's sustainability criteria bring environmental benefits in terms of acidification, eutrophication and freshwater ecotoxicity, with reductions of between $44.6 \%$ and $92.6 \%$ relative to the scenario with no double-counting and no emission constraint. For a given GHG emission threshold, emissions associated with these other impact categories dramatically increase when the share of imported virgin oils increases in the mix. Increasing the GHG savings thresholds yields greater welfare, since they favor the use of domestic oils. However, the transesterification stage still remains unprofitable for all the first-generation plants and for small UCO plants. One of the strengths of this model is that it allows for direct and indirect emissions (not only of $\mathrm{CO}_{2}$ ) from domestic rapeseed and sunflower biodiesel to be estimated separately. When including ILUC emissions, the GHG savings coefficient is reduced to $29 \%$ and $36 \%$ for rapeseed and sunflower pathways, respectively, so that domestic feedstocks would not be in compliance with the forthcoming sustainability criteria in the RED unless they are mixed with other oils with better sustainability characteristics. In this way, this tool could help to assess trade-offs and compare different policy settings in the Spanish context.

Finally, in section 3.5, a Computable General Equilibrium (CGE) model, known as Global Trade Analysis Project (GTAP), has been used to analyze the global environmental consequences, in terms of GHG emissions and LUC, of increasing the demand for biodiesel in the EU to meet the RED targets, although sustainability 
criteria have not been included. Recent measures affecting the biofuel market have been taken into account, namely the cap on the consumption of FGBs and antidumping duties on biodiesel imports from Argentina and Indonesia, added to the existing ones on US imports. The global effects of a shock in consumption in the Spanish transport sector could not be addressed by means of an economy-wide model, such as GTAP. In order to analyze the market responses in depth, biodiesel imports into the EU from major producing countries have been updated in the original database. Both increased biodiesel consumption in the EU by 2020 and increased import prices have been modeled as exogenous policy shocks. Two experiments have been performed under a static approach, one considering the effect of the blending mandate alone, and a second one including the anti-dumping measures in combination with the mandate. Specifically, the GTAP-BIO version of the standard model has been used, depicting the world economy in 2004. The latest version disaggregates biodiesel into soybean biodiesel, rapeseed biodiesel, palm biodiesel and biodiesel from other feedstocks. The land use module permits competition between traditional crops and dedicated energy crops for land in different agroecological zones (AEZs) based on historical observations during the period 2004-2010, when the greatest expansion of bioenergy occurred worldwide. Land conversion in each $\mathrm{AEZ}$ is assigned a $\mathrm{CO}_{2}$ emission factor, according to estimations of the California Air Resources Board.

The results show that biodiesel imports into the EU increase despite the antidumping measures, because of the enormous expansion of domestic demand, mainly for palm biodiesel. Biodiesel producers in the EU benefit from these policies as well; this is especially the case of those producing rapeseed and also palm biodiesel (due to imports of vegetable oils). As a consequence, the target biodiesel demand in the EU by 2020 (in combination with anti-dumping duties) will cause around $35.8 \mathrm{~g} \mathrm{CO}_{2} / \mathrm{MJ}, 35 \%$ lower than the default value in the new EC proposal (55 $\mathrm{g} \mathrm{CO}_{2} / \mathrm{MJ}$ ). This shows that limiting FGB consumption may be an effective way of reducing indirect GHG emissions from the EU blending mandate, but ILUC is still an issue of concern. Global LUC is expected to occur in other countries not necessarily involved in the biodiesel trade, since it arises from interactions in the food and feed markets. Land brought under agricultural production expands by 3.32 Mha, mainly in regions such as South-Saharan Africa, Brazil, South America, or the United States, while only $7.5 \%$ takes place in the EU. Although the estimation of ILUC is subject to great uncertainty, which makes it difficult to integrate into public policies, the results should serve to reinforce the commitment of the EC to quantify and control it. Uncertainty is inherent to any attempt to model the real world, but it seems certain that the LUC impacts from biofuels are not zero. Hence, ILUC emission factors should be used in compliance with the sustainability criteria in the RED once an acceptable level of uncertainty is defined. Despite the difficulty of predicting indirect effects due to their global dimension, analyzing 
interactions in the global markets is crucial. CGE models, such as GTAP, can be a valuable tool for policy-makers, although regulating ILUC still represents a challenge in the emerging area of bioenergy.

The need to consider the effects of LUC for the definition of future biofuel policies is not a temporary one. Projections point to a substantial reliance on biofuels that cause small changes to land carbon stock in order to meet climate goals. It can be expected that the LCA methodology will continue to play a pivotal role in the estimation of direct emissions from biofuel pathways, in compliance with the sustainability criteria in the RED. However, a range of estimates exists for emissions from direct LUC, varying greatly depending on the feedstock, the geographical region and the methodological assumptions. The GHG benefits of biofuels are largely conditional on these estimates. In addition, ILUC is deemed to be even more important than direct LUC and the EC proposal on ILUC encourages the application of different methodologies in the estimation of indirect emissions from biofuels, given the associated uncertainty. The present thesis is motivated by the new policy demands on the biofuel arena. The different methodologies applied aim to provide new information on the environmental impacts of biodiesel in the Spanish context, and highlight the need to define an acceptable level of uncertainty when defining $\mathrm{CO}_{2}$ emission factors. Economic concepts are incorporated for a more thorough analysis of the environmental consequences of political decisions in the biodiesel market. Improving the economic models that forecast ILUC presents an opportunity to provide robust estimates. Using one or another methodology depends on the goal and scope of the study, and they should be applied in a complementary manner for a better understanding of the global phenomenon of bioenergy, increasing the confidence in GHG emission results. Reducing uncertainty in ILUC and direct LUC estimates is essential to enhance the applicability of future biofuel policies. 



\section{Resumen}

En los últimos años, la demanda de biocombustibles en el sector del transporte ha aumentado de manera considerable en muchos países, fomentada por políticas públicas para la promoción de las energías renovables. Los biocombustibles más comunes son el etanol (procedente de la fermentación biológica de biomasa rica en almidón o azúcar) y el biodiesel (procedente de la transesterificación de aceites o grasas). La promoción de estos combustibles alternativos se basa en dos factores fundamentales, combatir el cambio climático y contribuir a la seguridad energética. En la Unión Europea (UE), la Directiva 2009/28/EC establece un objetivo del $10 \%$ para el uso de energías renovables en el sector del transporte de los Estados Miembro en 2020, con el fin de reducir los gases de efecto invernadero (GEI). Es por esto que también se conoce como Directiva de las Energías Renovables (RED, según las siglas en inglés). Esta coyuntura política ha llevado a una fuerte expansión del sector de los biocombustibles desde el año 2000 , en especial del de biodiesel. Sin embargo, en los últimos años, el aumento en las importaciones tanto de biocombustibles como de materias primas para su producción ha puesto en duda la independencia energética de la UE. Además, se ha empezado a cuestionar la idoneidad de los biocombustibles para cumplir con los objetivos climáticos. Esto surge de la evidencia del cambio en el uso del suelo (LUC, según las siglas en inglés) acontecido a escala global con el auge de los biocombustibles, ya que los cultivos energéticos se han expandido en regiones con grandes reservas de carbono y/o de alto valor biológico. Como resultado, las políticas de biocombustibles han ido incorporando distintas consideraciones ambientales. En particular, en la UE, éstas se basan en una serie de umbrales crecientes de reducción de GEI a partir de 2013, en combinación con categorías de uso del suelo no admitidas para la expansión de los cultivos energéticos. El objetivo último es promover únicamente el uso de biocarburantes que conlleven un ahorro sustancial de GEI, mediante el cómputo de las emisiones totales desde la producción de la materia prima hasta el uso final del combustible en base a la metodología de Análisis de Ciclo de Vida (ACV).

Las políticas públicas suelen distinguir entre biocombustibles de primera generación (BPG) y biocombustibles de segunda y tercera generación, también conocidos como biocombustibles avanzados. Mientras que los primeros se producen a partir de cultivos agrícolas, los segundos se fabrican a partir de residuos o material celulósico y lignocelulósico no alimentario, y los terceros de organismos acuáticos autótrofos (por ejemplo, algas). Los BPG causan generalmente mayores impactos ambientales debido a las prácticas agrícolas; incluso pueden requerir la conversión de tierras para el cultivo de la materia prima bioenergética, con el consiguiente cambio en las existencias de carbono en el suelo y la biomasa (conocido como LUC directo). En base a esto, la RED propone 
un sistema de doble conteo para los biocarburantes de segunda generación. Además, cada vez está más aceptada la existencia de efectos indirectos, ya que los BPG generalmente provienen de biomasa comestible, compitiendo con otras materias primas por las tierras de cultivo existentes. Al desplazar los usos previos, los cultivos afectados son susceptibles de ser producidos en otros lugares para satisfacer la demanda mundial. En última instancia, esto genera un cambio indirecto del uso de la tierra (ILUC, según las siglas en inglés), con las emisiones de GEI asociadas. La Comisión Europea (CE) ha hecho una nueva propuesta en materia de biocombustibles a fin de tener en cuenta estas emisiones por ILUC, la cual ha generado un intenso debate, ya que no hay una metodología consensuada para su cuantificación. Este fenómeno es el resultado de cambios mundiales en los patrones de cultivo en respuesta a los cambios en los precios de los bienes agrícolas y, por lo tanto, está sujeto a las fuerzas del mercado y es difícil de predecir.

El objetivo de la presente tesis ha sido analizar los efectos ambientales del consumo de biodiesel en el sector del transporte español, en cumplimiento de las políticas europeas más recientes en materia de biocombustibles y cambio climático. Con este fin, se han analizado diferentes sistemas de producción de biodiesel en el contexto español, aplicando las distintas metodologías disponibles bajo una perspectiva de ciclo de vida; ello ha dado lugar a diferentes casos de estudio. No sólo se han tenido en cuenta consideraciones ambientales, sino también económicas, con el objetivo de aportar nuevos datos en la evaluación de cuestiones controvertidas que afectan el comportamiento ambiental de los biocarburantes, como la incertidumbre, la multifuncionalidad o los efectos indirectos.

En primer lugar, se han evaluado los beneficios ambientales y económicos derivados de un proceso integrado para la producción de biodiesel a partir de aceite de cocina usado (ACU). Dicho sistema, desarrollado por una iniciativa europea LIFE denominada Proyecto Integral-b, propone hacer una gestión conjunta de los residuos sólidos orgánicos (RSO) y ACU de restaurantes y catering en España mediante digestión anaerobia y transesterificación, respectivamente. Aunque podría implementarse para mejorar la viabilidad de las plantas de biodiesel, el Integral-b se ha abordado como un sistema de gestión de residuos, el objetivo principal del cual es proporcionar un tratamiento adecuado para los residuos orgánicos de la hostelería, además de producir biodiesel. En concreto, el sistema Integral-b incorpora un digestor anaeróbico (DA) y un motor de cogeneración en la misma planta de biodiesel, proporcionando energía térmica y eléctrica, lo que mejora la eficiencia energética del proceso. El motor de cogeneración, especialmente adaptado para utilizar glicerina como combustible (además de biogás), permite valorizar el excedente de glicerina procedente de la 
transesterificación; este coproducto se está convirtiendo en un residuo a tratar (con el correspondiente coste) a medida que crece la producción mundial de biodiesel. La electricidad producida se vierte a la red mientras que el lodo del DA se vende con fines agronómicos. Con ello se espera aumentar el beneficio económico de las plantas de biodiesel.

Para poder analizar conjuntamente los resultados del análisis ambiental y financiero, se requiere que ambos compartan la misma unidad funcional (UF). La UF se ha definido pues como la gestión de la cantidad de ACU y RSO de hostelería producida per cápita durante un año en España. El análisis del comportamiento ambiental se ha llevado a cabo en la sección 3.1, mediante un ACV atribucional. Dado que el sistema Integral-b es, por definición, multifuncional, han de tenerse en cuenta las cargas ambientales generadas por los coproductos. En este caso, se ha elegido la expansión del sistema para comparar el sistema propuesto (escenario A) con un sistema de referencia que consiste en las opciones de gestión vigentes en España para el mismo tipo de residuos (escenario B). Así pues, se han sustraído las funciones indirectas de cada uno de los escenarios, lo que causa cargas evitadas según el método de sustitución. Concretamente, se ha considerado que la electricidad de cogeneración en el escenario A evita la producción de otros tipos de electricidad más convencionales, mientras que el excedente de glicerina en el escenario B se usa para fines industriales. Como la elección de los procesos evitados puede tener una gran influencia en los resultados ambientales, la incertidumbre debida a estos supuestos metodológicos ha sido convenientemente evaluada. Se han abordado dos opciones para la estimación de los créditos ambientales de la glicerina en el escenario B: el desplazamiento de glicerina sintética o de propilenglicol, con relaciones de sustitución diferentes. Del mismo modo, se ha considerado que la electricidad de cogeneración en el escenario A puede sustituir a electricidad procedente del mix español o de energía eólica. Por último, se ha tenido en cuenta en la definición de la UF la disponibilidad actual de ACU en España y la potencial. Esto ha dado lugar a ocho formulaciones con las que estudiar la diferencia en los impactos entre el escenario $B$ y el escenario $A$.

Cuando la UF representa los niveles actuales de ACU (80.000 t/a), el escenario A proporciona mejores resultados que el escenario $B$ en la mayoría de las categorías de impacto y formulaciones analizadas. Esto se debe principalmente a las cargas evitadas por los coproductos, especialmente cuando la electricidad de cogeneración sustituye a la electricidad del mix. El considerar los niveles potenciales de recogida de ACU (300.000 t/a) no supone beneficios ambientales notables para el escenario A. De hecho, el escenario B resulta preferible en la mitad de los casos. Esto es debido a la mayor producción de glicerina en la transesterificación, que beneficia claramente al escenario B bajo los supuestos 
realizados en cuanto a cargas evitadas. En general, remplazar el propilenglicol supone mayores beneficios ambientales a pesar de la menor relación de sustitución. El calentamiento global (CG) y la formación de ozono fotoquímico son las únicas categorías en las que los resultados favorecen claramente al sistema Integral-b en todas las formulaciones. El método de Monte Carlo ha permitido evaluar la incertidumbre de los resultados debida a la variabilidad en los datos de inventario y ha demostrado que sólo es relevante en aquellas formulaciones en que la distribución de probabilidad del impacto diferencial (escenario B-escenario A) muestra valores positivos y negativos. Para estos casos, se ha desarrollado un análisis de discernibilidad, lo que ha permitido concluir que la incertidumbre en los parámetros no es tan crítica como la debida a los supuestos en la definición de escenarios. Gracias a esto, se puede estar más seguro de que los impactos están dentro del rango obtenido, a pesar de que no se puede afirmar que el escenario $A$ sea mejor que el escenario B. Las distintas opciones respecto a los créditos ambientales de los coproductos no son, en sí mismas, oportunidades de reducción de los impactos del proceso Integral-b, ya que derivan de la aplicación de la metodología del ACV y no son ciertas, sino probables, en función del contexto. Sin embargo, la realización de un análisis de escenarios que capture los posibles resultados del ACV en función de estas opciones facilita la interpretación de los resultados y es útil para la toma de decisiones.

El estudio combinado de la viabilidad económica y el impacto ambiental del proceso Integral-b es un prerrequisito para una comprensión más completa de su sostenibilidad. Por lo tanto, los beneficios generados por la UF en los dos escenarios definidos en la sección $\mathbf{3 . 1}$ se han calculado posteriormente en la sección 3.2 desde un punto de vista financiero. Se ha aplicado el cálculo del Coste del Ciclo de Vida, considerando que los coproductos generan ingresos en el sistema en el que son producidos, en consonancia con la expansión del sistema (sustitución) en el ACV atribucional. No obstante, los precios de los coproductos están sujetos a gran incertidumbre, ya que vienen determinados por el mercado y las empresas son precio-aceptantes. Además, el precio de venta de la electricidad generada a partir de la gestión de residuos, cogeneración y fuentes renovables está determinado por las regulaciones del mercado, que han cambiado recientemente en España. Se han definido cuatro formulaciones diferentes para evaluar los beneficios diferenciales del escenario B-escenario $A$, considerando dos sistemas tarifarios (de 2012 y 2014) y dos niveles de disponibilidad de ACU (actual y potencial). Los beneficios en los escenarios $A$ y $B$ por separado son negativos (entre $-2,27$ y $-6,29 € / U F)$. El escenario A genera beneficios más bajos en todas las formulaciones, a pesar de aumentar los ingresos; esto se debe a los mayores costes, derivados mayoritariamente de la recogida de RSO. El nuevo sistema de tarifas eléctricas perjudica al Integral-b, ya que los precios de la electricidad están menos subsidiados y los beneficios totales del escenario A dependen en gran 
medida de la venta de este coproducto; por esta razón, la formulación que considera los niveles más bajos de recogida de ACU y las tarifas de 2014 ofrece beneficios más bajos. El aumento en la disponibilidad de ACU beneficia a los dos escenarios de forma similar, mientras que el cambio en las tarifas eléctricas no es neutral, ya que afecta a los beneficios de los dos escenarios de forma diferente dependiendo de la cantidad de electricidad producida y la fuente (por ejemplo, cogeneración o incineración). El análisis de incertidumbre mediante la simulación de Monte Carlo, esta vez incluyendo parámetros técnicos y precios, refuerza la solidez del análisis comparativo, aunque demuestra que existe cierta probabilidad de que el escenario A genere mayores beneficios que el B. La probabilidad más alta $(19,5 \%)$ se ha encontrado para aquellos escenarios que consideran una mayor disponibilidad de ACU y las tarifas eléctricas de 2012. El análisis de sensibilidad ha permitido identificar los parámetros clave para la optimización económica del proceso (por ejemplo, el coste de recogida de RSO, el rendimiento de la cogeneración, etc.).

Finalmente, se ha evaluado la relación existente entre los resultados ambientales y económicos, midiendo el cambio en el beneficio que implica la reducción de los impactos ambientales por la elección de una opción de tratamiento de residuos u otra. Se puede concluir que los impactos ambientales podrían reducirse sustancialmente al optar por el sistema Integral-b a escala municipal, a pesar del nuevo sistema de tarifas eléctricas, si bien esto ocurriría a expensas de los beneficios generados. Debe tenerse en cuenta que, desde la perspectiva de un productor de biodiesel que no es responsable de los costes de la recogida de RSO, el proceso Integral-b podría ocasionar beneficios positivos, además de reducir los impactos respecto al escenario de referencia. Sin embargo, la incertidumbre en las regulaciones de la electricidad se convierte en un obstáculo para llevar a cabo este tipo de proyectos.

En las siguientes secciones, se ha aplicado el ACV a distintos sistemas cuya principal función es la de producir biodiesel. En vista de las limitaciones del enfoque atribucional para medir los efectos indirectos, se ha identificado el ACV consecuencial como la metodología a aplicar para medir el ILUC de los biocombustibles. Existen diferentes enfoques para la realización de un ACV consecuencial y todos ellos requieren la aplicación de conceptos económicos; las metodologías empleadas a continuación difieren en su capacidad para capturar las respuestas mediadas por el mercado. Estas metodologías permiten estimar y comparar los principales impactos ambientales asociados a los procesos de producción de biodiesel considerados.

La sección 3.3 compara ambientalmente dos posibles vías de obtención de biodiesel para el sector del transporte español -incluyendo el ILUC- basándose en la expansión del sistema para el ACV consecuencial. Se han definido dos 
escenarios: el escenario 1, en el que $1 \mathrm{MJ}$ de biodiesel de soja se importa de Argentina, opción prevalente en el período 2010-2013; y el escenario 2, en el que $1 \mathrm{MJ}$ de biodiesel de ACU se fabrica en España. La expansión del sistema consiste en incluir las funciones adicionales desempeñadas por los coproductos, asumiendo que los efectos indirectos surgen de las interacciones de éstos con otros ciclos de vida en el mercado internacional, ceteris paribus. Esto requiere una observación de los mercados involucrados para identificar a los proveedores marginales de los principales coproductos, que son los que se verían más afectados por un cambio en la demanda de la UF. Las cantidades marginales de cada coproducto (harinas proteicas y aceites vegetales) se han estimado mediante un cálculo iterativo. En el escenario 1, la expansión en la producción de biodiesel de soja en Argentina provoca una reducción del aceite de soja disponible en el mercado internacional, que debe ser compensada con un aumento en la producción de aceite de palma en Malasia $(25,27 \mathrm{~g})$, el proveedor marginal; esto implica, a su vez, una disminución en la producción de harina de soja en Brasil $(3,44 \mathrm{~g})$. En el escenario 2, las interacciones en el mercado global de los aceites vegetales llevan a cambios en la dirección opuesta: la utilización del ACU disponible en España reduce la necesidad de importar aceite del proveedor marginal: la producción de aceite de palma caería en Malasia (26,31 g), mientras que la producción de harina de soja aumentaría en Brasil (3,58 g).

Cuando no se consideran las emisiones de LUC, el biodiesel de ACU español reduce los impactos respecto al biodiesel importado de Argentina en todas las categorías analizadas, excepto CG. En este caso, el impacto es 138,9\% más bajo en el escenario 1, principalmente debido a la absorción de $\mathrm{CO}_{2}$ durante el cultivo de la soja en Argentina y la palma en Malasia. Para no subestimar las consecuencias ambientales negativas, se han incluido las emisiones de GEI procedentes de LUC en cada país, siguiendo las directrices del IPCC. Como resultado, el escenario 2 causa una reducción respecto al escenario 1 de entre el $49,0 \%$ y $112,9 \%$ en todas las categorías de impacto. En cuanto al LUC, además de la transformación en Argentina $\left(+8,75 \cdot 10^{-2} \mathrm{~m}^{2}\right)$, el escenario 1 conduce a deforestación en Malasia $\left(+1,86 \cdot 10^{-3} \mathrm{~m}^{2}\right)$ y contracción de la superficie agraria en Brasil $\left(-1,73 \cdot 10^{-2} \mathrm{~m}^{2}\right)$, a raíz de las respuestas mediadas por el mercado. Como efectos secundarios, se pierde parte de las reservas de carbono: el LUC directo en Argentina libera $1137,5 \mathrm{~g}$ de $\mathrm{CO}_{2}$ a la atmósfera, mientras que el ILUC total genera $87,3 \mathrm{~g}$ de $\mathrm{CO}_{2}$ adicional. En el escenario 2, el LUC neto se estima en $1,61 \cdot 10^{-2} \mathrm{~m}^{2}$ (más de 5 veces menos que en el escenario 1), que procede íntegramente de ILUC en Malasia $\left(-1,94 \cdot 10^{-3} \mathrm{~m}^{2}\right)$ y Brasil $\left(+1,80 \cdot 10^{-2} \mathrm{~m}^{2}\right)$. Como consecuencia, se absorben 230,6 $\mathrm{g}$ de $\mathrm{CO}_{2}$ y se liberan $139,4 \mathrm{~g}$ de $\mathrm{CO}_{2}$, respectivamente. En este caso, las respuestas mediadas por el mercado mejoran incluso el perfil ambiental del sistema de biodiesel de ACU y el escenario 2 genera una absorción total de 28,6 g de $\mathrm{CO}_{2}$-eq., 1092,3 g menos que el escenario 1. Los 
resultados muestran que la utilización de biodiesel de ACU en España para cumplir con los objetivos de la UE supone grandes beneficios ambientales en comparación con el uso de biodiesel de soja importado de Argentina. La simulación de Monte Carlo refuerza nuevamente la confianza en la evaluación comparativa.

En vista de la larga crisis en el sector del biodiesel español, la sección 3.4 establece un marco operativo para optimizar toda la cadena de producción, permitiendo hallar la combinación óptima de materia prima de acuerdo a criterios medioambientales y económicos. Para ello se propone un modelo de programación matemática basado en la capacidad nominal del sector, hoy en día infrautilizada, con el fin de proteger las inversiones existentes. Se parte del supuesto de que la totalidad de la demanda proyectada para 2020 se satisface con la producción nacional de biodiesel. El modelo permite, además de la maximización del excedente de todos los actores involucrados, realizar simultáneamente un ACV que incluya las emisiones de LUC directo, con el objetivo de averiguar si los objetivos de reducción de GEI establecidos por la RED son compatibles con otros beneficios ambientales. La UF es la producción de 2,58 Mt de biodiesel a partir de materias primas tanto importadas como nacionales. Se ha modelizado con el Sistema General de Modelado Algebraico (GAMS) tanto la industria del biodiesel como el sector agrícola en España en un entorno multisectorial. La optimización conjunta de los módulos agrícola e industrial da como resultado la combinación de aceites óptima dada la configuración del sector, junto con el suministro óptimo de biomasa de la agricultura española. La producción industrial está definida por una función escalonada, basada en la capacidad existente e información de costes. El módulo agrícola está constituido por ecuaciones que capturan la disponibilidad de recursos, principales rotaciones, políticas y cuotas con el fin de representar las diferencias regionales. Para medir las emisiones directas (e indirectas) de GEI originadas como consecuencia de una expansión de la demanda industrial de semillas oleaginosas, se requiere una representación detallada del suministro de biomasa del país.

Se han propuesto cuatro escenarios con el fin de analizar la repercusión de distintos condicionantes normativos en términos de beneficio económico y ambiental. En particular, se han simulado los umbrales crecientes de reducción de GEI impuestos por la RED y dos precios para el biodiesel de ACU, uno que representa el precio actual de mercado en España y otro que se corresponde con el sistema de doble conteo. Además, se han definido diferentes factores de emisión de $\mathrm{CO}_{2}$ por LUC directo en el caso de los aceites vegetales crudos de importación; cada uno de ellos se corresponde con un ecosistema potencialmente convertible en cultivos oleaginosos en Argentina, Brasil y el Sudeste Asiático. La mezcla óptima de aceite para el sector depende en gran medida de estas 
suposiciones con respecto al LUC en los países de origen. Como cabía esperar, el aumento de los umbrales de reducción de GEI implica un mayor uso de ACU y semillas oleaginosas autóctonas, pudiendo representar hasta un $97,1 \%$ del mix. Al mismo tiempo, se evita la deforestación de ecosistemas ricos en carbono, siendo la única excepción la sabana del Cerrado en Brasil, que podría llegar a proporcionar el 7,3\% del aceite necesario incluso con el requisito de reducción del $60 \%$. La aplicación del doble conteo llevaría a las plantas con tecnología de segunda generación a trabajar a plena capacidad, contribuyendo a la rentabilidad del sector. Todo esto ofrece además otros beneficios ambientales. En concreto, los escenarios que consideran los criterios de sostenibilidad de la RED reducen los impactos de acidificación, eutrofización y ecotoxicidad acuática entre el $44,6 \%$ y el $92,6 \%$ respecto al escenario sin doble conteo ni limitación de GEI. Para un umbral de reducción de GEI dado, las emisiones asociadas a estas otras categorías de impacto aumentan drásticamente al incrementar-se la presencia de aceites vegetales importados en el mix. El aumento de los umbrales de GEI conlleva, a su vez, un mayor excedente a lo largo de la cadena de producción, ya que impulsa el uso de aceites nacionales, aunque la etapa de transesterificación siga sin resultar rentable para las plantas de primera generación y las de ACU de menor capacidad. Uno de los puntos fuertes de este modelo es que permite estimar por separado las emisiones directas e indirectas (no sólo de $\mathrm{CO}_{2}$ ) del biodiesel de colza y de girasol producido en España. Al incluir las emisiones de ILUC, el ahorro de GEl se reduce al $29 \%$ y $36 \%$ para el biodiesel de colza y girasol, respectivamente, con lo que no cumpliría con los futuros umbrales de la RED, a menos que estos aceites se mezclen con otros de menor impacto. De este modo, la herramienta propuesta permite evaluar las implicaciones ambientales y económicas de diferentes condicionantes de sostenibilidad en el contexto español.

Por último, en la sección 3.5, se ha aplicado un modelo de Equilibrio General Computable (EGC), conocido como Global Trade Analysis Project (GTAP), para el análisis de las consecuencias ambientales globales (en términos de emisiones de GEI y LUC) de un aumento en la demanda de biodiesel en la UE para cumplir con la RED, aunque no se han tenido en cuenta los criterios de reducción de GEI. Sin embargo, sí se han considerado las medidas adoptadas recientemente y que afectan al mercado de los biocombustibles, a saber, el límite sobre el consumo de BPG y los derechos antidumping sobre las importaciones de biodiesel de Argentina e Indonesia, añadidos a los ya existentes sobre las importaciones estadounidenses. Los efectos mundiales de un incremento del consumo en el sector del transporte español no podrían abordarse mediante el modelo GTAP. Con el objeto de analizar las respuestas en profundidad, las principales importaciones de biodiesel en la UE han sido actualizadas en la base de datos. EI incremento del consumo de biodiesel proyectado para 2020 y el aumento en los precios del biodiesel importado han sido simulados como shocks exógenos, dando 
lugar a dos experimentos bajo un enfoque estático: uno teniendo en cuenta el efecto del mandato de mezcla de forma aislada y otro en combinación con las medidas antidumping. Se ha empleado la versión GTAP-BIO del modelo estándar, que representa la economía mundial en 2004. Esta última versión desagrega el biodiesel en biodiesel de soja, colza, palma y biodiesel fabricado a partir de otras materias primas. El módulo de usos de la tierra permite modelizar la competencia entre cultivos tradicionales y energéticos en diferentes zonas agroecológicas (ZAE), en base a observaciones históricas correspondientes al período 2004-2010, cuando tuvo lugar la expansión más acusada de los cultivos energéticos en todo el mundo. A la conversión en cada ZAE se le asigna un factor de emisión de $\mathrm{CO}_{2}$, según estimaciones del California Air Resources Board.

Los resultados muestran que las importaciones de biodiesel aumentan en la UE a pesar de las medidas antidumping, debido a la enorme expansión de la demanda interna, sobre todo de biodiesel de palma. Los productores europeos de biodiesel salen beneficiados igualmente, especialmente aquellos que producen biodiesel de colza y también de palma (gracias a las importaciones de aceite). Como consecuencia del shock en la demanda de biodiesel en la UE (en combinación con los derechos antidumping), se generaría alrededor de $35,8 \mathrm{~g}$ de $\mathrm{CO}_{2} / \mathrm{MJ}$, un $35 \%$ menos que el valor por defecto en la nueva propuesta de la CE (55 g de $\left.\mathrm{CO}_{2} / \mathrm{MJ}\right)$. Esto demuestra que limitar la cuota de mercado de los BPG puede ser una forma efectiva de reducir las emisiones indirectas de GEI atribuidas al biodiesel consumido en la UE, aunque el ILUC sigue siendo un motivo de preocupación. Se espera que el LUC ocurra a escala global, en países no necesariamente involucrados en el comercio de biodiesel con la UE, ya que surge de las interacciones con los mercados de alimentos y piensos. La tierra en producción agrícola se expandiría por un total de 3,32 Mha, principalmente en regiones como el África Subsahariana, Brasil y resto de Sudamérica, o los Estados Unidos, mientras que sólo el 7,5\% tendría lugar en la UE. Aunque la estimación de ILUC está sujeta a gran incertidumbre, lo que complica su incorporación en políticas públicas, estos resultados deben servir para reforzar el compromiso de la CE en cuantificarlo y controlarlo. De hecho, la incertidumbre es inherente a cualquier intento de modelizar el mundo real, si bien es cierto que los impactos originados por LUC de los biocombustibles no son nulos. Por lo tanto, se recomienda utilizar factores de emisión de ILUC para evaluar el cumplimiento de los criterios de sostenibilidad de la RED una vez se haya definido un nivel aceptable de incertidumbre. A pesar de la dificultad de predecir los efectos indirectos debido a su alcance mundial, el análisis de las interacciones en los mercados internacionales es indispensable. Los modelos de EGC como GTAP constituyen una valiosa herramienta para los responsables políticos, aunque la regulación del ILUC siga representando un desafío en el área de la bioenergía. 
La necesidad de considerar los efectos del LUC en la definición de políticas futuras en materia de biocombustibles no es pasajera. Las proyecciones apuntan a una dependencia sustancial de aquellos biocarburantes que causen pequeños cambios en las reservas de carbono de los ecosistemas para cumplir con los objetivos climáticos. Es de esperar que la metodología de ACV siga desempeñando un papel fundamental en la estimación de las emisiones de LUC directo, en cumplimiento con los criterios de sostenibilidad de la RED. Sin embargo, las estimaciones difieren notablemente en función de la materia prima, la región geográfica y supuestos metodológicos, lo cual condiciona los beneficios de GEI atribuidos a los biocombustibles. Por otro lado, se considera que el ILUC puede ser aún más importante que el LUC directo y la misma propuesta de la CE sobre ILUC estimula la aplicación de diferentes metodologías con el fin de interpretar la incertidumbre asociada. La presente tesis está motivada por las recientes demandas en el ámbito normativo de los biocombustibles. Las metodologías aplicadas tienen como objetivo proporcionar nueva información sobre los impactos ambientales del biodiesel en el contexto español, lo que pone de relieve la necesidad de definir un nivel aceptable de incertidumbre para los factores de emisión de $\mathrm{CO}_{2}$. Se han incorporado conceptos económicos para un análisis más completo de las consecuencias ambientales de distintas decisiones políticas que afectan al mercado del biodiesel. El perfeccionamiento de los modelos económicos que sirven para pronosticar el ILUC se presenta como una oportunidad para proporcionar estimaciones más robustas. El uso de una u otra metodología depende del objetivo y el alcance de estudio; lo ideal es aplicarlas de forma complementaria para una mayor comprensión del fenómeno global de la bioenergía, contribuyendo a una mayor solidez en los resultados de GEl. Reducir la incertidumbre en las estimaciones de ILUC y LUC directo es fundamental para asegurar la aplicabilidad de las políticas de biocombustibles en el futuro. 


\section{Resum}

Els darrers anys hi ha hagut una demanda creixent de biocombustibles per al transport a molts països, fomentada per polítiques públiques de promoció de les energies renovables. Els biocombustibles més comuns són l'etanol (procedent de la fermentació biològica de biomassa rica en midó o sucre) i el biodièsel (procedent de la transesterificació d'olis o greixos). La promoció d'aquests combustibles alternatius es fonamenta en dos factors principals: combatre el canvi climàtic i contribuir a la seguretat energètica. A la Unió Europea (UE), la Directiva 2009/28/EC estableix un objectiu del 10\% per a l'ús d'energies renovables en el sector del transport dels estats membres l'any 2020, amb l'objectiu de reduir els gasos amb efecte hivernacle (GEH). És per això que també es coneix aquesta norma com Directiva de les energies renovables (RED, segons les sigles en anglès). Aquesta conjuntura política ha ocasionat una forta expansió del sector dels biocombustibles des de l'any 2000, especialment pel que fa al biodièsel. Malgrat això, els últims anys, l'augment en les importacions tant de biocombustibles com de matèries primeres per a produir-ne ha posat en dubte la independència energètica de la UE. A més, s'ha començat a qüestionar la idoneïtat dels biocombustibles per a complir els objectius climàtics. Això sorgeix de l'evidència del canvi en l'ús del sòl (LUC, segons les sigles en anglès) esdevingut a escala global amb l'auge dels biocombustibles, ja que els cultius energètics s'han expandit en regions amb grans reserves de carboni i/o d'alt valor biològic. Com a resultat, les polítiques de biocombustibles han anat incorporant diferents consideracions ambientals. En particular, a la UE, aquestes es basen en una sèrie de llindars creixents de reducció de GEH a partir del 2013, en combinació amb categories d'ús del sòl no admeses per a l'expansió dels cultius energètics. L'objectiu últim és promoure únicament l'ús de biocarburants que comporten un estalvi substancial de GEH, mitjançant el càlcul de les emissions totals des de la producció de la matèria primera fins a l'ús final del combustible basant-se en la metodologia d'Anàlisi de Cicle de Vida (ACV).

Les polítiques públiques solen distingir entre biocombustibles de primera generació (BPG), i biocombustibles de segona i tercera generacions, també coneguts com biocombustibles avançats. Mentre que els primers es produeixen a partir de cultius agrícoles, els segons es fabriquen a partir de residus o material cel.lulòsic $i$ lignocel.lulòsic no alimentari, i els tercers, a partir d'organismes aquàtics autòtrofs (per exemple, algues). Els BPG causen generalment majors impactes ambientals, a causa de les pràctiques agrícoles; fins i tot poden requerir la conversió de terres per al cultiu de la matèria primera bioenergètica, amb el consegüent canvi en les existències de carboni al sòl i la biomassa (canvi conegut com LUC directe). Sobre la base d'això, la RED proposa un sistema de doble comptatge per als biocarburants de segona generació. A més, cada vegada s'accepta més que 
també hi ha efectes indirectes, ja que els BPG provenen generalment de biomassa comestible i, per tant, competeixen amb altres matèries primeres per les terres de cultiu. Quan es desplacen els usos previs, els cultius afectats són susceptibles de ser produïts en altres llocs per a satisfer la demanda mundial. En última instància, això genera un canvi indirecte de l'ús de la terra (ILUC, segons les sigles en anglès), amb les emissions de GEH associades. La Comissió Europea (CE) ha fet una nova proposta en matèria de biocombustibles a fi de tenir en compte aquestes emissions per ILUC, la qual ha generat un intens debat, ja que no hi ha una metodologia consensuada per a quantificar-les. Aquest fenomen és el resultat de canvis mundials en els patrons de cultiu en resposta als canvis en els preus dels béns agrícoles i, per tant, està subjecte a les forces del mercat i és difícil de predir.

L'objectiu de la present tesi ha sigut analitzar els efectes ambientals del consum de biodièsel en el sector del transport espanyol, en compliment de les polítiques europees més recents en matèria de biocombustibles i canvi climàtic. Amb aquest objectiu s'han analitzat diferents sistemes de producció de biodièsel en el context espanyol, aplicant-hi les diferents metodologies disponibles sota una perspectiva de cicle de vida; això ha donat lloc a diferents casos d'estudi. No només s'han tingut en compte consideracions ambientals, sinó també econòmiques, a fi d'aportar noves dades en l'avaluació de qüestions controvertides que afecten el comportament ambiental dels biocarburants, com ara la incertesa, la multifuncionalitat o els efectes indirectes.

En primer lloc, s'han avaluat els beneficis ambientals i econòmics derivats d'un procés integrat per a la producció de biodièsel a partir d'oli de cuina usat (OCU). Aquest sistema, desenvolupat per una iniciativa europea LIFE denominada Projecte Integral-b, proposa fer una gestió conjunta dels residus sòlids orgànics (RSO) i OCU de restaurants i serveis d'àpats (catering) a Espanya mitjançant la digestió anaeròbica i la transesterificació, respectivament. Encara que podria implementar-se per millorar la viabilitat de les plantes de biodièsel, l'Integral-b s'ha abordat com un sistema de gestió de residus, el principal objectiu del qual és proporcionar un tractament adequat als residus orgànics de l'hostaleria, a més de produir biodièsel. En concret, el sistema Integral-b incorpora un digestor anaeròbic (DA) i un motor de cogeneració a la mateixa planta de biodièsel, motor que proporciona energia tèrmica i elèctrica i millora l'eficiència energètica del procés. El motor de cogeneració, especialment adaptat per a utilitzar glicerina com a combustible (a més de biogàs), permet valoritzar l'excedent de glicerina procedent de la transesterificació; aquest coproducte està convertint-se en un residu que cal tractar (amb el corresponent cost) a mesura que creix la producció mundial de biodièsel. L'electricitat produïda s'aboca a la xarxa mentre que el llot del DA es ven $a m b$ finalitats agronòmiques. Amb això s'espera augmentar el benefici econòmic de les plantes de biodièsel. 
Per a poder analitzar conjuntament els resultats de l'anàlisi ambiental i financera, es requereix que tots dos compartisquen la mateixa unitat funcional (UF). Aquesta s'ha definit, per tant, com la gestió de la quantitat d'OCU i d'RSO procedents de l'hostaleria produïda per capita durant un any a Espanya. L'anàlisi del comportament ambiental s'ha dut a terme en la secció 3.1, mitjançant l'ACV atribucional. Atès que el sistema Integral-b és, per definició, multifuncional, cal tenir en compte les càrregues ambientals generades pels coproductes. En aquest cas, s'ha optat per l'expansió del sistema per comparar el sistema proposat (escenari A) amb un sistema de referència que consisteix en les opcions de gestió vigents a Espanya per al mateix tipus de residus (escenari B). Així doncs, s'han sostret les funcions indirectes de cadascun dels escenaris, la qual cosa genera càrregues evitades d'acord al mètode de substitució. Concretament, s'ha considerat que l'electricitat de cogeneració en l'escenari A evita la producció d'altres tipus d'electricitat més convencionals, mentre que l'excedent de glicerina en l'escenari B s'usa per a finalitats industrials. Com que la tria dels processos evitats pot tenir una gran influència en els resultats ambientals, la incertesa a causa d'aquests supòsits metodològics ha sigut avaluada convenientment. S'han abordat dues opcions per a l'estimació dels crèdits ambientals de la glicerina en l'escenari B: el desplaçament de glicerina sintètica o de propilenglicol, amb relacions de substitució diferents. De la mateixa manera, s'ha considerat que l'electricitat de cogeneració en l'escenari A pot substituir electricitat procedent de la combinació energètica ( $m i x$ ) espanyola o bé d'energia eòlica. Finalment, s'ha tingut en compte per a la definició de la UF la disponibilitat actual d'OCU a Espanya i la potencial. Això ha donat lloc a vuit formulacions, amb les quals es pot estudiar la diferència en els impactes entre l'escenari $B$ i l'escenari $A$.

Quan la UF representa els nivells actuals d'OCU (80.000 t/a), l'escenari A genera millors resultats que l'escenari $B$ en la majoria de les categories d'impacte $i$ formulacions analitzades. Això es deu principalment a les càrregues evitades pels coproductes, especialment quan l'electricitat de cogeneració substitueix electricitat de la combinació energètica. El fet de considerar els nivells potencials de recollida d'OCU (300.000 t/a) no suposa beneficis ambientals notables per a l'escenari $A$. De fet, l'escenari $B$ resulta preferible en la meitat dels casos. Això es deu a la major producció de glicerina en la transesterificació, que beneficia clarament l'escenari $B$ en els supòsits realitzats amb relació a les càrregues evitades. En general, reemplaçar propilenglicol suposa majors beneficis ambientals malgrat la menor relació de substitució. L'escalfament global (EG) i la formació d'ozó fotoquímic són les úniques categories en les quals els resultats afavoreixen clarament el sistema Integral-b en totes les formulacions. El mètode de Monte Carlo ha permès avaluar la incertesa dels resultats deguda a la variabilitat en les dades d'inventari, i ha demostrat que només és rellevant en aquelles formulacions en què la distribució de probabilitat de l'impacte diferencial (escenari B-escenari A) 
mostra valors positius i negatius. Per a aquests casos, s'ha desenvolupat una anàlisi de discernibilitat, la qual cosa ha permès concloure que la incertesa en els paràmetres no és tan crítica com la deguda als supòsits en la definició d'escenaris. Gràcies a això, es pot estar més segur que els impactes es troben dins del rang obtingut, malgrat que no es pot afirmar que l'escenari A siga millor que l'escenari B. Les diferents opcions respecte als crèdits ambientals dels coproductes no són, en si mateixes, oportunitats de reducció dels impactes del procés Integral-b, ja que deriven de l'aplicació de la metodologia de l'ACV i no són certes, sinó probables, en funció del context. No obstant això, la realització d'una anàlisi d'escenaris que capture els possibles resultats de l'ACV en funció d'aquestes opcions facilita la interpretació dels resultats i és útil per a la presa de decisions.

L'estudi combinat de la viabilitat econòmica i l'impacte ambiental del procés Integral-b és un prerequisit per a una comprensió més completa de la sostenibilitat d'aquest. Per tant, els beneficis generats per la UF en els dos escenaris definits en la secció 3.1 s'han calculat posteriorment en la secció $\mathbf{3 . 2}$ des d'un punt de vista financer. S'ha aplicat el càlcul del Cost del Cicle de Vida, considerant que els coproductes generen ingressos en el sistema en el qual són produïts, d'acord amb l'expansió del sistema (substitució) en l'ACV atribucional. No obstant això, els preus dels coproductes estan subjectes a gran incertesa, ja que vénen determinats pel mercat i les empreses són preuacceptants. A més, el preu de venda de l'electricitat generada a partir de la gestió de residus, la cogeneració i les fonts renovables està determinat per les regulacions del mercat, que han canviat a Espanya fa poc. S'han definit quatre formulacions diferents per a avaluar els beneficis diferencials de l'escenari B-escenari A, considerant dos sistemes tarifaris (del 2012 i el 2014) i dos nivells de disponibilitat d'OCU (actual i potencial). Els beneficis en els escenaris A i B per separat són negatius (entre -2,27 i -6,29 €/UF). L'escenari A genera beneficis més baixos en totes les formulacions, malgrat que els ingressos augmenten; això es deu als majors costos, derivats majoritàriament de la recollida d'RSO. El nou sistema de tarifes elèctriques perjudica l'Integral-b, ja que els preus de l'electricitat estan menys subsidiats i els beneficis totals de l'escenari A depenen en gran mesura de la venda d'aquest coproducte; per aquesta raó, la formulació que considera els nivells més baixos de recollida d'OCU i les tarifes del 2014 ofereix beneficis més baixos. L'augment en la disponibilitat d'OCU beneficia els dos escenaris de forma similar, però el canvi en les tarifes elèctriques no és neutral, ja que afecta els beneficis dels dos escenaris de forma diferent depenent de la quantitat d'electricitat produïda i de la font (per exemple, cogeneració o incineració). L'anàlisi d'incertesa mitjançant la simulació de Monte Carlo, aquesta vegada incloent paràmetres tècnics i preus, reforça la solidesa de l'anàlisi comparativa, encara que demostra que hi ha una certa probabilitat que l'escenari A genere majors beneficis que no el B. La probabilitat més alta $(19,5 \%)$ s'ha trobat per a aquells escenaris que consideren una major disponibilitat d'OCU i 
les tarifes elèctriques del 2012. L'anàlisi de sensibilitat ha permès identificar els paràmetres clau per a l'optimació econòmica del procés (per exemple, el cost de recollida d'RSO, el rendiment de la cogeneració, etc.).

Finalment, s'ha avaluat la relació que hi ha entre els resultats ambientals i econòmics, mesurant el canvi en el benefici que implica la reducció dels impactes ambientals per la tria d'una opció de tractament de residus o una altra. Es pot concloure que els impactes ambientals podrien reduir-se substancialment en optar pel sistema Integral-b a escala municipal, malgrat el nou sistema de tarifes elèctriques, si bé això ocorreria a costa dels beneficis generats. Cal tenir en compte que, des de la perspectiva d'un productor de biodièsel que no és responsable dels costos de la recollida d'RSO, el procés Integral-b oferiria beneficis positius, a més de reduir els impactes respecte a l'escenari de referència. Tanmateix, la incertesa en les regulacions de l'electricitat es converteix en un obstacle per a dur a terme aquesta mena de projectes a nivell industrial.

En les seccions següents, s'ha aplicat l'ACV a diferents sistemes la principal funció dels quals és la de produir biodièsel. A la vista de les limitacions de l'enfocament atribucional per a mesurar els efectes indirectes, s'ha identificat l'ACV conseqüencial com la metodologia que cal aplicar per a mesurar I'ILUC dels biocombustibles. Hi ha diferents enfocaments per a la realització d'una ACV conseqüencial, i tots requereixen l'aplicació de conceptes econòmics; les metodologies emprades a continuació difereixen quant a la capacitat de capturar les respostes intervingudes pel mercat. Aquestes metodologies permeten estimar $\mathrm{i}$ comparar els principals impactes ambientals associats als processos de producció de biodièsel considerats.

La secció 3.3 compara ambientalment dues possibles vies d'obtenció de biodièsel per al sector del transport espanyol -inclòs l'ILUC- basant-se en l'expansió del sistema per a l'ACV conseqüencial. S'han definit dos escenaris: l'escenari 1, en el qual $1 \mathrm{MJ}$ de biodièsel de soia s'importa de l'Argentina, opció majoritària en el període 2010-2013, i l'escenari 2, en el qual 1 MJ de biodièsel d'OCU es fabrica a Espanya. L'expansió del sistema consisteix a incloure les funcions addicionals exercides pels coproductes, i assumir que els efectes indirectes sorgeixen de les interaccions d'aquests amb altres cicles de vida en el mercat internacional, ceteris paribus. Això requereix una observació dels mercats involucrats per identificar els proveïdors marginals dels principals coproductes, que són els que es veurien més afectats per un canvi en la demanda de la UF. Les quantitats marginals de cada coproducte (farines proteiques i olis vegetals) s'han estimat mitjançant un càlcul iteratiu. En l'escenari 1, l'expansió en la producció de biodièsel de soia a l'Argentina provoca una reducció de l'oli de soia disponible al mercat internacional, la qual ha de ser compensada amb un augment en la producció d'oli de palma a Malàisia (25,27 g), el proveïdor marginal; això implica, al seu torn, una disminució 
en la producció de farina de soia al Brasil (3,44 g). En l'escenari 2, les interaccions al mercat global dels olis vegetals porten a canvis en la direcció contrària: la utilització de l'OCU disponible a Espanya redueix la necessitat d'importar oli del proveïdor marginal: la producció d'oli de palma cauria a Malàisia $(26,31 \mathrm{~g})$, mentre que la producció de farina de soia augmentaria al Brasil (3,58 g).

Quan no es consideren les emissions del LUC, el biodièsel d'OCU espanyol redueix els impactes respecte al biodièsel importat de l'Argentina en totes les categories analitzades, excepte en l'EG. En aquest cas, l'impacte és un 138,9\% més baix en l'escenari 1, principalment a causa de l'absorció de $\mathrm{CO}_{2}$ durant el cultiu de la soia a l'Argentina i de la palma a Malàisia. Per no subestimar les conseqüències ambientals negatives, s'han inclòs les emissions de GEH procedents del LUC a cada país, seguint les directrius de l'IPCC. Com a resultat, l'escenari 2 causa una reducció respecte a l'escenari 1 entre el 49,0\% i el 112,9\% en totes les categories d'impacte. Pel que fa al LUC, a més de la transformació a l'Argentina $\left(+8,75 \cdot 10^{-2} \mathrm{~m}^{2}\right)$, l'escenari 1 condueix a la desforestació a Malàisia $\left(+1,86 \cdot 10^{-3} \mathrm{~m}^{2}\right)$ i a la contracció de la superfície agrària al Brasil $\left(-1,73 \cdot 10^{-2} \mathrm{~m}^{2}\right)$, arran de les respostes intervingudes pel mercat. Com a efectes secundaris, es perden part de les reserves de carboni: el LUC directe a l'Argentina allibera 1137,5 $\mathrm{g}$ de $\mathrm{CO}_{2}$ a l'atmosfera, mentre que l'ILUC total genera $87,3 \mathrm{~g}$ de $\mathrm{CO}_{2}$ addicional. En l'escenari 2, el LUC net s'estima en $1,61 \cdot 10^{-2} \mathrm{~m}^{2}$ (més de cinc vegades menys que en l'escenari 1), el qual procedeix íntegrament de l'ILUC a Malàisia $\left(-1,94 \cdot 10^{-3}\right.$ $\left.\mathrm{m}^{2}\right)$ i el Brasil $\left(+1,80 \cdot 10^{-2} \mathrm{~m}^{2}\right)$. Com a conseqüència, s'absorbeixen $230,6 \mathrm{~g}$ de $\mathrm{CO}_{2}$ i s'alliberen $139,4 \mathrm{~g}$ de $\mathrm{CO}_{2}$, respectivament. En aquest cas, les respostes intervingudes pel mercat fins $i$ tot milloren el perfil ambiental del sistema de biodièsel d'OCU i l'escenari 2 genera una absorció total de $28,6 \mathrm{~g}$ de $\mathrm{CO}_{2}$-eq., $1092,3 \mathrm{~g}$ menys que l'escenari 1 . Els resultats mostren que la utilització de biodièsel d'OCU a Espanya per complir els objectius de la UE suposa grans beneficis ambientals, en comparació amb l'ús de biodièsel de soia importat de l'Argentina. La simulació de Monte Carlo reforça novament la confiança en l'avaluació comparativa.

En vista de la llarga crisi en el sector del biodièsel espanyol, la secció $\mathbf{3 . 4}$ estableix un marc operatiu per optimar tota la cadena de producció, que permeta trobar la combinació òptima de matèria primera d'acord amb criteris mediambientals i econòmics. Així doncs, es proposa un model de programació matemàtica basat en la capacitat nominal del sector, avui dia infrautilitzada, amb la finalitat de protegir les inversions existents. Es parteix del supòsit que la totalitat de la demanda projectada per al 2020 se satisfà amb la producció nacional de biodièsel. El model permet, a més de la maximització de l'excedent de tots els actors involucrats, realitzar simultàniament una ACV que incloga les emissions del LUC directe, amb el propòsit de detectar si els objectius de reducció de GEH 
establerts per la RED són compatibles amb altres beneficis ambientals. La UF és la producció de 2,58 Mt de biodièsel a partir de matèries primeres, tant importades com nacionals. S'ha modelitzat amb el sistema general de modelització algebraica (GAMS n'és la sigla en anglès) tant la indústria del biodièsel com el sector agrícola a Espanya en un entorn multisectorial. L'optimació conjunta dels mòduls agrícola i industrial dóna com a resultat la combinació d'olis òptima, atesa la configuració del sector, juntament amb el subministrament òptim de biomassa de l'agricultura espanyola. La producció industrial està definida per una funció esglaonada, basada en la capacitat existent i en la informació dels costos. El mòdul agrícola està constituït per equacions que capturen la disponibilitat de recursos, les principals rotacions, les polítiques i les quotes, amb la finalitat de representar les diferències regionals. Per mesurar les emissions directes ( $\mathrm{i}$ indirectes) de $\mathrm{GEH}$ originades com a resultat d'una expansió de la demanda industrial de llavors oleaginoses, es requereix una representació detallada del subministrament de biomassa del país.

S'han proposat quatre escenaris amb la finalitat d'analitzar la repercussió de diferents condicionants normatius en termes de benefici econòmic $i$ ambiental. En particular, s'han simulat els llindars creixents de reducció de GEH imposats per la RED i dos preus pel biodièsel d'OCU, un que representa l'actual preu de mercat a Espanya i l'altre que es correspon amb el sistema de doble comptatge. A més, s'han definit diferents factors d'emissió de $\mathrm{CO}_{2}$ per LUC directe en el cas dels olis vegetals crus d'importació; cadascun d'aquests es correspon amb un ecosistema potencialment convertible a cultius oleaginosos a l'Argentina, el Brasil i el sud-est asiàtic. La mescla òptima d'oli per al sector depèn en gran mesura d'aquestes suposicions pel que fa al LUC als països d'origen. Com calia esperar, l'augment dels llindars de reducció de GEH implica un major ús d'OCU i llavors oleaginoses autòctones, les quals podrien representar fins a un $97,1 \%$ del mix. Al mateix temps, s'evita la desforestació d'ecosistemes rics en carboni, amb l'única excepció de la sabana del Cerrado al Brasil, la qual podria arribar a proporcionar el 7,3\% de l'oli necessari, fins i tot amb el requisit de reducció del 60\%. L'aplicació del doble comptatge faria que les plantes amb tecnologia de segona generació treballaren a plena capacitat, fet que contribuira a la rendibilitat del sector. Tot això ofereix, a més, beneficis ambientals. En concret, els escenaris que consideren els criteris de sostenibilitat de la RED redueixen els impactes d'acidificació, eutrofització i ecotoxicitat aquàtica entre el $44,6 \%$ i el $92,6 \%$ respecte a l'escenari sense doble comptatge ni limitació de GEH. Per a un llindar de reducció de GEH donat, les emissions associades a aquestes altres categories d'impacte augmenten dràsticament en incrementar-se la presència d'olis vegetals importats al mix. L'augment dels llindars de GEH comporta al seu torn un major excedent al llarg de la cadena de producció, ja que estimula l'ús d'olis nacionals, encara que l'etapa de transesterificació seguisca sense resultar rendible per a les plantes de primera 
generació i les d'OCU de menor capacitat. Un dels punts forts d'aquest model és que permet estimar per separat les emissions directes i indirectes (no sols de $\mathrm{CO}_{2}$ ) del biodièsel de colza i de gira-sol produïts a Espanya. En incloure les emissions d'ILUC, l'estalvi de GEH es redueix al 29\%, i al 36\% per al biodièsel de colza i girasol, respectivament, amb la qual cosa aquest no compliria els futurs objectius de la RED, tret que aquests olis es barregen amb altres de menor impacte. D'aquesta forma, l'eina proposada permet avaluar les implicacions ambientals i econòmiques de diferents criteris de sostenibilitat en el context espanyol.

Finalment, en la secció 3.5, s'ha aplicat un model d'equilibri general computable (EGC) -conegut com a Global Trade Analysis Project (GTAP) - a l'anàlisi de les conseqüències ambientals globals (en termes d'emissions de GEH i LUC) d'un augment de la demanda de biodièsel a la UE per complir amb la RED, encara que no s'han tingut en compte els criteris de reducció de GEl. Tanmateix, sí s'han considerat les mesures adoptades recentment i que afecten el mercat dels biocombustibles, això és, el límit sobre el consum de BPG i els drets antidúmping sobre les importacions de biodièsel de l'Argentina i Indonèsia, que s'afegeixen als ja existents sobre les importacions nord-americanes. Els efectes mundials d'un increment del consum en el sector del transport espanyol no podrien abordar-se mitjançant el model GTAP. Amb la finalitat d'analitzar les respostes en profunditat, les principals importacions de biodièsel a la UE s'han actualitzat en la base de dades. L'increment del consum de biodièsel projectat per al 2020 i l'augment en els preus del biodièsel importat han estat simulats com a xocs exògens, els quals originen dos experiments sota un enfocament estàtic: un que té en compte l'efecte de l'obligatorietat de mescla de forma aïllada i un altre on es combina amb les mesures antidúmping. S'ha emprat la versió GTAP-BIO del model estàndard, que representa l'economia mundial el 2004. Aquesta última versió desagrega el biodièsel en biodièsel de soia, colza, palma i biodièsel fabricat a partir d'altres matèries primeres. El mòdul d'usos de la terra permet modelitzar la competència entre cultius tradicionals i energètics en diferents zones agroecològiques (ZAE), sobre la base d'observacions històriques corresponents al període 2004-2010, quan va tenir lloc l'expansió més acusada dels cultius energètics arreu del món. A la conversió de cada ZAE s'assigna un factor d'emissió de $\mathrm{CO}_{2}$, segons estimacions del California Air Resources Board.

Els resultats mostren que les importacions de biodièsel augmenten a la UE malgrat les mesures antidúmping, a causa de l'enorme expansió de la demanda interna, sobretot de biodièsel de palma. Els productors europeus de biodièsel surten beneficiats igualment, especialment aquells que produeixen biodièsel de colza i també de palma (gràcies a les importacions d'oli). Com a conseqüència del xoc en la demanda de biodièsel a la UE (en combinació amb els drets antidúmping), es generarien al voltant de $35,8 \mathrm{~g}$ de $\mathrm{CO}_{2} / \mathrm{MJ}$, un $35 \%$ menys que el valor per defecte 
de la nova proposta de la $\mathrm{CE}$ ( $55 \mathrm{~g}$ de $\mathrm{CO}_{2} / \mathrm{MJ}$ ). Això demostra que el fet de limitar la quota de mercat dels BPG pot ser una forma efectiva de reduir les emissions indirectes de GEH atribuïdes al biodièsel consumit a la UE, encara que I'ILUC continua sent un motiu de preocupació. S'espera que el LUC ocórrega a escala global, en països no necessàriament involucrats en el comerç del biodièsel amb la UE, ja que sorgeix de les interaccions amb els mercats d'aliments i pinsos. La terra en producció agrícola s'expandiria un total de 3,32 Mha, principalment en regions com l'Àfrica subsahariana, el Brasil i la resta de l'Amèrica del Sud, o els Estats Units, mentre que només el 7,5\% tindria lloc a la UE. Encara que l'estimació de I'ILUC està subjecta a gran incertesa, la qual cosa complica la seva incorporació en polítiques públiques, aquests resultats han de servir per reforçar el compromís de la CE per quantificar-lo i controlar-lo. De fet, la incertesa és inherent a qualsevol intent de modelitzar el món real, si bé és cert que els impactes originats pel LUC dels biocombustibles no són nuls. Per tant, es recomana utilitzar factors d'emissió de l'ILUC per avaluar el compliment dels criteris de sostenibilitat de la RED una vegada s'haja definit un nivell acceptable d'incertesa. Malgrat la dificultat de predir els efectes indirectes a causa del seu abast mundial, l'anàlisi de les interaccions en els mercats internacionals és indispensable. Els models d'EGC com el GTAP constitueixen una valuosa eina per als responsables polítics, encara que la regulació de l'ILUC represente un desafiament en l'àrea de la bioenergia.

La necessitat de considerar els efectes del LUC en la definició de futures polítiques en matèria de biocombustibles no és passatgera. Les projeccions apunten a una dependència substancial d'aquells biocarburants que causen xicotets canvis en les reserves de carboni dels ecosistemes per complir els objectius climàtics. És previsible que la metodologia d'ACV seguisca exercint un paper fonamental en l'estimació de les emissions del LUC directe, en compliment dels criteris de sostenibilitat de la RED. Tanmateix, les estimacions difereixen notablement segons la matèria primera, la regió geogràfica i els supòsits metodològics, la qual cosa condiciona els beneficis dels GEH atribuïts als biocombustibles. D'altra banda, es considera que l'ILUC pot ser encara més important que el LUC directe i la mateixa proposta de la CE sobre ILUC suggereix l'aplicació de diferents metodologies amb la finalitat d'interpretar la incertesa associada. La present tesi està motivada doncs per les recents demandes en l'àmbit normatiu dels biocombustibles. Les metodologies aplicades tenen com a objectiu proporcionar nova informació sobre els impactes ambientals del biodièsel en el context espanyol, la qual cosa posa de manifest la necessitat de definir un nivell acceptable d'incertesa per als factors d'emissió de $\mathrm{CO}_{2}$. S'han incorporat conceptes econòmics per a una anàlisi més completa de les conseqüències ambientals de diferents decisions polítiques que afecten el mercat del biodièsel. El perfeccionament dels models econòmics que serveixen per pronosticar l'ILUC es presenta com una oportunitat per proporcionar estimacions més robustes. L'ús d'una metodologia o una altra depèn de l'objectiu i 
l'abast d'estudi; l'ideal és aplicar-les de forma complementària per a una millor comprensió del fenomen global de la bioenergia, i contribuir així a una major solidesa en els resultats dels GEH. Reduir la incertesa en les estimacions de I'ILUC i el LUC directe és fonamental per assegurar l'aplicabilitat de les polítiques de biocombustibles en el futur. 


\section{Acknowledgements}

First of all, I would like to acknowledge the Generalitat Valenciana for the four-year research contract ACIF/2010/200, and for the financial support under the project Prometeoll/2014/005; also, for providing the funds for a research stay (BEFPI2013) at the Department of Agricultural Economics of Purdue University (Indiana, United States).

I would also like to thank Ainia for entrusting us with the environmental evaluation of the Integral-b project, and all the partners for cooperating closely during the first stages of the dissertation, especially to Alfredo Rodrigo, who has been very keen on providing data.

Special thanks to all the outstanding people I have met over these years: to Prof. Tyner for offering me the opportunity to spend 6 months at Purdue, opening the doors of the GTAP team, and for his valuable comments; to Prof. Hertel for the GTAP course; to Badri for being so patient and offering me his help when it was most needed; to Stelios Rozakis for inviting me to the Agricultural University of Athens, for introducing me to that exciting world of the farm mathematical programming models, and for his kind advice in the field of bioenergy; to Casiano for his tremendous help in learning GAMS, for all the skype (summer) lessons and for his continued interest. All of them made this thesis possible. Finally, thanks to all the nice people I met in both the United States and Greece, and at the conferences as well.

Of course, many thanks to Neus and Gabi, my supervisors, for all their continuous effort and support, especially during the last few months, which have been really intense. Thanks to Antonio Mulet for the warm welcome to his research group. They paved the way for any initiative related to the dissertation and I am very much obliged to them all. Also thanks to Javier Ribal for his financial point of view and brilliant ideas. I wish you many other LCA theses to come after this!

I would also like to mention all the sunflower and rapeseed farmers who provided primary data for the agro-industrial model, despite the fact that it has not been finally included as such, namely: Marcel.lí Gangonells, Gemma Codina de Grans de Lluçanès, Ángel Rico de Gea\&gea, Mateu Casadevall de Servicentre Guitart, Joan Serra de l'IRTA de Girona, etc. I am also grateful to the following biodiesel producers, who offered their help despite the difficulties the sector is going through: David Vidal from Bioteruel, Miguel A. Grau from Saras Energía, and Javier Areños from Acor.

And, last but not least, the most special thanks to my family, for their unconditional support throughout my life, and to my friends and colleagues at the Department, those who are still there and those who have already left. 



\section{Preface}

The present thesis has been carried out at the Research Group for the Analysis and Simulation of Food Processes (ASPA), which belongs to the Food Technology Department of the Universitat Politècnica de València (Spain). It falls within the PhD programme on Food Science Technology \& Management, although it arises from the parallel research line on Life Cycle Assessment of food processes and products. Specifically, the thesis was motivated by the Integral-b project, funded by the European LIFE programme and coordinated by the Ainia Technology Centre, when the ASPA Group was given the task of estimating the environmental impacts of the waste treatment process proposed under a life cycle perspective. This led to a first study which paved the way for further research on biodiesel systems and their environmental implications.

The thesis aims to provide quantitative results on the environmental consequences of the introduction of biodiesel into the transport sector, by means of different methodologies and given the current legal framework. The most recent European policies on biofuels attempt to address impacts such as climate change by promoting the use of biofuels that deliver substantial $\mathrm{CO}_{2}$ savings. Despite an agreement that overall emissions from biofuel consumption must be addressed under a life cycle perspective, there is no consensus on the methodology to apply for estimating the emissions derived from land use change effects, mainly indirect ones. This phenomenon is associated to the production of biofuel feedstock that can also be used for food purposes, arising from interactions in the global market. This is expected to increase the greenhouse gas (GHG) emissions from bioenergy due to worldwide land cover changes. Hence, the present thesis seeks to contribute to a better understanding of the existing tools in order to analyze the environmental and economic performance of biofuel systems, while providing additional insights into both the estimation of GHG emission factors and their subsequent uncertainty, as required by the new proposal on biofuels from the European Commission. Most of the studies focus on the biodiesel sector in Spain, with clear indications of inefficiency.

The thesis is essentially based on the following papers, which have either been published or accepted or are under review in international peer-reviewed journals.

In section 3.1:

- Escobar, N., Ribal, F.J., Rodrigo, A., Clemente, G., Pascual, A., \& Sanjuán, N. (2015). Uncertainty analysis in the environmental assessment of an integrated management system for restaurant and catering waste in Spain. International Journal of Life Cycle Assessment, 20(2): 244-262. 


\section{Preface}

In section 3.2:

- Escobar, N., Ribal, F.J., Clemente, G., Rodrigo, A., Pascual, A., \& Sanjuán, N. (2015). Uncertainty analysis in the financial assessment of an integrated management system for restaurant and catering waste in Spain. Submitted to the International Journal of Life Cycle Assessment.

In section 3.3:

- Escobar, N., Ribal, J., Clemente, G., \& Sanjuán, N. (2014). Consequential LCA of two alternative systems for biodiesel consumption in Spain, considering uncertainty. Journal of Cleaner Production, 79: 61-73.

In section 3.4:

- Escobar, N., Manrique, C., Rozakis, S., Clemente, G., \& Sanjuán, N. (2015). Optimization of the biodiesel supply chain in Spain to meet the European GHG reduction targets. Submitted to Biomass and Bioenergy.

In section 3.5:

- Escobar, N., Narayanan, B., Sanjuán, N., Clemente, G., \& Tyner, W.E. (2015). Global land use change and GHG emissions due to recent European biofuel policies. Submitted to Land Use Policy.

In addition, during the dissertation period, the following oral communications and posters have been presented at conferences and are also part of this doctoral thesis:

- Escobar, N., Clemente, G., Rodrigo, A., Cárcel, J., \& Sanjuán, N. Consecuencias medioambientales del aumento de la demanda de biodiesel en España: biodiesel de aceite usado vs. aceite de soja. VI Congreso Nacional de Ciencia y Tecnología de Alimentos (Cyta), $8^{\text {th }}-10^{\text {th }}$ June 2011, Valencia (Spain).

- Escobar, N., Ribal, J., Rodrigo, A., Pascual, A., \& Sanjuán, N. Carbon footprint of an integrated management system for restaurants and catering waste considering uncertainty. The $5^{\text {th }}$ Conference on Life Cycle Assessment in Latin America (CILCA), 24 $-27^{\text {th }}$ March 2013, Mendoza (Argentina).

- Escobar, N., Fenollosa, M.L., Rodrigo, A., \& Sanjuán, N. Carbon footprint and primary energy demand of two alternative biodiesel B10 systems in Spain. The $5^{\text {th }}$ Conference on Life Cycle Assessment in Latin America (CILCA), $24^{\text {th }}-27^{\text {th }}$ March 2013, Mendoza (Argentina). 
- Ribal, R., Sanjuán, N., Escobar, N., \& Melero, A. Design of a model for estimating environmental impacts by means of FADN data. The $5^{\text {th }}$ Conference on Life Cycle Assessment in Latin America (CILCA), $24^{\text {th }}-27^{\text {th }}$ March 2013, Mendoza (Argentina).

- Clemente, G., Pérez-Sánchez, M., Ribal, J., Sanjuán, N, \& Escobar N. Influence of agro-food waste on sustainable food consumption. The $6^{\text {th }}$ International Conference on Life Cycle Management in Gothenburg (LCM), $25^{\text {th }}-28^{\text {th }}$ August 2013, Gothenburg (Sweden).

- Escobar, N., Narayanan, B., \& Tyner, W.E. Global land use change and greenhouse gas emissions due to recent European biofuel policies. The $17^{\text {th }}$ Annual Conference on Global Economic Analysis (GTAP conference), $18^{\text {th }}-20^{\text {th }}$ June 2014, Dakar (Senegal).

- Escobar, N., Ribal, J., Clemente, G., \& Sanjuán, N. Indirect Land Use Change and GHG emissions of two biodiesel pathways in Spain. XIV LCA Food Conference (LCA Foods), $6^{\text {th }}-8^{\text {th }}$ October 2014, San Francisco (US).

- Escobar, N., Manrique, C., Clemente, G., \& Rozakis, S. LCA of the biodiesel production in Spain driven by optimization criteria. The $2^{\text {nd }}$ Discussion Forum on Industrial Ecology, $5^{\text {th }}-6^{\text {th }}$ March 2015, Coimbra (Portugal).

- Escobar, N., Manrique, C., Sanjuán, N., \& Rozakis, S. Environmental and economic assessment of the optimized biodiesel production in Spain from domestic raw materials. Accepted for the $6^{\text {th }}$ Conference on Life Cycle Assessment in Latin America (CILCA), $13^{\text {th }}-16^{\text {th }}$ July 2015, Lima (Perú).

- Escobar, N., Cerveró, A., Boira, H., \& Sanjuán, N. LCA of Jatropha curcas L. production for biodiesel in the Southwestern Dominican Republic. Accepted for the $6^{\text {th }}$ Conference on Life Cycle Assessment in Latin America (CILCA), $13^{\text {th }}-16^{\text {th }}$ July 2015, Lima (Perú).

Finally, during the dissertation period, the opportunity to work in other fields, also related to the topic of the thesis, has led to the following paper, which has been accepted for publication in an international peer-reviewed journal:

- Ribal, F.J., Fenollosa, M.L., García-Segovia, P., Clemente, G., Escobar, N., \& Sanjuán, N. (2015). Designing healthy, climate friendly and affordable school lunches. Accepted for publication in the International Journal of Life Cycle Assessment. 


\section{Preface}

The doctoral thesis is also based on the methodology developed and the skills learned during the following courses and research stays:

- Introduction to LCA and Carbon Footprint. PE International \& Cyclus Vitae Solutions S.L. $1^{\text {st }}$ June 2011, Ainia Technology Centre, Valencia (Spain). Taught by: Gabriela Benveniste.

- Introduction to Gabi Software. PE International \& Cyclus Vitae Solutions S.L. $1^{\text {st }}$ June 2011, Ainia Technology Centre, Valencia (Spain). Taught by: Gabriela Benveniste.

- Advanced training in Gabi Software. PE International \& Cyclus Vitae Solutions S.L. $2^{\text {nd }}$ June 2011, Ainia Technology Centre, Valencia (Spain). Taught by: Gabriela Benveniste.

- $13^{\text {th }}$ Workshop on Economic Modeling. Computable General Equilibrium Analysis using GTAPinGAMS and New New Trade Theory. $11^{\text {th }}-15^{\text {th }}$ June 2013, Universidad de Las Palmas de Gran Canaria, Las Palmas de GC (Spain). Taught by: Prof. Christoph Boehringer, Edward J. Balistreri, and Casiano Manrique.

- Introduction to Applied General Equilibrium Analysis (618 Course). $19^{\text {th }}$ August-14 ${ }^{\text {th }}$ December 2013, Department of Agricultural Economics, Purdue University (Indiana, United States). Taught by: Prof. Thomas W. Hertel.

- Five-and-a-half-month stay at the Department of Agricultural Economics, Purdue University (Indiana, United States), from $1^{\text {st }}$ July-15 ${ }^{\text {th }}$ December 2013, under the supervision of Prof. Wallace E. Tyner.

- Agro-Economic Modelling with GAMS. $2^{\text {nd }}-6^{\text {th }}$ June 2014, Universidad Politécnica de Madrid, Madrid (Spain). Taught by: María Blanco-Fonseca.

- One-month-and-a-quarter stay at the Department of Agricultural Economics and Rural Development, Agricultural University of Athens (Greece), from $23^{\text {rd }}$ June- $30^{\text {th }}$ July 2014, under the supervision of Stelios Rozakis. 


\section{Figures}

Figure 1.1. Evolution in the world annual ethanol and biodiesel production.

Figure 1.2. Fossil fuel consumption in the motor sector of major biofuel- 5 producing countries and the world (kgoe: $\mathrm{kg}$ of oil equivalent; 1 $\mathrm{kgoe}=41,868 \mathrm{~kJ})$.

Figure 1.3. Evolution in ethanol production of leading countries and regions.

Figure 1.4. Development of world biodiesel production from 2000 to 2013.

8

Figure 1.5. Monthly biodiesel (B100) imports from Argentina, Indonesia and Malaysia into the EU, since January 2009.

Figure 1.6. Trends in consumption of fuels and biofuels in the European transport sector.

Figure 1.7. Biodiesel balance in major markets of the EU-27. Average data for the period 2008-2012.

Figure 1.8. Shares of feedstock underlying biodiesel consumption in the EU-27 in 2008 and 2010.

Figure 1.9. Projected shares of feedstock underlying biodiesel consumption in the EU in 2020.

Figure 1.10. Well-to-wheel approach in the LCA of fuel and motor systems, including the production and distribution (well-to-tank) and the subsequent combustion (tank-to-wheel).

Figure 2.1. Transdisciplinary methodological framework for the study of biodiesel systems under a life cycle perspective. The social dimension is not addressed in the dissertation and appears in gray.

Figure 2.2. Working plan and overview of the methods used in each section of the Results (chapter III).

Figure 2.3. Main steps for the application of the LCA methodology.

Figure 2.4. Underlying structure of a typical CGE model. Arrows show 58 monetary flows.

Figure 2.5. Production nest in the GTAP-BIO model. CES: constant elasticity of substitution function; $\sigma_{\mathrm{x}}$ : elasticities of substitution; $\Omega_{\mathrm{n}}$ : elasticities of land transformation.

Figure 3.1. System delimitation of the process studied in scenario A. Capital 83 goods are not outlined; the dashed line defines the system boundaries and energy flows. T: Transport. 


\section{Figures}

Figure 3.2. System delimitation of the process studied in scenario B. Capital goods are not outlined; the dashed line defines the system boundaries and energy flows. T: Transport.

Figure 3.3. Contribution of the constitutive processes of each scenario to the impact categories of acidification and eutrophication, according to the deterministic results of the impact per inhabitant and year.

Figure 3.4. Box and whiskers plots of the differential Monte Carlo simulations of Scenario B-Scenario A for the impact categories in which the sign of the difference is reversed in some scenario formulations.

Figure 3.5. Histograms of the differential Monte Carlo simulations of scenario $(a, b, c)$ B2-scenario A1 for the impact categories of eutrophication, GW and POC (inputs).

Figure 3.6. System delimitation of the process studied in scenario A. The flowchart does not outline capital goods. T: Transport.

Figure 3.7. System delimitation of the process studied in scenario B. The flowchart does not outline capital goods. T: Transport.

Figure 3.8. Probability distribution of the differential profits, after 10,000 $125-$ $(a, b, c, d)$ simulations, for the scenario formulations: a) B1-A1, b) B2-A2, c) $B 1^{\prime}-A 1$ ', and d) B2'-A2'

Figure 3.9. Tornado diagrams for the differential profits in the scenario (a, b, c, d) formulations: a) B1-A1, b) B2-A2, c) B1'-A1', and d) B2'-A2'. DTD: $127-$ door-to-door; MC: multi-container.

Figure 3.10. Graphical display of the trade-offs between the LCC and LCA $(a, b, c)$ results for the impact categories: a) global warming $\left(\mathrm{kg} \mathrm{CO}_{2}\right.$ eq./FU), b) abiotic depletion (kg Sb-eq./FU), and c) acidification (kg $\mathrm{SO}_{2}$-eq./FU)

Figure 3.11. System delimitation of scenario 1. A loop between palm oil and soybean meal is generated by the import of 1 additional $\mathrm{MJ}$ of soybean ME from Argentina into Spain. SP: Spain; ARG: Argentina; BR: Brazil; MY: Malaysia.

Figure 3.12. System delimitation of scenario 2. A loop between palm oil and soybean meal is generated by the production of 1 additional $\mathrm{MJ}$ of ME from UCO in Spain. SP: Spain; BR: Brazil; MY: Malaysia.

Figure 3.13. Contribution of sub-stages to $\mathrm{GW}$ in scenario 1 and scenario 2. 155 $(a, b)$ Total GHG emissions are broken down into $\mathrm{GW}$ input $\left(\mathrm{CO}_{2}\right.$-eq. uptake) and $\mathrm{GW}$ output ( $\mathrm{CO}_{2}$-eq. emissions).

Figure 3.14. Box-and-whisker plots of the outcomes from the Monte Carlo 158 simulation of scenario 1 and scenario 2. Only the impact categories for which results presented the greatest variability are shown. 
Figure 3.15. Calibration results from the agricultural module optimization through 178 the subsequent iterations. Iteration 0 (it0) refers to the observed situation, while Iteration 10 (it10) constitutes the baseline situation for the analysis.

Figure 3.16. Oil mix for domestic biodiesel production under the different policy 187 scenarios defined. Palmo.my_in: palm oil from Southeast Asia; rapo.sp: rapeseed oil from Spain; soyo.ar: soybean oil from Argentina; soyo.br: soybean oil from Brazil; sunfo.sp: sunflower oil from Spain; uco.fr: UCO from France; uco.sp: UCO from Spain; uco.us: UCO from the US.

Figure 3.17. Overall welfare of the biodiesel supply chain in Spain (million EUR), calculated as the sum of the stakeholder's individual surpluses (raw materials production, oilseeds crushing and oil transesterification).

Figure 3.18. Overall LCA outcomes for the analyzed impact categories (a, b, c, d) according to the CML 2001 (baseline) method. Palmo.my_in: palm oil from Southeast Asia; rapo.sp: rapeseed oil from Spain; soyo.ar: soybean oil from Argentina; soyo.br: soybean oil from Brazil; sunfo.sp: sunflower oil from Spain; uco.fr: UCO from France; uco.sp: UCO from Spain; uco.us: UCO from the US.

Figure 3.19. Changes in cropland extension (thousand hectares) in the Spanish 195 provinces considered, as a consequence of the increased demand for biodiesel by 2020 in combination with the 60\% GHG saving requirement. Andal: Andalucía; Cast_leon: Castilla y León; Cast_mancha: Castilla-La Mancha; Cat: Catalunya; Extr: Extremadura; Na: Navarra; Arag: Aragón.

Figure 3.20. Changes in cropland extension (million hectares) in the Spanish regions considered, as a consequence of the increased demand for biodiesel by 2020 in combination with the $60 \%$ GHG saving requirement.

Figure 3.21. Emission factors for those biodiesel pathways based on domestic oilseeds in scenario 4.1, with and without including the ILUC. Sunfo.sp: sunflower-based biodiesel; rapo.sp: rapeseed-based biodiesel; ref. fuel: reference fossil fuel.

Figure 3.22. Net imports of the main biodiesel feedstocks into the EU, compared 208 to increasing production and consumption of the final product. Other uses than biodiesel are, however, considered in the case of seeds (rapeseed and soybeans).

Figure 3.23. Underlying production structure in the GTAP-BIO model used. The 213 biodiesel composite is disaggregated between biod_soy, biod_rape, biod_palm and biod_oth (from other feedstock than soy, rape or palm), whereas the ethanol composite is disaggregated between eth1, eth2 and eth3 (from corn, sugarcane and corn stover, 


\section{Figures}

respectively). $\sigma_{\mathrm{x}}$ : elasticities of substitution; $E T L_{x}$ : elasticities of land transformation.

Figure 3.24. Composition of the biodiesel mix underlying private consumption in the EU before and after the experiments. Both exp 1 and $\exp 2$ depict identical shocks in biodiesel consumption between 2004 and 2020, under a static approach.

Figure 3.25 Changes in cropland extension (Mha), by region, due to the shock on biodiesel consumption in the EU with the additional anti-dumping duties (exp 2).

Figure 3.26. GHG emissions from LUC in all the regions, expressed in $\mathrm{Mg}$ of $\mathrm{CO}_{2}$ per ha of cropland expansion in exp 2.

Figure 4.1. GHG emission factors for those scenarios consisting of biodiesel 238 pathways based on UCO, with and without considering doublecounting. Ref. fuel: reference fossil fuel; marg. fuel: marginal fossil fuel.

Figure 4.2. GHG emission factors for those scenarios consisting of FGB 240 pathways. Ref. fuel: reference fossil fuel; marg. fuel: marginal fossil fuel.

Figure 4.3. Emission factors for acidification ( $\mathrm{g} \mathrm{SO}_{2}$-eq./MJ).

Figure 4.4. Emission factors for eutrophication ( $\mathrm{g} \mathrm{PO}_{4}{ }^{3-}$-eq./MJ).

Figure 4.5. Emission factors for freshwater aquatic ecotoxicity (g DCB-eq./MJ).

Figure 4.6. Market-mediated mechanisms driving total cropland increase as a 249 consequence of increased demand for biofuels. Source: Laborde (2011).

Figure A1. Histogram showing the parameters with the highest contribution (in 308 absolute value) to the overall input of abiotic depletion in the differential assessment of scenario B1-scenario A1.

Figure A2. Histogram showing the parameters with the highest contribution (in 308 absolute value) to the overall output of abiotic depletion in the differential assessment of scenario B1-scenario A1.

Figure A3. Histogram showing the parameters with the highest contribution (in 309 absolute value) to the overall input of acidification in the differential assessment of scenario B1-scenario A1.

Figure A4. Histogram showing the parameters with the highest contribution (in 309 absolute value) to the overall output of acidification in the differential assessment of scenario B1-scenario A1.

Figure A5. Histogram showing the parameters with the highest contribution (in absolute value) to the overall input of eutrophication in the 
differential assessment of scenario B1-scenario A1.

Figure A6. Histogram showing the parameters with the highest contribution (in absolute value) to the overall output of eutrophication in the differential assessment of scenario B1-scenario A1.

Figure A7. Histogram showing the parameters with the highest contribution (in 311 absolute value) to the overall input of global warming in the differential assessment of scenario B1-scenario A1.

Figure A8. Histogram showing the parameters with the highest contribution (in 311 absolute value) to the overall output of global warming in the differential assessment of scenario B1-scenario A1.

Figure A9. Histogram showing the parameters with the highest contribution (in absolute value) to the overall input of human toxicity in the differential assessment of scenario B1-scenario A1.

Figure A10. Histogram showing the parameters with the highest contribution (in absolute value) to the overall output of human toxicity in the differential assessment of scenario B1-scenario A1.

Figure A11. Histogram showing the parameters with the highest contribution (in absolute value) to the overall input of photochemical ozone creation in the differential assessment of scenario B1-scenario A1.

Figure A12. Histogram showing the parameters with the highest contribution (in absolute value) to the overall output of photochemical ozone creation in the differential assessment of scenario B1-scenario A1.

Figure A13. Contribution of the constitutive processes of each scenario to 316 abiotic depletion, according to the deterministic results of the impact per inhabitant and year.

Figure A14. Contribution of the constitutive processes of each scenario to global warming, according to the deterministic results of the impact per inhabitant and year.

Figure A15. Contribution of the constitutive processes of each scenario to human toxicity, according to the deterministic results of the impact per inhabitant and year.

Figure A16. Contribution of the constitutive processes of each scenario to photochemical ozone creation, according to the deterministic results of the impact per inhabitant and year.

Figure A17. Box-and-whiskers plots from the differential Monte Carlo simulations of scenario B-scenario A for the impact category abiotic depletion, as input and output. 


\section{Figures}

Figure A18. Box-and-whiskers plots from the differential Monte Carlo 320simulations of scenario B-scenario A for the impact category 321 acidification, as input and output.

Figure A19. Box-and-whiskers plots from the differential Monte Carlo 321 simulations of scenario B-scenario A for the impact category eutrophication (output).

Figure A20. Box-and-whiskers plots from the differential Monte Carlo simulations of scenario B-scenario A for the impact category global warming (output).

Figure A21. Box-and-whiskers plots from the differential Monte Carlo simulations of scenario B-scenario A for the impact category human toxicity (output).

Figure A22. Box-and-whiskers plots from the differential Monte Carlo simulations of scenario B-scenario A for the impact category photochemical ozone creation (output).

Figure A23. Histograms from the differential Monte Carlo simulation of scenario B1'-A1' for eutrophication (input).

Figure A24. Histograms from the differential Monte Carlo simulation of scenario B1-A1 for global warming (input).

Figure A25. Histograms from the differential Monte Carlo simulation of scenario B1-A2 for human toxicity (input).

Figure A26. Histograms from the differential Monte Carlo simulation of scenario B1'-A1' for human toxicity (input).

Figure A27. Histograms from the differential Monte Carlo simulation of scenario B1'-A1' for photochemical ozone creation (input).

Figure A28. Histograms from the differential Monte Carlo simulation of scenario B2'-A1' for photochemical ozone creation (input).

Figure B1. Calibration results from the agricultural module optimization through the subsequent iterations in provinces e01-e16. Iteration 0 (it0) refers to the observed situation.

Figure B2. Calibration results from the agricultural module optimization through the subsequent iterations in provinces e17-e32. Iteration 0 (it0) refers to the observed situation. 


\section{Tables}

Table 2.1. Example of scenario analysis in LCA.

Table 3.1. Alternative scenario formulations proposed to analyze uncertainty due to choices. The scenario B-scenario A difference was studied.

Table 3.2. LCIA results of the scenario B-scenario A difference for the different scenario formulations considered. The combinations of scenarios and impact categories in which the sign of the difference is reversed (scenario A>scenario B) appear in gray.

Table 3.3. Scenario formulations defined to capture the variability in electricity 115 rate systems and the Functional Unit in the financial assessment.

Table 3.4. Summary of probability distributions of costs, input and output prices.

Table 3.5. LCC results for the base scenarios (€/FU) taking into account the two Functional Units and the change in the electricity rate.

Table 3.6. Descriptive statistics for the distribution of the expected profits in each scenario.

Table 3.7. Elasticity profits-environmental impacts.

Table 3.8. Base values and uncertainty distributions of key parameters for the $148-$ Monte Carlo analysis of scenario 1, after sensitivity analysis. SP: Spain; ARG: Argentina; BR: Brazil; MY: Malaysia.

Table 3.9. Base values and uncertainty distributions of key parameters for the $149-$ Monte Carlo analysis of scenario 2, after sensitivity analysis. SP: Spain; BR: Brazil; MY: Malaysia.

Table 3.10. Impact assessment results from the base scenario 1, broken down by sub-stages. $\mathrm{CO}_{2}$-eq. emissions from LUC are not taken into account in GW.

Table 3.11. Impact assessment results from the base scenario 2, broken down by sub-stages. $\mathrm{CO}_{2}$-eq. emissions from LUC are not taken into account in GW.

Table 3.12. LUC results from the base scenario 1, including direct LUC and ILUC due to co-product displacements.

Table 3.13. LUC results from the base scenario 2, including direct LUC and ILUC due to co-product displacements.

Table 3.14. Provinces considered in the model, corresponding to major oilseedproducing regions in Spain. 


\section{Tables}

Table 3.15. Crops included in the model of the Spanish agricultural sector, and 175 their abbreviations in GAMS. B: for bioenergy uses, F: for food uses.

Table 3.16. Energy content of each co-product considered for the calculation of allocation factors in the emissions module. Note that, for the meal co-products, metabolizable energy content is calculated by taking into account a value of $8.40 \mathrm{MJ}$ per $\mathrm{kg}$ of protein (Balmer, 2011).

Table 3.17. Formulations of scenarios 2, 3 and 4 depending on the ecosystem 184 that is transformed in each region to produce $1 \mathrm{t}$ of vegetable oil for export, and the subsequent annualized $\mathrm{CO}_{2}$ emissions. Soyo: soybean oil; palmo: palm oil; chaco: Chaco forest; yungas: Yungas forest; tropic: Brazilian tropical forest; cerra: Cerrado savannah; peat: peatland; rainfo: tropical rainforest in Southeast Asia; crop: arable cropland; grass: degraded grassland.

Table 3.18. GHG emission factors ( $\mathrm{g} \mathrm{CO}_{2}$-eq./MJ) and saving coefficients (\%) of each feedstock in the optimal oil mix for each scenario formulation in which ecosystems make the difference. The emission factor of the reference fuel is $90.3 \mathrm{~g} \mathrm{CO}_{2} / \mathrm{MJ}$, gathered from Laborde (2011).

Table 3.19. Shock statements to perform each experiment. qp(i,r) refers to consumer demand for good $i$ in region $s ; \operatorname{tms}(i, r, s)$ is the power of the import tariff on imports of $i$ from region $r$ into regions $s$.

Table 3.20.

Import share of biodiesel commodities throughout the biodiesel supply chain in the EU.

Table 3.21. Changes in production, harvested area and yield, by crop, in the EU.

Table 3.22. Changes in production, harvested area and yield, by crop, in 223 S_Amer.

Table 3.23. Changes in production, harvested area and yield, by crop, in the US. 223

Table 3.24. Changes in production, harvested area and yield, by crop, in 223 Mala_Indo.

Table 4.1. UCO biodiesel pathways evaluated in the dissertation under different approaches, with and without double-counting.

234-

235

Table 4.2. First-generation biodiesel pathways evaluated in the dissertation 235under different approaches. Ar: Argentina; Br: Brazil; My_in: 237 Malaysia and Indonesia.

Table 4.3. Pros and cons of the methodologies used in the dissertation for the 248 estimation of the environmental impacts of biofuel systems.

Table A1. $\quad \mathrm{LCl}$ of the processes included in the scenarios under study, referred 303to the FU. 
Table A2. Different cut-off criteria for the identification of the risk parameters in 315 each impact category, and the number that should be selected in each case.

Table A3. Summary of mean and uncertainty distributions of risk parameters in 318all the scenario formulations considered. Key parameters selected by sensitivity analysis appear in gray.

Table C1. Regions, industries and commodities included in the GTAP-BIO version employed to analyze biofuel policies in depth.

Table C2. Main market responses as a consequence of a blending mandate in line with the new COM 595 (exp 1), as combined with import tariffs on biodiesel imports from Mala_Indo, S_Amer and the US (exp 2). Outcomes from the linearized equations in the model represent percentage changes of the variables, relative to the baseline. 



\section{List of acronyms, abbreviations and equivalences}

\begin{tabular}{|c|c|}
\hline$A D$ & Anaerobic digestion \\
\hline ADP & Abiotic depletion \\
\hline AEZ & Agroecological zone \\
\hline APPA & Spanish Association of Renewable Energy Producers \\
\hline Biod_oth & Biodiesel from other oils than palm, rapeseed or soybean oils \\
\hline Biod_palm & Palm biodiesel \\
\hline Biod_rape & Rapeseed biodiesel \\
\hline Biod_soy & Soybean biodiesel \\
\hline CAP & Common Agricultural Policy \\
\hline CAPRI & Common Agricultural Policy Regional Impact \\
\hline CARB & California Air Resources Board \\
\hline CES & Constant elasticity of substitution \\
\hline CET & Constant elasticity of transformation \\
\hline CFC & Chlorofluorocarbon \\
\hline CGE & Computable General Equilibrium \\
\hline $\mathrm{CH}_{4}$ & Methane \\
\hline $\mathrm{CHP}$ & Combined heat and power \\
\hline CIEMAT & Centre for Energy, Environment and Technology Research \\
\hline $\mathrm{CIF}$ & Cost, insurance and freight \\
\hline CNE & Spanish National Energy Commission \\
\hline CNMC & Spanish National Commission of Markets and Competition \\
\hline $\mathrm{CO}_{2}$ & Carbon dioxide \\
\hline CPO & Crude palm oil \\
\hline $\mathrm{CV}$ & Coefficient of variation \\
\hline DCB & Dichlorobenzene \\
\hline DDGS & Dried distillers grains with solubles \\
\hline DTD & Door-to-door \\
\hline EC & European Commission \\
\hline EPA & Environmental Protection Agency \\
\hline
\end{tabular}




\begin{tabular}{|c|c|}
\hline EPS & Environmental Priority Strategies \\
\hline ESIM & European Simulation Model \\
\hline ETA & $\begin{array}{l}\text { Ratio of marginal and average productivities, productivity of new cropland } \\
\text { versus the productivity of existing cropland }\end{array}$ \\
\hline ETL & Land transformation elasticities \\
\hline EU & European Union \\
\hline EU-27 & $\begin{array}{l}\text { European Union with } 27 \text { Member States, from } 1^{\text {st }} \text { January } 2007 \text { to } 30^{\text {th }} \text { June } \\
\text { 2013, including Austria, Belgium, Bulgaria, Cyprus, Czech Republic, } \\
\text { Denmark, Estonia, Finland, France, Germany, Greece, Hungary, Ireland, } \\
\text { Italy, Latvia, Lithuania, Luxembourg, Malta, Netherlands, Poland, Portugal, } \\
\text { Romania, Slovakia, Slovenia, Spain, Sweden, United Kingdom }\end{array}$ \\
\hline $\mathrm{EU}-28$ & $\begin{array}{l}\text { European Union with } 28 \text { Member States, from } 1^{\text {st }} \text { July } 2013 \text { to present, } \\
\text { including EU-27 + Croatia }\end{array}$ \\
\hline EVA & Economic value added \\
\hline FADN & Farm Accountancy Data Network \\
\hline FAE & Freshwater aquatic ecotoxicity \\
\hline FAME & Fatty acid methyl ester \\
\hline FAO & Food and Agricultural Organization \\
\hline FAPRI & Food and Agricultural Policy Research Institute \\
\hline FASOM & Forest and Agricultural Sector Optimization Model \\
\hline FGB & First-generation biofuel \\
\hline FQD & Fuel Quality Directive \\
\hline $\mathrm{FU}$ & Functional Unit \\
\hline GAMS & General Algebraic Modeling System \\
\hline GDP & Gross domestic product \\
\hline GHG & Greenhouse gas \\
\hline GTAP & Global Trade Analysis Project \\
\hline GW & Global warming \\
\hline HDPE & High-density polyethylene \\
\hline $\mathrm{HH}$ & Households \\
\hline HT & Human toxicity \\
\hline IDAE & Spanish Institute for Energy Diversification and Saving \\
\hline
\end{tabular}




\begin{tabular}{|c|c|}
\hline IEA & International Energy Agency \\
\hline IFPRI & International Food Policy Research Institute \\
\hline IISD & International Institute for Sustainable Development \\
\hline ILUC & Indirect land use change \\
\hline IMPACT & $\begin{array}{l}\text { International Model for Policy Analysis of Agricultural Commodities and } \\
\text { Trade }\end{array}$ \\
\hline INE & Spanish Institute of Statistics \\
\hline IPCC & Intergovernmental Panel on Climate Change \\
\hline JRC & Joint Research Centre \\
\hline LCA & Life Cycle Assessment \\
\hline LCC & Life Cycle Costing \\
\hline $\mathrm{LCl}$ & Life Cycle Inventory \\
\hline LCIA & Life Cycle Impact Assessment \\
\hline LCSA & Life Cycle Sustainability Assessment \\
\hline LCFS & Low-Carbon Fuel Standard \\
\hline LHV & Lower Heating Value \\
\hline LUC & Land use change \\
\hline MAE & Marine aquatic ecotoxicity \\
\hline MAGRAMA & Spanish Ministry of Agriculture, Food and Environment \\
\hline ME & Methyl ester \\
\hline MPOB & Malaysian Palm Oil Board \\
\hline MTBE & Methyl tert-Butyl Ether \\
\hline MS & Member State \\
\hline MSW & Municipal solid waste \\
\hline MTBE & Methyl Tert-Butyl Ether \\
\hline $\mathrm{N}_{2} \mathrm{O}$ & Nitrous oxide \\
\hline $\mathrm{NH}_{3}$ & Ammonia \\
\hline NMVOC & Non-methane volatile organic compounds \\
\hline NO & Nitric oxide or Nitrogen monoxide \\
\hline $\mathrm{NO}_{2}$ & Nitrogen dioxide or Nitrogen (IV) oxide \\
\hline OD & Ozone layer depletion \\
\hline
\end{tabular}


OPEC Organization of the Petroleum Exporting Countries

PE Partial Equilibrium

PER Spanish Plan on the Promotion of Renewable Energies

POC Photochemical ozone creation

RED Renewable Energy Directive

RFS Renewable Fuel Standard

RIN Renewable Identification Number

SAM Social Accounting Matrix

$\mathrm{Sb} \quad$ Antimony (element)

SEA Southeast Asia

SLCA Social Life Cycle Assessment

$\mathrm{SO}_{2} \quad$ Sulfur dioxide

Sow Solid organic waste

TE Terrestrial ecotoxicity

UCO Used cooking oil

US United States

USDA-FAS United States Department of Agriculture-Foreign Agricultural Service

UK United Kingdom

VEETC Volumetric ethanol excise tax credit

VOC Volatile organic compound

Vol_oth Other oils than palm, rapeseed or soybean oils

Vol_palm Palm oil

Vol_rape Rapeseed oil

Vol_soy_Soybean oil

WFD Waste Framework Directive

WTO World Trade Organization 



\subsection{The biofuel sector}

During the last few decades, the biofuel sector has gradually consolidated itself both in the EU and in the rest of the world. Both production and consumption have been growing steadily, more intensely since 2000 , as a result of public policies for the promotion of renewable energies. By definition, biofuels are those hydrocarbons derived from a biological process, at least $80 \%$ of which are renewable materials from organic matter. Although this implies being produced from any living organisms or metabolic by-products, they are usually obtained from plants; the organic matter is generated by photosynthesis, thus solar energy is used as the renewable energy source. Ethanol and biodiesel are the most commonly-used transportation biofuels, although methanol received as much consideration as ethanol at the dawn of the sector (Solomon et al., 2007). Ethanol fuel is, as the name already indicates, ethanol or ethyl alcohol obtained by means of biological fermentation, and subsequent distillation, of starch or sugar-rich biomass such as corn, sugar cane or sugar beets. Biodiesel is fatty acid methyl ester (FAME), obtained from the transesterification of fats with methanol (or other alcohols). These fats typically come from vegetable oils, such as soybean, rapeseed, or palm oil. While ethanol can be used as a substitute for gasoline in conventional engines at certain blending ratios, biodiesel can be used to replace diesel. Dehydrated (anhydrous) ethanol is required for blending with gasoline. Two common blends of ethanol with gasoline are called E5 and E10, which means that they contain $5 \%$ and $10 \%$ of ethanol by volume, respectively, and no engine adaptations are needed to use these blends. Ethanol can be blended in higher proportions, up to $85 \%$ (E85), in flexible-fuel vehicles, which are those especially designed to run on more than one fuel, usually gasoline blended with either ethanol or methanol fuel. Similarly, biodiesel is currently most often used in 5\%-20\% blends (called B5 and B20, respectively), or even in pure B100 form, requiring further engine modifications. Ethanol is also increasingly used as an octane-boosting, pollution-reducing additive in unleaded gasoline, thereby substituting chemical additives, such as Methyl Tert-Butyl Ether (MTBE).

\subsubsection{Leading biofuel countries}

Driven by policy mandates and worldwide renewable energy goals, the rapid expansion of the global biofuel supply is projected to continue up to 2020 (OECDFAO, 2011), and most likely from then onwards. However, governments have been promoting biofuels for many, many years. The interest initially came about in the late 1970 s as OPEC reduced crude oil supply on the world market and fuel prices increased substantially (Birur et al., 2009). As can be seen in Figure 1.1, ethanol production took off right after the 1973 oil crisis, when the first programs were 
launched in the United States (US) and Brazil. Both countries have remained the world's largest suppliers in the ethanol market since then, as Figure 1.3 confirms. Biodiesel production took off well after the development of the ethanol sector, at the same time as diesel fuel was becoming widespread.

Figure 1.2 shows how the importance of diesel has been increasing relative to gasoline not only in major biofuel-producing countries, but also in the entire world, especially since 2000 . It can be seen, however, that gasoline is by far the preferred fuel in the motor sector of the US and Canada. This figure also highlights the high consumption levels of fuel per capita in Spain, where diesel has prevailed over gasoline since 1988, according to the World Bank (2014) statistics. World production of ethanol from sugar cane, maize and sugar beet increased from less than 20 billion liters in 2000 to over 40 billion liters in 2005, representing around $3 \%$ of global gasoline use (United Nations, 2006). World biodiesel production greatly expanded from barely 0.5 billion liters to almost 4 billion liters, representing an increase of more than $360 \%$ over the same period (EPI, 2012).

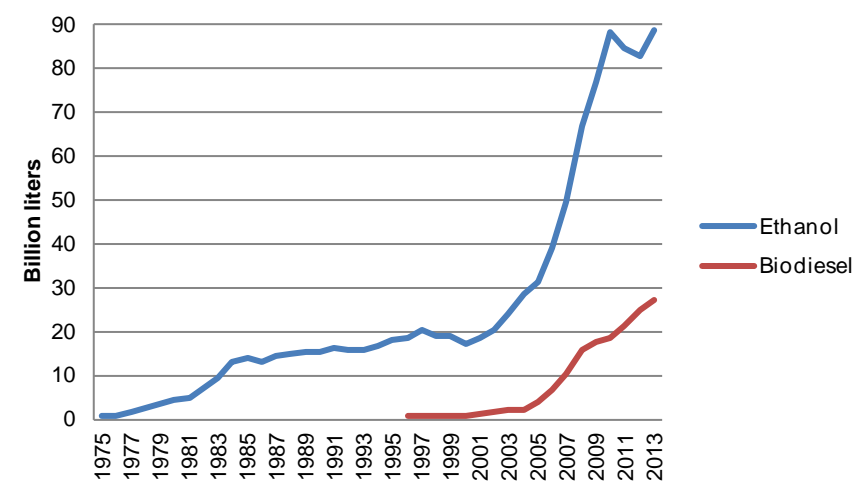

Figure 1.1. Evolution in the world annual ethanol and biodiesel production. Source: own elaboration from EPI's (2012) data, based on original data provided by F.O. Licht. This is part of a supporting dataset for Brown (2012). The graph was updated using current data from the RFA (2014) for ethanol, and OECD-FAO (2011) estimates for biodiesel. 

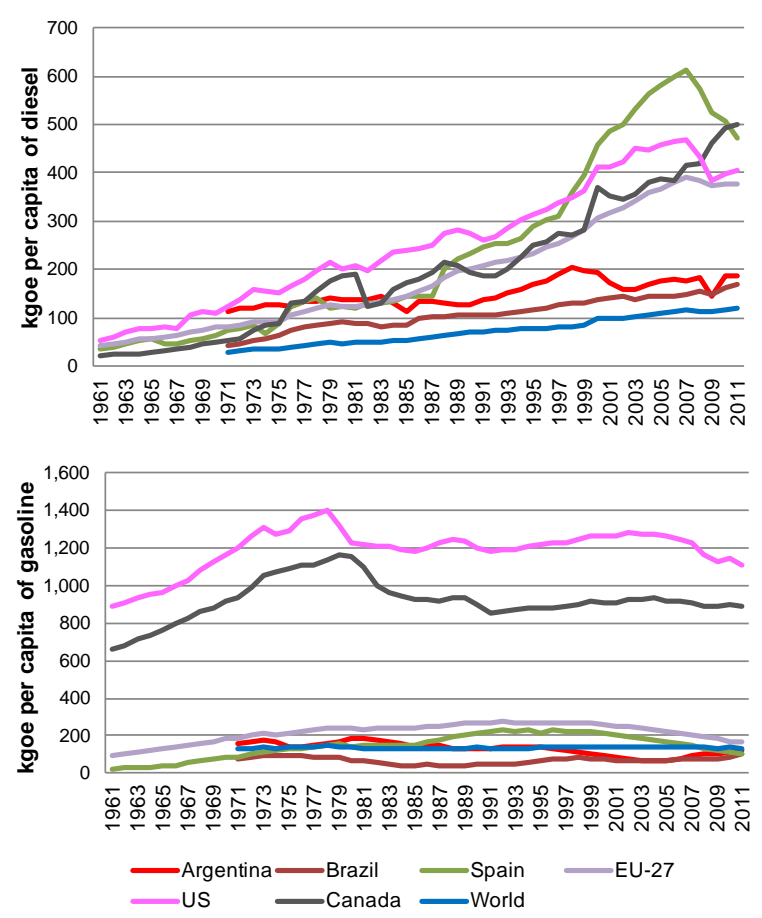

Figure 1.2. Fossil fuel consumption in the motor sector of major biofuel-producing countries and the world (kgoe: $\mathrm{kg}$ of oil equivalent; 1 kgoe $=41,868 \mathrm{~kJ}$ ). Source: own elaboration from the Word Bank (2014) data. Some data have only been reported since 1971, when they began to be gathered from countries of all income levels. China is not shown despite being the fourth largest ethanol supplier (AFDC, 2014), since fuel consumption per capita is relatively low.

\subsubsection{Ethanol-producing countries}

Brazil introduced the National Alcohol Program Proàlcool after the crisis of the 1970s, and the domestic production has been based on ethanol from sugarcane since then. The objective of the program was to limit energy supply constraints, provide a stable internal demand for the excess production of sugarcane and counterweight variations in international sugar prices, while also developing a market for purposely modified vehicles (Sorda et al., 2010). As a result, Brazil was the world's largest producer for many years, even during the 1980s when there was a sugar shortage and price hikes. However, it was finally overtaken by the US in 2006, as can be seen in Figure 1.3. At present, Brazil is still the only country that uses ethanol in its pure form, although it is also used in gasoline blends. The current nameplate capacity is about 40.7 billion liters per annum, corresponding to 399 plants, and the sector works at an average rate of $70 \%$ (Barros, 2013). 
For its part, the US sector has been based on corn ethanol since the Energy Tax Act of 1978 established tax credits for ethanol blenders. Specifically, there was a subsidy of $\$ 0.106$ per liter of ethanol, present in the form of an excise tax exemption until it expired at the end of 2011. During this period, it ranged between $\$ 0.106$ and $\$ 0.159$ per liter (Tyner, 2008), although it was combined with other measures. As the same author acknowledged, that subsidy was sufficient to stimulate domestic production when the crude oil prices were relatively low (around \$20 per barrel), growing about 563 million liters per year in the period 1984-2004. However, the real boom in the US began in 2005, when the price of crude oil started an upward trend from $\$ 70$ per barrel, that peaked at $\$ 105$ per barrel in 2012 (in nominal US\$), according to the World Bank (2013). Indeed, US biofuel production increased from 14.8 billion liters in 2005 to 50.4 billion liters in 2013 (RFA, 2014).

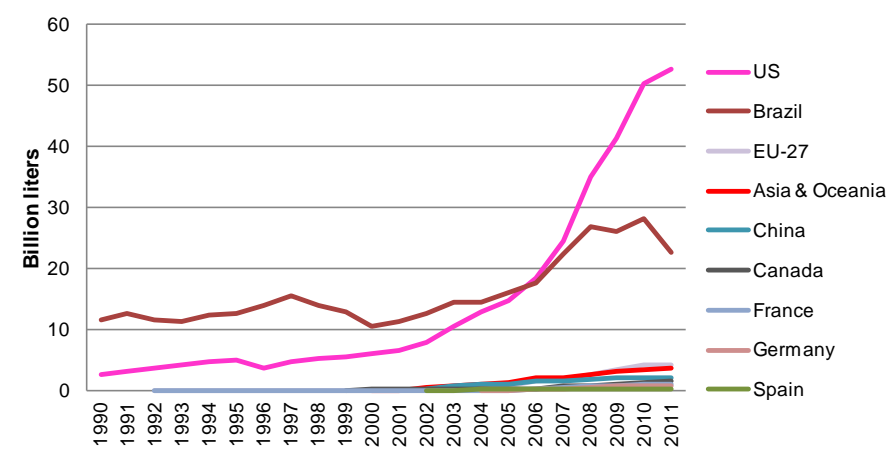

Figure 1.3. Evolution in ethanol production of leading countries and regions. Source: own elaboration from data provided by the EIA (2014).

Together with the European Union (EU), China and Canada are two more of the world's major ethanol producers, both mainly using corn and also, to a minor extent, wheat. This is despite the fact that they face very different energy situations. While Canada has the world's third largest proven oil reserves, China has greater problems to meet an increased demand for petroleum products, which causes serious air pollution problems too. Canada's limited production capacity, both in the short and medium term, suggests that Canada will not be a significant player in the global ethanol market any time soon (Evans, 2013). On the contrary, with the second largest area of planted corn in the world after the US (Faostat, 2014), and a blending mandate in place since 2004 under the Fuel-Ethanol Program, Chinese corn consumption for fuel ethanol is projected to increase from 2,363 thousand tons in the 2004/05 campaign to 4,317 thousand tons in the $2014 / 15$ campaign, representing around $80 \%$ of the domestic ethanol production (Koizumi and Ohga, 2007). 


\subsubsection{Biodiesel-producing countries}

The EU is the world's largest biodiesel producer, as can be observed in Figure 1.4. Since the first policy on the promotion of biofuels for transport, launched in 2001, the rise in biodiesel production has been particularly marked, under the leadership of Germany and France. Total biofuel production in the EU was around 2.9 billion liters in 2004 , of which biodiesel accounted for $79.3 \%$, with ethanol accounting for the remaining 620 million liters (United Nations, 2006). Although this proportion has, to date, remained practically unchanged, the installed capacity has increased tenfold over the course of 8 years (Eurobserver, 2013). The EU biodiesel sector is further described in the following section; hence, trade relationships between the EU and other key players in the global biodiesel market are the focus of the present section.

After the EU, the US is currently the second largest biodiesel producer in the world, followed by Brazil and Argentina, as shown in Figure 1.4. The category "others" in this figure mostly comprises countries in Southeast Asia (SEA) (Indonesia, Malaysia and Thailand), although production in Canada was included in 2011, 2012 and 2013. Biodiesel production in Brazil, Argentina, Indonesia, Malaysia and Thailand is export-oriented. The EU has accounted for a large share of the total exports from some of these origins, at least until 2013, when anti-dumping duties were imposed on the biodiesel from Argentina and Indonesia (Regulation 1194/2013). In most other developing countries, the purpose behind biofuel production is mainly that of energy independence (OECD-FAO, 2013). While the US biodiesel sector is essentially based on domestic soybeans, as is also the case in Brazil and Argentina, biodiesel in the chief countries in SEA is manufactured from palm oil derived feedstock, such as Crude Palm Oil (CPO), refined bleached deodorized palm oil, palm stearin, and free fatty acids of palm oil. Despite the fact that both Indonesia and Malaysia have blending mandates in force, it is clear that biodiesel production in both countries is mainly destined for export to the US and the EU (Lamers, 2011a). Although the EU biodiesel sector relies on a stable supply of rapeseed from domestic production in Central Europe, greater demand for oilseeds due to ambitious policies has led to an agricultural deficit (Banse et al., 2008). This is the reason why biofuel mandates have not only triggered biodiesel trade, but also imports of biodiesel feedstock (oils and oilseeds). 


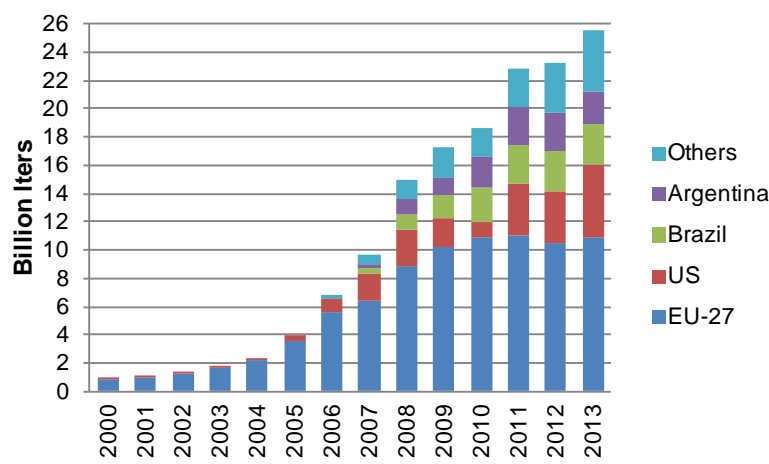

Figure 1.4. Development of world biodiesel production from 2000 to 2013. Source: own elaboration from data provided by the Lamers (2011a) up to 2010, combined with data from the USDA-FAS for each country (Barros, 2013; Evans, 2013; Flach et al., 2014; Joseph, 2014; Preechajarn and Prasertsri, 2014; Wahab, 2013; Wright and Wiyono, 2014), except for the US (EIA, 2014). Some of these studies include forecasts for 2013.

Indeed, trade plays a greater role in the international biodiesel market than it does in that of ethanol. The EU blending mandate has been one of the main forces driving world biodiesel trade in the last few years, while ethanol production has been mostly destined for domestic consumption in major markets. This trend remains consistent with OECD-FAO (2011) projections for 2020, although an increase in Brazilian ethanol exports to the US and the EU is also reported. This is because the new targets set in both regions tend to promote low-emission biofuels, and the energy balance of sugarcane ethanol is more favorable than that of corn ethanol (Goldemberg et al., 2008). Argentina stands out as an example of the influence that the EU blending mandate has in other markets. Since the early stages of the Argentinian industry, around 2006, biodiesel supply has mainly been aimed at the EU market (Lamers, 2011b). As a result, the country has been the most important biodiesel exporter for years and is currently one of the top biodiesel producers. Together with Indonesia, it accounted for the largest share of the EU market from 2009 to 2013, as a result of the tariff regime. The US had been the biggest source of foreign biodiesel, until Regulation 444/2011 imposed definitive anti-dumping duties on US biodiesel imports in 2011. Imports of biodiesel from Argentina and Indonesia into the EU in that very year amounted to 2.5 million tons. As shown in Figure 1.5, the escalation of Argentinian biodiesel imports in fact began in 2009, when anti-dumping duties were first imposed on B20 blends (or higher) from the US (Regulation 599/2009). Despite these early measures, the US was accused by the European Commission (EC) of still shipping the product from other origins (Canada and Singapore), or in blends with lower biodiesel content. As a result, only Argentina and Indonesia represented over 90\% of total imports of the 
product into the EU between 2010 and 2013, when anti-dumping duties were also imposed on them under Regulation 1194/2013 (Eurobserver, 2014). They will remain in force for the next five years. Figure 1.5 shows how Malaysia has benefited from the current situation.

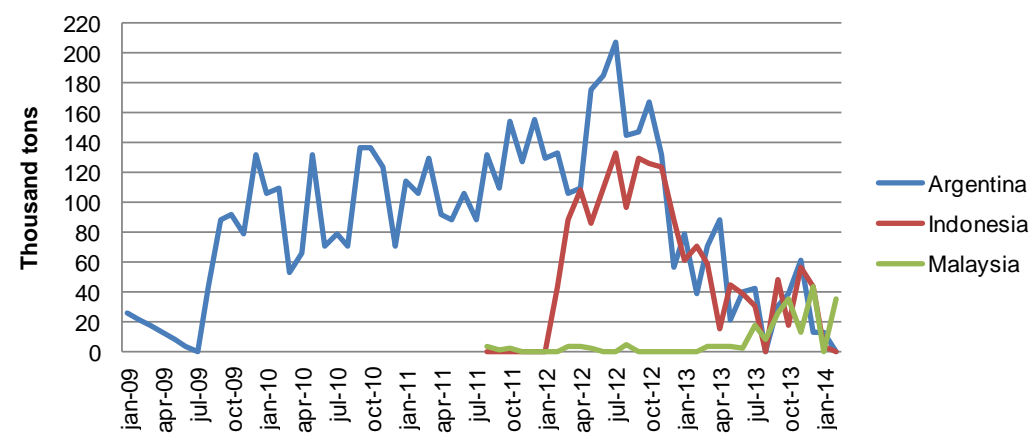

Figure 1.5. Monthly biodiesel (B100) imports from Argentina, Indonesia and Malaysia into the EU, since January 2009. Source: Flach et al. (2014).

The key factor is that the Argentinian industry of biodiesel for export is based on large-scale production, usually with access to strategic harbor locations (e.g. the port of Rosario) and its own soybean crushing facilities, while the supply for the local biodiesel market is characterized by small-scale, distributed production. After many years of heavy investment (around EUR 1.2 billion since 2007), production capacity went from 0 in 2007 to 5.15 billion liters in 2014 (Joseph, 2014). However, recent anti-dumping duties on B100 imports into the EU, combined with greenhouse gas (GHG) emission reduction targets for biofuels in the European transport sector, made the industry run at between $40 \%$ and $50 \%$ of the installed capacity in 2013 and the first months of 2014. In addition to complaining about these measures in the World Trade Organization (WTO, dispute DS459), the Argentinian government has decided to promote domestic consumption. Consequently, the national blending mandate was increased in 2014, and other measures, such as a reduction in the biodiesel export tax or an increase in the biodiesel mandate price, are expected to reduce the prevailing uncertainty in the local market. However, it must be pointed out that only a few biodiesel plants use feedstock other than soybean oil, and so far there is no other feedstock which could be used in the near future to produce biodiesel in significant volumes (Joseph, 2014). Hence, it remains to be seen how Argentina will face the new environmental requirements for biodiesel to be imported into the EU, which are described in detail in section 1.2. The Argentinian government has presented certification schemes to both the EU and the US in order to prove that good farming practices can improve the GHG balance of soybean-based biodiesel in 
compliance with the $\mathrm{CO}_{2}$ reduction targets, but they have not been officially recognized.

Similarly, Indonesia also challenged the EU (dispute DS473 in the WTO) over antidumping measures imposed on biodiesel imports. However, despite unfavorable biodiesel markets overseas, Indonesia's biodiesel sector maintained healthy growth in 2013. Biodiesel production increased from 2.2 billion liters in 2012 to 2.45 billion liters in 2013 (Wright and Wiyono, 2014). The new biofuel mandatory program has been the main driving force behind this expansion, which targeted 4 billion liters of biodiesel consumption for 2014. The country has sufficient nameplate capacity to fulfill that goal with domestic production (5.7 billion liters in 2013), while it is also expected to keep exporting palm biodiesel to minor markets, such as Japan, India or China. It has to be pointed out that the installed capacity in 2006 was only 215 million liters, which translates into an increase of 5.5 billion liters in just 7 years. In addition, palm biodiesel comes out better than soybean biodiesel when analyzing the GHG balance, which is of major importance in order to stay competitive in the global market, given the environmental demands included in the new biofuel policies. The palm oil industry will continue expanding anyway, despite the anti-dumping measures on biodiesel. Palm oil stands out as the most competitive in the international market due to its lower production costs compared with rapeseed, sunflower and even soybean oil. For instance, in July 2013 one ton of palm oil was $27 \%$ cheaper than one ton of rapeseed or soybean oil on the international market (Gerasimchuk, 2013). As a result, the palm oil share in the biodiesel feedstock mix of the EU is meant to increase from $16 \%$ to $24 \%$, mainly at the expense of soybean oil (Kretschmer et al., 2012; Laborde, 2011). In this context, it is also expected that Malaysia and Thailand, with a joint installed capacity of almost 4.2 billion liters of biodiesel (Preechajarn and Prasertsri, 2014; Wahab, 2013), will play a relevant role in the international biodiesel market in the medium-run, also supplying CPO. Brazil will remain in the background, due to the location of its plants and relatively high production prices in comparison with other exporters (e.g. Argentina) (Lamers, 2011a).

\subsubsection{The European biofuel sector}

As has been said, biodiesel is the most important biofuel in the EU and, on volume basis, has represented between $70-80 \%$ of the total transport biofuel market in the EU (Eurobserver, 2013; Gerasimchuk, 2013; Hélaine et al., 2013); this case is analogous to that of diesel, which has been the dominant fuel in final road transport consumption over the past decade (Figure 1.6). Biodiesel was the first biofuel developed and used in the European transport sector in the 1990s. At that time, the rapid expansion was driven by increasing crude oil prices, together with subsidies on the production of oilseeds under the Common Agricultural Policy 
(CAP) set-aside programs. The support given by the Memorandum of Understanding on Oilseeds (often referred to as the Blair House Agreement) for the production of certain oilseeds also contributed to this outcome, although it established some restrictions, such as the maximum area under support (Flach et al., 2013). Once the specific payment for energy crops under the set-aside regime was abolished after the CAP "Health Check" in 2008, there was no longer any restriction on the EU's oilseed area. Of course, the goals set out in the first biofuel Directive (2003/30/EC) were very instrumental in the sector's development, as were generous tax incentives on production, mainly in Germany and France. These two countries have since remained the leading producers in the EU. However, direct payments to farmers have been progressively cut-off (decoupling subsidies from particular crops since the 2003 reform), and tax exemptions have been substantially reduced in most of the Member States (MSs) due to the public budgeting costs they incurred, enhancing the role of the blending mandate alone under the new biofuels Directive (2009/28/EC), also known as the Renewable Energy Directive (RED). The targets in the RED encouraged the European industry players to invest in production capacity once again. As a result of these factors, the production of biodiesel grew from 4.7 billion liters in 2006 to 10.7 billion liters in 2011 (an increase of 130\%), according to Eurostat (2014). Biodiesel consumption increased in parallel (from 5.0 to 13.6 billion liters in the same period), and it is expected to continue rising, as shown in Figure 1.6. Although the EC (2010a) forecasts that biodiesel use in transport will reach around 23 billion liters in 2030, recent figures published by Eurobserver (2014) report a decrease for the first time since the sector's expansion. Specifically, in 2013, total biofuel consumption decreased by $6.8 \%$, relative to 2012 , while the incorporation rate in transport across the EU was $4.7 \%$. This contraction is mainly attributed to a decreased consumption in Spain, where mandated shares were cut, and to a lesser extent in Germany, where tax exemptions were totally abolished in 2013.

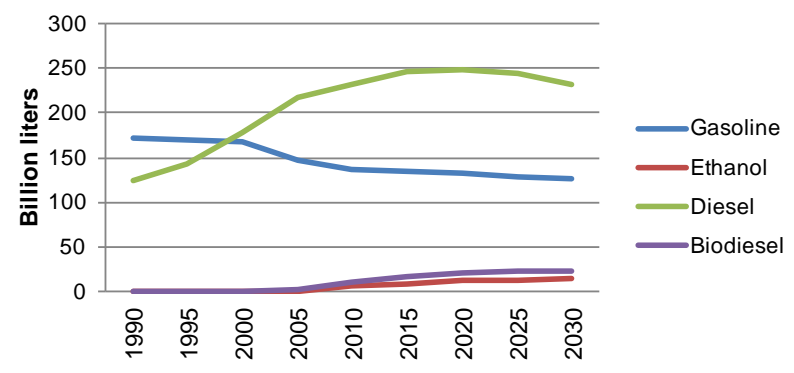

Figure 1.6. Trends in consumption of fuels and biofuels in the European transport sector. Source: own elaboration from data provided by the EC (2010a). 
Germany has been by far the largest biodiesel producer within the EU, followed by France. They account for almost $50 \%$ of the total biodiesel supply in the EU-28, producing around 2.4 and 1.9 billion liters in 2012, respectively (Eurostat, 2014). Both countries use mostly rapeseed, enjoying a well-integrated agro-industrial production. Overall EU rapeseed production increased from 16 million tons in 2006 to more than 24 million tons in 2011 and 2012 (EC, 2014). The main driving force behind the demand for rapeseed oil is the biodiesel industry, although there is also demand from the food industry. Despite the record harvest in the 2013/2014 campaign, mainly in France, total demand outstrips domestic supply, which leads to the import of large quantities of rapeseed for crushing. For instance, in 2010, the EU agricultural commodity production covered around $80 \%$ of its feedstock needs for ethanol, but only around $60 \%$ of its feedstock needs for biodiesel. The EU increased its rapeseed imports from 0.7 million tons in 2006 to 2.7 million tons in 2011 (Gerasimchuk, 2013).

Figure 1.7 shows average biodiesel consumption, production and imports in the major markets in the EU-27 for the period 2008-2012. The Netherlands, Poland, Spain, Sweden and Portugal accounted for $29 \%$ of the total biodiesel supply in 2012 (Eurostat, 2014). Germany, France, Spain, Italy, the United Kingdom (UK) and Poland are the leading countries in terms of biodiesel consumption for transport. However, a significant part of it has been covered by EU-external imports (except in Germany and France), which normally faced an ad valorem tariff of $6.5 \%$. This trend was reversed by the introduction of anti-dumping measures under Regulations 444/2011 and 1194/2013. Specifically, the first one imposed an average custom duty of $€ 214-€ 409$ per ton of biodiesel originated in the US. The second one translated into an average duty of $€ 216-€ 245$ per ton of Argentinian B100, and of $€ 145-€ 178$ per ton of Indonesian B100, with a single exception of a small-sized company for which a duty of $€ 76$ per ton applies. The last decision was justified on the grounds that producers in these two countries would have had an unfair advantage because they had access to artificially low-priced raw materials in comparison with the world market price. A really extreme situation was observed in Spain, where increased imports in the period 2010-2013 led to a crisis in the local industry, as explained in section 1.3. Spanish imports reached their peak in 2012, accounting for $76 \%$ of the overall biodiesel consumption in the country (APPA, 2013). It must be noted that the Netherlands plays an important role in the biofuel distribution within the EU, importing large amounts of vegetable oils through Rotterdam, and exporting biodiesel to other MSs. This is why production in that country by far exceeds domestic consumption, as shown in Figure 1.7. 


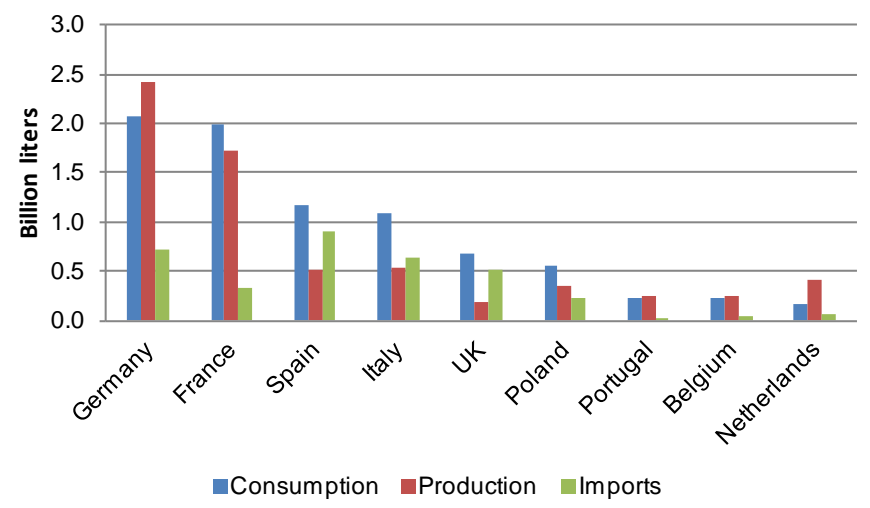

Figure 1.7. Biodiesel balance in major markets of the EU-27. Average data for the period 2008-2012. Source: own elaboration from Eurostat (2014) data.

An increasing supply of feedstock from developing countries leads to changes in the policy framework and the global landscape of the sector and, as a result, the composition of the biodiesel mix in the EU is subject to change too. Figure 1.8 shows shares of feedstock underlying biodiesel consumption in the EU-27 in 2008 and 2010. It can be observed how, in just two years, the share of used cooking oil (UCO) increased remarkably, although rapeseed was still by far the most widely used feedstock. Besides the growth in demand for biodiesel made from waste, projections point to a relative increase in the contribution of palm oil in the virgin oils mix, since, as previously discussed, it has become a marginal commodity in the international oil market, which is reflected in Figure 1.9. According to data from Ecofys et al. (2013) for 2010, most of the rapeseed used in the biodiesel sector is produced in the EU (86.3\%), together with smaller amounts of rapeseed from Ukraine (5.3\%), Canada (4.5\%) or Russia (1.7\%). Sunflower seed comes entirely from domestic production, while palm oil comes almost entirely from Malaysia and Indonesia. The origin of the soybeans is more diverse, coming mainly from Argentina (53.6\%), Brazil (18.8\%), the US (10\%) and Paraguay (8.3\%). As has been highlighted, these proportions are subject to change as a result of price variations driven by political and economic factors. 

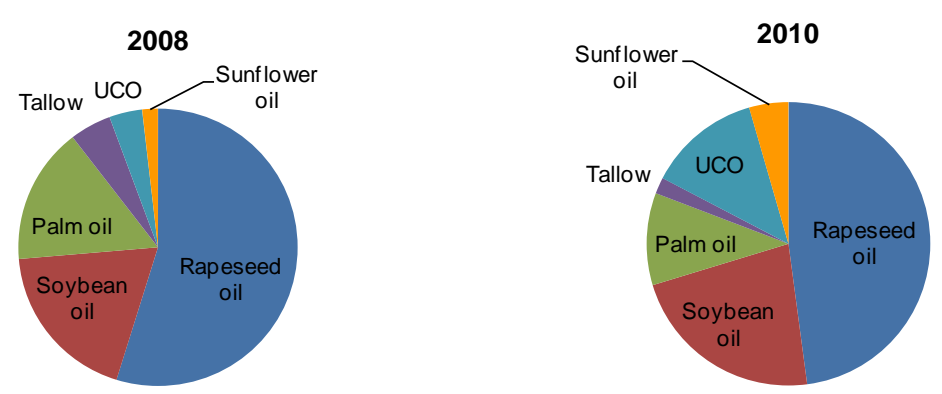

Figure 1.8. Shares of feedstock underlying biodiesel consumption in the EU-27 in 2008 and 2010. Source: own elaboration from data provided by Kretschmer et al. (2012) for 2008 and Ecofys et al. (2013) for 2010.

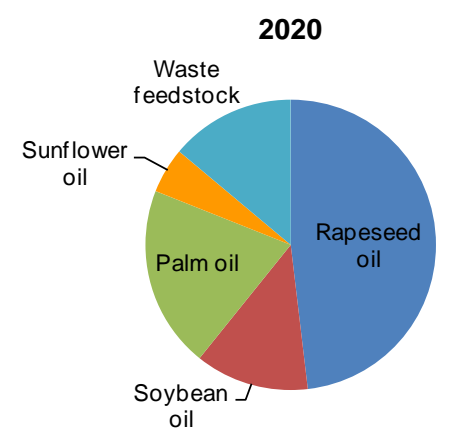

Figure 1.9. Projected shares of feedstock underlying biodiesel consumption in the $E U$ in 2020. Source: own elaboration from estimates of Laborde (2011) and Hélaine et al. (2013) for 2020.

The structure of the biodiesel sector in the EU is very diverse and plant sizes range from a capacity of $2000 \mathrm{t}$ per annum, owned by groups of farmers, to 600,000 t per annum, owned by large multi-national companies (Flach et al., 2014). However, if overall biodiesel capacity in the EU-27 increased by 360\% from 2006 to 2009, the increase in the subsequent years was smaller: 3\% and 6\% in 2010 and 2011, respectively (Flach et al. 2012, 2013). It has to be noted that France, Portugal, and Spain reported the largest production capacity increases in 2010 , coinciding with the enforcement of the RED. According to the same estimates of the USDA-FAS (Flach et al., 2014), overall production capacity of biodiesel is forecast to remain flat, at around $42 \%$, for the next few years, since some plants all over the EU temporarily stopped production or closed as a consequence of dumped imports in recent years. The phasing out of the tax exemptions in the MSs has also played a role since, together with high vegetable oil prices, this has significantly reduced biodiesel production margins. Probably driven by all these factors, the sector is 
currently under-utilized, with a nameplate capacity of $22.9 \mathrm{Mt}$ per annum, corresponding to approximately 26 billion liters.

Since the focus of the present thesis is on the biodiesel sector, the European ethanol sector is not described in detail. Additionally, the EU is only a minor producer of ethanol in the international context, compared with the US and Brazil. Ethanol in the EU is mainly produced from wheat, corn and sugar beet derivatives. Whereas wheat is mainly used in the northwestern part of the region, corn is predominantly used in Central Europe and Spain. Barley and rye are used for ethanol production in Germany, Poland, the Baltic Region and Sweden. In overall terms, and according to Ecofys et al. (2013), in 2010, domestic crops accounted for $78.7 \%$ of the feedstock mix in ethanol consumption, $37.6 \%$ of which corresponded to sugarbeet, $40 \%$ to wheat and $17.6 \%$ to corn. The ethanol sector in Europe is much less prominent than that of biodiesel, but that is precisely why it has greater expansion capacity. Specifically, production capacity is forecast to increase from about 2.1 billion liters in 2006 to 8.5 million liters in 2015. However, during the period $2007-2012$, only $60 \%$ of the nameplate capacity was used, partly due to high grain prices in some agricultural campaigns, resulting in more competitive imports (Flach et al., 2012; 2014). Most of the bioethanol shipped to the EU was imported as E90, subject to a lower import tariff. The EU finally took action to end the loophole in the tariff regime, from which the US had been benefiting (Regulation 211/2012), and also imposed anti-dumping duties on ethanol imports from the US in the following year (Regulation 157/2013). Therefore, a significant part of the sector expansion projected for the coming years is based on advanced technologies, also influenced by the new policy environment, which is presented in the section below. Ethanol is still expected to be imported from other origins with preferential trade measures (zero duty quotas), mainly used by Guatemala, Peru and Pakistan.

\subsection{Biofuel policies}

Besides enhancing countries' energy independence, biofuels are meant to reduce worldwide GHG emissions from the transport sector. This sector is estimated to have the second highest contribution after energy, with around 25\% in both the EU and the US, according to reports of the EC and the US EPA. To this end, governments around the world have been launching biofuel policies since the first stages of the sector's development, following in the footsteps of Brazil, the US and the EU. These policies have been traditionally based on blending and market share mandates, combined with financial support for domestic production in the form of subsidies or tax exemptions. The rationale behind these measures is that biofuel production has been traditionally unprofitable, with higher unit costs relative to fossil fuels, especially during the period 1992-1999 due to the low price of crude oil 
(Duncan, 2003). In the beginning, biofuels were supposed to have a much lower impact than conventional mineral fuels, since biomass used for their production absorbed $\mathrm{CO}_{2}$ from the atmosphere, acting presumably as carbon sinks. Studies such as those by Hill et al. (2006), Lam et al. (2009), Pleanjai and Gheewala (2009) or Yee et al. (2009) reinforced this view. However, concerns about the real benefits of biofuels have been growing hand in hand with blending targets in the US and the EU, since changes in land use patterns have been observed in other regions such as Argentina, Brazil or SEA, in favor of large energy crop monocultures. Hence, public policies have been subsequently adapted, trying to mainstream these effects in order not to lose sight of the original goal of reducing the transport carbon footprint. As a first step, they discriminate among biofuels depending on the feedstocks and technologies used, since this leads to a wide variation in GHG performance figures. Hence, four biofuel categories can be distinguished:

- First-generation biofuels (FGBs), which are those made from biomass that can be edible, such as starch, sugar or vegetable oils. Since the source of carbon for the biofuel is directly extracted from a plant, they are actually, or potentially, considered to be in competition with food. In addition, FGBs are usually obtained by using conventional production techniques; thus, they are also referred to as conventional biofuels.

- Second-generation biofuels, which are those manufactured from byproducts or residues. The biofuel carbon is derived from cellulose, hemicellulose, lignin or pectin. For example, this may include agricultural waste, forestry waste, or purpose-grown non-food feedstocks (e.g. short rotation coppice, energy grasses, such as switchgrass). This category also includes biodiesel made from tallow or UCO, since they are no longer fit for human consumption. UCO is also known as yellow grease in the US.

- Third-generation biofuels, which are those derived from aquatic autotrophic organisms, e.g. algae or other quickly growing biomass sources. Light, carbon dioxide and nutrients are used to produce the feedstock "extending" the carbon resource available for biofuel production. This means, however, that a heterotrophic organism (using sugar or cellulose to produce biofuels) would not be considered as part of this category.

- Fourth-generation biofuels, which are those made from specially engineered plants or biomass that may have higher energy yields or lower barriers to cellulosic breakdown. The process differs from second and third-generation production as, at all stages, $\mathrm{CO}_{2}$ is captured using technologies such as oxy-fuel combustion, which yields a carbon negative 
balance. The $\mathrm{CO}_{2}$ can then be geosequestered by storing it in old oil and gas fields or saline aquifers.

Since second, third and fourth-generation biofuels require the application of more sophisticated technologies, these are also known as advanced biofuels. They are usually associated with lower GHG emissions, although impacts across the entire supply chain must be evaluated before assuming that advanced biofuels are always more sustainable than first-generation ones. It must be taken into account that, of all the feedstocks potentially considered for the advanced biofuel category, $\mathrm{UCO}$ is the only one with a significant market penetration to date (Hélaine et al., 2013).

\subsubsection{European biofuel policies}

The EC introduced a policy to promote the use of biofuels for transport in 2001, based on a regulated market-based approach. However, the first biofuel Directive as such was launched in 2003 (2003/30/CE). It established indicative targets for reaching a $5.75 \%$ share of renewable energy in the transport sector by 2010 ; a target of $2 \%$ was accordingly set for 2005 . However, none of them were met, with a share of renewable fuel consumption in the EU transport of 1.3\% in 2005 and $4.8 \%$ in 2010 (Eurostat, 2014). These results motivated the EC to establish mandatory targets (United Nations, 2006). In parallel, legislation was developed on the taxation of energy sources (2003/96/EC). Additionally, the CAP had supported biomass production on set-aside land for non-food uses since 1992, with the objective of avoiding agricultural surpluses. This indirect aid came in the form of guaranteed minimum prices, per hectare payments, and compensatory payments (Lamers et al. 2011b). The support was explicitly included in the subsequent CAP reform in 2003, which introduced a crop premium of $€ 45$ per hectare for bioenergy, which was extended in 2006. The CAP "Health Check" reform, introduced by the end of 2008 , abolished both set-aside and energy crop payments.

\subsubsection{Renewable Energy Directive}

The RED (Directive 2009/28/EC) amended and repealed Directive 2003/30/CE in 2009 , and is still in force, setting the current regulatory framework for the promotion of energy from renewable sources, including biofuels. The RED is part of the 2020-20 objectives of the EU, established in 2007 with a 2020 horizon, which aim to: a) reduce by $20 \%$ the GHG emissions relative to 1990 levels, b) reduce by $20 \%$ the primary energy consumption compared to trend levels, and c) increase the use of renewable energies until they represent $20 \%$ of the gross final energy consumption in the MSs. Specifically, the RED is responsible for enacting the latter, for the purposes of which each MS should develop national action plans in order to define 
the minimum indicative trajectory for the mandatory share of energy from renewable sources to be consumed in transport, electricity and heat production, in order to meet the 2020 objective. As regards the transport sector, the RED establishes a $10 \%$ target in 2020 , which is expected to be met mostly with biodiesel, given the preferences of the European consumers and the low market penetration of other technologies, such as hydrogen or electricity.

Furthermore, the RED includes some sustainability criteria as a means of ensuring that only sustainable biofuels are eligible to meet the targets, and thus to benefit from national support schemes. The Directive is clear in that such criteria will only be effective if these biofuels are sold by economic operators at a higher price than the others. A biofuel is considered sustainable when it is not produced using raw materials from land with high biodiversity value or high carbon stock, and when it generates at least a 35\% reduction in GHG compared with fossil fuels. This minimum threshold for emission savings will increase to 50\% in 2017 and to $60 \%$ in 2018, but only for those biofuels produced in installations which will be in operation after $1^{\text {st }}$ January 2017. This is to ensure that increasing the consumption of biofuels does not take place at the expense of carbon-rich ecosystems (such as wetlands, densely forested areas or undrained peatlands). To fulfill these requirements, economic operators are urged to report GHG emissions released into the atmosphere throughout the entire production process, by following certain guidelines based on the LCA methodology. Emissions from carbon stock changes that take place when the land has been converted to biofuel production must also be considered, by following the same principles as the IPCC (2006). Annualized emissions from carbon stock changes caused by LUC must be calculated by dividing total emissions equally over 20 years. To facilitate this task, the RED includes default values of GHG savings for the main biofuel production pathways, although other numbers can be used, obtained by means of proper documentation and LCA procedures. The EC commissioned the Joint Research Centre (JRC) to calculate these values prior to the release of the Directive (Edwards et al., 2008). The sustainability criteria began to be binding in 2011, but only in some MSs. Only a few countries enjoyed $100 \%$ certified biofuel consumption in 2011, according to Eurobserver (2013): Germany, Denmark, Luxembourg, Lithuania and Slovenia. Certified biofuels are projected to continue gaining market share in most of the countries in the EU-28, as soon as they implement statistical reporting on life-cycle emissions. While only $29 \%$ of total consumption came from certified sustainable sources in 2011, the same figure increased to $57 \%$ in 2012.

There have been some concerns that these GHG thresholds can be used to hamper trade. Some authors (Ackrill and Kay, 2011; Lendle and Schaus, 2010) analyzed whether they conform to the WTO rules and principles or not. They concluded that there is no clear evidence to think that sustainability criteria 
discriminate on the basis of origin. The implementation and reporting rules apply equally to all biofuels. In fact, GHG savings may also go against rapeseed biodiesel, which is the most widely produced in the EU. Finally, the RED proposes a double-counting scheme in Article 21(2) for biofuels made from waste, residues, non-food cellulosic material, and ligno-cellulosic material, whose contribution to the target must be considered twice.

\subsubsection{Fuel Quality Directive}

Directive 2009/30/CE or the Fuel Quality Directive (FQD), also adopted in 2009 revises Directive 98/70/EC. It establishes the regulatory framework for monitoring the quality of the fuels used in road transport. It amends a number of elements of the petrol and diesel specifications, as well as introducing, in Article 7a, a requirement for fuel suppliers to reduce the GHG intensity of the energy supplied for road transport, following a Low-Carbon Fuel Standard (LCFS). Specifically, a $\mathrm{CO}_{2}$ reduction target of $6 \%$ is set, which is designed to be consistent with the use of $10 \%$ biofuel with an average carbon saving of $60 \%$ to comply with the target in the RED. This carbon intensity reduction could be achieved by any low carbon fuel options, such as hydrogen or electricity, but it is widely expected that the bulk of the target will be equally met by the use of biofuels. In addition, the FQD establishes identical sustainability criteria to those in the RED, which must be met by biofuels if they are to count towards the obligatory GHG intensity reduction.

\subsubsection{Draft Directive on Indirect Land Use Change}

Besides the constraint imposed by the sustainability requirements laid down in the RED/FQD for both domestic and imported biodiesel, the EC recently presented a new proposal to the Parliament and Council, known as COM 595 (EC, 2012a), in order to promote only those biofuels that deliver substantial GHG savings. This is meant to be done by setting a cap on the use of FGBs, while phasing out public support for them after 2020, and establishing a GHG saving requirement for new installations. The underlying reason is that biofuels made from edible biomass displace other crops on current agricultural land, crops which may be grown in other regions, with the subsequent land use change (LUC). The associated changes in the carbon stock in soil and biomass ultimately produce additional $\mathrm{CO}_{2}$ emissions, which are not taken into account by the sustainability criteria in the RED/FQD. This phenomenon is known as indirect land use change (ILUC) and is the result of global shifts in land cover and crop patterns in response to price changes. Since this is triggered by market forces, impacts from ILUC are difficult to quantify by using only LCA principles. However, studies such as those from 
Fargione et al. (2008) and Searchinger et al. (2008) showed that these impacts can negate the GHG benefits of biofuel mandates and should not be neglected.

The main measures set out in COM 595 were:

- To set a limit of $5 \%$ to the contribution of FGBs to the 2020 target.

- To urge biofuel suppliers to calculate and report ILUC emissions from biofuels to the MSs, according to default values corresponding to IFPRI estimates (Laborde, 2011). The MSs must report these emissions to the EC as well, but not in compliance with the sustainability criteria in the RED/FQD.

- To increase the minimum GHG reduction threshold for those biofuels produced in new installations to $60 \%$ with effect from $1^{\text {st }}$ July 2014 . For installations that were in operation before this date, a minimum GHG saving of $35 \%$ will be required until $31^{\text {st }}$ December 2017 , and a minimum GHG saving of $60 \%$ will be required from $1^{\text {st }}$ January 2018 . It will be considered that a system is in operation if the production of biofuels has taken place already.

- To introduce a multiple counting scheme for advanced biofuels, according to which the biofuels produced from cellulosic wastes, residues or algae will be counted four times towards the blending mandate, while fuels from non-food energy crops will be counted twice.

The original text was opposed by the entire European biofuel industry, including farmers and traders, who argued that ILUC considerations should be removed from any future Directive. The biofuel industry is afraid of growth prospects which are insufficient to recoup much of the investment made in the last few years, mostly in first-generation technologies. Given the controversy generated, the proposal has been reviewed in depth leading to a Parliamentary and Council positions which differ in some major points; mainly the level of the cap, the role of ILUC emission factors, the treatment of dedicated energy crops (potentially under the cap), and the types of feedstock under the definition of advanced biofuels and the type of support for them. For instance, the Parliamentary position on $11^{\text {th }}$ September 2013 proposed maintaining the $5 \%$ cap for all biofuels produced from any energy crops grown on land, while using ILUC emissions when assessing contribution towards the FQD target, but not when assessing compliance with sustainability criteria under the RED/FQD. Additionally, there would be a $2.5 \%$ binding sub-target for energy from advanced fuels, which would be those produced from cellulosic wastes and residues, algae, bacteria, renewable liquids and gaseous fuels of nonbiological origin and carbon capture. As in the original proposal, COM 595, only 
advanced biofuels with low ILUC impacts and a high overall GHG saving would be supported after 2020.

The Energy Council finally reached a political agreement on the draft directive on $13^{\text {th }}$ June 2014, which fell far short of the EC's initial ambitions. The cap has been finally set at $7 \%$ for biofuels from cereals and other starch-rich crops, sugars and oil crops, in order to protect current investments. Additionally, there is a $0.5 \%$ nonbinding sub-target for advanced biofuels, which gives more flexibility to the MSs for its implementation through economic operators. Biofuels made from cellulosic wastes and residues or algae are included in this category and count double towards the targets set by the RED. The Council has, however, reduced the role of the ILUC factors, which only have to be reported if firstly calculated using default values, but are not considered when assessing compliance with the sustainability criteria in the FQD/RED. Due to notable uncertainties in the quantification of the ILUC emissions, the Council's proposal is open to a possible review of the ILUC factors as soon as further research is carried out. In its current state, however, this agreement is a draft and further negotiations with the European Parliament will certainly take place, postponing the adoption of a common text to 2015 (Eurobserver, 2014).

\subsubsection{Main biofuel policies across the world}

\subsubsection{The United States}

The US was one of the first countries to implement regulations on the promotion of biofuels. As has been seen in section 1.1.1, in the late 1970s, the Energy Tax Act established a tax exemption of $\$ 0.40$ per gallon of ethanol ( $\$ 0.11$ per liter) on the $\$ 0.04$ gasoline excise tax. Although the level of the tax varied according to the subsequent amendments, this was almost the only measure adopted until the 1990s. In the late 1980s, however, some states began to use ethanol and other oxygenates in mandatory oxygenated fuel programs to reduce automobile tailpipe emissions of carbon monoxide. The success of these state-level programs led to a similar program at national level via the Clean Air Act Amendments of 1990. Beginning in November 1992, these amendments required cities with significant air quality problems to promote cleaner fuels by implementing mandatory oxygenated fuel programs during certain winter months. These programs have been crucial in promoting ethanol usage in the US, since this is the most widely used oxygenate additive in reformulated gasoline. In addition, the Energy Policy Act of 1992 established tax deductions on vehicles that could run on E85.

In the following years, new legislation was also passed in the US which had implications for biofuel consumption, namely the Farm Security and Rural 
Investment Act of 2002 and the American Jobs Creation Act of 2004. The former established new programmes and grants for eligible farmers, ranchers and rural small businesses to supply biomass for bioenergy production and expand production capacity. The latter changed the mechanism of the ethanol subsidy to a blender tax credit (known as volumetric ethanol excise tax credit, VEETC), replacing the previous excise tax exemption. The VEETC was in force until the end of 2010, and was an extremely useful means of boosting ethanol consumption (United Nations, 2006). However, the Energy Policy Act of 2005 was the first legislation that established a blending mandate itself, the Renewable Fuel Standard (RFS). This repealed the Clean Air Act requirement which stated that reformulated gasoline contain at least $2 \%$ oxygen by weight, and introduced the obligation to increase the annual consumption of renewable fuels, starting at 4 billion gallons (15.1 billion liters) in 2006 and rising to 7.5 billion (28.4 billion liters) in 2012. As has been seen, most of this requirement has been met with corn ethanol, since refiners made a wholesale switch, removing MTBE and blending fuel with ethanol, with the only limit being that of the blending wall. This refers to the maximum amount of ethanol that can be blended into gasoline, which is currently set at $10 \%$ (E10) since it is a blend that has been approved for virtually all gasoline engines. This implies that, when the national average ethanol blend starts to approach or exceed $10 \%$, more of the supply has to be channeled into the much smaller E85 market.

Additionally, numerous states have been subsidizing the production of biofuels by means of grants, exemptions and incentives of diverse nature. Most of these support measures were independent from the environmental impacts generated during the production process. Indeed, biofuel policies in the US have been mostly motivated by energy security considerations, culminating with the Energy Independence Security Act (EISA) of 2007, which expanded and extended the RFS. It required fuel suppliers to blend renewable fuel based on a percentage of their petroleum product sales, while establishing detailed compliance standards and a tracking system based on RINs with credit verification and trading, with no explicit environmental considerations yet. California pioneered the introduction of emission reduction targets. This state enacted the first LCFS mandate in the world in 2007, with effect since January 2011, which was the first regulation to include the concept of life cycle biofuel emissions. These refer to emissions arising from the production, transportation, and use of carbon fuels in motor vehicles. Specifically, the LCFS is designed to reduce the average life cycle carbon intensity of the transportation fuel pool by $10 \%$, including all petroleum and non-petroleum components sold for consumption in California from 2012 to 2020. The life cycle analysis is thus based on GHG emissions, including those from direct and indirect LUC, by using estimates of the California Air Resources Board (CARB) for some 
crop-based biofuels. The inclusion of ILUC emission factors has been subsequently mirrored in the recent European proposal, COM 595. The new US RFS2 of 2010 incorporates environmental considerations in combination with the blending mandate. It aggregates 36 billion gallons (136.3 billion liters) of renewable fuels to be used in transport by 2022, while distinguishing between conventional and advanced biofuels; this last category is further disaggregated between biomass-based, cellulosic and other advanced biofuels. Conventional fuels, such as corn ethanol, can only account for 15 million gallons from 2015 onwards, while cellulosic biofuels (e.g. from corn stover) must represent 16 billion gallons in 2022 . The total contribution of total advanced biofuels should not be less than 21 billion gallons by 2022. The RFS2 requires producers of advanced biofuels to reduce life cycle GHG emissions by at least $50 \%$ (60\% for cellulosic biofuel), while conventional biofuels have to achieve a reduction of $20 \%$. It also excludes feedstock produced from non-agricultural land, federal forest lands, and ecologically sensitive forestland. It must be highlighted that, when accounting for GHG emissions, both the RFS2 and California LCFS consider amortization times for LUC to be higher than those for the RED (30 vs. 20 years).

\subsubsection{Brazil}

The Brazilian market of cane-based ethanol is the only mature, integrated biofuel market in the world (Banse et al., 2008). According to the United Nations (2006), the total amount of investments in the entire ethanol supply chain during the period 1975-1989 came to around EUR 4 billion, while the resulting decrease in the need for petroleum products saved an estimated EUR 41.8 billion from 1975 to 2002. In addition, Brazilian ethanol is a major player in the international biofuel market since, apart from fulfilling sustainability requirements laid down in recent biofuel policies (e.g. RED, RFS2), it is recognized as the most price-competitive. Many factors contribute to this outcome: low production costs (mainly due to low costs of the raw material and low-input agriculture), land with high productivity levels, and high energy efficiency due to the possibility of using the co-product, bagasse, in integrated cogeneration engines. After years of tax incentives (amounting to EUR 12.8 billion during the period 1975-1995), there are no direct subsidies for ethanol production (Sorda et al., 2010). The blending mandate for ethanol is currently at $25 \%$, whereas the biodiesel use mandate has been at 5\% (B5) since 2010. Furthermore, there was a credit line available until $31^{\text {st }}$ December 2013 , to finance infrastructural improvements in sugarcane fields (Barros, 2013). 


\subsubsection{Argentina}

The regulatory framework to promote the production and use of biofuels in Argentina has been in place since 2007 (Decree 109/2007). This required a minimum biofuel content of $5 \%$ in gasoline and diesel from January 2010 onwards. There has been a huge investment in the biodiesel industry, initially geared towards exports to the EU, as has been mentioned in section 1.1.1. There are pricing schemes for both the ethanol and biodiesel which are destined to the internal market (Resolution 1294/2008, and 7/2010, respectively), while financial support is granted to biofuel manufacturers unless they export their products to the international market (Sorda et al., 2010). In view of the anti-dumping duties on Argentinian B100 exports to the EU, the government increased the blending mandate from $7 \%$ to $8 \%$ in June 2013 and finally to $10 \%$ in 2014 , in order to consolidate the domestic sector. Other measures that have recently been approved by the government are: a reduction in biodiesel export tax, an increase in the official mandate price and a temporary reduction in local taxes on biodiesel for energy use and also, but to a lesser extent, on that for transport use (Joseph, 2014).

\subsubsection{Southeast Asia}

Of the different biofuel policies in place in SEA, the most ambitious program is that in Indonesia, where the government launched mandatory levels for biodiesel and ethanol consumption, not only in transport, in 2008. Specifically, the share in transport fuels must reach $20 \%$ for biodiesel and $15 \%$ for ethanol by 2025 . Part of these biofuels is subsidized (Wright and Wiyono, 2014). Thailand has also successfully promoted the implementation of biofuels since 2008, by means of a biodiesel blending mandate on the one hand, and tax exemptions on ethanol consumption on the other hand. Ethanol blended with gasoline (E10) is commercialized as gasohol, and has significantly displaced standard gasoline since its price is $10-15 \%$ lower (Sorda et al., 2010). In 2011, a 10-year Alternative Energy Development Plan was approved with the objective of increasing the share of renewable and alternative energy from the existing $9.4 \%$ to $25 \%$ of the final energy consumption by 2021. The military government is promoting the use of E20 and E85 gasohol consumption through price incentives, while still subsidizing gasohol. The government also supports technology improvements on the supply side, such as yield increases in palm, sugarcane and cassava crops. The Plan sets annual targets for increases in daily ethanol and B100 consumption, to reach 9 million liters per day and 5.97 million liters per day by 2021, respectively (Preechajarn and Prasertsri, 2014). The public support for the biofuel sector in 
Malaysia is much more modest. A blending mandate of $5 \%$ was launched in Malaysia, but it has not been efficiently implemented yet (Wahab, 2013).

\subsection{The biodiesel sector in Spain}

\subsubsection{Regulatory framework}

In Spain, the National Energy Commission (CNE) enforced the biofuel mandate in 2008, supported by the law Orden ITC/2877/2008, which established an overall target of $3.4 \%$ in 2009 , and $5.83 \%$ in 2010 . These objectives were mirrored in the first Plan for the Promotion of Renewable Energies (PER) 2005-2010, released in 2000. The 2009 goal was fully met, and the 2010 one almost, with $4.99 \%$ of biofuel consumption in transport (IDAE, 2011a). That law was subsequently amended in tune with the objectives of the RED, culminating in the second PER 2011-2020. According to data from the current National Commission of Markets and Competition (CNMC) (2014), the body replacing the CNE, Spain met the corresponding biodiesel targets in 2011 and 2012 (6.2\% and 6.5\%, respectively). Since the first PER, Spain has been subsidizing biofuel production by means of direct financial support, tax deductions, loans and tradable certificate schemes. Specifically, Regulation 53/2002 introduced a special taxation regime for biofuels, which entered into force on $1^{\text {st }}$ January 2003; a tax of $€ 0$ per 1,000 liters applied only on the volume of biofuel, even if it was mixed with other products. As a result, biodiesel consumption was supported by an excise tax exemption of €0.31 per liter, resulting in an estimated EUR 562 million in foregone revenue. The government support for the biofuel industry totaled approximately EUR 1 billion in 2011 (Charles et al., 2013). However, after the end of the exemption on $1^{\text {st }}$ January 2013 , the sector is contingent upon the blending obligation alone. In addition, the Spanish government reduced overall targets in 2013 from $6.5 \%$ to $4.1 \%$, while the specific objectives of biofuels in petrol and diesel were reduced from $7.0 \%$ and $4.1 \%$ to $4.1 \%$ and $3.9 \%$, respectively. This differs from the observed upward trend in the other MSs and is apparently in conflict with the objectives proposed by the PER 2011-2020. For instance, the Spanish target is now between 35\% and $45 \%$ lower than those in the chief biofuel markets (mainly France and Germany), while it is $20 \%$ below the EU-28 average (APPA, 2014). However, from the government's point of view, these new targets should bring down fuel prices and give it time to analyze the technological developments in order to achieve the 2020 target. As a result, biofuel consumption dropped by 57\% in 2013 (Eurobserver, 2014).

The Royal Decree 1597/2011 transposed the sustainability criteria in the RED (Articles 17 to 21) to a national regulation, defining Spain's verification and certification schemes to be carried out by the Ministry of Industry and the CNE, respectively. The certification system was supposed to come into operation on $1^{\text {st }}$ 
January 2013, obliging all the actors within the biodiesel supply chain to provide the CNE (now the CNMC) with the information necessary to calculate life cycle emissions. However, in early 2013 (Royal Decree 4/2013), the scheme entered a period of grace, prior to a transitory period of 8 additional months until the verification system was fully in place. As a result, $0 \%$ of the biodiesel consumed in transport was certified as sustainable in that very year (Eurobserver, 2014). Those provisions in the RED related to double credit for certain biofuels are also included in the Decree, but they have no binding force yet either. Since producing biofuel is still more costly than fossil fuel, double-counting will reduce the volumes needed for mandate compliance, lowering production costs for fuel suppliers. Such a policy environment has led to two markets in the EU, where supply and demand for two differentiated products interact. On the one hand, first-generation biodiesel manufactured from raw vegetable oils is sold at around $€ 750$ per $\mathrm{m}^{3}$ to the blenders. On the other hand, advanced biodiesel is sold at around $€ 900$ per $\mathrm{m}^{3}$ in those EU countries in which the double-counting scheme is already implemented (personal communication with the person in charge of a Spanish biodiesel company). Hence, some plants in Spain produce biodiesel from UCO and animal fats, which is preferably exported to countries such as Germany, Italy, Romania or Denmark (with a double-counting scheme in force since the beginning of 2014), while other plants produce biodiesel from the cheapest vegetable oils, used for the national target.

\subsubsection{Sector overview}

Possibly driven by all these factors, and although it is one of the leading countries in the EU in terms of both consumption and production of biodiesel, as has been seen in section 1.1.2, the situation of the biodiesel sector in Spain is particularly delicate. The installed capacity (around 4.5 Mt per annum by the end of 2013) far exceeds its current production, formed by a large number of companies including large, medium and small-sized facilities, with plant capacities ranging from 5,000 to 600,000 tons of biodiesel per annum. However, most of them have ceased their activities after three years of working below-capacity, and remain idle. Only a few are still active despite all the subsidies and investment injected into the sector during the starting period. According to the APPA (2013), the sector was working at a ratio of approximately $10 \%$ of the nameplate capacity in 2012 , when the escalation of biodiesel imports from Argentina and Indonesia reached its peak. Besides anti-dumping duties, which finally alleviated the pressure on the Spanish industry in 2013, producers have been awaiting a quota system since it was first proposed in 2010. After months of a tug-of-war between the Spanish and Argentinian governments, the law Orden IET/2736/2012 established a method for allocating 5.5 million tons of biodiesel per annum, for a period of two years and 
renewable for two additional years, which initially included Argentinian companies. However, the list of companies that have finally been awarded biodiesel quotas for 2014 and 2015 (resolution of $24^{\text {th }}$ January 2014) includes only European companies, excluding some from Argentina, Indonesia and Malaysia, among other countries. As a result, a quota of 3.60 million tons of biodiesel has been awarded to Spanish companies, and 1.18 million tons to other EU companies. It has to be noted that this amount is higher than the target in Spain: it exceeds Spain's installed capacity and quadruples the forecast consumption, which is meant to increase competitiveness among biofuel companies.

Despite the sharp decline in biodiesel imports from Argentina and Indonesia, biodiesel from other countries, such as Malaysia and India, have been gaining market share during 2013. Furthermore, Spain's biodiesel sector relies heavily on imports of raw materials (mostly palm oil and, to a lesser extent, soybean oil), and also on soybeans to be crushed domestically (CNE, 2013; Guerrero, 2013). This is in contrast to the situation in neighboring France, where most of the biodiesel is produced from rapeseed oil, extracted from both domestic and imported seeds. In fact, since the biofuel activity kicked-off in 1993, the French government has been engaged in preserving equilibrium among different chains (for historical and lobbying reasons) (Rozakis and Sourie, 2005). In Spain, oils from domestic seeds cannot compete with palm oil, which is by far the cheapest vegetable oil on the world market. A report from the IISD (Gerasimchuk and Yam Koh, 2013) showed that total imports of CPO for biodiesel production in Spain increased from 30 thousand tons in 2006 to 200 thousand tons in 2012. This represents a 567\% increase, the second highest after that in the Netherlands, which concentrates $80 \%$ of the EU's imports of edible oils, partly for re-export. Palm oil exporters have benefited from the GHG emission savings in the RED, since soybean biodiesel appears not to be eligible and has experienced a declining role in the production mix. However, imports of soybean oil recovered from 2012 to 2013, suggesting that Spain continues to rely on raw materials from Argentina, in spite of anti-dumping duties on the final product. According to USDA-FAS estimates (Guerrero, 2013), palm oil still accounts for the largest share in the biodiesel production mix, with an increasing role in 2013 relative to 2012 (47\%). It is followed by UCO and animal fats (29\%); soybean oil represents $23 \%$, when it accounted for $43 \%$ of the market in 2009. These shares are consistent with the latest report from the CNE (2013) about the biofuel situation in Spain: UCO was the second most commonly used feedstock in 2011 (25.0\%), after palm oil (44.8\%). The strong and simultaneous increase in the use of recycled oils and animal fats for biodiesel production that has been observed during the last few years in Spain is in tune with overall trends in the EU market (Ecofys et al., 2013), as pointed out previously. 


\subsection{The problem of glycerol glut}

The transesterification of vegetable oils and animal fats with methanol leads to the production of FAME together with glycerol as the main by-product, also known as glycerin. The production of one ton of biodiesel yields approximately $100 \mathrm{~kg}$ of crude glycerol ( $10 \% \mathrm{w} / \mathrm{w})$, containing $55-90 \%$ of pure glycerol (Siles López et al., 2009). The fatty acid industry was considered as the main source of glycerol until 2003, but was finally surpassed by the biodiesel industry in 2008 (Gholami et al., 2014). The sharp expansion in the biodiesel sector in the last few years has resulted in a glut in the glycerol market, shifting glycerin production to countries that were not traditionally large producers, such as Brazil. The world's supply of crude glycerol exceeds the current commercial demand for purified glycerol, despite the wide range of applications this organic compound can be put to in industries such as that of food, pharmaceuticals, tobacco, pulp and paper, textile, cosmetics, and many others. In addition, refining the crude glycerol to a high purity for more sensitive uses (such as medicine) is very costly and energy intensive, which is a hindrance for medium and small-sized biodiesel producers when they need to get rid of it (Pachauri and He, 2006). According to Amaral et al. (2009), worldwide glycerol production increased by $10 \%$ in 2010 , while demand for the traditional uses it is put to only grew by $3.7 \%$ in that very year. This has resulted in a dramatic 10-fold decrease in crude glycerol prices (Siles López et al., 2009), and it is now a low-price stable commodity, with the risk of increasingly becoming a waste to be disposed of safely. As recently reported by Gholami et al. (2014), the prices of crude glycerol have fallen to virtually zero, and even producers (particularly biodiesel ones) are forced to pay to have it taken away from their plants and incinerated. This issue clearly affects the viability of biodiesel plants, which is already compromised mainly due to the high costs of the raw materials. For instance, Haas et al. (2006) examined the impact of changes in the glycerol market price on the production cost of biodiesel and found a linear relationship, with each US\$0.01 reduction in the value of glycerol causing a rise of approximately US $\$ 0.8$ cents in the production cost. Hence, it is increasingly necessary to find alternative treatments for the glycerol surplus, making biodiesel production more profitable and sustainable. Research is being carried out around the world to develop new pathways to convert crude glycerol to a variety of valueadded products. Although most of these processes are not implemented on an industrial scale, the most promising applications are as follows:

- Bioconversion through microbial fermentation to high value compounds such as succinate, ethanol, xylitol, propionate, hydrogen, etc. Glycerol constitutes a carbon source that may substitute traditional carbohydrates, such as sucrose, glucose and starch. For instance, 1,3-propanediol is an 
emerging commodity chemical and is highly specific for glycerol fermentation and cannot be obtained from any other anaerobic conversion (Da Silva et al., 2009). It is used as an intermediate compound for the synthesis of polymers used in cosmetics, foods, lubricants, and medicines (Tang et al., 2009). Dihydroxyacetone can also be obtained and is frequently intended for the cosmetic industry. Biofuels, such as ethanol, can also be generated by means of microbial metabolic routes (Yazdani and Gonzalez, 2007; 2008).

- Anaerobic digestion to produce biogas for energy purposes, the main constituents of which are methane and carbon dioxide (Siles López et al., 2009).

- Conversion into propylene glycol and acetone through thermo-chemical processes (Siles López et al., 2009).

- Conversion into acrolein by catalytic dehydration. Acrolein is used in many fine chemical products, such as pharmaceuticals, detergents, and polymers (Gholami et al., 2014).

- Etherification of glycerol with either alcohols (e.g. methanol or ethanol) or alkenes (e.g. isobutene) and the production of oxygen-containing components, which could have suitable properties for use in fuel additives, solvents, non-ionic surfactants and agrochemicals (Gholami et al., 2014; Siles López et al., 2009).

- Production of hydrogen by different processes, such as steam reforming, partial oxidation, autothermal reforming, aqueous-phase reforming and supercritical water (Leoneti et al., 2012).

- As a supplement in animal feed. For instance, the Brazilian government recommended using glycerol at a proportion of $10 \%$ to this end. At least $80 \%$ of it must come from the transesterification of vegetable oils, containing up to $150 \mathrm{ppm}$ of methanol in accordance with the US Food and Drug Administration (Leoneti et al., 2012).

- As a fuel for electricity and heat production in a cogeneration system operating in a steam cycle (Albarelli et al., 2011).

Therefore, when analyzing the sustainability of biofuels it would be interesting to take the fate of glycerol into account, since different uses can lead to different consequences and impacts on the environment. 


\subsection{Life cycle perspective in the environmental assessment of biofuels}

As has been seen, many of the policies which promote a reduction in the GHG emissions from transport fuels require the application of a life cycle perspective. For instance, the RED proposes a Life Cycle Assessment (LCA) methodology to quantify the environmental benefits arising from biofuel production and consumption, in terms of $\mathrm{CO}_{2}$ savings. This methodology is, thus, necessary for the application of the sustainability criteria across the MSs, and has been chosen as the reference tool with which to carry out the research of this thesis. Specifically, the LCA methodology aims to employ a holistic approach to quantify the environmental impacts associated with a product, process or service "from cradle to grave". This concept has been widely used in literature to indicate that the impacts arising from all the stages of its existence are considered: extraction of raw materials, production, distribution, use and disposal (Fullana and Puig, 1997; Fullana and Samitier, 1996). This methodology emerged in the 60s and has progressively developed, especially since 1990. Today it is widely applied in environmental analysis in multiple productive sectors (Ardente et al., 2005; Burgess and Brennan, 2001; Cederberg and Mattson, 2000; Corbiere-Nicollier et al., 2001; Milà i Canals et al., 2006).

\subsubsection{Life Cycle Assessment of biofuels}

LCA has been commonly used to analyze the environmental effects of the production and consumption of biofuels in different parts of the world. Early studies tried to prove their suitability to combat climate change (Hill et al., 2006; Huo et al., 2008; Kim and Dale, 2005; Wang et al., 1999). Most of them focused on analyzing the impact of global warming, also known as the carbon footprint, arguing that the use of alternative fuels causes a reduction in GHG (usually expressed per $\mathrm{MJ}$ biofuel), since part of the $\mathrm{CO}_{2}$ released during the combustion is absorbed by the biomass during photosynthesis. Besides the GHG saving, the ratio between the energy contained in the biofuel and the fossil energy required for its production has been frequently used, too (e.g. Larson, 2006; Shapouri et al., 2002). For instance, the study by Shapouri et al. (2002) revealed an energy saving of $38 \mathrm{GJ}$ per ha dedicated to US corn, a value that has been subject to further debate (Von Blottnitz and Curran, 2007). In their review of bioenergy systems, Cherubini and Strømman (2011) still detected that around half of these early studies were undertaken in a European or North American context, and were limited to evaluating GHG and energy balances. With the exception of a few studies, most of them proved that there was a significant reduction in both indicators when bioenergy replaced fossil energy. However, in the case of the LCAs that address other impacts, such as 
human and ecosystem toxicity, the majority of them lead to increased impacts, especially when bioenergy crops were produced by means of intensive agricultural practices (e.g. Halleux et al., 2008).

As more ambitious blending mandates were established, triggering an expansion of biofuels in other regions beyond the EU and the US, some authors raised concerns about the impacts from the production of bioenergy crops at the expense of natural areas of high ecological value. Some examples are the studies by Panichelli et al. (2009) about the soybean expansion in Argentina (entailing deforestation in El Chaco); Reijnders and Huijbregts (2008), considering the transformation of rainforest and the Cerrado savannah for soybean production in Brazil; or Wicke et al. (2008), who analyzed GHG emissions from CPO production in Malaysia under different land conversion options (from peatland, natural rainforest, logged-over forest and degraded land). All of them included emissions from direct land conversion when assessing the global warming impact; this is an important aspect when the original land use implies large carbon pools, namely biomass, dead wood, litter and soil. Specifically, they all estimated the differences in the carbon content of the aboveground biomass, belowground biomass and soil before and after the bioenergy crop establishment, by using data from literature and/or the IPCC guidelines (2006). Results showed that emissions from LUC make the highest contribution to overall GHG, to the point that biofuels perform worse than the reference fuel, except when transformation of degraded land is considered, as in the study of Wicke et al. (2008). For instance, and according to the studies mentioned above, the Argentinian soybean biodiesel leads to $27 \%$ higher emissions than fossil diesel; the biodiesel from Brazilian soybeans causes an emissions increase of $286 \%$ when it comes from tropical rainforest, or $50 \%$ when it comes from the Cerrado ecosystem; the palm biodiesel in Malaysia can lead to a $364 \%$ or $42 \%$ increase when palms are grown on peatland or at the expense of tropical rainforest, respectively; on the contrary, palm biodiesel can cause carbon uptake if it is produced on degraded lands (with 122\% lower emissions). This is a general finding when set-aside land is brought into production, since bioenergy crops stimulate carbon sequestration (Cherubini and Strømman, 2011).

In the Spanish context, the studies carried out by the Centre for Energy, Environment and Technology Research (CIEMAT) also opted for the LCA methodology to calculate the GHG emissions and primary energy consumption generated by the use of different biofuel-fossil fuel blends. In particular, Lechón et al. $(2005 ; 2006)$ concluded that, relative to the reference fossil fuel, the energy and GHG savings (per $\mathrm{km}$ ) of biofuels vary from $0.28 \%$ to $96 \%$, and from $3 \%$ to $91 \%$, respectively, depending on the blend and the raw material used. Blends containing biodiesel from UCO were included in a second study, with the B100 causing the highest reduction in both indicators. Lechón et al. (2009) performed the same 
analysis, but taking into account emissions from direct land conversion, in accordance with the RED sustainability requirements. Although they considered that part of the oilseeds are imported from the major producing countries, they found that biodiesel from crude vegetable oils can generate an emission reduction of $56 \%$, whereas biodiesel from UCO can avoid $88 \%$ of the GHG emissions when replacing fossil diesel, well above the thresholds in the RED. Ethanol can reduce GHG emissions by around $77 \%$ compared with gasoline, under baseline scenario assumptions which consider that all the cereals are locally produced.

\subsubsection{Field-to-wheel analysis}

The life-cycle approach has also been applied in biofuel systems under the name field-to-wheel, which is just another way of referring to the concept "cradle to grave", as it involves a comprehensive analysis from the production of raw materials to further combustion in the engine. This approach has been typically applied to fossil fuels, referred to in this case as well-to-wheel, since the life cycle begins with the oil extraction and ends with the power delivered to the vehicle (Williamson and Emadi, 2005). When this implies biofuel use, feedstock is either extracted from the biosphere, as in the case of first and second-generation biofuels, or from the technosphere, as in the case of third-generation ones. Two sub-stages can be clearly identified within a well-to-wheel analysis: well-to-tank and tank-to-wheel, as illustrated in Figure 1.10. While the system boundaries in the well-to-tank approach encompass all the stages from the fuel production to its distribution to final consumers, the tank-to-wheel approach completes the life cycle including the impacts of the fuel consumption. It is worth mentioning that LCA studies may go beyond the combustion, considering other stages such as the vehicle disposal, depending on the goal and scope of the analysis.

Both well-to-wheel and well-to-tank studies can be found in the literature devoted to the analysis of the environmental impacts of alternative fuel systems. In the first case, results are usually expressed per kilometer driven by a specific vehicle (e.g. Edwards et al., 2008; Hekkert et al., 2005; Lechón et al., 2005, 2006, 2009), also per MJ consumed in the engine (Ou et al., 2009). In the second, impacts are usually expressed per unit of fuel produced, either $\mathrm{kg}, \mathrm{MJ}$, etc. (e.g. Hoefnagels et al., 2010; Malça and Freire, 2010; Spatari et al., 2005). The well-to-wheel approach should be the preferred means of assessing the performance of biofuels in different transportation services, since fuels may have different engine energy efficiencies. This approach is often used to compare vehicles (e.g. Choudhury et al., 2002), based on on-road testing, engine dynamometer experiments or fleet operation data (Malça and Freire, 2011). On the contrary, the well-to-tank approach is particularly appropriate when comparing biofuel production processes for a generic energy 
carrier, without considering a particular transportation or energy conversion system.
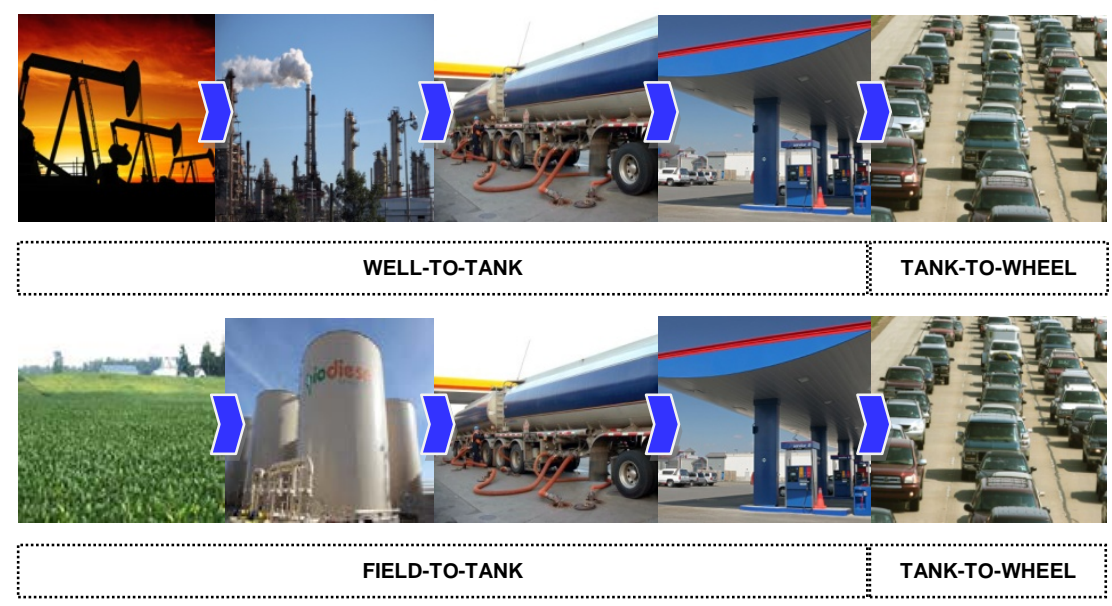

Figure 1.10. Well-to-wheel approach in the LCA of fuel and motor systems, including the production and distribution (well-to-tank) and the subsequent combustion (tank-to-wheel).

\subsubsection{Consequential Life Cycle Assessment}

The studies mentioned in sections 1.5.1 and 1.5.2 are built on the traditional LCA framework, also known as attributional LCA, which calculates the environmental impacts associated with the delivery of a specific amount of product. However, this approach fails when estimating the indirect effects associated with a change in the demand for the same amount of product engendered in the markets by the underlying actions (Vázquez-Rowe et al., 2013). Therefore, the application of attributional LCA in the quantification of the emissions from ILUC is limited. This is because, as has been pointed out in section 1.2.1, it is the result of price responses and, thus, its estimation requires a detailed understanding of the dynamics of agricultural markets and land management (Hoefnagels et al., 2010). LUC can take place in two ways: a) direct LUC occurs when bioenergy crops expand on land not previously used for the same purpose, and b) ILUC occurs on a global scale when previous uses are undertaken in other regions to keep up with demand. By definition, food-based biofuels are likely to produce more marked ILUC effects, increasing pressure on arable land.

There are different methodologies for estimating changes in land carbon stock brought about as a consequence of direct LUC, and the one laid down by the IPCC (2006) is widely applied, allowing for different levels of regionalized data to be used depending on the Tier. Lange (2011) underlines the need for a more precise 
classification of the grassland category in the IPCC guidelines (2006), and recommends considering the diversity of land available for bioenergy production, even determining the land carbon content at farm level. Despite some uncertainties regarding the calculation of carbon stocks, as pointed out by Malça and Freire (2011), including the direct GHG emissions in LCA is relatively straightforward (Börjesson and Tufvesson, 2011). However, the correlation between ILUC and its link to biofuel expansion cannot be directly measured, thus ILUC must be modeled (Broch et al., 2013). This implies analyzing cross-sector relationships, which makes it harder to allocate emissions from ILUC to the biofuel life cycle. Indeed, Börjesson and Tufvesson (2011) argue that ILUC cannot be estimated by using conventional LCA techniques.

In view of these limitations, a new approach has emerged in the last few years within the LCA methodology, one which is closely linked to the impact assessment of biofuels: the consequential LCA. The main idea of this is that the assessment includes the consequences of a change affecting the initial product system studied, and which may affect other life cycles not connected by mass or energy flows to the studied system (Dandres et al., 2011). While attributional LCA calculates the environmental burdens of a given production system under status-quo conditions (Brander et al., 2009), consequential LCA attempts to quantify the environmental consequences of a particular decision (Zamagni et al., 2012). This is why the second approach is also called the "change-oriented", "market-based", "marginal" or "prospective" method. Put simply, consequential LCA represents the convergence of LCA and economic modeling methods (Earles and Halog, 2011). Hence, it is more complex and may require the application of complementary tools based on economic modeling to predict market behavior. Coinciding with the classification of Vazquez-Rowe et al. (2013), we identify three main approaches to address a consequential LCA: a) by applying system expansion, identifying marginal suppliers and establishing causal relationships, b) by using Partial Equilibrium (PE) models, or c) by using economy-wide, Computable General Equilibrium (CGE) models. All of them are described in detail in section 2.3 of the chapter II.

\subsubsection{Discrepancies between GHG calculations in biofuel studies}

LCA was conceived as an environmental management tool to support decisionmaking, and has potential application in the definition of biofuel policies when implementing GHG reduction targets. However, the application of the LCA methodology is subject to different sources of uncertainty, as further discussed in section 2.5 of the following chapter, which translate into a wide range of outcomes when analyzing environmental indicators. Specifically, when analyzing GHG balances of biofuels, results can differ even for apparently similar systems, the key 
aspects being: the estimation of organic carbon pools, LUC effects (both direct and indirect), emissions from agricultural soils (mainly $\mathrm{N}_{2} \mathrm{O}$ and $\mathrm{CH}_{4}$ ), as well as the effects of crop residue removal (Cherubini, 2010). Additionally, it is widely known that environmental benefits brought about by biofuels depend greatly on the feedstock and on the conversion technology as well. This issue has been long incorporated in the biofuel regulations in the EU and US for sustainability reasons; both the RED and the RFS2 distinguish among biofuel pathways in order to provide guidance values for the calculation of life-cycle GHG emissions. According to the definition of the US EPA, biofuel pathway refers to the combination of 3 components, namely: 1) feedstock, 2) production process (technology) and 3) fuel type. For comparative purposes, the resulting net GHG emissions are expressed in terms of carbon intensity, that is, converted to equivalents of $\mathrm{CO}_{2}$ and typically normalized by the energy content of the fuel $\left(\mathrm{g} \mathrm{CO}_{2}\right.$ per $\left.\mathrm{MJ}\right)$. For example, default well-to-wheel values for sugarcane ethanol in the RED are 14, 1,9 and $0 \mathrm{~g} \mathrm{CO}_{2}$ per $\mathrm{MJ}$ for the cultivation, processing, distribution and combustion steps, respectively. However, as discussed by Richardson et al. (2013), the same pathway is associated with different emission values in the RFS2 and the LCFS: 33 and 20.4, respectively. For soybean biodiesel, the range is even greater, varying from $8 \mathrm{~g} \mathrm{CO}_{2}$ per $\mathrm{MJ}$ in the RFS2 to $58 \mathrm{~g} \mathrm{CO}_{2}$ per $\mathrm{MJ}$ in the RED. These differences arise from different modeling approaches, mainly when addressing the effects allocated to co-products and $\mathrm{N}_{2} \mathrm{O}$ emissions from agriculture. Underlying methodological approaches to the modeling of LUC translate into even greater differences when including the associated GHG emissions. While the RED only considers direct emissions, based on the IPCC guidelines (2006), the RFS2 uses agro-economic models to attempt to include emissions from direct LUC both at national and international levels. The LCFS is the only regulation including ILUC estimates which are based on the economy-wide model, GTAP. Since it has been applied in the present dissertation, the entire section 2.3.3.1 has been devoted to it in chapter II. Additionally, since emissions from direct and indirect LUC take place over long periods of time, they are usually annualized. The same amortization times apply to both kinds of LUC, although the RED considers a period of 20 years while the RFS2 (LCFS) considers one of 30.

Given the implications that the emission factors (and the corresponding GHG saving requirements) may have in defining future biofuel consumption patterns in two major regions, such as the EU and the US, many studies have emerged in the last few years highlighting the associated uncertainty. For instance, Mullins et al. (2011) argue that GHG reduction thresholds in the RFS2 are based on point estimates, reflecting historic trends in the literature for the calculations of biofuel life-cycle emissions. Authors performed uncertainty analyses and found that corn ethanol emissions can range from 50 to $250 \mathrm{~g} \mathrm{CO}_{2}$ per MJ. They also considered switchgrass ethanol, an advanced fuel, and concluded that greater emissions than 
those from the reference gasoline are likely to be caused depending on the technology. Darlington et al. (2009) found serious difficulties when trying to replicate EPA's evaluated emissions in the RFS2, especially when calculating GHG emissions from LUC outside the US. After applying different models too, and reviewing the available literature, the authors concluded that land use impacts could have been overestimated, mainly in other countries such as Brazil. They also question the adequacy of the models used to support such an analysis.

As has been highlighted, ILUC considerations are likely to be incorporated in future biofuel policies in the EU and the US, following the example of California with the LCFS. However, the estimation of the indirect GHG emissions is very controversial and highly uncertain, too. Not even the RFS2 and LCFS agree on a single modeling routine, and use entirely different approaches. The review of Broch et al. (2013) underlines the variability in ILUC estimates, with particular focus on US policy. For corn ethanol, results vary between $-4 \mathrm{~g} \mathrm{CO}_{2}$ per MJ in the RFS2 to 106 $\mathrm{g} \mathrm{CO}_{2}$ per $\mathrm{MJ}$ in the reference study of Searchinger et al. (2008), due to different assumptions in the estimation of the location and type of land converted. In general, the authors found that, when models point to larger ILUC in regions such as Latin America and SEA, deforestation is assumed to occur to a greater extent, leading to higher emissions. This is one of the reasons behind the fact that soybean biodiesel causes higher emissions than corn ethanol, between 62 and $340 \mathrm{~g} \mathrm{CO}_{2}$ per MJ according to the same studies reviewed. Plevin et al. (2010) applied a reduced-form model to analyze uncertainty in ILUC emissions associated with US corn ethanol and found that the bounding range goes from 10 to $340 \mathrm{~g}$ $\mathrm{CO}_{2}$ per $\mathrm{MJ}$, whereas ILUC estimates in the LCFS are only $30 \mathrm{~g} \mathrm{CO}_{2}$ per $\mathrm{MJ}$ (CARB, 2009). Similarly, Laborde (2011) performed uncertainty analyses on the ILUC emission factors to be included in the future EU biofuel directive, as commissioned by the EC. As a consequence of the increased biofuel consumption in the EU, overall ILUC emissions ranged between 24 and $50 \mathrm{~g} \mathrm{CO}_{2}$ per MJ, with the range for corn ethanol being particularly small. The author points out that the extreme values were much lower than those found by Plevin et al. (2010), since some significant sources of uncertainties were omitted in the analysis. All these results underline the need to take uncertainty into account when defining GHG emission thresholds and default values for biofuel directives, in order to avoid wrong policy instruments, especially when addressing ILUC.

In addition to helping policy-making, the life-cycle perspective has also been applied in the economic optimization of biofuel supply chains, with the aim of assisting strategic design and investment capacity planning (e.g. Haque et al., 2009; Zamboni et al., 2009a, b). One of the challenges for the emerging industry is the high level of uncertainty in biomass costs and availability, market demands, market prices of biofuels and co-products, transport logistics and processing 
technologies (especially for second-generation biofuels). These uncertainties affect the overall profitability of the activity and complicate the assessment of investment decisions. Studies, such as those by Dal-Mas et al. (2011) and Kim et al. (2011), address the uncertainty caused by the changing market conditions that these production systems are subject to, trying to provide reliable tools for decisionmakers.

\subsection{Motivation for the dissertation}

The dissertation is mainly motivated by the following facts:

- In terms of both the consumption and production of biodiesel, Spain is one of the leading biofuel countries in the EU-28. Despite this, the sector is facing a long and lasting crisis. The massive imports from Argentina and Indonesia in the period 2010-2013 made the sector work at a much lower production capacity than the installed one. This situation became persistent due to the lack of any strategic direction in the definition of policy actions, and most of the plants are currently at a standstill, or even closed. As a result, the sector is currently suffering from excess capacity.

- Unlike other European countries, the biodiesel supply chain in Spain is not well-integrated. The industrial sector relies on oil imports, either virgin or residual, whereas domestic feedstock, such as rapeseed, is mainly exported. Using domestic oilseeds would help to increase the energy independence, given the availability of arable land in the country. According to IDAE (2011a), using current levels of oilseeds and UCO from the hospitality sector in Spain would help to meet $17.6 \%$ of the blending mandate for 2020. If potential levels were considered (also using fallow land for oilseed production, as well as UCO from households), biodiesel production from domestic feedstock would account for approximately $47.6 \%$ of the expected demand in 2020.

- Sustainability criteria in the RED, as well as recent proposals on ILUC, are intended to promote the use of biofuels made from non-food feedstock, also known as advanced biofuels. The current share of UCO in the Spanish biodiesel mix is strong (around 24\% in 2011, according to CNE 2013), and it is expected to increase as soon as the double-counting and the certification schemes are effectively implemented. Improving the viability of UCO biodiesel plants is a challenge for the Spanish sector and the role of the glycerol is critical.

- Deforestation and forest degradation for agricultural expansion, conversion to pastureland, infrastructure development, destructive logging and fires 
cause nearly $20 \%$ of the global GHG emissions (UN-REDD, 2009). This figure is greater than that of the entire global transportation sector and second only to that of the energy sector. In particular, Brazil and Indonesia have experienced the largest increase in the production of feedstocks for biofuels, and contribute to $61 \%$ of the world's $\mathrm{CO}_{2}$ emissions from LUC (Lange, 2011).

- Despite the capital importance of land use impacts in the environmental profile of biofuels, in the literature prior to 2011 there are a few studies which include direct LUC emissions (Cherubini and Strømman, 2011). Although the IPCC guidelines (2006) have been increasingly used by LCA practitioners, there is still a lack of a widely accepted methodology for the estimation of GHG emissions from land transformation.

- The need to consider the effects of LUC for the definition of future biofuel policies is not temporary. Projections point to a substantial reliance on biofuels that cause small changes to land carbon stock in order to meet climate goals. However, a range of estimates exist for emissions from direct LUC, varying greatly depending on the feedstock, the geographical region, and methodological assumptions. GHG benefits of biofuels are largely conditional on these estimates, and thus are subject to uncertainty.

- Despite the evidence of ILUC, which is deemed to be even more important than direct LUC (Hertel et al., 2010; Searchinger et al., 2008), there is no consensus on the methodology to be used for its calculation. The EC's proposal on ILUC includes emission factors from Laborde (2011), but encourages the application of different methodologies in the estimation of indirect emissions from biofuels, too. This is to contribute to the understanding of this phenomenon, while providing an acceptable level of uncertainty when defining $\mathrm{CO}_{2}$ emission factors.

- Improving the economic models that forecast ILUC presents an opportunity to provide robust estimates and increase the confidence in GHG emission results, given the associated uncertainty. This can greatly help to enhance future biofuel policies.

\subsection{Objectives of the dissertation}

The main objective of the doctoral thesis is to provide quantitative results on the environmental consequences of the production of biodiesel for the Spanish transport sector, in fulfillment of the most recent European policies on biofuels and climate change. Different methodologies are applied, under a life cycle perspective, in order to offer additional insights into the evaluation of controversial issues that 
affect the environmental performance of biofuel systems and analyze the influence of the methodological approaches on the results. This yields several case studies, allowing for some specific goals to be established as follows, corresponding to the main sections outlined in chapter III:

1) To assess the environmental and economic performance, including the uncertainty, of a system to produce biodiesel from UCO in Spain, as a way of increasing the viability of the plants that are currently at a standstill. A combined study of the economic viability and the environmental impact of the process is a pre-requisite for a more thorough understanding of its sustainability. Specifically, the proposed process consists of an integrated system in which the glycerin obtained as a by-product is used as fuel in a combined heat and power (CHP) engine.

2) To analyze the influence of including direct and indirect LUC emissions when comparing the environmental performance of different biofuel life cycles. For this purpose, the environmental impacts arising from two pathways for biodiesel consumption in Spain have been compared: the production of biodiesel from UCO collected in the hospitality sector vs. importing soybean biodiesel from Argentina, which was the prevailing option in the period 2010-2013, as has been seen.

3) To discuss the potentials of using economic modeling linked to LCA to optimize the biofuel supply in the Spanish context, taking economic and environmental criteria into account. To this end, the economic surplus and the environmental impact across the entire biodiesel supply chain in Spain are estimated by developing a country-specific, multi-chain optimization model of the industry and the agricultural sector. Given its current nameplate capacity, this model determines the optimal configuration of the biodiesel sector in Spain, which will allow the 2020 target amount of biodiesel to be produced in compliance with the sustainability criteria in the RED.

4) To apply a CGE model as a tool with which to analyze the global environmental consequences, in terms of GHG emissions and LUC, of increasing the demand for biodiesel in the EU to meet the 2020 target. The main measures recently proposed by the EC affecting international biodiesel markets have been considered simultaneously, and interactions between sectors have been addressed in an economy-wide perspective. 



\section{Chapter II. Methodological overview}





\subsection{General outline and working plan}

The thesis is based on different tools which are applied in the literature for the purposes of estimating the environmental impacts of biofuels under a life cycle perspective. This requires expanding the traditional focus on manufacturing processes in order to incorporate various aspects associated with a product over its entire life cycle. Ultimately, the aim of this holistic approach is to provide information about the sustainability of a product, service or process.

In accordance with the original definition in the Brundtland Report (WCED, 1987), an activity is sustainable if it meets the needs of the present without compromising the ability of future generations to meet their own needs. This is a vague definition that has subsequently been refined to be made more operationally concrete. The standard model, often called the triple bottom line, is the "three-pillar" interpretation of sustainability. That is, an activity or initiative will only be sustainable if it causes environmental, economic and social gains. This means generating low environmental impacts and little non-renewable resource depletion, and ensuring economic growth, profits and an equitable distribution of wealth. In the field of biofuels, according to the definition of Hill et al. (2006), in order to be a sustainable alternative, a biofuel should provide a net energy gain, have environmental benefits, be economically competitive, and be producible in large quantities without reducing food supplies. This implies that the environmental, economic and social aspects have to be tuned and checked against each other. Due to the broad scope of the "three-pillar" definition, there are different approaches to addressing biofuel sustainability under a life cycle perspective. Figure 2.1 summarizes the main methodologies available and the gap filled by each one in the context of sustainability analysis. These are classified in accordance to two characteristics: the dimension of the sustainability they aim to assess and the scope of the analysis.

At the product level, each of the proposed methodologies generally aims to assess one dimension, according to the scheme for Life Cycle Sustainability Assessment (LCSA), which requires combining Life Cycle Assessment (LCA), Life Cycle Costing (LCC) and Social Life Cycle Assessment (SLCA). The results for different dimensions can be subsequently integrated in one single index for further interpretation (e.g. cost-effectiveness as defined by Rozakis et al., 2013; ecoefficiency as calculated by Kuosmanen and Kortelainen, 2005, and Sanjuán et al., 2011, etc). Sector-oriented and economy-wide methodologies allow more than one dimension to be analyzed at the same time. For instance, most Partial Equilibrium (PE) and Computable General Equilibrium (CGE) models combine economic and environmental outcomes. 


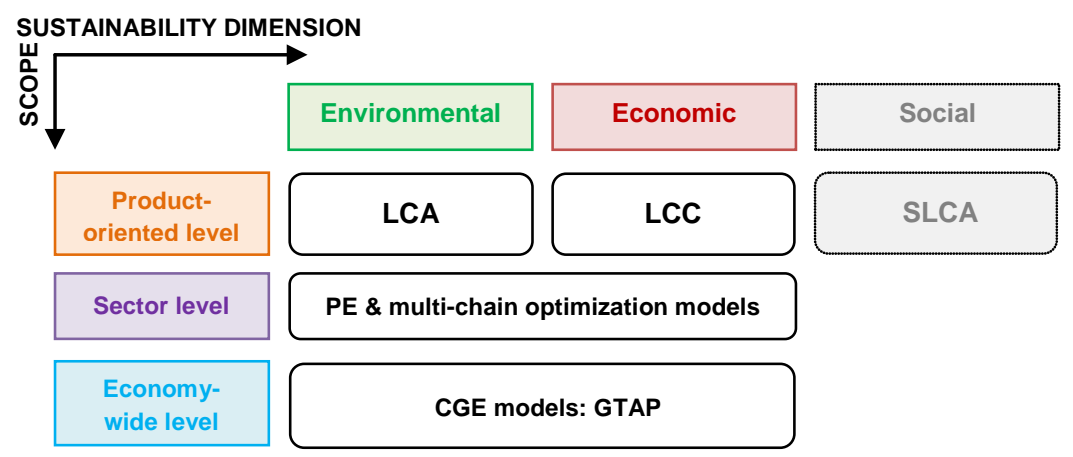

Figure 2.1. Transdisciplinary methodological framework for the study of biodiesel systems under a life cycle perspective. The social dimension is not addressed in the dissertation and appears in gray. Source: own elaboration based on Guinée et al. (2011).

The present thesis focuses on the environmental and the economic dimensions, and tries to cover all the scopes of analysis by using the outlined methodologies. Note that the social dimension is beyond the scope of the dissertation, thus the identified methodology used to address social impacts, known as SLCA, has not been applied. According to Guinée et al. (2011), LCA together with LCC will generally suffice to support a process-designing decision. These tools have also been used in the management of plants and companies (Swarr et al., 2011). For policy analysis, however, the environmental assessment requires an extended approach, analyzing inter-sectorial and economy-wide effects which interact with other disciplines. This can only be addressed under the consequential LCA perspective, typically requiring the application of complementary tools, such as economic modeling and mathematical programming, as will be emphasized in this chapter. This usually entails the use of PE and CGE models. It is also worth highlighting at this point that PE models have not been used as such either, although a country-specific, multi-sector optimization model has been specifically built for the Spanish biodiesel supply chain, as a previous step to carry out an analysis in a PE setting.

In accordance with the methodological framework previously set out, Figure 2.2 shows the working plan of the dissertation, including the methodological procedure followed in each section of the Results (chapter III). Chapters I and II correspond to the Introduction and Methodological Overview, respectively. Section 3.1 relies on the traditional LCA methodology to analyze, at product level, the environmental performance of a specific biodiesel system built on second-generation technologies within the framework of the European Integral-b project, further explained in the corresponding section. As one of the three pillars of sustainability, the economic performance of the same system is analyzed in section 3.2 by using LCC, 
complementing the environmental results. In section 3.3, the scope of the analysis is broadened and two biodiesel alternatives for the Spanish transport sector are compared under the consequential approach, by applying a simplified procedure. A thorough analysis of the uncertainty inherent to the LCA methodology is carried out in these three sections (3.1, 3.2 and 3.3) in order to provide reliable results and influence decision-making. As the research progressed in the consequential approach at sector level, economic concepts have been applied for the purposes of estimating the direct and indirect effects of an increased demand for biodiesel in Spain as a result of consumption targets. The aforementioned model of the biodiesel supply chain in Spain is built and run in section 3.4, to simultaneously analyze its environmental and economic implications under different scenario assumptions. Finally, an economy-wide level is considered, and the CGE model, Global Trade Analysis Project (GTAP), is used in section 3.5 to analyze the global impacts of recent European biofuel policies, under a static approach. All these methodologies are further reviewed and described in the corresponding sections of the present chapter. The interpretation of the preliminary outcomes has been carried out at all stages of the research on a cross-cutting basis, in order to identify flaws and weaknesses, and improve the robustness of the models used in the analysis. Chapter IV includes the general discussion of the findings from sections $3.1,3.2,3.3,3.4$ and 3.5 , while in chapter $\vee$ the conclusions of the dissertation are drawn. 


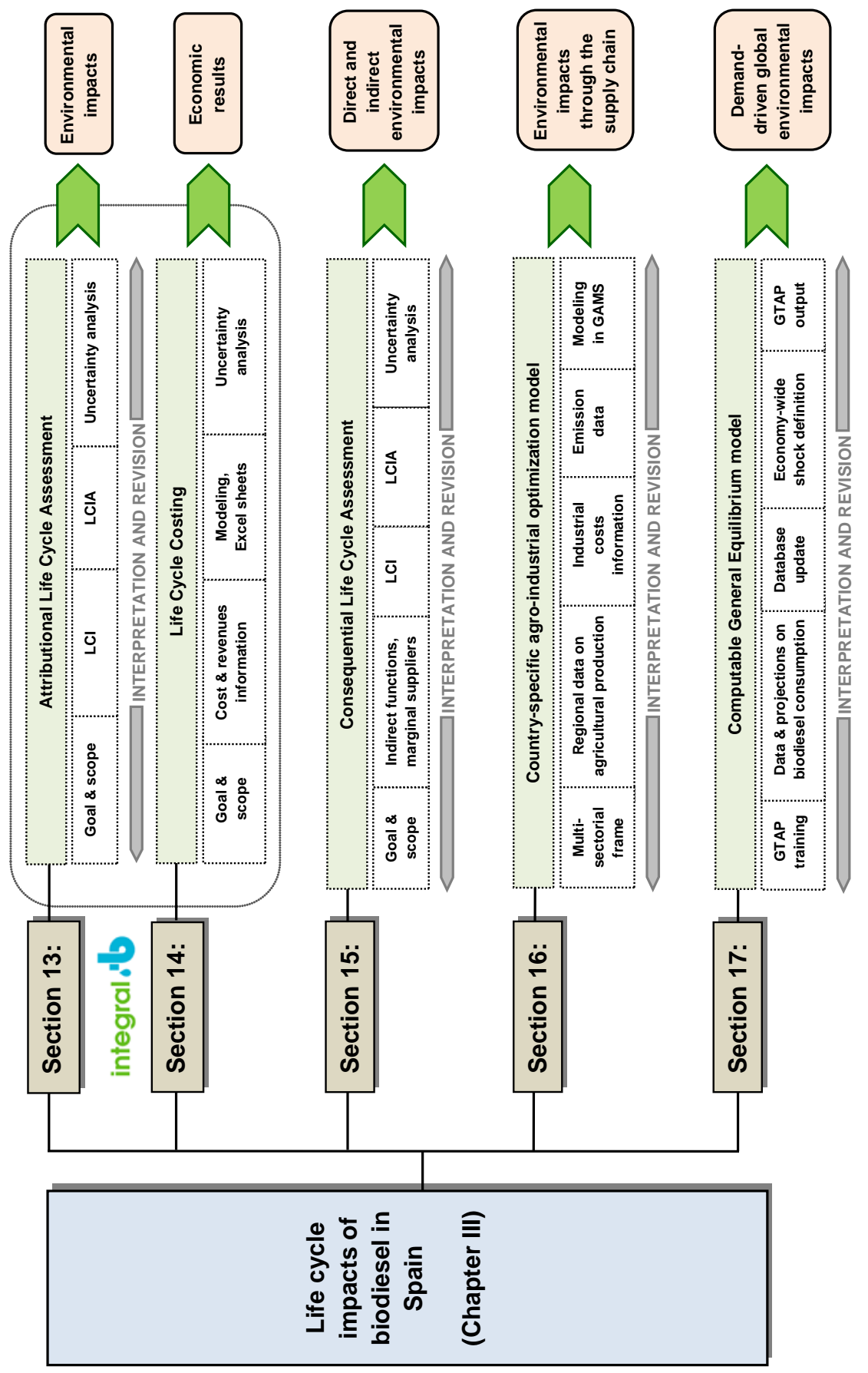

Figure 2.2. Working plan and overview of the methods used in each section of the Results (chapter III). 


\subsection{Attributional Life Cycle Assessment}

The procedures for the implementation of the LCA methodology lie within the environmental management standards ISO 14000, specifically ISO 14040 (2006a) and 14044 (2006b). The first describes the main steps for conducting an LCA, which are summarized in Figure 2.2, namely: a) definition of the goal and scope of the study, b) phase of Life Cycle Inventory $(\mathrm{LCl}), \mathrm{c})$ phase of Life Cycle Impact Assessment (LCIA), and d) interpretation, which must be carried out in parallel at every stage.

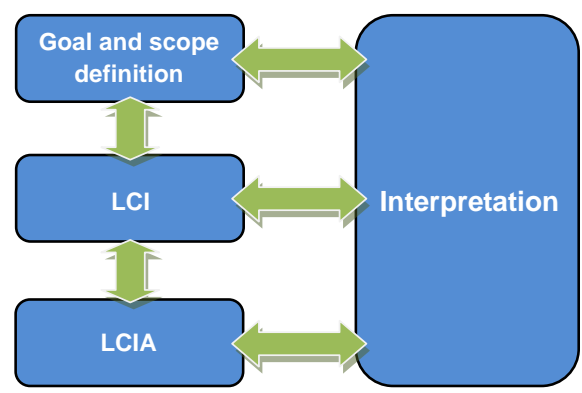

Figure 2.3. Main steps for the application of the LCA methodology. Source: ISO standard 14040 (ISO, 2006a).

These steps consist of:

a) Defining the system boundaries and the Functional Unit (FU). The FU is a key element of the analysis since it is a measure of the function delivered by the system. It represents the reference flow to which the inputs and outputs of the system can be related, and thus quantified. Changing the FU changes the impact results to the same extent since outputs are scaled in a linear fashion. The system boundaries determine the unit processes to be included in the LCA study, that is, which inputs and outputs are considered to be directly linked to the process under study. System boundaries can also refer to the specific geographical area and time horizon in which the process is considered to take place. To compare two systems, they must have the same FU and system boundaries.

b) Dealing with data retrieval and management, that is, collecting quantitative information on the input and output flows of materials, energy and emissions entering and leaving the previously defined system boundaries. These flows must be expressed in terms of the reference flow of the FU.

c) Evaluating the significance of potential environmental impacts using the results from the $\mathrm{LCl}$ phase. Inputs and outputs are classified depending on the impacts to which they contribute. They are subsequently characterized 
following different methods which reflect their relative contribution to the environmental impact, as compared to a reference substance. This stage allows the magnitude of the impacts associated with the delivery of the FU to be determined in terms of compound equivalents (e.g. $\mathrm{CO}_{2}$-eq. integrates the effects of all the compounds causing global warming, $\mathrm{GW}$ ).

d) Interpreting the LCIA results in accordance with the defined goal and scope of the study. ISO 14044 includes a number of checks that can be applied to ensure that the conclusions are adequately supported by the data and procedures used in the study, such as sensitivity and uncertainty analyses. These actions often lead to the re-definition of some aspects of the analysis across all the previous sub-stages (FU, system boundaries, data quality, impact characterization methods, etc).

Impact results are expressed in terms of standardized environmental indicators, which can be chosen either at the midpoint or endpoint level. The midpoint approach, also known as the problem-oriented or traditional approach, translates impacts into environmental themes, such as climate change, acidification, human toxicity, etc. The endpoint approach, also known as the damage-oriented approach, translates environmental impacts into issues of concern, such as human health, natural environment, and natural resources. The term midpoint expresses that the resulting indicator is located on the impact pathway at an intermediate position between the $\mathrm{LCl}$ results and the ultimate environmental damage, the endpoints. As a consequence, the damage-oriented approach requires further allocating the impacts at the midpoint level to one or more damage categories, the latter representing quality changes in the environment which are the ultimate object of society's concern (Jolliet et al., 2004). Both approaches present advantages and disadvantages, using one or another will depend on the goal and scope of the study. Although endpoint indicators are more conclusive from the point of view of decision-makers, their determination entails greater uncertainty in the application of characterization methods. In addition, endpoint modeling can be detrimental to the comprehensiveness of the results (de Haes et al., 1999; Goedkoop, 1995).

\subsubsection{Multi-functional systems}

One of the main issues to deal with when defining the system boundaries during the first step of the LCA procedure is multi-functionality. This is when the system under study delivers other functions than that captured by the FU, which is observed in many real-world processes, such as biodiesel production. As their name suggests, multi-functional systems produce several functional flows, which may be used in turn in other product systems; whenever a system generates product 1 , it also generates product 2 . Hence, it can be considered that impacts are 
not only caused by the production of the FU (product 1 ), but are also motivated by the production of co-products (product $2 \ldots$...). In addition, as has been said, two systems can only be compared if they produce identical functional flows. The environmental burdens thus need to be apportioned between the co-products or multiple functions. There are two approaches to deal with this problem within the LCA framework: system expansion (which is often referred to as substitution) or partitioning (also known as allocation). It must be pointed out that allocation can refer to any method of dealing with multi-functionality, distinguishing between system expansion and partitioning (e.g. Malça and Freire, 2011). ISO 14044 (2006b) recommends "expanding the product system to include the additional functions related to the co-products" whenever possible. On the contrary, other authors recommend the second approach since it is more straightforward (Heijungs and Guinée, 2007). Again, opting for one method or another depends on the goal and scope of the study. These practices can be described as follows:

a) System expansion consists of including the additional function(s) provided by the co-product(s). It is based on the assumption that co-products replace outputs from other life cycles. However, according to Brander and Wylie (2011), this is a vague definition and can refer to two distinct approaches. The first one is the system expansion itself, which implies expanding the boundaries by adding the functions delivered by the coproducts into the systems to be compared, until they fulfill identical functions. The second approach is known as substitution, and implies estimating the environmental burdens avoided by co-products, in order to subtract them from the overall impact caused by the main system and remove indirect functions. These avoided burdens are often referred to as co-product credits. Heijungs and Guinée (2007) argue that ISO standards on LCA implicitly support the substitution method. It must be noted that Finnveden et al. (2009) consider the substitution method a variant of the system expansion method, with the only difference that additional functions are subtracted in the system under study instead of being added to the reference system.

b) Partitioning consists of allocating the environmental burdens to independent mono-functional processes. This is done by applying allocation factors to the impacts generated by all the downstream substages, that is, those processes that take place prior to the sub-stage generating more than one product. These allocation factors can be determined by using different criteria: according to the economic value, the energy content, or the mass of each co-product, among others.

These procedures are in fact artificial constructs, since neither strict monofunctional processes nor avoided processes exist in reality (Heijungs and Guinée, 
2007). As regards system expansion, it must be borne in mind that no process can in practice generate negative environmental burdens or lead to negative environmental impacts. In addition, this approach can pose additional challenges, such as expanding the system ad infinitum if the processes added are also multifunctional. The avoided processes can also be in conflict with the physical and temporal boundaries of the study. Both partitioning and system expansion bring further uncertainty when defining the allocation factors, or when choosing the avoided processes, respectively. The system expansion method usually requires more data than the partitioning method, and increases the complexity of the methodology (Heijungs and Guinée, 2007). The advantages and disadvantages of applying one method or another have been the focus of discussions held to date within the LCA community (Curran, 2007; Suh et al., 2010; Wang et al., 2011).

Both approaches are indeed identified among the studies dedicated to the analysis of the environmental implications of biofuels, since major first-generation feedstocks entail the production of a co-product with diverse potential uses. Kim and Dale (2002) opted for the system expansion approach in their LCA of ethanol production from corn. Their results on the net energy balance were compared with those from other studies (Shapouri et al., 1995; Wang, 1999), which were obtained by means of different allocation procedures. They found that the allocation approach chosen influences the final results more than any other parameter investigated, with differences of up to $37 \%$. Wang et al. (2011) recognize that both mass-based and energy-content-based allocations are problematic when coproducts have distinctly different uses, such as those from biofuel supply chains; although market-based allocation is preferred by economists, this method is subject to a great fluctuation in product prices.

Brander and Wylie (2011) estimated GHG emissions from ethanol production under different scenarios, performing both system expansion and partitioning. As was expected, results exhibited great variability; however, the substitution method was unique in generating negative values. That said, the authors did not recommend the substitution method for life cycle emissions accounting, since considering co-product credits can lead to the wrong conclusion, that the process itself entails the physical removal of $\mathrm{CO}_{2}$, being greater than physical emissions. On the contrary, they consider this procedure appropriate for a consequential analysis, rather than for an attributional, with the aim of evaluating consequences that have already been observed. This is at variance with the guidelines from the Joint Research Centre (JRC, 2010), which points to the substitution approach as the preferred method. In their review of biodiesel studies in the European context, Malça and Freire (2011) detect different allocation methods. Although they do not lean towards any of them, they recommend conducting a sensitivity analysis whenever several allocation approaches seem applicable, to illustrate how different 
methods change the results, as they did in their previous study (Malça and Freire, 2010).

In the biofuel policy arena, both the United States (US) Energy Independence and Security Act (EISA) and the California Low-Carbon Fuel Standard (LCFS) recommend the substitution method to take into account co-product credits when calculating the GHG reductions associated to each biofuel pathway (Mullins et al., 2011). On the contrary, both the European Renewable Energy Directive (RED) and Fuel Quality Directive (FQD) advocate the partitioning method based on the coproducts' energy content, probably following the example of petroleum refinery models, where most products are indeed energy products (Wang et al., 2011).

\subsection{Consequential Life Cycle Assessment}

The consequential LCA aims to evaluate the environmental consequences of a change in the demand for the FU, and tries to overcome the limitations of the attributional approach when quantifying the indirect effects from a decision. This relatively new approach tries to provide a comprehensive framework with which to assess the environmental impacts induced by changes in production and consumption patterns, most often determined by policy and strategic drivers.

As has been seen in chapter I (sections 1.2.1.3 and 1.5.3), one of the effects that has received great attention in recent years is indirect land use change (ILUC), mainly because of its incidence on the GHG balance of biofuels, among other impacts on biodiversity and social structures (Jansen and Rutz, 2011; Phalan, 2009). The multi-functionality of biofuel supply plays an important role in the understanding of ILUC. Most of these market-mediated responses arise precisely from interactions among co-products in the international market, since they may fulfill other functions in different sectors. However, substitution mechanisms are difficult to predict due to its global dimension, and are equally determined by actions underlying the whole economy. Faced with such a challenge, many authors have focused their efforts on modeling the indirect effects of an increased demand for biofuels in different countries as a consequence of public policies, mainly in the European Union (EU) and the US. According to Sánchez et al. (2012), performing a consequential LCA requires choices that are often not transparent in analyses. These are mainly related to the definition of the system boundaries and the treatment of co-products, the estimation of GHG emission factors (including carbon stocks), world market fluxes, future trends in production technologies (including yield improvements), or the appropriate assessment of data uncertainty. However, for a thorough analysis, we agree with the classification established by VázquezRowe et al. (2013), which distinguishes three different consequential modeling approaches, outlined below. 


\subsubsection{System expansion}

As has been seen, system expansion is one of the methodological practices employed to overcome the "multi-functionality problem" in LCA. The substitution method has been specifically used by some practitioners to perform consequential LCAs. They developed accounting devices to describe how the environmentally relevant physical flows to and from the technological system change in response to possible changes in the output levels of the life cycle. These models lie within the simplified approach as referred to by Marvuglia et al. (2013), and are based on causal relationships to define the system boundaries, which mainly depend on technical connections and average data. The associated decisions are usually motivated by the close observation of the markets involved, thus, it can be said that these models are of an economic nature although they usually do not incorporate either economic concepts, or price responses. Hence, they entail a simplification of the real world, since substitution mechanisms usually assume long-term full market elasticity. This is the ceteris paribus assumption that the demand for the functions fulfilled by other product life cycles is constant (Ekvall, 2000). In other words, it is assumed that there will always be an average consumer able to absorb the additional amount of product introduced into the market and there will always be an average supplier able to meet the demand coming from the market (Marvuglia et al., 2013). One of the main implications of this is that these models do not include environmental consequences related to constrained production factors (e.g. the effects from the switch among production factors on the supply side). The only indirect effects arise from an additional, or reduced, availability of co-products from multi-functional processes (Vázquez-Rowe et al., 2013).

In biofuel production systems, indirect functions are generated by co-products, such as protein meals, dried distillers grains with solubles (DDGS) or glycerin, with potential uses in other life cycles (e.g. for animal feed). Despite all the limitations, the system expansion approach in consequential LCA has often been applied to the biofuel context since Ekvall and Weidema (2004) proposed procedural guidelines, consistent with their previous studies (Ekvall, 2000; Weidema et al., 1999). According to them, marginal suppliers must be identified, in order to establish simple inter-sectorial linkages based on co-product displacement. The marginal supplier or technology is that which is affected by a change in demand for the main product in the system. Although this approach considers that the existing market and surrounding production systems are not affected by the studied life cycle (Marvuglia et al., 2013), it is known as a "market-oriented" approach because marginal suppliers come from market figures. The changes are so small (or marginal) though, that they do not affect the determining parameters for the overall market situation, i.e., the direction of the trend in market volume and production costs of the products and technologies involved (Weidema, 2004). For instance, 
Dalgaard et al. (2008) and Schmidt and Weidema (2008) considered palm oil to be the marginal oil in the international market since it has become the most competitive, expanding its market share at the expense of other oils, which is consistent with recent data included in chapter I (section 1.1.2). At the same time, the palm kernel meal, obtained through palm oil processing, may fulfill the same function as marginal fodder products; these were assumed to be soybean meal or barley, depending on the displacement criteria. Similar rules of thumb were followed by Reinhard and Zah $(2009,2011)$. All these studies establish iteration loops to determine the final amount of oil and meal resulting from co-product interactions; loops are based on data on dry matter, oil, protein and energy contents. Since this approach arises from the substitution method, the identification of the actual marginal processes is an obvious source of uncertainty, as happens with avoided processes in attributional LCAs.

In order to address land use change (LUC) impacts, this approach considers that an additional supply of bioenergy crops can be met by means of three mechanisms influencing the agricultural stage (Reinhard and Zah, 2009): expansion, displacement and intensification. The first happens when non-arable land (such as forest or set-aside land) is brought into agricultural production; the second implies the transformation of other crops into bioenergy crops; finally, intensification refers to an increase in yields to meet expanding demand. This is possible thanks to higher input levels and/or technological development, while avoiding LUC. However, neither Dalgaard et al. (2008) nor Schmidt and Weidema (2008) considered any other mechanism but expansion. The authors only report land expansion rates (in terms of $\mathrm{m}^{2}$ per annum). Similarly, Reinhard and Zah (2009) estimated area expansion as a good proxy for the actual effects taking place. They went a step further and quantified the associated $\mathrm{CO}_{2}$ emissions by using the IPCC guidelines (2006). To this end, marginal land uses must similarly be identified, that is, those types of land that are likely to be transformed in a given region. The authors recognize that modeling intensification is challenging since numerous factors contribute to the yield of a given crop. However, in their next study, Reinhard and Zah (2011) included intensification effects as the differences between all the intensive and extensive agricultural production practices.

\subsubsection{Partial Equilibrium approach}

One of the main limitations of the system expansion approach is that it assumes that processes involved in the life cycle are operated under steady-state conditions, and prices of co-products remain unchanged. This means that producers' decisions, including farmers, are not affected by changes in the life cycle, which has important implications when assessing impacts from bioenergy supply chains. In addition, no mechanism of revenue maximization and price equilibrium under 
external constraints are considered (Marvuglia et al., 2013). Nevertheless, it is well known that farmers' decisions are driven by multiple factors, such as profit maximization or risk aversion (Arriaza and Gómez-Limón, 2003). This is why mathematical programming models have been widely applied in literature to predict farmers' responses to external shocks, mainly policy interventions. On the one hand, there are farm models, which try to determine the optimal activity levels under resource constraints; agricultural input levels are conditional on optimization criteria. For instance, Glithero et al. (2012) developed a linear programming optimization model for the financial and environmental assessment of bioenergy production in the United Kingdom, based on crop rotations. Since only the supply side is captured, assuming exogenous prices of agricultural inputs and outputs, these kinds of models are known as supply models. The main limitation of the farm models is the lack of interaction with the rest of the economy, since input-output prices cannot be generated within the model as they have to be set exogenously (Ciaian et al., 2013). On the other hand, one can also find farm-type models, as referred to by the same authors, which try to simulate the effects of agricultural policies on markets, prices and trade. These depart from perfect market assumptions, capturing both the demand and the supply side of a limited number of sectors in the economy, in which markets are cleared at the equilibrium point. The analysis not only concerns the product markets of the technology system itself, but also those in markets influenced by it (Huppes and Ishikawa, 2009). This is why these are known as PE models, in which prices are endogenous, meaning that producers change their price in response to demand, while consumers change their demand in response to price. Hence, these models account for the effects of the prices of other commodities on the consumption and investment decisions.

At industry level, supply models (also called in this case technical models) try to predict how technologies might adapt to different situations, which cannot be done in the linear LCA-type models with fixed input-output relations (Huppes and Ishikawa, 2009). Industrial production is typically multi-chain, since inputs are in turn obtained from other supply chains, entailing interactions among different sectors. This is particularly true in the case of biofuel supply chains, which also interact with the agricultural sector and even with the animal feed sector. Hence, multi-chain optimization models devoted to determining industry configurations for biofuel production under different design conditions are commonly found in literature. These are frequently applied in analyzing investment decisions and can be governed by both economic and environmental criteria, also yielding LCA outcomes. For instance, Zamboni et al. (2011) developed a tool for the strategic design of ethanol production systems based on economic modeling in combination with LCA. Dal-Mas et al. (2011) provide a design framework for the purposes of assessing the economic performance and the investment risk in the entire ethanol 
supply chain, taking into account the degree of uncertainty involved in biomass production costs and ethanol selling prices. Kim et al. (2011) apply similar computational modeling principles in order to determine the optimal supply chain structure for transforming biomass into biofuels in the US, also considering uncertainty.

Although these models are economic in nature and, by definition, multi-sectorial, they do not represent the economic equilibrium between supply and demand of different sectors, since this implies price adjustments. Thus, it is worth noting that neither stand-alone supply models nor multi-sector optimization models are considered PE models unless they implement supply and demand representations to form market models (Britz and Heckelei, 2008). Having supply and demand curves implies endogenous price variations. Nevertheless, these multi-chain economic models present the advantage of being very descriptive while also being "normative", in the sense that they aim to guide actions towards optimal outcomes (Zamboni et al., 2011). In fact, these modeling tools are widely applied to biofuel systems, also incorporating environmental considerations, such as reducing GHG emissions (e.g. Čuček et al., 2012; Freire et al., 2004; Mele et al., 2009; Zamboni et al., 2009b). Biofuel supply chains are complex, and analytical tools can be a very helpful means of fully understanding a multifaceted problem, such as LUC, in response to specific goals.

On the other hand, the approach used by the PE models is that of analyzing the international markets focusing on a limited set of goods, e.g. agricultural goods. They consider the agricultural system as a closed system without linkages with the rest of the economy (Van Tongeren et al., 2001). There is, however, a great diversity of PE models, since they are "problem-oriented", that is, these models are usually built according to the purpose of the study. There is no common model structure, apart from including only the relevant markets and excluding everything else. Hence, we find single-market models, multi-commodity models, agricultural models, multi-chain models, single-country models, multi-country models, etc. Their application in policy analysis is directly proportional to the number of sectors and commodities included, and inversely proportional to the strength of the linkages with the rest of the economy. In general, PE models show the ability to flexibly integrate a wide range of policy instruments, represented as external shocks, since they permit the analysis of the supply and demand responses, trade flows, producer and consumer prices, income indicators and even environmental indicators. Such tools have been commonly used in the field of bioenergy (Ignaciuk et al., 2006; Johansson and Azar, 2007; Sourie et al., 2006; Thompson et al., 2011), and are increasingly applied in consequential LCAs, in which changes in the FU are demand-driven (Vázquez-Rowe et al., 2013; 2014). 
There are some robust PE models specially designed for decision-making processes. Specifically, AGLINK-COSIMO, CAPRI and ESIM are agro-economic models commissioned by the European Commission (EC), scientifically acknowledged as a means of simulating policy changes within the European agricultural sector, which have been used in the estimation of ILUC effects from biofuel mandates (Blanco-Fonseca et al., 2010; Hélaine et al., 2013). Havlík et al. (2011) used the GLOBIOM model with the same aim; it covers 30 world regions, 18 crop products and the three most land-intensive sectors (agriculture, forestry and bioenergy) to analyze the interaction of economic activity and biophysical indicators. The IMPACT model, built by the IFPRI, is a global PE model which covers over 40 agricultural commodities (accounting for virtually all world food production and consumption) and a set of 115 country-level supply and demand equations where each country model is linked to the rest of the world through trade. It has been used, for instance, to understand the role of biofuel policies in the recently observed food-price hikes (Rosegrant, 2008). Such these models could be applied in the study of early Common Agricultural Policy instruments (e.g. price support), as Ciaian et al. (2013) point out, but addressing the current support scheme may require clear methodological development to take into account farm heterogeneity, including farming practices. This is why PE models are increasingly incorporating farm-level detailed modules or "layers" (e.g. CAPRI-FT by Gocht and Britz, 2011).

Besides being classified according to the sectors, commodities and countries they include, PE models can be static or dynamic. In static models, endogenous variables (those determined inside the model) are all in equilibrium with the given values of the exogenous variables (those determined outside the model). Then they will remain at those values until the system is perturbed by a shock. This means that the equilibrium maintains the same conditions from shock to shock. Static PE models thus simulate a single period market outcome without and with regulation. Each solution of the model is, therefore, static in nature. Dynamic PE models are extended to incorporate temporal dynamics, such as the adoption of new technology. This approach assumes that some factors are time-dependent, that is, their value in period $t$ is different to their value in period $t-1$. FASOM is an example of a dynamic, non-linear programming model which was originally developed to evaluate the welfare and market impacts of alternative policies for sequestering carbon in trees in the US, although it has been applied to a wider range of forest and agricultural sector policy scenarios (Lee et al., 2005; Link et al., 2008). Indeed, it has been used in the shaping of the second US Renewable Fuel Standard (RFS2), for evaluating domestic land use changes, in parallel with the FAPRI model, which is a static, multi-market, PE model with a more detailed representation of international land use (Darlington et al., 2009). 


\subsubsection{Computable General Equilibrium approach}

While PE models only capture inter-linkages between a limited number of sectors, CGE models incorporate the modeling of all the markets in an economy. This is why they are referred to as economy-wide models (Vázquez-Rowe et al., 2013). There is a wide variety of them, again depending on the level of aggregation, the policy issues to be addressed, and their temporal scope (static or dynamic). One can find single-country models or multi-country models, with the only requirement being the inclusion of all the sectors in the economy. Typically, a base year is used to build a CGE model; that is a year in which the modeler can find consistent production, consumption, input-output structure, policy and trade data. This baseline data is usually organized in Social Accounting Matrices (SAMs), matrix representations of the flows of all economic transactions that take place within an economy (regional or national). The core assumption is that the economy is in equilibrium in the base year, with all the markets cleared, and all the accounts consistent (Marvuglia et al., 2013). Figure 2.3 depicts the underlying structure of a typical CGE model. Essentially, firms carry out their economic activity at the expense of intermediate inputs and primary production factors (land, labor, capital). Wages translate into money for households, which is spent on commodities (services), private savings and taxes for the government. The government spends its income on purchasing commodities and savings, while savings-investment also generates a demand for commodities. These can come from the domestic or foreign markets. This structure is common to all the regions in the model. In the initial equilibrium, balances must hold for the government, saving-investment and foreign trade, and supply equals demand in all the markets. In other words, spending on goods and services, taxes and savings must equal income.

Depending on whether it is savings or investment that is assumed to adjust to maintain the savings-investment equilibrium, we find savings-driven models, such as GTAP, or investment-driven models. In the first group, the savings rate is exogenous and constant, thus investment is forced to change to accommodate the change in the supply of savings. In the other group, the aggregate value of investment is fixed and the savings rate has to adjust until savings are equal to investment spending. This is known as "macro-closure" and must be borne in mind when interpreting the results, since using one or the other will lead to a different commodity composition of demand (Burfisher, 2011). 


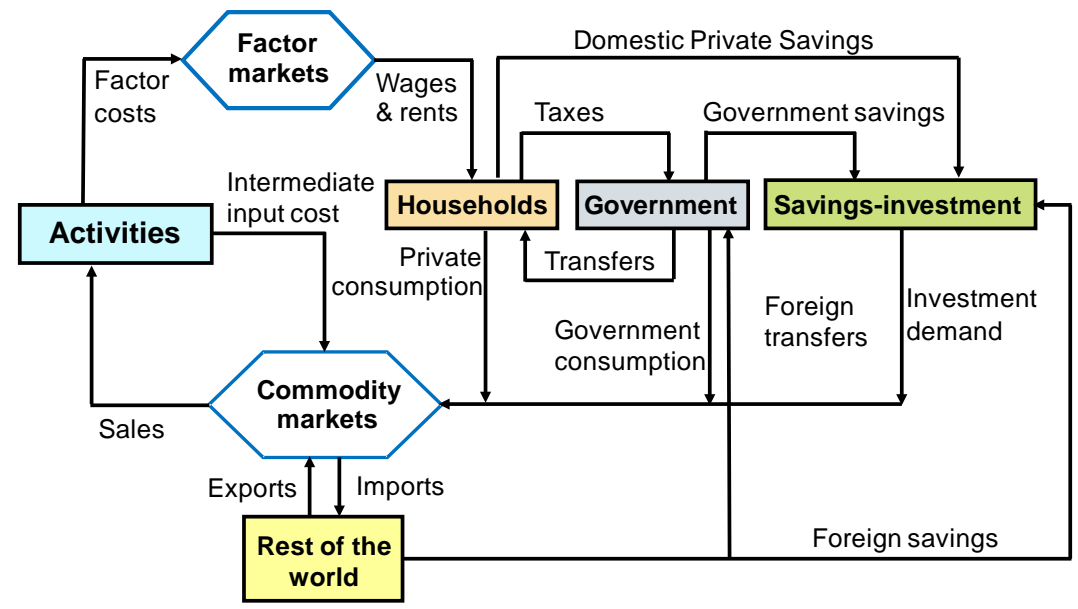

Figure 2.4. Underlying structure of a typical CGE model. Arrows show monetary flows. Source: Robinson (2014).

Furthermore, CGE models must define behavioral equations for both producers and consumers in order to represent their decisions. In some models, producers are assumed to be cost-minimizers who choose the least-cost level of inputs for a given level of output, given input and output prices and technological feasibility. Other models assume that producers are profit-maximizers (Burfisher, 2011). The supply-side consists of production functions describing the ways that inputs are combined with each other during the production process. These functions are "nested" because inputs are organized in subsets before they are assembled to make the final product. In the simplest structure, the producer chooses how to combine inputs in the sub-nest of primary production factors, and independently chooses how to combine intermediate inputs in the corresponding sub-nest. Finally, intermediate inputs and primary factors are combined in the aggregate production function. All these relationships are governed by elasticities of substitution, based on econometric studies and/or calibration as well as ad-hoc assumptions, which express the relationship between changes in the ratio of input quantities and the ratio of input prices in each sub-nest.

Apart from representing both the structural features and macroeconomic constraints affecting the supply side and the functioning of the factor markets, CGE models aim to capture the households' heterogeneity. To this end, modelers try to choose the utility functions that best describe consumer preferences. These equations quantify how much utility, or satisfaction, consumers derive from any given combination of goods. There are some specific functional forms that are widely used by CGE modelers, and differ in terms of income and substitution elasticities (in consumption, not to be confused with those in the production 
function). Income elasticity measures the responsiveness of the demand for a good to a change in income, while substitution elasticity expresses the change in relative quantities of goods given a change in their price ratio. Consumer preferences for domestic and imported goods are also modeled under different approaches, the most common of these being the Armington approach. Any further description of micro-economic theory that goes beyond the CGE models is also beyond the scope of the present dissertation.

CGE models are highly regarded in public policy analysis (e.g. trade policies) and show even greater applicability in decision-making than PE models, something which is also true in the field of bioenergy. It must be taken into account that although PE models allow for a detailed observation of the responses across the sectors related to biofuel production, indirect effects most likely take place outside the biofuel supply chain (Marvuglia et al., 2013). The microeconomic foundation of CGE models provides a consistent framework for studying price-dependent interactions between the energy system and the rest of the economy (Böhringer, 1998). As for examples of CGE models that have become a standard tool for biofuel policy analysis, the dynamic model MIRAGE, built by the IFPRI, has been used to determine ILUC emissions factors to be included in the EC's new proposal on biofuels (Laborde, 2011), as mentioned in section 1.2.1.3 of the Introduction. The GTAP-BIO model has been used in the shaping of California's LCFS (CARB, 2009; Taheripour and Tyner, 2013a). At the same time, the World Bank continues relying on the use of the GTAP model to address the implications of trade policies and agreements in terms of poverty and development (e.g. Hertel and Winters, 2006; Ianchovichina and Martin, 2003). Different models may give different answers to the same policy question; this depends on their structure, the dataset and parametric assumptions.

\subsubsection{The Global Trade Analysis Project}

The GTAP model is a static multi-region, multi-sector applied general equilibrium model developed by the GTAP team at Purdue University. It was first released in the year 1992 and has been evolving since then, even extending GTAP's standard modeling framework to incorporate dynamic behavior. GTAP consists of a fully global database, a standard general equilibrium framework, and software for manipulating the data and implementing the standard model. The global data base combines detailed bilateral trade, transport and protection data characterizing economic linkages among regions, together with individual country input-output databases which account for inter-sectorial linkages within regions (Hertel and Walmsley, 2008). The data set is mainly structured in the form of SAMs, provided by a worldwide network of researchers and institutions. It also contains estimated values of the substitution elasticities obtained from the literature. Under the static 
approach, the original dataset represents the benchmark equilibrium in the world economy over a period of time. The initial equilibrium is calibrated for the parameter values in the underlying dataset. For instance, the GTAP 7 (Narayanan and Walmsley, 2008) depicts the world economy in 2004, disaggregated in 57 sectors and 113 regions.

Due to its global scope, the GTAP model is an appropriate tool to analyze large perturbations affecting a large system such as a significant European substitution of fossil fuels by renewable energies under a consequential LCA approach (Dandres et al., 2011). It models price variations and non-linear effects on each economic sector including those which are not directly affected by the perturbation itself. This is especially useful when estimating bioenergy impacts, given the direct and indirect relationships that this sector maintains with the rest of sectors in the economy (Kretschmer and Peterson, 2010). Sánchez et al. (2012) also agree that the estimation of ILUC from biofuels requires the use of economy-wide models such as GTAP. However, it must be noted that CGE models do not distinguish between direct and indirect LUC effects, as pointed out by Laborde (2011); their outcomes depict overall changes at the global scale, and it is not possible to know where additional production of biofuel feedstock exactly occurs.

Specifically, there is an extension of the standard GTAP version (Hertel, 1997), the GTAP-E (Burniaux and Truong, 2002), especially designed to capture the effects of changing energy policies on climate change (e.g. Nijkamp et al., 2005). It models the energy-economy-environment-trade linkages by incorporating energy substitution in the primary factors sub-nest of the production function. This version was subsequently extended by McDougall and Golub (2007) to improve its applicability to a wider range of energy-environmental policy scenarios. Taheripour et al. (2007) further modified it to incorporate the potential for biofuels to act as a substitute for petroleum products; biofuels from coarse grains, sugarcane and oilseeds were introduced, together with a by-product which could be used in the livestock sector. Finally, Birur et al. (2008) calibrated the model in tune with observations of key economic indicators in the period 2001-2006, coinciding with an intense expansion of the biofuel sector in the US and the EU. Specifically, they calibrated some elasticities of energy substitution between biofuels and petroleum products in each region and implemented a land use module permitting the estimation of LUC in different agroecological zones (AEZs), with the associated emissions. The prominence given to energy substitution makes this model a useful tool for the study of the implications of a biofuel mandate, which will have a huge effect on the economy if alternative fuels are not good substitutes for petroleum products and the other way round (Golub and Hertel, 2012). The land use module tries to capture land heterogeneity by including 18 AEZs, based on climate, precipitation and moisture conditions. The competition between the differing uses 
to which land can be put in a given AEZ, triggered by biofuel policies, is based on historical observations and governed by transformation elasticities. Crop yields are endogenous. The only limitation is that price-induced increases in cropland must be at the expense of pasture or commercial forests, and the depletion of rainforests or other ecologically-valuable non-commercial land cannot be simulated (BlancoFonseca et al., 2010). GHG emissions are also calculated by the land use module, incorporating detailed data on ecosystem carbon stock in order to determine $\mathrm{CO}_{2}$ emission factors (according to the Woods Hole Research Center database). The underlying production function in the GTAP-BIO model (Birur et al., 2008) is shown in Figure 2.4.

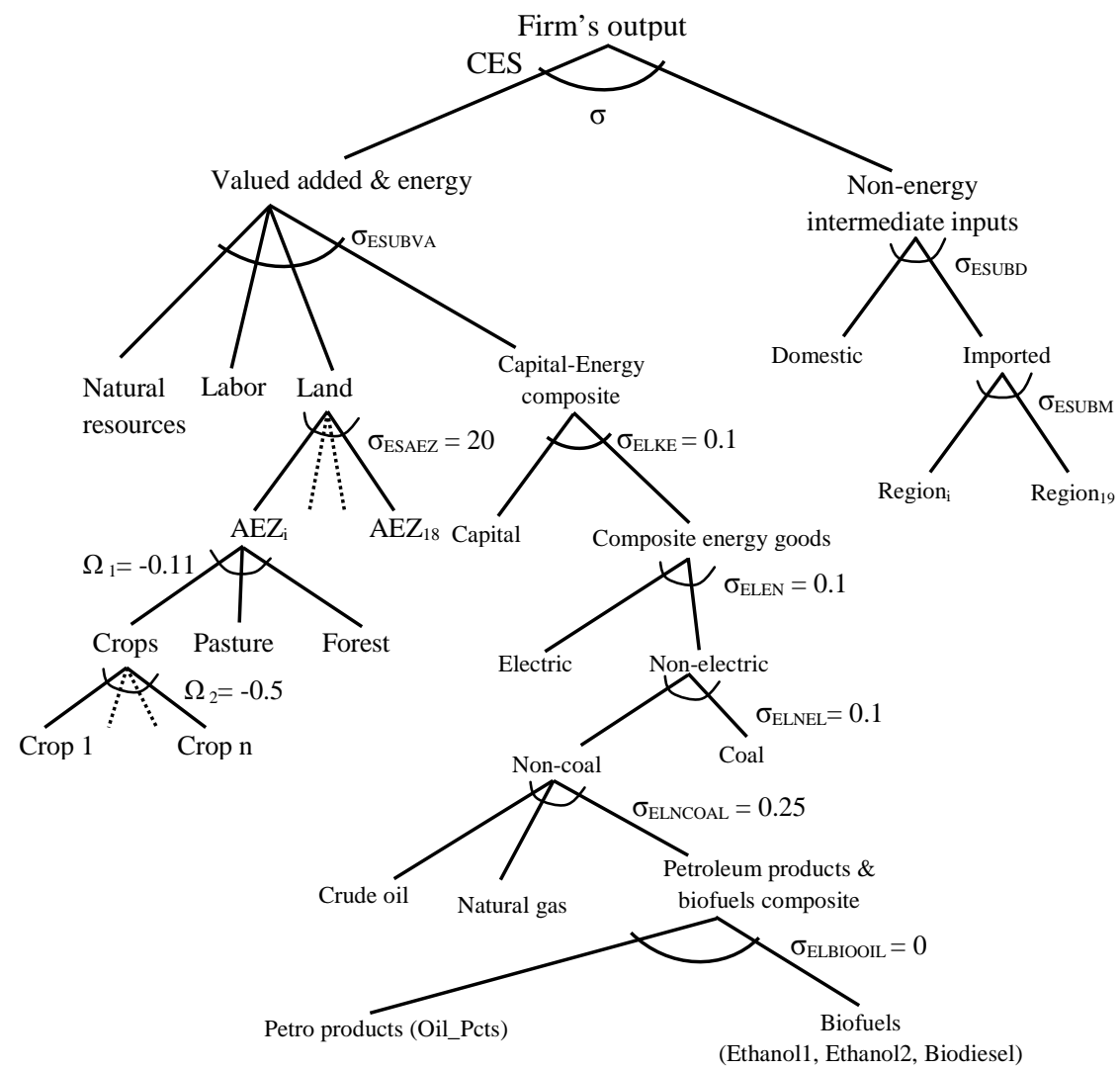

Figure 2.5. Production nest in the GTAP-BIO model. CES: constant elasticity of substitution function; $\sigma_{\mathrm{x}}$ : elasticities of substitution; $\Omega_{\mathrm{n}}$ : elasticities of land use transformation. Source: Birur et al. (2008).

The GTAP-BIO has been broadly applied to analyze large-scale impacts of biofuel mandates, mainly in the US and the EU (Banse et al., 2008, 2011; Hertel et al., 
2008; 2010). Both regions have approved ambitious targets but have limited capacity for agricultural land expansion. However, it must be pointed out that different assumptions on the model structure can lead to divergences in the LUC results. For instance, Taheripour et al. (2010) examined global impacts from biofuel mandates by taking into account the 2007 EISA for the US, and a conservative target of a $6.25 \%$ share for the EU by 2015 , permitting, and not, that biofuel byproducts substitute animal feed. Results illustrate how considering substitution mechanisms reduces the demand for cropland and moderates the indirect effects from first-generation biofuel consumption. The GTAP-BIO model is continually updated in different directions, e.g. to incorporate second-generation biofuels (Taheripour and Tyner, 2011).

\subsection{Life Cycle Costing}

LCC arises from the application of the a life cycle perspective to economic analysis: it aims to explain the total cost of goods throughout their full life cycle, which includes research, procurement and development, construction, operation and maintenance, and finally disposal. This tool was originally conceived to help in decision-making; to determine the most cost-effective option from different competing investment alternatives, especially when long-term investment is required and when the implementation of each option is equally appropriate on technical grounds. Not surprisingly, the LCC methodology was firstly applied to the building sector (Woodward, 1997). The main difference between conventional investment calculus and LCC is that the LCC approach was expanded to consider not only investment costs, but also operating costs during the product's estimated lifetime (Gluch and Baumann, 2004). Under this early definition, LCC seeks to optimize the cost of acquiring, owning and operating physical assets throughout their useful lives by attempting to identify and quantify all the significant costs involved (Woodward, 1997). In this way, LCC results provide a first indication of the economic feasibility of the process, although "hidden costs", as referred to by Campbell et al. (2011), are not included; these include tax exemptions and subsidies, which are borne by tax payers, or other costs for the society (e.g. for treating the health effects of fuel combustion). It must be borne in mind that, in the case of the biofuel sector, these two aspects, subsidies and potential environmental benefits, have been one of the main drivers of investment, as explained in chapter I (sections 1.1, 1.2.2 and 1.3).

It is important to emphasize that a "traditional" LCC does not become an environmental accounting tool just because it contains the words life cycle; the system boundaries do not include all environmental costs (Gluch and Baumann, 2004), understood as externalities. According to a more up-to-date perspective, the LCC should also include external costs from environmental damages connected 
with the products (Shapiro, 2001). This ensures the estimation of the whole economic burden of the activity. These costs are not incurred by the company (nor by the consumer, except some taxes intended to prevent environmental damages) but rather by the society (governments) or even by future generations. To return to the analysis of biofuel systems, the direct cost comparison of biodiesel and diesel by means of LCC would not be a true reflection of their real potential benefits or costs if environmental externalities were not included. However, the quantification of the associated costs is difficult because it is not often clear which damages are, or will be, connected to the interventions caused by a product system (Swarr et al., 2011). As an example of the quantification of these potential benefits, Silalertruksa et al. (2012) evaluated the influence of externalities on the cost performance of various palm oil biodiesel blends (B5, B10 and B100) when internalized into their respective production cost for the case of Thailand. The authors used an income elasticity of willingness-to-pay as a multiplier factor for the transferral of the values of selected environmental damage costs, obtained by means of the Environmental Priority Strategies (EPS) methodology. The results indicate that the total environmental cost of palm biodiesel, in comparison with diesel, is about $3-76 \%$ lower; this depends on the blending levels, mainly due to a lower depletion of fossil resources and lower $\mathrm{CO}_{2}$ emissions. It must be noted that the authors did not include LUC for the calculation of these emissions, although they point out that the subsequent impacts may be important in Thailand in the future. Hence, incorporating LUC into the LCC procedure may be interesting as a way of estimating the overall environmental costs of the expansion of bioenergy crops. This directly points to other approaches included in this dissertation, namely PE and CGE models described in sections 2.3 .2 and 2.3.3, respectively, to estimate GHG emissions from direct and indirect LUC.

The application of LCC in combination with LCA has been gaining in importance in an attempt to address the multi-dimensional aspects of the term "sustainability", since it implies not only environmental goals but also others of an economic and social nature, as has been stated in section 2.1. Just as LCA can help to identify those critical sub-stages in environmental terms, LCC helps to identify those stages that constitute an opportunity to reduce costs. However, although both LCA and LCC apply a life cycle approach, they differ in some methodological aspects, mainly the purpose and the system boundaries. However, there are also differences as regards the accounting principles and their treatment of time since, as Norris (2001) points out, they try to answer different questions. Authors, such as Heijungs et al. (2013), have made an effort to align LCA and LCC. In spite of these obstacles, combining LCA with LCC allows the important relationships and tradeoffs between the economic and life cycle environmental performance of alternative scenarios to be taken into account. 
In regard to the system boundaries, while LCA considers all the processes causally connected to the physical life cycle of the product, LCC considers all the activities causing direct costs or benefits to the decision-maker during the economic life of the investment. This is why the first includes flows of pollutants, resources, and materials within the system boundaries, and the second includes the cost and benefit monetary flows directly affecting the decision. As an example, LCCs of bioenergy often consider capital goods, whereas including impacts from capital goods is not a common practice in LCA, since their relevance depends on the process and the impact category (Frischknecht et al., 2007). For instance, Luo et al. (2009) included the annualized costs of capital investment, while Campbell et al. (2011) took the annual amortization costs incurred when establishing the production system into account. Zhang et al (2013) took process scale into account as well, since the size can significantly affect the expected economic performance. As happens in LCA, another important issue is the way the co-products' contribution is taken into account. In LCC, co-products with market value can simply translate into revenues for the producer, improving the viability of biofuel facilities. This would be equivalent to the substitution approach, while partitioning can also be applied. For instance, Luo et al. (2009) allocated fixed capital investment and operating costs between ethanol and co-products based on their economic values.

Another critical aspect in LCC is data quality, which mainly depends on cost allocation methods, cost management systems, data availability and confidentiality (Ciroth, 2009). Data quality covers different aspects such as time horizon, market dynamics, or the life cycle stage that is being addressed. For instance, the use of LCC in the design phase implies greater uncertainties than applying LCC in the operation phase (Schmidt, 2003). In addition, since the market dynamics are significantly strong, the uncertainty in LCC may be much greater than the parameter uncertainty in LCA. Specifically, the uncertainty in LCC outcomes is affected by aspects that do not necessarily influence the uncertainty of future environmental performance, such as taxation, wages, discount rates, changes in market prices driven by surpluses and market trends, etc (Schmidt, 2003).

\subsection{Uncertainty analysis}

Although the LCA methodology emerged as a decision-making aid, uncertainties in the results have often been raised as a major obstacle to a broader use. The present section aims both to clarify concepts related to uncertainty and to provide tools for its quantification in order to enhance the applicability of the life cycle methodologies. 
The term uncertainty generally refers to random errors (e.g. imprecision in measurements), whereas variability accounts for stochastic variation in data (e.g. seasonal and spatial variation of precipitation) (Geisler et al., 2005). According to the definition of Huijbregts (1998a), uncertainty comes from inaccurate measurements, wrong estimations, unrepresentative or missing data, modeling assumptions, etc., which are implicit to any attempt to model the real world. A distinction has been traditionally made between epistemic or systematic uncertainty, which is due to an incomplete state of knowledge, and stochastic or statistical uncertainty, which is observed every time the same experiment is run due to inherent variability of the natural phenomena. These two different natures of uncertainty are usually treated together and referred to by the term "uncertainty" (Clavreul et al., 2012).

There are different sources of uncertainty when performing an LCA, namely:

a) Uncertainty due to choices, arising from assumptions when outlining the goal and scope of the study. Both the definition of the FU and that of the system boundaries entail choices, steps which become critical for the reliability of the results.

b) Parameter uncertainty, due to data variability. Inventory data is usually subject to variability as a consequence of multiple factors, such as imprecise or incomplete measurements, lack of data, or variability in the process conditions. However, practitioners usually assign a single value to each model parameter leading to a deterministic result.

c) Model uncertainty, due to the mathematical models underlying LCIA calculations. There are several impact assessment methods with which to characterize the environmental interventions in the $\mathrm{LCl}$, which can lead to divergences in the environmental results.

Apart from these sources of uncertainty, arising from the application of the LCA methodology, results are also influenced by spatial and temporal variability, since the location and the time frame in which a process takes place obviously determines the physico-chemical and ecological properties of the environment.

Biofuel systems are not an exception, and LCA outcomes are subject to great uncertainty. Obviously, results of the environmental performance of biofuels vary substantially depending on the feedstock and technology considered, as might be understood from the intense debate in the policy arena which has been outlined throughout chapter I (sections 1.2 and 1.5.4). Von Blottnitz and Curran (2007) focused their review on ethanol studies, and analyzed the results in terms of replaced fossil energy per hectare of land used, energy yield ratio, GHG saving and other potential impacts on human health and the environment. They reached 
divergent conclusions when comparing results arising from identical FU and system boundaries, mainly driven by crop productivity under different climatic conditions and the nature of the feedstock.

However, result variability is also detected when analyzing the same type of feedstock and location. Malça and Freire (2011) reviewed 28 LCA studies addressing the production of biodiesel from the most representative feedstock in the EU, which is rapeseed. These studies were selected because they included detailed information on the methodology, assumptions and data used, which permitted the comparison of results in terms of the same FU. They concluded that uncertainty depends on methodological procedures (or modeling choices), rather than on data or production conditions. Specifically, key issues were the treatment of co-products and the land use modeling approach (including $\mathrm{N}_{2} \mathrm{O}$ emissions from soil). D'Avino et al. (2015) calculated the GW impact of biodiesel based on rapeseed and Ethiopian mustard cultivated in Italy, with special emphasis on the influence of co-product treatment within the LCA methodology (energy allocation vs. system expansion). They found that co-product valorization is critical for the sustainability characteristics of the supply chain.

In view of this drawback to the quality and robustness of the LCA outcomes, efforts have been made within the scientific community to quantify uncertainty and make it explicit. Increasingly, uncertainty assessments are being included in the interpretation phase of the LCA procedure, although different methodologies can be applied, depending on the goal and nature of the model. The most common techniques are outlined below, which have also been applied in the different sections that make up chapter III. All the aforementioned sources of uncertainty also interfere when PE and CGE approaches are incorporated into the LCA methodology, mainly uncertainty due to modeling choices and parameter uncertainty.

\subsubsection{Scenario analysis}

Multi-functionality is a critical issue in biofuel systems, as has previously been seen. The way that practitioners deal with indirect functions brings further uncertainty, in addition to that arising from the definition of goal and scope. We can thus distinguish 3 levels of uncertainty due to choices when performing an LCA:

1) In regard to the system boundaries: considering a greater or smaller quantity of processes in the life cycle obviously leads to different results. For instance, considering emissions from LUC can be detrimental to the GHG balance of biofuels when biomass is produced in carbon-rich ecosystems, as sections 3.3 and 3.4 demonstrate. Another common cut-off is the exclusion of capital goods from inventories; how the decision to do 
this influences the LCA results for different sectors has been addressed by Frischknecht et al. (2007).

2) In regard to the allocation method: LCA results are largely dependent on the allocation method selected for co-product evaluation (partitioning vs. system expansion).

3) In regard to the allocation criteria: even when applying the same method for taking the contribution of co-products to the overall impact into account, additional uncertainty arises from the allocation criteria chosen. Specifically, when performing partitioning, allocation factors can be defined according to different properties or principles of causality (mass, economic value, energy content, etc.); when performing system expansion (substitution), defining co-product credits entails choosing which processes are equivalent and in which conditions they operate. In addition, price ratios or another indicator for value-corrected substitution, can be estimated, if desired. This "what-if" reasoning, as referred to by Heijungs and Guinée (2007), is due to the speculative nature of the LCA methodology.

Opting for an attributional LCA or a consequential LCA is, in the end, a methodological procedure with its associated uncertainty. This decision implies choices at levels 1, 2 and 3, simultaneously. Firstly, the system boundaries must be expanded in order to include indirect effects; this requires the application of the system expansion approach, usually by means of substitution. Secondly, the estimation of market-mediated responses entails what-if reasoning, such as determining those marginal products affected by changes in the demand for the main product in the life cycle.

According to ISO 14044 (2006b), whenever several allocation approaches seem applicable, an uncertainty analysis shall be conducted to illustrate how different methods change the results. Scenario analysis is presented as a tool for dealing with all these sources of uncertainty, thus keeping the what-if reasoning as much as possible out of the LCA methodology itself (Heijungs and Guinée, 2007). It consists of testing different options individually and observing the effect of these changes on the final result (Clavreul et al., 2012). This yields discrete results which relate the LCA outcomes with the corresponding assumption. To this end, scenarios must first be defined during the goal and scope definition phase. For instance, when performing substitution, biofuel co-product credits can be diverse; glycerin can be used for process energy (which would set up scenario 1), animal feed (scenario 2), and displacing propylene glycol (scenario 3) or synthetic glycerin (scenario 4). Each scenario will lead to different results, which can be compared with each other provided they have the same FU (and temporal and spatial scope). 
One practical example is the study by Reinhard and Zah (2009). The authors expressed the study's results in terms of different scenario formulations, as summarized in Table 2.1, and found that they varied significantly. Gnansounou et al. (2009) and Wang et al. (2011) also carried out thorough scenario analyses of co-product allocation methods in the well-to-wheel analysis of first-generation ethanol.

Table 2.1. Example of scenario analysis in LCA. Source: Reinhard and Zah (2009).

\begin{tabular}{lll}
\hline Scenario: & Approach: & Description: \\
\hline REF & Attributional & Diesel is imported \\
SME_ATT & Attributional & Soybean biodiesel is imported, allocation factors \\
SME_NO & Attributional & Soybean biodiesel is imported, no allocation factors \\
SME_OIL_R & Consequential & Soybean biodiesel is imported, rapeseed oil from the EU as marginal oil \\
SME_OIL_P & Consequential & Soybean biodiesel is imported, palm oil from Malaysia as marginal oil \\
PME_ATT & Attributional & Palm biodiesel is imported, allocation factors \\
PME_NO & Attributional & Palm biodiesel is imported, no allocation factors \\
PME_OIL_R & Consequential & Palm biodiesel is imported, rapeseed oil from the EU as marginal oil \\
PME_OIL_P & Consequential & Palm biodiesel is imported, palm oil from Malaysia as marginal oil \\
\hline
\end{tabular}

These are also referred to as "assumption scenarios" by the EC (2010b), and should combine variations of the most influential assumptions for the purposes of representing reasonable worst and reasonable best cases around the system(s). Finally, as Heijungs and Guinée (2007) conclude, the goal and scope definition phase provides an excellent place to define scenarios that take into account, for example, differing levels of technological development, market shifts, etc, which can be an extremely useful means of moving towards the implementation of the consequential approach in LCA.

\subsubsection{Sensitivity analysis}

In general, a sensitivity analysis consists of evaluating the influence of input changes on the model results, which could overlap with the definition of scenario analysis given in the previous paragraphs. This is why, according to the definition of the EC (2010b), "assumption scenarios" refer to both varying the key data in the model and/or changing key methodological assumptions. In the present dissertation, we use the concept of sensitivity analysis to designate the technique that changes model parameters one-at-a-time to quantify their influence in overall results. This allows the identification of where the uncertainties are, and how large they can be. As Malça and Freire (2010) stated, the contribution of each parameter to the overall uncertainty is a combination of two factors: the model's sensitivity to the parameter, and the inherent uncertainty of the parameter. For instance, many studies into biofuel life cycles including LUC pointed to $\mathrm{N}_{2} \mathrm{O}$ emissions from soil as being a critical factor when analyzing GHG emissions (Malça and Freire, 2011; 
Mullins et al., 2011). This is the result of the two components: on the one hand, the inherent variability of $\mathrm{N}_{2} \mathrm{O}$ emissions (since they depend on multiple factors, such as soil properties, climatic conditions, type and dose of the fertilizers applied, etc); on the other hand, the major contribution of this gas to GW since, according to Forster et al. (2007), the characterization factor of $\mathrm{N}_{2} \mathrm{O}$ is 298 , as compared to the reference compound $\mathrm{CO}_{2}$, which has exactly 1 . The aim of the sensitivity analysis is to analyze the first factor, providing valuable information on which of the key parameters most influence the uncertainty of the results to a larger extent. In this sense, a sensitivity analysis may be an extremely helpful tool with which to identify which parameters require accurate statistical information in order to reinforce the results' robustness. Finally, the model's sensitivity to input parameters can be expressed in terms of their contribution to the variance of the results.

A common practice in LCA is to change parameters arbitrarily (e.g. $\pm 20 \%$ around the average value), as Bernesson et al. (2006) or Röös et al. (2010) did, and analyze the model outcomes separately for each parameter. This can be understood as a "perturbation analysis" as defined by Heijungs and Kleijn (2001). Performed in this way, a sensitivity analysis does not require additional data on actual parameter variability to be specified. Another way of performing a sensitivity analysis when uncertainty estimates of input parameters are available is to change parameters one-at-a-time according to their associated variability. Sonnemann et al. (2003) performed the sensitivity analysis in this way, which proved very useful for the subsequent Monte Carlo simulation. Hence, sensitivity analysis is often used as a complementary tool for stochastic uncertainty assessment when dealing with uncertainty in the inventory data.

\subsubsection{Monte Carlo analysis}

In the early stages of the development of the LCA methodology, conclusions were frequently drawn from the outcomes of deterministic models, which assigned a single value to each parameter. However, LCA practitioners have become increasingly aware that there is inherent variability associated with each parameter, thus using only average values may be misleading and detrimental to its ability to influence decision-making (Lloyd and Ries, 2007). For example, Huijbregts et al. (2003) found parameter uncertainty more important than uncertainty due to choices or model uncertainty. Much research work has been conducted with the aim of clarifying the concepts linked with uncertainty in the $\mathrm{LCl}$ data and conceiving tools for its quantification (Heijungs, 1996; Heijungs and Kleijn, 2001; Huijbregts et al., 2001). The EC (2010b) recommends combining scenario analysis with stochastic uncertainty calculation when performing an LCA, especially when comparing life cycle alternatives (e.g. Mullins et al., 2011). The Monte Carlo simulation is 
specifically mentioned in the handbook as an especially suitable method for addressing such stochastic uncertainty.

Stochastic modeling consists of propagating input uncertainties to calculate the uncertainty in the results. Although there are different methods for the propagation of data uncertainty, the Monte Carlo analysis is the most frequently-used method in LCA (e.g. Mullins et al., 2011; Sonnemann et al., 2003; Spatari et al., 2010). It was also chosen by Laborde (2011) and Plevin et al. (2010) to analyze the uncertainty in ILUC emission factors. This method refers to the traditional technique for using random or pseudo-random numbers to sample from a probability distribution (Palisade Corporation, 2009). It converts the deterministic model into a probabilistic model as it builds up random scenarios which are consistent with the key process parameters and their probability distributions. In each simulation run, the randomly selected values from all the previously defined uncertainty distributions are used for the impact calculations. The outcome of repeated calculations is, in turn, a probability distribution of the possible expected outputs, which approaches the distribution of the true results when the number of calculations rises sufficiently (often above 1000), according to the EC (2010b). To perform the Monte Carlo simulation, quantitative information on the parameters' uncertainty, like standard deviations or coefficients of variation, must be available in order to specify the probability distribution. Obtaining the right uncertainty information and deciding which statistical distribution is appropriate is not an easy task (Heijungs and Frischknecht, 2005), and assumptions have to be made. As noticed by Clavreul et al. (2012), probability distributions are often arbitrarily selected according to different criteria. The characterization of the most frequent probability distributions is, however, beyond the scope of the present dissertation.

The Monte Carlo simulation requires quite some computing time since around 10,000 runs are recommended in order to get reliable results (Morgan and Small, 1992). This means performing the impact assessment 10,000 times, and building the corresponding inventory analysis each time. In this sense, as previously stated in section 2.5.2, performing a sensitivity analysis in advance can help to reduce the number of input parameters for the simulation, by pre-selecting those with the highest contribution to the model's uncertainty. Morgan and Small (1992) acknowledge that Latin Hypercube sampling is a more efficient method that needs less simulation runs, since it is based on the stratification of the input probability distributions. This feature aids the analysis of situations where low probability outcomes are represented in input probability distributions, making it more suitable for highly skewed or long-tailed distributions. Unfortunately, this technique is still not widely available in commercial LCA software, while Monte Carlo sampling is, and the calculation is reasonably fast (Clavreul et al., 2012). It is assumed that performing the simulation 10,000 times overcomes the Monte Carlo method's 
limitation with regard to highly skewed distributions. Finally, it has to be taken into account that, when performing a Monte Carlo analysis, and if it is known the correlation among the various data values and impact factors should be considered in order not to overestimate or underestimate parameter uncertainty (EC, 2010b). 



\section{Chapter III. Results}



International Journal of Life Cycle Assessment, 2015, 20(2):244-262

\subsection{Uncertainty analysis in the environmental assessment of an integrated management system for restaurant and catering waste in Spain}

Escobar, N. ${ }^{a}$, Ribal, F.J. ${ }^{b}$, Rodrigo, A. ${ }^{c}$, Clemente, G. ${ }^{a}$, Pascual, A. ${ }^{c}$, Sanjuán, N. ${ }^{a}$

${ }^{a}$ Grup ASPA. Departament de Tecnologia d'Aliments, Edifici 3F, Universitat Politècnica de València. Camí de Vera s/n, 46022, Valencia, Spain

${ }^{b}$ Departament d'Economia i Ciències Socials, Edifici 3P, Universitat Politècnica de València. Camí de Vera s/n, 46022, Valencia, Spain

${ }^{\mathrm{c}}$ Ainia Centro Tecnológico, Parque Tecnológico de Valencia. C/ Benjamin Franklin 5-11, 46980, Paterna (Valencia), Spain 



\section{Abstract}

Purpose:

The goal of section 3.1 is to analyze the environmental improvement brought about by an alternative system for waste management proposed by the Integral-b project, funded by the European Union (EU). Its aim is to treat both used cooking oil (UCO) and organic waste by biodiesel production and anaerobic digestion (AD), respectively; a cogeneration engine adapted to use glycerin is implemented.

Methods:

The Functional Unit (FU) is the management of the UCO and solid organic waste (SOW) from restaurants and catering produced per person and year in Spain. The system proposed (scenario $A$ ) is compared to a system consisting of the prevailing management options for the same kind of waste (scenario B). Apart from including biodiesel production from the UCO, this reference scenario assumes that the SOW is allocated to different streams, according to Spanish statistics. System expansion is performed and different scenario formulations are set to analyze the influence of assumptions regarding co-product credits in the results. Finally, Monte Carlo simulations are carried out to analyze parameter uncertainty.

Results and discussion:

The environmental benefits caused by scenario A are conditional on the choices regarding co-product credits. Scenario A causes a reduction of the impact (43\%$655 \%)$ in most of the scenario formulations when the current levels of UCO collection are considered. However, when higher levels are taken into account for the FU, scenario B performs better for half of the scenario formulations, due to the increase in the environmental credits from glycerin production. The only impact categories for which scenario A performs unconditionally better than scenario $B$ are global warming (GW) and photochemical ozone creation (POC). Parameter uncertainty appears to influence the comparative results to a lesser extent.

Conclusions:

Although system expansion is an option for dealing with the multi-functionality of waste management processes, uncertainty caused by choices must be assessed. Under our scenario assumptions, re-using the glycerol in the system proposed by Integral-b can be detrimental, and the reference scenario results in higher avoided burdens in some scenario formulations. Including glycerin valorization in scenario B should be considered if the biodiesel production keeps increasing in Spain. Analyzing parameter uncertainty helps to provide reliable results.

Keywords: food waste, Monte Carlo, organic waste, system expansion, uncertainty, used cooking oil, waste management 


\subsubsection{Introduction}

In light of the rapid increase in the levels of waste production that has taken place over the last few decades, there has been growing worldwide concern about the environmental consequences, and public policies such as European Directive 2008/98/EC have subsequently been adopted. This Directive encourages recovery over disposal in order to reduce the amount of waste going to landfill, while laying down end-of-waste criteria based on life cycle thinking. In addition, it considers the economic implications of waste management activities, since waste is often of value as a resource, creating economic opportunities. The European Commission (EC) (2011) estimated that, in 2009, the waste management and recycling industries in the EU had a turnover of €95 billion.

The separate collection and proper treatment of biodegradable waste is also recommended as a means of reducing greenhouse gas (GHG) emissions, including organic waste from households, restaurants, caterers and retail premises. Food consumption outside the household is of great importance in Spain and can be a suitable source for energy recovery if appropriate collection systems are established. Total food consumption in Spanish retailers (restaurants, catering and institutions) reached 8.43 million tons in 2010 (Muñoz-Cidad and Sosvilla, 2012), around $20 \%$ of the total annual food consumption. Waste from restaurants and catering is basically made up of three types of residues: UCO, SOW and packaging. UCO is mostly collected for biodiesel production, by authorized management companies through specific collection points (usually metal and plastic containers located at the retailer's). The solid organic fraction usually enters the municipal solid waste (MSW) stream, and is mainly treated by landfilling or composting (Eurostat, 2013a).

There are no statistics about the amount of UCO produced by catering in Spain, but it was estimated that it could be more than 80,000 tons per year (Rodrigo et al., 2011). Since EU Regulation 1774/2002 forbade using UCO for animal feed, biodiesel production has become the best alternative for its recovery. Crude glycerol is obtained as a by-product, which can be used by the cosmetic and pharmaceutical industries, among others. However, as mentioned in section 1.4, the world's glycerol supply is growing much faster than the traditional uses it is put to as a consequence of the expansion of the biodiesel industry in the new energy landscape. This issue may become a problem especially in leading producer countries such as those in the EU, Brazil or the United States (US).

The Integral-b project, funded by the European LIFE programme (LIFE07 ENV/E/000820), proposes an integrated system for the joint management of both $\mathrm{UCO}$ and SOW from the restaurant and catering sector. Apart from valorizing the UCO by biodiesel production and the SOW by $A D$, the Integral-b project 
establishes a cogeneration system to improve the energy efficiency of the whole process. One of the main advantages of the integrated system is that it recycles the glycerol in situ, which is used as a fuel in a combined heat and power (CHP) engine adapted to this end. This allows valorizing the main by-product from biodiesel production. In addition, part of the thermal energy obtained from the CHP engine is re-used in the process, and the electricity is sold to the grid, constituting an additional source of revenues for biodiesel companies. The Integral-b project was carried out in Spain from January 2009 to December 2011, under the coordination of the Ainia Technology Centre, with the objective of analyzing the performance of a biodiesel production scheme which integrated an on-site byproducts energy valorization system. Although treatment processes for both UCO and hospitality SOW are currently carried out on an industrial scale, the environmental and economic benefits of integrating them in the same installation had not been studied yet. All the processing modules were designed and built by the partners of the project (the Cidaut Foundation, Biogas Fuel Cell and Bionorte), and were finally implemented jointly at the Bionorte facility, with the subsequent trial tests.

In the present section, the Life Cycle Assessment (LCA) methodology is used to analyze the environmental advantages of the system proposed under the framework of the Integral-b project. This tool has been broadly applied to evaluate MSW management systems (Bovea et al., 2010; Clift et al., 2000; Winkler and Bilitewski, 2007). However, these systems usually entail the "multi-functionality problem", as referred to by Heijungs and Guinée (2007), because they produce several functional flows, which may be used in turn in other product systems. This problem can be solved by means of two approaches, as thoroughly explained in Chapter II: system expansion, to estimate the environmental burdens avoided by co-products (e.g. electricity from incineration) or partitioning, which consists of allocating the environmental burdens to independent mono-functional processes. Although the first approach is the one most commonly used in the available literature about waste management (Arena et al., 2003; Beccali et al., 2001; Cherubini et al., 2009; Giugliano et al., 2011; Güereca et al., 2006), allocation is also applied by Cherubini et al. (2009) or Iriarte et al. (2009). There are some specific LCA studies into the use of UCO for biodiesel production (Niederl and Narodoslawsky, 2006; Talens et al., 2008, 2010), in which the authors also opt for system expansion, calculating co-product credits. The advantages and disadvantages of applying one method or another have been discussed in section 2.2.1. It must be born in mind that, in principle, the choice between possible avoided processes implies several assumptions, as well as the choice between alternative allocation criteria. 
Given the complexity of waste management systems and the wide range of conditions in which they can operate, uncertainty has been considered since the first LCA studies were published (Ekvall, 1999; Huijbregts, 1998a, b). As described in section 2.5 (chapter II), there are different sources of uncertainty, namely: parameter uncertainty (due to data variability), uncertainty due to choices (due to scenario assumptions) and model uncertainty (due to different impact assessment methods). For instance, when analyzing different strategies for energy recovery from solid waste, Finnveden et al. (2005) observed that there is often greater uncertainty due to choices than there is because of data variability. All these sources of uncertainty have been addressed in literature; authors such as Björklund (2002), Ciroth et al. (2004), Clavreul et al. (2012) or Heijungs and Huijbregts (2004) even provide some tools to measure the overall uncertainty in the results, increasing the reliability of the conclusions drawn.

The goal of section 3.1 is to assess the environmental performance of the system proposed by the Integral-b project, as compared to a conventional management system working with the same kind of waste. Uncertainty due to choices when modeling the alternative scenarios is also taken into account, as well as uncertainty due to parameter variability. The economic performance is further analyzed in the following section of the same chapter, also from a life cycle perspective. The results from the combined study, together with those from the respective uncertainty analyses, are expected to prove the adequacy of the Integral-b process from the point of view of sustainability, and are readily available for decisionmakers in the present dissertation.

\subsubsection{Methods}

The environmental assessment was performed according to the main steps described in section 2.2. The Life Cycle Inventory $(\mathrm{LCl})$ and Life Cycle Imapct Assessment (LCIA) were carried out using the GaBi 6 software (PE International, 2013), and the Ecoinvent v2.2 database (Hischier et al., 2010). Sensitivity and uncertainty analyses were performed by using the Analyst tool of the GaBi 6 software.

\subsubsection{Funtional Unit}

For the definition of the FU, the following consideration given by Cleary (2009) was taken into account: it must ensure that all of the environmental emissions are based on identical inputs to each waste management system. From this perspective, the Integral-b system has a double function: to manage both the UCO and SOW from restaurants and catering which are produced in a specific region. There are two functional inflows (according to the definition of Guinée et al., 2004), 
and the FU was therefore defined as the management of the amount of UCO and SOW from restaurants and catering, both produced per person during a year in Spain. Waste generation per capita was considered an appropriate unit of measure, since the Integral-b project was not designed for any specific area of application, but Spain. However, in terms of collection processes, it was assumed that the proposed system would be established in urban settings, where there is a greater density of restaurants.

The two functional inflows were determined based on available data and Spanish statistics. Using the level of UCO production in the Spanish restaurant and catering sector given by Rodrigo et al. (2011), with a population of 47.02 million people in 2010 (INE, 2011), the UCO functional flow is $1.70 \mathrm{~kg} / \mathrm{inh}$ abitant and year. According to MAGRAMA (2012), $177.50 \mathrm{~kg}$ of food were consumed per person in Spanish restaurants and caterers in that very year. Based on estimations from Engström and Carlsson-Kanyama (2004), approximately $20 \%$ of food weight turns into waste in restaurants and institutions; thus, the resulting functional flow for the SOW inflow is $35.50 \mathrm{~kg} / \mathrm{inh}$ abitant and year. All the inputs and outputs considered in each system depend on these two functional flows, as well as the impact results. Packaging residues are beyond the scope of this study, since they enter other recycling streams. Uncertainty due to different assumptions regarding the $F U$ is also assessed.

\subsubsection{System description and scenario formulations}

To quantify the environmental improvements generated by the process proposed by the Integral-b project (scenario A), it was compared to a reference system (scenario B), based on current management systems for the same kind of waste. Although both scenarios have the same functional inflows, there are several functions provided by the treatment methods in addition to that of taking care of the waste (Finnveden et al., 2005). These indirect functions were subtracted by applying the substitution method, causing avoided burdens and, thus, uncertainty due to the associated assumptions. Hence, according to the recommendation of Heijungs and Guinée (2007), several versions of each scenario were defined in order to keep the "what-if" reasoning outside the methodological choices as much as possible.

The two base scenarios studied for the management of the FU are as follows:

- Scenario A, which includes: a) UCO collection, b) biodiesel production, c) SOW collection and sorting d) AD of the SOW, and e) energy cogeneration in a CHP engine (as shown in Figure 3.1). 
- Scenario B, which includes: a) UCO collection, b) biodiesel production as the current treatment for the UCO, c) SOW collection and sorting, d) landfilling of most of the SOW, e) composting of part of the SOW, and f) incineration of the remaining part (as shown in Figure 3.2).

Although partitioning entails fewer choices (Heijungs and Guinée, 2007), only regarding allocation factors, system expansion was preferred in order to make both scenarios equivalent in terms of waste treatment functions. It should be taken into account that the system under study was originally designed as an integrated waste management process, and one of the goals of the Integral-b project is to jointly manage all the co-products (mainly glycerin, by means of the thermal energy from cogeneration and the subsequent $A D$ ). These are then necessarily used as input flows in other sub-stages, which are equally important for the operation of the whole system. The subtitution method ensures that the indirect functions are entirely allocated to that system that is generating them, causing avoided burdens or environmental credits (e.g. electricity from cogeneration in scenario A). This is also helpful for the economic assessment, since the avoided burdens translate into revenues for the plant, emphasizing that the Integral-b process involves the production of co-products with market value. Another option to deal with these coproducts would have been to create equal functional systems (with the same functional inflows and outflows) by adding the corresponding processes to the other scenario instead of subtracting them in the main one. Since we are interested in the scenario B-scenario A difference, considering one or another possibility has no implications for the environmental analysis. In order to analyze how specific choices regarding these subtracted processes may influence the results, different versions of each scenario were defined. Although including partitioning as an option for the comparison between scenarios could have provided additional information, it would have implied defining allocation factors between functional inflows and co-products, with the subsequent uncertainty (see, e.g., Jung et al. 2014). The present study is focused on examining the influence of system expansion choices in relation to parameter uncertainty.

Biodiesel production is common to both scenarios, as is UCO collection, and glycerol is obtained as a co-product from the transesterification. The Integral-b project proposes making use of it as a fuel in the CHP engine after purification by means of the combustion flue gases from that very process. On the contrary, glycerol becomes an outflow in scenario B, which has to be credited in order to make both systems entirely comparable. This compound may have different uses, depending on its market price, which further depends on its availability. Two options were considered to account for this co-product's credits in scenario B (same as Lechón et al., 2009): displacing synthetic glycerin or propylene glycol. Specifically, the displacement ratio with synthetic glycerin was assumed to be 1:1 
since, as Johnson and Taconi (2007) stated, the majority of glycerol is currently used directly and without further chemical modification; both synthetic glycerin and glycerol from biodiesel production share many industrial uses, such as soaps or alkyd resins. On the contrary, it was considered that $1 \mathrm{~kg}$ of glycerol yields $0.9 \mathrm{~kg}$ of propylene glycol, according to the same study. The possibility of replacing grain for animal feed (suggested by Malça and Freire, 2011, among others) was not covered since this would entail more "what-if" questions (e.g. which grain, locally produced or imported, what its nutritional value is, etc).

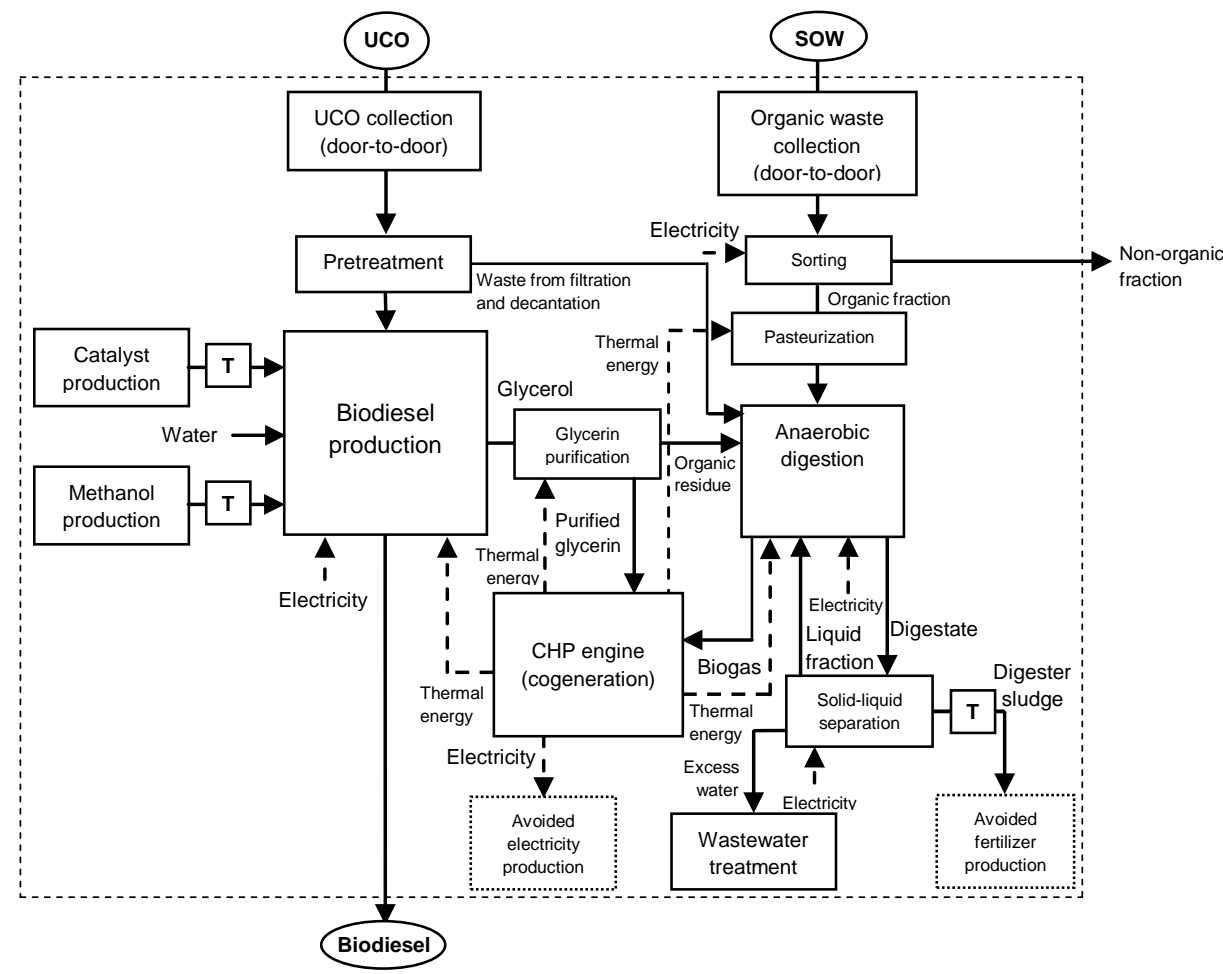

Figure 3.1. System delimitation of the process studied in scenario A. Capital goods are not outlined; the dashed line defines the system boundaries and energy flows. T: Transport.

In scenario A, electricity from the CHP engine can replace the average or the marginal source of electricity (Cleary, 2009). Avoided burdens from two different options were thus considered: replacing the average mix of electricity in Spain, or replacing wind-generated electricity, which is the most environmentally-friendly. This second choice may be detrimental to the performance of the Integral-b process since it entails less environmental credits in many impact categories. Landfilling and incineration also generate electricity in scenario B, but in smaller quantities. For comparative purposes, it was assumed that this electricity can only 
replace electricity from the average Spanish mix (with higher avoided burdens), which is to be expected. Although the fairest comparison would have been to consider the same marginal source of electricity in both scenarios (wind-wind, mix$\mathrm{mix}$ ), this option has been chosen because the Integral-b project tries to highlight the environmental benefits of the process even in a worst-case scenario. Furthermore, this can be interpreted to mean that only the fate of the electricity in scenario $A$ is subject to uncertainty, since it comes from a system that is not yet implemented on an industrial scale.

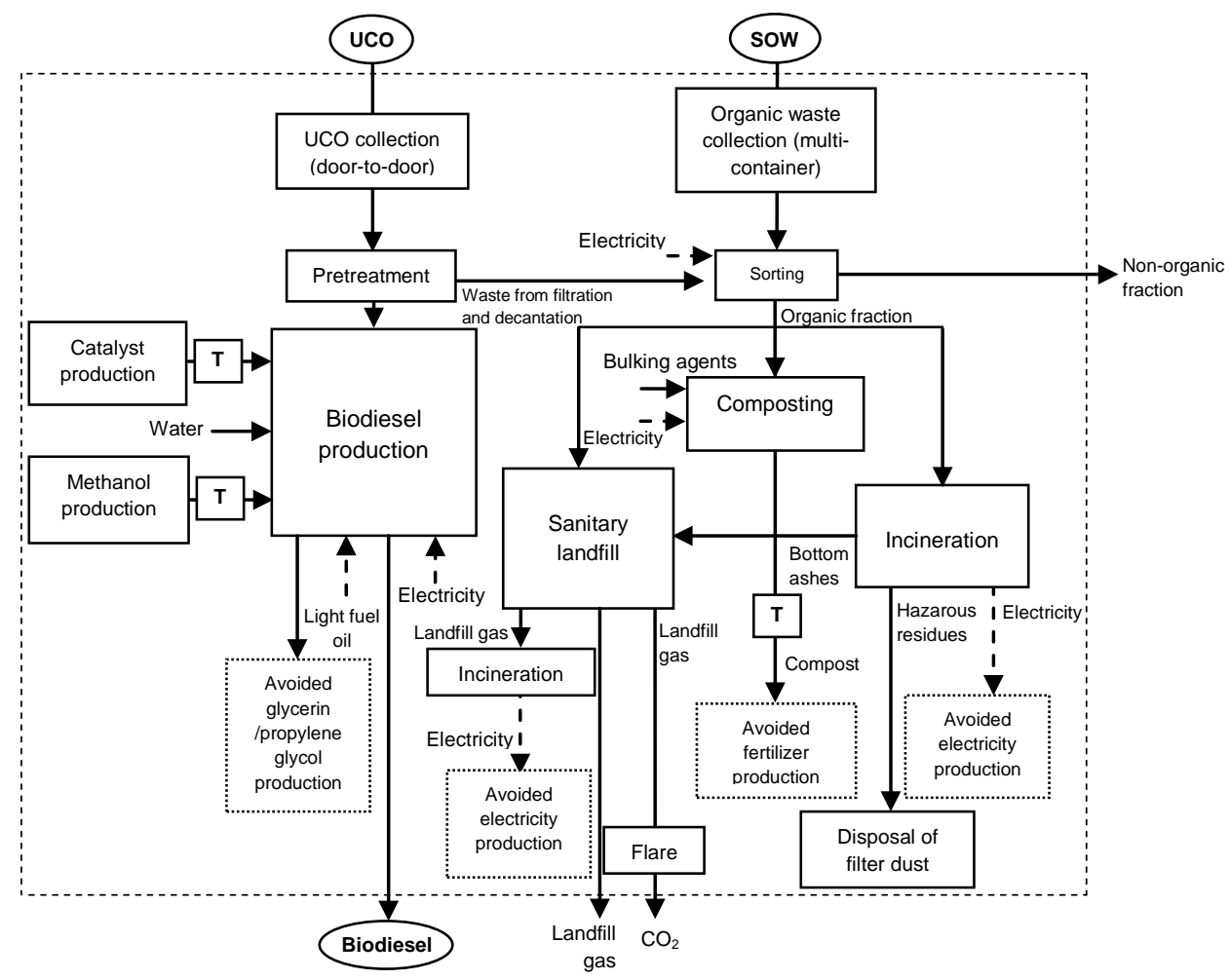

Figure 3.2. System delimitation of the process studied in scenario B. Capital goods are not outlined; the dashed line defines the system boundaries and energy flows. T: Transport.

Furthermore, whereas the entire amount of SOW is treated by $A D$ in scenario $A$, it is assumed that it is distributed to different streams in the reference scenario, according to the percentages reported by Eurostat (2012) for MSW in Spain: 68.2\% goes to sanitary landfill, $21.2 \%$ to composting and $10.6 \%$ to incineration (without considering previously sorted packaging residues). Digester sludge is therefore obtained in scenario A as a co-product, whereas compost is produced in scenario B. Both can be used as fertilizer, depending on its nutrient content. Using the 
nutrient content data from Finnveden et al. (2000) and taking into account that the amount of waste composted is much lower than the waste treated by AD (see Table $A 1$ in annex A), scenario A produces around 10 times more nitrogen (in the digester sludge) than scenario $B$ (in the compost), and 6 times more phosphorus. Hence, the avoided production of ammonium nitrate (as $N$ ) and single superphosphate (as $\mathrm{P}_{2} \mathrm{O}_{5}$ ) were included in scenario $\mathrm{A}$, following the example in the latter study.

The scenario B-scenario A difference was calculated for the comparative analysis, since it allows the extent to which scenario A is better (or worse) than the reference one to be quantified, while providing further advantages for the uncertainty analysis; this originally resulted in four scenario formulations to be covered. However, statistics used for the calculation of the functional inflows may be a source of uncertainty, since all inputs and emissions are based on them. According to a personal communication from the Spanish Institute for Energy Diversification and Saving (IDAE), the current technical capacity for UCO collection reaches approximately $300,000 \mathrm{t}$ per year. Assuming that implementing the Integral-b project increases the collection efficiency to this level, the UCO functional flow would be $6.38 \mathrm{~kg} / \mathrm{inhabitant}$ and year, changing the ratio between UCO and SOW in the FU. As a result, eight scenario formulations were established by considering these two feasible collection capacities of UCO. In the first four, the functional inflows are $1.70 \mathrm{~kg}$ of UCO $+35.50 \mathrm{~kg}$ of SOW per inhabitant and year, while in the rest the functional inflows are $6.38 \mathrm{~kg}$ of UCO $+35.50 \mathrm{~kg}$ of SOW per inhabitant and year, as shown in Table 3.1. Uncertainty due to the avoided production of $\mathrm{N}$ and $P$ fertilizers was not studied through a scenario analysis, since the environmental burdens of different substitutable commercial fertilizers in databases are of the same order of magnitude.

Table 3.1. Alternative scenario formulations proposed to analyze uncertainty due to choices. The scenario B-scenario A difference was studied.

\begin{tabular}{|c|c|c|c|c|c|}
\hline & & \multicolumn{2}{|c|}{$\begin{array}{c}\text { FU: } 1.70 \text { kg UCO + } 35.50 \text { kg SOW } \\
\text { l inhab·year }\end{array}$} & \multicolumn{2}{|c|}{$\begin{array}{c}\text { FU: } 6.38 \mathrm{~kg} \mathrm{UCO}+35.50 \mathrm{~kg} \mathrm{SOW} \mathrm{I} \\
\text { inhab·year }\end{array}$} \\
\hline \multirow{2}{*}{\multicolumn{2}{|c|}{ Scenario formulations }} & & Choices in & scenario A & \\
\hline & & $\begin{array}{c}\text { Electricity } \\
\text { displaces } \\
\text { electricity from } \\
\text { the Spanish mix }\end{array}$ & $\begin{array}{c}\text { Electricity } \\
\text { displaces wind- } \\
\text { generated } \\
\text { electricity }\end{array}$ & $\begin{array}{c}\text { Electricity } \\
\text { displaces } \\
\text { electricity from } \\
\text { the Spanish mix }\end{array}$ & $\begin{array}{c}\text { Electricity } \\
\text { displaces wind- } \\
\text { generated } \\
\text { electricity }\end{array}$ \\
\hline \multirow{2}{*}{ 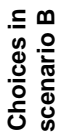 } & $\begin{array}{l}\text { Glycerin displaces } \\
\text { synthetic glycerin }\end{array}$ & Scenario B1-A1 & Scenario B1-A2 & Scenario B1'-A1' & Scenario B1'-A2' \\
\hline & $\begin{array}{l}\text { Glycerin displaces } \\
\text { propylene glycol }\end{array}$ & Scenario B2-A1 & Scenario B2-A2 & Scenario B2'-A1' & Scenario B2'-A2' \\
\hline
\end{tabular}

Additionally, the percentages that determine the amount of waste going to landfill, composting and incineration in scenario $B$ are subject to change according to the 
Spanish strategy under the EU Landfill Directive. Specifically, the amount of biodegradable waste from MSW produced in 1995 must be reduced by $65 \%$ in 2016 (Decree 1481/2001). These percentages will be analyzed under parameter uncertainty, as will other assumptions, such as the percentage of food losses in the catering and restaurant sector (determining the functional flow of SOW), or the percentage of biogas recovery in the sanitary landfill (in scenario B).

\subsubsection{Life Cycle Inventory}

In this section, the main processes are described and quantified with regard to the $\mathrm{FU}$, based on the same sub-stages defined in section 3.1.2.2 for each scenario. This required a detailed data collection process, as a result of which Table A1 in annex A was built. In addition to primary data provided by the partners of the Integral-b project, secondary data were used to complete both scenarios. The base scenarios were built with these average data, under a deterministic assumption.

Scenario A consists of:

a) Collection of UCO by means of a door-to-door (DTD) container system, the same as described by Vinyes et al. (2013). Despite the fact that in our study the UCO comes from restaurants and not from households, both case studies use similar FU in terms of $\mathrm{kg} / \mathrm{inhabitant}$ and year. However, we considered that caterers store the UCO in containers of greater capacity (60-L barrels, the same as Talens et al., 2008) and higher collection efficiency (90\%) was estimated, accounting for oil losses during cleaning; this parameter is included for the subsequent uncertainty analysis. After its collection, the UCO is also transported $100 \mathrm{~km}$ to the biodiesel plant.

b) When the UCO is delivered to the plant, pretreatment and conditioning processes are performed to remove solids and charred food (by decantation) and to control humidity and acidity; then biodiesel production starts. The transesterification takes place in a closed vessel using a catalyst and methanol, previously mixed. Once both phases are separated by decantation, the excess of methanol in each one is removed and reused in the same process. All the data on biodiesel production were gathered from the company Bionorte, which processed $5295 \mathrm{t}$ of UCO per year. The transport of inputs was included: the methanol comes from nearby Spanish cities in equal proportions, whereas the catalyst comes from China (by tanker and lorry) and from Germany (by lorry) in the proportion 6:4. The methanol and catalyst production processes, wastewater treatment, as well as capital goods production, were taken from Ecoinvent v2.2. 
c) The Integral-b project proposes carrying out a selective collection of the SOW by means of a DTD system, similar to the one described by Iriarte et al. (2009). Caterers store the SOW in bins of $340 \mathrm{~L}$; the high-density polyethylene (HDPE) and water for cleaning were included in the inventory. The SOW is then collected and transported to the AD facility, after sorting so as to separate the non-organic residues. The highest distance considered by Iriarte et al. (2009), which is $30 \mathrm{~km}$, was assumed for this inter-city transport. Although the organic fraction is collected separately, it is assumed that there are also some other residues in the same bin (5\%). The amount of waste collected for the FU is then slightly greater ( 37.37 $\mathrm{kg} / \mathrm{inhabitant}$ and year), with subsequent collection inputs. It was assumed that sorting takes place at the same facility as the $A D$, and the power needed was obtained from Arena et al. (2003). The non-organic fraction is mostly packaging and goes to recycling facilities not within the system boundaries.

d) The organic mix fed to the digester is composed of the SOW from caterers (previously pasteurized), residues from the UCO pretreatment (filtration solids, charred food) and residues from glycerol purification. The $A D$ makes use of electricity for stirring and some thermal energy from the CHP engine to heat the digester. The generated digester sludge goes through a solid-liquid separation before being used for agricultural purposes; the liquid fraction is re-circulated into the digester to avoid water input, and the surplus is assumed to be treated as wastewater (process from Ecoinvent v2.2). All the data involved in the $A D$ were provided by the Ainia Technology Centre and Biogas Fuel Cell. Specifically, the digester plant of the Integral-b project has a processing capacity of $20,000 \mathrm{t}$ of SOW per year. The specific heat of the organic mix was estimated as an average value from a group of food products. Methane losses were calculated by following the guidelines of Bachmaier and Gronauer (2007). The anaerobic reactor has self-consumption rates of $5 \%$ in power and $10 \%$ in thermal energy from CHP. Some external power supply is needed for the solidliquid separation process of the digester sludge and the solid fraction was assumed to be delivered to a farm located $25 \mathrm{~km}$ from the production plant. The avoided production processes of ammonium nitrate and single superphosphate were obtained from Ecoinvent v2.2.

e) As mentioned, the CHP engine was specifically adapted in the Integral-b project to use not only biogas, but also purified glycerin, as fuel. Apart from that which is re-used in the $A D$, the thermal energy produced is consumed in the transesterification (instead of using heat from light fuel oil), glycerol purification and pasteurization of the SOW collected. The electricity 
generated is sold to the power grid. Furthermore, there is heat and electricity self-consumption in the CHP engine. Data related to the cogeneration (thermal energy and electricity production rates, etc) were provided by Cidaut, which implemented a 500-kW CHP engine. Waste heat was calculated by means of energy balances. No $\mathrm{CO}_{2}$ emissions were considered because they all arise from biogenic carbon, as specified by PAS:2050 (BSI, 2011). $\mathrm{CH}_{4}$ emissions caused by both the engine and the digester sludge storage were calculated following the same guidelines of Bachmaier and Gronauer (2007).

Stages a) and b) of scenario $B$ are exactly the same as the ones described for scenario $A$, with the only difference being that the transesterification uses external thermal energy (from light fuel oil). The rest of the sub-stages included in scenario $B$ are described as follows:

c) In the reference scenario, there is no selective collection system for the SOW from restaurants and catering. The current situation in Spain is that this waste is unloaded into the same street-side containers where MSW is collected. The SOW was thus assumed to be collected by means of the multi-container system from Iriarte et al. (2009), including the consumption of HDPE and water. However, we estimated that the organic fraction was $62 \%$ of the unsorted SOW (from the baseline scenario defined by Bovea et al., 2010), resulting in a greater waste inflow to be collected than that in scenario A. These $57.26 \mathrm{~kg} / \mathrm{inh}$ abitant and year increase the consumption of inputs per FU only in the collection and sorting sub-stages, even though the multi-container system is less input intensive than the DTD system. Urban transport from collection points and inter-city transport to the MSW treatment facilities are considered. The sorting consists of bag-ripping, trommel screening, magnetic separation, shredding and manual screening, according to Arena et al. (2003). No distances between the MSW management facility and the subsequent stages were taken into account. The organic fraction, together with the organic residues from the UCO pretreatment, are allocated to different waste streams after sorting, as explained in section 3.1.2.2.

d) More than half of the resulting SOW is buried in a sanitary landfill, undergoing anaerobic decomposition. By adopting the same assumptions as Cherubini et al. (2009), under Mediterranean conditions, a fraction of the $50 \%$ of the biogas obtained is assumed to be burnt to produce electricity, while the rest is burnt in flares to be converted into $\mathrm{CO}_{2}(25 \%)$ or directly released to the atmosphere (25\%). Inputs and outputs of the Sow disposal in a sanitary landfill were gathered from that very study, specifically from the scenario "landfill with biogas recovery". Emissions 
from biogas were considered, as well as the leachate from the anaerobic decomposition of the biodegradable fraction ( $100 \%$ in this case). Around $240 \mathrm{Nm}^{3}$ of biogas per ton of SOW input are produced, which is consistent with the value reported by McDougall et al. (2008). Besides the $\mathrm{CH}_{4}$ and $\mathrm{CO}_{2}$ reported by Cherubini et al. (2009), emissions of other compounds from the biogas combustion were taken from McDougall et al. (2008), too. The leachate was assumed to be treated as sewage (process from Ecoinvent v2.2), since average technology in Spain is very similar to that in wastewater treatment plants.

e) An industrial composting process (known as in-vessel composting or windrow composting) was considered, the same as that described by Martínez-Blanco et al. $(2009,2010)$, based on a plant treating 15,000 t of Sow per year. It includes the collection of bulking agents, the subsequent pretreatment, composting in tunnels with forced aeration and irrigation, curing in piles, final refining and transport to the final user. The leachate is completely re-used in the composting process. We considered a consumption of bulking agents of 1:10 relative to the total organic fraction, because it is closer to the average ratio in Spanish composting plants. The compost was assumed to be delivered to a farm situated $25 \mathrm{~km}$ from the production facility.

f) The remaining SOW is treated by incineration to produce electricity. Inputs in the waste incineration were gathered from Cherubini et al. (2009). To calculate the electricity generation from the organic fraction, a low heating value (LHV) of $4.6 \mathrm{MJ} / \mathrm{kg}$ of biowaste was considered (Wright Tech Systems, 2007), together with a net production efficiency of $28.4 \%$ (Giugliano et al., 2011). The level of detail of the process was again increased by coupling literature data with emission factors reported in European Directive 2000/76/CE for waste incineration. The emissions of metals were neglected, since the waste burnt is entirely organic, and a stack gas production of $5,000 \mathrm{~m}^{3}$ per ton (McDougall et al., 2008) was considered to calculate overall emissions. Bottom ashes are re-circulated into the sanitary landfill stream, whereas filter dust and sludge from gasscrubbing are disposed of safely in residual material landfills from Ecoinvent v2.2.

In all the processes where electricity was necessary, the Spanish production mix from the Ecoinvent v2.2 database was used. The production processes of the compounds embodied in capital goods were taken from the same database, as well as other inputs, such as water or energy. Similarly, all transport processes included fuel production, and a lorry of 20-28 t total capacity was chosen for road 
transport. The avoided production processes of propylene glycol and synthetic glycerin were also taken from Ecoinvent v2.2.

\subsubsection{Environmental assessment}

The CML 2001 (baseline) method (Guinée et al., 2002) was used to characterize the environmental interventions in the $\mathrm{LCl}$. Besides the impact categories which, according to Cleary (2009), are typically included in the study of MSW systems, toxicity in humans was also analyzed, since this study identified that this is not often addressed in literature. As a result, the impact categories considered were: abiotic depletion, acidification, eutrophication, GW, human toxicity (HT) and POC.

\subsubsection{Sensitivity and uncertainty analyses}

When performing LCAs, conclusions are most often drawn from the outcomes of a deterministic model, which assigns a single value to each parameter. Using only average values may be misleading because there is inherent variability associated to each parameter, as discussed in section 2.5. This is why the Joint Research Centre of the EC (JRC, 2010) recommends combining scenario analysis with stochastic uncertainty calculation, which may help to support the comparison of systems. Although there are different methods to propagate data uncertainty through the results, the Monte Carlo simulation has been typically used in LCA because the number of parameters is not excessively large, and the calculation is reasonably fast (Clavreul et al., 2012). Indeed, it has often been applied in MSW systems (Bao-guo et al., 2007; Kaplan et al., 2004; Sonnemann et al., 2003). In this case, a Monte Carlo simulation was carried out for the scenario B-scenario A differential of each combination shown in Table 3.1. This implies simulating common parameters to both systems at a time, which guarantees that these parameters have the same value in each run, providing a fair comparison. This can be understood as a "discernibility analysis" (as referred to by Heijungs and Kleijn, 2001), since it seeks to test if system A is statistically discernible from system B by counting the number of times that the first alternative has a higher impact than the second, and the other way round.

In order to perform the Monte Carlo simulation, uncertainty distributions had to be specified for the input parameters. A sensitivity analysis was carried out in order to select those parameters for the Monte Carlo simulation that contributed the most to the results' uncertainty. The steps subsequently taken are detailed in section A2 of the annex A, supported by figures and tables (Figures A1 to A12, and Table A2); the same procedure applied for all the scenario formulations in Table 3.1. 
Table A3 was drawn up showing the risk parameters from the sensitivity analysis together with their estimated probability distributions. Due to the drawback that the GaBi 6 Analyst Tool only offers equal and normal distributions, and all selected parameters must follow the same distribution type in each run, the normal one was chosen. Although the lognormal type is the one that best describes the probabilistic distribution of technical and environmental variables (Limpert et al., 2001), especially those for which no negative values are possible, such as emissions (Clavreul et al., 2012), the normal distribution is also suitable to describe technical variables or transport distances as seen in the study of Sonnemann et al. (2003). Since no historical data were available for any of the risk parameters, the same criteria specified in section A2 of the annex A to determine the coefficients of variation (CVs) were used, except for those parameters for which Integral-b partners provided minimum and maximum bounds. In that case, it was assumed that the interval within these limits includes $95.4 \%$ of the data and, thus, the difference with respect to the mean value corresponds to two standard deviations. Similarly, the CV for the parameter UCO collection efficiency was calculated considering an interval of between 57\% (minimum efficiency for the UCO from households in Vinyes et al., 2013) and 100\%; and the CV for fraction of waste diverted to sanitary landfill was calculated in accordance with a range of between $50 \%$ and $100 \%$ (the maximum value would imply no waste going to composting or to incineration). Finally, the contribution to the uncertainty of the selected risk parameters was assessed by means of 10,000 runs of the Monte Carlo simulation using the GaBi 6 Analyst Tool. Random values from the probabilistic distribution of each parameter were selected in each run and a forecast distribution for the difference between scenarios was obtained for each impact category.

\subsubsection{Results}

\subsubsection{Impact assessment of the base scenarios}

Based on the inventory data described in section 3.1.2.3, the LCIA of each scenario formulation was carried out. The deterministic results for all the analyzed impact categories are shown in Table 3.2. A negative value indicates that the impact in scenario $A$ is higher than in scenario $B$.

As can be seen, when the FU represents the current collection levels of UCO, scenario A performs better than scenario $B$ in most of the impact categories and scenario formulations. The acidification results are higher in scenario $A 2$, that is, when electricity displaces wind-generated electricity (regardless of the glycerin credits in scenario B), as well as for eutrophication when glycerin displaces propylene glycol (scenario B2). The same is observed in HT only when glycerin displaces propylene glycol (scenario B2), regardless of the electricity credits in 
scenario A. However, when considering potential levels of UCO collection, scenarios A' do not distinctly improve the environmental performance relative to the reference system. In fact, scenarios B' appear to be better in half of the cases. Specifically, scenarios B' are always better in the case of abiotic depletion; in that of acidification only when electricity displaces wind-generated electricity (A2'); and in every case of eutrophication and $\mathrm{HT}$, except when electricity displaces electricity from the Spanish mix and glycerin displaces synthetic glycerin, that is, in scenario B1'-A1'. Summarizing, GW and POC are the only categories in which the results from all the scenario formulations are entirely favorable for the Integral-b system. To better understand why this occurs, the contribution of each sub-stage to the overall impact was analyzed. Only the results for acidification and eutrophication are shown in Figure $3.3(a, b)$, while the rest of the analyzed categories appear in section $A 3$ of the annex $A$.

Table 3.2. LCIA results of the scenario B-scenario A difference for the different scenario formulations considered. The combinations of scenarios and impact categories in which the sign of the difference is reversed (scenario A>scenario B) appear in gray.

\begin{tabular}{|c|c|c|c|c|c|c|c|c|}
\hline & \multicolumn{4}{|c|}{$\begin{array}{c}\text { FU: } 1.70 \text { kg UCO + } 35.50 \text { kg SOW I } \\
\text { inhab-year }\end{array}$} & \multicolumn{4}{|c|}{$\begin{array}{c}\text { FU: } 6.38 \mathrm{~kg} \mathrm{UCO}+35.50 \mathrm{~kg} \text { SOW I } \\
\text { inhab-year }\end{array}$} \\
\hline & $\begin{array}{c}\text { Scenarios } \\
\text { B1-A1 }\end{array}$ & $\begin{array}{l}\text { Scenarios } \\
\text { B1-A2 }\end{array}$ & $\begin{array}{c}\text { Scenarios } \\
\text { B2-A1 }\end{array}$ & $\begin{array}{c}\text { Scenarios } \\
\text { B2-A2 }\end{array}$ & $\begin{array}{c}\text { Scenarios } \\
\text { B1'-A1' }\end{array}$ & $\begin{array}{l}\text { Scenarios } \\
\text { B1'-A2' }\end{array}$ & $\begin{array}{l}\text { Scenarios } \\
\text { B2'-A1' }\end{array}$ & $\begin{array}{c}\text { Scenarios } \\
\text { B2'-A2' }\end{array}$ \\
\hline $\begin{array}{l}\text { Abiotic } \\
\text { Depletion [kg } \\
\text { Sb-eq.] }\end{array}$ & $2.17 \cdot 10^{-6}$ & $2.52 \cdot 10^{-6}$ & $3.17 \cdot 10^{-6}$ & $3.53 \cdot 10^{-6}$ & $-3.43 \cdot 10^{-5}$ & $-3.39 \cdot 10^{-5}$ & $-3.05 \cdot 10^{-5}$ & $-3.01 \cdot 10^{-5}$ \\
\hline $\begin{array}{l}\text { Acidification [kg } \\
\mathrm{SO}_{2} \text {-eq.] }\end{array}$ & $6.65 \cdot 10^{-2}$ & $-7.23 \cdot 10^{-3}$ & $6.74 \cdot 10^{-2}$ & $-6.33 \cdot 10^{-3}$ & $5.38 \cdot 10^{-2}$ & $-2.10 \cdot 10^{-2}$ & $5.72 \cdot 10^{-2}$ & $-1.77 \cdot 10^{-2}$ \\
\hline $\begin{array}{l}\text { Eutrophication } \\
\text { [kg Phosphate- } \\
\text { eq.] }\end{array}$ & $1.61 \cdot 10^{-2}$ & $1.94 \cdot 10^{-3}$ & $1.33 \cdot 10^{-2}$ & $-8.58 \cdot 10^{-4}$ & $8.47 \cdot 10^{-3}$ & $-5.91 \cdot 10^{-3}$ & $-2.02 \cdot 10^{-3}$ & $-1.64 \cdot 10^{-2}$ \\
\hline $\begin{array}{l}\text { GW (100 years) } \\
{\left[\mathrm{kg} \mathrm{CO}_{2} \text {-eq.] }\right.}\end{array}$ & 18.54 & 10.87 & 18.90 & 11.24 & 14.95 & 7.17 & 16.34 & 8.56 \\
\hline HT [kg DCB-eq.] & 2.98 & 0.96 & $-6.71 \cdot 10^{-2}$ & -2.09 & 0.99 & -1.06 & -10.44 & -12.49 \\
\hline $\begin{array}{l}\text { POC [kg } \\
\text { Ethene-eq.] }\end{array}$ & $6.43 \cdot 10^{-3}$ & $2.68 \cdot 10^{-3}$ & $6.18 \cdot 10^{-3}$ & $2.43 \cdot 10^{-3}$ & $5.08 \cdot 10^{-3}$ & $1.28 \cdot 10^{-3}$ & $4.14 \cdot 10^{-3}$ & $3.40 \cdot 10^{-4}$ \\
\hline
\end{tabular}

As the systems are credited for producing several functions, all of the impact categories present inputs and outputs of resources and emissions due to the avoided processes. The avoided burdens due to electricity production in scenario $A$ make the difference in acidification (Figure 3.3a). In terms of $\mathrm{SO}_{2}$-eq. emissions, conventional electricity generated by means of the average Spanish mix is substantially more polluting than wind-generated electricity. As a result, the impact of scenario A1 is much lower than either scenario B (594\% and 655\% lower than scenarios B1 and B2, respectively), despite the environmental credits allocated to glycerin and to electricity from landfill. However, when scenario $A 2$ is evaluated, scenarios $\mathrm{B} 1$ and $\mathrm{B} 2$ lead to lower $\mathrm{SO}_{2}$-eq. emissions $(65 \%$ and $61 \%$, 
respectively), essentially due to the avoided burdens from electricity production, which are higher than the ones generated by the avoided fertilizer production in scenario A. The same can be observed in the second four scenario formulations, where greater acidification is caused by sub-stages depending on the UCO reference flow (mainly UCO collection and biodiesel production). On the contrary, the avoided burdens due to electricity and fertilizer production are approximately the same as in the first four combinations, since they depend on the amount of sow treated, which is exactly the same. However, the greater avoided emissions from glycerin credits in scenarios B' are not enough to reverse the effect from the avoided conventional electricity production; scenario A1' implies less impact (390\% and $548 \%$ lower than B1' and B2', respectively). This is not the case with scenario A2' (152\% and $169 \%$ higher than B1' and B2', respectively), in which the avoided $\mathrm{SO}_{2}$-eq. emissions from wind-generated electricity are very low compared to the overall avoided emissions in scenarios B'. Apart from that, the positive emissions are very similar in all the scenarios, since acidification is mainly caused by energy consumption in the different processes. The $\mathrm{SO}_{2}$-eq. emissions in scenarios $\mathrm{A}$ are slightly higher than in scenarios $B$ (without taking the avoided processes into account), because of the contribution of $A D$, despite emissions from composting and sorting in scenarios $B$ (mostly caused by ammonia release in composting and electricity consumption in both).

A similar situation can be observed in eutrophication (Figure 3.3b), but co-product credits and the amount of UCO collected interact in a different way. There is a more significant contribution of avoided fertilizer production in scenario A than in acidification, because it avoids the release of nitrate and other compounds which cause eutrophication, such as xylene. The total of this sub-stage and the avoided production of electricity from the Spanish mix is enough to outperform scenarios B1 and B2 when the FU is $1.70 \mathrm{~kg}$ of UCO $+35.50 \mathrm{~kg}$ of SOW per inhabitant and year; this impact is between $76 \%$ and $632 \%$ lower in scenario A. However, the production of propylene glycol generates much greater emissions of phosphorus, nitrate or inorganic compounds, such as methanol or hexane, and thus scenario B2 causes $16 \%$ less eutrophication than scenario A2 (when wind-electricity is displaced). On the contrary, the avoided production of synthetic glycerin does not produce enough avoided emissions to offset the ones from fertilizer production in scenario B1-A2. When a FU of $6.38 \mathrm{~kg}$ of UCO $+35.50 \mathrm{~kg}$ of SOW per inhabitant and year is considered, more glycerin is obtained from biodiesel production and thus the avoided burdens from both glycerin and propylene glycol lower the impact of scenario $B$ to below that of scenarios $A 1$ ' and $A 2$ ' (between $11 \%$ and $88 \%$ ), except for the combination scenario B1'-A1' (in which scenario A1' causes a $103 \%$ lower impact). When taking only positive emissions into account, scenarios $B$ generate more eutrophication due to emissions from composting $\left(\mathrm{NH}_{3}\right)$, incineration ( $\mathrm{NO}$ and $\mathrm{NO}_{2}$ ) and sorting. 


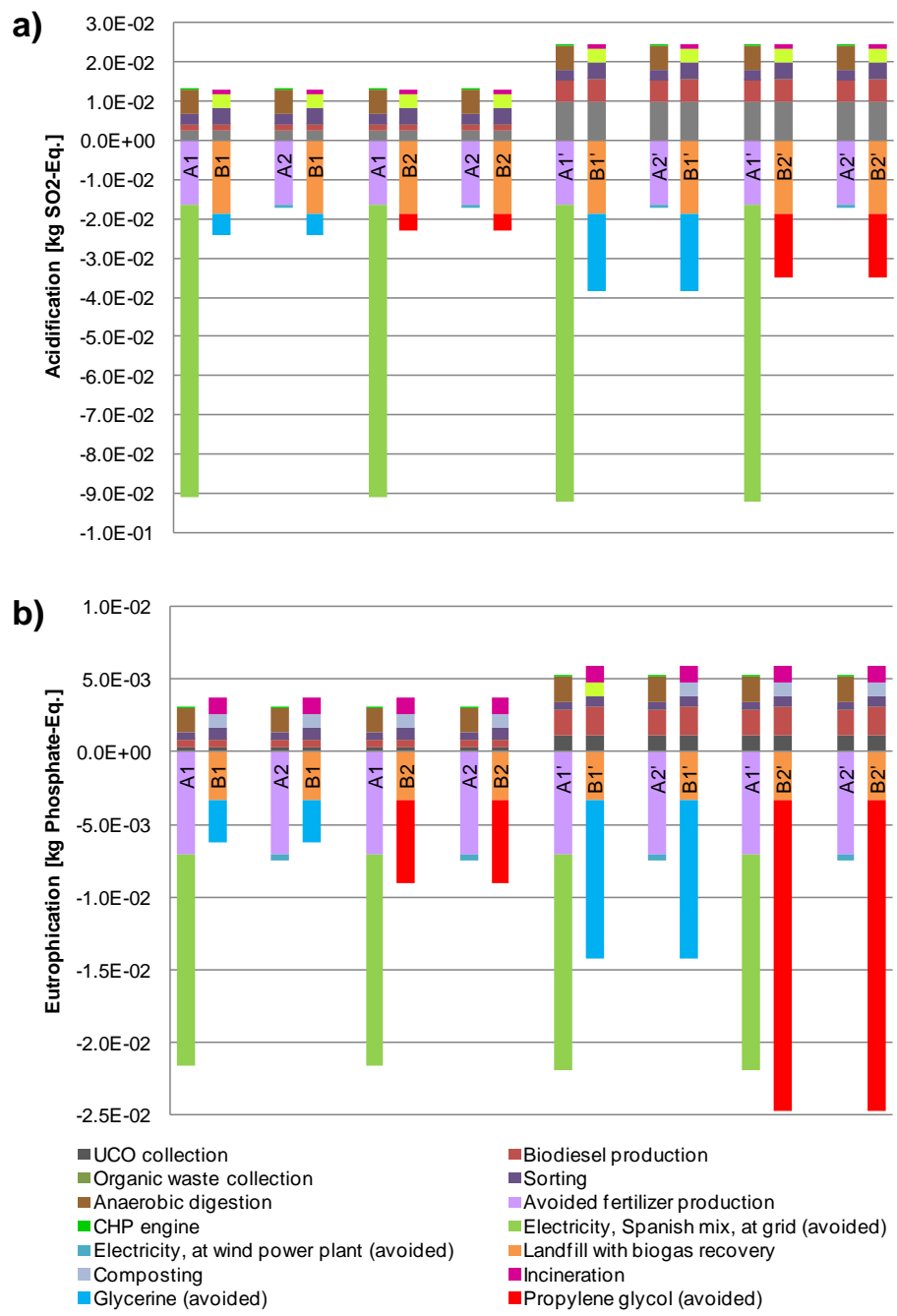

Figure 3.3. Contribution of the constitutive processes of each scenario to the impact categories of acidification and eutrophication, according to the deterministic results of the impact per inhabitant and year.

As regards the rest of categories shown in annex $A$, it must be noted that both conventional electricity and wind-generated electricity cause similar abiotic depletion in terms of Sb-eq. consumption. This happens because the production of capital goods is included in all the sub-processes, and wind power is also very input-intensive (due to turbine manufacturing). Hence, avoided glycerin production is the sub-stage that makes the difference in this impact category. Both synthetic 
glycerin and propylene glycol production are very input-intensive processes in their use of chemicals and energy. However, these avoided burdens are only enough to offset those generated in scenarios $A$ by avoided fertilizer production when the amount of UCO collected is higher, which is scenarios B1' and B2', despite the greater abiotic depletion by transesterification due to input production (methanol and catalyst). In GW, the contribution of emissions from sanitary landfill, such as CFC12, CFC11 or VOC compounds in scenarios B, is remarkable. This is why these scenarios perform between $49 \%$ and $120 \%$ worse in every case, in spite of methane losses from the $A D$ in scenarios $A$. GHG emissions from the rest of the sub-stages are mainly caused by energy consumption. In HT, the sub-stage with the greatest contribution is again the avoided production of glycerin and propylene glycol; displacing the second compound generates higher environmental credits in terms of DCB-eq., despite the lower displacement ratio. As a result, scenarios B cause between $2 \%$ and $89 \%$ less HT in those scenario formulations in which propylene glycol is considered (B2 and B2'); the avoided burdens from synthetic glycerin production are enough for scenario B1' to outperform scenario A2' (41\% lower impact), that is, only when wind-electricity is displaced in the Integral-b scenario. Finally, scenarios A lead to lower emissions of Ethene-eq. for all the scenario formulations, as a consequence of the emissions from sanitary landfill and composting (such as NMVOC and VOC, respectively). AD and cogeneration also release methane in scenarios $A$, but with a less negative effect due to a lower characterization factor. The POC impact is between $7 \%$ and $134 \%$ lower in scenarios A.

Finally, it has to be mentioned that the selective collection of the SOW by means of a DTD system in scenario A generates greater impact in all the categories due to higher capital goods consumption. On the contrary, it entails less electricity consumption in sorting than the non-selective collection in scenario $B$, since more unsorted waste has to be collected in this case to obtain the same amount of organic fraction in the FU.

\subsubsection{Results from the uncertainty analysis}

The outcome of the Monte Carlo simulation of all the scenario formulations is represented in Figure 3.4 by box and whiskers plots, where the variability of the selected process parameters was taken into account. The bold line in the middle of the box shows the median values of each impact category, per year and inhabitant as they depend on the FU. The box shows the $25^{\text {th }}$ and the $75^{\text {th }}$ percentiles obtained from the Monte Carlo simulation and the whiskers are the minimum and maximum values of the impact between the $10^{\text {th }}$ and $90^{\text {th }}$ percentiles. 

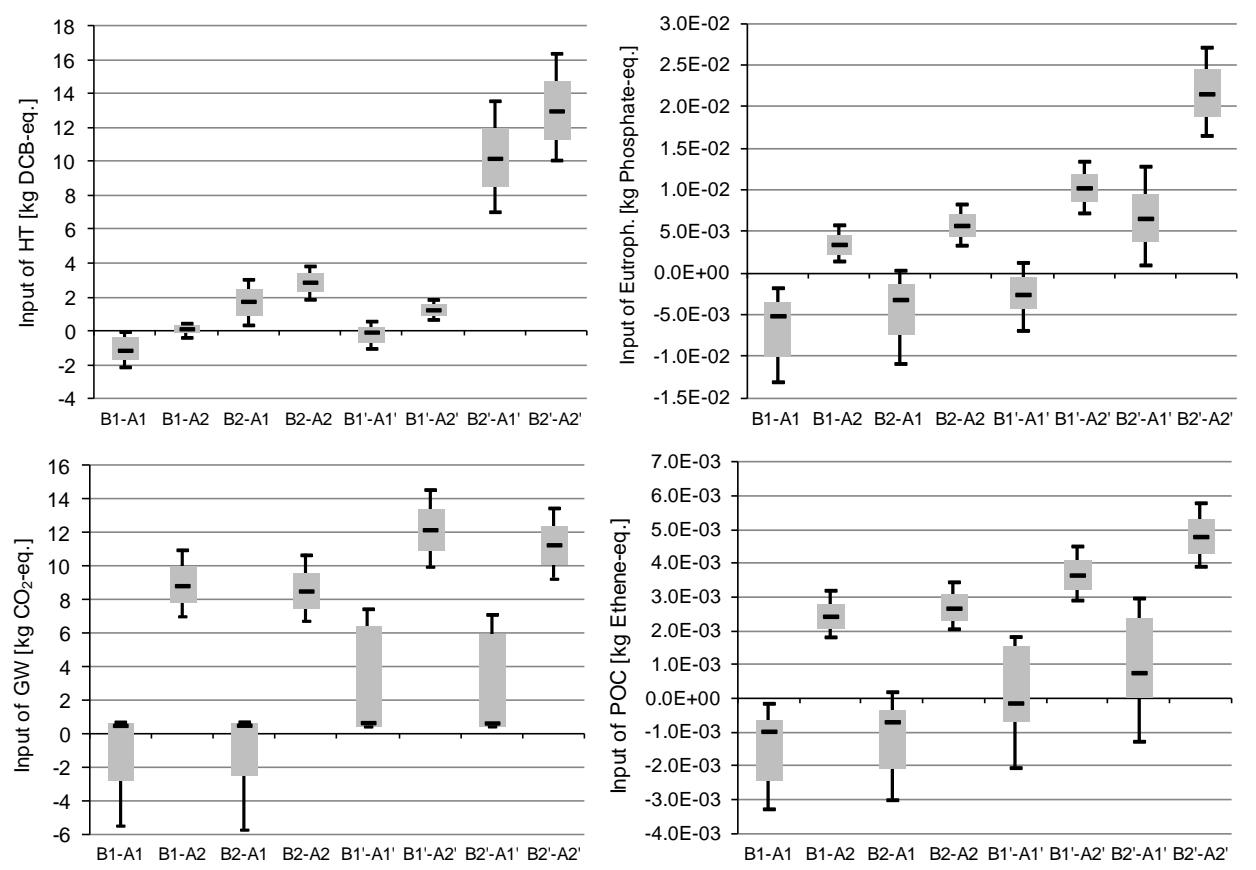

Figure 3.4. Box and whiskers plots of the differential Monte Carlo simulations of scenario Bscenario A for the impact categories in which the sign of the difference is reversed in some scenario formulations.

Since both systems (A and B) cause avoided burdens, impact categories are broken down into input and output effects, depending on the contribution of the sub-processes in each system: input means avoided emissions, whereas output means net emissions, except for abiotic depletion (where input means avoided resource consumption). The higher the input, the better the environmental performance. It has to be pointed out though that the input values are not exactly the difference between the result of adding together the avoided burdens in both scenarios, which appear in Figure 3.3 as bars below the x-axis; these bars show the contribution of processes causing overall negative impact. However, as was said, incineration also generates avoided burdens from electricity, despite the fact that the overall impact has a positive sign. This input contribution is taken into account in Figure 3.4. The same occurs with the outputs, which in Figure 3.4 also include net emissions from landfilling, although the overall impact is negative due to electricity production. In addition, default transport processes in Gabi 6 consider that a small part of the total fuel comes from renewable sources, thus individually causing carbon uptake. This is the reason why the input of GW also includes some effects from each of the transport processes considered in all the sub-stages, and the output includes a small part of the $\mathrm{CO}_{2}$ emissions from the avoided biofuel 
consumption in transport. Similarly, output values show the difference between all the emissions from each sub-stage in both scenarios.

For comparative purposes, uncertainty due to parameter variability is only relevant in those scenario formulations for which the value of the impact in some simulation results shows positive and negative values. That is, when the box and/or the whiskers cross the $x$-axis, meaning that the sign of the scenario B-scenario $A$ difference is reversed. This is the reason why only the impact categories in which the uncertainty may compromise the sign of the difference are shown in this section. As can be seen in Figure 3.4, this happens for some scenario formulations and only in some categories in their role as inputs, because uncertainty is mainly due to the variability of the parameters involved in the avoided processes: the avoided production of electricity, fertilizers and glycerin/propylene glycol. Since only the "input side" of some impact categories is shown in Figure 3.4, it is important to notice that above zero values on the $y$-axis indicate that scenario $B$ outperforms scenario $A$. This means that pollutants uptake is higher in scenario $B$ due to co-product credits. Below zero values on the $y$-axis indicate that scenario $A$ is better than scenario B. When discussing the "output side" (in section A4 of the annex $A$ ), above zero values on the $y$-axis indicate that scenario $A$ outperforms scenario B (lower emissions), and the other way round. The rest of the scenario formulations are also included to assess the whole picture; the remaining categories appear in section A4 of the annex A.

As regards the eutrophication input, Figure 3.4 shows that parameter variability proved to be critical only for the two scenario formulations in which the mean result of the difference between scenarios was the lowest (around $2 \cdot 10^{-3}$ phosphate-eq.): B2-A1 and B1'-A1'. Note that this means that scenario A causes marginally more phosphate-eq. uptake than scenario $B$ due to co-product credits. Since the difference between inputs is low, there is a slight probability that scenario $B$ outperforms scenario A in those specific scenario formulations, as well; in the rest, scenario $B$ causes a higher input of eutrophication as a result of the contribution of glycerin/propylene glycol and electricity from landfilling and incineration.

According to mean and median values, scenarios $\mathrm{B}$ cause higher $\mathrm{CO}_{2}$-eq. uptake than scenarios $A$ in all the formulations, despite the negative emissions from the avoided electricity and fertilizer production. However, for scenarios B1-A1 and B2A1 the difference between overall GW input of both scenarios is close to zero and may change its sign as a consequence of parameter variability. This variability is greater in those scenario formulations that consider the avoided electricity from the average Spanish mix (scenarios $\mathrm{A} 1$ and $\mathrm{A}^{\prime}$ ), and the box and whiskers are more asymmetrical than in other cases due to the combined effect of variation in some process parameters, which is especially critical when determining this sub-stage. Specifically, it has to be taken into account that the parameter fraction to landfill 
determines the amount of waste going to composting and to incineration too, making these two flows negligible when fraction to landfill is close to $100 \%$, with the subsequent effects on the GHG balance. In addition, both fraction to landfill and UCO collection efficiency were also assigned asymmetrical probability distributions, and they affect significantly the determination of all the impacts, especially those from co-product credits.

A similar analysis can be applied in the case of HT. Uncertainty may be critical only for the scenario B1-A2 and B1'-A1' comparison, for which the difference in HT input is minimal; depending on the simulation runs, scenario $B$ may outperform scenario A or the other way round. For the rest of the combinations the difference is clear, especially for those in which the avoided burdens from propylene glycol are the highest (scenarios B2'-A1' and B2'-A2'). In POC, the uncertainty is again more relevant in those scenario formulations with electricity from the average Spanish mix. A variation on the incidence of this sub-stage due to the variability of risk parameters (selected in turn due to its contribution to that very sub-stage) can make the difference in scenarios B2-A1, B1'-A1' and B2'-A1'.

Uncertainty is irrelevant for the rest of the impact categories as either inputs or outputs, because results between the $10^{\text {th }}$ and $90^{\text {th }}$ percentiles prove that the sign of the scenario B-scenario A difference remains the same. However, there is some room for debate. In the abiotic depletion input, the highest CVs (around 35-40\%) are obtained for the scenario formulations that consider current UCO collection levels, where the parameters related to biodiesel production play the major role. In this case, the abiotic depletion input corresponds to the positive bars in Figure 3 , but subtracting burdens from the electricity produced by incineration in scenario $B$, which have to be added to the negative bars representing the abiotic depletion output. For this category, the probability distributions of the second four scenario formulations exhibit the highest CVs (80-120\%), due to the contribution of the glycerin/propylene glycol production parameters to the overall uncertainty.

The relative variability for the four scenario formulations that consider displaced electricity from the average Spanish mix in scenario $A$ is greater than in the others for both acidification input and output. As was said, this sub-stage also makes the difference for this impact category and, thus, the risk parameters involved. The same occurs for the eutrophication and HT outputs: the highest CVs are found for scenarios B1-A1 and B2-A1, where this avoided process is crucial for the difference between the scenarios. All the scenario formulations exhibit similar uncertainty in GW and POC outputs, with the CVs ranging around $50 \%$. 


\subsubsection{Discussion}

The results prove that potential environmental benefits caused by the Integral-b system are conditional on the methodological choices regarding the co-product credits and, to a lesser extent, on parameter variability. In general, displacing electricity from the average Spanish production mix generates much higher avoided burdens than the wind-generated electricity in scenario A, except in the case of abiotic depletion. The avoided burdens from synthetic glycerin and propylene glycol are similar, but their relative incidence varies depending on the impact category.

Obviously, the effect of both sources of uncertainty also depends on the levels of UCO collection, which are expected to change if the integrated system leads to retailers and caterers being more motivated to collect the residual oil. The only impact categories for which scenario A performs better than scenario $B$, regardless of scenario assumptions and the UCO reference flow, are GW and POC. For current levels of UCO collection, the alternative process proposed by Integral-b clearly improves the environmental profile, causing a reduction in most of the impact categories of between $43 \%$ and $632 \%$, and in most of the scenario formulations. Essentially, this is due to the avoided burdens of electricity from cogeneration and digester sludge, which are greater than those from glycerin and electricity from incineration and sanitary landfill in the reference system. However, in those cases where it is assumed that electricity from the CHP replaces windgenerated electricity, scenario B appears to have a lower impact: this is the case of acidification (around $60-65 \%$ ) and eutrophication, but in this case only if glycerin displaces propylene glycol (16\%). The same occurs in HT again when propylene glycol is considered, regardless of the marginal electricity in scenario A ( $2 \%$ and $53 \%$ lower impact than scenario $A 1$ and $A 2$, respectively).

Increasing the UCO collection is clearly detrimental to the environmental benefits from scenarios $A$, which is apparently in contrast to what could be expected. The impact of those scenario formulations considering the avoided wind-electricity and/or the avoided propylene glycol production is lower in scenario B for most of the impact categories, even for scenario $\mathrm{B1}^{\prime}-\mathrm{A} 1^{\prime}$ in the case of abiotic depletion (170\% lower). Expanding the UCO reference flow increases the impact both of its collection and of the biodiesel production to the same extent in both scenario $A$ and scenario B. As a consequence, the glycerin production also increases significantly, causing greater benefits from the increased electricity production from the CHP, but also higher environmental credits due to the avoided production of synthetic glycerin or propylene glycol. These two processes are very input-intensive and generate higher credits than the avoided electricity, in part because the displacement ratios are 1 or close o 1 , whereas the CHP engine needs highly 
purified glycerin (containing only $15 \%$ of the crude glycerin), with the subsequent electricity conversion efficiency. In other words, the glycerin in scenario A plays a smaller role in terms of co-product credits. That is why not using the glycerol from biodiesel production is favorable to scenario B under these scenario assumptions.

Nevertheless, it must be taken into account that this may not be a realistic scenario if the biodiesel sector in Spain grows faster than the capacity of the chemical and pharmaceutical sectors to accommodate glycerol. This has already happened in countries such as Brazil. In fact, on a global scale, the biodiesel industry has converted glycerol into a low-value, price-stable commodity, as mentioned in section 1.4. Under this perspective, glycerol would become a waste to be treated instead of a by-product. In that case, scenario A would cause greater environmental benefits since, by performing system expansion, scenario $B$ should include the disposal or valorization of glycerin. The last few years have seen a proliferation of studies trying to promote a viable process with which to convert crude glycerol into value-added products, increasing the profitability of the biodiesel industry (Amaral et al., 2009; Leoneti et al., 2012; Yazdani and Gonzalez, 2008). For instance, Johnson and Taconi (2007) and Yazdani and Gonzalez (2007) suggested the biological conversion of glycerol into 1,3-propanediol, apart from other uses such as animal feed or fuel, which barely increase the market price of crude glycerol. However, none of these options has been taken into account in this study because no standard valorization processes have been found in literature and most of the studies were only implemented at pilot level. Considering these valorization options could be interesting for further studies, although it may entail increasing uncertainty due to choices concerning system expansion, since these alternative processes usually have co-products and affect other sectors. As a consequence, using glycerin as a fuel in the CHP engine would add environmental incentives for the system proposed by the Integral-b project.

Parameter uncertainty is not as critical as uncertainty due to scenario assumptions, as Finnveden et al. (2005) also found. For example, for CHP systems, it is more important to know the marginal technology used to produce electricity, than to have precise emission factors. Despite the fact that not only emission factors but also other parameters from scenario assumptions (such as distances, percentage of food losses or waste allocation) were included in the analysis of data uncertainty, Monte Carlo results show that, in most of the impact categories and scenario formulations, the variability of the risk parameters does not substantially change the results. However, there are some special cases in which uncertainty due to parameter variability changes the sign of the differential forecast distribution; for those aforementioned scenario formulations shown in Figure 3.4, histograms were built to discern the probability of scenario $B$ outperforming scenario $A$ and the other way round. 
a)

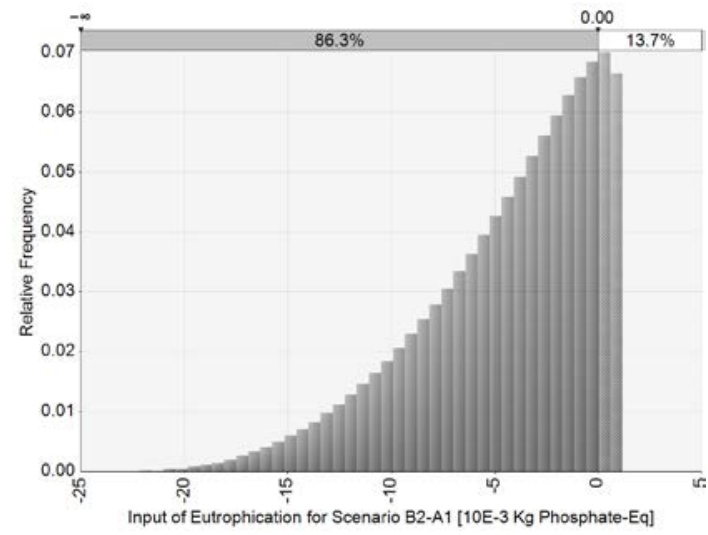

b)

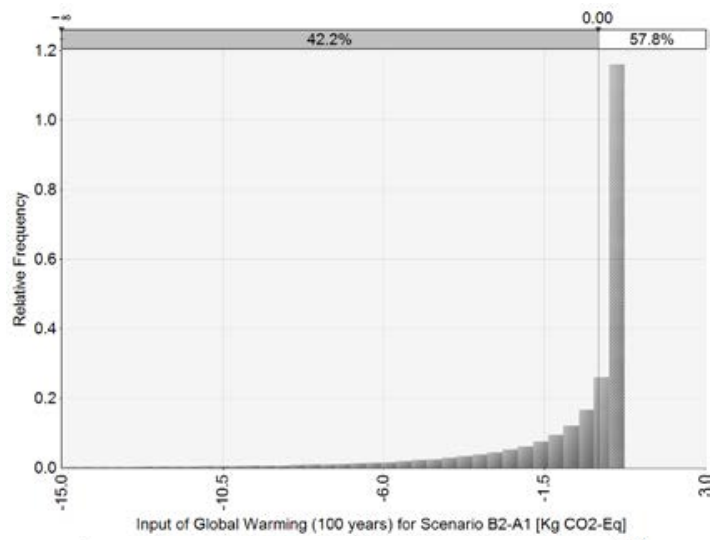

c)

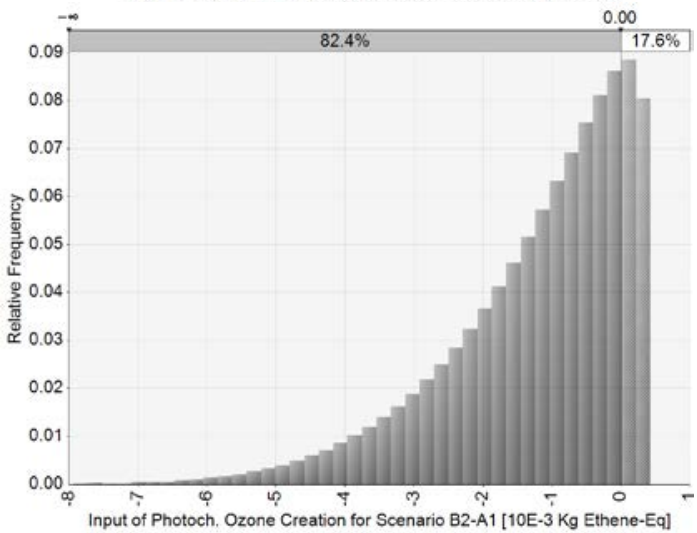

Figure 3.5. Histograms of the differential Monte Carlo simulations of scenario B2-scenario A1 for the impact categories of eutrophication, GW and POC (inputs).

These histograms were obtained by means of the Risk 5.5 software (Palisade Corporation, 2009) from the same percentiles used for the box and whiskers diagrams, since no detailed outcomes for all the simulation runs can be obtained 
from Gabi 6 . Hence, results were adjusted to the best fit probability distribution, and are represented in Figure $3.5(\mathrm{a}, \mathrm{b}, \mathrm{c})$, only for the scenario B2-A1, which appears to be critical in three impact categories (as inputs); the rest of the scenario formulations for which the impact result can change its sign within the forecast distribution are included in section A4 of the annex A (Figures A23 to A28). It can be deduced from the histograms in Figure 3.5 that scenario A1 causes a higher input and thus outperforms scenario B2 in $86.3 \%$ of the results for eutrophication, $42.2 \%$ of the results for GW and $82.4 \%$ for POC. These diagrams show that for these specific categories the distribution of the scenario B2-A1 difference rather follows a lognormal distribution, with fewer values between the median and the $90^{\text {th }}$ percentile than between the median and the $10^{\text {th }}$ percentile. Similarly, there is a greater probability of scenario A1' outperforming scenario B1' in eutrophication input (80.5\%) and for HT input (56.3\%); but there is more probability of scenario B1 causing a higher input of GW than scenario A1 (56.0\%), and a higher input of HT than $A 2(67.0 \%)$; finally, the probability of scenario $A 1$ ' performing better than scenario B1' in POC input is around $50 \%$, while it is much lower when compared to scenario B2' (27.8\%).

\subsubsection{Conclusions}

In section 3.1, an environmental assessment has been performed on an alternative integrated system for the management of SOW from catering and restaurants, including UCO, as compared to a reference system. Since both systems are multifunctional, they were credited for producing co-products by performing system expansion. Hence, the electricity from cogeneration caused avoided burdens in the proposed system (scenarios $A$ ), whereas glycerol was assumed to be a by-product with potential uses delivered by the reference system (scenarios B). Uncertainty due to choices regarding these co-product credits has proved to be very influential, since differences in the comparative analysis are mainly caused by these avoided processes. As a general conclusion, the same idea as Moberg et al. (2005) can be drawn: the scenario assumptions and system boundaries used are of great importance when comparing waste treatment options.

In order to analyze this source of uncertainty, recommendations from the JRC (2010) were taken into account, and the choice-related variation leads to a number of discrete results to be presented as possible outcomes of the LCA, depending on which choices are made. The choices that were considered are reduced to a manageable number in order to ease the interpretation of the results. In order to enhance the robustness of the results, parameter uncertainty was also assessed by means of the Monte Carlo simulation, which is readily available in commercial LCA software but still with some limitations that are detrimental to its reliability. For those specific scenario formulations for which parameter uncertainty appeared to 
be critical, histograms were built to quantify the probability of scenario A outperforming scenario B and the other way around. This approach is proposed as a discernibility analysis that can be helpful for decision-makers when judging the significance of the differences in the comparison of processes.

By analyzing parameter uncertainty, we are more certain that the impacts are within the range obtained, even though it cannot be concluded that scenario $A$ is always better than scenario $B$ because it depends on scenario choices. These choices regarding co-product credits are not in themselves opportunities to reduce the impact of the proposed system; decision-makers cannot control the avoided processes since they arise from the LCA methodology and they are not certain, but likely, to happen, depending on the technical or political context. The results leave the question of which system is better as an open conclusion, conditional to what really would happen in Spain with the electricity from cogeneration in scenario $A$ or with glycerin in scenario B. However, the system proposed by Integral-b is better in most of the analyzed scenario formulations. In order to achieve more conclusive results, it would be advisable to assess the third source of uncertainty according to Huijbregts et al. (2001), due to different impact assessment methods, or the influence of performing partitioning, although these two issues in themselves could lead to separate studies. Furthermore, the results underline the need to define an acceptable level of uncertainty when assessing waste management systems.

For the Monte Carlo simulation, it has to be taken into account that all process parameters and elementary flows are assumed to vary independently, while some technical variables are usually correlated and vary depending on each other. In order to prevent this issue from leading to any overestimation or underestimation of the real uncertainty, we recommend that LCA practitioners define as many parameters and relations as possible, leaving only the independent parameters to be selected for the sensitivity and uncertainty analyses. Besides the software limitations, which are beyond our reach, more data needs to become available in order to assess parameter uncertainty with more precision, avoiding an arbitrary selection of probability distributions. For this reason, we encourage the partners of the Integral-b project to gather historical data about all the processes in order to reinforce the reliability of results with the final aim of implementing the system. More studies analyzing in depth uncertainty in waste management systems would also be appreciated in order to establish accurate probability distributions for the reference system. In this sense, a sensitivity analysis may be an extremely helpful tool with which to identify which parameters require accurate statistical information.

Finally, it has to be pointed that results for those cases in which both scenarios generate a negative impact $(<0)$ may lead to the wrong conclusion that the more waste produced by retailers, the better for the environment. This is a theoretical construct arising from the substitution approach but, in practice, no waste 
management process can generate negative emissions by itself, thus increasing the amount of waste does not result in lower overall emissions. In this section, the process proposed by Integral-b has been simply presented as a waste management option to fulfill the requirements of Directive 2008/98/EC, in the urban context. According to this, the very producer of the waste must guarantee its proper treatment. To reinforce this idea, the environmental results are coupled with those from the Life Cycle Costing in the following section, since waste management activities generate a cost for the society. The combined study would help to choose the least expensive option with the lowest environmental impact, while never neglecting uncertainty. However, the appropriateness of implementing the Integralb process in an existing UCO biodiesel plant would require a smaller scope, at producer level. 
Submitted to the International Journal of Life Cycle Assessment

\subsection{Uncertainty analysis in the financial assessment of an integrated management system for restaurant and catering waste in Spain}

Escobar, N. ${ }^{a}$, Ribal, F.J. ${ }^{b}$, Clemente, G. ${ }^{a}$, Rodrigo, A. ${ }^{c},{\text { Pascual, } \text { A. }^{c}, \text { Sanjuán, N. }}^{a}$

${ }^{a}$ Grup ASPA. Departament de Tecnologia d'Aliments, Edifici 3F, Universitat

Politècnica de València. Camí de Vera s/n, 46022, Valencia, Spain

${ }^{b}$ Departament d'Economia i Ciències Socials, Edifici 3P, Universitat Politècnica de València. Camí de Vera s/n, 46022, Valencia, Spain

${ }^{\mathrm{c}}$ Ainia Centro Tecnológico, Parque Tecnológico de Valencia.

C/ Benjamin Franklin 5-11, 46980, Paterna (Valencia), Spain 



\section{Abstract}

Purpose:

The goal of section 3.2 is to analyze the economic performance of an alternative system for waste management proposed by the European Integral-b project. Its aim is to treat both used cooking oil (UCO) and solid organic waste (SOW) from the hospitality sector in Spain, by biodiesel production and anaerobic digestion, respectively. A cogeneration engine adapted to use glycerol as a fuel is implemented. These results complement those from section 3.1.

Methods:

The system proposed (scenario $A$ ) is compared to a system consisting of average waste management options (scenario B) by means of Life Cycle Costing (LCC). The functional unit $(\mathrm{FU})$ is the same as in section 3.1. The profits generated by the FU under the two scenarios are calculated from a financial point of view. Since both systems are multi-functional, it is considered that the co-products translate into revenues for waste managers. Scenario analysis assesses different electricity rates, subject to market regulations, and different levels of UCO availability. Monte Carlo simulations are carried out to analyze parameter and price uncertainty.

Results and discussion:

The profits in all the scenarios are negative, and those of scenario $A$ are lower than those of scenario $B$ under all the scenario formulations. Scenario A generates greater income than scenario $B$ but also higher expenses, mainly due to SOW collection. The new electricity rates are detrimental for the financial performance of the Integral-b, since the overall profits mostly depend on the sale of electricity. Readier UCO availability benefits both scenarios to a similar extent. The uncertainty analysis shows that there is some likelihood scenario A will generate greater profits. Trade-offs between the LCC and Life Cycle Assessment (LCA) results have been evaluated.

Conclusions:

Results from the financial analysis show that the Integral-b process delivers greater income losses as compared to a reference scenario. Both generate negative profits, meaning that stakeholders have to finance the functions provided. Uncertainty in the electricity regulations constitutes an obstacle for such projects as these to be implemented on an industrial scale. As in LCA, the definition of the system boundaries and FU is critical in LCC.

Keywords: food waste, Life Cycle Costing, Monte Carlo, organic waste, uncertainty, used cooking oil, waste management 


\subsubsection{Introduction}

Concerns about the environmental consequences of increased levels of food waste have been raised in recent years, as demonstrated by the publication of several reports on the quantities of food lost throughout our supply chains (e.g. FAO, 2013; NRDC, 2012; WRAP, 2015). As a result, public policies are increasingly aimed at both preventing the production of food waste and promoting proper treatments for it. Specifically, in the European Union (EU), Directive 2008/98/EC, also known as the Waste Framework Directive (WFD), was adopted in order to establish the regulatory framework for future waste management plans and prevention programmes in the Member States. Specifically, the WFD is based on the "polluter pays principle" and "extended producer responsibility", according to which producers are responsible for the costs of managing their products at end of life. In other words, the ultimate producer of the waste must ensure its proper treatment. This is to encourage manufacturers to design environmentally-friendly products in order to reduce both pollution and also waste management costs. The separate collection and proper treatment of biodegradable waste is also recommended for the purposes of reducing greenhouse gas (GHG) emissions, including organic waste from households, restaurants, caterers and retail premises.

According to the FAO (Gustavsson et al., 2011), the average food waste per capita generated by consumers in the EU and North America is about 95 to $115 \mathrm{~kg} / \mathrm{year}$, more than $40 \%$ of which occurs in the final steps of the chain, namely at the retail and consumer stages. Spain has the seventh highest level of food wastage of any EU country (7.7 million tons per year), and it is stated that annual national food losses are $175.9 \mathrm{~kg}$ per capita (MAGRAMA, 2013a). Apart from households, the hospitality sector is no doubt a significant producer of food waste. In Spain, total food consumption in restaurants, catering and institutions represents around $20 \%$ of the total annual food consumption, 8.43 million tons in 2010 (Muñoz-Cidad and Sosvilla, 2012). According to estimations from Engström and Carlsson-Kanyama (2004), approximately $20 \%$ of this amount turns into waste; this would imply around 1.7 million tons per year, with the potential of becoming a suitable source for energy recovery if appropriate collection systems are established.

Waste from restaurants and catering is basically made up of three types of residues: packaging, SOW and UCO. The organic fraction usually enters the municipal solid waste (MSW) stream, and is mainly treated by landfilling or composting (Eurostat, 2013a). The amount of UCO produced annually by restaurants and catering in Spain is estimated at around 80,000-100,000 tons (IDAE, 2011a; Rodrigo et al., 2011). It is mostly collected by authorized management companies through specific collection points (usually metal and plastic containers located at the retailer's); it is then diverted to biodiesel 
production, since EU Regulation 1774/2002 forbade using UCO for animal feed. Crude glycerol is obtained as a by-product, since, after purification, it is in frequent demand by the cosmetic and pharmaceutical industries. The production of 1 ton of biodiesel yields approximately $100 \mathrm{~kg}$ of crude glycerol $(10 \% \mathrm{w} / \mathrm{w})$, containing 55$90 \%$ of pure glycerol (Siles López et al., 2009), and the biodiesel industry has indeed become the main source of this compound since 2008 (Gholami et al., 2014). However, glycerol may no longer represent a significant profit for the biodiesel industry due to its low price and high purification costs, as a consequence of the growing market for biodiesel (Posada et al., 2012). Otherwise, glycerol will have to be disposed of as waste (Albarelli et al., 2011), as already happens to some small and moderate-scale producers, who cannot afford to purify it (Thompson and He, 2006).

The Integral-b project, developed within the context of a European LIFE initiative, proposes an integrated system for the joint management of both UCO and SOW from the hospitality sector. It is seen as a means of improving the viability of biodiesel plants in Spain, most of which are currently at a standstill as a result of the low production margins and other market factors. Specifically, the system consists of implementing an anaerobic digester and a cogeneration engine in the same biodiesel facility. This allows for the SOW to be treated by anaerobic digestion (AD). The resulting biogas is used as a fuel in a combined heat and power (CHP) engine, producing thermal energy and electricity simultaneously. This improves the energy efficiency of the whole process, and the electricity is sold to the grid. Additionally, digester sludge is obtained from the AD, with agronomic properties. These co-products could increase revenues for biodiesel plants. The CHP engine is specially adapted to use glycerol together with biogas, performing an in situ recycling of this co-product of transesterification and avoiding future market surpluses. The Integral-b project was carried out by the Ainia Technology Centre, the Cidaut Foundation, Biogas Fuel Cell and Bionorte, all of them located in Spain. All the processing modules were designed and built by each partner, and were finally implemented jointly at the Bionorte facility, with the subsequent trial tests. The environmental benefits of the Integral-b process have been studied in a previous paper (Escobar et al., 2015), which constitutes section 3.1. Nevertheless, its economic feasibility must be conveniently assessed in order to influence decision-making.

In response to an increase in the public expenditure derived from a rising population, the analysis of the economic implications of waste management activities has been gaining in importance in the scientific and policy arena. Some studies have included the assessment of economic aspects under a life cycle perspective and propose integrating the economic and environmental points of view in municipal waste management processes (Carlsson Reich, 2005; Eriksonn 
et al., 2005; Finnveden et al., 2007; Kim et al., 2011). Carlsson Reich (2005) defines the financial LCC as a parallel analysis tool to LCA, for which all the costs of fulfilling the FU must be included. Just as LCA can help to identify those critical sub-stages in environmental terms, LCC helps to identify those stages that constitute an opportunity to reduce costs. However, although both LCA and LCC apply a life cycle approach, they differ in some methodological aspects, mainly the purpose and the system boundaries, but also in the accounting principles and treatment of time. This is because, as Norris (2001) points out, they try to answer different questions. Authors, such as Heijungs et al. (2013), have made an effort to align LCA and LCC. In spite of these obstacles, combining LCA with LCC allows for the important relationships and trade-offs between the economic and life cycle environmental performance of alternative scenarios to be taken into account.

As regards the system boundaries, while LCA considers all the processes causally connected to the physical life cycle of the product, LCC considers all the activities that represent either direct costs to the decision-maker or make them a profit during the economic life of the investment. This is why the first includes flows of pollutants, resources and materials within the system boundaries, and the second includes the cost and benefit monetary flows directly impacting the decision. Hence, LCCs of waste treatment systems often consider capital goods, as an important part of the total costs of the system (Eriksson et al. 2005). On the contrary, including impacts from capital goods is not a common practice in LCA despite the fact that the burden contribution from capital goods can become quite large if a waste fraction has low pollutant content (Frischknecht et al. 2007). As is the case in LCA, multi-functionality is another important issue when carrying out LCC, especially when dealing with waste treatment plants; this arises when coproducts may, in turn, be used in other product systems. In LCA, this multifunctionality has been tackled by system expansion (e.g. Güereca et al., 2006) or partitioning (e.g. Iriarte et al., 2009). In LCC, co-products with market value can simply translate into revenues for the producer (e.g. Erikksson et al., 2005; Kim et al., 2011; Zhang et al., 2013), which must be included so as to fully understand the financial performance. Revenues generated by co-products may have a great influence on the viability of waste treatment plants and biofuel facilities as well (e.g. Hass et al., 2006). This procedure would be equivalent to the substitution approach in LCA, while partitioning can also be applied in LCC. For instance, Luo et al. (2009) allocated fixed capital investment and operating costs between ethanol and co-products based on their economic values.

Another critical aspect in LCC is data quality, which mainly depends on cost allocation methods, cost management systems, data availability and confidentiality (Ciroth, 2009). Data quality covers different aspects, such as time horizon, market dynamics, or the life cycle stage that is being addressed. Zhang et al. (2013) took 
the process scale into account, since the size can significantly affect the expected economic performance. In addition, the quality of cost data, especially price variability, also influences LCC results and result uncertainty. In fact, in the case of LCC, the uncertainty may be much greater than parameter uncertainty in LCA, since the market dynamics are significantly strong. Specifically, the uncertainty in LCC outcomes is affected by aspects that do not necessarily influence the uncertainty of future environmental performance, such as taxation, wages, discount rates, changes in market prices driven by surpluses and market trends, etc (Gluch and Bauman, 2004; Schmidt, 2003). For all these reasons, an analysis that relies on the estimation and valuation of uncertain future incidents and outcomes is problematic. In spite of the importance of these issues in terms of LCC outcomes, uncertainty analysis is not very common in LCC studies, and only a few studies address parameter uncertainty by applying the Monte Carlo method (Kleyner and Sandborn, 2008; Zhang et al., 2013).

The goal of this section is to assess the financial performance of the system proposed by the Integral-b project as compared with a conventional management system for the same kind of waste. The uncertainty caused by variability in both technical and economic parameters will be analyzed, as will that arising from assumptions in regard to changing electricity rate regulations and UCO availability conditions. Analyzing the financial feasibility of the Integral-b project is crucial for its implementation on an industrial scale, while allowing for a more thorough understanding of its sustainability. An uncertainty analysis of the financial results is equally necessary in order to facilitate decision-making.

\subsubsection{Methods}

In order to obtain meaningful results, the financial assessment must be consistent with the environmental one. According to Carlsson Reich (2005), the time frame and system boundaries must be exactly the same.

\subsubsection{Functional Unit}

The same FU as in the environmental assessment (Escobar et al., 2015) was used for the economic one. Hence, the double function of the Integral-b system was considered, which is to manage both the UCO and SOW from restaurants and catering produced in a specific region in the Spanish context. The FU was defined accordingly as the management of the amount of organic waste from restaurants and catering (excluding packaging residues) produced per person during a year in Spain. To this end, two functional inflows were calculated: $1.70 \mathrm{~kg}$ UCO/inhabitant and year and $35.50 \mathrm{~kg}$ SOW/inhabitant and year. All the inputs and outputs 
considered in each system, as well as the impact results, depend on these two functional flows.

\subsubsection{System description and scenario formulations}

To quantify the possible economic improvements generated by the process proposed by the Integral-b project (scenario A), it was compared to a reference system (scenario B), based on current management systems for the same kind of waste. The two scenarios studied for the management of the FU are as follows:

- Scenario A, which includes: a) UCO collection, b) biodiesel production, c) SOW collection and sorting d) AD of the SOW, and e) energy cogeneration in a CHP engine (as shown in Figure 3.6).

- Scenario B, which includes: a) UCO collection, b) biodiesel production as the current treatment for the UCO, c) SOW collection and sorting, d) landfilling of most of the SOW, e) composting of part of the SOW, and $f$ ) incineration of the remaining part (as shown in Figure 3.7).

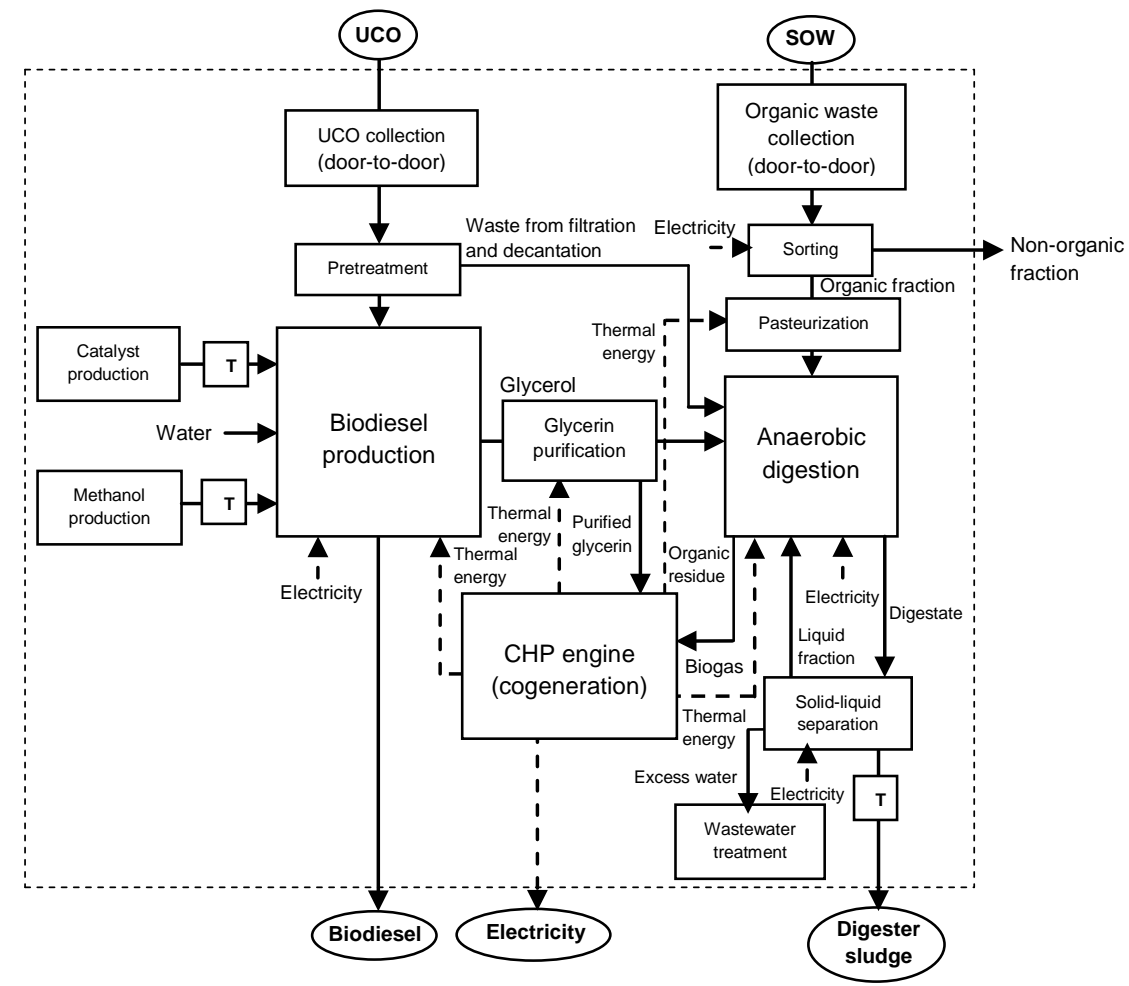

Figure 3.6. System delimitation of the process studied in scenario A. The flowchart does not outline capital goods. T: Transport. 
Scenario A was conceived as a real plant that started operating in 2012. Scenario $B$ was designed as the marginal provider of all the aforementioned functions, that is to say, the processes most likely to happen in Spain. This means that there is no such plant providing all those very functions at the same time, but this scenario represents average Spanish waste collection and processing systems. The main features of these scenarios are briefly described in the following paragraphs; further information on the analyzed systems is contained in section 3.1.2. As mentioned in section 3.2.1, in this case, co-products with market value translate into revenues for the producer, which can be understood as avoided costs (mirroring the procedure adopted in the environmental assessment).

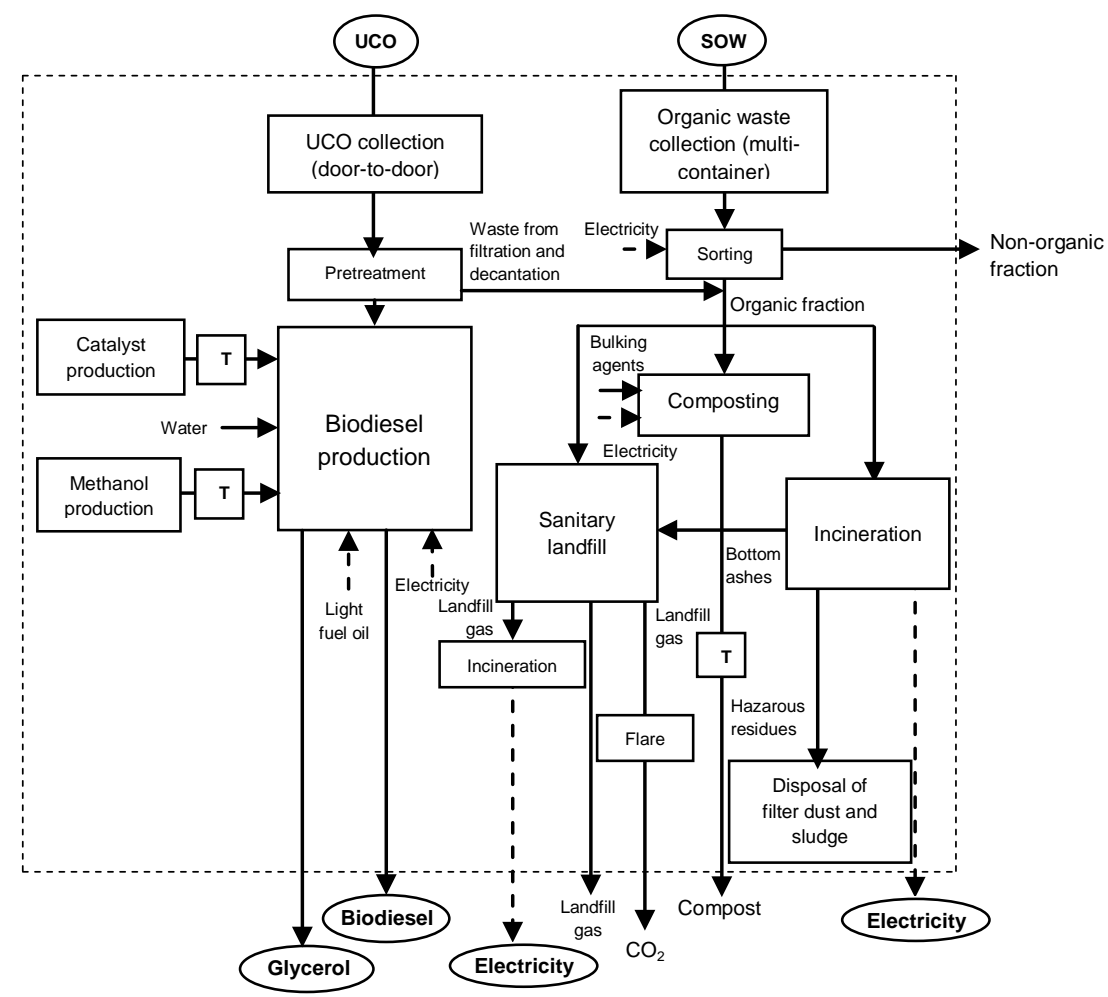

Figure 3.7. System delimitation of the process studied in scenario B. The flowchart does not outline capital goods. T: Transport.

Biodiesel production is common to both scenarios, as is UCO collection, and glycerol is obtained as a co-product from the transesterification in both scenario $A$ and scenario B. The Integral-b project proposes making use of it as a fuel in the $\mathrm{CHP}$ engine after purification by means of the combustion flue gases from that very process. On the contrary, glycerol becomes an outflow in Scenario B. In scenario 
$\mathrm{B}$, the SOW in the FU was assumed to be distributed to different streams, according to the percentages reported for Spain by Eurostat (2012): $68.2 \%$ goes to sanitary landfill, $21.2 \%$ goes to composting, and $10.6 \%$ goes to incineration. As a consequence, electricity and compost are generated by the reference scenario in addition to biodiesel and glycerol (as shown in Figure 3.7). While electricity comes from cogeneration in scenario $A$, it comes from both the sanitary landfill and incinerator in scenario $B$; in both scenarios, it was assumed that the electricity output is sold to the Spanish grid. Finally, digester sludge from $A D$ in scenario $A$ and compost in scenario $B$ were also assumed to be sold as organic amendment. To summarize, apart from biodiesel, the most relevant co-products in scenario $A$ are the electricity from the CHP engine and the digester sludge from the AD; electricity, glycerol and compost are the main co-products obtained from scenario B.

Revenues from the sale of electricity in scenarios A and B were calculated by using the electricity rate at the moment of the development of the Integral-b project, which is, that of 2012. The electricity is evacuated to the electricity grid under the "regime of special production facilities" (BOE, 2007). That electricity rate offered high primes over the market rate for special regime facilities (BOE, 2011). However, the Spanish electricity rate has recently been changed, with a view to discouraging electricity generation from those special regime facilities (BOE, 2014a; 2014b). Therefore, these primes have been removed, although there is a certain fixed compensation for those facilities which were built at the time the new regulatory framework came into force. In order to take this normative change into account, alternative scenarios were defined by considering the new electricity rates.

The difference between profits of scenario B-scenario A was calculated for the comparative analysis, since it permits the quantification of how much scenario $A$ is better (or worse) than the reference one, while providing further advantages for the uncertainty analysis. This would yield two differential scenario formulations to be covered; one considering the 2012 electricity rates in both scenario A and B, and another one considering the 2014 electricity rate system. However, the statistics used for the calculation of the functional inflows may be a source of uncertainty too, since all inputs and emissions are based on them. According to IDAE (2011a), the current technical capacity for UCO collection comes to approximately 300,000 t per year. Assuming that implementing the Integral-b project in the Spanish context increases the collection efficiency to this level, the UCO functional flow would be $6.38 \mathrm{~kg} / \mathrm{inhabitant}$ and year. In this way, scenarios $A$ and $B$ are equivalent to those defined in section 3.1.2. As a result, four differential scenario formulations were finally assessed, as shown in Table 3.3. The differential scenario approach will enable us to check which scenario performs better financially, how a normative 
change in electricity rates affects financial results, and also to assess the influence of maximizing the collection of UCO. It must be taken into account, though, that the scenario formulations are based on different criteria, capturing different sources of uncertainty depending on whether they influence the environmental or financial results. In other words, the change in electricity rate systems is not directly linked to the environmental avoided burdens.

Table 3.3. Scenario formulations defined to capture the variability in electricity rate systems and the Functional Unit in the financial assessment.

\begin{tabular}{|c|c|c|}
\cline { 2 - 3 } \multicolumn{1}{c|}{} & $\begin{array}{c}\text { FU: } 1.70 \mathrm{~kg} \text { UCO + } \\
35.50 \mathrm{~kg} \text { SOW per } \\
\text { inhabitant and year }\end{array}$ & $\begin{array}{c}\text { FU: } 6.38 \mathrm{~kg} \mathrm{UCO}+ \\
35.50 \mathrm{~kg} \mathrm{SOW} \text { per } \\
\text { inhabitant and year }\end{array}$ \\
\hline $\begin{array}{c}\text { Electricity rates } \\
\text { of } 2012\end{array}$ & B1-A1 & B1'-A1' \\
\hline $\begin{array}{c}\text { Electricity rates } \\
\text { of } 2014\end{array}$ & B2-A2 & B2'-A2' \\
\hline
\end{tabular}

Additionally, the percentages that determine the amount of waste going to landfill, composting and incineration in Scenario B are subject to change according to the Spanish strategy under the EU Landfill Directive. Specifically, the amount of biodegradable waste from MSW produced in 1995 must be reduced by $65 \%$ in 2016 (Decree 1481/2001). The variability of these percentages, as well as that arising from price variability, was addressed by means of parameter uncertainty analysis.

\subsubsection{Inventory data}

In this section, the main processes are described and quantified with regard to the FU, following the same sub-stages defined in section 3.2.2.2 for each scenario. The data gathering for the financial LCC ran parallel to the Life Cycle Inventory in LCA. Most of the technical parameters needed in the latter were also needed in the modeling of the economic performance, and were provided by the partners of the Integral-b project. The LCC also required data on operational and capital costs and output prices to be collected; for this purpose, both primary and secondary data were used. The base scenarios were built on average data, under a deterministic assumption.

Scenario A consists of the following:

a) Collection of UCO by means of a door-to-door (DTD) container system. The cost of the UCO collection, including the transport to the Integral-b plant, was obtained from MAGRAMA (2013b).

b) Biodiesel production. All the technical data on the UCO transesterification for biodiesel production were gathered from the Bionorte company, as 
were the depreciation costs. The cost of chemicals (catalyst and methanol) was directly gathered from industrial suppliers. Hourly labor cost was taken from official statistics (INE, 2015).

c) Selective collection of SOW by means of a DTD system. The cost of the collection in MAGRAMA (2013b) includes transport to the Integral-b plant. As pointed out by Escobar et al. (2015), although the organic fraction is collected separately, it was assumed that there are also some other nonorganic residues in the same bin (5\%). The amount of waste collected for the $\mathrm{FU}$ is then slightly greater $(37.37 \mathrm{~kg} / \mathrm{inh}$ abitant and year), with the associated collection inputs.

d) Anaerobic digestion (AD). All the technical data involved in the $A D$ were provided by Ainia Technology Centre and Biogas Fuel Cell as explained in Escobar et al. (2015). Specifically, the digester plant designed for the Integral-b project had a processing capacity of $20,000 \mathrm{t}$ of SOW per year. The $A D$ makes use of external electricity for stirring and some thermal energy from the CHP engine to heat the digester. The digester sludge generated goes through a solid-liquid separation before being used in agriculture; the price of the solid fraction was obtained from Álvarez de la Puente (2007).

e) Cogeneration. As already mentioned in section 3.2.1, the CHP engine was specifically adapted in the Integral-b project in order to use not only biogas, but also purified glycerin, as fuel. Data related to the cogeneration (thermal and electrical efficiency, self-consumption rates, etc.) were provided by Cidaut, which implemented a 500-kW CHP engine. Part of the thermal energy generated by the CHP is used to purify the crude glycerol. The excess of electricity, that which is not self-consumed by the CHP engine, is sold to the Spanish electricity grid.

Stages a) and b) in scenario $B$ are exactly the same as the ones described for scenario $A$, with the only difference being that biodiesel production requires external thermal energy from light fuel oil in scenario $B$, while thermal energy from cogeneration is used in scenario $A$. The price of fuel oil was obtained from MINETUR (2012). The rest of the sub-stages included in scenario B are described as follows:

c) Sow collection by means of a multi-container system. In the reference scenario there is no selective collection system for the SOW from restaurants and catering. The current situation in Spain is that this waste is unloaded into the same street-side containers where MSW is collected. As in Escobar et al. (2015), the organic fraction was estimated to be $62 \%$ of the unsorted SOW, resulting in a greater waste inflow to be collected than 
that in scenario A. The resulting amount of SOW is $57.26 \mathrm{~kg} / \mathrm{inhabitant}$ and year, generating greater collection and sorting costs per FU. The costs of these two sub-stages were gathered from Muñoz Colomina et al. (2011).

d) Sanitary landfill. More than half of the resulting SOW (68.2\%) is buried in a sanitary landfill, undergoing anaerobic decomposition. DGPT Valdemingómez (2012) provided the cost of landfilling the corresponding amount of waste. Around $240 \mathrm{Nm} 3$ of biogas per ton of SOW input are produced, and the electricity obtained from its combustion is sold to the Spanish electricity grid.

e) Composting. $21.2 \%$ of the SOW is composted based on an average industrial plant treating $15,000 \mathrm{t}$ of SOW per year. Both the cost of composting and the price of the compost were obtained from Álvarez de la Puente (2007).

f) Incineration. The remaining SOW (10.6\%) is treated by incineration to produce electricity, which is equally sold to the Spanish grid. The cost of this process was gathered from Greenpeace (2010).

As mentioned in section 3.2.2.2, the prices of the electricity obtained from e) in scenario $A$, and from d) and $f$ ) in scenario $B$ were estimated in accordance with the Spanish legislation (BOE, 2007; BOE, 2014a; 2014b).

\subsubsection{Financial assessment}

The estimation of the financial results by means of an LCC implies the quantification of costs and revenues. Under the system expansion approach, financial LCC includes revenues as negative costs. However, this leads practitioners to decide whether all the costs should be included or only those really borne on the decision-maker, as Norris (2001) points out. This depends, in turn, on the scope of the analysis. By using costs and revenues, two kinds of measurements could be calculated: the economic value added (EVA) and the profit. The EVA is measured as the revenues minus the costs of intermediate inputs, and the profit is measured as the revenues minus the costs of material inputs, labor, capital and purchased services. Whereas the estimation of EVA aims to measure how much money the studied system adds to the Gross Domestic Product (GDP), the profit estimation measures the earnings of an enterprise. EVA is, thus, an economic result measured from a social point of view, expressing the wealth which the studied system contributes to society, while the profits capture a financial point of view. Using both variables could lead to interesting conclusions. Unfortunately, it is not easy to break down the costs from secondary sources in order to calculate the EVA. The breaking down is usually done by following a 
KLEMS approach (Capital, Labor, Energy, Material inputs and purchased Services). The main issue is, however, the treatment of labor costs, since most of the secondary information includes purchased services, that is, services hired from other companies which sometimes include hidden labor costs, as Coelli et al. (2005) warned. Measuring the EVA could be interesting but labor costs are likely to be underestimated, with the subsequent underestimation of the EVA. For this reason, profits were chosen as the most suitable variable with which to carry out the economic assessment of the Integral-b process.

Biodiesel production, $A D$ and cogeneration are the most relevant and distinctive processes of scenario $A$. The operational costs of these facilities were calculated by breaking down the total costs into different kinds (labor, depreciations, electricity, etc). On the contrary, the rest of the functions in both scenarios come from very established systems (SOW collection, composting, landfilling, etc), concerning which, economic data are readily available. It must be pointed out that the cost information was gathered from big municipal facilities which manage a huge amount of raw materials; in this way, the unit treatment cost $(€ / \mathrm{kg})$ is deemed to be more reliable. The costs of composting, biogas combustion and landfilling in scenario B were taken from public information about the costs and budgets of representative facilities in Spain. Given the great diversity of plants, the unit cost of large-scale facilities was again chosen in order to avoid outliers. Based on the aforementioned information, a cost sheet was built up for each scenario by using Microsoft Excel 2010, including costs of materials, capital, labor and other costs, such as specific services and overhead costs.

In the case of biodiesel production, depreciation costs were estimated from the capital stock. To quantify this stock, the machinery was priced by using a new replacement value and a straight-line depreciation model was subsequently applied. The information about the value of new equipment and lifespan was provided by machinery suppliers. The labor costs were estimated by considering the number of working hours of specialized workers in each shift. The wages were fixed as the average wage of specialized workers and included the firm's social security expenses, which increased the cost by $29.9 \%$. The overhead costs are heavily dependent on each company; consequently, a 10\% overhead cost ratio was considered, consistent with Bionorte estimations obtained from the average measurement of the last three accounting years.

\subsubsection{Uncertainty analysis}

As mentioned in section 3.2.1, LCC outcomes are subject to uncertainty due not only to the variability to be found in costs and prices, but also to that present in the technical parameters. In order to test the robustness of the differential scenario 
results, the technical and economic parameters were defined as probability distributions instead of deterministic values. The technical parameters were modeled in accordance with Escobar at al. (2015), while the modeling of economic parameters is detailed in Table 3.4.

Table 3.4. Summary of probability distributions of costs, input and output prices.

\begin{tabular}{|c|c|c|c|}
\hline Input prices & $\begin{array}{l}\text { Probability } \\
\text { distribution }\end{array}$ & $\begin{array}{l}\text { Kind of data } \\
\text { source }\end{array}$ & Data source \\
\hline Methanol $(€ / t)$ & Uniform (330-380) & Primary & Industrial suppliers \\
\hline Sodium methoxide $(€ / t)$ & Uniform $(1,650-2,200)$ & Primary & Industrial suppliers \\
\hline $\begin{array}{l}\text { Sow collection (door-to- } \\
\text { door) }(€ / t)\end{array}$ & Uniform(120; 180) & Secondary & AMCRSPP (2013) \\
\hline $\begin{array}{l}\text { Sow collection (multi- } \\
\text { container) }(€ / t)\end{array}$ & PERT $(78.7 ; 82.7 ; 89.7)$ & Secondary & $\begin{array}{l}\text { Muñoz Colomina et al. } \\
\text { (2011) }\end{array}$ \\
\hline Composting $(€ / t)$ & Uniform (45.10; 56) & Secondary & $\begin{array}{l}\text { DGPT Valdemingómez } \\
(2012)\end{array}$ \\
\hline Landfill $(€ / t)$ & $\begin{array}{l}\text { Uniform (23.144; } \\
\quad 34.716)\end{array}$ & Secondary & $\begin{array}{c}\text { DGPT Valdemingómez } \\
(2012)\end{array}$ \\
\hline Incineration $(€ / t)$ & $\begin{array}{c}\text { PERT (34.50; 48.96; } \\
65.00)\end{array}$ & Secondary & Greenpeace (2010) \\
\hline Water (€/m3) & Uniform $(0.68 ; 2.6)$ & Primary & Official statistics \\
\hline Fuel (€/MJ) & $\begin{array}{c}\text { PERT (0.0168; 0.0240; } \\
0.0312) \\
\end{array}$ & Primary & Official price $+30 \%$ \\
\hline Output prices & $\begin{array}{c}\text { Probability } \\
\text { distributions }\end{array}$ & $\begin{array}{l}\text { Kind of data } \\
\text { source }\end{array}$ & Data source \\
\hline Biodiesel (€/m3) & Uniform (780; 1,022) & Primary & Integral-b partners \\
\hline Crude glycerol $(€ / t)$ & Uniform $(0 ; 160)$ & Primary & Integral-b partners \\
\hline $\begin{array}{l}\text { Electricity base price } 2012 \\
\text { (€/Mwh) }\end{array}$ & $\begin{array}{c}\text { PERT (41.93; 59.90; } \\
77.86)\end{array}$ & Primary & Official price $\pm 30 \%$ \\
\hline $\begin{array}{c}\text { Cogeneration electricity } \\
(€ / M w h)\end{array}$ & $\begin{array}{c}\text { PERT (140.72; 184.13; } \\
192.57)\end{array}$ & Secondary & Official price $\pm 30 \%$ \\
\hline Landfill electricity (€/Mwh) & $\begin{array}{c}\text { PERT (102.06; 107.43; } \\
139.66)\end{array}$ & Secondary & Official price $\pm 30 \%$ \\
\hline $\begin{array}{l}\text { Incineration electricity } \\
(€ / M w h)\end{array}$ & $\begin{array}{c}\text { PERT (56.65; 59.63; } \\
77.52)\end{array}$ & Secondary & Official price $\pm 30 \%$ \\
\hline Compost $(€ / t)$ & Real distribution & Secondary & $\begin{array}{l}\text { Álvarez de la Puente } \\
\qquad(2007)\end{array}$ \\
\hline Digester sludge $(€ / t)$ & $\begin{array}{l}50 \%-75 \% \text { of the } \\
\text { compost price }\end{array}$ & Secondary & Own estimation \\
\hline
\end{tabular}

In the case of the distributions of input costs, the same sources as for the deterministic value were used. In those cases for which enough representative information was available, a PERT distribution was chosen; this, just as the normal one, is bell-shaped. Its main advantage relative to the normal distribution is that it is bounded, which prevents negative values. In those cases for which less information was available, a uniform distribution was built by considering minimum and maximum values.

Output prices are determined by the market since companies are price-takers and they have no influence on the market dynamics. The uncertainty distributions were again defined, based on the information available. Most of them follow a uniform 
distribution, which means that the available information was restricted to a minimum and a maximum. The biodiesel prices, in particular, show great variability, according to the information supplied by the Integral-b partners. The price of crude glycerol is highly variable as well. When there is a demand for glycerol, the price can range between 100 and $150 € / t$, although if there is an excess of supply, this price can drop to zero. On the contrary, when there is no market for it, glycerol disposal can even imply a cost of $20 € /$ t. For these reasons, the distribution that best fit the variability of the price of glycerol was a mixed distribution; this means that the probability of the $20 € / t$ cost is $50 \%$ and that of a uniform distribution ranging between 100 and $150 € / t$ is also $50 \%$.

The compost is usually sold to farmers, but the retail prices vary greatly depending on the Spanish region involved, the facilities and product quality. Despite the fact that there was enough information about the retail prices and quantities sold, no distribution fitted the data properly, even when different quality levels were taken into account. The price sample exhibited great variability and $34.54 \%$ of the compost was even given for free, while the average price of the rest was $4.83 € / t$. Therefore, the price was modeled by building a discrete distribution following the real data, as shown in Table 3.4. As was previously mentioned, the digester sludge obtained in scenario $A$ can be sold as an organic amendment, due to its nutrient content, in the same way as the compost from scenario B. Its introduction into the market is quite uncertain, though. For this reason, the same price distribution as that for the compost price was set, but reduced by $50 \%-75 \%$.

As for the prices of the output electricity, they were modeled as a PERT distribution with the most likely price equal to the base value, a minimum (basis value -30\%) and a maximum (basis value $+30 \%$ ). In the case of the electricity sold in scenarios A1, B1, A1' and B1', official 2012 prices were chosen as the most likely value for several PERT distributions. At that time, the rate was different depending on the electricity source (e.g. cogeneration, incineration, etc). In the case of electricity sold in scenarios A2, B2, A2' and B2', the official 2012 price was chosen again as the base price, although the rate system was that in force in 2014. This decision is based on the grounds that the aim of the study is not to analyze the difference between prices, but the change in the electricity rate system. If a different base price was applied, any difference between scenario results could be due to either the change in base prices or in the rate system. It must be noted that, under the new rate system, the base price is the same regardless of the plant technology. However, there are some other components of the electricity rate designed to balance the sharp drop in the official price, since the 2012 price was subsidized. A higher base price is also established for those plants that were already in operation, depending on the technology and power of the plant, in order to compensate for this drop in 2014. Scenarios A2 and A2' were supposed to start 
operating in 2012, thus the corresponding compensation under the new electricity rate system was also taken into account.

Besides the price distributions, the lifespan of some equipment used for biodiesel production was introduced in the cost spreadsheet, since it determines the amortization cost. Specifically, according to the information provided by one of the partners of the project, the lifespan of the anaerobic digester in scenarios A was modelled as a uniform distribution of between 20 and 25 years, while the lifespans of the CHP engine and the distiller for glycerol purification were estimated at between 10 and 12 years.

Once the probability distributions were defined, the Monte Carlo simulation was chosen to analyze stochastic uncertainty, simulating the aforementioned economic and technical parameters. In every simulation run, each parameter can vary according to the previously fixed distribution functions. No correlation conditions were imposed between the different prices, and 10,000 simulation runs were carried out, yielding 10,000 prices for each input and each output, that is, 10,000 sets of prices and 10,000 sets of profit measurements. Thanks to the differential scenario B-scenario A assessment, the prices and costs vary between simulation runs but not between the scenarios in each simulation run. This means that each simulation run represents a state of nature, which the producers cannot control. The same happens with the simulation of common technical parameters. The @Risk 5.5 Software (Palisade Corporation, 2009), compatible with Excel, was used to perform the Monte Carlo simulation and to obtain Tornado diagrams.

\subsubsection{Results}

\subsubsection{Financial results from the base scenarios}

Based on the inventory data described in section 3.2.2.3, the LCC of each scenario was carried out, and the costs and income ( $€ / F U$ ) under a deterministic assumption are shown in Table 3.5. As can be seen, the profits in all the scenarios are negative, which means that costs are greater than income. The profits of scenario B1 (and B2) are, however, greater than the ones of scenario A1 (and A2).

For the same amount of processed UCO, the collection of the SOW by means of a DTD system in scenario A implies greater costs. This sub-stage accounts for $69 \%$ of the total cost in scenarios A, while the collection of SOW by means of a multicontainer system represents $72 \%$ of the cost in scenarios B. It must be noted that these shares are similar, although the collection cost is quite different. $26 \%$ of overall costs in scenarios $A$ are generated by the $A D$ and CHP stages, whereas $20 \%$ of the cost in scenarios B is generated by landfilling, composting and incineration. The cost of biodiesel production is slightly lower in scenarios A than in 
scenarios $B$, since thermal energy from the CHP engine is used in scenario A, instead of heat from light fuel oil.

Table 3.5. LCC results for the base scenarios (€/FU) taking into account the two Functional Units and the change in the electricity rate.

\begin{tabular}{|c|c|c|c|c|c|c|c|c|}
\hline \multirow{2}{*}{$\begin{array}{c}\text { FU } \\
\begin{array}{c}\text { Electricity rate } \\
\text { system }\end{array}\end{array}$} & \multicolumn{4}{|c|}{$\begin{array}{c}1.70 \mathrm{~kg} \mathrm{UCO}+35.50 \mathrm{~kg} \text { SOW } \\
\text { per inhabitant and year }\end{array}$} & \multicolumn{4}{|c|}{$\begin{array}{c}6.38 \mathrm{~kg} \mathrm{UCO}+35.50 \mathrm{~kg} \mathrm{SOW} \text { per } \\
\text { inhabitant and year }\end{array}$} \\
\hline & 2012 & 2012 & 2014 & 2014 & 2012 & 2012 & 2014 & 2014 \\
\hline Costs & A1 & B1 & A2 & B2 & A1' & B1' & A2' & B2' \\
\hline UCO collection & 0.22 & 0.22 & 0.22 & 0.22 & 0.86 & 0.86 & 0.86 & 0.86 \\
\hline SOW collection & 6.07 & 4.54 & 6.07 & 4.54 & 6.07 & 4.54 & 6.07 & 4.54 \\
\hline $\begin{array}{l}\text { Biodiesel } \\
\text { production }\end{array}$ & 0.23 & 0.26 & 0.23 & 0.26 & 0.9 & 1 & 0.9 & 1 \\
\hline $\mathrm{AD}+\mathrm{CHP}$ & 2.31 & & 2.31 & & 2.32 & & 2.32 & \\
\hline Landfilling & & 0.72 & & 0.72 & & 0.72 & & 0.72 \\
\hline Composting & & 0.42 & & 0.42 & & 0.42 & & 0.42 \\
\hline Incineration & & 0.14 & & 0.14 & & 0.14 & & 0.14 \\
\hline Total Costs & 8.84 & 6.31 & 8.84 & 6.31 & 10.15 & 7.69 & 10.15 & 7.69 \\
\hline Income & A1 & B1 & A2 & B2 & $\mathbf{A 1}^{\prime}$ & B1' & A2' & B2' \\
\hline Biodiesel & 1.31 & 1.31 & 1.31 & 1.31 & 4.89 & 4.89 & 4.89 & 4.89 \\
\hline Electricity CHP & 2.29 & & 1.23 & & 2.29 & & 1.23 & \\
\hline Digester sludge & 0.08 & & 0.08 & & 0.08 & & 0.08 & \\
\hline $\begin{array}{l}\text { Electricity } \\
\text { landfill }\end{array}$ & & 0.47 & & 0.17 & & 0.47 & & 0.17 \\
\hline $\begin{array}{l}\text { Electricity } \\
\text { incineration }\end{array}$ & & 0.06 & & 0.1 & & 0.07 & & 0.1 \\
\hline Compost & & 0 & & 0 & & 0 & & 0 \\
\hline Glycerol & & -0.01 & & -0.01 & & -0.02 & & -0.02 \\
\hline Total Income & 3.67 & 1.84 & 2.61 & 1.57 & 7.25 & 5.4 & 6.19 & 5.14 \\
\hline PROFITS & -5.17 & -4.47 & -6.23 & -4.73 & -2.9 & -2.28 & -3.96 & -2.55 \\
\hline
\end{tabular}

The income generated by biodiesel production is the same in all the scenarios with the same FU, although the weight of the total income which it represents varies across scenarios. Specifically, the share of the income from biodiesel in the total income increases from $36 \%$ in scenario $A 1$ to $50 \%$ in scenario A2, as a consequence of the change in the electricity rate; while the share of the biodiesel income increases from $71 \%$ in scenario B1 to 83\% in scenario B2. Under the 2014 electricity rate system, a lower price is paid for the cogeneration electricity; thus, the revenues from the integral-b plant are lower, as is the overall income. Specifically, this income accounts for $62 \%$ of the total income of scenario A1, whereas the change in the electricity rates decreases this share to $47 \%$ in scenario A2. The share of the income generated by the sale of electricity from landfilling and incineration with respect to the total income decreases from $28 \%$ in scenario B1 to $17 \%$ in scenario B2 as a consequence of the new rate, since this electricity form is also sold at a lower price, too. However, the sale of electricity has a lower impact 
on the overall income because the overall amount of electricity output is lower in scenarios $B$ than in scenarios $A$.

When the FU is changed to capture potential UCO collection levels, the figures also change. The UCO collection costs and biodiesel production costs are obviously greater, but the income generated from the biodiesel sale increases to a greater extent, due to the high price of the biodiesel relative to other co-products. This is, indeed, the greatest contributor to the overall income in all the scenarios that consider potential UCO availability. As a result, the share of the UCO collection and biodiesel production costs increases to $17 \%$, as does the share of the income generated by the sale of biodiesel increases (67\% in A1', $90 \%$ in B1', $79 \%$ in A2' and 95\% in B2'). The change in the rates causes a decrease in the income generated by the sale of electricity from 2012 to 2014, and the contribution of this co-product to the total income decreases as well.

The differential profits of B1-A1 come to $0.70 € / F U$, while they are $1.50 € / F U$ in the case of B2-A2. The results for the potential UCO collection scenarios are very similar: $0.61 € / F U$ for $B 1$ '-A1' and $1.41 € / F U$ for B2'-A2'. Increasing the UCO collection levels benefits both $A$ and $B$ scenarios to a similar extent, although the differential profits, B-A, are slightly reduced, since the Integral-b process avoids using external fuel oil. The new electricity rate again increases the differential profits, B-A, for the same amount of UCO, since it lowers the income in scenario A2' to a greater extent than it does for scenario B2' (relative to A1' and B1', respectively). These figures show, however, how a normative change in electricity prices may not be neutral for electricity generating plants, since changes in electricity rates affect the scenario profits in a different way depending on the electricity source, as can be seen in Table 3.5.

\subsubsection{Results from the uncertainty analysis}

The probability distributions of the expected profits were obtained for each scenario by means of the Monte Carlo simulation, and their descriptive statistics are shown in Table 3.6. As can be observed, all the scenarios lead to negative profits in all the simulation runs and scenario B1' shows the least negative profit. There is greater variability in the scenarios that include potential UCO collection levels (scenarios $A^{\prime}$ and $\left.B^{\prime}\right)$.

The difference between the profits in each pair of scenarios (B1-A1; B2-A2; B1'$A 1$ '; B2'-A2') was equally calculated in each simulation run, and plotted by means of histograms in Figure $3.8(a, b, c, d)$. It must be taken into account that, if the difference between scenario B-scenario A profits is greater than zero, it means that the profit in scenario $B$ is greater than the profit generated by scenario $A$. The area of the distribution below zero in the $y$-axis measures the probability of scenario $A$ 
outperforming scenario $B$, while the area above zero measures the complementary probability, which is, that of scenario $B$ outperforming scenario $A$. As can be seen, scenario B1 outperforms Scenario A1 in $81.7 \%$ of the simulation runs (Figure 3.8a); the probability of scenario B2 clearly outperforming scenario A2 is almost $100 \%$ (Figure 3.8b). That is to say, the probability that scenario $A$ is better than scenario $B$ is reduced when the new electricity rates are taken into consideration. The simulation helps us to see that scenario A1 can be more profitable than scenario B1 in some circumstances, and this figure is not perceptible under the deterministic analysis. This pattern may equally be observed when a readier availability of UCO is considered for the definition of the FU; in this case, scenario B1' generates greater profits than scenario $A 1$ ' in $80.5 \%$ of the simulation runs (Figure 3.8c). The new electricity rates make the relative performance of scenario A2' worse, since the profits from scenario B2' are greater in almost $100 \%$ of the simulation runs (Figure 3.8d).

Table 3.6. Descriptive statistics for the distribution of the expected profits in each scenario.

\begin{tabular}{|c|c|c|c|c|c|c|c|c|}
\hline \multirow{3}{*}{$\begin{array}{c}\text { FU definition } \\
\begin{array}{c}\text { Electricity } \\
\text { rate }\end{array} \\
\text { Scenario }\end{array}$} & \multicolumn{4}{|c|}{$\begin{array}{c}1.70 \mathrm{~kg} \mathrm{UCO}+35.50 \mathrm{~kg} \text { SOW per } \\
\text { inhabitant and year }\end{array}$} & \multicolumn{4}{|c|}{$\begin{array}{c}6.38 \mathrm{~kg} \mathrm{UCO}+35.50 \mathrm{~kg} \mathrm{SOW} \text { per } \\
\text { inhabitant and year }\end{array}$} \\
\hline & \multicolumn{2}{|c|}{2012} & \multicolumn{2}{|c|}{2014} & \multicolumn{2}{|c|}{2012} & \multicolumn{2}{|c|}{2014} \\
\hline & A1 & B1 & A2 & B2 & A1' & B1' & A2' & B2' \\
\hline $\begin{array}{l}\text { Minimum } \\
(€ / F U)\end{array}$ & -7.14 & -5.17 & -7.89 & -5.30 & -5.43 & -3.46 & -6.1 & -3.58 \\
\hline $\begin{array}{l}\text { Maximum } \\
(€ / F U)\end{array}$ & -2.19 & -3.49 & -3.97 & -4.11 & -0.34 & -0.76 & -1.52 & -1.25 \\
\hline Mean (€/FU) & -5.18 & -4.45 & -6.25 & -4.71 & -2.91 & -2.2 & -3.98 & -2.47 \\
\hline Mode (€/FU) & -5.23 & -4.52 & -6.52 & -4.71 & -3.29 & -2.45 & -3.83 & -2.49 \\
\hline $\begin{array}{l}\text { Std Dev } \\
(€ / F U)\end{array}$ & 0.76 & 0.22 & 0.71 & 0.17 & 0.9 & 0.44 & 0.86 & 0.42 \\
\hline $\begin{array}{l}\text { Coefficient of } \\
\text { variation }\end{array}$ & 0.15 & 0.05 & 0.11 & 0.04 & 0.31 & 0.2 & 0.22 & 0.17 \\
\hline Variance & 0.58 & 0.05 & 0.5 & 0.03 & 0.82 & 0.2 & 0.73 & 0.18 \\
\hline Skewness & 0.05 & 0.23 & 0.03 & 0.03 & 0.02 & 0.04 & 0 & 0.01 \\
\hline Kurtosis & 2.3 & 3.13 & 2.04 & 2.83 & 2.41 & 2.4 & 2.27 & 2.23 \\
\hline
\end{tabular}

A sensitivity analysis of the differential profits between scenario $B$ and scenario $A$ was carried out by means of a Tornado diagram, which allows for the parameters (including prices) that have the greatest influence on the differential profits to be identified. It is built from a regression analysis model of the differential profits, which considers the costs of inputs and the price of outputs as the dependent variables, and the values of the technical parameters as the independent variables. The associated coefficients show the influence of each independent variable on the differential profit. A positive coefficient means that an increase in the parameter value implies an increase in the difference between profits in both scenarios, thus favoring scenario B; the higher the coefficient, the greater the influence. Figure 3.9 
(a, b, c, d) shows four Tornado diagrams of all the differential profits calculated (B1-A1; B2-A2; B1'-A1'; B2'-A2'). The variables (bars) with a positive value favor scenarios $B$, while those variables with a negative value favor scenarios $A$. The unit of measurement is 1 standard deviation of the differential profits. The list of the most influential variables shows a mixture between cost, technical parameters and prices.

a)

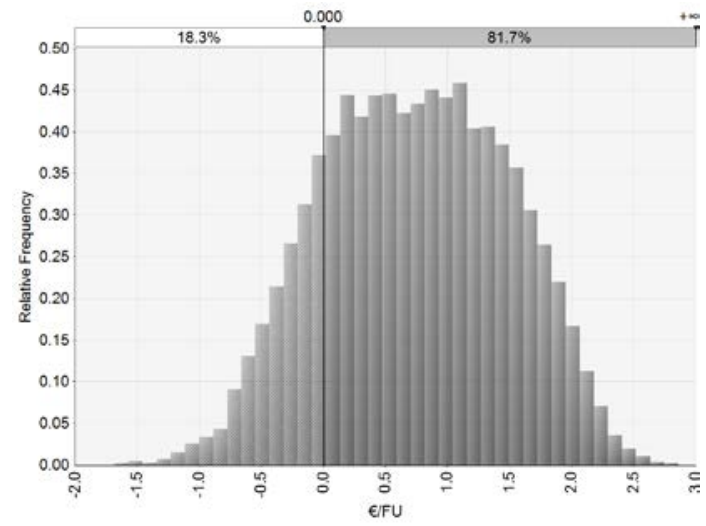

b)

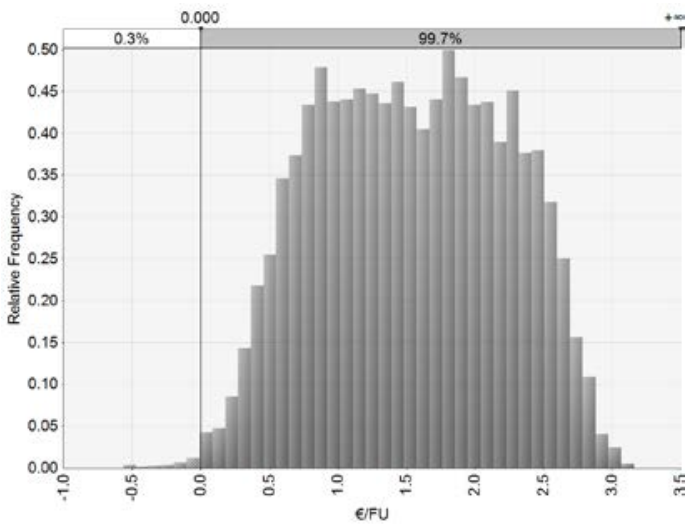

c)

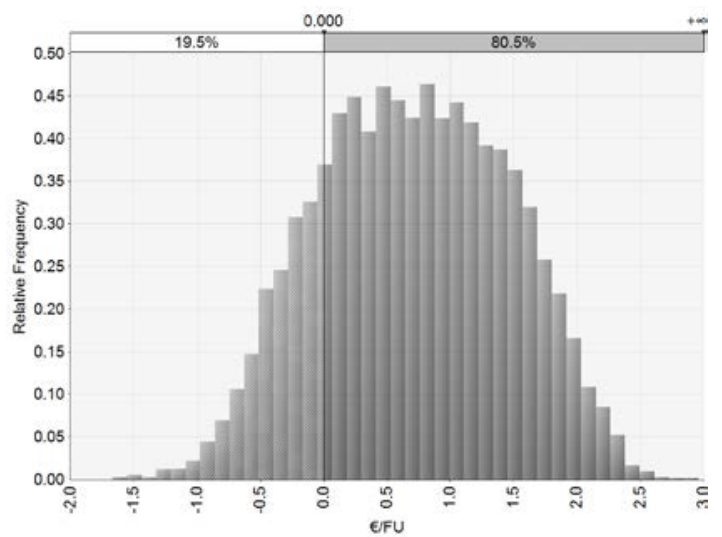


d)

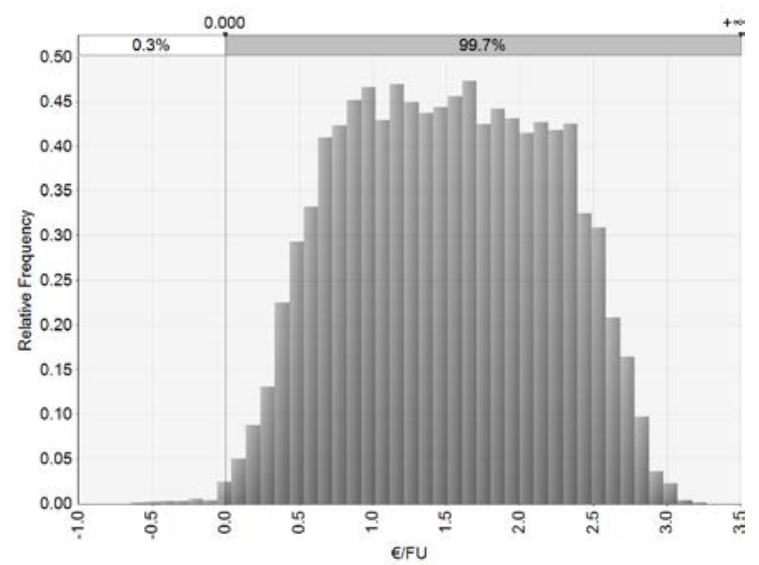

Figure 3.8. Probability distribution of the differential profits, after 10,000 simulations, for the scenario formulations: a) B1-A1, b) B2-A2, c) B1'-A1', and d) B2'-A2'.

According to Figure 3.9a, the SOW collection by means of the DTD system in the Integral-b process is the most influential variable, this decreases the profits in scenario A1, thus favoring scenario B1. Specifically, an increase of one standard deviation in the cost of the DTD increases the differential profit B1-A1 by 0.85 standard deviations. When descaling this figure by using the standard deviation of the differential profit and the standard deviation of the cost of the SOW collection, it can be inferred that an increase of $0.01 € / \mathrm{kg}$ in the cost of the SOW collection increases the differential profit B1-A1 by $0.04 € / F U$. The other influential variables are technical parameters related to CHP and AD. An improvement in the efficiency of these process parameters would imply an increase in the electricity production; this would increase the profits in scenario A1, reducing the B1-A1 difference. The prices of two of the outputs from scenario A1 (electricity from cogeneration and digester sludge) are also decisive; higher prices lessen the difference between scenarios. For instance, a $25 \%$ increase in the price of the digester sludge would imply a decrease in the differential B1-A1 profits of $0.01 € / F U$.

Figure $3.9 \mathrm{~b}$ represents the differential profits $\mathrm{B} 2-\mathrm{A} 2$, which are obtained with the new electricity rates and, again, the cost of the DTD collection of the SOW is the most influential variable. One more time, the income generated by the $\mathrm{CHP}$ electricity is lower, and the price of the other co-product from scenario A2, digester sludge, becomes more decisive. Differential profits are also very sensitive to variations in the technical parameters related to CHP and AD and to the landfill cost and MSW collection cost; any increase in the last two would diminish the profits of B2 and, hence, it would reduce the differential B2-A2 profits. Figures 3.9c and $3.9 \mathrm{~d}$ show the Tornado plots obtained when considering the potential UCO collection levels for the FU (scenarios A' and B'). The cost of the SOW collection is 
the most influential variable as observed in the previous scenario formulations. The technical parameters influencing the performance of the AD and CHP engine are decisive under both electricity rate systems.

The most influential parameters for each individual scenario could be analyzed by using the same procedure. When considering current levels of UCO collection for the $\mathrm{FU}$, the cost of the SOW collection is again the most decisive parameter for scenarios $A$, whereas the landfill cost and the fraction of waste to landfill are the most important ones for scenarios B. On the other hand, for potential UCO collection levels, the price of biodiesel is the second most influential parameter in scenarios A', whereas it is the most influential parameter in scenarios B'.

a) sow collection (DTD) cost

Electrical performance $\mathrm{CHP}$

$\mathrm{CH} 4$ biogas content $\mathrm{CHP}$

Biogas production

Electricity from cogeneration price

Digester sludge price

Landfill cost

MSW collection (MC) cost

$\mathrm{CH} 4$ emission in landfill biogas

Waste for electricity landfill

Fraction to landfill

$\mathrm{CH} 4$ landfill biogas content

Landfill turbine efficiency

$\mathrm{CH} 4 \mathrm{LHV}$ in biogas

Digester lifespan

Landfill biogas electricity price

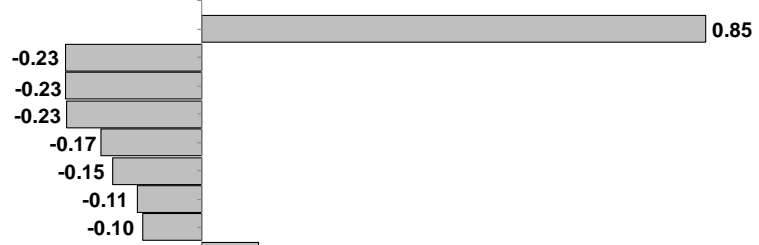

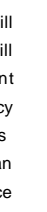
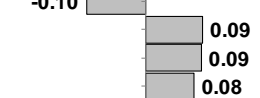

$-0.05$

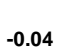

$-0.04$

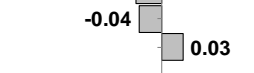

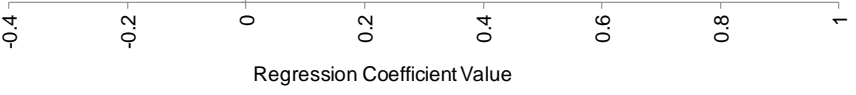

b) sow collection (DTD) cost Digester sludge price Electrical Performance CHP $\mathrm{CH} 4$ biogas content $\mathrm{CHP}$

Biogas production ratio Landfill cost

MSW collection (MC) cost Fraction to composting Digester lifespan $\mathrm{CH} 4$ emission in landfill biogas Composting cost Waste for electricity landfill $\mathrm{CH} 4 \mathrm{LHV}$ in biogas Electricity base price Incineration cost Fraction to landfill

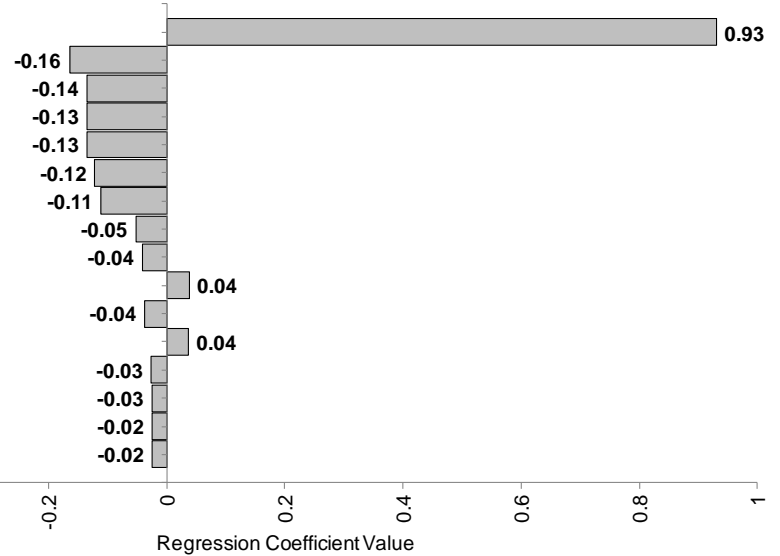


c)

$$
\begin{array}{r}
\text { SOW collection (DTD) cost } \\
\text { Electrical Performance CHP } \\
\text { Biogas production ratio } \\
\mathrm{CH} 4 \text { Biogas Content CHP } \\
\text { Electricity from cogeneration price } \\
\text { Digester sludge price } \\
\text { Landfill cost } \\
\text { MSW collection (MC) cost } \\
\mathrm{CH} 4 \text { emission in landfill biogas } \\
\text { Waste for electricity landfill } \\
\text { Fraction to landfill } \\
\text { Landfill turbine efficiency } \\
\mathrm{CH} 4 \text { landfill biogas content } \\
\mathrm{CH} 4 \text { LHV in biogas } \\
\text { Fraction to composting } \\
\text { Digester lifespan }
\end{array}
$$

d) $\operatorname{sow}(\mathrm{DTD})$ collection cost Digester sludge price $\mathrm{CH} 4$ biogas content $\mathrm{CHP}$ Electrical Performance CHP Biogas production ratio Landfill cost MSW collection (MC) cost Fraction to composting Digester lifespan Composting cost Waste for electricity landfill $\mathrm{CH} 4$ emission in landfill biogas Fraction to landfill $\mathrm{CH} 4 \mathrm{LHV}$ in biogas Electricity base price Incineration cost
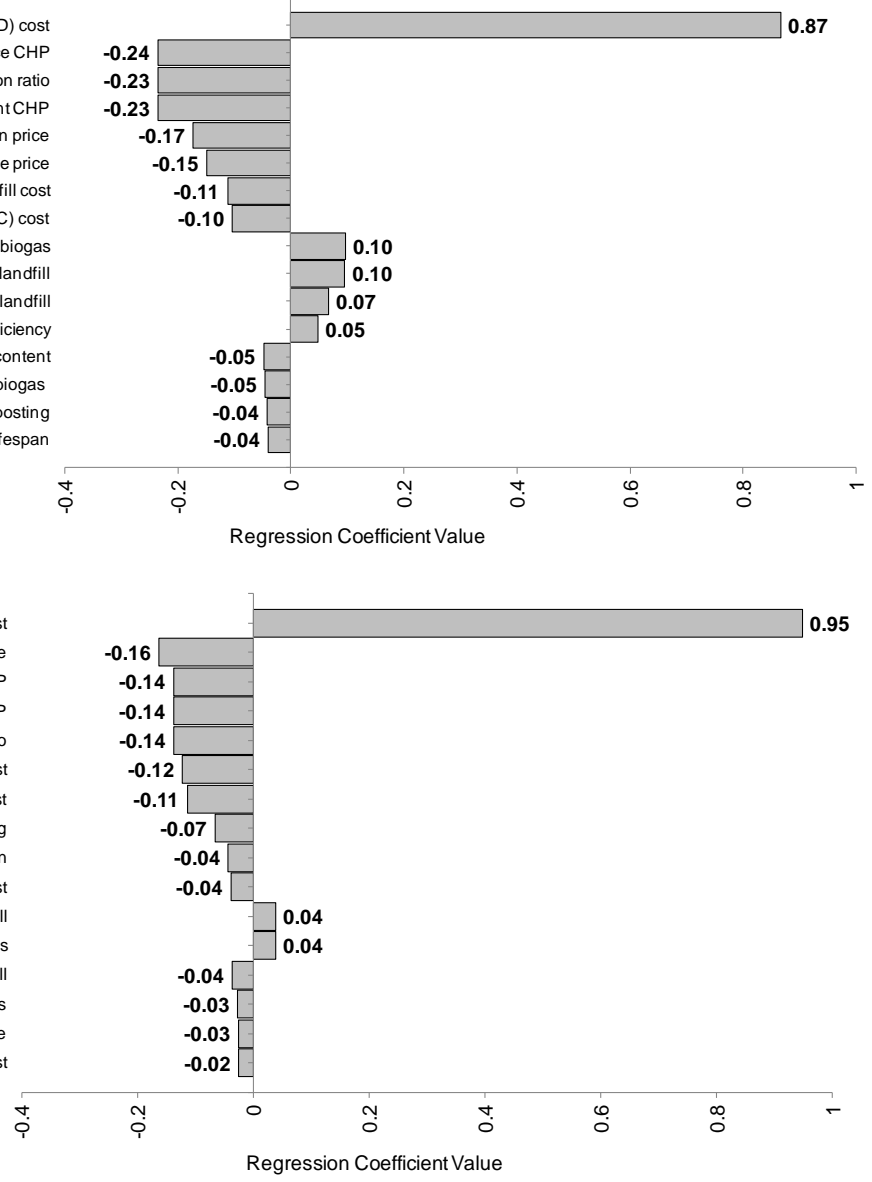

Figure 3.9. Tornado diagrams for the differential profits in the scenario formulations: a) B1A1, b) B2-A2, c) B1'-A1', and d) B2'-A2'. DTD: door-to-door; MC: multi-container.

\subsubsection{Discussion}

\subsubsection{Discussion of the LCC results}

The results from the financial analysis of the Integral-b process show that the proposed system delivers greater income losses as compared to a reference scenario. Both generate negative profits, which means that stakeholders have to finance the provided functions. In this case, it could be expected that the main stakeholders affected are the users of the waste management system, tax payers and electricity users. Indeed, losses are smaller in those scenarios that consider the 2012 electricity rates, which were more subsidized. This indicates that part of 
the deficit of these kinds of facilities was borne by electricity users. The current electricity rates are less subsidized; thus, the extra deficit generated by waste treatment activities has to be borne by users, through higher waste disposal charges, or by tax payers. In any event, it seems clear that the new electricity rate system is detrimental to the economic performance of the Integral-b, since the overall profits are highly dependent on the sale of electricity. The income generated in scenario $A$ is substantially reduced, compromising the viability of a hypothetical integrated plant implementing this alternative system. The price of electricity from cogeneration is greatly influenced by governmental decisions and even the expected future trend is unknown and hard to predict. This uncertainty in the normative landscape becomes an obstacle for such projects as these to be implemented on an industrial scale.

Although scenario B is not profitable under any scenario assumption either, it clearly outperforms scenario A. This is mainly due to the higher Sow collection costs by means of the DTD system proposed by the Integral-b project. The SOW collection sub-stage makes the greatest contribution in both scenarios. However, it can be calculated from data in Table 3.5 that if a multi-container system had also been considered in scenario $A$, the Integral-b system would have delivered greater profits (less negative) than the reference system in all the scenario formulations, especially for those considering the electricity rates of 2012. For the scenario formulations B2-A2 and B2'-A2' the profits obtained in both scenarios would have been very similar. It must be taken into account that the Integral-b project was conceived on a pilot scale, but the viability of using a DTD or a multi-container system would depend on specific characteristics of the municipality, such as population, area and topography. In principle, a DTD system reduces labor costs in sorting, which could be interesting depending on the process scale. In addition, there is another possible way whereby the SOW collection costs are not borne by the stakeholder (e.g. a biodiesel producer implementing the CHP+AD); municipalities are usually responsible for them through other companies or third parties. By considering an efficient public collection system for SOW (with a zero cost for the decision-maker), the Integral-b process would deliver greater profits than the reference system; profits from scenario A would even be positive in all the scenario formulations at the 2014 electricity rates, except B2-A2. Increasing the UCO collection capacity from the hospitality sector translates into greater profits for both systems due to the income generated by the sale of biodiesel, the co-product with the highest market price. This has an even greater influence in scenarios $B$ than $A$, since biodiesel is the main co-product in scenarios $B$, while the electricity from the CHP is the main co-product in scenarios $A$. This is also the reason why changes in electricity rates affect the economic performance of the Integral-b system to a greater extent. 
The sensitivity analysis allows for the key parameters to be identified in order to optimize the process further. The most influential parameters in the financial LCC of scenario $A$ are the sale prices of biodiesel, cogeneration electricity and digester sludge. In scenario $B$, the price of biodiesel is by far the greatest contributor to overall profits. As already mentioned, these prices are determined by market forces and waste managers (e.g. sanitary landfill, composting and AD facilities, etc) have scarce scope for action. The sensitivity analysis of the differential profits, B-A, shows that, besides the cost of the SOW collection in scenario $A$, the cost of collecting the MSW in scenario B also makes a substantial contribution to the uncertainty of the results. This shows that there is room for improvement in the economic performance of the analyzed waste management systems; actions should be taken in regard to these two parameters in order to reduce the overall costs of both scenarios separately. As far as the Integral-b process is concerned, optimizing the collection routes for the DTD collection is a key factor to deliver economic gains (in terms of greater profits) relative to the reference scenario, as has been previously discussed in the present section. Furthermore, a combined DTD system for both UCO and SOW might reduce this cost, provided this option is feasible in a specific municipality. Similarly, results also show that any technical improvement in the electrical efficiency of the CHP would improve the financial performance of scenario $A$ as well. This electrical efficiency also depends on parameters related to the quality of the biogas, which, in turn, depends on the composition of the digester mix. Optimizing these aspects would also imply a beneficial effect on the profits of scenario A. Finally, the significant influence of the price of the digester sludge on the profits of scenario $A$, together with its highly uncertain selling price, highlights its critical role in the differential analysis of the scenarios. The higher its price, the greater the profits in scenario $A$ and, thus, the more viable the process proposed by the Integral-b project.

\subsubsection{Comparison of the LCA and LCC results}

When comparing waste treatment options by means of life cycle methodologies, the same FU must be considered in all the scenarios. However, when analyzing integrated, multi-functional systems, such as the Integral-b one, establishing the system boundaries is not necessarily straightforward and entails different assumptions which may be critical for the financial modeling in the LCC. In our case study, one crucial decision was the allocation of the total costs of MSW collection and sorting. Although the functional SOW inflow is exactly the same in both scenario $A$ and $B$, as already explained in section 3.2.2.3, the multi-container system in scenario $B$ implies that a greater amount of non-organic fraction has to be collected in order to obtain the FU. This means that the amount of waste collected in scenario B $(57.26 \mathrm{~kg})$ is greater than that in scenario A $(37.37 \mathrm{~kg})$; both 
MSW inflows are subsequently sorted to obtain the SOW in the FU $(35.50 \mathrm{~kg})$. In order to establish the unit cost of the SOW collection in scenario $B$, the overall costs from a multi-container system were gathered and subsequently allocated to the amount of organic fraction (by weight). If no allocation had been applied, scenario B would have provided the additional function of collecting a greater amount of non-organic fraction, and the subsequent costs would have had to be included in scenario A as well. In the case of sorting, the costs of processing the entire amount of MSW collected in scenario B were considered. This implies that the non-selective collection in the reference scenario generates greater sorting costs than those in scenario A, which are close to zero since the SOW is collected separately. As happens in LCA with environmentally relevant flows (inputs and outputs), it may be necessary to allocate costs of multi-functional sub-stages (based on mass criteria) in order to obtain equivalent systems in terms of their functional inflows and outflows.

In environmental terms, the Integral-b system showed potential benefits relative to the reference scenario, although they were conditional on the methodological choices regarding the co-product credits. The influence of assumptions in regard to possible uses for the glycerol co-product is much smaller in financial terms than it is in environmental terms. In the study of Escobar et al. (2015) (section 3.1), under the substitution approach (for system expansion), glycerol caused avoided burdens in scenario $B$, favoring its environmental performance. In this way, using the glycerol from biodiesel production was detrimental to scenarios $A$, and potential UCO collection levels translated into greater glycerol output in scenarios $B$, thus causing greater avoided burdens from synthetic glycerin and propylene glycol displacement. In financial terms, this uncertainty as regards the possible uses for crude glycerol was assessed as parameter uncertainty. The demand for glycerol is determined by market mechanisms, ultimately defining its market price. Hence, price variability captures the different uses glycerol may be put to. However, the income generated by the sale of glycerol is almost negligible; thus, the glycerol market price is not a significant source of uncertainty despite the wide range of prices considered (from -20 to $150 € / \mathrm{t}$ ). In this way, the possibility of glycerol becoming a waste to be treated has also been modeled, which is not the case in the environmental assessment. Although it has been proved that selling glycerol is important for the profitability of biodiesel plants (Haas et al., 2006), the present study shows that the influence of the price of glycerol is not relevant for the Integral-b system understood as a waste management system on a municipal scale.

As has been seen, the LCC results are also influenced by scenario assumptions, although these choices are not exactly methodological in nature; they are not dependent on the criteria of the LCC practitioner, but on the regulatory framework 
(in the case of changing electricity rate policies) or technical limitations (in the case of the UCO collection capacity). As Gluch and Baumannm (2004) pointed out, the LCC outcomes are greatly influenced by changing regulations, unpredictable market fluctuations and institutional regulations. In order to improve the uncertainty analysis in the LCC, we thus recommend taking possible normative changes (e.g. in the electricity and biofuel markets) that affect regulated prices into account, by means of a scenario analysis.
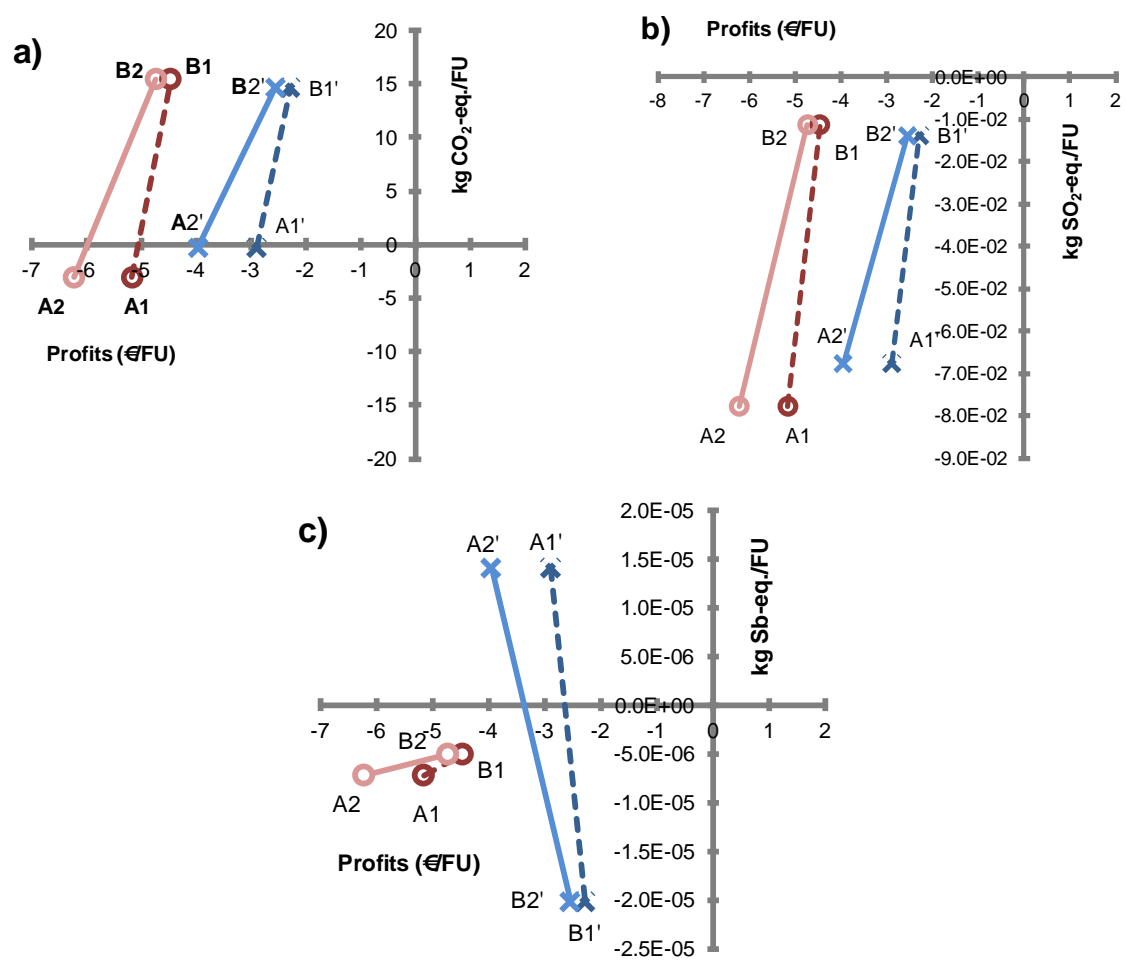

Figure 3.10. Graphical display of the trade-offs between the LCC and LCA results for the impact categories: a) global warming ( $\mathrm{kg} \mathrm{CO}_{2}$-eq./FU), b) abiotic depletion (kg Sb-eq./FU), and c) acidification ( $\mathrm{kg} \mathrm{SO}_{2}$-eq./FU).

The plots in Figure $3.10(a, b, c)$ have been built for the purposes of analyzing possible trade-offs between the LCA and LCC results. The slope indicates the extent to which a change in profits leads to a change in a specific environmental impact; the greater the slope (in absolute terms), the more marked the effect. For the sake of simplicity, only those scenario formulations in which the electricity from the mix was displaced (in the environmental assessment) have been considered. This allows for the effect of different electricity rates and different UCO collection capacities to be analyzed. For instance, as can be observed in Figure 3.10a, in 
scenario formulation B1-A1, a 16\% decrease in profits due to the implementation of the Integral-b is needed to generate a $120 \%$ decrease in the impact of global warming (GW), while a $32 \%$ decrease is needed for the same GW saving in scenario B2-A2. This means that the new electricity rate system makes it more costly to reduce $\mathrm{CO}_{2}$-eq. emissions from the same $\mathrm{FU}$ by switching to the Integralb system from the reference scenario. Similarly, in scenario B1'-A1', a $27 \%$ decrease in profits generates a $102 \% \mathrm{GW}$ saving, while a $55 \%$ decrease in profits is required for the same decrease in scenario B2'-A2'. This shows that, when increasing the UCO collection levels, it is more expensive to reduce the impacts of scenario $A$ relative to scenario $B$, since the reference scenario causes per se a smaller impact under the glycerol displacement assumptions considered for the LCA.

A positive slope means that there is an actual trade-off, inasmuch as increasing profits translate into increased environmental impacts. The slope is positive for all the environmental impacts, except for abiotic depletion, when the FU is based on the potential UCO collection capacity (A1', B1', A2', B2'), as shown in Figure 3.10b. In this case, a $27 \%$ decrease in profits when moving from scenario $\mathrm{B1}^{\prime}$ ' to $\mathrm{A} 1^{\prime}$ translates into a $170 \%$ increase in the impact. This is because the avoided burdens associated with glycerol production in scenario $B$ had a crucial effect on the differential abiotic depletion, scenario B-scenario A, in such a way that increasing the UCO collection capacity reversed the sign of the difference, favoring the environmental profile of the reference scenario. When considering 2014 electricity rates, a $55 \%$ increase in profits (thanks to scenario B2') generates a $170 \%$ decrease in abiotic depletion, which does not constitute a trade-off in itself. On the contrary, for current levels of UCO availability (A1, B1, A2, B2), scenario A caused a higher input of abiotic depletion than scenario $B$. Thus a $16 \%$ decrease in profits delivers abiotic depletion impacts that are $43 \%$ smaller in B1-A1, and $22 \%$ smaller in B2-A2. As for acidification (Figure 3.10c), a 16\% decrease in profits due to the Integral-b process generates a 594\% impact saving (B1-A1), while a $32 \%$ decrease is needed to bring about the same environmental improvement (B2-A2). In this case, readier UCO availability is also detrimental to scenario A, although to a much lesser extent than it was for abiotic depletion.

The slope of each trade-off has been calculated as the quotient between the change in the relative impact and the change in relative profits (from scenario $B$ to scenario A). It can be interpreted as an elasticity that measures how an increase (or decrease) in profits entails a change in a specific environmental impact. Table 3.7 gathers the elasticity of the impacts in each scenario. The maximum value can be found for eutrophication in both B1 and A1: an increase of $1 \%$ in profits would mean a $40 \%$ increase in eutrophication. As can be seen, increasing the UCO collection capacity doubles the elasticity values, indicating that it makes it twice as 
difficult, in terms of costs, to deliver environmental gains by implementing the Integral-b system (except for abiotic depletion). In this way, the LCC and LCA results provide indications on the cost-efficiency of decreasing impacts. The best waste treatment option will be that causing the greatest decrease in impacts (relative to a reference situation), with the lowest cost. However, there may be other "hidden costs", as referred to by Campbell et al. (2011), such as tax exemptions and subsidies, which are borne by tax payers or other stakeholders. In fact, under the 2012 electricity rate systems, these "hidden costs" were borne by electricity users.

Table 3.7. Elasticity profits-environmental impacts.

\begin{tabular}{|c|c|c|c|c|c|c|}
\hline $\begin{array}{l}\text { Scenario } \\
\text { formulationsI } \\
\text { Impacts }\end{array}$ & $\begin{array}{c}\text { Abiotic } \\
\text { depletion }\end{array}$ & Acidification & Eutrophication & $\begin{array}{c}\text { Human } \\
\text { toxicity }\end{array}$ & $\begin{array}{c}\text { Global } \\
\text { warming }\end{array}$ & $\begin{array}{c}\text { Photochemical } \\
\text { ozone creation }\end{array}$ \\
\hline B1-A1 & 2.76 & 38.17 & 40.35 & 21.24 & 7.69 & 8.46 \\
\hline B2-A2 & 1.36 & 18.78 & 19.86 & 10.45 & 3.78 & 4.16 \\
\hline B1'-A1' & -6.34 & 14.55 & 3.79 & 1.42 & 3.81 & 3.08 \\
\hline B2'-A2' & -3.07 & 7.05 & 1.84 & 0.69 & 1.85 & 1.49 \\
\hline
\end{tabular}

The main goal of the combined study is to discern which scenario is better in environmental terms and which one is better in financial terms. Despite the fact that the reference scenario generates smaller economic losses, the Integral-b is better in most of the impact categories. Any measure aimed at internalizing possible environmental externalities, such as the carbon footprint, would favor the financial performance of the proposed system, while providing a better picture of real societal gains. It must be borne in mind that waste management activities entail costs and require financial support from the public sector. Thus, achieving a consensus on a method for internalizing the environmental impacts in the LCC would help the decision-making. In the field of bioenergy, Silalertruska et al. (2012) proposed a method based on the willingness-to-pay.

\subsubsection{Conclusions}

The economic performance of an integrated system for the management of organic waste from catering and restaurants (SOW and UCO) in Spain has been assessed and compared to a reference system. The profits generated by each waste management option have been calculated by means of an LCC from a financial point of view. These results are aimed at complementing those from section 3.1, assessing the environmental performance of systems that are identical to the ones defined in the present section in terms of provided functions. Under a life cycle perspective, both the FU and the system boundaries must be exactly the same for the purposes of comparison. Since the systems under study are multi-functional, 
the substitution approach was applied for the LCA; they were credited with delivering co-products by performing system expansion. Uncertainty due to choices regarding these co-product credits was analyzed through scenario analysis; in this way, a number of discrete results were obtained as possible outcomes of the LCA, generated by choice-related variations. These choices proved to be very influential, since differences in the comparative analysis were mainly caused by these avoided processes.

In the LCC, the substitution approach has been understood as co-products generating revenues in waste treatment facilities which translate into negative costs. Uncertainty then arises from price variability, in addition to that present in technical parameters. Two of the most uncertain prices are those of the electricity from cogeneration in scenario $A$ and electricity from landfilling and incineration in scenario $B$, since these prices are conditional on market regulations. Hence, a scenario analysis has been performed by considering two different electricity rates in Spain, the one that was in force in 2012 (when the environmental assessment was carried out), and the current one, which started in 2014. Scenario analysis is identified as a suitable tool with which to understand the associated uncertainty, increasing the robustness of the results. It can be concluded that the 2014 electricity rates, which lowered the sale price, are detrimental to scenario A to a greater extent than they are to scenario $B$. The main reason is that electricity from cogeneration is the greatest contributor to total income in the first scenario and electricity based on this technology is less subsidized; thus, a change in its market price has a substantial impact on the financial performance of the Integral-b system. Similarly, uncertainty in terms of the availability of UCO in Spain has also been assessed, in tune with the previous study. Increasing the UCO collection improves the financial performance of both scenario $A$ and $B$, regardless of the electricity rate system. It must be recalled that, in the comparative environmental assessment, a greater UCO collection capacity was disadvantageous for the proposed system, since, under the assumptions made for system expansion, it implied greater glycerol credits in the reference scenario.

Although deterministic estimates of cost are useful for comparing alternative strategies, LCC outcomes are subject to data uncertainty in the same way as those from LCA. Indeed, a greater parameter uncertainty can be expected in LCC than in LCA, since input and output prices are included as process parameters in the modeling of the systems. In this sense, uncertainty in prices can be compared with uncertainty in characterization factors in LCA, since it is precisely this factor, the price, which multiplies the input/output flow in order to calculate profits. It must be recalled that uncertainty in characterization factors was not addressed by Escobar et al. (2015), who found that parameter uncertainty had a negligible effect compared to uncertainty due to choices. In the present study, parameter 
uncertainty has been assessed by means of the Monte Carlo simulation based on the differential profits, scenario B-scenario A. This allows for the parameters common to both scenarios to be simulated at the same time; in this way, they have exactly the same value in each simulation run, thus yielding a fair comparison. The Monte Carlo analysis shows that it is not only variability in co-product prices which is a great source of uncertainty, but also the variability in technical parameters. Results show that there is a much greater probability of scenario $B$ outperforming scenario A in every scenario formulation; this also proves, however, that in some circumstances there is some likelihood that scenario A will generate greater profits than scenario B, especially for the lowest UCO collection capacity. It can be said that outcomes from the analysis of the economic uncertainty are more reliable than those from that of the environmental uncertainty since the tools used for the stochastic uncertainty calculation in economic variables are usually more robust.

The Integral-b system does not outperform the reference system in financial terms. It causes greater income losses as compared to a reference scenario, although both generate negative profits. By analyzing the possible trade-offs between the LCA and LCC results, it can be concluded that reducing environmental impacts by switching to the Integral-b system comes at the expense of the profits generated, although, despite the new electricity rates, the saving in most of the impacts is substantial. It should be noted that if no compensation had been considered in the definition of scenarios, the base price under the 2014 electricity rates alone would have been even more detrimental to the Integral-b project. Ultimately, these kinds of projects should be implemented by actors with limited resources, such as municipalities; thus, changing regulations may be critical in the transition to environmentally-friendly waste management options.

The DTD collection system for the SOW plays a key role in the economic results, since the SOW is collected in greater amounts than the UCO. However, this proportion is subject to change depending on the scale of the process and the area of application. Excluding the SOW collection costs would completely change the conclusion, improving the viability of the Integral-b process. This highlights the idea that the cut-off criteria applied to establish the system boundaries are critical in the LCC. According to Norris (2001), only economic costs or profits for the decisionmaker should be included. In any event, it must be taken into account that waste management processes incur costs for society; so, the most suitable system from the financial point of view would be that which generates lower costs. In order to enhance the applicability of the LCA and LCC results, further harmonization in life cycle methodologies is both desirable and crucial for decision-making. Heijungs et al. (2013) propose a computational structure for unifying the LCA and LCC in a sustainability analysis. 
Journal of Cleaner Production, 2014, 79:61-73

\subsection{Consequential Life Cycle Assessment of two alternative systems for biodiesel consumption in Spain, considering uncertainty}

Escobar, N. ${ }^{a}$, Ribal, F.J. ${ }^{b}$, Clemente, G. ${ }^{a}$, Sanjuán, N. ${ }^{a}$

${ }^{a}$ Grup ASPA. Departament de Tecnologia d'Aliments, Edifici 3F, Universitat

Politècnica de València. Camí de Vera s/n, 46022, Valencia, Spain

${ }^{\mathrm{b}}$ Departament d'Economia i Ciències Socials, Edifici 3P, Universitat Politècnica de València. Camí de Vera s/n, 46022, Valencia, Spain 



\begin{abstract}
Section 3.3 assesses two possible biodiesel pathways for the Spanish transport sector, representing the actual situation before the end of 2013. A Life Cycle Assessment (LCA) has thus been carried out for two scenarios: scenario 1, in which $1 \mathrm{MJ}$ of soybean biodiesel is imported from Argentina, and scenario 2, in which $1 \mathrm{MJ}$ of biodiesel from used cooking oil (UCO) is manufactured in Spain. System expansion is performed to include the marginal products involved and additional functions are considered under a consequential approach. Scenario 1, then, includes the production of palm oil in Malaysia $(25.27 \mathrm{~g})$, as the marginal supplier in the global market. This also implies a decrease in the production of soybean meal in Brazil $(3.44 \mathrm{~g})$. In scenario 2, interactions in the global oil market lead to changes in the opposite direction: the production of palm oil decreases in Malaysia $(26.31 \mathrm{~g})$, whereas the production of soybean meal increases in Brazil $(3.58 \mathrm{~g})$. When emissions from land use change (LUC) are not taken into account, the UCO biodiesel produced in Spain performs better than the imported biodiesel from Argentina in every analyzed impact category, except in global warming (GW). In this case, the impact is $138.9 \%$ lower in scenario 1 , mainly due to the carbon uptake by soybeans in Argentina and palm trees in Malaysia. Since these results may underestimate the negative environmental consequences, greenhouse gas (GHG) emissions from LUC in each country are included, too. Indirect functions of the expanded systems appear to make a great contribution to the overall GW impact, especially in scenario 2. Results show that there are clear environmental benefits arising from the use of UCO biodiesel in Spain to meet the European targets, as compared to the use of imported soybean biodiesel from Argentina. The Monte Carlo simulation for both scenarios also reinforces confidence in the comparative assessment.
\end{abstract}

Keywords: biodiesel, Monte Carlo, consequential LCA, system expansion, uncertainty 


\subsubsection{Introduction}

The last few years have seen a marked rise in the worldwide production of biofuels. Rising oil prices have been very influential, as have public policies, such as the Renewable Energy Directive (RED). To reduce the GHG emissions, this Directive urged the Member States (MSs) to establish a $10 \%$ biofuel share in the motor fuel market by 2020. Its adoption led to the construction of many biodiesel plants in Spain; in 2010, there were 45 , but one year later, only 31 plants remained in operation, with the sector working at $25 \%$ of their nameplate capacity (around 4.5 Mt per annum) (CNE, 2013). As has been emphasized in chapter I (section 1.3.2), most of the current plants are currently at a standstill. This situation contrasts sharply with the growing consumption of biodiesel in Spain. The target for renewable energy use in the transport sector, which was 6.4\% in 2011 (Decree 459/2011), was almost reached: biofuels accounted for $5.9 \%$ of the total fuel demand in that year (Eurostat, 2013b). The key issue is that most of the biodiesel consumed in Spain in the period 2010-2013 was imported. For instance, imports accounted for around $76 \%$ of the market share in 2012 (APPA, 2013). Argentina was the largest supplier, providing almost half of the total consumed (CNE, 2013), until the European Commission (EC) enforced the anti-dumping duties on biodiesel imports from Argentina and Indonesia under the Regulation 1194/2013.

In addition, as thoroughly explained in section 1.2.1.3, the EC is debating a new proposal amending the RED, to start the transition to biofuels that deliver substantial GHG savings, known as advanced biofuels. These emissions must be accounted over the entire life cycle, including emissions from LUC. This refers to the combined effect of direct land conversion to grow bioenergy feedstock to meet the increased demand, and shifts in land cover and crop patterns in regions elsewhere (e.g. in Brazil). This second effect is known as indirect LUC (ILUC) and can cause changes in the carbon stock of the soil and biomass when current activities are displaced. Specifically, the new proposal, COM 595 (EC, 2012a), urges the MSs to report ILUC emissions from the biofuels produced, and sets a limit on the contribution of the food-based ones (also known as first generation biofuels, FGBs) to the $10 \%$ target, which is expected to be around $7 \%$.

The production of biodiesel from UCO may represent an interesting alternative means for the Spanish transport sector to fulfill the requirements of the new COM 595. Besides avoiding the conflict between food and energy, this option reduces the risk of indirect GHG emissions while reducing the amount of oil to be managed. In 2011, UCO was the second most commonly used feedstock for biodiesel production in Spain, accounting for $24.95 \%$ of the total domestic production (CNE, 2013). More than $114,000 \mathrm{t}$ of UCO generated in Spain were used to this end in that very year. Lechón et al. $(2009,2011)$ included biodiesel from used vegetable 
oils in their comparative assessment of biofuel impacts in the Spanish context. FGBs were produced from a mix of domestic and imported feedstock; authors studied the influence of their origin by means of a sensitivity analysis. However, no reference was found to an analysis of the environmental consequences of using UCO biodiesel in Spain, as compared to imported biodiesel.

Studies addressing the issue of LUC in the environmental performance of biofuel systems have proliferated in the last few years (Fargione et al., 2008; Kim et al., 2009; Lapola et al., 2010; Panichelli and Gnansounou, 2008; Searchinger et al., 2008), since indirect emissions may have a detrimental effect on the benefits that are supposed to be generated by alternative fuels. In this sense, the LCA methodology has played a significant role because it aims to estimate the environmental impacts from producing raw materials to be used for biofuel purposes. However, the shortcomings of the traditional approach are evident when estimating ILUC, since market-mediated responses are not easy to capture. Crop displacement effects are the result of interactions among global agricultural markets, and must be addressed from a consequential perspective, as drawn in section 2.3. Although there is no scientific consensus on the methodology to be applied in the study of these indirect effects, most authors used economic modeling (Banse et al., 2011; Havlík et al., 2011; Hertel et al., 2010; Kløverpris et al., 2008).

Furthermore, some LCA practitioners developed accounting devices to describe how the environmentally relevant physical flows to and from the technological system will change in response to possible changes in the life cycle (Zamagni et al., 2012). For example, Ekvall and Weidema (2004) proposed procedural guidelines for consequential LCA methodology, based on their previous studies (Ekvall, 2000; Weidema et al., 1999). These guidelines were subsequently used by Dalgaard et al. (2008), Reinhard and Zah (2009, 2011), Schmidt (2010), and Schmidt and Weidema (2008) in the study of agricultural systems related to biofuel consumption. All these analyses were carried out by performing system expansion to include all the co-products (since they may fulfill different functions in other markets), and by identifying marginal suppliers affected by changes in the production system (see section 2.3.1). Most of these models were built on simple causal relationships, although it can be said that they are of an economic nature because these substitution assumptions are based on the observation of the markets involved (Vázquez-Rowe et al., 2013), but assuming long-term full market elasticity (the ceteris paribus assumption, according to Ekvall, 2000).

Uncertainty analysis is another important issue in LCA, as mentioned in section 2.5. Average data is usually used without considering the associated variability, and these deterministic results can be misleading when comparing systems. Some authors performed uncertainty analyses to determine the influence of some assumptions on the overall results, such as Halleux et al. (2008), Kim and Dale 
(2005), Bernesson (2004) or Malça and Freire (2010), who studied the effect of input and output variation through sensitivity and Monte Carlo analyses. Plevin et al. (2010) also used a Monte Carlo simulation to estimate a plausible range of ILUC emissions from corn ethanol production in the US, to provide results robust enough to influence public policies.

The aim of this section is to assess the direct and indirect environmental impacts to be expected if the demand of biodiesel in Spain increases to meet current European Directives. Two alternative pathways are compared under a consequential approach. The first pathway was indeed the prevailing one until the end of 2013, and consists of increasing the imported soybean biodiesel from Argentina. The second pathway consists of increasing the production of biodiesel from UCO. To reinforce the results, emphasis is placed on the assessment of parameter uncertainty, as it may influence decision-making.

\subsubsection{Materials and methods}

LCA was performed according to the ISO standards (ISO 2006a, b). In the following sections, some methodological aspects are explained, by following the main steps described in section 2.2.

\subsubsection{Functional Unit}

Two scenarios representing two alternatives for the Spanish transport sector in the period 2010-2013 were defined and compared: scenario 1, in which biodiesel is imported from Argentina (the leading exporter to both the European Union and Spain for many years), and scenario 2, in which biodiesel is produced from UCO collected in Spain. For the definition of the Functional Unit (FU), the same approach as Reinhard and Zah $(2009,2011)$ was followed: $1 \mathrm{MJ}$ of biodiesel in regional storage in Spain.

\subsubsection{System description and system boundaries}

In order to define the two scenarios, the same principles used by Dalgaard et al. (2008) and Reinhard and Zah (2009) to identify the marginal suppliers of coproducts were applied. These consist of expanding the boundaries of the systems under study to include the indirect functions (Ekvall and Finnveden, 2001).

In scenario 1, the core process is the production of biodiesel in Argentina, which consists of soybean farming, soybean oil extraction at the mill and the subsequent oil refining, and soybean methyl ester (ME) production by transesterification. Soybean farming considers the emissions and fuel consumed during the farming 
practices, together with the production and provision of the agricultural inputs. Hexane and phosphoric acid are used in oil extraction, whereas methanol, hydrochloric acid and phosphoric acid are used in transesterification. The production of these chemicals is included, as well as wastewater treatments. The biodiesel is exported from Argentina to Spain by tanker, with the subsequent road transport. In scenario 2, the core process is also the production of biodiesel, in Spain in this case, which starts with the UCO collection, and the subsequent transport to the biodiesel plant. After UCO pretreatment and conditioning, transesterification takes place in a closed reactor, by using a catalyst previously mixed with methanol. The production of both methanol and catalyst was taken into account together with the associated transport. Trucks were used to distribute the biodiesel in Spain and this was also considered.

However, these systems are actually more complex and the indirect effects caused by co-product interaction in the international market must be considered (Figures 3.11 and 3.12). In the present study, the ceteris paribus assumption was made, that is, the demand of the functions fulfilled by another product is constant (Ekvall, 2000). It was also assumed that agricultural production increases by area expansion and not by intensification, since this would entail predicting changes in the type and amount of inputs required to increase crop yields. According to this, expanding the production of soybean biodiesel in Argentina to meet the Spanish demand would cause a reduction in the soybean oil available in the international market. Weidema (2003) assumed this gap was filled by the marginal supplier of oil, which is Malaysia. In terms of production cost, palm oil stands out as the least expensive oil to be produced per ton compared with other major vegetable oils (Kee Lam et al., 2009), and it was also identified by Schmidt and Weidema (2008) as the marginal oil in the global market. According to the Malaysian Palm Oil Board (MPOB, 2012), Malaysia was the world's largest exporter of palm oil in 2011. As a consequence, palm oil production in Malaysia would increase in scenario 1, with the subsequent expansion in the agricultural land needed for the production of palm fruit bunches, causing LUC. The total output of crude palm oil (CPO) is a mix of oil from the mesocarp of palm fruit bunches and oil from palm kernels. Palm kernel meal is also produced and becomes an indirect function of the system, since it can be used as animal feed. An additional amount of protein meal in the global market would affect the protein source that is most sensitive to changes in demand, which was assumed to be soybean meal from Brazil, since it is the longterm marginal supplier (Reinhard and Zah, 2011). A loop between palm oil and soybean meal is then identified: when production of soybean meal in Brazil decreases, the amount of soybean oil in the international market contracts too, which is again compensated for by the marginal supplier. This loop iterates till the flows tend to zero, causing a net increase in the production of palm oil in Malaysia $(+25.27 \mathrm{~g})$ and a decrease in the production of soybean meal in Brazil $(-3.44 \mathrm{~g})$. 


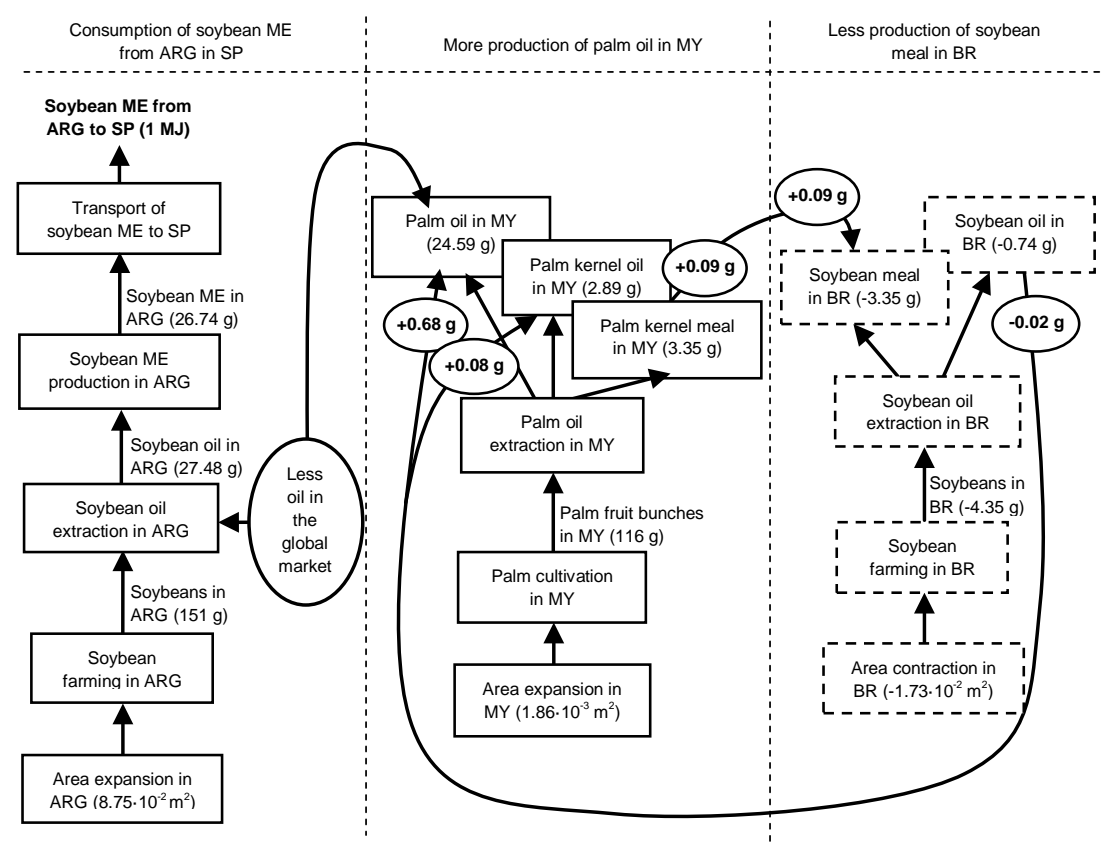

Figure 3.11. System delimitation of scenario 1. A loop between palm oil and soybean meal is generated by the import of 1 additional MJ of soybean ME from Argentina into Spain. SP: Spain; ARG: Argentina; BR: Brazil; MY: Malaysia.

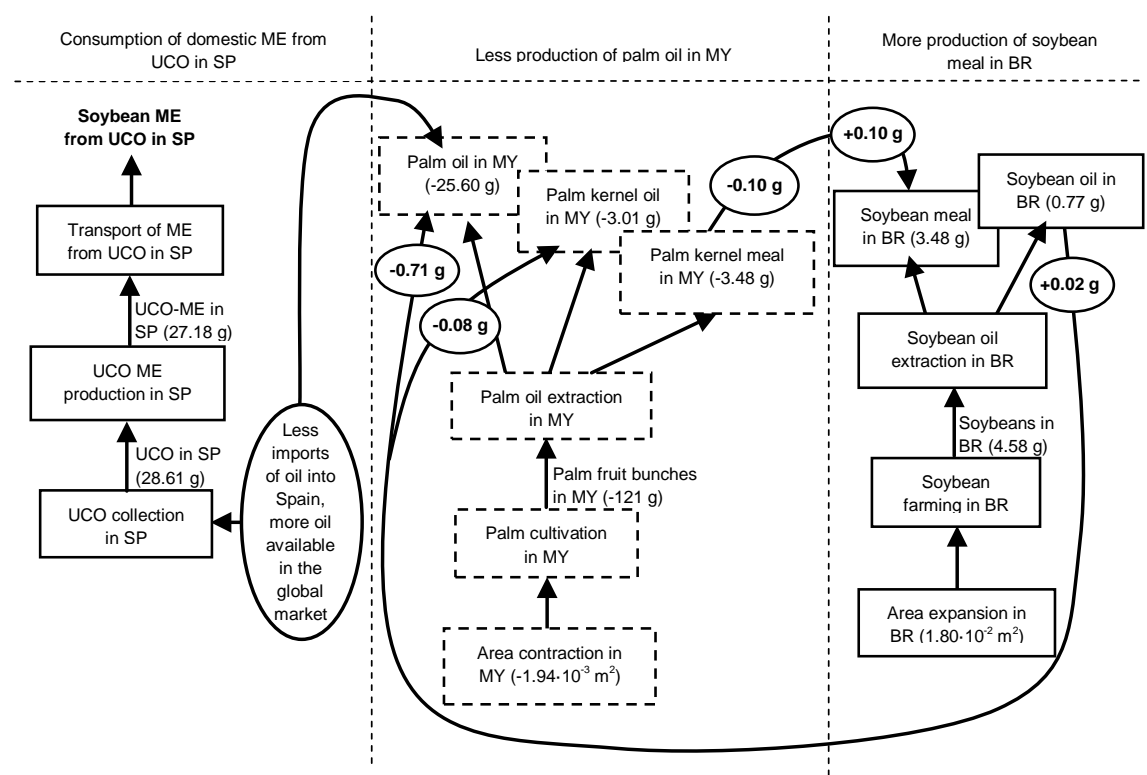

Figure 3.12. System delimitation of scenario 2. A loop between palm oil and soybean meal is generated by the production of 1 additional MJ of ME from UCO in Spain. SP: Spain; BR: Brazil; MY: Malaysia. 
In scenario 2, the demand of $1 \mathrm{MJ}$ in Spain is supposed to be met by producing biodiesel from domestic UCO. This would avoid the need to import CPO from a marginal supplier. Although Indonesia was the main exporter of this oil to Spain in 2011 (CNE, 2013), Malaysia was considered to be the marginal supplier in our case study, since average production practices are very similar in the main palm producing countries (Lechón et al., 2009), and available inventory data for Malaysia had more quality. Similarly to scenario 1, less palm meal would be delivered to the global feed market, causing an increase in soybean production in Brazil with the subsequent LUC in both Brazil and Malaysia. A loop is also generated and iterated against zero, causing a net decrease in the production of palm oil in Malaysia $(-26.31 \mathrm{~g})$ and an increase in the production of soybean meal in Brazil (+3.58 g).

In both scenarios, palm oil extraction in Malaysia includes the production and transport of chemicals (phosphoric acid, hexane, chlorine, sodium chloride, etc), and wastewater treatment. The cultivation of palm fruit bunches takes into account not only the emissions and fuel consumed in agriculture (including wood chopping when deforestation occurs), but also the production and provision of fertilizers and pesticides, as well as irrigation. The same criteria were used to determine the flows to be considered in soybean farming and oil extraction in Brazil. Besides the processes already depicted, the production of all the energy inputs was also taken into account in both scenarios: fossil fuel production at the refinery and the production of electricity and heat from natural gas. The production of capital goods was included in the agricultural and transport processes, since, as Frischknecht et al. (2007) concluded, capital goods of these type of processes may contribute substantially to the overall impact, depending on the category. On the contrary, the production of capital goods was not included in the Life Cycle Inventory (LCI) for biodiesel production and oil extraction. The evaluation of these sub-stages shows large amounts of product, together with long life spans of the main investments, making the impact per FU negligible. Following Heijungs et al. (1992) and Frischknecht et al. (2007), if these costs (maintenance and depreciation) are a substantial part of the product price, the environmental impacts of capital goods should not be excluded a priori. In the case of UCO biodiesel, maintenance and depreciation costs represent less than $4 \%$ of the product price. Hence, capital goods in the soybean ME production were also neglected, as they were by Panichelli et al. (2009).

\subsubsection{Inventory data}

This section presents the data used to characterize the described scenarios. Using these data the base scenarios were set, which assume an absence of variability, implying a deterministic assumption. It must be pointed out that data used for the 
$\mathrm{LCl}$ are representative average data from secondary sources, or data gathered from reliable primary sources.

In scenario 1, the complete inventory for the soybean biodiesel pathway in Argentina was provided by Panichelli et al. (2009). Soybean farming was modeled accordingly, but all the inputs were calculated as a weighted average of the four studied production systems. The sub-stages of soybean oil extraction and soybean ME production include the transport of the feedstock and inputs. The distance between the oil mill and the transesterification plant was zero because both are commonly located at the same facility, close to the port of Rosario, which even has its own bulk loading terminals. The export sub-stage was modeled according to the following: it started with the biodiesel being transported by truck through the province of Buenos Aires to the port of Rosario, since this is the province with the largest soybean area (MECON, 2011a). It is then transported to Rotterdam (the Netherlands) by transoceanic tanker, and finally to Valencia (Spain) by truck. All the processes included in the production of both the palm oil in Malaysia and the soybean meal in Brazil were gathered from Ecoinvent v.2.2 database (Hischier et al., 2010). This database contains one single process for each co-product; the original economic allocation was undone and processes were unified considering mass ratios between co-products. It must be noted that the palm oil extraction yield in the Malaysian process was extremely close to the value reported by Kamahara et al. (2010) for Indonesia. All the input production processes (chemicals and energy) were taken from the same database. In scenario 1, the Argentinian electricity mix was modeled according to MECON (2011b).

In scenario 2, all the data about UCO ME production, that is collection distances, energy use, and origin of the chemicals, were provided by a company which is representative of the sector (Bionorte, located in Northern Spain). The production of methanol and catalyst, together with the subsequent transport and energy consumption, were taken from Ecoinvent v2.2. The distance for the UCO ME transport in Spain was that between Bionorte and Valencia. The UCO collection distance was estimated to be $100 \mathrm{~km}$, the same as Vinyes et al. (2013) for the system "urban collection centers", in which UCO is brought to specific collection points. All the trucks considered were about 20-28 $t$ fleet average.

After a prior analysis, emissions from LUC were added to the inventory to carry out the Life Cycle Impact Assessment (LCIA). GHG emissions from land transformation in Argentina, Malaysia and Brazil were calculated by multiplying the area diverted to arable land in each region by emission factors associated with each land conversion, which depend, in turn, on the previous use (forest, grassland, shrub land or other crops). Specifically, land transformation was assumed to occur in the same way as reported by Panichelli et al. (2009) for the 
soybean expansion in Argentina, while area values from Ecoinvent v2.2 were considered in Malaysia. In Brazil, updated values from Prudêncio da Silva et al. (2010) for the Central-West scenario were used, which are representative of most of the Brazilian territory dedicated to soybean (87\% of which corresponds to the Mato Grosso state). Emission factors for each of those land conversion types in each country were calculated according to the guidelines from the IPCC (2006), for a baseline of 20 years. Overall emissions from LUC include carbon losses arising from changes in biomass, soil and dead organic matter before and after the transformation, as recommended by the IPCC (2006), and also emissions from biomass burning when deforestation takes place (process from Ecoinvent v2.2).

\subsubsection{Impact assessment}

The LCIA was carried out using the GaBi 6 software (PE International, 2013). The CML 2001 (baseline) impact assessment method (Guinée et al., 2002) was applied. The impact categories included were: abiotic depletion (ADP elements and ADP fossil), acidification, eutrophication, freshwater aquatic ecotoxicity (FAE), GW, human toxicity (HT), marine aquatic ecotoxicity (MAE), ozone layer depletion (OD), photochemical ozone creation potential (POC) and terrestrial ecotoxicity (TE).

\subsubsection{Sensitivity and uncertainty analyses}

A conventional sensitivity analysis was first conducted to find out how sensitive the model was to changes in all the input parameters, including those involved in LUC, as well as transport distances. One parameter was changed at a time $( \pm 20 \%)$ and the influence on the results was studied (Bernesson, 2004). Those parameters that caused a variation of at least $2 \%$ in one or more impact categories were selected for the Monte Carlo analysis. Both the sensitivity and Monte Carlo analyses were performed using the Analyst tool of GaBi 6.

The contribution to the uncertainty of the selected parameters was assessed by means of 10,000 runs of the Monte Carlo simulation for each impact category. Random values from the probability distribution of each parameter are selected in each run and a forecast distribution for each impact category is obtained between the $10^{\text {th }}$ and $90^{\text {th }}$ percentiles. The Analyst tool only allows for normal and uniform distributions to be simulated and all the risk parameters must adopt the same type of distribution, thus in this study the uniform type was used due to the lack of historic data. The base values of the risk parameters of scenario 1 and scenario 2, as well as the minimum and maximum bounds, are shown in Tables 3.8 and 3.9, respectively.

In scenario 1, the maximum distance for the transport of biodiesel from the European port of import to Valencia was the same as the base scenario, which is 
the distance from Rotterdam. For the shortest distance, it was assumed that the biodiesel was delivered directly from Rosario to the port of Valencia. The lowest transesterification yield in Argentina was taken from Donato et al. (2008). Since the maximum yield in the same study was 95\%, lower than that in the base scenario, this base value was assumed to be the highest bound. The maximum bound for the oil extraction yield in Argentina corresponded to the average oil content of the firstclass soybean (Cuniberti et al., 2012). The lowest bound was assumed to be the value from the base scenario, since it was even lower than the average oil content of the second-class soybean in the same study.

Table 3.8. Base values and uncertainty distributions of key parameters for the Monte Carlo analysis of scenario 1, after sensitivity analysis. SP: Spain; ARG: Argentina; BR: Brazil; MY: Malaysia.

\begin{tabular}{|c|c|c|c|c|}
\hline \multicolumn{5}{|c|}{ SCENARIO 1} \\
\hline Parameter & Sub-stage & $\begin{array}{l}\text { Base } \\
\text { value }\end{array}$ & $\begin{array}{l}\text { Uncertainty } \\
\text { distribution }\end{array}$ & $\begin{array}{l}\text { Bound data } \\
\text { source }\end{array}$ \\
\hline $\begin{array}{l}\text { Distance from European port } \\
\text { of import to Valencia by truck } \\
20-28 \mathrm{t}(\mathrm{km})\end{array}$ & $\begin{array}{l}\text { Transport of soybean } \\
\text { ME from ARG to SP }\end{array}$ & 1890 & Uniform $(0 ; 1890)$ & Google Maps \\
\hline $\begin{array}{l}\text { Net calorific value of soybean } \\
\text { biodiesel }(\mathrm{MJ} / \mathrm{kg})\end{array}$ & $\begin{array}{c}\text { Soybean ME } \\
\text { production in ARG }\end{array}$ & 37.40 & Uniform $(36.95 ; 37.56)$ & $\begin{array}{l}\text { Pradhan et al., } \\
\text { 2008; CEPA, } 2008\end{array}$ \\
\hline $\begin{array}{l}\text { Transesterification yield (kg } \\
\text { biodiesel/kg oil) }\end{array}$ & $\begin{array}{c}\text { Soybean ME } \\
\text { production in } A R G\end{array}$ & 0.973 & Uniform $(0.85 ; 0.973)$ & Donato et al., 2008 \\
\hline Hard coal (MJ/kg oil) & $\begin{array}{c}\text { Soybean ME } \\
\text { production in ARG }\end{array}$ & 0.90 & Uniform $(-10 \% ;+10 \%)$ & - \\
\hline $\begin{array}{l}\text { Oil extraction yield (kg oil/kg } \\
\text { soybean) }\end{array}$ & $\begin{array}{l}\text { Soybean oil extraction } \\
\text { in ARG }\end{array}$ & 0.182 & Uniform $(0.182 ; 0.228)$ & $\begin{array}{l}\text { Cuniberti et al., } \\
2012\end{array}$ \\
\hline Natural gas (MJ/kg soybean) & $\begin{array}{c}\text { Soybean oil extraction } \\
\text { in ARG }\end{array}$ & 0.40 & Uniform $(-10 \% ;+10 \%)$ & - \\
\hline $\begin{array}{l}\text { Transport of soybeans from } \\
\text { field to mill, by truck } 3.5-16 \mathrm{t} \\
(\mathrm{tkm} / \mathrm{kg} \text { oil) }\end{array}$ & $\begin{array}{l}\text { Soybean oil extraction } \\
\text { in ARG }\end{array}$ & 0.24 & Uniform $(0.08 ; 0.96)$ & Google Maps \\
\hline $\begin{array}{l}\text { Transformation from other } \\
\text { crops }\left(\mathrm{m}^{2} / \mathrm{kg} \text { soybean }\right)\end{array}$ & $\begin{array}{l}\text { Soybean farming in } \\
\text { ARG }\end{array}$ & 0.185 & Uniform $(-10 \% ;+10 \%)$ & - \\
\hline $\begin{array}{l}\text { Transformation from pasture } \\
\text { and meadow ( } \mathrm{m}^{2} / \mathrm{kg} \text { soybean) }\end{array}$ & $\begin{array}{l}\text { Soybean farming in } \\
\text { ARG }\end{array}$ & 0.156 & Uniform $(-10 \% ;+10 \%)$ & - \\
\hline $\begin{array}{l}\text { Transformation from forest } \\
\left(\mathrm{m}^{2} / \mathrm{kg} \text { soybean) }\right.\end{array}$ & $\begin{array}{l}\text { Soybean farming in } \\
\text { ARG }\end{array}$ & 0.127 & Uniform $(-10 \% ;+10 \%)$ & - \\
\hline $\begin{array}{l}\mathrm{CO}_{2} \text { emission factor from soil } \\
\text { carbon stock change due to } \\
\mathrm{LUC} \text { from forest to soybean (t } \\
\mathrm{CO}_{2} / \mathrm{ha} \text { ) }\end{array}$ & $\begin{array}{l}\text { Soybean farming in } \\
\text { ARG }\end{array}$ & 26.10 & Uniform $(8.50 ; 42.46)$ & IPCC, 2006 \\
\hline $\begin{array}{l}\mathrm{CO}_{2} \text { emission factor from soil } \\
\text { carbon stock change due to } \\
\mathrm{LUC} \text { from other crops to } \\
\text { soybean }\left(\mathrm{t} \mathrm{CO}_{2} / \mathrm{ha}\right)\end{array}$ & $\begin{array}{l}\text { Soybean farming in } \\
\text { ARG }\end{array}$ & 26.10 & Uniform $(8.50 ; 42.46)$ & IPCC, 2006 \\
\hline $\begin{array}{l}\mathrm{CO}_{2} \text { emission factor from soil } \\
\text { carbon stock change due to } \\
\mathrm{LUC} \text { from grassland to } \\
\text { soybean }(\mathrm{t} \mathrm{CO} / \mathrm{ha})\end{array}$ & $\begin{array}{l}\text { Soybean farming in } \\
\text { ARG }\end{array}$ & 19.12 & Uniform $(1.52 ; 35.50)$ & IPCC, 2006 \\
\hline $\begin{array}{l}\text { Biomass stock in continental } \\
\text { forest in Argentina, before the } \\
\text { conversion (t C /ha) (Bbefore) }\end{array}$ & $\begin{array}{l}\text { Soybean farming in } \\
\text { ARG }\end{array}$ & 130 & Uniform $(50,200)$ & IPCC, 2006 \\
\hline $\begin{array}{l}\text { Carbon uptake by biomass } \\
\left(\mathrm{kg} \mathrm{CO}_{2} / \mathrm{kg} \text { soybean) }\right.\end{array}$ & $\begin{array}{l}\text { Soybean farming in } \\
\text { ARG }\end{array}$ & 1.37 & Uniform $(-10 \% ;+10 \%)$ & - \\
\hline
\end{tabular}




\begin{tabular}{|c|c|c|c|c|}
\hline \multicolumn{5}{|c|}{ SCENARIO 1} \\
\hline Parameter & Sub-stage & $\begin{array}{l}\text { Base } \\
\text { value }\end{array}$ & $\begin{array}{l}\text { Uncertainty } \\
\text { distribution }\end{array}$ & $\begin{array}{l}\text { Bound data } \\
\text { source }\end{array}$ \\
\hline $\begin{array}{l}\text { Emissions of nitrates to water } \\
\text { (kg nitrates } / \mathrm{kg} \text { soybean) }\end{array}$ & $\begin{array}{l}\text { Soybean farming in } \\
\text { ARG }\end{array}$ & $3.71 \cdot 10^{-2}$ & $\begin{array}{l}\text { Uniform }\left(3.19 \cdot 10^{-2}\right. \\
\left.4.43 \cdot 10^{-2}\right)\end{array}$ & $\begin{array}{l}\text { Panichelli et al., } \\
2009\end{array}$ \\
\hline $\begin{array}{l}\text { Emissions of ammonia to air } \\
\text { (kg ammonia/kg soybean) }\end{array}$ & $\begin{array}{c}\text { Soybean farming in } \\
\text { ARG }\end{array}$ & $1.15 \cdot 10^{-3}$ & $\begin{array}{c}\text { Uniform }\left(9.89 \cdot 10^{-4}\right. \\
\left.1.37 \cdot 10^{-3}\right)\end{array}$ & $\begin{array}{l}\text { Panichelli et al., } \\
2009\end{array}$ \\
\hline $\begin{array}{l}\text { Emissions of cypermethrin to } \\
\text { soil (kg cypermethrin/kg } \\
\text { soybean) }\end{array}$ & $\begin{array}{l}\text { Soybean farming in } \\
\text { ARG }\end{array}$ & $1.96 \cdot 10^{-5}$ & $\begin{array}{l}\text { Uniform }\left(3.11 \cdot 10^{-6}\right. \\
\left.\quad 7.12 \cdot 10^{-5}\right)\end{array}$ & $\begin{array}{l}\text { Panichelli et al., } \\
2009\end{array}$ \\
\hline $\begin{array}{l}\text { Oil extraction yield (kg crude } \\
\text { palm oil/kg palm fruit } \\
\text { bunches) }\end{array}$ & $\begin{array}{l}\text { Palm oil extraction in } \\
\text { MY }\end{array}$ & 0.218 & Uniform $(0.194 ; 0.230)$ & $\begin{array}{l}\text { Yee et al., 2009; } \\
\text { FAO, } 2002\end{array}$ \\
\hline $\begin{array}{l}\text { Emissions of hexane to air (kg } \\
\text { hexane/kg palm fruit bunches) }\end{array}$ & $\begin{array}{l}\text { Palm oil extraction in } \\
\text { MY }\end{array}$ & $6.72 \cdot 10^{-4}$ & Uniform $(-10 \% ;+10 \%)$ & - \\
\hline $\begin{array}{l}\text { Transport of palm bunches to } \\
\text { the mill, by truck } 3.5-16 \mathrm{t} \\
\text { (tkm/kg palm fruit bunches) }\end{array}$ & $\begin{array}{l}\text { Palm oil extraction in } \\
\text { MY }\end{array}$ & 0.10 & Uniform $(-10 \% ;+10 \%)$ & - \\
\hline $\begin{array}{l}\text { Transformation from forest, } \\
\text { intensive, clear-cutting }\left(\mathrm{m}^{2} / \mathrm{kg}\right. \\
\text { palm fruit bunches) }\end{array}$ & Palm cultivation in MY & 0.016 & Uniform $(-10 \% ;+10 \%)$ & - \\
\hline $\begin{array}{l}\mathrm{CO}_{2} \text { emission factor from } \\
\text { carbon stock change due to } \\
\mathrm{LUC} \text { from forest to palm } \\
\text { plantations ( } \mathrm{CO}_{2} / \mathrm{ha} \text { ) }\end{array}$ & Palm cultivation in MY & -27.65 & Uniform $(-455,277)$ & IPCC, 2006 \\
\hline $\begin{array}{l}\text { Biomass stock in tropical } \\
\text { rainforest in Malaysia, before } \\
\text { the conversion (t C /ha) } \\
\text { (Bbefore) }\end{array}$ & Palm cultivation in MY & 350 & Uniform $(280,520)$ & IPCC, 2006 \\
\hline $\begin{array}{l}\text { Carbon uptake by biomass } \\
\text { (kg CO } \mathrm{k}_{2} / \mathrm{kg} \text { palm fruit } \\
\text { bunches) }\end{array}$ & Palm cultivation in MY & 1.15 & Uniform $(-10 \% ;+10 \%)$ & - \\
\hline $\begin{array}{l}\text { Irrigating }\left(\mathrm{m}^{2} / \mathrm{kg} \text { palm fruit }\right. \\
\text { bunches) }\end{array}$ & Palm cultivation in MY & 0.701 & Uniform $(-10 \% ;+10 \%)$ & - \\
\hline $\begin{array}{l}\text { Transformation from arable } \\
\text { land }\left(\mathrm{m}^{2} / \mathrm{kg} \text { soybean) }\right.\end{array}$ & Soybean farming in BR & 3.76 & Uniform $(-10 \% ;+10 \%)$ & - \\
\hline $\begin{array}{l}\text { Transformation from forest, } \\
\text { intensive, clear-cutting }\left(\mathrm{m}^{2} / \mathrm{kg}\right. \\
\text { soybean) }\end{array}$ & Soybean farming in BR & $3.93 \cdot 10^{-2}$ & Uniform $(-10 \% ;+10 \%)$ & - \\
\hline $\begin{array}{l}\mathrm{CO}_{2} \text { emission factor from } \\
\text { carbon stock change due to } \\
\mathrm{LUC} \text { from other crops to } \\
\text { soybean (t } \mathrm{CO}_{2} / \mathrm{ha} \text { ) }\end{array}$ & Soybean farming in BR & 66.7 & Uniform $(-10.8 ; 125.1)$ & IPCC, 2006 \\
\hline $\begin{array}{l}\text { Carbon uptake by biomass } \\
\left(\mathrm{kg} \mathrm{CO}_{2} / \mathrm{kg} \text { soybean) }\right.\end{array}$ & Soybean farming in BR & 1.37 & Uniform $(-10 \% ;+10 \%)$ & - \\
\hline
\end{tabular}

Table 3.9. Base values and uncertainty distributions of key parameters for the Monte Carlo analysis of scenario 2, after sensitivity analysis. SP: Spain; BR: Brazil; MY: Malaysia.

\begin{tabular}{|c|c|c|c|c|}
\hline \multicolumn{5}{|c|}{ SCENARIO 2} \\
\hline Parameter & Sub-stage & $\begin{array}{l}\text { Base } \\
\text { value }\end{array}$ & $\begin{array}{l}\text { Uncertainty } \\
\text { distribution }\end{array}$ & $\begin{array}{c}\text { Bound data } \\
\text { source }\end{array}$ \\
\hline $\begin{array}{l}\text { Net calorific value of UCO } \\
\text { biodiesel }(\mathrm{MJ} / \mathrm{kg})\end{array}$ & $\begin{array}{c}\text { Production of ME from } \\
\text { UCO in SP }\end{array}$ & 36.8 & Uniform $(31.4 ; 36.8)$ & $\begin{array}{l}\text { Talens et al., 2007; } \\
\text { Dorado et al., } 2006\end{array}$ \\
\hline $\begin{array}{l}\text { Transesterification yield (kg } \\
\text { biodiesel/kg oil) }\end{array}$ & $\begin{array}{c}\text { Production of ME from } \\
\text { UCO in SP }\end{array}$ & 0.95 & $\begin{array}{l}\text { Uniform (0.850; } \\
\quad 0.978)\end{array}$ & $\begin{array}{l}\text { Bionorte; Kulkarni } \\
\text { et al., } 2006\end{array}$ \\
\hline Methanol (kg methanol/kg oil) & $\begin{array}{c}\text { Production of ME from } \\
\text { UCO in SP }\end{array}$ & 0.151 & Uniform $(-5 \% ;+5 \%)$ & Bionorte \\
\hline Catalyst (kg catalyst/kg oil) & $\begin{array}{c}\text { Production of ME from } \\
\text { UCO in SP }\end{array}$ & 0.009 & Uniform $(-5 \% ;+5 \%)$ & Bionorte \\
\hline
\end{tabular}




\begin{tabular}{|c|c|c|c|c|}
\hline \multicolumn{5}{|c|}{ SCENARIO 2} \\
\hline Parameter & Sub-stage & $\begin{array}{l}\text { Base } \\
\text { value }\end{array}$ & $\begin{array}{l}\text { Uncertainty } \\
\text { distribution }\end{array}$ & $\begin{array}{l}\text { Bound data } \\
\text { source }\end{array}$ \\
\hline Diesel (MJ/kg oil) & $\begin{array}{l}\text { Production of ME from } \\
\text { UCO in SP }\end{array}$ & 0.663 & $\begin{array}{l}\text { Uniform }(-10 \% \\
+10 \%)\end{array}$ & Bionorte \\
\hline Electricity (MJ/kg oil) & $\begin{array}{c}\text { Production of ME from } \\
\text { UCO in SP }\end{array}$ & 0.330 & $\begin{array}{l}\text { Uniform }(-10 \% \\
\quad+10 \%)\end{array}$ & Bionorte \\
\hline $\begin{array}{l}\text { Oil extraction yield (kg crude } \\
\text { palm oil/kg palm fruit bunches) }\end{array}$ & Palm oil extraction in MY & 0.218 & $\begin{array}{l}\text { Uniform (0.194; } \\
0.230)\end{array}$ & $\begin{array}{l}\text { Yee et al., 2009; } \\
\text { FAO, } 2002\end{array}$ \\
\hline $\begin{array}{l}\text { Emissions of hexane to air (kg } \\
\text { hexane/kg palm fruit bunches) }\end{array}$ & Palm oil extraction in MY & $6.72 \cdot 10^{-4}$ & $\begin{array}{l}\text { Uniform }(-10 \% \\
\quad+10 \%)\end{array}$ & - \\
\hline $\begin{array}{l}\text { Transport of palm bunches to } \\
\text { the mill, by truck } 3.5-16 \mathrm{t} \\
\text { (tkm/kg palm fruit bunches) }\end{array}$ & Palm oil extraction in MY & 0.10 & $\begin{array}{l}\text { Uniform }(-10 \% \\
\quad+10 \%)\end{array}$ & - \\
\hline $\begin{array}{l}\text { Transformation from forest, } \\
\text { intensive, clear-cutting }\left(\mathrm{m}^{2} / \mathrm{kg}\right. \\
\text { palm fruit bunches) }\end{array}$ & Palm cultivation in MY & 0.016 & $\begin{array}{l}\text { Uniform }(-10 \% \\
\quad+10 \%)\end{array}$ & - \\
\hline $\begin{array}{l}\mathrm{CO}_{2} \text { emission factor from } \\
\text { carbon stock change due to } \\
\mathrm{LUC} \text { from forest to palm } \\
\text { plantations }\left(\mathrm{t} \mathrm{CO}_{2} / \mathrm{ha}\right)\end{array}$ & Palm cultivation in MY & -27.65 & Uniform $(-455,277)$ & IPCC, 2006 \\
\hline $\begin{array}{l}\text { Biomass stocks in tropical } \\
\text { rainforest in Malaysia, before } \\
\text { the conversion ( } \mathrm{C} / \mathrm{ha} \text { ) } \\
\text { (Bbefore) }\end{array}$ & Palm cultivation in MY & 350 & Uniform $(280,520)$ & IPCC, 2006 \\
\hline $\begin{array}{l}\text { Carbon uptake by biomass (kg } \\
\mathrm{CO}_{2} / \mathrm{kg} \text { palm fruit bunches) }\end{array}$ & Palm cultivation in MY & 1.15 & $\begin{array}{l}\text { Uniform }(-10 \% \\
+10 \%)\end{array}$ & - \\
\hline $\begin{array}{l}\text { Irrigating }\left(\mathrm{m}^{2} / \mathrm{kg} \text { palm fruit }\right. \\
\text { bunches) }\end{array}$ & Palm cultivation in MY & 0.701 & $\begin{array}{l}\text { Uniform }(-10 \% \\
+10 \%)\end{array}$ & - \\
\hline $\begin{array}{l}\text { Wood-chopping (kg wood/kg } \\
\text { palm fruit bunches) }\end{array}$ & Palm cultivation in MY & 1.09 & $\begin{array}{l}\text { Uniform }(-10 \% \\
+10 \%)\end{array}$ & - \\
\hline $\begin{array}{l}\text { Carbamate (kg carbamate/kg } \\
\text { palm fruit } \\
\text { bunches) }\end{array}$ & Palm cultivation in MY & $2.04 \cdot 10^{-5}$ & $\begin{array}{l}\text { Uniform }(-10 \% \\
\quad+10 \%)\end{array}$ & - \\
\hline $\begin{array}{l}\text { Diammonium phosphate }(\mathrm{kg} \\
\text { diammonium } \\
\text { phosphate/kg palm fruit } \\
\text { bunches) }\end{array}$ & Palm cultivation in MY & $1.28 \cdot 10^{-3}$ & $\begin{array}{l}\text { Uniform }(-10 \% \\
\quad+10 \%)\end{array}$ & - \\
\hline $\begin{array}{l}\text { Potassium chloride, as } \mathrm{K}_{2} \mathrm{O}(\mathrm{kg} \\
\text { potassium chloride } / \mathrm{kg} \mathrm{palm} \\
\text { fruit bunches) }\end{array}$ & Palm cultivation in MY & $9.46 \cdot 10^{-3}$ & $\begin{array}{l}\text { Uniform }(-10 \% \\
\quad+10 \%)\end{array}$ & - \\
\hline $\begin{array}{l}\text { Oil extraction yield (kg oil/kg } \\
\text { soybean) }\end{array}$ & $\begin{array}{c}\text { Soybean oil extraction in } \\
\text { BR }\end{array}$ & 0.177 & $\begin{array}{l}\text { Uniform }(0.174 \\
0.180)\end{array}$ & $\begin{array}{l}\text { Mattsson, et al. } \\
\text { 2000; Janssen and } \\
\text { Rutz, 2011 }\end{array}$ \\
\hline $\begin{array}{l}\text { Hexane (kg hexane/kg } \\
\text { soybean) }\end{array}$ & $\begin{array}{c}\text { Soybean oil extraction in } \\
\text { BR }\end{array}$ & $2.14 \cdot 10^{-3}$ & $\begin{array}{l}\text { Uniform }(-10 \% \\
+10 \%)\end{array}$ & - \\
\hline $\begin{array}{l}\text { Heat from natural gas }(\mathrm{MJ} / \mathrm{kg} \\
\text { soybean) }\end{array}$ & $\begin{array}{c}\text { Soybean oil extraction in } \\
\text { BR }\end{array}$ & 0.81 & $\begin{array}{l}\text { Uniform }(-10 \% \\
+10 \%)\end{array}$ & - \\
\hline $\begin{array}{l}\text { Transport of soybeans from } \\
\text { field to mill, by truck } 3.5-16 \mathrm{t} \\
\text { (tkm/kg soybean oil) }\end{array}$ & $\begin{array}{c}\text { Soybean oil extraction in } \\
\text { BR }\end{array}$ & 0.10 & $\begin{array}{l}\text { Uniform }(-10 \% \\
\quad+10 \%)\end{array}$ & - \\
\hline $\begin{array}{l}\text { Transformation from arable } \\
\text { land }\left(\mathrm{m}^{2} / \mathrm{kg} \text { soybean) }\right.\end{array}$ & Soybean farming in BR & 3.76 & $\begin{array}{l}\text { Uniform }(-10 \% \\
+10 \%)\end{array}$ & - \\
\hline $\begin{array}{l}\text { Transformation from forest, } \\
\text { intensive, clear-cutting }\left(\mathrm{m}^{2} / \mathrm{kg}\right. \\
\text { soybean) }\end{array}$ & Soybean farming in BR & $3.93 \cdot 10^{-2}$ & $\begin{array}{l}\text { Uniform }(-10 \% \\
\quad+10 \%)\end{array}$ & - \\
\hline $\begin{array}{l}\mathrm{CO}_{2} \text { emission factor from } \\
\text { carbon stock change due to } \\
\mathrm{LUC} \text { from other crops to } \\
\text { soybean ( } \mathrm{CO}_{2} / \mathrm{ha} \text { ) }\end{array}$ & Soybean farming in BR & 66.7 & $\begin{array}{l}\text { Uniform }(-10.8 \\
\quad 125.1)\end{array}$ & IPCC, 2006 \\
\hline $\begin{array}{l}\text { Carbon uptake by biomass }(\mathrm{kg} \\
\mathrm{CO}_{2} / \mathrm{kg} \text { soybean) }\end{array}$ & Soybean farming in BR & 1.37 & $\begin{array}{l}\text { Uniform }(-10 \% \\
+10 \%)\end{array}$ & - \\
\hline $\begin{array}{l}\text { Soybean seeds (kg seeds/kg } \\
\text { soybean) }\end{array}$ & Soybean farming in BR & $4.17 \cdot 10^{-2}$ & $\begin{array}{l}\text { Uniform }(-10 \% \\
+10 \%)\end{array}$ & - \\
\hline
\end{tabular}




\begin{tabular}{|l|c|c|c|l|}
\hline \multicolumn{1}{|c|}{ SCENARIO 2 } \\
\hline \multicolumn{1}{|c|}{ Parameter } & Sub-stage & $\begin{array}{c}\text { Base } \\
\text { value }\end{array}$ & $\begin{array}{c}\text { Uncertainty } \\
\text { distribution }\end{array}$ & $\begin{array}{c}\text { Bound data } \\
\text { source }\end{array}$ \\
\hline Harvesting $\left(\mathrm{m}^{2} / \mathrm{kg}\right.$ soybean) & Soybean farming in BR & 1.25 & $\begin{array}{c}\text { Uniform }(-10 \% ; \\
+10 \%)\end{array}$ & - \\
\hline Harrowing $\left(\mathrm{m}^{2} / \mathrm{kg}\right.$ soybean) & Soybean farming in BR & 3.49 & $\begin{array}{c}\text { Uniform (-10\%; } \\
+10 \%)\end{array}$ & - \\
\hline Ploughing $\left(\mathrm{m}^{2} / \mathrm{kg}\right.$ soybean) & Soybean farming in BR & 1.09 & $\begin{array}{c}\text { Uniform (-10\%; } \\
+10 \%)\end{array}$ & - \\
\hline $\begin{array}{l}\text { Application of plant protection } \\
\text { products }(\mathrm{m} 2 / \mathrm{kg} \\
\text { soybean) }\end{array}$ & Soybean farming in BR & 2.99 & $\begin{array}{c}\text { Uniform }(-10 \% ; \\
+10 \%)\end{array}$ & - \\
\hline $\begin{array}{l}\text { Sulfonyl-urea compounds }(\mathrm{kg} \\
\text { compounds/kg soybean) }\end{array}$ & Soybean farming in BR & $2.56 \cdot 10^{-4}$ & $\begin{array}{c}\text { Uniform }(-10 \% ; \\
+10 \%)\end{array}$ & - \\
\hline $\begin{array}{l}\text { Emissions of nitrates to water } \\
\text { (kg nitrates/kg soybean) }\end{array}$ & Soybean farming in BR & $3.66 \cdot 10^{-2}$ & $\begin{array}{c}\text { Uniform }(-10 \% ; \\
+10 \%)\end{array}$ & - \\
\hline
\end{tabular}

For the calculation of the soybean transport to the mill by truck, Panichelli et al. (2009) estimated that soybeans were transported $300 \mathrm{~km}$. For the Monte Carlo simulation, it was considered that the soybeans were transported within the province of Santa Fe (minimum bound), or from the province of Salta to Santa Fe (maximum bound). Salta is the most distant soybean-producing region from Santa Fe (MECON, 2011a), where most mills are located. All the bounds for the parameters related to soybean farming were gathered from minimum and maximum values of the four production systems analyzed by Panichelli et al. (2009). In scenario 2, the maximum distance for the UCO ME transport was assumed to be that from the Spanish city farthest from Valencia, which is La Coruña. The minimum bound was zero, assuming that the biodiesel was produced in Valencia. Bounds for all the technical parameters related to the transesterification were provided by Bionorte, and those for the UCO collection distance were based on Bionorte estimates. For the rest of parameters, minimum and maximum bounds were gathered from available literature. When no data were found or when the risk parameters concerned processes directly obtained from Ecoinvent v2.2 database, minimum and maximum bounds of $\pm 10 \%$ were applied. For the parameters involved in the calculation of $\mathrm{CO}_{2}$ emission factors, the associated uncertainty reported by the IPCC (2006) was used.

\subsubsection{Results}

\subsubsection{Impact assessment of the base scenarios}

Firstly, an impact assessment of both scenarios was carried out taking the base values reported in sections 3.3.2.2 and 3.3.2.3 as inventory data, without considering GHG emissions from LUC a priori. As can be seen in Tables 3.10 and 3.11 , when comparing the system proposed in scenario 2 with the prevailing system defined in scenario 1, scenario 2 led to a reduction in all the analyzed impact categories, except in GW. Specifically, scenario 2 exhibited values that 
were between $49.0 \%$ and $125.4 \%$ lower than scenario 1 in all the impact categories but GW, for which the impact in scenario 1 was $138.9 \%$ lower. As for $\mathrm{GW}$, it is remarkable that scenario 2 caused net GHG emissions, whereas scenario 1 caused negative ones. This is mainly due to the carbon uptake by crops during photosynthesis in the agricultural stage, which affected the two scenarios in opposite directions. In scenario 1, both soybean farming in Argentina and palm cultivation in Malaysia generated a $\mathrm{CO}_{2}$ uptake, whereas soybean farming in Brazil caused $\mathrm{CO}_{2}$ emissions, since this process is reversed and appears with a minus sign in the main system (see Figure 3.11). In scenario 2, palm cultivation in Malaysia contracts while soybean farming in Brazil expands, although net carbon uptake from Brazilian soybeans is not enough to offset net $\mathrm{CO}_{2}$-eq. emissions from the other processes in the system (Figure 3.12).

Tables 3.10 and 3.11 show the contribution of each sub-stage to the impact results, without as yet considering GHG emissions from LUC. As can be observed, the sub-stage contributing the most to every impact category (except for GW) in scenario 1 is soybean farming in Argentina (between 24.2\% and 89.8\%), due to emissions from pesticides and fertilizer application. The use of agricultural machinery in this sub-stage increases ADP fossil the most. Palm cultivation in Malaysia has the greatest effect on GW (42.5\%), because of the aforementioned carbon uptake; the contribution of palm cultivation in Malaysia is also remarkable (responsible for $29.3 \%$ of GW). Although soybean farming in Argentina is the prevailing sub-stage in ADP fossil (24.2\%), the contribution of soybean ME production (23.2\%), soybean oil extraction (19.4\%) and soybean ME transport from Argentina to Spain (15.4\%) is also substantial, due to energy and fuel consumption. These sub-stages account for $14.1 \%, 19.0 \%$ and $16.7 \%$ of the overall impact in OD, respectively. Palm cultivation in Malaysia makes a strong contribution too, representing between $2.4 \%$ (of POC) and $29.3 \%$ of the overall impact (of GW), depending on the impact category. The effect of all the sub-stages related to soybean meal production in Brazil is negligible because the amount of soybeans that comes into play in Brazil as a consequence of an increase in the production of biodiesel in Argentina is very small (4.35 g).

In scenario 2, the prevailing sub-stage in absolute terms in almost every impact category is palm cultivation in Malaysia, accounting for between $53.3 \%$ and $99.4 \%$ of the whole impact, except in OD (33.1\%), ADP fossil (30.4\%), ADP elements (23.6\%) and POC (10.4\%). This is due to the use of pesticides and fertilizers, whereas GW is almost entirely caused by the carbon uptake during palm cultivation. All the impact values from this sub-stage are negative (except in GW), since it appears with a negative sign in the system under study (Figure 3.12). With regard to GW, palm oil extraction in Malaysia is also responsible for $30.6 \%$ of the impact, due to the emissions of hydrocarbons and inorganic compounds to the air 
from the production of reagents. The extraction of palm oil is more input intensive than it is for soybeans; hence, this sub-stage contributes significantly to other impact categories, such as POC (74.0\%), AP (16.2\%) or OD (15.9\%). The prevailing sub-stage in the remaining categories is UCO ME production in Spain, causing $73.9 \%$ of the impact of ADP elements, $53.2 \%$ of ADP fossil and $42.1 \%$ of $\mathrm{OD}$, mainly because of the energy production and the transport and production of the chemicals.

Table 3.10. Impact assessment results from base scenario 1, broken down into sub-stages. $\mathrm{CO}_{2}$-eq. emissions from LUC are not taken into account in $\mathrm{GW}$.

\begin{tabular}{|c|c|c|c|c|c|c|c|c|c|c|}
\hline $\begin{array}{l}\text { Impact } \\
\text { category }\end{array}$ & Units & $\begin{array}{c}\text { SCENARIO } \\
1 \text { TOTAL }\end{array}$ & $\begin{array}{c}\text { Transport of } \\
\text { soybean ME } \\
\text { from ARG to SP }\end{array}$ & $\begin{array}{l}\text { Soybean ME } \\
\text { production } \\
\text { in ARG }\end{array}$ & $\begin{array}{c}\text { Soybean oil } \\
\text { extraction } \\
\text { in ARG }\end{array}$ & $\begin{array}{l}\text { Soybean } \\
\text { farming in } \\
\text { ARG }\end{array}$ & $\begin{array}{l}\text { Palm oil } \\
\text { extraction } \\
\text { in MY }\end{array}$ & $\begin{array}{c}\text { Palm } \\
\text { cultivation } \\
\text { in MY }\end{array}$ & $\begin{array}{l}\text { Soybean oil } \\
\text { extraction } \\
\text { in BR }\end{array}$ & $\begin{array}{c}\text { Soybean } \\
\text { farming in } \\
\text { BR }\end{array}$ \\
\hline ADP elements & $\mathrm{kg} \mathrm{Sb}$-eq. & $1.98 \cdot 10^{-7}$ & $8.80 \cdot 10^{-10}$ & $1.21 \cdot 10^{-8}$ & $2.41 \cdot 10^{-9}$ & $1.41 \cdot 10^{-7}$ & $1.04 \cdot 10^{-9}$ & $4.44 \cdot 10^{-8}$ & $-7.88 \cdot 10^{-11}$ & $-3.51 \cdot 10^{-9}$ \\
\hline ADP fossil & MJ & $8.59 \cdot 10^{-1}$ & $1.36 \cdot 10^{-1}$ & $2.05 \cdot 10^{-1}$ & $1.72 \cdot 10^{-1}$ & $2.15 \cdot 10^{-1}$ & $3.69 \cdot 10^{-2}$ & $1.08 \cdot 10^{-1}$ & $-6.96 \cdot 10^{-3}$ & $-6.87 \cdot 10^{-3}$ \\
\hline Acidification & $\begin{array}{l}\mathrm{kg} \mathrm{SO}_{2-} \\
\text { eq. }\end{array}$ & $7.54 \cdot 10^{-4}$ & $9.19 \cdot 10^{-5}$ & $5.23 \cdot 10^{-5}$ & $4.40 \cdot 10^{-5}$ & $4.06 \cdot 10^{-4}$ & $3.57 \cdot 10^{-5}$ & $1.38 \cdot 10^{-4}$ & $-1.45 \cdot 10^{-6}$ & $-1.18 \cdot 10^{-5}$ \\
\hline Eutrophication & $\begin{array}{l}\mathrm{kg} \mathrm{PO}_{4}^{-} \\
\text {eq. }\end{array}$ & $9.55 \cdot 10^{-4}$ & $2.51 \cdot 10^{-5}$ & $1.67 \cdot 10^{-5}$ & $1.45 \cdot 10^{-5}$ & $7.95 \cdot 10^{-4}$ & $1.33 \cdot 10^{-5}$ & $1.19 \cdot 10^{-4}$ & $-3.68 \cdot 10^{-7}$ & $-2.72 \cdot 10^{-5}$ \\
\hline FAE & $\begin{array}{l}\mathrm{kg} \text { DCB- } \\
\text { eq. }\end{array}$ & $6.75 \cdot 10^{-1}$ & $2.10 \cdot 10^{-4}$ & $2.33 \cdot 10^{-3}$ & $6.77 \cdot 10^{-4}$ & $6.02 \cdot 10^{-1}$ & $3.15 \cdot 10^{-4}$ & $7.00 \cdot 10^{-2}$ & $-2.77 \cdot 10^{-5}$ & $-1.04 \cdot 10^{-4}$ \\
\hline GW & $\begin{array}{l}\mathrm{kg} \mathrm{CO}_{2^{-}} \\
\text {eq. }\end{array}$ & -0.161 & 0.01 & 0.015 & 0.021 & -0.155 & 0.052 & -0.107 & $-7.40 \cdot 10^{-4}$ & $3.28 \cdot 10^{-3}$ \\
\hline HT & \begin{tabular}{|l|} 
kg DCB- \\
Eq.
\end{tabular} & $4.24 \cdot 10^{-2}$ & $1.03 \cdot 10^{-3}$ & $2.84 \cdot 10^{-3}$ & $1.02 \cdot 10^{-3}$ & $2.57 \cdot 10^{-2}$ & $1.67 \cdot 10^{-3}$ & $1.08 \cdot 10^{-2}$ & $-5.67 \cdot 10^{-5}$ & $-5.03 \cdot 10^{-4}$ \\
\hline MAE & $\begin{array}{l}\mathrm{kg} \text { DCB- } \\
\text { eq. }\end{array}$ & 26.42 & 0.78 & 7.05 & 2.03 & 10.43 & 0.50 & 6.25 & -0.11 & -0.51 \\
\hline OD & $\begin{array}{l}\text { kg R11- } \\
\text { eq. }\end{array}$ & $8.57 \cdot 10^{-9}$ & $1.48 \cdot 10^{-9}$ & $1.25 \cdot 10^{-9}$ & $1.68 \cdot 10^{-9}$ & $3.06 \cdot 10^{-9}$ & $3.99 \cdot 10^{-10}$ & $8.34 \cdot 10^{-10}$ & $-6.01 \cdot 10^{-11}$ & $-8.18 \cdot 10^{-11}$ \\
\hline POC & $\mid \begin{array}{l}\mathrm{kg} \mathrm{C} \mathrm{C}_{2} \mathrm{H}_{4^{-}} \\
\text {eq. }\end{array}$ & $2.32 \cdot 10^{-4}$ & $8.81 \cdot 10^{-6}$ & $4.21 \cdot 10^{-6}$ & $1.62 \cdot 10^{-4}$ & $1.53 \cdot 10^{-5}$ & $4.14 \cdot 10^{-5}$ & $5.84 \cdot 10^{-6}$ & $-4.74 \cdot 10^{-6}$ & $-5.41 \cdot 10^{-7}$ \\
\hline TE & $\begin{array}{l}\text { kg DCB- } \\
\text { eq. }\end{array}$ & $2.99 \cdot 10^{-1}$ & $1.35 \cdot 10^{-5}$ & $3.18 \cdot 10^{-5}$ & $1.50 \cdot 10^{-5}$ & $2.69 \cdot 10^{-1}$ & $9.49 \cdot 10^{-5}$ & $3.02 \cdot 10^{-2}$ & $-7.41 \cdot 10^{-7}$ & $-7.50 \cdot 10^{-5}$ \\
\hline
\end{tabular}

When including GHG emissions from LUC, GW input and GW output were studied separately for further interpretation, as shown in Figure $3.13(a, b)$. It must be taken into account that LUC sub-stages also include the provision of stubbed land (process from Ecoinvent v2.2) only when transformation from forest takes place. This makes a contribution not only to GW but to other categories, such as AP. As to GW input, the higher its value, the lower the impact. The overall GW in scenario 2 was $102.7 \%$ lower than in scenario 1 . In scenario 1, the carbon uptake by soybeans in Argentina generates $60.4 \%$ of GW input, whereas palm cultivation in Malaysia causes $37.8 \%$. Since soybean farming in Brazil has a negative sign in the main system, LUC generates a net carbon uptake as well, due to area contraction, but this sub-stage is included in GW output (8.1\%). The remaining contribution to GW input arises from the fact that default transport processes from Ecoinvent v2.2 consider that part of the fuels is produced from vegetable feedstock. In regard to GW output, LUC occurring in Argentina generates 68.6\% of the impact, and $12.1 \%$ is caused by LUC in Malaysia. Emissions from soybean farming in Argentina are also remarkable (3.5\%) due to the use of agricultural machinery, as well as 
emissions from palm oil extraction in Malaysia (3.2\%), mainly due to the transport of the palm fruit bunches and the use of reagents.

Table 3.11. Impact assessment results from base scenario 2, broken down into sub-stages. $\mathrm{CO}_{2}$-eq. emissions from $\mathrm{LUC}$ are not taken into account in $\mathrm{GW}$.

\begin{tabular}{|c|c|c|c|c|c|c|c|c|c|}
\hline $\begin{array}{l}\text { Impact } \\
\text { category }\end{array}$ & Units & $\begin{array}{l}\text { SCENARIO } \\
2 \text { TOTAL }\end{array}$ & $\begin{array}{l}\text { Transport of } \\
\text { ME from UCO } \\
\text { in SP }\end{array}$ & $\begin{array}{l}\text { UCO ME } \\
\text { production } \\
\text { in SP }\end{array}$ & $\begin{array}{c}\text { UCO } \\
\text { collection } \\
\text { in SP }\end{array}$ & $\begin{array}{l}\text { Palm oil } \\
\text { extraction } \\
\text { in MY }\end{array}$ & $\begin{array}{c}\text { Palm } \\
\text { cultivation } \\
\text { in MY }\end{array}$ & $\begin{array}{l}\text { Soybean oil } \\
\text { extraction } \\
\text { in BR }\end{array}$ & $\begin{array}{c}\text { Soybean } \\
\text { farming in } \\
\text { BR }\end{array}$ \\
\hline ADP elements & kg Sb-eq. & $.01 \cdot 10^{-7}$ & $9.66 \cdot 10^{-12}$ & $1.45 \cdot 10^{-7}$ & $4.06 \cdot 10^{-11}$ & $-1.09 \cdot 10^{-9}$ & $-4.63 \cdot 10^{-8}$ & $8.22 \cdot 10^{-11}$ & $3.65 \cdot 10^{-9}$ \\
\hline ADP fossil & Mu & $6.82 \cdot 10^{-2}$ & $1.47 \cdot 10^{-03}$ & $1.97 \cdot 10^{-1}$ & $6.20 \cdot 10^{-3}$ & $-3.84 \cdot 10^{-2}$ & $-1.13 \cdot 10^{-1}$ & $7.25 \cdot 10^{-3}$ & $7.15 \cdot 10^{-3}$ \\
\hline Acidification & $\begin{array}{l}\mathrm{kg} \mathrm{SO}_{2-}^{-} \\
\text {eq. }\end{array}$ & $-1.33 \cdot 10^{-4}$ & $6.20 \cdot 10^{-7}$ & $3.09 \cdot 10^{-5}$ & $2.61 \cdot 10^{-6}$ & $-3.72 \cdot 10^{-5}$ & $-1.44 \cdot 10^{-4}$ & $1.51 \cdot 10^{-6}$ & $1.23 \cdot 10^{-5}$ \\
\hline Eutrophication & $\begin{array}{l}\mathrm{kg} \mathrm{PO}_{4^{-}} \\
\text {eq. }\end{array}$ & $-9.78 \cdot 10^{-5}$ & $1.72 \cdot 10^{-7}$ & $1.01 \cdot 10^{-5}$ & $7.24 \cdot 10^{-7}$ & $-1.39 \cdot 10^{-5}$ & $-1.24 \cdot 10^{-4}$ & -7 & $0^{-5}$ \\
\hline FAE & $\begin{array}{l}\text { kg DCB- } \\
\text { eq. }\end{array}$ & -0.072 & $2.19 \cdot 10^{-6}$ & $1.32 \cdot 10^{-3}$ & $9.22 \cdot 10^{-6}$ & $-3.28 \cdot 10^{-4}$ & $-7.29 \cdot 10^{-2}$ & )$^{-5}$ & $1.08 \cdot 10^{-4}$ \\
\hline GW & $\begin{array}{l}\mathrm{kg} \mathrm{CO}_{2^{-}} \\
\text {eq. }\end{array}$ & $6.26 \cdot 10^{-2}$ & $1.09 \cdot 10^{-4}$ & $7.64 \cdot 10^{-3}$ & $4.60 \cdot 10^{-4}$ & $-5.47 \cdot 10^{-2}$ & $1.12 \cdot 10^{-1}$ & $7.71 \cdot 10^{-4}$ & $-3.41 \cdot 10^{-3}$ \\
\hline HT & $\begin{array}{l}\text { kg DCB- } \\
\text { Eq. }\end{array}$ & $-1.08 \cdot 10^{-2}$ & $6.76 \cdot 10^{-6}$ & $1.60 \cdot 10^{-3}$ & $2.84 \cdot 10^{-5}$ & $-1.74 \cdot 10^{-3}$ & $-1.13 \cdot 10^{-2}$ & $5.91 \cdot 10^{-5}$ & $5.24 \cdot 10^{-4}$ \\
\hline MAE & $\begin{array}{l}\text { kg DCB- } \\
\text { eq. }\end{array}$ & -1.87 & $6.74 \cdot 10^{-3}$ & 4.50 & $2.84 \cdot 10^{-2}$ & -0.52 & -6.51 & 0.11 & 0.53 \\
\hline OD & $\begin{array}{l}\text { kg R11- } \\
\text { eq. }\end{array}$ & $5.28 \cdot 10^{-11}$ & $1.65 \cdot 10^{-11}$ & $1.10 \cdot 10^{-9}$ & $6.94 \cdot 10^{-11}$ & $-4.16 \cdot 10^{-10}$ & $-8.69 \cdot 10^{-10}$ & $6.26 \cdot 10^{-11}$ & $8.51 \cdot 10^{-11}$ \\
\hline POC & $\begin{array}{l}\mathrm{kg} \mathrm{C}_{2} \mathrm{H}_{4^{-}} \\
\text {eq. }\end{array}$ & $-4.01 \cdot 10^{-5}$ & $8.35 \cdot 10^{-8}$ & $3.18 \cdot 10^{-6}$ & $3.52 \cdot 10-^{7}$ & $-4.31 \cdot 10^{-5}$ & $-6.09 \cdot 10^{-6}$ & $4.93 \cdot 10^{-6}$ & $5.63 \cdot 10^{-7}$ \\
\hline TE & $\begin{array}{l}\text { kg DCB- } \\
\text { eq. }\end{array}$ & $-3.15 \cdot 10^{-2}$ & $1.31 \cdot 10^{-7}$ & $2.42 \cdot 10^{-5}$ & $5.51 \cdot 10^{-7}$ & $-9.89 \cdot 10^{-5}$ & $-3.15 \cdot 10^{-2}$ & $7.75 \cdot 10^{-7}$ & $7.81 \cdot 10^{-5}$ \\
\hline
\end{tabular}

In scenario 2, LUC in Malaysia is negative (area contraction), causing carbon uptake and thus $49.7 \%$ of the GW output (in absolute terms). The carbon uptake by palm trees during palm cultivation declines when less palm kernel meal is produced: this causes negative GW input (95.4\%), which means net GHG emissions. Due to avoided emissions from agriculture, 5.9\% of GW output (in absolute terms) is caused by palm cultivation as well, whereas decreasing palm oil extraction generates another $11.8 \%$. Both sub-stages contribute negatively to GW output (causing carbon uptake), whereas soybean farming in Brazil generates positive GW output (0.7\%), with the subsequent GHG emissions from LUC (30.0\%). The processes involved in the UCO ME production in Spain also contribute to GW output, but to a lesser extent. Total LUC values (direct and indirect) in scenario 1 and scenario 2 are shown in Tables 3.12 and 3.13, respectively. 

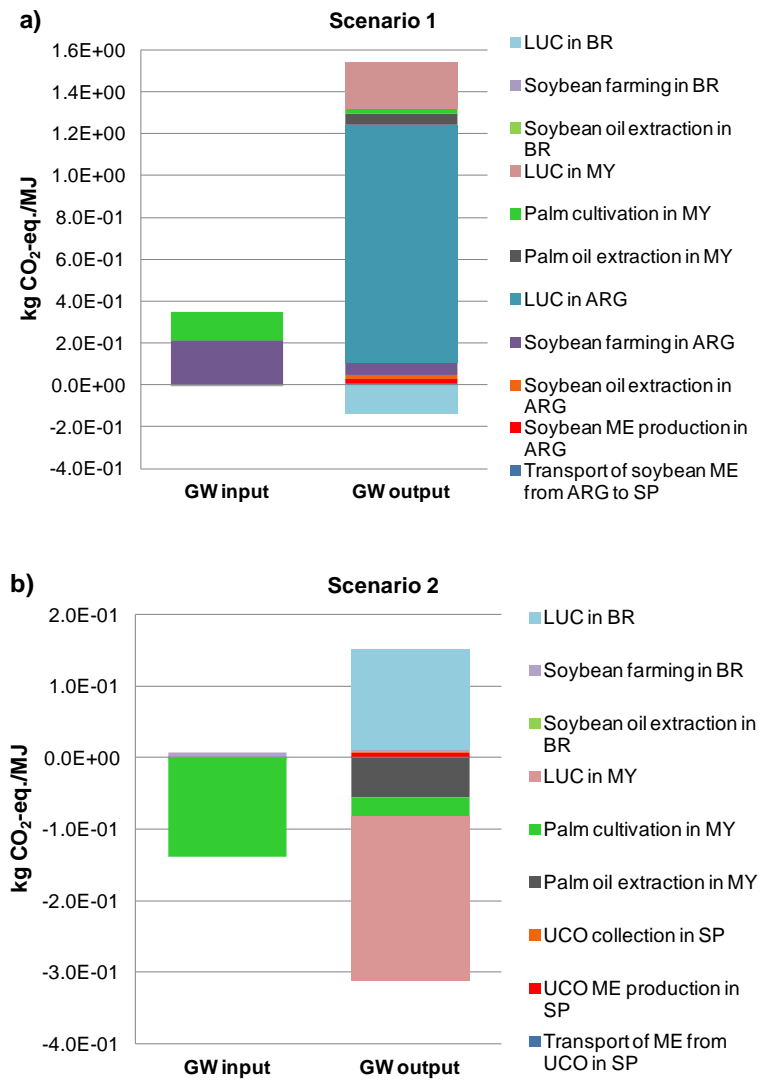

Figure 3.13. Contribution of sub-stages to $\mathrm{GW}$ in scenario 1 and scenario 2. Total GHG emissions are broken down into $\mathrm{GW}$ input $\left(\mathrm{CO}_{2}\right.$-eq. uptake) and $\mathrm{GW}$ output $\left(\mathrm{CO}_{2}\right.$-eq. emissions).

Table 3.12. LUC results from base scenario 1, including direct LUC and ILUC due to coproduct displacements.

\begin{tabular}{|c|c|c|c|c|}
\hline SCENARIO 1 & Units & $\begin{array}{c}\text { Soybean farming } \\
\text { in ARG }\end{array}$ & $\begin{array}{l}\text { Palm cultivation } \\
\text { in MY }\end{array}$ & $\begin{array}{c}\text { Soybean } \\
\text { farming in BR }\end{array}$ \\
\hline Land Use Change, transformation to arable land & $\mathrm{m}^{2}$ & $8.75 \cdot 10^{-2}$ & $1.86 \cdot 10^{-3}$ & $-1.73 \cdot 10^{-2}$ \\
\hline Transformation from arable land, non irrigated crops & $\mathrm{m}^{2}$ & $2.80 \cdot 10^{-2}$ & 0 & $-1.65 \cdot 10^{-2}$ \\
\hline Transformation from forest, clear cutting & $\mathrm{m}^{2}$ & $1.93 \cdot 10^{-2}$ & $1.86 \cdot 10^{-3}$ & $-1.73 \cdot 10^{-4}$ \\
\hline Transformation from pasture and meadow & $\mathrm{m}^{2}$ & $2.36 \cdot 10^{-2}$ & 0 & 0 \\
\hline Transformation from shrub land & $\mathrm{m}^{2}$ & $1.66 \cdot 10^{-2}$ & 0 & $-5.88 \cdot 10^{-4}$ \\
\hline \multicolumn{2}{|l|}{ Total LUC $=7.23 \cdot 10^{-2} \mathrm{~m}^{2}$} & $\begin{array}{l}\text { Direct LUC = } \\
8.75 \cdot 10^{-2} \mathrm{~m}^{2}\end{array}$ & \multicolumn{2}{|c|}{ ILUC $=-1.52 \cdot 10^{-2} \mathrm{~m}^{2}$} \\
\hline
\end{tabular}


Table 3.13. LUC results from base scenario 2, including direct LUC and ILUC due to coproduct displacements.

\begin{tabular}{|c|c|c|c|}
\hline SCENARIO 2 & Units & $\begin{array}{c}\text { Palm cultivation } \\
\text { in } \mathrm{MY}\end{array}$ & $\begin{array}{c}\text { Soybean farming } \\
\text { in BR } \\
\end{array}$ \\
\hline Land Use Change. transformation to arable land & $\mathrm{m}^{2}$ & $-1.94 \cdot 10^{-3}$ & $1.80 \cdot 10^{-2}$ \\
\hline Transformation from arable land, non irrigated crops & $\mathrm{m}^{2}$ & 0 & $1.72 \cdot 10^{-2}$ \\
\hline Transformation from forest, clear cutting & $\mathrm{m}^{2}$ & $-1.94 \cdot 10^{-3}$ & $1.80 \cdot 10^{-4}$ \\
\hline Transformation from pasture and meadow & $\mathrm{m}^{2}$ & 0 & 0 \\
\hline Transformation from shrub land & $\mathrm{m}^{2}$ & 0 & $6.12 \cdot 10^{-4}$ \\
\hline \multicolumn{2}{|l|}{ Total LUC $=1.61 \cdot 10^{-2} \mathrm{~m}^{2}$} & \multicolumn{2}{|c|}{ ILUC $=1.61 \cdot 10^{-2} \mathrm{~m}^{2}$} \\
\hline
\end{tabular}

\subsubsection{Sensitivity and uncertainty analyses}

When analyzing the results from the base scenarios in section 3.3.3.1, all the inputs and outputs were discussed as single mean values. This is a deterministic assumption, but normally most of them show some variability which should not be ignored. To assess this uncertainty caused by parameter variation, a Monte Carlo simulation was carried out. This method enables probability distributions of the impact categories to be obtained according to the probability distributions of the previously defined risk parameters. It has to be recalled that the influence of the risk parameters related to the LUC calculations was also included in the assessment.

The coefficient of variation (CV) shows the variability in each impact category brought about by the risk parameters. In scenario 1, the CVs were calculated at between $0.0 \%$ (in TE) and $2.3 \%$ (in AP) in almost all the impact categories. The greatest uncertainty was observed in HT (4.0\%), GW output (4.0\%), GW input $(4.2 \%)$ and POC (4.6\%). Specifically, the uncertainty in GW output arose mainly from the variability of all the risk parameters involved in the calculation of GHG emissions from LUC in Argentina, Malaysia and Brazil. On the contrary, parameters determining the carbon uptake by biomass in the three countries greatly influenced GW input. In addition, the risk parameter of land transformation from forest also determines the intensity of the associated wood burning and is a great source of uncertainty in both POC and HT, among other categories (such as $A P)$. The $C V$ in POC was also the highest because of the variability of hexane emissions from palm oil extraction in Malaysia, apart from the contribution of those general parameters, such as the transesterification yield, upon which all the substages depend. However, even for the impact categories with the highest CVs, approximately $100 \%$ of the results were in the range of $\pm 10 \%$ around the mean values. In scenario 2, the uncertainty was greater: the CVs ranged between $0.0 \%$ (in TE) and $6.1 \%$ (in GW input) in all the impact categories, except in ADP fossil (8.1\%), GW output (9.3\%), MAE (13.1\%) and OD (71.7\%). For instance, only 
$10.2 \%$ of the results in OD were in the range of $\pm 10 \%$ around the mean values. The highest CVs are the result of a combination of two factors: the high incidence of the selected risk parameters in these impact categories and the mean value of the impact, which is very close to zero.

The most influential key parameters in both scenarios were those determining the amount of biodiesel to be produced in Argentina and Spain: the net calorific value and transesterification yield in each scenario. For the same reason, the oil extraction yield in Argentina and the palm oil extraction yield in Malaysia were also risk parameters in both scenarios on which the dimension of the agricultural production in both countries directly depends, with the subsequent LUC emissions, which make a great contribution to GW output. There is a remarkable influence of irrigation on almost every impact category, because additional water is used in Malaysia to improve yields, with the associated impacts from capital goods production and the energy inputs for pumps. In scenarios 1 and 2, some parameters of the ME production and oil extraction (energy and chemicals) proved influential, due to resource depletion and the emissions associated with their production, or simply the emissions of some compounds which are directly released.

The oil extraction yield in Brazil was only selected in scenario 2 since the soybean meal pathway in Brazil had a greater influence on the results than in scenario 1. The parameters involved in palm cultivation in Malaysia made a great contribution to impact categories, such as ADP fossil and OD, due to their respective production processes. Subsequent emissions from both fertilizers and pesticides were a source of uncertainty in impact categories, such as HT, FAE or EP. It has to be pointed out that the default transport process of palm fruit bunches to the mill included in palm oil extraction by Ecoinvent v2.2 also appeared to be influential in both scenarios; it is assumed that they are transported by small trucks (3.5-16t of cargo), which are very inefficient in terms of fuel consumption per tkm. In scenario 2, wood-chopping for land clearing in Malaysia was selected because of its contribution to ADP fossil, AP, MAE and OD, due to diesel consumption. The parameters involved in soybean farming in Brazil also generated uncertainty in OD, given the weight of capital goods and diesel consumption in the process. All the parameters determining the LUC emissions in the different countries appeared to be risk parameters in the two scenarios because of their contribution to GW output. As was said, besides the GHG emissions from biomass, soil and dead organic matter after the land conversion, the parameter of land transformation from forest also determines the impacts from the subsequent burning of the wood debris.

Figure 3.14 shows the outcomes of the Monte Carlo simulation for the impact categories in which uncertainty can be detected in the box-and-whiskers plots: ADP elements, AP, GW input, GW output, HT and POC. The box shows the $25^{\text {th }}$ 


\section{Chapter III. Results}

and the $75^{\text {th }}$ percentiles, the whiskers show the minimum and maximum values between the $10^{\text {th }}$ and $90^{\text {th }}$ percentiles and the bold line in the middle of the box shows the median values of each impact category. As can be seen, the uncertainty is in no way relevant in the comparative assessment, because even for those categories with the highest $\mathrm{CV}$, the variation around the mean is barely detectable.
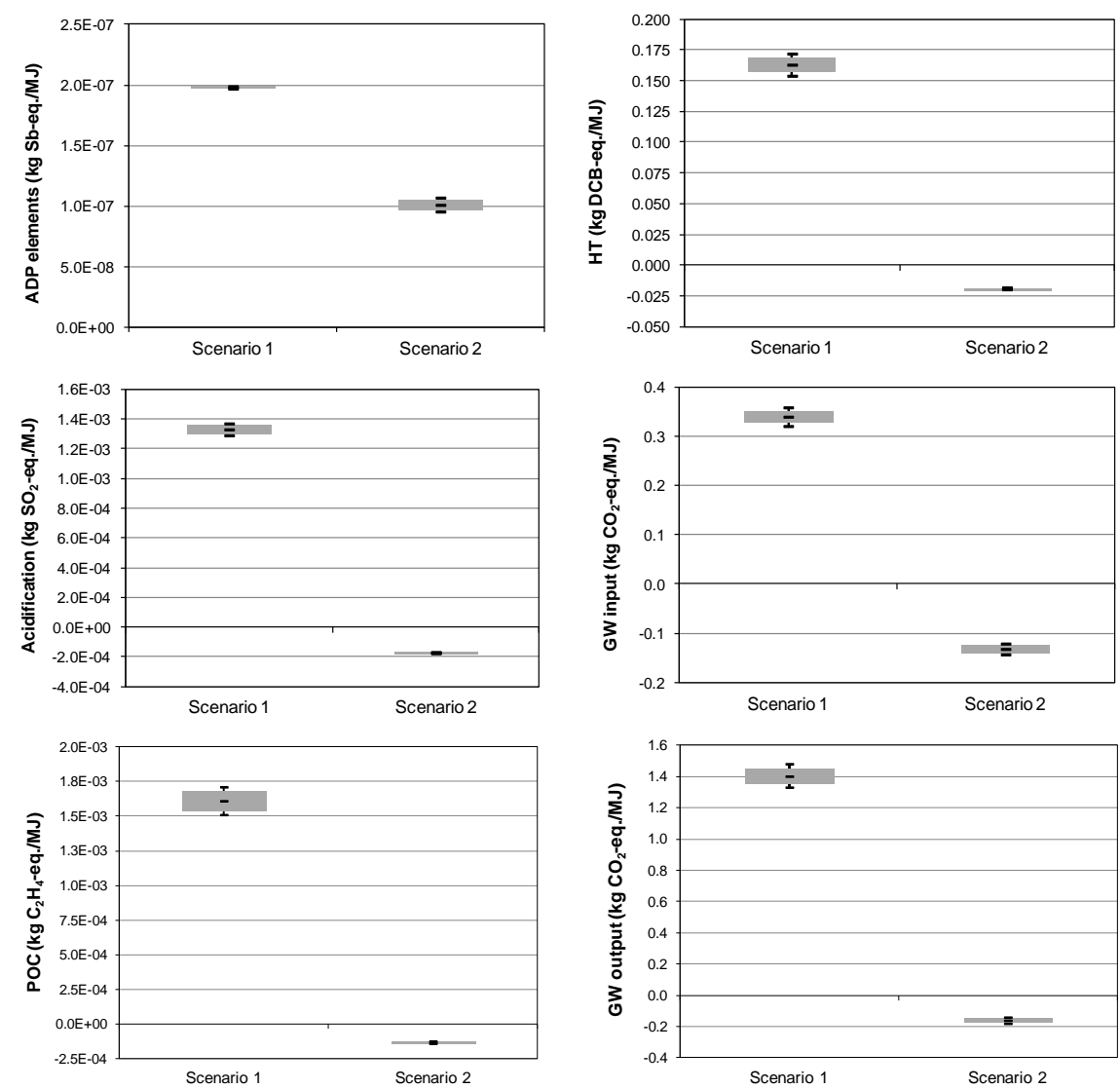

Figure 3.14. Box-and-whisker plots of the outcomes from the Monte Carlo simulation of scenario 1 and scenario 2. Only the impact categories for which results presented the greatest variability are shown.

\subsubsection{Discussion}

Results show that, as could be expected, UCO biodiesel produced in Spain performs better than imported biodiesel from Argentina in environmental terms, when performing system expansion under a consequential approach. However, 
when emissions from LUC are not taken into account, scenario 1 is better than scenario 2 in terms of GW, mainly due to the carbon uptake by crops. Results like these were used in the early environmental assessments of biofuels (e.g. Hill et al., 2006), trying to highlight the advantages they may have as compared to fossil fuels (regardless of the feedstock used for bioenergy production), before the debate about LUC effects emerged. As an example, Yee et al. (2009) concluded that the production of palm biodiesel has no negative impact on the environment, as the amount of $\mathrm{CO}_{2}$ emitted into the atmosphere is much lower than the $\mathrm{CO}_{2}$ absorbed from the atmosphere by palm plantations.

However, these environmental benefits are totally cancelled out when emissions from LUC are considered. Scenario 2 causes a reduction of between $49.0 \%$ and $112.9 \%$ in all the impact categories with respect to scenario 1 . As for the LUC effects, apart from the land transformation in Argentina $\left(+8.75 \cdot 10^{-2} \mathrm{~m}^{2}\right)$, scenario 1 leads to deforestation in Malaysia $\left(+1.86 \cdot 10^{-3} \mathrm{~m}^{2}\right)$ and area contraction in Brazil ($1.73 \cdot 10^{-2} \mathrm{~m}^{2}$ ), due to market-mediated responses. As a result, net ILUC leads to $1.52 \cdot 10^{-2} \mathrm{~m}^{2}$ of global agricultural land, but total LUC associated with this scenario represents an increase of $7.23 \cdot 10^{-2} \mathrm{~m}^{2}$ per each $\mathrm{MJ}$ of biodiesel in regional storage in Spain. As side effects, some carbon stock is lost into the biomass and soils: LUC in Argentina releases $1137.5 \mathrm{~g}$ of $\mathrm{CO}_{2}$ into the atmosphere, whereas LUC in Malaysia generates $221.1 \mathrm{~g}$ of $\mathrm{CO}_{2}$, and LUC in Brazil causes an uptake of $133.8 \mathrm{~g}$ of $\mathrm{CO}_{2}$.

In scenario 2, the domestic production of $1 \mathrm{MJ}$ of UCO biodiesel also has indirect effects, given the interaction in the global oil and feed markets. Net LUC is estimated at $1.61 \cdot 10^{-2} \mathrm{~m}^{2}$ (more than 5 times lower than in scenario 1 ), which comes entirely from ILUC in Malaysia $\left(-1.94 \cdot 10^{-3} \mathrm{~m}^{2}\right)$ and Brazil $\left(+1.80 \cdot 10^{-2} \mathrm{~m}^{2}\right)$. As a consequence, $230.6 \mathrm{~g}$ of $\mathrm{CO}_{2}$ are absorbed and $139.4 \mathrm{~g}$ of $\mathrm{CO}_{2}$ are released into the atmosphere, respectively. In this case, the market-mediated responses even improve the environmental profile of the UCO biodiesel system, and scenario 2 generates an overall uptake of $28.6 \mathrm{~g}$ of $\mathrm{CO}_{2}$-eq., $1092.3 \mathrm{~g}$ of $\mathrm{GHG}$ emissions less than scenario $1 ; 1315.9 \mathrm{~g}$ of $\mathrm{CO}_{2}$ less only in terms of emissions from LUC.

Results from scenario 1 can be partially compared with those from Reinhard and Zah (2009); specifically, with the scenario in which $1 \mathrm{MJ}$ of soybean ME was imported into Switzerland from Brazil, Malaysia being the marginal supplier of the oil in the global market. Figures show that the additional production of palm oil in Malaysia generates around $140 \mathrm{~g}$ of $\mathrm{CO}_{2}$-eq. from LUC (instead of the $221 \mathrm{~g}$ obtained in the present study). These differences can be explained by different assumptions in land transformation processes. For instance, they considered that $33 \%$ of the transformation in Malaysia took place at the expense of grassland, whereas, in our case study, the entire LUC in Malaysia was assumed to occur at the expense of rainforest. This has a much higher emission factor, since 
conversion from grassland generates net carbon uptake according to the IPCC guidelines. However, the Monte Carlo simulation in the present study showed that a $\pm 10 \%$ change in land transformation parameters could not reverse the comparative results.

In their subsequent study, Reinhard and Zah (2011) concluded that the production of marginal palm oil in Malaysia generated $+345 \mathrm{~g}$ of $\mathrm{CO}_{2}$-eq., of which approximately $90 \%$ were caused by LUC (around $310 \mathrm{~g}$ of $\mathrm{CO}_{2}$ ). These differences with regard to the previous study may arise from the fact that, in this case, palm oil is displacing rape oil in the international market, instead of soybean oil. More rape oil is needed to obtain $1 \mathrm{MJ}$ of rape ME in Switzerland because of the lower transesterification yield. In addition, it has to be highlighted that, besides the differences in land transformation, none of these studies included emissions from biomass burning in the GW calculation, which make a significant contribution when forests are converted to cropland. Another important difference is that Reinhard and Zah $(2009,2011)$ did not consider the direct LUC due to soybean farming in the biodiesel-producing country. They assumed that soybeans in Brazil were produced entirely for the meal. On the contrary, we considered that soybeans in Argentina are essentially produced for biodiesel for export, as did Panichelli et al. (2009), who stated that it consists of an export-oriented biodiesel pathway. As a result, whereas in our case the environmental impacts of scenario 1 mainly depend on the core process, which is soybean biodiesel production in Argentina, the most influential sub-stage in scenario 2 is palm cultivation in Malaysia (in 7 of the analyzed impact categories). In scenario 2 , the biodiesel supply chain substantially influences ADP elements, ADP fossil, MAE and OD. This agrees with the finding of Reinhard and Zah (2009), according to which the overall impact depends to a great extent on the marginal replacement products in the world market.

\subsubsection{Conclusions}

Biodiesel can be produced from oilseed crops (such as soybean or palm), known as first-generation biodiesel, or from non-food feedstock (such as UCO). Worldwide public policies have led to the increased production of FGBs, which has proved to cause environmental impacts arising from the global expansion in the amount of agricultural land diverted to the cultivation of oilseed. This has, in turn, led to a heated discussion about the indirect consequences of changes in crop patterns, and different methodologies for their quantification have emerged. In fact, the new proposal, COM 595, urges biofuel producers in the EU to report emissions from ILUC by applying default emission factors. This paper estimates total GHG emissions, together with other impacts, caused by two possible alternative ways for the Spanish transport sector to be able to meet the $10 \%$ target set out by the RED. It must be taken into account though that the imports of biodiesel from Argentina 
have markedly declined, as a consequence of the anti-dumping duties which were approved in final form by the EC by the end of 2013, in force for a period of five years. However, most of the biodiesel is still produced from imported feedstock, and soybean oil from Argentina accounts for a remarkable market share of the Spanish market, only surpassed by palm oil from Malaysia and Indonesia. This biodiesel pathway also has ILUC effects, similar to those arising from importing the manufactured product, with the only difference that now the transesterification takes place in Spain. The results presented in this section are, thus, still meaningful for an understanding of the environmental consequences of the biodiesel consumption mix in Spain.

Results also show that focusing solely on GHG emissions without considering LUC effects can be misleading. The need to address LUC in biofuel policies is not temporary, and projections point to a substantial reliance on land-based biofuels as a means of meeting climate goals. The present study shows that, under the current production conditions in Spain, there are clear environmental benefits arising from the use of UCO biodiesel compared to the use of imported soybean biodiesel from Argentina. The Monte Carlo simulation for both scenarios improves the reliability of the comparative assessment, since parameter uncertainty is negligible in all the impact categories. Hence, it can be concluded that the domestic UCO biodiesel can be a suitable option for advanced biofuel consumption according to the COM 595 requirements, even considering market-mediated responses in the feed market. However, given the effect that considering different land conversion values may have on the GW results, analyzing LUC emissions under different scenario assumptions is recommended as a way of reinforcing confidence in the conclusions.

Despite the fact that the adopted ceteris paribus assumption may be a rough simplification of the global economy, where all the markets interact with each other, the proposed methodology requires a deep knowledge of the markets affected by the decision under investigation (Vázquez-Rowe et al., 2013). Computable Global Equilibrium (CGE) models may help to overcome this limitation, and can be used to estimate how the global equilibrium affects the oil and protein meal markets. Nevertheless, the present approach for consequential LCA also allows LUC effects and the subsequent GHG emissions to be determined, providing additional insights on the variability of ILUC factors. The study also encourages the study of global consequences beyond environmental effects, since biofuels can also affect social structures, as Janssen and Rutz (2011) suggested. 

Submitted to Biomass and Bioenergy

\subsection{Optimization of the biodiesel supply chain in Spain to meet the European GHG reduction targets}

Escobar, N. ${ }^{a}$, Manrique, C. ${ }^{b}$, Rozakis, S. ${ }^{c}$, Clemente, G. ${ }^{a}$, Sanjuán, N. ${ }^{a}$

${ }^{a}$ Grup ASPA. Departament de Tecnologia d'Aliments, Edifici 3F, Universitat Politècnica de València. Camí de Vera s/n, 46022, Valencia, Spain

${ }^{b}$ Departamento de Análisis Económico Aplicado, Edificio D-2-21, Universidad de Las Palmas de Gran Canaria, Saulo Torón 4, 35300, Las Palmas de GC (Spain)

'Laboratory of Agribusiness Management, Department of Agricultural Economics and Rural Development, Agricultural University of Athens, lera Odos 75, 11855, Athens (Greece) 



\begin{abstract}
Only five years after the enforcement of the Renewable Energy Directive (RED), the situation of the biodiesel sector in Spain is extremely delicate. Its nameplate capacity almost doubles the target demand for 2020 , and most of the plants remain idle. The present section aims to provide an operational framework so as to optimize the entire supply chain in accordance with both environmental and economic criteria. A mathematical programming model is proposed in a multisectorial setting. It allows for the optimal feedstock mix to be determined, in order to supply the country with the entire amount of biodiesel to be consumed in compliance with the RED, while a life cycle assessment is simultaneously carried out.

The optimal oil mix for the sector as a whole is highly dependent on assumptions regarding land use change (LUC) in the oil-exporting countries considered. In general, increasing greenhouse gas (GHG) savings thresholds enhance the use of waste oils and domestic oilseeds, which may even account for $97.1 \%$, while preventing the deforestation of carbon-rich ecosystems. The only exception is the Cerrado savannah in Brazil, which could still provide $7.3 \%$ of the oil needed under the $60 \%$ reduction requirement. A double-counting scheme is necessary to make plants with second-generation technology work at full capacity, while increasing the profitability of the sector. In combination with emission reduction targets, this delivers further environmental benefits. One of the strengths of this model is that it allows for direct and indirect emissions from domestic first-generation biodiesel to be estimated separately, according to recent demands of the European Commission (EC).
\end{abstract}

Keywords: biodiesel supply chain, economic optimization, greenhouse gases, life cycle assessment, mathematical programming 


\subsubsection{Introduction}

\subsubsection{Biofuel policy landscape in the EU}

Since the European biofuel industry's development in the 1990s, the sector has experienced gradual consolidation. Both the consumption and production of biofuels have been on the rise since then, especially that of biodiesel, and consequently the European Union (EU) is currently the world's largest biodiesel producer, led by Germany and France. Public policies on the promotion of renewable energies were certainly one of the main drivers of the rapid expansion observed during the period 1990-2008, together with rising crude oil prices and tax exemptions on biofuel production across the Member States (MSs). For instance, in Spain, this led to a rapid expansion of the installed capacity, resulting in an oversized sector (Guerrero, 2013). Biofuel policies in the EU have been in force on the basis of blending mandates, setting out indicative targets for renewable energy consumption relative to the total energy used in the transport sector. Directive 2009/28/EC, commonly known as the Renewable Energy Directive (RED), replaced Directive 2003/30/CE in 2009 and is still in force, requiring $20 \%$ of the gross final energy consumed in the EU to come from renewable sources, in order to meet the EU's 20-20-20 goals ${ }^{1}$. As regards the transport sector, the RED establishes a $10 \%$ target by 2020 , which is expected to be mostly met with biodiesel, since it has been accounting for $80 \%$ of the total transport biofuel market on an energy basis (Eurostat, 2013c). In a parallel effort, Directive 2009/30/CE or the Fuel Quality Directive (FQD) sets a 6\% reduction target in the carbon intensity of the fuels used in vehicles within the same time horizon, given the contribution of this sector to overall GHG emissions in the EU (around 20\%). This will also benefit the use of biofuels, at least in the short term, due to the low market penetration of other technologies, such as hydrogen or electricity.

Despite these new, ambitious targets, recent circumstances in the international markets have slowed down the development of the biodiesel sector in the EU. More specifically, comparatively low crude oil prices, high vegetable oil prices, increased imports from other leading biodiesel countries, and the phasing out of the tax exemptions in the MSs have been decisive in limiting the expansion of the production capacity, after years of sharp increases. According to estimates from Flach et al. (2011; 2013), the biodiesel consumption in the EU has reached its peak (around 11 billion liters during the last four years) and the overall sector's capacity use will remain stable at around $42 \%$ in the short term.

\footnotetext{
${ }^{1}$ The 20-20-20 targets are part of the Energy and Climate Package of the EU, which sets out a triple 2020 objective: to have a $20 \%$ (or even $30 \%$ ) reduction in $\mathrm{CO}_{2}$ emissions compared with 1990 levels; for $20 \%$ of the energy, on the basis of consumption, to come from renewable sources; and for there to be a $20 \%$ increase in energy efficiency.
} 
The situation of the biodiesel sector in Spain is extremely delicate. As has been seen in section 1.3.2, the installed capacity, around 4.5 Mt per annum, far exceeds its current production, and most of the plants remain idle. This is the result of multiple factors, the main ones being: the end of the exemption on biofuel production on January $1^{\text {st }} 2013$; the reduction in the 2013 and 2014 blending targets by the Spanish government; the escalation of biodiesel imports from Argentina and Indonesia in 2011 and 2012; and the lack of determination on the part of the government to implement a quota system proposed in 2010. Antidumping duties on biodiesel imports from Argentina and Indonesia were finally approved in 2013 , and the resolution of January $24^{\text {th }} 2014$ finally enforced the law, Orden IET/2736/2012, allocating a quota of $5.5 \mathrm{Mt}$ of biodiesel per annum solely to European companies for a period of two years. Despite the sharp decline in biodiesel imports already observed, the Spanish supply relies heavily on imports of raw materials, which hinders energy independence. Although domestic oilseeds are partially devoted to biodiesel production, food uses dominate, particularly in the case of sunflower (MAGRAMA, 2010a); the supply of rapeseed is mainly exported, especially to France, which has a stable and well-developed crushing sector. Hence, the deficit in oil production is compensated by imports, mostly of palm oil, since it is by far the cheapest vegetable oil on the world market (Gerasimchuk, 2013). The contribution of soybean to the overall oil mix is also remarkable, although to a lesser extent (CNE, 2013; Guerrero, 2013). However, following overall trends in the EU market (Ecofys et al., 2013), a strong and simultaneous increase in the use of recycled oils and animal fats has been observed in Spain during the last few years. In particular, used cooking oil (UCO) was the second most widely used feedstock in 2011 (24.96\%) after palm oil (CNE, 2013), and it is expected that its market share will remain strong.

Biofuel expansion can generate much greater GHG emissions than presumed when it comes at the expense of carbon-rich ecosystems in regions such as South America or Southeast Asia (e.g. Panichelli et al., 2009; Reijnders and Huijbregts, 2008). To reduce these emissions from LUC, that is, those arising from carbon stock changes on the land that has been diverted to biofuel production, the sustainability criteria in the RED/FQD are oriented in two directions. Firstly, certain land types are excluded from the options considered suitable for the production of biofuels to be consumed in the EU, assuming that they always contain high carbon stocks (such as wetlands, densely forested areas or undrained peatlands). Secondly, biofuels used for compliance with the mandate must fulfill minimum emission reduction targets: at least a 35\% reduction in GHG compared with fossil fuels; $50 \%$ from 2017; and 60\% from 2018, but only for those biofuels produced in installations which will be in operation after January $1^{\text {st }} 2017$. Additionally, the RED proposes a double-counting scheme for biofuels made from waste, residues, nonfood cellulosic material, and ligno-cellulosic material, whose contribution towards 
reaching the target must be considered twice. These are known as secondgeneration, or simply, advanced biofuels, as opposed to first-generation biofuels (FGBs), which are those made from edible biomass contained in arable crops.

Besides emissions from direct land conversion, FGBs have the potential to cause additional GHG from what is known as indirect land use change (ILUC). Governed by market forces, those crops that are displaced on current agricultural land may have to be relocated elsewhere, with the subsequent changes in the carbon stock in soil and biomass. In principle, ILUC emissions are not taken into account by the sustainability criteria in the RED/FQD. These lay down some Life Cycle Assessment (LCA) guidelines for the economic operators to report GHG emissions from the entire production pathway. Default values of GHG savings are provided for the main biofuels, based on the calculations of the Joint Research Center (Edwards et al., 2008) including emissions from direct LUC. However, these values have been subject to debate, since there are no international standards in place for their calculation. In fact, the RED/FQD allows the use of other emission saving coefficients obtained by means of other LCA procedures. Furthermore, there have even been some concerns that these GHG thresholds can be used to hamper trade. Some authors (Akrill and Kay, 2011; Lendle and Schaus, 2010) concluded that there is no clear evidence to think that sustainability criteria discriminate on the basis of origin, since they apply equally to all biofuels, regardless of the source country. Thus, they apparently conform to the World Trade Organization rules.

In view of the evidence that ILUC can negate the GHG benefits from biofuel mandates (Al-Riffai et al., 2010; Banse et al., 2008; Fargione et al., 2008; Hertel et al., 2010; Searchinger et al., 2008), there has been a new EC proposal to limit the contribution of FGBs to the national targets. It is expected that the cap on FGBs will finally be set at $7 \%$, while adding a $0.5 \%$ non-binding target for advanced biofuels, but this still has to be ratified. The EC's original proposal included ILUC emission factors corresponding to estimates from Laborde (2011), to be used for reporting purposes but not in compliance with the RED/FQD accounting requirements. The Council's position, adopted in June 2014, maintains the role of the ILUC emission factors, although it envisages the possibility of reviewing them since there is no scientific consensus on the methodology to apply. It also encourages the use of alternative models and approaches, in order to improve the understanding of ILUC effects.

\subsubsection{Environmental impact of biofuels}

LCA has played an important role in evaluating the sustainability of the biofuel industry (e.g. Hill et al., 2006; Kaltschmitt et al., 1997; Kim and Dale, 2005; Pimentel and Patzek, 2005), since it aims to quantify the environmental impacts 
from a production process under status-quo conditions. As commented on above, it is now agreed that not considering emissions from direct LUC leads to an overestimation (or underestimation) of the carbon benefits of bioenergy (Panichelli et al., 2009; Reijnders and Huijbregts, 2008; Wicke et al., 2008). These emissions are commonly incorporated into the LCA by applying the IPCC guidelines (2006) under the attributional approach, which calculates the environmental impacts associated with the delivery of a specific amount of product. This approach has limited application in terms of the quantification of the emissions from ILUC and other environmental responses, which are in fact mediated by market behavior. Hence, an attributional LCA is used as a complementary methodology in disciplines that are more closely aligned with industrial ecology, engineering or even industrial economics (Davis et al., 2009), with a limited capacity to influence public policies.

Consequential LCA aims to overcome the aforementioned limitation on ILUC calculation by implementing micro-economic and macro-economic concepts, depending on the scope. According to Vázquez-Rowe et al. (2013), Partial Equilibrium (PE) modeling is one of the optional means of carrying out a consequential LCA. It consists of analyzing one particular sector of the economy as operating in isolation from the other sectors, ceteris paribus. Although economywide models show greater applicability in decision-making, PE models can provide more detailed information on the effects that a policy decision may have on a reduced number of markets (directly related to the products under study). Since these markets may represent a very small part of the global economy, a shock in their demand or supply side is barely detectable under a wider approach. Indeed, the EC has developed its own PE models to understand the ILUC implications of EU biofuel mandates, mainly caused through interactions among agricultural markets (Blanco-Fonseca et al., 2010; Hélaine et al., 2013). The aim of the studies carried out by lliopoulos and Rozakis (2010), Rozakis et al., (2013), and Rozakis and Sourie (2005), was that of optimizing the biofuel supply in different European countries. Specifically, Rozakis et al. (2013) estimated the most suitable bioethanol activity and subsidy levels, as well as life cycle GHG, due to an exogenous, policydriven, demand for biomass in Greece. In line with this last study, we can also find other specific models in the literature devoted to determining the optimal industry configurations of biofuel supply chains. Although they are economic in nature and, by definition, multi-sectorial, they cannot be considered as PE models since prices do not adjust as a consequence of the economic equilibrium between supply and demand. As optimization models, they are frequently applied in the analysis of investment decisions (e.g. Dal-Mas et al., 2011; Kim et al., 2011; Leão et al., 2011; Zamboni et al., 2011). In fact, these modeling tools are widely applied in biofuel systems, also incorporating environmental considerations, such as reducing GHG emissions (e.g. Čuček et al., 2012; Mele et al., 2009; Zamboni et al., 2009; 2011). 
Glithero et al. (2012) developed a bio-economic model for optimizing crop rotations at farm level for the production of bioenergy in the United Kingdom, also based on environmental criteria. Most of these models are defined as multi-objective, aiming to optimize the economic and environmental performances simultaneously. Biofuel supply chains are complex, and analytical tools like these can be very helpful to obtain a full understanding of a multifaceted problem such as LUC, in response to specific goals.

In view of the long and lasting crisis of the Spanish biodiesel sector, the present paper aims to provide an operational framework with which to optimize the entire supply chain, allowing for the optimal feedstock mix to be determined in accordance with both environmental and economic criteria. A mathematical programming model is proposed based on the sector's nameplate capacity, today underused, so as to protect current investments. To the best of our knowledge, there is no model addressing the economic feasibility of the biodiesel production in Spain together with global warming mitigation demands, in spite of all the problems that have previously been explained. It can be expected that the GHG reduction targets in the RED/FQD reinforce the role of domestic feedstock in the production mix, enhancing the self-sufficiency of the sector. The model allows for an LCA to be carried out simultaneously, for the purposes of discerning whether the targets are compatible with other environmental gains, together with the welfare maximization of all the actors involved. A detailed representation of the biomass supply in the country, capturing regional differences, needs to be developed in order to measure direct and indirect emissions from the expansion of domestic oilseeds. In this way, this tool could help to assess trade-offs and compare different policy settings in the Spanish context.

\subsubsection{Materials and methods}

An integrated model of the biodiesel industry and the agricultural sector in Spain is developed in a multi-sectorial setting. The simulated policy exercise corresponds to an exogenous demand for biodiesel to meet the RED target by 2020. Specifically, the overall amount of biodiesel that will be demanded in Spain is drawn from the study of the Spanish Institute for Energy Diversification and Saving (IDAE, 2011a). This estimates a demand of 2,313 ktoe in compliance with the Plan on the Promotion of Renewable Energies (PER) 2011-2020, which is equivalent to 2.58 $\mathrm{Mt}$, an amount that is smaller than the sector's capacity $(4.46 \mathrm{Mt})$. This target would trigger biodiesel supply and, for the present study, it is assumed that it is entirely manufactured in Spain from domestic and imported feedstock. Biodiesel imports are not considered since they dramatically decreased in 2013, after anti-dumping duties were approved, as explained in section 3.4.1.1. One of the further goals of this section is to identify sustainable ways in which to stimulate the activity of the 
Spanish industry. The optimal feedstock mix is derived from the maximization of the agro-industry system's welfare, calculated as the sum of the stakeholders' individual surpluses. The joint optimization of the agricultural module and the industry module gives us the optimal oil input combination given the configuration of the biodiesel sector, together with the optimal biomass supply, given the farming sector in Spain and its regional differences. An emission balance module is implemented to estimate the environmental impacts across all the sub-stages in the supply chain, including global warming. This permits the introduction of a GHG saving constraint in order to obtain the optimal mix in compliance with the sustainability criteria in the RED. For the LCA, the complete production pathway consists of five main stages, following the life-cycle methodology suggested in the RED/FQD: biomass production, oilseed transport to the mill, virgin oil extraction and refining, oil transport to the transesterification plant and biodiesel production. The optimization model is described in detail in the following paragraphs. It is written in General Algebraic Modeling System (GAMS) (Brooke et al., 1998) for mathematical programming, and the general architecture is shown in section B1 of annex B. The model essentially consists of mass balances, production and conversion constraints, cost functions, the welfare objective function, and a GHG saving constraint.

\subsubsection{Industrial module}

Given the biodiesel sector's structure in Spain, with plant capacities ranging from 5,000 to $600,000 \mathrm{t}$ of biodiesel per annum, the industrial module defines a stepfunction for the domestic biodiesel supply to meet the 2020 demand. According to this, biodiesel is produced by those plants with the highest production margins, limited by their maximum capacity; this typically depicts a supply function which resembles a staircase. Each plant is designed to operate with a given technology depending on the feedstock (virgin vs. recycled oil), thus it is not possible to switch from first-generation to advanced technology or the other way round. Those biodiesel plants that were active in Spain by the end of 2013, according to reports from the Association of Renewable Energy Producers, are taken into account in order to estimate the total processing capacity for UCO and virgin oils separately. Different raw materials are available as inputs, namely: a) domestic vegetable oils from indigenous oilseeds (rapeseed and sunflower), b) imported vegetable oils (palm and soybean), c) UCO collected in Spain, and d) imported UCO. Despite the fact that oils from domestic crushing are scarcely used for energy purposes (representing only $1.5 \%$ of the Spanish biodiesel mix in 2011, according to the latest report of the CNE, 2013), they are seen as an alternative means of promoting the integration of the agro-industrial biofuel production in Spain, as can be drawn from the PERs 2005-2010 \& 2011-2020 (IDAE, 2005; 2011a). 


\section{Chapter III. Results}

Furthermore, they can provide additional GHG savings, since the associated emissions from direct LUC or even transport are substantially reduced as compared with the main imported virgin oils. This must, however, be supported or refuted by numerical results. The most competitive vegetable oils on the global market, which are also the most important in Spain (CNE, 2013; EC, 2012b), are included in the model, namely: palm oil from Southeast Asia (taking Indonesia and Malaysia as a single source), soybean oil from Argentina and soybean oil from Brazil. The UCO availability in Spain varies approximately between 100,000 and 300,000 t per annum (IDAE, 2011a); the lowest value corresponds to the estimated collection capacity in the hospitality sector, while the highest includes households. UCO is assumed to be imported too, which is consistent with data from the CNE (2013). France and the United States (US) are the possible foreign sources considered for emission calculation purposes, the first representing a country within the EU and the second an overseas country. The maximum amount of UCO to be imported from France is established at $11,000 \mathrm{t}$, calculated as the sum of the imports from all the European countries in 2011, according to data from CNE (2013).

In the industrial module, not only is the biodiesel production (by transesterification of the oils with methanol) modeled but also the oil extraction where domestic oilseeds are concerned, as part of the Spanish biodiesel supply chain. Technical and economic information on the biodiesel manufacturing was gathered from the studies from IDAE (2011b), together with primary data from three biodiesel plants. Due to the competition among firms in the Spanish sector, only some of them offered to provide economic data. Cost data was thus complemented with that in the PER 2005-2010, for an average plant using sunflower oil, with a capacity of $50,000 \mathrm{t}$ per annum. Other input data in the model refer to the transesterification and extraction yields, transport distances, transformation ratio from seed to meal, corresponding prices and input quantities (e.g. chemicals, energy, etc). While the transesterification yield is considered to be the same regardless of the oil used, the oil extraction yield depends on the seed: $41.9 \%$ for sunflower and $39.1 \%$ for rapeseed. The amount of meal obtained is thus slightly different. By-product generation is relevant since it determines industry revenues. Extraction plants buy the domestic seeds and sell the corresponding oils and meals, while transesterification plants buy the refined oils and sell biodiesel and glycerin. Although glycerin has enjoyed wide applicability in other sectors, such as cosmetics, prices have dramatically decreased over the last few years due to the boom in biodiesel. Total extraction -and refining- costs were gathered after personal communication with a multinational company operating in Western Europe. They were set at approximately $€ 40$ per ton of oil, including equipment amortization. 
Transesterification costs include operation personnel, maintenance services, insurance, and other costs, together with variable costs (methanol, additives, energy, fuel, and distribution) and investment cost. All the costs are linear, depending on the biodiesel capacity, except investment cost, for which a negative exponential function is introduced (Haas et al., 2006). Specifically, the same exponential term calculated by Haque et al. (2009) is used, according to expert opinion. That was estimated by means of robust methods commonly used in process costing, based on detailed information, thus it was considered representative enough to link bioenergy investment costs to capacity. Investment cost is then scale-dependent, decreasing as plant capacity increases. Base capacity is set at 5,000 t per annum, as corresponds to the smallest biodiesel plant in Spain. The base investment cost in the exponential function is different depending on whether virgin oils or UCO are used as raw material, according to the primary and secondary data sources mentioned. Specifically, it is set at EUR $1,995,000$ for virgin oils and EUR 2,000,000 for UCO. It is also considered that using UCO entails higher operational costs. Energy, fuel, maintenance and personnel costs are multiplied by a factor of 2 when UCO is considered, according to estimates from Szulczyk and McCarl (2010). This allows the unit cost of each production pathway to be determined, depending on the plant. The capacity of those plants using UCO ranges from 5,000 to $220,000 \mathrm{t}$ per annum, while the capacity of those plants using virgin oils ranges from 6,000 to 800,000 t per annum.

\subsubsection{Agricultural module}

Biodiesel demand can trigger a demand for domestic oilseeds if sunflower and/or rapeseed appear in the optimal mix. The industrial module is thus coupled with an agricultural module which estimates changes in the production of major crops in Spain as a consequence of the increased demand for biomass under a comparative-static approach, taking 2009 as the baseline year. To this end, a region-based model of Spanish arable agriculture is built, capturing the heterogeneity of the sector. Due to the scarcity of official EC data for Spain, the agricultural supply could not be modeled at farm level but at regional level. Hence, those administrative territorial units or Autonomous Communities ${ }^{2}$ (hereinafter called "regions") that concentrate the bulk of oilseed production were included in the model. Table 3.14 shows these regions and their corresponding provinces, which accounted for $99.7 \%$ and $96.5 \%$ of the total production of sunflower and rapeseed in Spain in 2009, respectively (MAGRAMA, 2010a). Subsequently, crops

\footnotetext{
2 Autonomous Communities in Spain correspond to the NUTS-2 level of the EU, while provinces correspond to the NUTS-3 level. The NUTS classification system (from "Nomenclature of Units for Territorial Statistics") is a geocode standard for referencing the subdivisions of countries in the EU for statistical purposes and currently consists of three levels (NUTS-1, -2 and -3 ) established by Eurostat. The NUTS system is instrumental in the EU's Structural Fund delivery mechanisms.
} 
covering at least $2 \%$ of the total arable land in each province were included, accounting for almost the entire agricultural land available in each region, between $92 \%$ and $100 \%$, depending on the case. All the crops in the agri-module, as well as their abbreviations, are shown in Table 3.15.

Under this approach, the model selects the set of activities (cropping plan) that maximizes the total agricultural surplus in each province (as an aggregate of all the farms in it), given the expansion of bioenergy crops. This permits an analysis of the effects of the increased supply of oilseeds on farmers' incomes, and the subsequent emissions. The demand for non-energy crops is assumed to be constant at a national level (as the sum of the regions considered), implying that the overall production of each of these crops must be the same before and after the policy shock. Bioenergy uses are separated from food uses in the case of both rapeseed and sunflower, leading to two different commodities, as can be seen in Table 3.15, which prevents an increase in production at the expense of food consumption. The gross margin of a unit of area diverted to each crop is calculated based on prices, yields and variable costs. Increased bioenergy production, as well as displaced crops, will be relocated to those provinces in which yields are higher and costs are lower, in order to keep overall production of food crops constant. At the same time, the crop distribution is governed by resource availability and technical and policy constraints (as shown in section B1 of annex B). The main constraints are mainly related to total available land (irrigated and non-irrigated), irrigation water availability, crop rotations, market quotas, and cross-compliance criteria ${ }^{3}$. Fallow is included as an activity and a minimum fallow land requirement is introduced too, since it is indeed needed for agronomic reasons (e.g. to improve the soil structure and fertility, the hydrological balance, etc) although it is not profitable in the short term. Perennial crops, such as fruit trees, are not considered since they are not readily convertible into annual crops or vice versa; land use change would imply additional investment, not captured in the gross margin calculation. For this reason, greenhouse crops (e.g. in Almería) are neglected too, although the possibility of switching from rainfed crops to irrigated ones is allowed, and vice versa, entailing differences in electricity and water consumption (with higher costs).

\footnotetext{
${ }^{3}$ Cross-compliance measures are a set of rules on good agricultural and environmental conditions of rural areas, aimed at making European agriculture more sustainable in the long-run. These are mainly designed on the bases of nitrate limits in fertilization, the protection of Natura 2000 areas, food safety, animal welfare and the traceability of food from animals. They mainly cover directives and regulations (referred to as "statutory management requirements") that apply to all farmers, especially to those receiving CAP payments.
} 
Table 3.14. Provinces of each region considered in the model, corresponding to major oilseed-producing regions in Spain.

\begin{tabular}{|c|c|c|c|c|c|c|c|c|c|c|c|c|c|}
\hline \multicolumn{2}{|c|}{ Andalucía: } & \multicolumn{2}{|c|}{ Castilla y León: } & \multicolumn{2}{|c|}{$\begin{array}{l}\text { Castilla-La } \\
\text { Mancha: }\end{array}$} & \multicolumn{2}{|c|}{ Catalunya: } & \multicolumn{2}{|c|}{ Extremadura: } & \multicolumn{2}{|c|}{ Navarra: } & \multicolumn{2}{|c|}{ Aragón: } \\
\hline e01 & Almería & e09 & Ávila & e18 & $\begin{array}{l}\text { Albacete } \\
\text { Ciudad }\end{array}$ & & Barcelona & e27 & Badajoz & e29 & Navarra & & Huesca \\
\hline e02 & Cádiz & e10 & Burgos & e19 & Real & e24 & Girona & e28 & Cáceres & & & e31 & Teruel \\
\hline e03 & Córdoba & e11 & León & e20 & Cuenca & e25 & Lleida & & & & & e32 & Zaragoza \\
\hline e04 & Granada & e12 & Palencia & e21 & Guadalajara & e26 & Tarragona & & & & & & \\
\hline e05 & Huelva & e13 & Salamanca & e22 & Toledo & & & & & & & & \\
\hline e06 & Jaén & e14 & Segovia & & & & & & & & & & \\
\hline e07 & Málaga & e15 & Soria & & & & & & & & & & \\
\hline e08 & Sevilla & e16 & Valladolid & & & & & & & & & & \\
\hline & & e17 & Zamora & & & & & & & & & & \\
\hline
\end{tabular}

Table 3.15. Crops included in the model of the Spanish agricultural sector and their abbreviations in GAMS. B: for bioenergy uses, $\mathrm{F}$ : for food uses.

\begin{tabular}{|c|c|c|c|c|c|c|c|c|c|}
\hline \multicolumn{2}{|c|}{ Cereals: } & \multicolumn{2}{|c|}{ Vegetables: } & \multicolumn{2}{|c|}{ Industrial crops: } & \multicolumn{2}{|c|}{ Legumes: } & \multicolumn{2}{|c|}{ Fodder crops: } \\
\hline trb & Soft wheat & esp & Asparagus & sgb & Sugarbeet & hab & Broad beans & alf & Alfalfa \\
\hline $\operatorname{trd}$ & Durum wheat & let & Lettuce & $\cot$ & Cotton & Ien & Lentils & sve & $\begin{array}{l}\text { Fodder } \\
\text { vetch }\end{array}$ \\
\hline bar & Barley & san & Watermelon & gir & Sunflower (F) & gar & Chick peas & Tub & \\
\hline ave & Oats & tom & Tomato & girb & Sunflower (B) & gui & Peas & pat & Potato \\
\hline cen & Rye & ceb & Onion & rap & Rapeseed (F) & vez & Vetch & Fall & \\
\hline trt & Triticale & alc & Artichoke & rapb & Rapeseed (B) & & & fall & Fallow \\
\hline ric & Rice & pim & Pepper & ani & Anis & & & & \\
\hline mze & Corn & & & & & & & & \\
\hline
\end{tabular}

The agri-model is built on the input data on the yields, area, variable costs and water needs of each crop in each province under the corresponding technique (irrigation vs. no irrigation). The crop yield and area vary depending on the province and technique, according to 2009 data from the Statistical Yearbook of the Spanish Ministry of Agriculture (MAGRAMA, 2010a). For fallow land, the lowest yields detected in the dataset under both irrigation and rainfed conditions were considered, following the approach of IDAE (2011b), in the event that cropland expands at the cost of fallow. Variable costs include seeds or seedlings, fertilizers, pesticides, electricity, fuels, water, insurance and other miscellaneous costs, and labor. As far as variable costs are concerned, it must be noted that the Spanish Farm Accountancy Data Network (FADN) has available data about the cost structure of agricultural holdings up to 2005. In the absence of more detailed information, variable costs from Catalunya (gathered and reported annually by the Catalan FADN) were applied to the remaining regions, except for specific crops (e.g. sunflower, soft wheat, durum wheat, barley, etc), particularly important in some regions, for which there were official regional reports on the cost structure (MAGRAMA, 2010c,d). The availability of irrigation water was calculated by using data about the blue water consumption of crops reported by Mekonnen and Hoekstra (2010). Finally, prices are assumed to be constant and set exogenously, 
calculated as the 2009 average of each crop in the most important wholesale markets in Spain, assuming that all agricultural goods are sold in a single domestic market and, thus, prices are the same across the territory. The resulting dataset represents the situation of the agricultural sector in 2009, which is the baseline for the simulation.

It must be highlighted that the gross margin in the model is not exactly the same as that in the FADN data (defined in Regulations 79/65/EEC and 868/2008), since family and hired labor are both considered in the calculation underlying the present model. This is in order to take the opportunity cost into account, since employing family labor avoids hiring people, although this can slightly reduce some gross margins. Indeed, some rainfed crops result in negative margins. However, these are offset when adding up agricultural support from the Common Agricultural Policy (CAP) under Regulations 1782/2003 and 73/2009, which still include direct payments despite the trend to decouple subsidies since the CAP Health Check in 2003. Specifically, direct aids exist for:

- Durum wheat, but only in some specific provinces (where yields are the lowest), under a regionalization scheme.

- Protein crops and cereals, also under a regionalization scheme.

- Sugarbeet, according to Regulation 318/2006.

- Rice, peas and cotton, assuming that cross-compliance criteria are met.

The current CAP (Regulations 202/2012 and 1013/2013) enacts a single payment scheme for totally decoupling support, based on income-support to farmers subject to cross-compliance measures. In Spain, Royal Decree 1680/2009 transposes EC Regulation 73/2009, while Royal Decree 486/2009 establishes the environmental requirements to be fulfilled by farmers in compliance with the cross-compliance scheme.

Besides resource constraints, a quota for sugarbeet is implemented in the same way as Haque et al. (2009). Since sugarbeet is very profitable, it is assumed that the total area diverted to this crop in 2009 corresponds to those farms holding a quota and possessing considerable experience as to its cultivation; thus, that is the maximum area for sugarbeet in a given region. The most representative rotation constraints affecting rainfed agriculture in the regions in the model are also defined (according to Urbano and Moro 1992). Unfeasible combinations of crop-technique, such as rainfed rice, are not allowed. These constraints try to avoid arbitrary adjustments or ad hoc data manipulations to capture farmers' behavior, as recommended by Rozakis et al. (2008). The algebraic notation of the model equations together with the associated indices, parameters and decision variables are detailed in section B1 of annex B. 


\subsubsection{Agri-model calibration}

Despite all the constraints explained above, a validation process revealed that the outcome of the agricultural model was significantly different to the observed activity patterns. This means that the actual situation is suboptimal and farmers do not necessarily produce those crops with higher margins. In fact, crops with negative margins appear in the baseline. These practices are actually observed when analyzing agricultural systems. Apart from the influence that using average variable costs may have on these margins, this indicates that there are other forces besides profit maximization that equally drive farmers' decisions but are not taken into account, such as risk-aversion, opportunity costs, etc. Even climatic conditions and unpredictable natural events can result in higher, but usually lower, production levels than farmers planned. Arriaza and Gómez-Limón (2003) found, in their comparative study focused on Spanish agriculture, that the best predictions of farmers' responses (e.g. for policy impact assessment) are obtained by means of models that include both expected profit and a qualitative measure of crop riskiness. However, implementing these features requires good quality data, often available after interaction with the decision-maker, which is not our case. The agricultural module can be considered a farm-type model, as referred to by Ciaian et al. (2013); however, due to the lack of detailed data, it does not explicitly capture farm heterogeneity, making it necessary to conform to the use of aggregated regional data. Hence, another approach was chosen to calibrate the agricultural model, which does not require the use of detailed data at farm level. It consists of defining a multi-objective function with two attributes in order to maximize total agricultural income, while minimizing the relative deviation between the initially observed areas in 2009 and the ones obtained by the model in absolute terms. The weight given to this second attribute in the objective function is relatively small in order not to overshadow the optimization criteria. Hence, a calibration process still had to be carried out in order to find a stable solution which represented a baseline for the biodiesel shock. In total, 10 iterations were performed, and outcomes are shown in Figure 3.15, after aggregating areas at regional level. Outcomes at provincial level are discussed in section B2 of annex B. As can be observed, the optimal results of the agri-model closely approach the observed areas of each crop at regional level; thus, they can be used as a baseline in order to predict the farmers' behavior when different policies are in force or under different market conditions, as in the present section. 


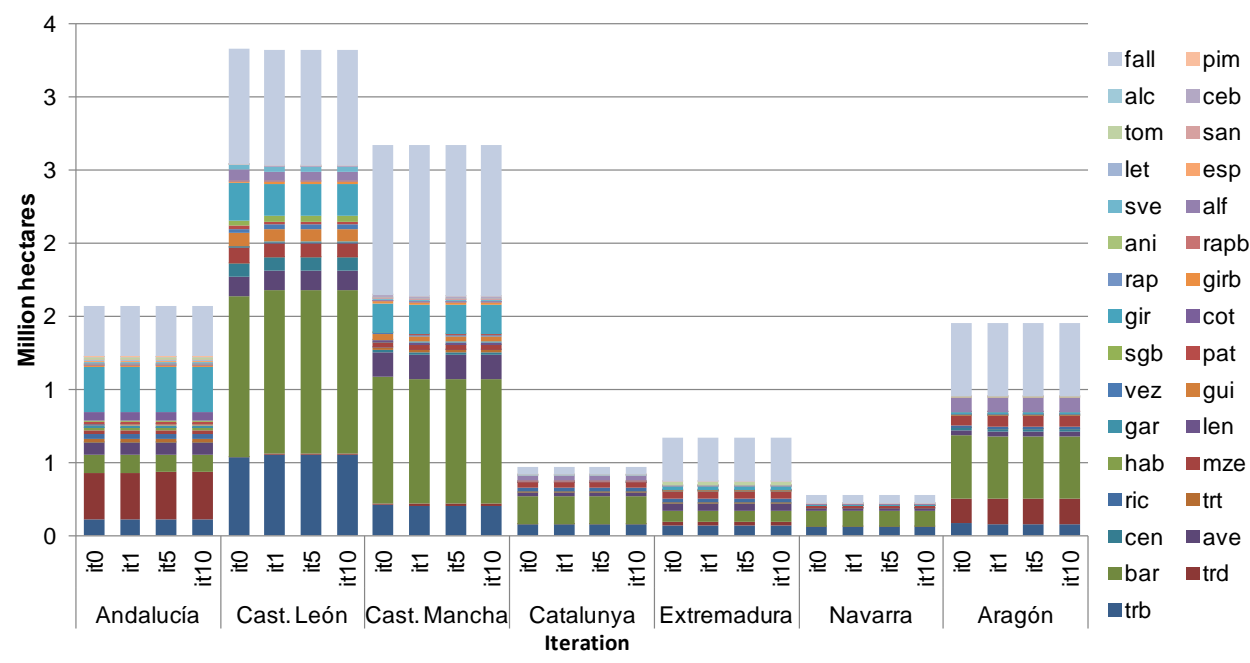

Figure 3.15. Calibration results from the agricultural module optimization through the subsequent iterations. Iteration 0 (it0) refers to the observed situation, while iteration 10 (it10) constitutes the baseline situation for the analysis.

\subsubsection{Emissions module}

Environmental effects generated by the optimal activities are estimated by means of the LCA methodology, by following the guidelines under ISO 14040 (and 14044) $(2006 a, b)$. The outcomes are referred to a Functional Unit (FU), which, in this section, is the amount of biodiesel to be produced in Spain (2.58 Mt) so as to meet the projected demand in 2020 in compliance with the RED's targets and sustainability criteria. For the impact assessment, the CML 2001 (baseline) (Guinée et al., 2002) is applied in order to analyze the following impact categories under a midpoint approach: global warming ( $\mathrm{GW}$, in terms of $\mathrm{CO}_{2}$-eq.), eutrophication (in terms of $\mathrm{PO}_{4}{ }^{3-}$-eq.), freshwater aquatic ecotoxicity (FAE, in terms of DCB-eq.), and acidification (in terms of $\mathrm{SO}_{2}$-eq.). These are critical impact categories when assessing agricultural systems and, thus, biofuel ones (Börjesson and Tufvesson, 2011; Brentrup et al., 2004). For the purposes of quantifying GW, $\mathrm{CO}_{2}, \mathrm{~N}_{2} \mathrm{O}$ and $\mathrm{CH}_{4}$ emissions are taken into account, as the RED/FQD specifies, with the corresponding $\mathrm{CO}_{2}$ equivalence factors drawn from the IPCC (2006) for a 100 -year time horizon. Another module is thus implemented to calculate these impacts, arising from the corresponding emissions through the entire supply chain, which is explained in detail. 


\subsubsection{Biodiesel pathways from domestic virgin oils}

Emissions from the production pathway of the biodiesel manufactured from domestic virgin oils are calculated, based on the following sub-stages and the corresponding data sources:

a) Seed production and appropriation (for sowing). For the calculation of the emissions from the production of the seeds for sowing and the subsequent transport to the farms, the standard processes from the Ecoinvent v.2.2 database (Hischier et al., 2010) were used; specifically, rapeseed in Central Europe and sunflower seed in Castilla y León (Spain).

b) Fertilizer production and application. Fertilization needs (expressed as $\mathrm{N}$, $\mathrm{P}_{2} \mathrm{O}_{5}$ and $\mathrm{K}_{2} \mathrm{O}$ ) were included for all the crops, depending on the province in which they were cultivated so as to further analyze the indirect impacts arising from the relocation of the activities. They were gathered from MAGRAMA (2010b) for all the crops, except in the case of rice and asparagus, for which specific reports from the Valencian Institute for Agricultural Research (IVIA) and the Navarre Institute of Agrotechnology (INTIA) were used, respectively. GHG emissions from fertilizer production, also including the transport to the farm, were taken from Annex II of the study by IDAE (2011b). Procedures described by Nielsen et al. (2003) were applied to estimate the rest of the emissions, based on the energy consumption in the production of fertilizers. Subsequently, GHG emissions from fertilizer application and land management $\left(\mathrm{CH}_{4}\right.$ and direct and indirect $\mathrm{N}_{2} \mathrm{O}$ ) were calculated by means of the IPCC guidelines (2006) under the Tier 1 procedure. Other emissions were estimated by using different data sources: for $\mathrm{NH}_{3}$ emissions to the air, the EMEP/EEA guidebook (2013) was used; and for nitrate leaching, the average runoff per region was calculated as a percentage of the $\mathrm{N}$ input of each crop (MAGRAMA, 2011).

c) Pesticide production and application. The quantity of pesticides needed varies from crop to crop and this information was gathered from IDAE (2011b), in terms of carbofuran, linuron, deltamethrin, pendimethalin, dimethenamide and metazachlor. GHG emissions from their production were taken from the same source, while emissions involved in the rest of the impact categories were extracted from Ecoinvent v.2.2 (Hischier et al., 2010). For the purposes of estimating the FAE impact associated with the pesticide application, the same principles used by Berthoud et al. (2011) were chosen to determine the fraction of the pesticide that goes to each environmental compartment. Specifically, they assume that $0.5 \%$ of the dose applied goes to surface water; the fraction going to air is drawn from 
the vapor pressure of the pesticide, and the remaining fraction goes to soil (with a maximum of $85 \%$ ).

d) Agricultural machinery and electricity from irrigation. The input data on agricultural practices, in terms of hours per ha, was gathered again from IDAE (2011b) for each region, as well as the electricity demand for irrigation purposes. In order to calculate the associated emissions, the fuel consumption of the average machinery included in the study by Nemecek et al. (2007) was used, together with the emissions from fuel and electricity production from Ecoinvent v2.2 (Hischier et al., 2010).

e) Seed transport. Emissions from the transport of oilseeds to the oil extraction plant were calculated based on data from IDAE (2011b) (tkm of road and rail transport, at regional level), in combination with Ecoinvent v2.2 data (Hischier et al., 2010) (emissions per tkm).

f) Oil transport. Emissions from the oil transport to the transesterification plant, including those from the collection of UCO, are estimated by using average distances per ton of oil in the study of Lechón et al. (2006), and emissions from Ecoinvent v2.2 (Hischier et al., 2010).

g) Industrial production. Emissions from industrial production are calculated based on the inventory in IDAE (2011b), including oil extraction, refining and transesterification. The production of all the inputs is considered for the impact assessment. Specifically, the extraction requires water, hexane, electricity and natural gas. The amount of each input depends on the seed being processed. The refining uses water, phosphoric acid, caustic soda, bleaching clay, and other chemicals, together with energy. These inputs also depend on the type of seed. It is assumed that these sub-stages are carried out in the same facility. Finally, the transesterification is carried out separately, implying the use of water, methanol, catalyst, hydrochloric acid, and energy. The overall emissions-eq. generated per unit of input are obtained from Ecoinvent v.2.2 (Hischier et al., 2010), by using average industrial production processes (as in IDAE, 2011b).

Adding up the emissions of compound-eq. $\left(\mathrm{CO}_{2}\right.$-eq., $\mathrm{PO}_{4}{ }^{3-}$-eq., DCB-eq., and $\mathrm{SO}_{2}$-eq.) from the sub-stages a), b), c), d) and e) permits the establishment of the emission factors per hectare of crop cultivated in each specific region, with or without irrigation. In order to determine the impacts arising from those biodiesel pathways entailing domestic oilseeds, emission factors must be multiplied by the area extension devoted to bioenergy crops in the corresponding provinces. In addition, the calculation of emission factors per crop at provincial level allows the overall impacts from the arable sector before and after the experiment to be determined. This can be considered a proxy for ILUC emissions from oilseed 
expansion in Spain in the period 2009-2020, as a consequence of the increase in biodiesel demand, which can be used for further discussion on the RED's sustainability criteria. Since the agricultural model assumes that the expansion of bioenergy in Spain only takes place at the expense of available arable land, emissions from direct LUC in those biodiesel pathways using domestic feedstock are zero, according to the Tier 1 procedure in the IPCC guidelines (2006).

\subsubsection{2 . Biodiesel pathways from imported virgin oils}

In the case of the imported virgin oils pathways, the emissions are estimated based on the inventory in section 3.3.2.3, which are, in turn, gathered from Panichelli et al. (2009) and Ecoinvent v.2.2 (Hischier et al., 2010). Life cycle emissions from the biomass production up to the transport to the biodiesel plant are added up, allowing the calculation of compound-eq. emission factors per unit of imported vegetable oil in regional storage in Spain. These include exactly the same substages as those considered for the production of domestic vegetable oils, together with the transoceanic transport. Emissions from this last sub-stage are estimated by using average distances between ports and transportation systems from Ecoinvent v2.2. The carbon uptake by plant photosynthesis is excluded, as mandated by the RED/FQD. It is assumed that the data associated with Malaysian palm oil production in the study by Escobar et al. (2014) also apply to the aggregated commodity palm oil from Malaysia-Indonesia defined in the current model, since average production practices are very similar in both palm-producing countries. However, some modifications with respect to the study in section 3.3 regarding the calculation of GHG emissions from direct LUC are introduced. For the present assessment, the carbon pools reported by Gasparri et al. (2008), Germer and Sauerborn (2008), and Reijnders and Huijbregts (2008) have been taken into account. These studies include detailed information on the carbon stock in soil and biomass of different ecosystems in the exporting countries considered (Argentina, Malaysia-Indonesia and Brazil, respectively), which provides greater versatility when analyzing increases in the $\mathrm{GHG}$ reduction thresholds. $\mathrm{CO}_{2}$-eq. emissions per ton of palm and soybean oil have subsequently been estimated by assuming an average oil yield of $4 \mathrm{t} / \mathrm{ha}$ and $0.5 \mathrm{t} / \mathrm{ha}$, respectively (Carter et al., 2007), and annualized by following the IPCC guidelines (2006). Reijnders and Huijbregts (2008) assume that soybeans in Brazil are grown in rotation with corn on cleared land; hence, only half of the corresponding emissions are allocated to soybean oil. Panichelli et al. (2009) state that soybeans in Argentina can be grown in monoculture as well as in rotation with corn or sunflower. Since no data is available on the actual proportion of soybean being cultivated in monoculture or rotation, the same allocation coefficient as in Brazil has been considered in order to determine direct LUC emission factors. 


\subsection{Biodiesel pathways from UCO}

Obviously, all the stages listed take place within the FGBs' production pathways. As explicitly indicated in the RED/FQD for the calculation of GHG savings, the UCO pathway starts with its collection and all the emissions up to this stage are assumed to be zero. In the case of the imported UCO, the emissions from the export sub-stage are also calculated in this module, based on estimations of the distance between the main exporting countries (US and France) and Spain, and the fuel consumption from average transportation systems in Ecoinvent v2.2.

\subsection{Partitioning}

For the LCA of those biofuel pathways involving virgin oils, when co-products are generated, a partitioning method is applied to estimate the environmental burdens allocated to the main product (oil and biofuel). In this case, partitioning is applied based on the energy content, as recommended by the RED/FQD. The allocation factor in biodiesel production was determined on the basis of the co-products' lower heating value (LHV), while allocation factors in the oil extraction stages were determined on the basis of the LHV of the vegetable oil and the metabolizable energy content of the protein meals (as in Esteban et al., 2011). For the purposes of summarizing, the energy content considered for each co-product, as well as the data sources, is drawn up in Table 3.16.

Table 3.16. Energy content of each co-product considered for the calculation of allocation factors in the emissions module. Note that, for the meal co-products, the metabolizable energy content is calculated by taking a value of $8.40 \mathrm{MJ}$ per $\mathrm{kg}$ of protein into account (Balmer, 2011).

\begin{tabular}{lcl}
\multicolumn{1}{c}{ Co-product } & $\begin{array}{c}\text { Energy content } \\
\text { (MJ/kg) }\end{array}$ & \multicolumn{1}{c}{ Data source } \\
\hline $\begin{array}{l}\text { a) Transesterification: } \\
\text { Biodiesel }\end{array}$ & 37.53 & GREET 2010 \\
Glycerin & 14.30 & Albarelli et al. 2011 \\
b) Oil extraction: & & \\
Soybean oil & 37.56 & Mehta and Anand 2009 \\
Palm oil & 37.36 & Mehta and Anand 2009 \\
Rapeseed oil & 37.64 & Mehta and Anand 2009 \\
Sunflower oil & 37.59 & Mehta and Anand 2009 \\
Soybean meal & 3.70 & Reinhard and Zah 2011 \\
Palm kernel meal & 1.25 & Reinhard and Zah 2011 \\
Rapeseed meal & 2.77 & Reinhard and Zah 2011 \\
Sunflower meal & 2.52 & Reinhard and Zah 2011
\end{tabular}

As a result of integrating all the aforementioned modules, the model calculates the life cycle emissions of $\mathrm{CO}_{2}$-eq., $\mathrm{PO}_{4}{ }^{3-}$-eq., DCB-eq., and $\mathrm{SO}_{2}$-eq. generated by the optimal configuration of the supply chain in Spain. This allows for the GHG saving 
thresholds in the RED/FQD to be implemented as a constraint on the agroindustrial supply. Hence, the model's output is exactly the same as the FU: $2.58 \mathrm{Mt}$ of biodiesel, leading to an overall GHG emissions saving of $35 \%$ (and higher) relative to the reference fossil fuel as considered by Laborde (2011). As in the Directives, the model allows consignments of raw materials or biofuels with differing sustainability characteristics to be mixed, in order to fulfill the overall GHG savings requirements.

\subsubsection{Policy and land use scenarios}

Four different scenarios have been considered, allowing for different policy issues to be analyzed, in terms of supply-chain welfare and environmental impacts. Specifically, the proposed scenarios depict both the increasing levels of GHG reduction thresholds in accordance with the RED/FQD and two different prices of biodiesel from UCO, one representing the current market price in Spain (the same as that of biodiesel from virgin oils) and another representing a double-counting scheme. This measure reduces the overall amount of biodiesel in the blend by half (and thus the actual input of UCO necessary for the mandate), which is beneficial for the blenders since biodiesel is still not competitive with fossil diesel. Hence, the double-counting translates into a higher market price for advanced biofuels. For this possibility, the sale price of the Spanish UCO biodiesel in France has been considered. The neighboring country already implemented a double-counting scheme, becoming a great market for the UCO biodiesel manufactured in Spain, since it is sold at a higher price. Prices have been established after personal communication with some biodiesel plants in Spain. The four scenarios consist of the following policy measures: 1) no double-counting scheme, no GHG emission constraint, 2) double-counting scheme, 35\% GHG emission reduction requirement, 3) double-counting scheme, 50\% GHG emission reduction requirement, and 4) double-counting scheme, 60\% GHG emission reduction requirement. In addition, when the emission constraint holds, different emission factors of $\mathrm{CO}_{2}$ from direct LUC per ton of oil have been considered for the imported virgin feedstock, as introduced in section 3.4.2.4.2. Each of these factors corresponds to an ecosystem that can be potentially converted into oil crops in Argentina, Brazil and MalaysiaIndonesia. Specifically, the ecosystems that have been taken into account are as follows:

- In Argentina ("ar"): continuous dry forest of El Chaco ("chaco"), and tropical montane Andean or Yungas forest ("yungas"), according to Gasparri et al. (2008).

- In Brazil ("br"): tropical Brazilian forest ("tropic") and Cerrado savannah ("cerra"), according to Reijnders and Huijbregts (2008). 
- In Malaysia-Indonesia ("my_in"): peatland ("peat"), tropical rainforest ("rainfo") and degraded grassland ("grass"), with previous biomass burning, according to Germer and Sauerborn (2008).

Table 3.17. Formulations of scenarios 2, 3 and 4 depending on the ecosystem that is transformed in each region to produce $1 \mathrm{t}$ of vegetable oil for export, and the subsequent annualized $\mathrm{CO}_{2}$ emissions. Soyo: soybean oil; palmo: palm oil; chaco: Chaco forest; yungas: Yungas forest; tropic: Brazilian tropical forest; cerra: Cerrado savannah; peat: peatland; rainfo: tropical rainforest in Southeast Asia; crop: arable cropland; grass: degraded grassland.

\begin{tabular}{c|cc|cr|ll} 
& \multicolumn{5}{|c}{ Land Use Change emissions (t of $\mathbf{C O}_{2}$ I $\mathbf{t}$ of vegetable } \\
oil-year)
\end{tabular}

The sustainability criteria in the RED/FQD also specify that biofuels coming from some of the aforementioned ecosystems are ineligible to meet the targets. Hence, conversion from cropland ("crop") has been considered in Argentina and Brazil, assuming that soybeans cause a small carbon uptake when no-tillage farming systems are established, according to data from Reijnders and Huijbregts (2008). It is expected that the GHG saving requirements would promote such land conversion, since biofuels produced on land with high carbon content are less likely to fulfill them. By considering different land uses, it is possible to discern whether the GHG saving thresholds are indeed sufficient in themselves to prevent the conversion of carbon-rich ecosystems, such as peatlands, tropical rainforests or even the Cerrado savannah. Hence, three versions of those scenarios in which the RED is binding have been formulated, as summarized in Table 3.17, including the corresponding emissions factors per ton of vegetable oil. The three ecosystem combinations may be understood as a worst-case, intermediate and best-case scenario, respectively. Scenario 1 considers the same ecosystems as scenarios 2.1, 3.1 and 4.1. 


\subsubsection{Results}

\subsubsection{Optimal mix, emission factors and GHG savings}

Non-linear solvers are used in GAMS to determine which sector configuration is optimal for the production of $2.58 \mathrm{Mt}$ of first and second-generation biodiesel in Spain. The emission factors and unit costs of each pathway in the consumption mix, as well as the subsequent impacts, are also obtained as model outcomes. Figure 3.16 shows the composition of the optimal oil mix for the different scenarios, which amounts to $2.66 \mathrm{Mt}$ in scenario 1 (without double-counting) and $1.76 \mathrm{Mt}$ in the rest. It must be noted that around $80.5 \%$ of the sector's capacity is devoted to producing first-generation biodiesel, while the remaining $19.5 \%$ is intended for the production of advanced biodiesel, mostly from UCO. The GHG emission factors and saving coefficients in each scenario formulation are shown in Table 3.18 for further discussion.

In scenario 1, since the sector is only driven by profit-maximization, with no environmental constraints, biodiesel is entirely produced from virgin oils, while UCO plants remain idle. UCO biodiesel is highly unprofitable due to higher operational costs as compared with first-generation biodiesel, while market prices are the same. As a result, the two cheapest oils on the international market, palm and soybean, account for almost the entire market share in Spain (98.9\%). Producers opt for Argentinian soybean oil over Brazilian since freight costs are lower (€54.74 vs. €68.17 per ton according to OECD, 2015) and the biodiesel producers are responsible for them. This composition is consistent with the consumption mix in Spain of the last few years (CNE, 2013) before the imports of the final product from Argentina and Indonesia were severely reduced under the new tariff regime. The absence of a national double-counting scheme favors exports of UCO biodiesel to other MSs. Although there are no official reports after 2011, the monthly statistics for January 2013 (CNMC, 2013) reveal the following oil mix for domestic biodiesel production: $64.1 \%$ of palm oil, $24.2 \%$ of soybean oil, $10.1 \%$ of rapeseed oil and $1.5 \%$ of other oils. It must be borne in mind that imports of rapeseed oil from other European countries into Spain have not been considered in the model. In fact, as Carter et al. (2007) state, palm oil has become the major discount oil in the pivotal EU market, even allowing for its freight disadvantage in supplying this market from the opposite end of the globe. In this scenario, the mix does not depend on the ecosystems subject to LUC, since the associated GHG emissions are not decisive. 
Table 3.18. GHG emission factors ( $\mathrm{g} \mathrm{CO}_{2}$-eq./MJ) and saving coefficients (\%) of each feedstock in the optimal oil mix for each scenario formulation in which ecosystems make the difference. The emission factor of the reference fuel is $90.3 \mathrm{~g} \mathrm{CO}_{2} / \mathrm{MJ}$, gathered from Laborde (2011).

\begin{tabular}{|c|c|c|c|c|c|c|}
\hline & \multicolumn{2}{|c|}{ Scenario 2.1} & \multicolumn{2}{|c|}{ Scenario 2.2} & \multicolumn{2}{|c|}{ Scenario 2.3} \\
\hline Feedstock & $\begin{array}{c}\text { GHG } \\
\text { emission } \\
\text { factor }\end{array}$ & GHG saving & $\begin{array}{l}\text { GHG } \\
\text { emission } \\
\text { factor }\end{array}$ & GHG saving & $\begin{array}{c}\text { GHG } \\
\text { emission } \\
\text { factor }\end{array}$ & GHG saving \\
\hline sunfo.sp & 43.5 & $52 \%$ & 43.8 & $52 \%$ & 43.9 & $51 \%$ \\
\hline rapo.sp & 52.0 & $42 \%$ & 52.4 & $42 \%$ & 53.4 & $41 \%$ \\
\hline palmo.my_in & 285.8 & $-216 \%$ & 52.4 & $42 \%$ & 23.2 & $74 \%$ \\
\hline soyo.ar & & & & & 147.79 & $-64 \%$ \\
\hline soyo.br & & & & & 105.6 & $-17 \%$ \\
\hline uco.sp & 5.5 & $94 \%$ & 5.5 & $94 \%$ & 5.5 & $94 \%$ \\
\hline uco.fr & 11.5 & $87 \%$ & 11.5 & $87 \%$ & 11.5 & $87 \%$ \\
\hline \multirow[t]{2}{*}{ uco.us } & 15.0 & $83 \%$ & 15.0 & $83 \%$ & 15.0 & $83 \%$ \\
\hline & \multicolumn{2}{|c|}{ Scenario 3.1} & \multicolumn{2}{|c|}{ Scenario 3.2} & \multicolumn{2}{|c|}{ Scenario 3.3} \\
\hline Feedstock & $\begin{array}{c}\text { GHG } \\
\text { emission } \\
\text { factor }\end{array}$ & GHG saving & $\begin{array}{l}\text { GHG } \\
\text { emission } \\
\text { factor }\end{array}$ & GHG saving & $\begin{array}{l}\text { GHG } \\
\text { emission } \\
\text { factor }\end{array}$ & GHG saving \\
\hline sunfo.sp & 43.2 & $52 \%$ & 43.3 & $52 \%$ & 43.9 & $51 \%$ \\
\hline rapo.sp & 52.5 & $42 \%$ & 51.8 & $43 \%$ & 53.4 & $41 \%$ \\
\hline palmo.my_in & 285.8 & $-216 \%$ & & & 23.2 & $74 \%$ \\
\hline soyo.ar & & & & & 147.8 & $-64 \%$ \\
\hline soyo.br & & & 152.5 & $-69 \%$ & & \\
\hline uco.sp & 5.5 & $94 \%$ & 5.5 & $94 \%$ & 5.5 & $94 \%$ \\
\hline uco.fr & 11.5 & $87 \%$ & 11.5 & $87 \%$ & 11.5 & $87 \%$ \\
\hline \multirow[t]{2}{*}{ uco.us } & 15.0 & $83 \%$ & 15.0 & $83 \%$ & 15.0 & $83 \%$ \\
\hline & \multicolumn{2}{|c|}{ Scenario 4.1} & \multicolumn{2}{|c|}{ Scenario 4.2} & \multicolumn{2}{|c|}{ Scenario 4.3} \\
\hline Feedstock & $\begin{array}{c}\text { GHG } \\
\text { emission } \\
\text { factor }\end{array}$ & GHG saving & $\begin{array}{c}\text { GHG } \\
\text { emission } \\
\text { factor }\end{array}$ & GHG saving & $\begin{array}{c}\text { GHG } \\
\text { emission } \\
\text { factor }\end{array}$ & GHG saving \\
\hline sunfo.sp & 43.2 & $52 \%$ & 43.2 & $52 \%$ & 43.9 & $51 \%$ \\
\hline rapo.sp & 52.4 & $42 \%$ & 51.8 & $43 \%$ & 53.4 & $41 \%$ \\
\hline palmo.my_in & 285.8 & $-216 \%$ & & & 23.2 & $74 \%$ \\
\hline soyo.ar & & & & & 147.8 & $-64 \%$ \\
\hline soyo.br & & & 152.5 & $-69 \%$ & & \\
\hline uco.sp & 5.5 & $94 \%$ & 5.5 & $94 \%$ & 5.5 & $94 \%$ \\
\hline uco.fr & 11.5 & $87 \%$ & 11.5 & $87 \%$ & 11.5 & $87 \%$ \\
\hline uco.us & 15.0 & $83 \%$ & 15.0 & $83 \%$ & 15.0 & $83 \%$ \\
\hline
\end{tabular}




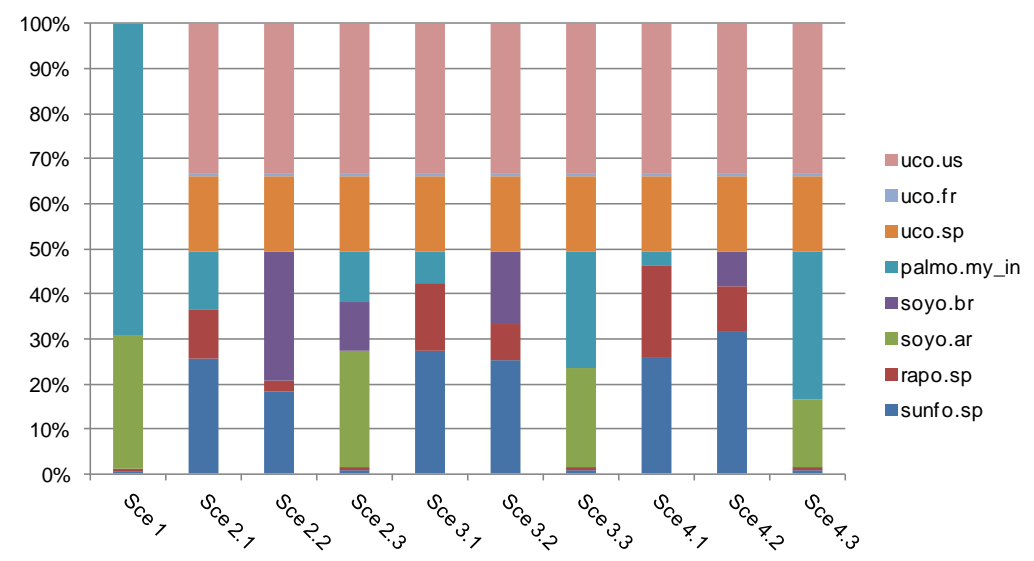

Figure 3.16. Oil mix for domestic biodiesel production under the different policy scenarios defined. Palmo.my_in: palm oil from Southeast Asia; rapo.sp: rapeseed oil from Spain; soyo.ar: soybean oil from Argentina; soyo.br: soybean oil from Brazil; sunfo.sp: sunflower oil from Spain; uco.fr: UCO from France; uco.sp: UCO from Spain; uco.us: UCO from the US.

The 35\% GHG saving obligation together with the double-counting implementation encourage the use of both domestic oilseeds and UCO. The share of UCO from US, Spain and France remains at 33.2\%, $17.0 \%$ and $0.6 \%$, respectively, in every formulation of scenario 2, with all the second-generation plants working at full capacity. All the UCO from France and Spain available on the market is used, due to lower transportation GHG emissions and costs than US UCO; however, this feedstock is also needed in order to meet the firms' demand. The remaining $49.2 \%$ of the market share corresponds to virgin oils, and, in this case, the presence of each feedstock depends on the ecosystems being transformed, since this greatly influences the GHG balance. Scenario 2.1 clearly promotes the use of domestic oilseeds, accounting for $36.6 \%$ of the overall biodiesel consumption in the country. This is because the biodiesel coming from both types of oilseeds, especially sunflower, avoids many more $\mathrm{CO}_{2}$-eq. emissions than imported oils, relative to the reference fuel. In scenario 2.2, soybean oil from Brazil gains market share (28.5\%) at the expense of palm oil, sunflower and rapeseed oil, becoming the only imported vegetable oil in the mix; this is because converting the Cerrado savannah generates much lower emissions than converting peatland or Yungas forest in Argentina and Malaysia-Indonesia, respectively. Scenario 2.3 again promotes the use of virgin oils, which account for $47.5 \%$ of the market. As observed in all the scenarios in which only low-carbon ecosystems are transformed, domestic oilseeds represent barely $1.7 \%$ of the oil mix. In this case, Argentinian soybean oil accounts for the largest share of the virgin oils (25.6\%) because it incurs lower feedstock costs (due to lower freight charges) than both the Brazilian and the Southeast Asian pathways. Although the direct LUC in Argentina generates carbon uptake, 
life cycle emissions from the manufacture of biodiesel lead to a $64 \%$ increase in the carbon intensity, while palm oil causes a $74 \%$ net carbon reduction. This indicates that the $35 \%$ GHG emission constraint leaves room for the profit-maximization criteria to prevail when choosing the mix.

When the GHG saving threshold is subsequently increased to $50 \%$ (and $60 \%$ ), the minimum fallow land constraint must be completely eliminated in order not to affect the supply of the remaining crops at national level. This indicates that the only way to fulfill greater reduction requirements is by using large quantities of domestic feedstock (provided that carbon-rich ecosystems are affected in biodiesel-exporting countries). As a consequence, under these scenario assumptions (scenarios 3.1, 3.2, 4.1, and 4.2), oilseed crops for bioenergy partly expand at the expense of fallow land, and the area diverted to this activity decreases in every province, mainly in non-irrigated land. LUC effects in Spain are further discussed in sections 3.4.3.3 and 3.4.4. As can be seen in Table 3.18, the carbon intensity of those pathways based on domestic feedstock is not exactly the same in all the scenario formulations. In each case, raw materials originate from different provinces, leading to different amounts of emissions from fertilizer application, which in turn depend on yields.

This particularly fosters the presence of rapeseed oil in the mix, which even reaches $20.3 \%$ in scenario 4.1 . The underlying reason is that this crop is generally produced in rotation with fallow land; with sunflower as well, but only in some regions (Castilla-La Mancha and Castilla León) (see section B1 of annex B for further information on how agricultural constraints work). However, sunflower oil still accounts for a larger share than rapeseed oil in all the aforementioned scenario formulations (between $25.4 \%$ and $31.5 \%$ ); it is more widely grown across Spain, as reflected in the baseline data, and has lower carbon footprints, as observed in Table 3.18. All the UCO plants keep running at full capacity, mostly due to the double-counting scheme. In scenario 3.1, palm oil is used for the production of $6.8 \%$ of the biodiesel, since it delivers the lowest GHG emissions compared with the rest of the imported oils, and the same occurs in scenario 3.2 with Brazilian soybean oil, since it comes from the Cerrado savannah; its share is, however, reduced relative to scenario $2.2(15.8 \%$ vs. $28.5 \%)$. In scenario 3.3 , palm oil and soybeal oil from Argentina take almost the entire market share of first-generation biodiesel (25.5\% and $21.9 \%$, respectively) for both environmental and economic reasons. As has been said, palm oil biodiesel brings much greater GHG benefits than soybean biodiesel, but soybean oil from Argentina still accounts for a remarkable share, due to its competitive price and lower freight costs.

Finally, the $60 \%$ GHG saving threshold in scenarios $4.1,4.2$ and 4.3 reinforces the trend observed in scenarios 3.1, 3.2 and 3.3. It encourages the use of larger amounts of domestic vegetable oils, delivering higher GHG savings, as seen in 
Table 3.18. As will be discussed below, this comes at the expense of the supply chain's welfare, since sunflower oil is the most expensive oil on the Spanish market. The share of palm biodiesel increases in scenario 4.3 relative to scenario 3.3 ; this pathway brings the highest carbon savings (74\%) of the virgin oils, since palm fruit bunches are grown on degraded grassland. It must be highlighted that scenario 4.1 is the one in which biodiesel production relies on domestic oilseeds and UCO to the greatest extent (97.1\%); thus, it is the most interesting option in terms of the Spanish supply chain's welfare, as Figure 3.17 confirms.

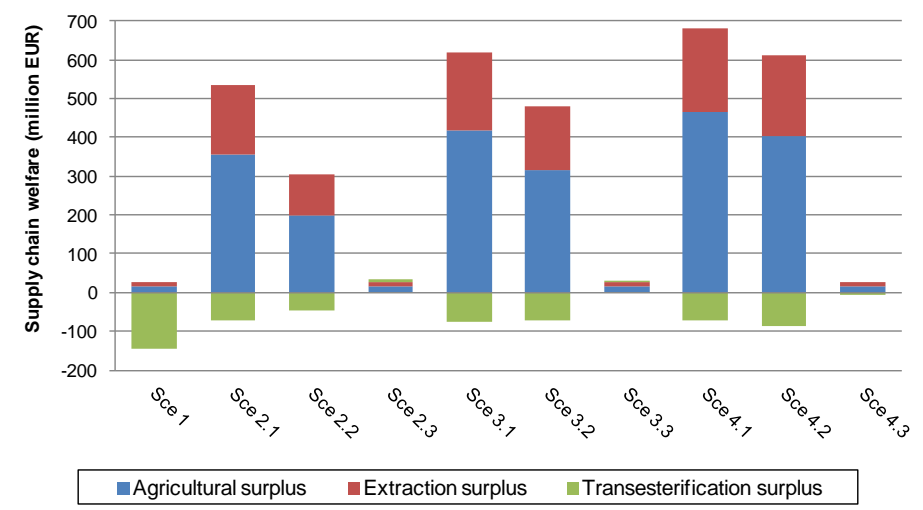

Figure 3.17. Overall welfare of the biodiesel supply chain in Spain (million EUR), calculated as the sum of the stakeholder's individual surpluses (raw material production, oilseed crushing and oil transesterification).

As expected, the greater the share of oil from domestic oilseeds in the mix, the higher the levels of welfare. The lowest welfare is obtained for scenario 1 , since all the biodiesel plants incur losses (between €27.2 and €92.3 per ton), while UCO plants remain idle due to higher operational costs. Even the biggest plants based on first-generation technology show negative margins because they are assigned those oils from domestic oilseeds, implying higher feedstock costs. It must be noted that the greatest contributor to the overall costs of the biodiesel plants in scenario 1 is the cost of the raw material (between $75.6 \%$ and $78.4 \%$ ). In the subsequent scenarios, when double-counting is introduced, feedstock costs represent between $66.0 \%$ and $75.0 \%$ of the total costs of UCO plants, even accounting for as much as $80.4 \%$ in the case of the least profitable first-generation plants. In general, those plants with a higher nameplate capacity show lower unit production costs based on the function for investment cost estimation in the model, as outlined in the corresponding section (section 3.4.2.1), although margins also depend on the feedstock used and its origin. Apart from capital and freight costs, it must be recalled that others, such as energy, chemical, operational, personnel and distribution costs, are included. 
Increased thresholds of GHG savings yield greater welfare, since they favor the use of domestic oils (except in the case of scenario formulations 2.3, 3.3 and 4.3). This entails farming and extraction activities in the Spanish territory, activities that are highly profitable. For a given threshold, the scenario formulations yielding bigger profits across all the sub-stages are those that consider the first ecosystem combination (scenarios 2.1, 3.1 and 4.1), since it is detrimental to the environmental profile of the imported oils. However, the transesterification stage still remains unprofitable for both all the first-generation plants and for the three smallest plants using UCO, for which the double-counting price is not enough to compensate for higher unit investment costs. When the second ecosystem combination (scenarios 2.2, 3.2 and 4.2) is taken into account, overall welfare is lower; soybean oil from Brazil benefits from these scenario assumptions, as has been seen above. As a result, overall welfare ranges between 258.4 and 608.4 million EUR in the aforementioned scenario formulations, while it ranges between 19.3 and 32.9 million EUR in scenarios 2.3, 3.3 and 4.3, with the agricultural stage yielding the highest profits. Specifically, the agricultural surplus represents between $51.6 \%$ and $88.1 \%$ of the overall welfare in all the scenarios, with the exception of scenario 1 which has the highest share of imported feedstock. This scenario yields the lowest welfare results (-120.8 million EUR), since the added value of the oil benefits the producing countries.

\subsubsection{LCA results}

Environmental impacts arising from the production of $2.58 \mathrm{Mt}$ of biodiesel in Spain under each scenario formulation are shown in Figure 3.18 ( $a, b, c, d)$. LCA outcomes depend, on the one hand, on the oil mix underlying biodiesel consumption, and, on the other hand, on the emissions associated with the substages in each biodiesel pathway. Since estimating these emissions would have been very time-consuming, they were gathered from reliable literature depicting representative processes, and expressed in terms of $\mathrm{kg}$ of compound-eq. per $\mathrm{kg}$ of oil (or per $\mathrm{kg}$ of biodiesel in the case of transesterification). Agricultural emissions arising from the production of domestic oilseeds are expressed per unit of area; thus, they depend on the province in which the bioenergy crops are cultivated. 
a)

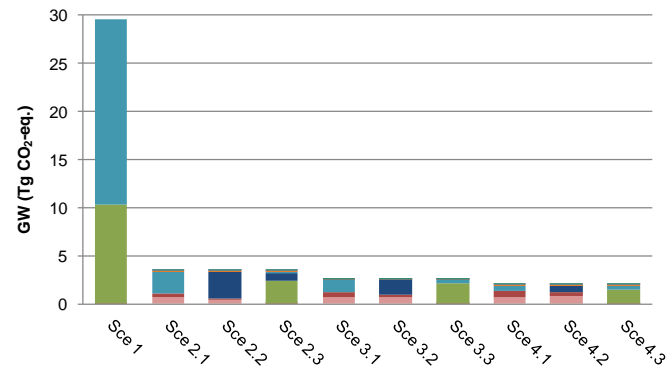

b)

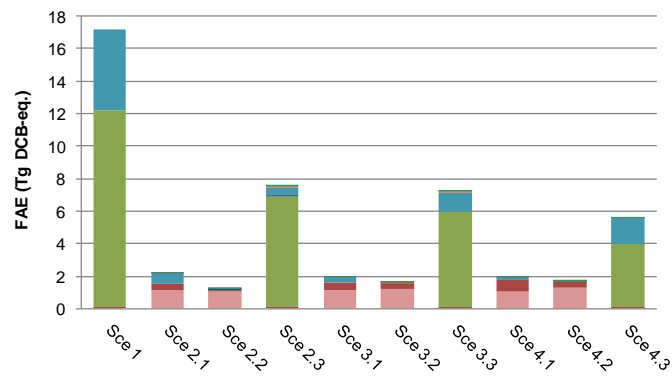

c)

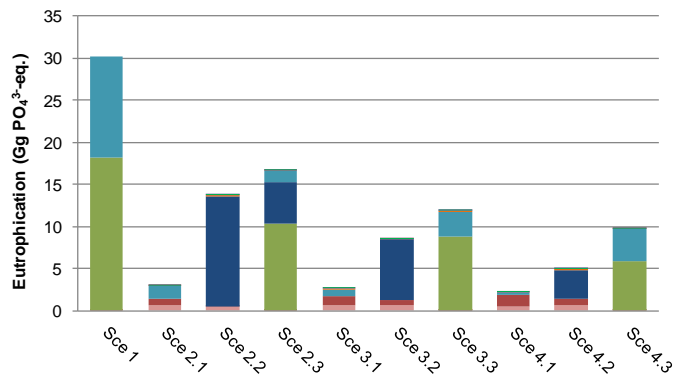

d)

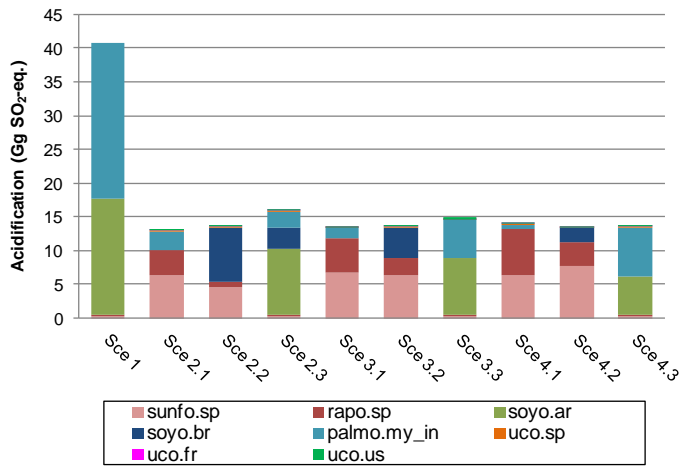

Figure 3.18. Overall LCA outcomes for the analyzed impact categories according to the CML 2001 (baseline) method. Palmo.my_in: palm oil from Southeast Asia; rapo.sp: rapeseed oil from Spain; soyo.ar: soybean oil from Argentina; soyo.br: soybean oil from Brazil; sunfo.sp: sunflower oil from Spain; uco.fr: UCO from France; uco.sp: UCO from Spain; uco.us: UCO from the US. 
The effects of the GHG saving threshold on the GW impact can be clearly observed in Figure 3.18 (a, b, c, d). Overall emissions show a downward trend from scenario 1 to scenario 4 . Specifically, scenario 2 causes an $87.9 \%$ reduction in GW relative to scenario 1 , which can be read as a reference situation, as previously discussed. Scenarios 3 and 4 entail a $90.9 \%$ and $92.8 \%$ reduction, respectively. $\mathrm{GW}$ is the highest in scenario 1 , mainly due to the contribution of the direct $\mathrm{CO}_{2}$ emissions from LUC when huge amounts of imported vegetable oils are used. This sub-stage accounts for $76.4 \%$ of the life cycle GHG emissions of palm biodiesel, while it accounts for $57.7 \%$ of the same kind of emissions from the Argentinian soybean biodiesel pathway. As an arable crop, soybean farming is substantially more input-intensive than palm plantations, thus the agricultural sub-stage also plays an important role in the soybean biodiesel life cycle, representing $35.7 \%$ of GW. In addition, it must be recalled that 1 ha of palm yields approximately 8 times more oil than 1 ha of soybean. As a result, the Argentinian soybean biodiesel pathway is more unfavorable than the pathway of palm biodiesel from MalaysiaIndonesia when considering the deforestation of el Chaco forest and tropical rainforest, respectively (13.4 vs. $10.8 \mathrm{~kg}$ of $\mathrm{CO}_{2}$-eq. per $\mathrm{kg}$ of product).

Introducing UCO in the oil input mix clearly helps to meet the GHG reduction targets; firstly, because it avoids producing the same amount of biodiesel, and secondly because the $\mathrm{GW}$ intensity varies between 0.2 and $0.6 \mathrm{~kg}$ of $\mathrm{CO}_{2}$-eq. per $\mathrm{kg}$ of biodiesel, depending on whether the residual oil is collected in Spain or imported. Similarly, using oil from domestic sunflower and rapeseed generates fewer GHG emissions than using imported virgin oils, around 1.5 and $2.0 \mathrm{~kg}$ of $\mathrm{CO}_{2}$-eq. per $\mathrm{kg}$ of biodiesel, respectively. It should be noted that these values may vary slightly depending on the scenario formulation, since the provinces in which the oilseeds are cultivated are not always the same. Besides producing zero emissions from direct LUC, as has been taken into account, GHG emissions from the agricultural sub-stage are less than half of those from soybean farming in both Argentina and Brazil, and even less than those from palm plantations. However, when low-carbon ecosystems are considered (in scenarios 2.3, 3.3 and 4.3), the GHG balance of the imported virgin oils is substantially improved. Under these scenario assumptions, the palm pathway only causes $0.9 \mathrm{~kg}$ of $\mathrm{CO}_{2}$-eq. per $\mathrm{kg}$ of biodiesel, while the soybean pathway generates 4.0 and $5.6 \mathrm{~kg}$ of $\mathrm{CO}_{2}$-eq. per $\mathrm{kg}$ of biodiesel when it starts from Brazilian and Argentinian seeds, respectively. Agricultural production in Argentina entails higher emissions than in Brazil due to a greater use of pesticides, such as cypermethrin and glyphosate. In scenarios 2.2, 3.2 and 4.2, in which the Cerrado savannah is taken into account, the soybean biodiesel based on Brazilian soybeans exhibits the lowest carbon intensity of the imported oil pathways, with only $5.8 \mathrm{~kg}$ of $\mathrm{CO}_{2}$-eq. per $\mathrm{kg}$ of product, as compared with $19.1 \mathrm{~kg}$ of $\mathrm{CO}_{2}$-eq. when peatland is diverted to palm plantations, or to $23.8 \mathrm{~kg}$ 
of $\mathrm{CO}_{2}$-eq. when the Yungas forest is converted in Argentina. Under these LUC assumptions, soybean biodiesel from Brazil would become an interesting option for the Spanish transport sector, since it is combined with a relatively low market price.

However, improving the GHG balance of the biodiesel consumption mix in Spain does not necessarily imply lowering other impacts, although all the scenario formulations that enforce the RED's sustainability criteria perform better than scenario 1 in the rest of the impact categories, too. It should be noted that emission factors per unit of biodiesel do not depend on the scenario formulation for impact categories other than GW, since ecosystems have no influence apart from LUC. For a given level of GHG emission threshold, emissions of $\mathrm{PO}_{4}{ }^{3-}$-eq. dramatically increase when the share of imported virgin oils increases in the mix. Specifically, the biodiesel pathway with the largest phosphate intensity is that from Brazilian soybeans ( $26.8 \mathrm{~kg}$ per ton of product), followed by that from Argentinian soybeans (22.8 kg per ton). The two sub-stages contributing the most to this impact category are agricultural production and export. Soybean farming requires more inputs than palm, and export from Brazil implies even larger transport distances than from Argentina. Hence, the greater the share of soybean oil in the mix, the worse the eutrophication performance. As regards FAE, the same is true but only in the case of soybean oil from Argentina, since this pathway requires the use of heavy doses of cypermethrin and deltamethrin, according to Panichelli et al. (2009), highly toxic substances in terms of DCB-eq. (15.7 kg per ton of biodiesel). The production of soybeans in Brazil leads to much lower emissions of DCB-eq. ( $0.2 \mathrm{~kg}$ per ton) because it does not require the use of these two compounds, according to Ecoinvent v2.2. Somewhere in between the two soybean biodiesel pathways we find the palm and domestic oilseed pathways, which use cypermethrin and deltamethrin to a similar extent, yielding around $2.7 \mathrm{~kg}$ of DCB-eq. per ton of biodiesel. In any event, those scenario formulations capturing RED's sustainability criteria bring environmental benefits in terms of both eutrophication and FAE, with reductions varying between $44.6 \%$ and $92.6 \%$ relative to scenario 1 .

A similar figure is obtained when analyzing acidification results, although the reduction in the impact is slightly lower: between $60.4 \%$ and $67.7 \%$, compared with scenario 1 . This is mainly caused by the introduction of UCO into the oil mix, since, in this case, all the first-generation biodiesel pathways produce similar emissions of $\mathrm{SO}_{2}$-eq. per ton of product. The agricultural stage is again the most influential, due to the emissions from the application of fertilizers, such as ammonia; the export sub-stage also makes a noteworthy contribution when imported feedstocks are considered, though. Specifically, the worst performance is that of the soybean pathway based on Argentinian soybeans (22.3 $\mathrm{kg} \mathrm{SO}_{2}$-eq. per ton of biodiesel), while the domestic rapeseed pathway leads to the second highest emissions (19.6 $\mathrm{kg} \mathrm{SO}_{2}$-eq. per ton of biodiesel). 


\subsubsection{Shifts in land use in the Spanish agriculture}

Increasing the share of domestic feedstock in the Spanish biodiesel consumption mix requires a significant expansion of the agricultural land diverted to oilseeds in major producing regions. As has been highlighted, this expansion comes partially at the expense of fallow land, although it also entails changes in cropping plans across the different provinces. The most significant differences between the baseline situation and the resulting areas under cultivation for each crop are found in scenario formulations 2.1, 3.1, 3.2, 4.1 and 4.2, with the greatest presence of domestic oilseeds. Only land use shifts in scenario 4.1 are shown in Figure 3.19, as an illustrative example of potential LUC effects that may take place in Spain as a consequence of the RED targets. This is the most extreme case, since domestic oilseeds account for almost $50 \%$ of the oil mix in 2020 .

Figure 3.19 displays the absolute changes in the cropland extension in each province. Results are not shown in terms of irrigated/non-irrigated crops in order to make the information easier to understand. Nevertheless, the greatest changes affect rainfed crops. Bioenergy crops are relocated inside those provinces which exhibit reasonably high yields, while the same happens with the rest of the crops in order to maintain a constant supply of food and feed products. In this sense, the whole agricultural sector runs more efficiently. The total agricultural surplus is 7.23 billion EUR in scenario 4.1, while it was very negative (-142,160.5 billion EUR) in the baseline situation (after calibration), which represented the arable sector at provincial level in 2009, as discussed in section 3.4.2.3 Specifically, rainfed sunflower ("girb.t0") expands in e03 (5,535\%), e08 (2,496\%), e10 (8,338\%) and e15 $(7,342 \%)$, while rainfed rapeseed ("rapb.t0") expands in e09 $(5,037 \%)$, e22 $(22,074)$, e23 (1,943\%), e29 (5,221\%) and e30 (14,836\%). This occurs mainly at the expense of crops, such as cereals (especially barley, with lower margins), food sunflower, chick peas, vetch, alfalfa and fodder vetch, as well as fallow to a large extent. Irrigated sunflower ("girb.t1") only expands in e08 (8,337\%), at the cost of reducing the area diverted to potato, cereals, food sunflower, or even corn. The area diverted to rapeseed under irrigation ("rapb.t1") only increases in e22 $(12,607 \%)$ at the expense of fallow, alfalfa, potato, peas, or corn. Since irrigated crops have very high margins, they are usually produced in those regions offering the highest returns; it can be said that the distribution of irrigated crops is nearer optimum than that of rainfed ones in the baseline situation. Thus, oilseeds in this case only expand in those specific regions in which the yield is the highest, in order to avoid larger crop displacements. At regional level, sunflower for biodiesel ("girb") mainly expands in Andalucía and Castilla y León (0.81 Mha), while rapeseed production for biodiesel ("rapb") increases in all the regions except Extremadura and Andalucía (0.37 Mha), as summarized in Figure 3.20. The implications of these land use shifts in terms of GHG emissions are further discussed in section 3.4.4. 


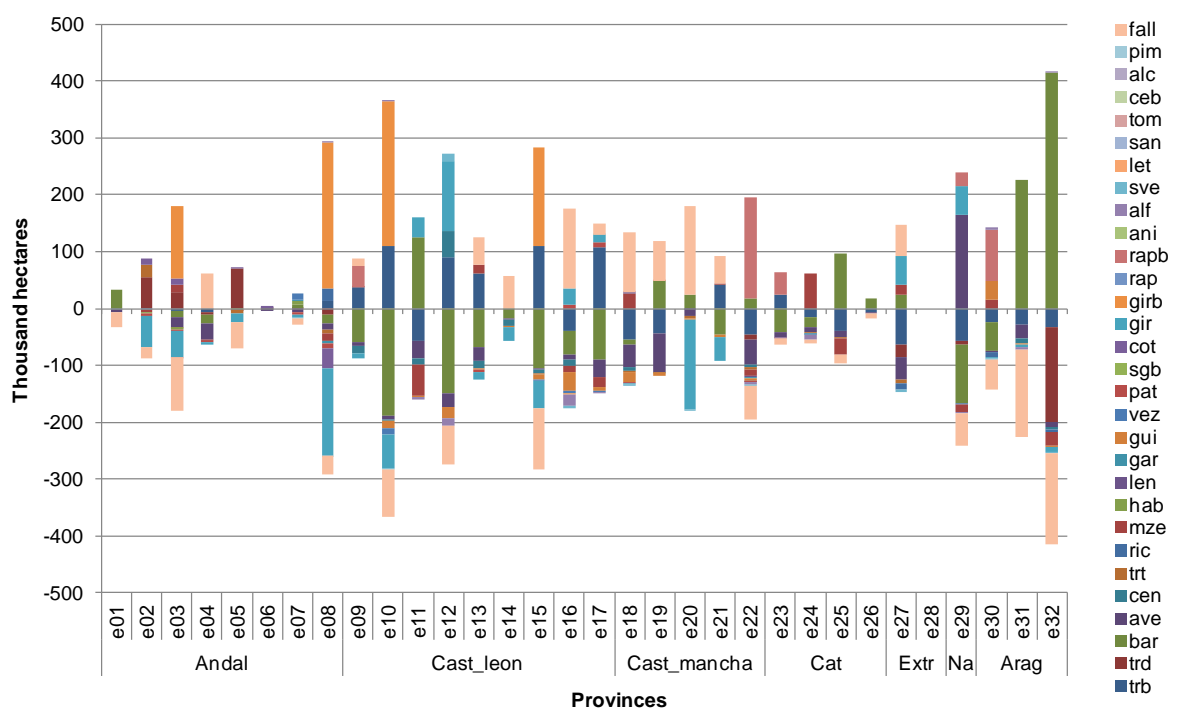

Figure 3.19. Changes in cropland extension (thousand hectares) in the Spanish provinces considered, as a consequence of the increased demand for biodiesel by 2020 in combination with the $60 \%$ GHG saving requirement. Andal: Andalucía; Cast_leon: Castilla y León; Cast_mancha: Castilla-La Mancha; Cat: Catalunya; Extr: Extremadura; Na: Navarra; Arag: Aragón.

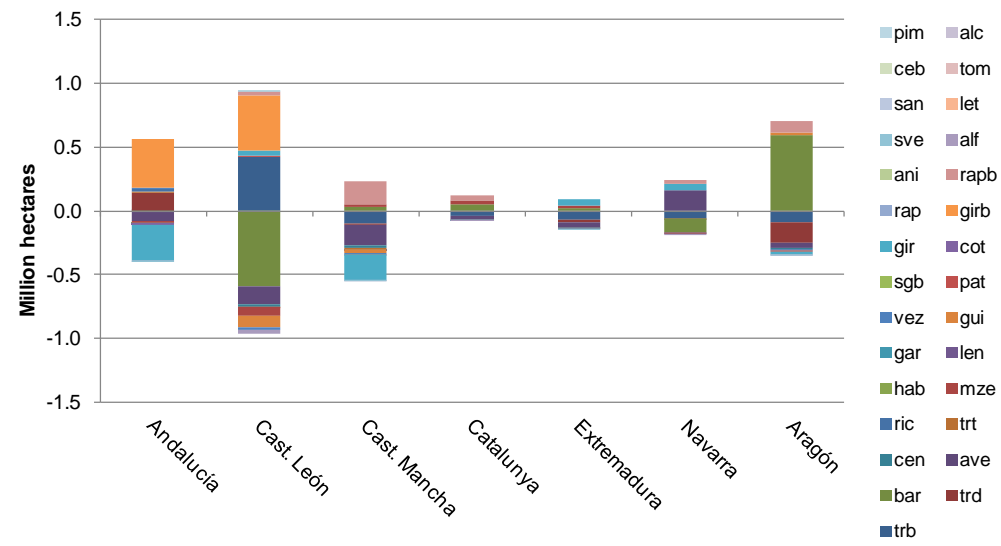

Figure 3.20. Changes in cropland extension (million hectares) in the Spanish regions considered, as a consequence of the increased demand for biodiesel by 2020 in combination with the $60 \%$ GHG saving requirement. 


\subsubsection{Discussion}

\subsubsection{ILUC impacts from domestic oilseeds}

The expansion of biomass crops under agricultural land constraints causes the rest of crops to be relocated, as has been seen. This can be understood as indirect effects according to Cherubini (2010), who states that ILUC (or leakage) occurs when land currently used for feed or food crops is changed into bioenergy feedstock production and the demand for the previous land use (e.g. feed, food) remains. The displaced agricultural production will then move to other places where unfavourable LUC may occur. Increased feedstock quantities can be obtained by means of: a) biomass use substitution (e.g. destined to biofuel production instead of for food purposes), b) crop area expansion, c) shortening of the rotation length, and d) increase in yield of the same land. Our model only captures the first mechanism, since yields are not endogenous, while agricultural constraints set out the most important rotations and the total cropland extension in each province, with no other flexibility than that of reducing fallow land. However, Rozakis et al. (2013) point out that, in practice, this LUC should be considered as the result of changes in crop rotations rather than direct substitutions. In addition, our model assumes that demand for all crops remains constant at national level, except for those dedicated to bioenergy. This prevents biofuel expansion at the expense of food consumption, in tune with Padella et al. (2012), who state that this could lead to an underestimation of the ILUC effects under a CGE approach, besides causing starvation. Under our model assumption, the expansion of domestic oilseeds will cause ILUC, but only within the Spanish borders; this allows the regionalized ILUC emissions factors for rapeseed and sunflower to be estimated, in compliance with the new EC proposal. This represents an improvement over the study of Lechón et al. (2011), who assumed that domestic sunflower and rapeseed could expand into fallow and idle land in Spain with no further ILUC implications.

Indirect impacts associated with the expansion of biodiesel feedstock in Spain are thus calculated as the difference in emissions from the whole arable sector before and after the increase in biodiesel demand. In order to quantify these emissions, Cherubini's approach (2010) has been applied, according to which the manufacture of additional fertilizer and emissions from $\mathrm{N}$ fertilizer application must also be accounted for as indirect effects. GHG emissions induced by LUC effects (GHGLUC) can be calculated as follows (eq.1):

$\mathrm{GHG}_{\mathrm{LUC}}=\Delta \mathrm{SOC}+\Delta \mathrm{N}_{2} \mathrm{O}+\Delta \mathrm{CH}_{4}+\Delta \mathrm{FM}$

Where $\triangle \mathrm{SOC}$ is the change (either increase or decrease) in soil organic carbon (SOC) as a consequence of the crop displacement, $\Delta \mathrm{N}_{2} \mathrm{O}$ is the change in $\mathrm{N}_{2} \mathrm{O}$ 
emission from soil arising from additional $\mathrm{N}$ fertilizer application, $\Delta \mathrm{CH}_{4}$ is the change in soil methane emissions from fertilizer use, and $\triangle F M$ is the change in GHG emissions due to the manufacture of the inputs needed. This would imply calculating the differences in the emissions from the application and manufacturing of all the agricultural inputs that varied per crop and province in the baseline data. However, in our model, only fertilizer doses meet this condition, since they depend on the yields, while pesticide application rates hardly vary in the inventory of IDAE (2011b). This is the reason why neither the use nor the production of pesticides lead to ILUC, although emissions from both stages have been considered for the impact assessment in section 3.4.3.2; the same occurs with the production of electricity for irrigation and fuel for agricultural machinery. Furthermore, some LCA studies on biofuels have found that the contribution of pesticides to the overall GW impact is minor, since the application rates are usually very low in terms of active ingredients (Panichelli et al., 2009; Zah et al., 2009). Despite the fact that the soil carbon sequestration, arising from different management techniques in the different regions, is highly likely to influence ILUC emissions, $\mathrm{CO}_{2}$-eq. emissions from changes in SOC have also been neglected, according to the Tier 1 procedure of the IPCC (2006) and also the PAS specification (BSI, 2011), since only conversion from cropland to cropland occurs. In addition, quantifying this is complex. As in Adler et al. (2007), it can be assumed that the long term GHG emissions are zero because Spanish soils are equilibrated and no longer sequestering additional carbon.

As a result of all these features, the model allows for ILUC emissions to be calculated not only with regard to GW but also to all the impact categories analyzed. Figure 3.21 shows emission factors for each one (g of compound-eq. per $\mathrm{MJ}$ ) for both rapeseed and sunflower biodiesel pathways in scenario 4.1, with and without considering the ILUC. Since it is not possible to trace where the indirect effects associated with each feedstock occur, overall emissions are allocated to each biodiesel pathway based on the corresponding share in the consumption mix.

ILUC emission factors are of the same order of magnitude in all the scenario formulations that cause the largest indirect effects in Spain (2.1, 3.1, 3.2, 4.1 and 4.2). The sunflower pathway performs better than the rapeseed one in almost all the analyzed impact categories due to lower fertilization needs in terms of $\mathrm{N}, \mathrm{P}, \mathrm{K}$. The only exception is FAE, in which sunflower performs worse since this crop requires the use of pesticides with a greater incidence in this impact category; this is partly because a large fraction of the applied amount goes to agricultural soils. As for GW, indirect emissions represent around $26 \%$ and $18 \%$ of total GHG emissions per MJ from sunflower and rapeseed biodiesel pathways, respectively; $32 \%$ and $21 \%$ in the case of acidification. On the contrary, as can be seen in Figure 3.19 , the contribution of indirect emissions to eutrophication, especially 
FAE, is negligible. It must be recalled that ILUC emissions causing FAE depend only on the differences in the production of fertilizers, while ILUC emissions causing acidification, eutrophication and GW also arise from differences in the emissions from fertilizer application as a consequence of crop relocation. However, indirect eutrophication impacts from fertilizer application are only estimated in terms of nitrate runoff, which has a minor incidence in this impact category compared with other compounds, such as ammonia or phosphoric acid.
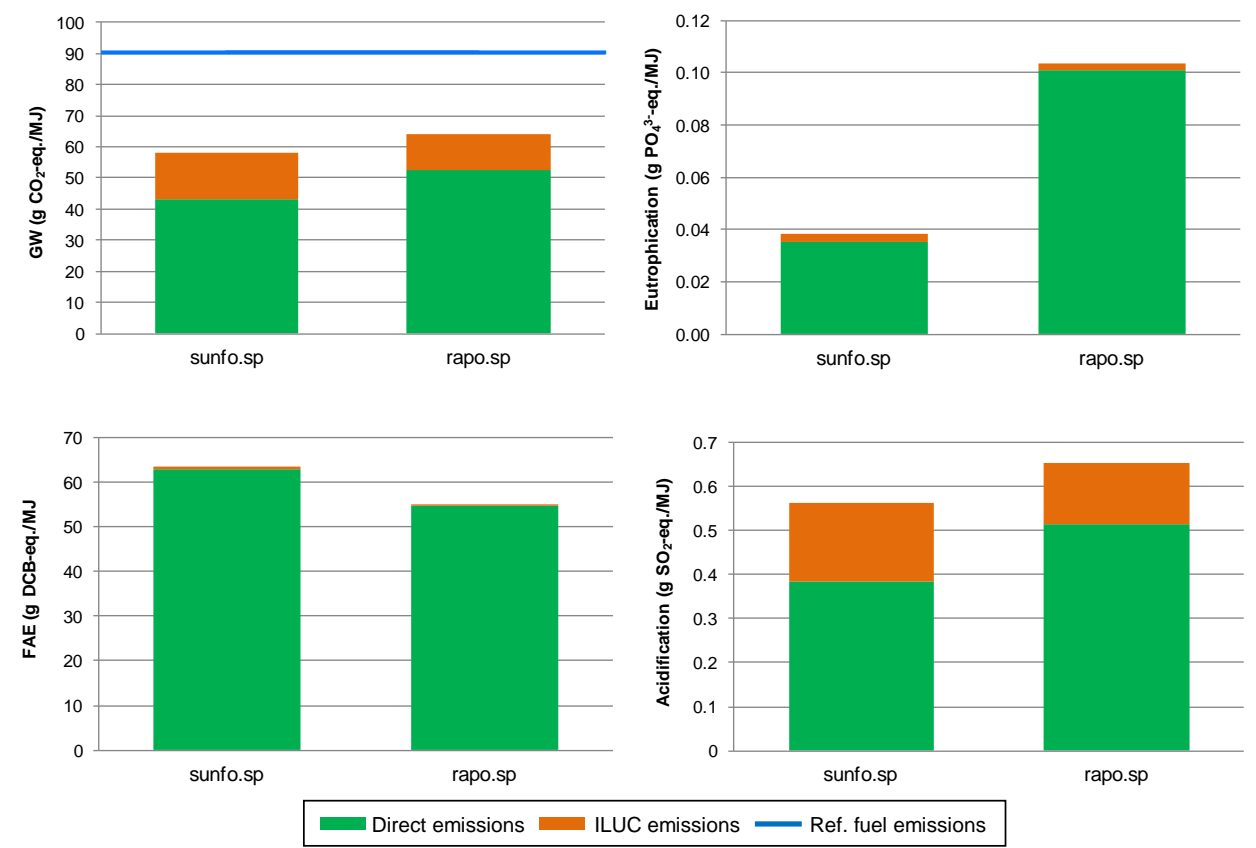

Figure 3.21. Emission factors for those biodiesel pathways based on domestic oilseeds in scenario 4.1, including and not the ILUC. Sunfo.sp: sunflower-based biodiesel; rapo.sp: rapeseed-based biodiesel; ref. fuel: reference fossil fuel.

Since only GHG emission factors are regulated in European directives, the results can only be discussed in terms of GW. When ILUC emissions are not included in the life cycle, rapeseed-based pathway delivers a $42 \%$ saving, while the sunflowerbased pathway generates $52 \%$ fewer GHG emissions than the reference fossil fuel. These GHG emission factors, obtained by considering direct emissions only, are consistent with the default values included in the RED, although Spanish rapeseed biodiesel slightly improves the GHG balance. They are also within the same range as those from the study of Lechón et al. (2009) under the current biofuel production and use conditions in Spain. When including ILUC emissions, the GHG saving coefficient is reduced to $29 \%$ and $36 \%$ for rapeseed and sunflower pathways, 
respectively, so that domestic feedstocks would not be in compliance with the forthcoming sustainability criteria in the RED, unless they are mixed with other oils with better sustainability characteristics. The figures obtained (11.7 and $15.0 \mathrm{~g}$ $\mathrm{CO}_{2} / \mathrm{MJ}$, respectively) are, however, much lower than those included in the original EC proposal on ILUC, which assigns a factor of $55 \mathrm{~g} \mathrm{CO}_{2} / \mathrm{MJ}$ to first-generation biodiesel manufactured from oil crops, in general. It must be noted that these reference values were determined by Laborde (2011) by using the CGE model MIRAGE, addressing the indirect effects of bioenergy expansion on a global scale. The author points out that the assumptions underlying the model calculations may well result in an overestimation of the overall LUC effects of biofuels. Similarly, limiting ILUC effects to the Spanish territory may lead to an underestimation of the ILUC emissions in this section, although it can serve as a proxy to determine ILUC emissions at regional or national level. If the constraint to ensure a constant supply of other food commodities was relaxed, larger crop displacements would be expected, with the subsequent indirect emissions.

\subsubsection{Policy recommendations}

The results show that the highest threshold is not enough in itself to prevent the imports of feedstocks that do not generate substantial GHG savings (e.g. oil from Cerrado soybeans), although it may be effective at preventing the destruction of large forested areas (e.g. Yungas and tropical forest) and peatlands. However, when applied to each biodiesel pathway individually (instead of to the target demand as a whole), the highest thresholds could not be fulfilled by biodiesel based on domestic feedstock, despite the fact that, in Spain, the land conversion happened a long time ago and there is no margin for deforestation. Indeed, Spanish rapeseed biodiesel will not fulfill the $50 \%$ threshold when only emissions from DLUC are considered; neither will Spanish sunflower biodiesel when indirect GHG emissions are included, even if ILUC is estimated at national level and mostly affects fallow land and crop rotations. This may serve to stimulate the debate about the adequacy of the GHG emissions reduction targets. In principle, a biofuel should be promoted if it causes a reduction in impacts relative to those produced by fossil fuels, however small it may be. Our recommendation would be to relax those GHG emissions reduction targets in order to protect current investments; domestic oilseeds are still necessary in the EU biodiesel sector to enhance a well-integrated supply chain. Maintaining categories of ineligible land would still be recommended as a means of preventing deforestation so as to supply feedstock for the MSs, while measures such as the double-counting would be very interesting for both environmental and economic reasons. In addition, defining emissions factors for other impact categories, such as eutrophication, would be advisable in order to promote sustainable agriculture in the EU. This may work against imports of 
soybean oil, since soybean farming requires high fertilization doses as compared with other oilseeds. The indirect effects should equally be captured, since they can be substantial in terms of acidification.

We also encourage policy makers to define ILUC emission factors at national level, since, of the effects that compromise the environmental performance of the biodiesel based on domestic oilseeds, it is the most uncertain. In this sense, the proposed model establishes a framework for estimating ILUC emissions in the Spanish context. Regionalized studies can provide additional insights into the understanding of ILUC effects and the associated uncertainty. In the proposed model, ILUC emissions arise from differences in fertilizer inputs among arable crops once they are relocated among the different provinces, as a consequence of the increase in biodiesel production relative to 2009 levels. Higher yields translate into higher emissions from fertilizer production and application. In this way, the model captures how increasing yields implies crop intensification, challenging the goal of sustainable production. This approach can provide an idea of the associated emissions if ILUC was restricted to the Spanish territory, but shows some limitations. For instance, changes in SOC have been neglected, despite the fact that changes of the carbon in soil and other pools are very site-specific and heavily dependent on former and current agronomic practices, climate, and soil characteristics (Cherubini and Strømman, 2011). Furthermore, most of the LUC takes place at the expense of fallow land, which may not be feasible for agronomic reasons, and would probably imply lower yields of those crops in rotation with fallow; this relationship is not endogenized. It must be noted, however, that the study of IDAE (2011a) envisages the possibility of increasing the production of sunflower and rapeseed for biodiesel at the expense of all the available fallow land.

A double-counting scheme would indeed be very helpful to ensure the fulfillment of the sustainability criteria in Spain, while making the plants with second-generation technology work at full capacity. In addition, the RED/FQD states that "sustainability criteria will be effective only if they lead to changes in the behavior of market actors. Those changes will occur only if biofuels and bioliquids meeting those criteria command a price premium compared to those that do not". This implies that a higher price should be paid for advanced biodiesel in order to promote its consumption. Such a measure as this would definitely improve the economic performance of the sector, in view of the great losses incurred by biodiesel plants. Indeed, the greatest negative margins are found for those plants operating with virgin oils due to the high costs in raw materials; unit production costs even exceed the exogenous selling price of biodiesel especially in the case of the smallest ones, and also in second-generation plants when no doublecounting is considered. The adequacy of a subsidy in terms of welfare and environmental effects should be better addressed under a PE approach, with 
endogenous prices. This also highlights the need for the development of technologies allowing the use of lower value feedstocks.

\subsubsection{Conclusions}

This section develops a multi-chain optimization model based on mathematical programming in order to determine the optimal configurations of the biodiesel sector in Spain, given all the inefficiencies that it faces as a consequence of the international trade and policy context. The model represents the agro-energy chain structure, integrating the agricultural and industry sectors, together with an emissions module in order to analyze the impacts generated across all the substages. The experiment consists of an exogenous biodiesel demand to meet the RED targets in the Spanish transport sector, which translates into a FU of $2.58 \mathrm{Mt}$ of biodiesel. Given the industry's technology level and cost structure, the prices of the commodities involved, and the regional characteristics of the Spanish arable sector, the model seeks to maximize the overall welfare, calculated as the sum of the surpluses of all the actors within the supply chain, namely biodiesel plants, the extraction phase, and the agricultural production of bioenergy crops. In addition, a sustainability criterion constraint is implemented by adding up life cycle GHG emissions to ensure that the optimal biodiesel consumption mix is in compliance with the reduction thresholds in the RED/FQD. In this way, the model allows the optimal feedstock mix to be obtained for the biodiesel plants, based on their nameplate capacity, driven by both environmental and economic goals. For the purposes of analyzing the sustainability and self-sufficiency of the biodiesel consumption in Spain, the experiment assumes that the demand is met entirely with biodiesel manufactured nationally from both domestic and imported feedstock, either virgin or residual. This is perfectly possible since the current installed capacity almost doubles the mandated biodiesel consumption in 2020. A step function in the industrial supply allows the most efficient producers to capture the market.

The optimal oil mix for the sector as a whole is heavily dependent on assumptions regarding direct LUC in major exporting countries of virgin oils to Spain. In general, increasing GHG savings thresholds reduces the use of oils coming from carbonrich ecosystems, with the exception of the Cerrado savannah, which could still provide $7.3 \%$ of the oil needed under the $60 \%$ reduction requirement, even though it is a highly biodiverse land. In spite of this, GHG savings thresholds may enhance the presence of domestic feedstock in the mix, limited by the availability of UCO in Spain, and provided that vegetable oils from major exporting countries come at the cost of carbon-rich land. On the contrary, producing biodiesel feedstock on land diverted to agriculture prior to January 2008 in those very countries can potentially increase the use of foreign vegetable oils in the Spanish biodiesel sector. 
Nevertheless, as Johansson and Azar (2007) point out, if the allocation of land is carried out by commercial farmers and companies, it seems unlikely that they will choose degraded and lower-quality land if it is not the most profitable land type. Only policy measures, such as implementing national certification schemes to sell on the EU market, could influence the farmers' decision in this regard.

The model developed in this section responds to the EC requirements for a proper implementation of the current biofuel directive, which sets out the obligation for economic operators to report life cycle GHG associated with biofuel production. Additionally, the subsequent proposal encourages researchers to provide additional information on ILUC emission factors. One of the strengths of this model is that it allows direct and indirect emissions to be estimated separately, which can help decision-makers in the implementation of a certification scheme, as mandated by the RED. The accuracy of predictions is vital for the correct assessment of the impact of such policy changes. In this sense, a sensitivity analysis of critical parameters, such as prices and variable costs, could improve the robustness of the results. Finally, the model can also serve as an aid for biofuel suppliers in the search for optimal configurations under different policy scenarios at the sector level (e.g. the recently approved quota system), although technical models at the plant level could provide more detailed insights. Similarly, building the agricultural module on actual farm data can give further information on the effect of agricultural practices and new CAP policy instruments (i.e. Single Payment Scheme and crosscompliance measures) on the GHG balance of biofuels, as well as on farmers' income. 
Submitted to Land Use Policy

3.5. Global land use change and greenhouse gas emissions due to recent European biofuel policies

Escobar, N. ${ }^{a}$, Narayanan, B. ${ }^{b}$, Sanjuán, N. ${ }^{a}$, Clemente, G. ${ }^{a}$, Tyner, W.E. ${ }^{b}$

${ }^{a}$ Grup ASPA. Departament de Tecnologia d'Aliments, Edifici 3F, Universitat Politècnica de València. Camí de Vera s/n, 46022, Valencia, Spain

${ }^{\mathrm{b}}$ Department of Agricultural Economics, Purdue University. 403 West State St. West Lafayette, IN 47907-2056, United States 



\section{Abstract}

The The European Union (EU) has emerged as a major producer and consumer of biodiesel due to policy initiatives. Recent policies seek to curb imports from Argentina and Indonesia by imposing anti-dumping duties, added to the existing ones on biodiesel from the United States (US). Further, there has been a proposal to set a cap on first-generation biofuels (FGBs), which are those obtained from edible biomass, to reduce greenhouse gas (GHG) emissions from land use change (LUC). In this section, the widely used GTAP-BIO model is employed to examine the global effects of these recent EU policies, in terms of overall LUC and the associated $\mathrm{CO}_{2}$ emissions. In order to analyze the market responses in depth, biodiesel imports into the EU from major producing countries have been updated in the original database. Increased biodiesel consumption in the EU by 2020 by taking the cap proposed into account, together with increased import prices, are both modeled as exogenous policy shocks. Two experiments are performed under a static approach, one considering the effect of the blending mandate alone, and a second one including the anti-dumping measures in combination with the mandate.

The results show that biodiesel imports into the EU increase despite the antidumping measures, because of the enormous expansion of domestic demand, mainly for palm biodiesel. Biodiesel producers in the EU benefit from these policies as well; this is especially the case of those producing rapeseed and also palm biodiesel (due to imports of vegetable oils). Global LUC is expected to occur in other countries not necessarily involved in the biodiesel trade, since it arises from interactions in the food and feed markets. Land brought under agricultural production expands by $3.32 \mathrm{Mha}$, mainly in regions such as South-Saharan Africa, Brazil, South America, or the US, while only $7.5 \%$ takes place in the EU. The target biodiesel demand in the EU by 2020 (in combination with anti-dumping duties) will cause around $35.8 \mathrm{~g} \mathrm{CO}_{2} / \mathrm{MJ}$, lower than the default value in the new EU proposal. This shows that limiting FGB consumption may be an effective way of reducing indirect GHG emissions from the EU blending mandate, but ILUC is still an issue of concern. Although the estimation of ILUC is subject to great uncertainty, which makes it difficult to integrate into public policies, the results should serve to reinforce the commitment of the EC to quantify and control it.

Keywords: anti-dumping, biodiesel, biofuel policies, greenhouse gas, GTAP, land use change 


\subsubsection{Introduction}

Biofuels production has been on the rise all around the world during the last decade, as a consequence of rising prices of oil together with the approval of public policies to mitigate the effects of global warming (GW). Most of these policies, such as the European Directive 2009/28/CE, aim at reducing the GHG emissions while increasing energy independence by introducing a blending mandate. Specifically, this Directive (also known as the Renewable Energy Directive, hereinafter called RED), establishes a $10 \%$ biofuel share in the motor fuel market of the Member States (MSs) by 2020, while setting out sustainability criteria to ensure that increasing biofuels consumption does not take place at the expense of carbon-rich ecosystems. This is pursued by preventing raw materials production in some specific areas (such as wetlands, undrained peatland or biodiverse forests) while requiring biofuels to emit at least 35\% less GHG than the replaced fossil fuel. Besides consolidating these sustainability requirements, the Directive 2009/30/CE, also known as the Fuel Quality Directive (FQD), simultaneously monitors biofuel suppliers to reduce life cycle GHG emissions to at least $6 \%$ by $31^{\text {st }}$ December 2020 , compared to average levels of emissions from fossil fuels in 2010 . The minimum savings rate of $35 \%$ only applies initially. From 2017 onwards, all the biofuels used will have to fulfill a 50\% threshold, which will be even increased to $60 \%$ in 2018, but only for those installations in operation in 2017 or later.

In estimating these emissions, both the RED and the FQD set out an identical life cycle methodology according to which the corresponding losses in carbon stocks of the land diverted to bioenergy crops must be included. This impact is known as direct land use change (DLUC) and the rules provided for its calculation are based on the principles of the IPCC (2006). Wastes, agricultural crop residues (such as straw), and residues from processing (such as crude glycerin) are considered to generate zero GHG emissions up to the process of collection of the raw material. That is why, in a parallel effort, the RED proposes a double-counting scheme according to which biofuels made from waste, residues, non-food cellulosic and ligno-cellulosic material can count double towards the mandate. Not all MSs have, however, taken provisions to make this effective. The ultimate goal of all these measures is to encourage only the use of feedstock that generates environmental benefits as compared to fossil fuels throughout the entire production pathway.

RED's approval was supposed to give a boost to the European biofuel industry. Indeed, both consumption and production of biofuel (particularly biodiesel) has increased sharply since 2010 (see Figure 1.6), especially in those countries that have been the leading producers from then onwards (Germany and France). The EU is currently the world's largest biodiesel producer (see Figure 1.4). Biodiesel is 
also the most important biofuel and, on volume basis, represents about $80 \%$ of the total transport biofuels market in the EU (Hélaine et al., 2013), analogous to diesel that prevails over gas in the motor fuel market. However, while the expansion in the period 2000-2012 was mainly driven by increasing crude oil prices, generous tax incentives, and subsidies on the production of oilseeds on set-aside land under the Common Agricultural Policy (CAP), the decoupling of aid for farmers and the abolishment of tax exemptions in most of the MSs have enhanced the role of the blending mandate alone. According to Flach et al. (2013), EU biodiesel consumption seems to have reached its peak. The production of biodiesel is still expanding, although at a much slower pace than previously anticipated (Krautgartner et al., 2014).

In any case, the targets set out in the RED have also triggered the need for more raw materials, as can be seen in Figure 3.22. Rapeseed is the main feedstock in the EU market, and comes largely from domestic production in countries such as Germany, France and Poland. The supply of rapeseed has indeed grown in parallel with biodiesel production. In 2010, more than half of the total biodiesel production in the EU-27 was manufactured from domestic feedstock, $69 \%$ of which was rapeseed (Ecofys et al., 2013). Rapeseed oil has been accounting for the largest share of the overall feedstock mix since the sector's development, around $60-70 \%$ depending on the year and the source (Ecofys et al., 2013; Flach et al., 2014; Krautgartner et al., 2014). However, the remaining share mostly relies on imports; this is especially true for oilseeds with no or limited domestic production, such as palm and soybean oil. At least 1.5 million tons of vegetable oils were imported into the EU in 2012 and 2013 for biodiesel production only (Flach et al., 2013; 2014). Specifically, palm oil has been increasingly used due to its price competitiveness, and is massively imported through The Netherlands. Gerasimchuk and Yam Koh (2013) reported that the highest increase in vegetable oil imports underlying biodiesel production over the period 2006-2012 was observed for palm oil (around 365\%). This trend is expected to continue, as shown in Figure 3.22, with net imports of palm oil expanding steadily, well above imports of soybean oil and rapeseed. This will consolidate itself as the second most important feedstock in the EU biodiesel market, accounting for $24 \%$ of the market share in 2020, while soybean oil will represent $15 \%$ (Ecofys et al., 2013). Argentina is currently the main supplier of soybean oil into the EU market, followed by the US, while Malaysia and Indonesia are the leading exporting countries of palm oil (Flach et al., 2014). It must be noted that soybeans are mostly imported as such, and subsequently crushed in the EU, but a downward trend in net imports is equally observed in the figure. 


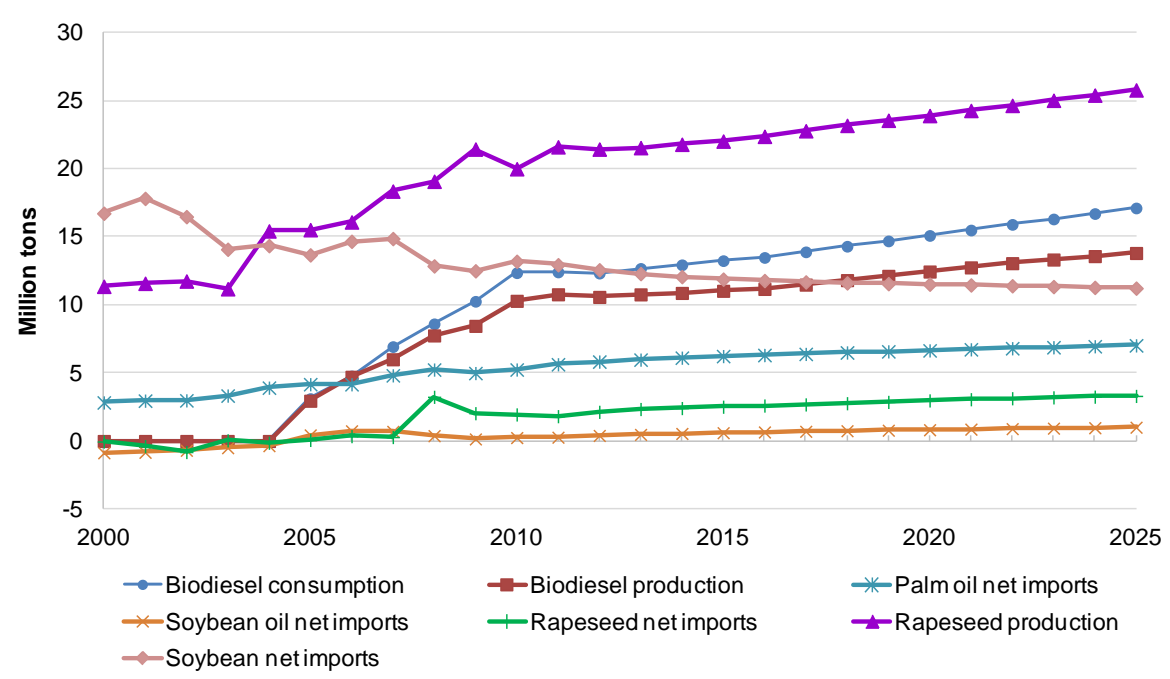

Figure 3.22. Net imports of the main biodiesel feedstocks into the EU, compared to increasing production and consumption of the final product. Other uses than biodiesel are, however, considered in the case of seeds (rapeseed and soybeans). Source: own elaboration from FAPRI (2013) data.

Because of the huge demand for biodiesel, imports of the final product significantly increased too, until they almost reached 50\% of the consumption in the EU in 2012 (Eurostat, 2013c). Biodiesel from the leading exporting countries is very competitive and usually cheaper than domestic product. In March 2011, the European Commission (EC) chose to impose anti-dumping duties on all the biodiesel blends imported from the US (Regulation 444/2011), after having set provisional measures on imports of B20 blends or higher, and in pure form (Regulation 193/2009) since biodiesel had been exported in blends containing 20\% or less. Biodiesel imports from Argentina and Indonesia then took the US market share (see Figure 1.5). These two countries have come to represent approximately $40 \%$ of the total biodiesel imports into the EU (EC, 2013). Simultaneously, the EU has accounted for almost $88 \%$ of the total biodiesel exports from Indonesia (Slette and Wiyono, 2013). After investigation, the EC finally enforced anti-dumping duties on biodiesel imports from both Argentina and Indonesia (Regulation 1194/2013). Overall EU biodiesel imports have dramatically decreased since the beginning of 2014 (Flach et al., 2014). Figure 1.5 also shows how Malaysia has benefited from these measures and has recently increased B100 exports to the EU.

Furthermore, the EC presented a new proposal regulating the biofuels market, known as COM 595 (EC, 2012a), which still has to be ratified. It aims at starting the transition to biofuels that deliver substantial GHG savings, which is meant to be done by setting a cap on the contribution of FGBs to the $10 \%$ target (those made 
from biomass which is generally edible), while phasing out of public support for them after 2020 and establishing a GHG saving requirement of at least $60 \%$ for new installations. All these measures would apply to both domestic and imported biofuels, same as the sustainability requirements laid down in the RED/FQD. The proposal in its original form generated intense debate on some major points, mainly the level of the cap, the treatment of dedicated energy crops (potentially under the cap), the types of feedstock under the definition of "advanced" biofuels (generally from non-food feedstock) and the type of support for them. Another controversial issue was the introduction of indirect land use change (ILUC) emission factors, and their consideration of compliance with the aforementioned sustainability criteria. ILUC is one of the effects of expanding FGBs at the cost of arable crops, since previous uses are displaced and undertaken in other regions, with the subsequent changes in the carbon balance in soil and biomass, often referred to as marketmediated impacts (Hertel and Tyner, 2013). The discussion focuses on whether the associated GHG emissions should be allocated to the biofuel production pathway, in addition to those from DLUC.

Specifically, the COM 595 proposed to set a cap of $5 \%$ for FGBs, to use ILUC emission factors only for reporting, and to introduce a multiple counting scheme for advanced biofuels, according to which biofuels produced from cellulosic wastes, residues or algae would be counted four times towards the blending mandate, while fuels from non-food energy crops would be counted twice. All the pressure groups within the biofuel supply chain, such as European farmers, crushers, traders and producers, immediately opposed the draft text (EBB, 2013a, b), arguing to remove ILUC considerations from any future Directive (COPACOGECA, 2012). However, the European Parliament adopted its first reading position in September 2013, being even more ambitious and reinforcing the ILUC compromise of the EU. Emission factors were proposed to be considered when assessing the contribution towards the FQD target, but not when assessing compliance with the sustainability criteria. Finally, the Energy Council reached a political agreement on the draft directive amending the RED/FQD in June 2014. The cap has been finally set at $7 \%$ for biofuels from cereal and other starch-rich crops, sugars and oil crops, in order to protect current investments. Additionally, there is a $0.5 \%$ non-binding sub-target for advanced biofuels, which gives more flexibility to the MSs for its implementation through economic operators. Biofuels made from cellulosic wastes and residues or algae are included in this category and count double to the targets in the RED. Due to notably uncertainties in their quantification, the role of ILUC factors has been downgraded to reporting items only, following the estimates of Laborde (2011), although they might be reviewed as soon as further research is carried out. 
Since the first studies warning about the risk of indirect GHG emissions from the boom in biofuels (Fargione et al., 2008; Gibbs et al., 2008; Searchinger et al., 2008), much research work has been conducted on the ILUC effects from increased demand. While some authors developed different accounting methods relying on statistical data and methodological assumptions (Goldemberg et al., 2014; Kim and Dale, 2011; Overmars et al., 2011), most agree on the use of economic models (Blanco-Fonseca et al., 2010; Havlík et al., 2011; Hélaine et al., 2013), allowing for future responses to biofuel shocks to be estimated based on economic studies rather than on historical observations. In particular, Computable General Equilibrium (CGE) models have become increasingly prominent, in view of the global dimension of the bioenergy development. Specifically, the Global Trade Analysis Project (GTAP) (Hertel, 1997) has been broadly used in the study of ILUC responses, since Taheripour et al. (2007) introduced biofuel commodities in the version 6 of the GTAP database. This model provided the basis for further improvement and yielded a large number of studies addressing ILUC mainly due to US and EU policies (Banse et al., 2008, 2011; Hertel et al., 2010; Taheripour et al., 2010; Van Meijl et al., 2006). The MIRAGE model is based in turn on the GTAP 7 database (Narayanan and Walmsley, 2008), and was specially developed by IFPRI, commissioned by the EC, for estimating the ILUC impacts arising from European biofuel mandates (Al-Riffai et al., 2010; Laborde, 2011; Laborde et al., 2014). Assuming that biofuel targets will be met by both land and yield adjustments, these studies show that significant changes in land use are expected to occur not only in those countries driving the demand for biofuels, but also in other parts of the world due to the interaction among agricultural-biofuel markets. In fact, one of the largest sources of potential GHG emissions associated with biofuels production results from the ILUC, which will take place in different regions of Latin America, Asia or Africa.

Despite the great relevance of all of these studies, none of them considers the recent anti-dumping duties on biodiesel imports in combination with the blending mandate, subject to a cap on FGBs. The objective of the present section is thus to analyze the global environmental consequences, in terms of GHG emissions and LUC, of these recent measures with a direct impact on the international markets. Results aim at providing additional information on ILUC emission factors for biodiesel to be consumed in the EU. This paper is organized into the following sections: section 3.5.2 describes the methodology, the database updates and the experiments performed; major market responses and the subsequent environmental effects are analyzed in section 3.5.3; results are discussed in section 3.5.4, in regard to other prominent studies; finally, conclusions and policy implications are drawn in section 3.5.5, providing insights for further improvement. 


\subsubsection{Methodology}

\subsubsection{The GTAP-BIO version}

A version of the standard GTAP model (Hertel, 1997) has been used, specifically the latest version of the GTAP-BIO, described by Taheripour and Tyner (2013b), and built on the version of Birur et al. (2008). The original version modified the GTAP-E model (Burniaux and Truong, 2002), whose main contribution was to incorporate energy substitution in the production nest following a constant elasticity of substitution (CES) function. It was subsequently extended by McDougall and Golub (2007) to improve its applicability to a wider range of energy-environmental policy scenarios, while Taheripour et al. (2007) further modified it to incorporate the potential for biofuels to substitute for petroleum products. Authors began by introducing three biofuel commodities into the GTAP 6 database (Dimaranan, 2006): ethanol from coarse grains, ethanol from sugarcane, and biodiesel from oilseeds, all of them with a by-product that could be used for animal feed. Taheripour and Tyner (2011) updated first and second-generation biofuel technologies into the GTAP 7 database (Narayanan and Walmsley, 2008), according to input-output tables of some regions/countries for 2004. Biofuel production figures were adjusted in the main biofuel-producing regions, although only trade of sugarcane ethanol between Brazil and the US was included. Authors modeled the role of oilseed meals in an economy with biofuels more precisely, defining a new industry (voln) which uses oilseeds to produce crude vegetable oil and oilseed meals.

The prominence given to energy substitution in the GTAP-BIO makes it a suitable tool for the study of the implications of biofuel mandates; the mandate will be more costly for the economy if alternative fuels are not good substitutes for petroleum products and the other way round (Golub and Hertel, 2012). Additionally, Birur et al. (2008) implemented a land use module permitting the estimation of LUC in different agroecological zones (AEZs) and the associated emissions. The competition for land within a given AEZ across uses is governed by the corresponding transformation elasticities (see Figure 2.5), as described below, which are based on historical observations on the activities that have been carried out in each AEZ. GHG emissions are also calculated within the land use module, by incorporating detailed data on ecosystems carbon stock in order to determine $\mathrm{CO}_{2}$ emission factors (according to the Woods Hole Research Center database). Overall, the GHG accounting in the model captures $\mathrm{CO}_{2}$ emissions from energy use by the energy sector (i.e., by the coal, oil, natural gas, and petroleum products sectors), and $\mathrm{CO}_{2}$ emissions (or sequestration) from LUC in the agricultural and forestry sectors. 
The version of GTAP-BIO used is also based on the version 7 of the GTAP database, depicting the world economy in 2004. The feature that makes it more interesting for our analysis is that this particular version disaggregates biodiesel into soybean biodiesel, rapeseed biodiesel, palm biodiesel and biodiesel from other feedstocks (hereinafter biod_soy, biod_rape, biod_palm and biod_oth), as shown in Figure 3.23. This is essential in determining ILUC emission factors for each feedstock, and it allows performing the corresponding tariff shock on each biodiesel type. Four different agricultural commodities (soybeans, rapeseed, palm and other oilseeds) are considered for biodiesel production as well. These four agricultural industries compete in land, capital, labor, and intermediates, and sell their products to other industries (mainly vegetable oil, food and feed industries) and households $(\mathrm{HH})$. The vegetable oil industry in GTAP-BIO is thus divided accordingly into soybean oil (vol_soy), rapeseed oil (vol_rape), palm oil (vol_palm) and other oils (vol_oth). Substitution among all these types of vegetable oils in the $\mathrm{HH}$ and firms demand for goods and services is possible thanks to a new elasticity parameter. This parameter represents how demand for oils shifts to cheaper oils when the price of one particular type of oil increases sharply as a consequence of the increased demand by biodiesel firms. It is assigned a high value in the regions which produce different oilseeds or import them from other regions (e.g. China and MSs in the EU), while is small in the regions which mainly produce one type of vegetable oil (e.g. Brazil and the US). The database covers 19 regions, 42 industries and 48 commodities, as shown in Table C1 (annex C).

In regard to the land use module, it allows competition among traditional crops and dedicated energy crops for land by introducing two different transformation elasticities, ETL1 and ETL2. The main contribution of Taheripour and Tyner (2013b) with regard to the production nest in the model of Birur et al. (2008) was to change the land supply tree in tune with what was actually observed in the different regions during the period 2004-2010, when the strongest expansion of bioenergy occurred worldwide. Authors used historical data on managed land extension from the FAO statistics. In the original GTAP-BIO, ETL1 governed land allocation among managed forest, cropland and pasture land, while ETL2 distributed available cropland among alternative crops $\left(\Omega_{1}\right.$ and $\Omega_{2}$ in Figure 2.5). The model did not include different values for these parameters depending on the region where the land conversion took place. 


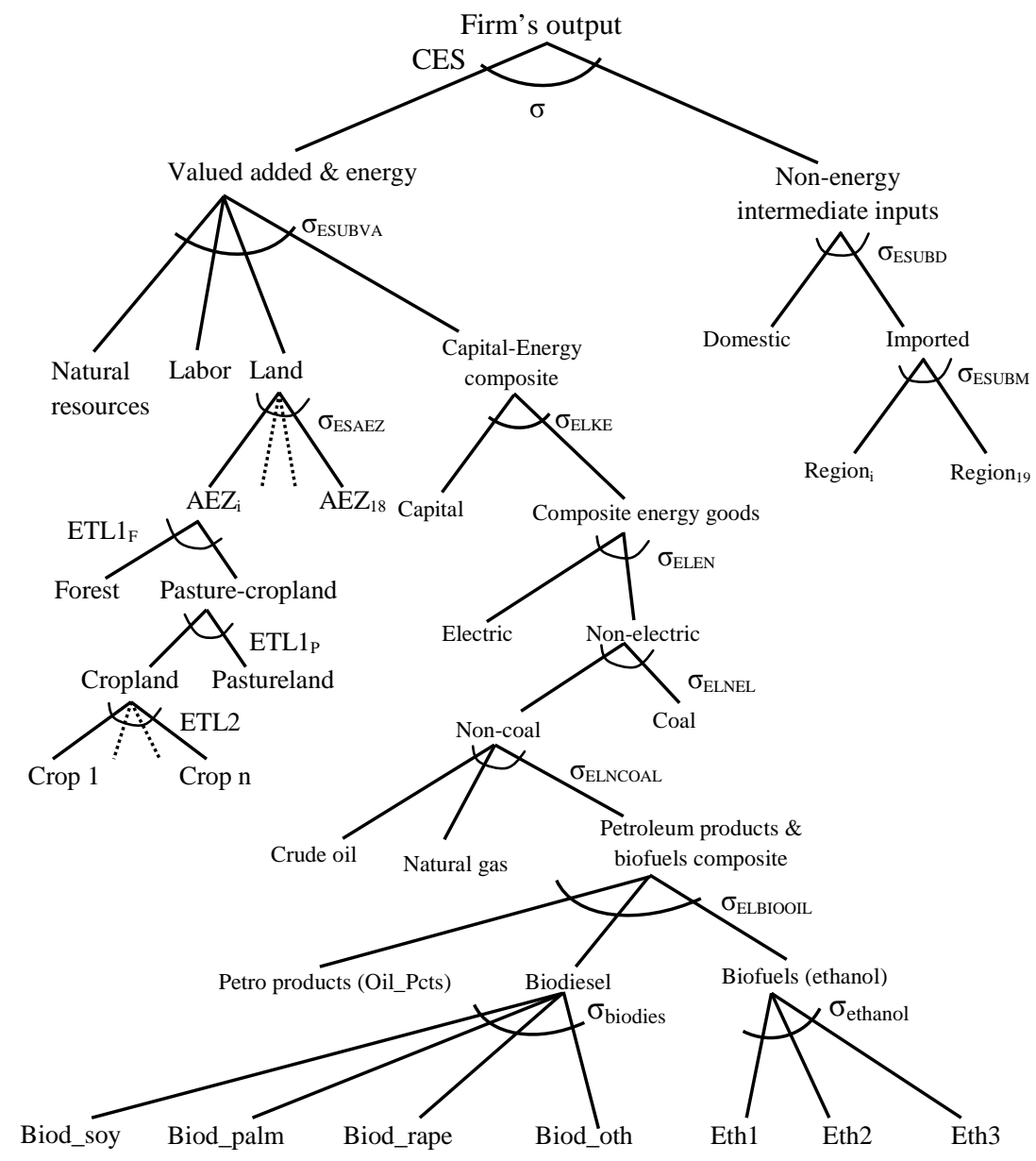

Figure 3.23. Underlying production structure in the GTAP-BIO model used. The biodiesel composite is disaggregated between biod_soy, biod_rape, biod_palm and biod_oth (from other feedstock than soy, rape or palm), whereas the ethanol composite is disaggregated between eth1, eth2 and eth3 (from corn, sugarcane and corn stover, respectively). $\sigma_{x}$ : elasticities of substitution; ETL $L_{x}$ : elasticities of land transformation. Source: production nest of Birur et al. (2008) with the new land supply trees defined by Taheripour and Tyner (2013b).

Based on regional observations, Taheripour and Tyner (2013b) concluded that the ease to transform forest into cropland -and vice versa- is not the same as the ease to transform pasture into cropland -and vice versa-. In general, the opportunity costs of the first conversion are often higher than the second. Therefore, the three land types should not be included in the same sub-nest of the tree, since this could lead to biased results. Hence, a combined pasture-cropland category was created, as can be seen in Figure 3.23, which can be converted into forest, or the other way 
round, according to $E T L 1_{F}$ (elasticity of transformation for land cover at bottom of supply tree). In a second level, the possibility for transformation from cropland to pasture or the other way round is implemented by means of ETL1 $1_{P}$, while ETL2 allows for crop shifting. The combination of these parameters distributes the sluggish endowment "land" (under economic activity) across sectors. In addition, whereas the original GTAP-BIO model used the same value of ETL1 and ETL2 all across the world, Taheripour and Tyner (2013b) distinguished four groups of regions according to land allocation patterns observed during the period of 20042010. Values for ETL1 ranged from -0.02 to -0.3 , while values for ETL2 ranged from -0.25 to 0.75 depending on the region. Each land conversion in each AEZ is assigned a $\mathrm{CO}_{2}$ emission in the land use module factor based on estimations of the California Air Resources Board (Gibbs and Yui, 2011).

\subsubsection{Intensive and extensive margins}

Crop yields are endogenous in GTAP-BIO, and crucial in deciding LUC. The size of expansion in cropland is determined by yield responses to crop price changes and by the productivity of new cropland. Hence, besides the land transformation elasticities, two other parameters governing ILUC effects are the yield and land supply elasticities with respect to crop prices. These are often referred to as intensive and extensive margins, respectively. Whereas the intensive margin captures the increase in yields as a response of higher prices of agricultural commodities due to increased biofuels demand, the extensive margin is defined as the change in yield when land employed in other uses is diverted to grow biofuel feedstock. Yield response to prices is estimated at 0.25 , although it has been subject to debate given its influence on the ILUC responses (see Golub and Hertel, 2012, for further discussion). In regard to the extensive margin, a nested constant elasticity of transformation (CET) structure of land supply is implemented (Ahammad and Mi, 2005) whereby the land owner decides on the allocation of land among three uses (forest, cropland and pasture) in order to maximize his rent. Two main drivers for the extensive margin are then considered: expansion of dedicated energy crops into existing agricultural land and/or into land not previously used for agricultural purposes. When other crops are displaced, supply elasticity is estimated from the differential in net returns to land in existing uses, based on the assumption that land will be allocated to its highest value use and mediated by the CET parameters. Cropland area can be expanded into uncultivated land (managed forest or pasture), with a tendency for average crop yields to decline. In this context, "cropland pasture" refers to low productivity land that has been previously used for agriculture but is not under cultivation at present. An endogenous yield adjustment for this land is included when it is brought into production, in response 
to changes in cropland pasture rent. However, this possibility only exists for the US and Brazil.

The extensive margin thus responds to the elasticity of output with respect to acreage expansion, also known as the ratio of marginal and average productivities (ETA), since it measures the productivity of new cropland versus the productivity of existing cropland. In the current version, ETA varies across regions and among AEZs, offering greater flexibility in acreage switching among uses in response to price changes. Specifically, the ETA parameter varies between 0.42 and 1 depending on the region and the AEZ. The lowest value means that diverting three hectares of current cropland to biofuel feedstock production takes seven additional hectares of cropland pasture, implying the lowest productivity of the land which can be potentially diverted to dedicated energy crops (marginal land). On the contrary, if ETA is 1, the converted land has the same productivity as the existing cropland in that $A E Z$, indicating that bioenergy expansion takes place at the expense of other crops. As a result, if dedicated energy crops expand onto lower productivity land, then the extensive margin will be negative, whereas the extensive margin may be positive if producer switches from other cropland uses.

\subsubsection{Calculation}

The policy experiments performed have been inspired by the policies mentioned in section 3.5.1 and in the Introduction (chapter I), namely the new proposal COM 595, and Regulations 444/2011 and 1194/2013. It must be pointed out that the GHG reduction thresholds in the RED/FQD have not been included as such. Calculation is based on energy projections from the EC (2010a), obtained by using the dynamic model PRIMES -in combination with other CGE-, which simulates a market equilibrium solution for energy supply and demand in the EU and its MSs by taking into account National Energy Plans. 2009 was established as the baseline in that study since this year captures significantly lower forecasts on economic growth and energy consumption (relative to 2007), together with new legislation regulating the energy markets in the MSs (such as energy efficiency measures or national levels). Population and GDP growth were the main drivers on energy projections. According to this, total fuel consumption in road transport will be 338.14 Mtoe in the EU-28 in 2020. When applying the RED target for biofuel consumption, we obtain 33.81 Mtoe of biofuel to be consumed in 2020 , with a ratio ethanol-biodiesel around 3/8. Our study is focused only on the biodiesel side because: a) diesel will remain the most used fuel by European consumers, b) the behavior of the biodiesel market is subject to great uncertainty as a consequence of recent anti-dumping measures, c) this uncertainty can greatly influence ILUC effects and the subsequent emission factors of the overall biodiesel mix which will be consumed in the EU, and d) it is assumed that anti-dumping duties will not 
interfere with gasoline/ethanol consumption since they are not substitutes with diesel/biodiesel.

Starting from the GTAP-BIO database, two experiments have been performed using the comparative-static model, representing 2004-2020 shocks, namely:

- Experiment 1 (exp 1): Increased biodiesel consumption in response to the $10 \%$ target in the RED and considering a 6\% contribution of FGBs; that was the cap being discussed at the time when the study was prepared, between the Parliamentary and the Council's positions.

- Experiment 2 (exp 2): Increased biodiesel consumption (exp 1) in combination with anti-dumping duties on the biodiesel imported into the EU from Southeast Asia (Mala_Indo), South America -excluding Brazil- (S_Amer) and the US.

For the mandate shock, overall biodiesel consumption in the EU was calculated at 28.6 billion liters in $2020,60 \%$ of which (17.2 billion liters) corresponds to FGBs in both exp 1 and 2. It has been assumed that biod_oth represents those types of biodiesel not under the cap, hence this commodity accounts for the remaining $40 \%$ of the biodiesel consumption. In order to allocate final FGBs consumption to each type of food-based biodiesel in the database, shares reported by Ecofys et al. (2013) have been applied. Specifically, the first-generation biodiesel mix in 2020 is assumed to be composed by biod_soy, biod_rape and biod_palm at 15.6\%, 59.4\% and $25.0 \%$, respectively. For the tariff shock in exp 2, average duties between those imposed on the companies concerned have been applied to biodiesel imports from the corresponding origin. The aforementioned Regulations define antidumping duty rates, expressed as an increase over the CIF Union border price. The shocks in each experiment are summarized in Table 3.19; the experiments do not include any explicit modeling of the sustainability criteria in the RED/FQD. It has to be pointed out that the sharp increase in demand for biod_oth is due to very low consumption levels in the base data ( 0.15 billion liters), relative to the expected consumption in 2020 (11.5 billion liters).

The GTAP model is formulated as a system of differential equations in percentage change form, in which equations are linearized. Since the change in the market price of imported goods is calculated as follows (see eq. 1), the parameter tms was shocked in exp 2 in order to cause an increase in CIF prices of the specific commodities.

$\operatorname{pms}(\mathrm{i}, \mathrm{r}, \mathrm{s})=\operatorname{pcif}(\mathrm{i}, \mathrm{r}, \mathrm{s})+\mathrm{tm}(\mathrm{i}, \mathrm{s})+\operatorname{tms}(\mathrm{i}, \mathrm{r}, \mathrm{s})$

where pms $(i, r, s)$ is the price of imported commodity $i$ from source $r$ in region $s$, pcif(i,r, s) is the CIF price of this, $\operatorname{tm}(i, r)$ is the power of the import tariff (that is, 1 plus the ad valorem rate) on all imports of $\mathrm{i}$ into regions $\mathrm{s}$ (irrespective of the source region), while tms $(i, r, s)$ is the power of the import tariff on imports of $i$ from 
region $r$ into regions $s$. The variables $p m s, p c i f, t m$ and tms actually represent the percentage changes in the corresponding levels quantities.

Table 3.19. Shock statements to perform each experiment. $q p(i, r)$ refers to consumer demand for good i in region $s$; tms $(i, r, s)$ is the power of the import tariff on imports of $i$ from region $r$ into regions $\mathrm{s}$.

\begin{tabular}{lcc} 
Shock statements & Exp 1 & Exp 2 \\
\hline shock qp("biod_rape","EU27") & $727.35 \%$ & $727.35 \%$ \\
shock qp("biod_palm","EU27") & $177.48 \%$ & $177.48 \%$ \\
shock qp("biod_soy","EU27") & $37.82 \%$ & $37.82 \%$ \\
shock qp("biod_oth","EU27") & $7,327.81 \%$ & $7,327.81 \%$ \\
shock tms("biod_palm","Mala_indo","EU27") & & $18.90 \%$ \\
shock tms("biod_soy","S_amer","EU27") & & $24.60 \%$ \\
shock tms("biod_soy","US","EU27") & & $10.80 \%$ \\
\hline
\end{tabular}

As has been mentioned 16.2.1, the GTAP-BIO database does not include biodiesel trade in principle. This drawback could have led to underestimation of ILUC effects from the EU blending mandate, since imports have been accounting for a large share of the biodiesel market, as has been thoroughly explained above. Hence, bilateral trade flows between the chief biodiesel exporting countries and the EU have been introduced in the database in order to better understand the implications of the tariff shock. Specifically, biodiesel imports into the EU have been updated until they reached 2009 levels by using the Altertax closure (Malcolm, 1998); 2009 has been chosen since this year depicts a situation in which the EU market was already filled with imported biodiesel, triggering the definitive anti-dumping duties on US imports, as explained by Lamers et al. (2011b). The database has been thus updated according to the following:

- Soybean biodiesel exports from S_Amer to the EU-27: 973.8 million liters.

- Soybean biodiesel exports from the US to the EU-27: 596.5 million liters.

- Palm biodiesel exports from Mala_Indo to the EU-27: 321.0 million liters.

- Rapeseed biodiesel exports from Canada to the EU-27: 159.9 million liters.

\subsubsection{Results}

As a market-mediated impact, LUC can only be estimated if demand-driven responses are conveniently evaluated throughout the supply chain. Changes in the most significant variables (shown in Table $\mathrm{C} 1$, annex $\mathrm{C}$ ) are analyzed in the following section, comparing the results with and without the anti-dumping measures (exp 1 vs. exp 2). In summary, the main responses are as follows: 1) increase in biodiesel imports despite the tariffs, but also 2) a greater expansion of 
domestic biodiesel production, which triggers 3 ) a sharp increase in firms demand for both vegetable oils and oilseeds; this generates 4) an increased production of biodiesel feedstock in the EU and in main exporting countries, which ultimately translates in LUC. However, as pointed out by Laborde (2011), CGE models do not allow keeping the traceability on where indirect effects associated with each feedstock occur. In other words, they do not distinguish between direct and indirect LUC effects; outcomes depict overall changes at the global scale, and it is not possible to know whether additional production of biofuel feedstock is triggered by biofuel supply or is the result of product displacements in the international market.

\subsubsection{Market responses}

As has been previously outlined, biodiesel imports into the EU from major exporting countries (Argentina, the US, Canada, Indonesia and Malaysia) have been updated in the database, using data from Lamers et al. (2011b). Import shares of biodiesel and biodiesel feedstock across all the sectors involved in the supply chain are shown in Table 3.20 to better understand market responses and the subsequent LUC. The share of imported biodiesel relative to total consumed in the private sector has then changed from almost zero to $78.5 \%, 83.2 \%$, and $12.2 \%$ for biod_soy, biod_palm, biod_rape respectively, depicting a more realistic situation. On the contrary, the shares of imported oils in biodiesel firms' demand are around $50 \%$ for soybean, rapeseed and others, whereas the entire demand for palm oil is met with imported oil. Overall, S_Amer accounts for $10.9 \%$ of the EU private consumption of biodiesel, while the US and Mala_Indo account for $6.1 \%$ and $3.5 \%$, respectively.

Table 3.20. Import share of biodiesel commodities throughout the biodiesel supply chain in the EU.

\begin{tabular}{cccc} 
& $\begin{array}{c}\text { Share of imported } \\
\text { biodiesel in HH demand }\end{array}$ & $\begin{array}{c}\text { Share of imported oils in } \\
\text { biodiesel firms' demand }\end{array}$ & $\begin{array}{c}\text { Share of imported oilseeds in } \\
\text { crushing industries' demand }\end{array}$ \\
\hline Soy & $78.5 \%$ & $50.3 \%$ & $96.6 \%$ \\
Palm & $83.2 \%$ & $100.0 \%$ & $97.4 \%$ \\
Rape & $12.2 \%$ & $49.6 \%$ & $36.1 \%$ \\
Others & $0.0 \%$ & $49.6 \%$ & $43.2 \%$ \\
\hline
\end{tabular}

The biodiesel mix composition in private consumption before and after the mandate shock (in both exp 1 and 2) is represented in Figure 3.24. It can be seen how the market penetration of biod_oth increases the most, accounting for $40 \%$ of overall biodiesel demand in 2020 in accordance with the cap on FGBs that has been simulated. This expansion comes mostly at the expense of biod_soy, which filled more than a half of the market in 2004 but hardly represents a 10\% of it in 2020 . 
Biod_rape increases its presence in consumers' demand relative to the baseline, while biod_palm maintains its market share.

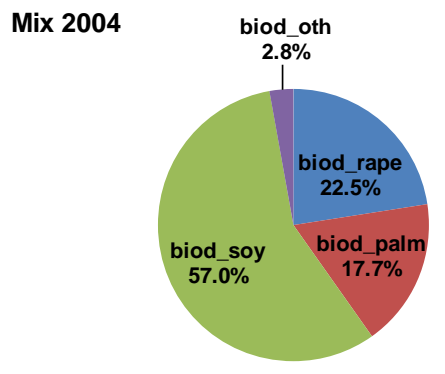

Mix 2020

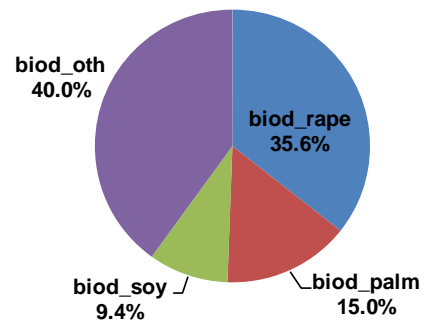

Figure 3.24. Composition of the biodiesel mix underlying private consumption in the EU before and after the experiments. Both exp 1 and exp 2 depict identical shocks in biodiesel consumption between 2004 and 2020, under a static approach.

After the experiments, once biodiesel trade has been introduced and the shares in Table 3.20 apply, the increased demand for biodiesel in the EU is met by both, imports and domestic production. Without the tariff shock (exp 1), increased demand for biod_soy causes an increase in exports from S_Amer (67.29\%), while exports from the US only expand by $2.70 \%$. Imports from other European countries increase by $426.77 \%$, manufactured from both imported and domestic soybeans. The corresponding shock on EU demand for palm biodiesel increases exports from Mala_Indo by $32.79 \%$. Even introducing the tariff shock (exp 2), biodiesel exports from the US, S_Amer and Mala_Indo to the EU expand, triggered by the sharp increase in private consumption. As can be observed in Table C1 (annex C), imports from S_Amer increase less (24.91\%) than in exp 1 due to the anti-dumping duties, which are the highest for that country of origin. Exports of soybean biodiesel from the US increase much more (93.20\%), since they take part of the S_Amer's market share despite the anti-dumping duties on its own exports. It can be said that the anti-dumping duties have the most detrimental consequences on biod_soy exports from S_Amer, which are subject to the greatest shock on the CIF price.

On the contrary, it is noted that exports from Mala_Indo are even greater (34.19\%) than in exp 1 because of two main causes: this region is the only biodiesel source of biod_palm into the EU and thus accounts for the entire import share in the database; the elasticity of substitution between domestic and imported biodiesel is 2 for biod_palm (the lowest), while it is almost 5 for the rest. This results in a decrease in the price of domestic biod_palm to private $\mathrm{HH}$ in the $\mathrm{EU}$ in both exp 1 and 2, which means that EU consumers are shifting from biod_palm from Mala_Indo to biod_palm domestically produced (from imported vol_palm) under the 
Armington structure. However, the decrease in the price of domestic biod_palm is slightly smaller with the tariff shock than without; private $\mathrm{HH}$ shift to domestic biod_palm to a lower extent in exp 2. Imports of vol_palm increase exactly the same as demand for domestic biod_palm in the two experiments, since there is no production of palm in the EU. This implies that the EU is completely reliant on imports to meet the demand for biod_palm. Not surprisingly, the elasticity of substitution between domestic and imported biod_palm is the lowest. It is well known that applied CGE models that rely on the Armington approach are extremely sensitive to these substitution elasticities, with huge effects on policy considerations (McDaniel and Balistreri, 2003).

The situation is different for biod_soy imports. Consumers cannot opt for biodiesel that is not-dumped in the international market because there are no other partners exporting biod_soy to the EU. This occurs also for biod_palm from Mala_Indo, but the Armington elasticity of substitution for biod_soy is more than twice than that for biod_palm. Hence, consumers can shift from imported biod_soy to biod_soy domestically produced (from imported vol_soy) to a large extent. In addition, since the increase in the market price of the biodiesel from S_Amer in the EU is greater than that for the biodiesel from the US as a consequence of the duty, the decrease in exports from S_Amer to the EU is much greater as well. It has to be pointed out that the same shock was previously performed without considering anti-dumping duties in US biodiesel. In that case, exports of biod_soy from the US expanded by more than 100\%, with exports from S_Amer decreasing by $25 \%$ and the US filling the gap left in the European market of biod_soy.

On the other hand, as could be expected, the greatest benefits of the combined shock in exp 2 are enjoyed by the biodiesel producers in the EU, regardless the feedstock they use for biodiesel production. Specifically, the production of biod_oth expands the most $(16,313.78 \%)$, followed by biod_palm (852.94\%), biod_rape (685.00\%) and Biod_soy (36.37\%). These changes are also driven by the shocks on private consumption, although the increase in domestic production can differ from the magnitude of the shock itself depending on the shares of domestic consumption in total private demand for each type of biodiesel (Table 3.15). The domestic production of biod_soy and biod_palm in the EU increases less than with the mandate shock alone because exports from the US and Mala_Indo, respectively, increase even more, as explained in the previous paragraphs.

Consumption of vegetable oils in the European biodiesel sector expands as well, at the expense of both imported and domestic feedstock in similar proportions since the shares in firms' demand are around 50\% for all the oils except vol_palm (which comes entirely from abroad). Imports of vol_rape, vol_palm and vol_soy into the EU are actually substantial also according to the EC (2013). In regard to the oilseed sector, the demand for oilseeds by the European crushing industry 
increases for both domestic and imported feedstock, according to the shares of imported feedstock in total firms' demand in Table 3.20. Specifically, demand for imported feedstock increases more than for domestic one in the case of soybean and palm, while it is just the opposite in the case of domestic rapeseed and other feedstocks. As a consequence, the production of oilseeds also expands in those countries exporting to the EU, with the subsequent LUC due to crops displacement. This effect is further analyzed in the following section. In terms of prices, all the biodiesel feedstocks in the EU market become more expensive, especially oils and seeds for biod_rape production and for biod_oth production; the price of soybeans increases the least, since soybean production is also oriented to several sectors such as food and feed in many countries and thus is not influenced by the European biodiesel mandates to the same extent as the price of other oilseeds.

\subsubsection{Land use change effects and GHG emissions}

The policy shocks addressed in the present section lead to a new equilibrium in the global market, which ultimately translates into a re-allocation of the agricultural land in many parts of the world, especially in those regions directly affected by the measures simulated. Changes in crop patterns and the subsequent yield and area effects in the EU, S_Amer, the US and Mala_Indo are shown in Tables 3.21, 3.22, 3.23 and 3.24 , respectively. In this section, results are only displayed for exp 2, since it has been found that the contribution of the anti-dumping measures alone is negligible compared to the blending mandate. In other words, impacts in exp 2 are mostly driven by the policy shock, rather than by the tariff shock, thus LUC outcomes barely diverge between exp 1 and exp 2. However, discussion about ILUC emissions factors will be drawn in section 3.5.4 considering both experiments in order to see the impacts of the anti-dumping measures in terms of global GHG emissions. The word LUC hereinafter refers to both direct and indirect impacts, due to the fact that it is not possible to identify the causes driving each phenomenon in GTAP, as has been previously highlighted.

Regarding the land use and yield implications of the blending mandate in combination with the anti-dumping duties, there is obviously a significant expansion in the harvested area for oilseeds in the EU, mainly rapeseed and other oilseeds, for which firms' demand increases the most. This is because the biodiesel supply from these feedstocks in the EU mostly relies on domestic oilseeds, while the biod_soy sector relies on imports of vegetable oils to a large extent. As a result, the agricultural land diverted to rapeseed and other oilseeds expands $52.84 \%$ and $52.18 \%$, respectively. As shown in Table 3.21, this expansion takes place not only at the expense of soybean (which is not a widespread crop in the EU) but also at the expense of other crops, especially paddy rice, wheat, other coarse grains and other agricultural commodities. However, these four groups of crops still account 
for $80.2 \%$ of the overall agricultural land in the EU. Even if the model's output shows an increase in the production of palm, it has to be pointed out that the initial level of production in the database is zero, thus the \% change is meaningless, same as happens with sugarcane. Higher oilseeds prices lead to higher yields under the intensive margin. There is also a significant yield adjustment in the rest of the crops for which area is contracting, in order to avoid greater production slowdowns. The extensive margin prevails though, which is positive in this case, suggesting that in much of the EU the productivity of land that might be converted to dedicated energy crops is about the same as that of existing cropland. LUC in the EU mainly takes place at the cost of land already under agricultural production, since commercial forests and pastureland are scarcely available as compared to other regions such as the US or Mala_Indo.

In regard to the biodiesel exporting countries, there is a huge increase in the land dedicated to rapeseed and other oilseeds in the US and S_Amer to feed the European crushing industry, which comes partially at the cost of soybean production. It must be recalled that the share of this feedstock is decreasing in the biodiesel consumption mix in the EU relative to the baseline, as shown in Figure 3.24. In addition, this suggests that part of the available soybeans are no longer used in other sectors in these two regions, in order to increase biod_soy exports to the EU. In fact, oilseed demand by other important sectors decreases, such as livestock or feed processing industries. Mala_Indo is not a rapeseed-producing region thus the reported increase in Table 3.24 is also meaningless.

The area diverted to palm in S_Amer expands as well, to increase exports of vol_palm to the European market. However, LUC effects in S_Amer are the least remarkable, since demand for oilseeds is much diversified across sectors, and the effect of the increased demand for biodiesel becomes diluted; the livestock sector is indeed very important in countries such as Argentina. As can be observed in Table 3.22, the intensive margin still prevails, even if the converted land is, in some cases, less productive for current uses than for the previous ones. The land use module has more detailed information for the US, including the modeling of LUC from pastureland and commercial forests. As can be seen in Table 3.23, only the area diverted to soybeans is decreasing, which suggests that other uses apart from farming are being diverted to bioenergy; this is why yields decrease. Finally, in Mala_Indo, production of palm increases the most, while the increase in rapeseed production is not relevant because it is initially zero. As can be seen in Table 3.24, the resulting area dedicated to rapeseed, wheat and sorghum is zero in Mala_Indo, whereas only palm and rice account for $60.2 \%$ of the total acreage in the region. The intensive margin again determines the subsequent yield adjustments, while the extensive margin is negative leading to the conclusion that the new cropland is less productive. 
Table 3.21. Changes in production, harvested area and yield, by crop, in the EU.

\begin{tabular}{|c|c|c|c|c|c|c|c|c|c|c|}
\hline EU27 & Soybeans & Rapeseed & Palm & $\begin{array}{c}\text { Other } \\
\text { oilseeds }\end{array}$ & Wheat & Sorghum & $\begin{array}{c}\text { Other } \\
\text { coarse } \\
\text { grains }\end{array}$ & $\begin{array}{l}\text { Paddy } \\
\text { rice }\end{array}$ & Sugarcane & $\begin{array}{l}\text { Other } \\
\text { crops }\end{array}$ \\
\hline \multicolumn{11}{|c|}{ Decomposition of output changes (\%) } \\
\hline Output & -7.76 & 61.10 & 15.51 & 61.48 & -3.50 & 1.09 & -0.33 & -4.79 & -0.70 & -2.80 \\
\hline Yield & 4.43 & 5.40 & 0.00 & 6.10 & 4.54 & 4.80 & 4.94 & 4.72 & 4.58 & 4.63 \\
\hline Area & -11.69 & 52.84 & 0.00 & 52.18 & -7.41 & -3.55 & -5.03 & -9.16 & -4.90 & -6.89 \\
\hline \multicolumn{11}{|c|}{ Decomposition of yield changes (\%) } \\
\hline Yield & 4.40 & 5.33 & 0.00 & 6.02 & 4.51 & 4.76 & 4.89 & 4.70 & 4.54 & 4.59 \\
\hline Intensive margin & 0.60 & 1.90 & 0.00 & 1.95 & 0.87 & 1.18 & 1.18 & 0.68 & 0.97 & 1.01 \\
\hline Extensive margin & 3.80 & 3.43 & 0.00 & 4.07 & 3.64 & 3.58 & 3.71 & 4.02 & 3.57 & 3.58 \\
\hline Harvested area (Mha) & 0.35 & 6.83 & 0.00 & 13.60 & 24.51 & 0.10 & 32.05 & 0.39 & 2.12 & 35.94 \\
\hline
\end{tabular}

Table 3.22. Changes in production, harvested area and yield, by crop, in S_Amer.

\begin{tabular}{|c|c|c|c|c|c|c|c|c|c|c|}
\hline S_Amer & Soybeans & Rapeseed & Palm & $\begin{array}{l}\text { Other } \\
\text { oilseeds }\end{array}$ & Wheat & Sorghum & $\begin{array}{l}\text { Other } \\
\text { coarse } \\
\text { grains }\end{array}$ & $\begin{array}{l}\text { Paddy } \\
\text { rice }\end{array}$ & Sugarcane & $\begin{array}{l}\text { Other } \\
\text { crops }\end{array}$ \\
\hline \multicolumn{11}{|c|}{ Decomposition of output changes (\%) } \\
\hline Output & -2.85 & 29.27 & 32.04 & 26.98 & -0.67 & 0.46 & 0.74 & -0.26 & -0.18 & 0.54 \\
\hline Yield & -0.01 & 2.12 & 3.19 & 2.38 & 0.26 & 0.51 & 0.50 & 0.87 & 0.79 & 0.65 \\
\hline Area & -2.84 & 26.59 & 27.96 & 24.03 & -0.99 & -0.05 & 0.24 & -1.04 & -0.91 & -0.21 \\
\hline \multicolumn{11}{|c|}{ Decomposition of yield changes (\%) } \\
\hline Yield & 0.00 & 2.12 & 3.18 & 2.38 & 0.26 & 0.51 & 0.50 & 0.87 & 0.78 & 0.65 \\
\hline Intensive margin & 0.27 & 2.40 & 2.70 & 2.43 & 0.49 & 0.57 & 0.59 & 0.58 & 0.49 & 0.68 \\
\hline Extensive margin & -0.27 & -0.28 & 0.48 & -0.05 & -0.23 & -0.06 & -0.09 & 0.29 & 0.29 & -0.03 \\
\hline Harvested area (Mha) & 17.03 & 0.06 & 0.44 & 3.27 & 7.26 & 0.91 & 6.71 & 2.09 & 1.21 & 17.92 \\
\hline
\end{tabular}

Table 3.23. Changes in production, harvested area and yield, by crop, in the US.

\begin{tabular}{|c|c|c|c|c|c|c|c|c|c|c|}
\hline US & Soybeans & Rapeseed & Palm & $\begin{array}{l}\text { Other } \\
\text { oilseeds }\end{array}$ & Wheat & Sorghum & $\begin{array}{l}\text { Other } \\
\text { coarse } \\
\text { grains }\end{array}$ & $\begin{array}{l}\text { Paddy } \\
\text { rice }\end{array}$ & Sugarcane & $\begin{array}{l}\text { Other } \\
\text { crops }\end{array}$ \\
\hline \multicolumn{11}{|c|}{ Decomposition of output changes (\%) } \\
\hline Output & -4.74 & 40.68 & 3.84 & 32.73 & 2.50 & 0.26 & 0.52 & 0.51 & -0.01 & 0.73 \\
\hline Yield & -0.73 & 1.60 & 0.00 & 1.11 & -0.06 & -0.33 & -0.41 & -0.68 & -0.27 & -0.21 \\
\hline Area & -4.05 & 38.47 & 0.00 & 31.27 & 2.56 & 0.59 & 0.93 & 1.19 & 0.25 & 1.03 \\
\hline \multicolumn{11}{|c|}{ Decomposition of yield changes (\%) } \\
\hline Yield & -0.73 & 1.60 & 0.00 & 1.13 & -0.06 & -0.33 & -0.40 & -0.67 & -0.26 & -0.21 \\
\hline Intensive margin & 0.03 & 1.88 & 0.00 & 1.75 & 0.44 & 0.28 & 0.27 & 0.32 & 0.42 & 0.37 \\
\hline Extensive margin & -0.76 & -0.28 & 0.00 & -0.62 & -0.50 & -0.61 & -0.67 & -0.99 & -0.68 & -0.58 \\
\hline Harvested area (Mha) & 28.71 & 0.46 & 0.00 & 2.03 & 20.24 & 2.65 & 32.17 & 1.37 & 0.93 & 39.16 \\
\hline
\end{tabular}

Table 3.24. Changes in production, harvested area and yield, by crop, in Mala_Indo.

\begin{tabular}{|c|c|c|c|c|c|c|c|c|c|c|}
\hline Mala_Indo & Soybeans & Rapeseed & Palm & $\begin{array}{c}\text { Other } \\
\text { oilseeds }\end{array}$ & Wheat & Sorghum & $\begin{array}{l}\text { Other } \\
\text { coarse } \\
\text { grains }\end{array}$ & $\begin{array}{l}\text { Paddy } \\
\text { rice }\end{array}$ & Sugarcane & $\begin{array}{l}\text { Other } \\
\text { crops }\end{array}$ \\
\hline \multicolumn{11}{|c|}{ Decomposition of output changes (\%) } \\
\hline Output & -1.13 & 19.08 & 5.14 & 0.75 & 3.68 & -2.22 & -0.58 & -0.44 & -0.30 & -0.27 \\
\hline Yield & -0.11 & 0.00 & 1.56 & 0.43 & 0.00 & 0.00 & 0.09 & 0.15 & 0.23 & 0.25 \\
\hline Area & -1.03 & 0.00 & 3.53 & 0.32 & 0.00 & 0.00 & -0.68 & -0.58 & -0.50 & -0.45 \\
\hline \multicolumn{11}{|c|}{ Decomposition of yield changes (\%) } \\
\hline Yield & -0.11 & 0.00 & 1.56 & 0.44 & 0.00 & 0.00 & 0.09 & 0.15 & 0.24 & 0.25 \\
\hline Intensive margin & 0.12 & 0.00 & 1.85 & 0.72 & 0.00 & 0.00 & 0.33 & 0.40 & 0.52 & 0.52 \\
\hline Extensive margin & -0.23 & 0.00 & -0.29 & -0.28 & 0.00 & 0.00 & -0.24 & -0.25 & -0.28 & -0.27 \\
\hline Harvested area (Mha) & 0.56 & 0.00 & 6.96 & 0.00 & 0.00 & 0.00 & 3.37 & 12.53 & 0.43 & 8.53 \\
\hline
\end{tabular}

These LUC effects in the EU and main biodiesel-exporting regions generate in turn indirect effects in other regions. Figure 3.25 shows absolute changes in the distribution of the global agricultural land, by crop and region, as a consequence of the shock on biodiesel consumption in the EU by 2020 under the exp 2 assumptions. Overall, there is a net expansion of $0.25 \mathrm{Mha}$ in the agricultural land 
in the EU, only surpassed by Brazil and SS_Africa. In particular, results show also a huge acreage expansion in Sub-Saharan Africa (SS_Africa) $(1.80 \mathrm{Mha})$, Brazil (0.33 Mha), Canada (0.16 Mha), other CEE countries (Oth_CEE_CIS) (0.13 Mha), and S_Amer (0.11 Mha), mainly to supply other oilseeds, rapeseed and palm oil into the EU market. The area dedicated to all the oilseeds increases worldwide by 11.39 Mha, while the area dedicated to cereals decreases by 4.68 Mha. An increase of $7.01 \mathrm{Mha}$ in the acreage of rapeseed and other oilseeds is observed in the EU, which will partially take place at the expense of 6.76 Mha from other crops, wheat and other coarse grains.

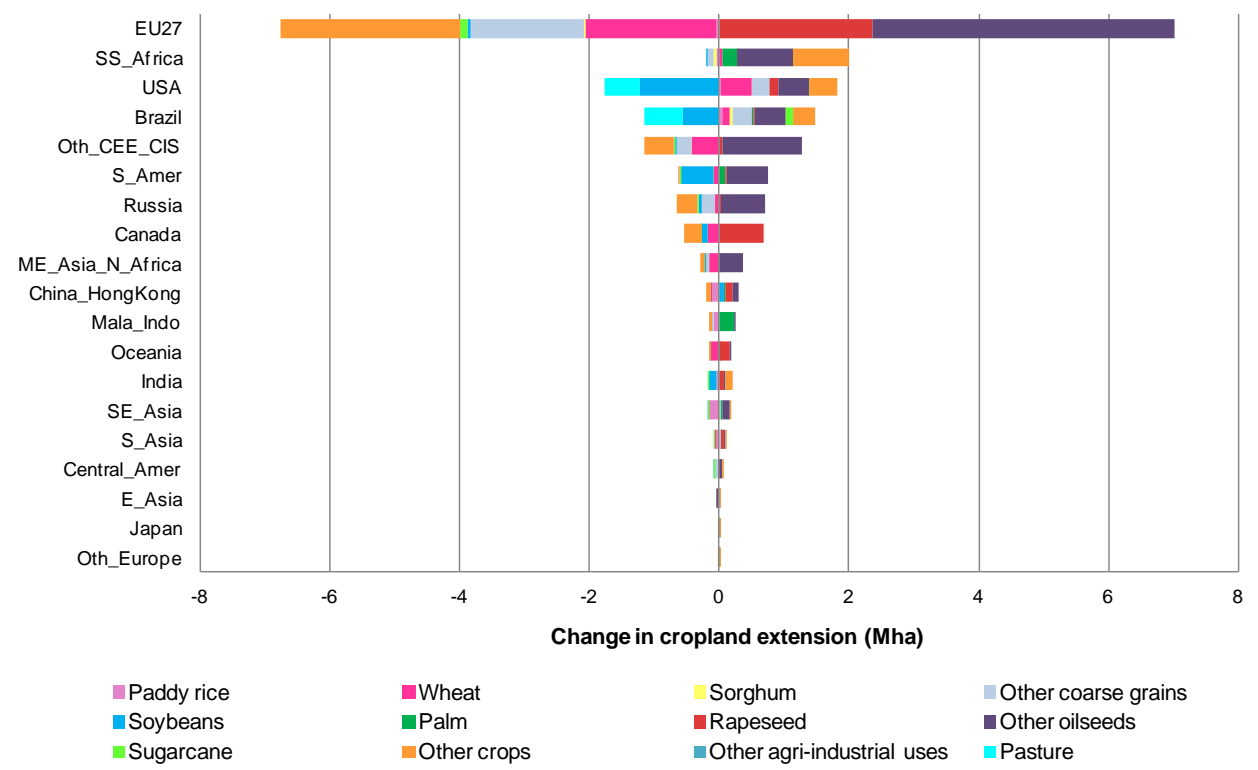

Figure 3.25. Changes in cropland extension (Mha), by region, due to the shock on biodiesel consumption in the EU with the additional anti-dumping duties (exp 2).

This expansion in agricultural land translates into increased global GHG emissions. Not surprisingly, the highest emissions are generated by the LUC in SS_Africa (around $300 \mathrm{Tg}$ of $\mathrm{CO}_{2}$ ), followed by Canada $\left(89 \mathrm{Tg}\right.$ of $\mathrm{CO}_{2}$ ) and Mala_Indo (82 Tg of $\mathrm{CO}_{2}$ ), while emissions in the $\mathrm{EU}$ amount only $56 \mathrm{Tg}$ of $\mathrm{CO}_{2}$. This is because LUC from forestry generates much greater GHG emissions than converting other crops, and managed forestland is highly available in SS_Africa, Canada and Mala_Indo. Figure 3.26 is obtained when dividing overall GHG emissions in each region (as the sum of emissions from forestry, pasture and cropland) by the total acreage increase reported in Figure 3.25, to get the idea on where LUC may cause greater global warming impact. Relative emissions from cropland expansion are the same in all the regions, since the calculation is based on the same emission 
factor (-18 $\left.\mathrm{Mg} \mathrm{CO}_{2} / \mathrm{ha}\right)$, indicating that this type of transformation leads to carbon uptake in all the AEZs. Bioenergy crops usually improve the GHG balance relative to other arable crops, and they are expanding globally. However, it can be seen how expanding cropland in regions such as Mala_Indo, S_Asia, Japan, Canada and India can result in the highest GHG emissions. Indeed, although the net increase in the agricultural land in Mala_Indo is only 0.1 Mha (as compared to 0.25 Mha in the $\mathrm{EU}$ ), it leads to much higher $\mathrm{CO}_{2}$ emissions relative to the acreage increase (828 Mg CO$/ 2 / h a)$, since the decline of tropical rainforest and specially peatland is coupled with higher emission factors in the model. Transformation from livestock activities prevails in regions such as Brazil, China-HongKong, S_Amer or Russia, with a lower emission factor than forest.

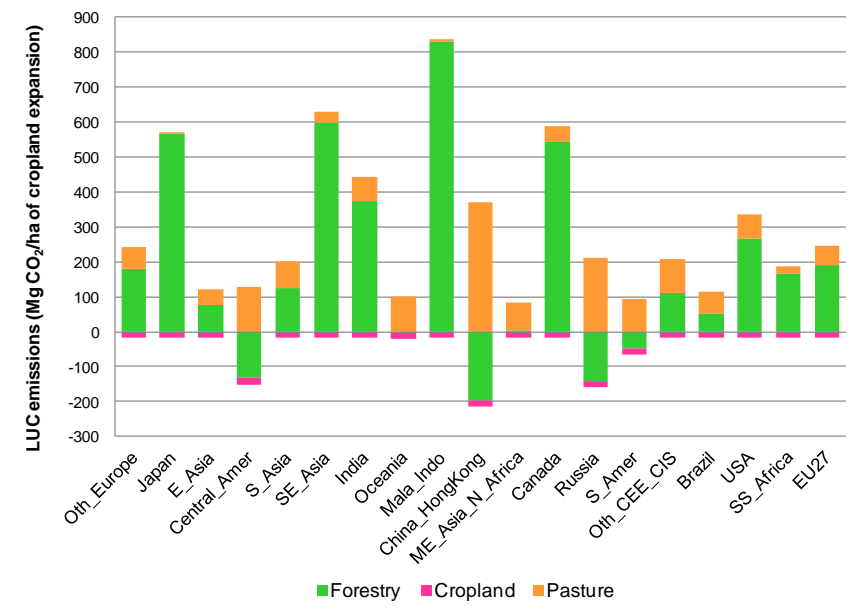

Figure 3.26. GHG emissions from LUC in all the regions, expressed in $\mathrm{Mg}$ of $\mathrm{CO}_{2}$ per ha of cropland expansion in exp 2.

\subsubsection{Discussion}

This expansion in agricultural land worldwide translates into global GHG emissions, as has been seen, which should be attributed to the biofuels consumed in the EU according to the new EC's proposal. In order to evaluate the environmental consequences of the blending mandate, the COM 595 provides default values of ILUC emission factors depending on the feedstock, based on Laborde (2011). Specifically, oilseed-based biodiesel is supposed to generate $55 \mathrm{~g} \mathrm{CO}_{2} / \mathrm{MJ}$. Results from section 3.5.3.2 allow us to calculate the corresponding emission factors associated with the overall EU consumption mix of biodiesel after the two experiments. A lower heating value of $37.8 \mathrm{MJ} / \mathrm{kg}$ has been considered (GREET, 2010), together with an amortization period of 20 years to calculate annualized emissions, consistent with the guidelines in the RED/FQD. This yields an emission 
factor of $35.7 \mathrm{~g} \mathrm{CO}_{2} / \mathrm{MJ}$ in exp 1 and $35.8 \mathrm{~g} \mathrm{CO}_{2} / \mathrm{MJ}$ in $\exp 2$, arising from 24.5 Mtoe of biodiesel. These results again confirm that the effect of the anti-dumping duties on the environmental outcomes is negligible in comparison with that of the blending mandate alone. In fact, anti-dumping duties slightly increase global emissions since they generate a greater expansion in exports of oilseeds and vegetable oils to the EU, and also an increase of palm biodiesel exports from Mala_Indo, as has been seen; this region brings the highest GHG emissions from LUC due to forest and peatland destruction.

In any manner, these emission factors are lower than those in the COM 595 due to the high share of biod_oth in the mix. Laborde (2011) considered an $8.6 \%$ share of FGBs in 2020 (27.2 Mtoe), while our case study assumes that they will only account for $6 \%$ of the target biodiesel consumption (14.7 Mtoe). It must be pointed out though, that the cap on FGBs should deliver even lower LUC emissions if the commodity biod_oth was entirely devoted to biodiesel from waste products, as has been assumed. According to the life cycle methodology proposed in the RED/FQD, second-generation pathways lead to zero GHG emissions up to the collection stage. Disaggregating these other FGBs from the biod_oth commodity would provide a better picture of the COM 595 effects, since, in the GTAP-BIO database, it can be manufactured from other oilseeds such as sunflower or olives, thus competing with food production. Laborde (2011) considered a sunflower commodity separately, included as such in the MIRAGE model, due to its relative importance in the EU sector. The author performed marginal shocks on each biodiesel type, over the target situation, in order to estimate individual emission factors for each pathway. Specifically, LUC GHG intensity ranged from 52 to $56 \mathrm{~g}$ $\mathrm{CO}_{2} / \mathrm{MJ}$ for all the oilseeds, with the minimum value corresponding to sunflower biodiesel. Therefore, GHG emissions from LUC may be overestimated in our case study, due to the enormous increase in the land diverted to other oilseeds.

It is worth mentioning that, in their subsequent study, Laborde et al. (2014) performed the same shock as Laborde (2011) but under different scenario assumptions, commissioned by the EC in order to analyze uncertainty in ILUC estimates. One of the assumptions was to prevent increase of arable cropland into land diverted to other oilseeds in the EU, assuming that this commodity mainly captures the olive oil sector, which is actually very stable in the EU. Although the obtained emission factors for different oilseeds are really close to those from the preliminary study, this highlights the need to refine the definition of the other oilseed commodity, in view of the great heterogeneity of oilseed crops also in terms of land conversion.

What seems to be more relevant is that the EU biodiesel mandate (in combination or not with anti-dumping duties), will have important implications for LUC patterns worldwide even with the cap. Exp 2 leads to an expansion in the worldwide 
agricultural land of 3.32 Mha, $54.1 \%$ of which takes place in SS_Africa while only $7.5 \%$ takes place within the EU borders. These results are consistent with those from Laborde (2011), who found that the cropland expansion taking place within the EU remains under $6 \%$ of global cropland extension. Note that the author shocked consumption of both ethanol and biodiesel, and ethanol usually leads to lower LUC effects than biodiesel. Specifically, he applied a ratio ethanol/biodiesel very similar to that considered in our case study for the calculation of the biodiesel shock (2/5 vs. 3/8). However, the fact of shocking overall biofuel consumption may indeed have further implications in the conclusions drawn, due to trade consequences arising from the increased demand for ethanol and ethanol feedsotcks. Hence, no further comparisons in terms of LUC effects should be made between both studies. Other CGE studies on biofuel policies that have received attention in the scientific arena are those from Al-Riffai et al. (2010), Banse et al. (2008), Hertel et al. (2010) and Taheripour and Tyner (2013b). Most of them identify potential large LUC effects in S_Amer and especially in SS_Africa as a consequence of US and EU biofuel mandates. Although results vary depending on the baseline and modeling assumptions, it seems clear that both the US and the EU will incur a trade deficit, triggering imports of biofuel feedstock from Mala_Indo, S_Amer, SS_Africa and Brazil. In addition, S_Amer and SS_Africa are likely to become the main suppliers in the international market of those agricultural commodities previously displaced in traditional producing regions, thus suffering the largest indirect effects.

Besides yield elasticities, land elasticities and other land modeling approaches play a critical role in the assessment of LUC (e.g. Taheripour and Tyner 2013b). For instance, total land supply is exogenous in the standard GTAP model. One the main limitations of the GTAP-BIO is that price-induced increases in cropland must be at the expense of pasture or commercial forests, and the depletion of rainforests or other ecologically-valuable non-commercial land cannot be simulated (BlancoFonseca et al., 2010), which can lead to an underestimation of GHG emissions. In other words, the GTAP model restricts the potential land sources for increased biomass production to pasture or forests as it does not take into account idle land. On the contrary, Banse et al. (2008) implemented land supply curves to represent the process of land conversion and land abandonment endogenously, due to the importance that this phenomenon may have in defining biofuel and agricultural policies in the EU. This approach allows for cropland expansion to occur also at the cost of idle land. According to this, increased demand for oilseeds in the EU leads to land use in South and Central America but reduces land abandonment in the EU. Apart from this, there can be other positive LUC effects in other regions resulting in carbon sequestration (Hertel et al., 2010). Finally, another critical point would be the estimation of emissions from other land use types such as peatland or degraded grasslands, which are readily available in Mala_Indo (Chouychai et al., 
2009; Germer and Sauerborn, 2008). Emissions from peatland drainage cannot be assessed in terms of carbon stock changes because changes occur on the overall peat soil profile (not only on the first $30 \mathrm{~cm}$ ) (Carré et al., 2010). All these issues generate further uncertainty in the estimation of ILUC by means of CGE models.

\subsubsection{Conclusions}

The widely used GTAP-BIO model has been employed to examine the global effects, in terms of overall LUC and the associated $\mathrm{CO}_{2}$ emissions, of recent European policies regulating the biodiesel market, namely the proposed cap on the contribution of FGBs to the 2020 target, and anti-dumping duties on imports from the US, Mala_Indo and S_Amer (under Regulations 444/2011 and 1194/2013). In order to analyze the market responses in depth, biodiesel imports into the EU from major producing countries have been updated in the original database. Two experiments have been performed under a static approach, one considering the effect of the blending mandate alone, and a second one including the anti-dumping duties in combination with the mandate.

Despite the tariff measures, which have a minor impact compared to the blending mandate, biodiesel imports increase because of the enormous expansion of domestic demand, mainly for palm biodiesel. While the US gains of market share at the expense of S_Amer (subject to higher anti-dumping duties), exports of palm biodiesel from Mala_Indo to the EU are even fostered by the tariff shock, since European consumers continue to depend on them to meet the targets. Biodiesel producers in the EU benefit from these policies as well, especially those producing rapeseed and non-food-based biodiesel, but, due to imports of vegetable oils, palm biodiesel producers also benefit. Indeed, the results obtained show that establishing a $6 \%$ target for FGBs and a $4 \%$ target for advanced biofuels (with or without anti-dumping measures) is a great incentive for the biodiesel sector in the $\mathrm{EU}$, since the market is filled with imported biodiesel but also with domestic product.

The expansion in demand for biodiesel in the EU is thus satisfied by imports for a substantial share, either in the form of biofuels or biofuel inputs. This creates in turn an increased demand for feedstock, not only in the EU but also in the main exporters of both vegetable oils (such as Mala_Indo, S_Amer, Brazil or India) and oilseeds (such as the US, Brazil, S_Amer, China, Russia or Canada). As a consequence, 3.32 Mha of land are brought into agricultural production to supply more oilseeds (mainly rapeseed, palm and other oilseeds) but also those commodities displaced. Changes in crop patterns are observed all across the world, in the EU but also in regions outside the EU, mainly SS_Africa, Brazil and S_Amer. Global LUC ultimately translates into GHG emissions, the highest being 
produced in Mala_Indo, SE_Asia, Canada and Japan, due to forest and peatland conversion. These effects are expected to cause changes in agricultural structures worldwide, with other potential impacts of social and economic nature. In this sense, analyzing welfare effects would be useful to estimate the cost of these policies for the society

The fact is that recent biofuel policies in the EU will require the use of a significant amount of biomass, and the global economy is expected to be affected in several ways. The latest proposals on biofuel policies (such as the RFS2, COM 595, etc) implement ILUC considerations, while setting some constraints regarding foodbased biofuels. This paper is an example of the application of the GTAP-BIO model to estimate the environmental consequences (in terms of GHG emissions and LUC) of recent regulations on the biodiesel sector in the EU, allowing for ILUC emission factors to be calculated. Specifically, the target biodiesel demand in the EU by 2020 (in combination with anti-dumping duties) will cause around $35.8 \mathrm{~g}$ $\mathrm{CO}_{2} / \mathrm{MJ}$, lower than the default value in the proposal. This shows that limiting FGB consumption may be an effective way of reducing indirect GHG emissions from the EU blending mandate, but ILUC is still an issue of concern. Although its estimation of ILUC is subject to great uncertainty, which makes it difficult to integrate into public policies, the results should serve to reinforce the commitment of the EC to quantify and control it. Uncertainty is inherent to any attempt to model the real world, but it seems certain that the LUC impacts from biofuels are not zero. Hence, ILUC emission factors should be used in compliance with the sustainability criteria in the RED/FQD once an acceptable level of uncertainty is defined. Despite the difficulty of predicting indirect effects due to their global dimension, analyzing interactions in the global markets is crucial. CGE models, such as GTAP, can be a valuable tool for policy-makers, although regulating ILUC still represents a challenge in the emerging area of bioenergy. 



\section{Chapter IV. Discussion}



The main objective of the doctoral thesis has been to analyze the environmental impacts of biodiesel consumption in the Spanish transport sector, in fulfillment of the most recent European policies on biofuels and climate change. With this aim in mind, and in view of the long and lasting crisis that the sector has been facing in the last few years, different systems for biodiesel production have been analyzed in the Spanish context. Different methodologies have been applied under a life cycle perspective. In order to provide additional insights into the evaluation of controversial issues that affect the environmental performance of biofuel systems, such as uncertainty, multi-functionality and indirect effects, not only have environmental considerations been taken into account, but also economic ones. As has been outlined in chapter II, each section of the Results (chapter III) applies one specific methodology, with different scopes (see Figure 2.2).

Apart from the appropriateness of biodiesel subsidies, one of the issues that has recently been subject to hot debate among researchers, policy makers and biofuel producers and traders is indirect land use change (ILUC), as has been highlighted throughout the dissertation. Its importance relies on the role this phenomenon plays in increasing the global warming (GW) impact caused by biofuel mandates, thereby compromising the suitability of biofuels to meet climate goals. Ultimately, ILUC translates into changes in the carbon stock of ecosystems as a consequence of crop relocation worldwide, with the subsequent greenhouse gas (GHG) emissions. The calculation of these emissions entails great uncertainty, due to the unpredictable nature of agricultural and energy markets. In spite of this, biofuel policies are expected to increasingly incorporate ILUC considerations following the examples of the European Union (EU) and the United States (US), leading consumer markets since the early stages of the sector. The general trend is that of transport leading to a reduced demand for first-generation biofuels (FGBs), while promoting the use of advanced technologies that cause substantially lower GHG than fossil fuels. In a parallel effort, recent policies in these two regions have proposed the quantification of indirect GHG emissions associated with different biofuel pathways, by using ILUC emission factors. FGBs are proved to generate greater indirect effects, but there is no consensus on the methodology to apply for the calculation of these factors. Biofuel policies even encourage researchers to provide additional estimations in order to contribute to the understanding of ILUC and the associated uncertainty.

\subsection{GHG emission factors}

Expressing all the environmental results from the dissertation in terms of $\mathrm{g} \mathrm{CO}_{2} / \mathrm{MJ}$ can be a good starting point for the discussion. This allows for an analysis of compliance with European biofuel directives, namely the Renewable Energy Directive (RED), the Fuel Quality Directive (FQD), and the new proposal on ILUC, 
known as COM 595. GHG emission factors are drawn from sections 3.1, 3.3, 3.4 and 3.5, allowing biodiesel alternatives to be compared, as well as the life cycle methodologies employed. Tables 4.1 and 4.2 summarize all the biodiesel pathways assessed (hereinafter called scenarios), which are further included in Figures 4.1 and 4.2, together with the corresponding emission factors $\left(\mathrm{g} \mathrm{CO}_{2} / \mathrm{MJ}\right)$. For those pathways based on UCO biodiesel (second-generation ones) in Figure 4.1, results are calculated with and without considering a double-counting scheme, to highlight the importance of this measure not only in the biodiesel consumption mix, but also in terms of emission factors. Emission factors of first-generation biodiesel pathways in Figure 4.2 are calculated in regard to both direct emissions and ILUC. According to the definition in the RED/FQD, direct emissions arise from the production of the biofuel from cradle to grave: that is, from the extraction of the raw materials (including direct land use change, DLUC) to the transesterification stage. In this way, this discussion may provide insights into how diverging methodological approaches influence the environmental performance of the biodiesel pathways considered.

Table 4.1. UCO biodiesel pathways evaluated in the dissertation under different approaches, with and without double-counting.

\begin{tabular}{|c|c|c|c|c|c|c|}
\hline $\begin{array}{c}\text { UCO } \\
\text { pathways } \\
\text { (Fig. 4.1) }\end{array}$ & Feedstock & Section & $\begin{array}{l}\text { Scenario } \\
\text { formulation }\end{array}$ & Approach & Description & $\begin{array}{l}\text { Double- } \\
\text { counting }\end{array}$ \\
\hline 1 & UCO & Section 3.1 & Scenario A1 & $\begin{array}{l}\text { Attributional } \\
\text { LCA }\end{array}$ & $\begin{array}{l}\text { Integral-b system, electricity } \\
\text { displacing electricity from the } \\
\text { Spanish mix, lower UCO } \\
\text { collection capacity }(80,000 \mathrm{t} / \mathrm{a})\end{array}$ & NO \\
\hline 2 & UCO & Section 3.1 & Scenario A2 & $\begin{array}{l}\text { Attributional } \\
\text { LCA }\end{array}$ & $\begin{array}{l}\text { Integral-b system, electricity } \\
\text { displacing wind-generated } \\
\text { electricity, lower UCO collection } \\
\text { capacity }(80,000 \text { t/a) }\end{array}$ & NO \\
\hline 3 & UCO & Section 3.1 & Scenario A1' & $\begin{array}{l}\text { Attributional } \\
\text { LCA }\end{array}$ & $\begin{array}{l}\text { Integral-b system, electricity } \\
\text { displacing electricity from the } \\
\text { Spanish mix, higher UCO } \\
\text { collection capacity }(300,000 \mathrm{t} / \mathrm{a})\end{array}$ & NO \\
\hline 4 & UCO & Section 3.1 & Scenario A2' & $\begin{array}{l}\text { Attributional } \\
\text { LCA }\end{array}$ & $\begin{array}{l}\text { Integral-b system, electricity } \\
\text { displacing wind-generated } \\
\text { electricity, higher UCO collection } \\
\text { capacity } 300,000 \text { t/a) }\end{array}$ & NO \\
\hline 5 & UCO & Section 3.3 & Scenario 2 & $\begin{array}{l}\text { Consequential } \\
\text { LCA }\end{array}$ & $\begin{array}{l}\text { UCO biodiesel collected in Spain, } \\
\text { system expansion }\end{array}$ & NO \\
\hline 6 & UCO & Section 3.4 & uco.sp & $\begin{array}{l}\text { Multi-chain } \\
\text { optimization }\end{array}$ & $\begin{array}{l}\text { UCO biodiesel collected in Spain, } \\
\text { energy allocation }\end{array}$ & NO \\
\hline 7 & UCO & Section 3.4 & uco.fr & $\begin{array}{l}\text { Multi-chain } \\
\text { optimization }\end{array}$ & $\begin{array}{l}\text { UCO biodiesel imported from } \\
\text { France, energy allocation }\end{array}$ & NO \\
\hline 8 & UCO & Section 3.4 & uco.us & $\begin{array}{l}\text { Multi-chain } \\
\text { optimization }\end{array}$ & $\begin{array}{l}\text { UCO biodiesel imported from the } \\
\text { US, energy allocation }\end{array}$ & NO \\
\hline 9 & UCO & Section 3.1 & Scenario A1 & $\begin{array}{l}\text { Attributional } \\
\text { LCA }\end{array}$ & $\begin{array}{l}\text { Integral-b system, electricity } \\
\text { displacing electricity from the } \\
\text { Spanish mix, lower UCO } \\
\text { collection capacity }(80,000 \text { t/a) }\end{array}$ & YES \\
\hline
\end{tabular}


Chapter IV. Discussion

\begin{tabular}{|c|c|c|c|c|c|c|}
\hline $\begin{array}{c}\text { Uco } \\
\text { pathways } \\
\text { (Fig. 4.1) }\end{array}$ & Feedstock & Section & $\begin{array}{l}\text { Scenario } \\
\text { formulation }\end{array}$ & Approach & Description & $\begin{array}{l}\text { Double- } \\
\text { counting }\end{array}$ \\
\hline 10 & UCO & Section 3.1 & Scenario A2 & $\begin{array}{l}\text { Attributional } \\
\text { LCA }\end{array}$ & $\begin{array}{l}\text { Integral-b system, electricity } \\
\text { displacing wind-generated } \\
\text { electricity, lower UCO collection } \\
\text { capacity }(80,000 \text { t/a) }\end{array}$ & YES \\
\hline 11 & UCO & Section 3.1 & Scenario A1' & $\begin{array}{l}\text { Attributional } \\
\text { LCA }\end{array}$ & $\begin{array}{l}\text { Integral-b system, electricity } \\
\text { displacing electricity from the } \\
\text { Spanish mix, higher UCO } \\
\text { collection capacity }(300,000 \text { t/a) }\end{array}$ & YES \\
\hline 12 & UCO & Section 3.1 & Scenario A2' & $\begin{array}{l}\text { Attributional } \\
\text { LCA }\end{array}$ & $\begin{array}{l}\text { Integral-b system, electricity } \\
\text { displacing wind-generated } \\
\text { electricity, higher UCO collection } \\
\text { capacity } 300,000 \text { t/a) }\end{array}$ & YES \\
\hline 13 & UCO & Section 3.3 & Scenario 2 & $\begin{array}{l}\text { Consequential } \\
\text { LCA }\end{array}$ & $\begin{array}{l}\text { UCO biodiesel collected in Spain, } \\
\text { system expansion }\end{array}$ & YES \\
\hline 14 & UCO & Section 3.4 & uco.sp & $\begin{array}{l}\text { Multi-chain } \\
\text { optimization }\end{array}$ & $\begin{array}{l}\text { UCO biodiesel collected in Spain, } \\
\text { energy allocation }\end{array}$ & YES \\
\hline 15 & UCO & Section 3.4 & uco.fr & $\begin{array}{l}\text { Multi-chain } \\
\text { optimization }\end{array}$ & $\begin{array}{l}\text { UCO biodiesel imported from } \\
\text { France, energy allocation }\end{array}$ & YES \\
\hline 16 & UCO & Section 3.4 & uco.us & $\begin{array}{l}\text { Multi-chain } \\
\text { optimization }\end{array}$ & $\begin{array}{l}\text { UCO biodiesel imported from the } \\
\text { US, energy allocation }\end{array}$ & YES \\
\hline
\end{tabular}

Table 4.2. First-generation biodiesel pathways evaluated in the dissertation under different approaches. Ar: Argentina; Br: Brazil; My_in: Malaysia and Indonesia.

\begin{tabular}{|c|c|c|c|c|c|}
\hline $\begin{array}{l}\text { FGB } \\
\text { pathways } \\
\text { (Fig. 4.2) }\end{array}$ & Feedstock & Section & $\begin{array}{c}\text { Scenario } \\
\text { formulation }\end{array}$ & Approach & Description \\
\hline 17 & Rapeseed & Section 3.4 & Scenario 1 & $\begin{array}{l}\text { Multi-chain } \\
\text { optimization }\end{array}$ & $\begin{array}{l}\text { Rapeseed produced in Spain when there is LUC } \\
\text { from Chaco in } \mathrm{Ar} \text {, rainforest in } \mathrm{Br} \text { and rainforest } \\
\text { in My_in }\end{array}$ \\
\hline 18 & Rapeseed & Section 3.4 & Scenario 2.1 & $\begin{array}{l}\text { Multi-chain } \\
\text { optimization }\end{array}$ & $\begin{array}{l}\text { Rapeseed produced in Spain when there is LUC } \\
\text { from Chaco in } \mathrm{Ar} \text {, rainforest in } \mathrm{Br} \text { and rainforest } \\
\text { in My_in }\end{array}$ \\
\hline 19 & Rapeseed & Section 3.4 & Scenario 2.2 & $\begin{array}{l}\text { Multi-chain } \\
\text { optimization }\end{array}$ & $\begin{array}{l}\text { Rapeseed produced in Spain when there is LUC } \\
\text { from Yungas in } \mathrm{Ar} \text {, Cerrado in } \mathrm{Br} \text { and peatland } \\
\text { in My_in }\end{array}$ \\
\hline 20 & Rapeseed & Section 3.4 & Scenario 2.3 & $\begin{array}{l}\text { Multi-chain } \\
\text { optimization }\end{array}$ & $\begin{array}{l}\text { Rapeseed produced in Spain when there is LUC } \\
\text { from cropland in } \mathrm{Ar} \text { and } \mathrm{Br} \text {, and degraded } \\
\text { grassland in } \mathrm{My} \text { in }\end{array}$ \\
\hline 21 & Rapeseed & Section 3.4 & Scenario 3.1 & $\begin{array}{l}\text { Multi-chain } \\
\text { optimization }\end{array}$ & $\begin{array}{l}\text { Rapeseed produced in Spain when there is LUC } \\
\text { from Chaco in Ar, rainforest in } \mathrm{Br} \text { and rainforest } \\
\text { in My_in }\end{array}$ \\
\hline 22 & Rapeseed & Section 3.4 & Scenario 3.2 & $\begin{array}{l}\text { Multi-chain } \\
\text { optimization }\end{array}$ & $\begin{array}{l}\text { Rapeseed produced in Spain when there is LUC } \\
\text { from Yungas in } \mathrm{Ar} \text {, Cerrado in } \mathrm{Br} \text { and peatland } \\
\text { in My_in }\end{array}$ \\
\hline 23 & Rapeseed & Section 3.4 & Scenario 3.3 & $\begin{array}{l}\text { Multi-chain } \\
\text { optimization }\end{array}$ & $\begin{array}{l}\text { Rapeseed produced in Spain when there is LUC } \\
\text { from cropland in } \mathrm{Ar} \text { and } \mathrm{Br} \text {, and degraded } \\
\text { grassland in My_in }\end{array}$ \\
\hline 24 & Rapeseed & Section 3.4 & Scenario 4.1 & $\begin{array}{l}\text { Multi-chain } \\
\text { optimization }\end{array}$ & $\begin{array}{l}\text { Rapeseed produced in Spain when there is LUC } \\
\text { from Chaco in Ar, rainforest in } \mathrm{Br} \text { and rainforest } \\
\text { in My_in }\end{array}$ \\
\hline 25 & Rapeseed & Section 3.4 & Scenario 4.2 & $\begin{array}{l}\text { Multi-chain } \\
\text { optimization }\end{array}$ & $\begin{array}{l}\text { Rapeseed produced in Spain when there is LUC } \\
\text { from Yungas in } \mathrm{Ar} \text {, Cerrado in } \mathrm{Br} \text { and peatland } \\
\text { in My_in }\end{array}$ \\
\hline
\end{tabular}




\begin{tabular}{|c|c|c|c|c|c|}
\hline $\begin{array}{l}\text { FGB } \\
\text { pathways } \\
\text { (Figure } \\
\text { 4.2) }\end{array}$ & $\begin{array}{l}\text { Raw } \\
\text { material }\end{array}$ & Section & $\begin{array}{l}\text { Scenario } \\
\text { formulation }\end{array}$ & Approach & Description \\
\hline 26 & Rapeseed & Section 3.4 & Scenario 4.3 & $\begin{array}{l}\text { Multi-chain } \\
\text { optimization }\end{array}$ & $\begin{array}{l}\text { Rapeseed produced in Spain when there is LUC } \\
\text { from cropland in } \mathrm{Ar} \text { and } \mathrm{Br} \text {, and degraded } \\
\text { grassland in My_in }\end{array}$ \\
\hline 27 & Sunflower & Section 3.4 & Scenario 1 & $\begin{array}{l}\text { Multi-chain } \\
\text { optimization }\end{array}$ & $\begin{array}{l}\text { Sunflower seed produced in Spain when there is } \\
\text { LUC from Chaco in } \mathrm{Ar} \text {, rainforest in } \mathrm{Br} \text { and } \\
\text { rainforest in My_in }\end{array}$ \\
\hline 28 & Sunflower & Section 3.4 & Scenario 2.1 & $\begin{array}{l}\text { Multi-chain } \\
\text { optimization }\end{array}$ & $\begin{array}{l}\text { Sunflower seed produced in Spain when there is } \\
\text { LUC from Chaco in Ar, rainforest in } \mathrm{Br} \text { and } \\
\text { rainforest in My_in }\end{array}$ \\
\hline 29 & Sunflower & Section 3.4 & Scenario 2.2 & $\begin{array}{l}\text { Multi-chain } \\
\text { optimization }\end{array}$ & $\begin{array}{l}\text { Sunflower seed produced in Spain when there is } \\
\text { LUC from Yungas in } \mathrm{Ar} \text {, Cerrado in } \mathrm{Br} \text { and } \\
\text { peatland in My_in }\end{array}$ \\
\hline 30 & Sunflower & Section 3.4 & Scenario 2.3 & $\begin{array}{l}\text { Multi-chain } \\
\text { optimization }\end{array}$ & $\begin{array}{l}\text { Sunflower seed produced in Spain when there is } \\
\text { LUC from cropland in } \mathrm{Ar} \text { and } \mathrm{Br} \text {, and degraded } \\
\text { grassland in My_in }\end{array}$ \\
\hline 31 & Sunflower & Section 3.4 & Scenario 3.1 & $\begin{array}{l}\text { Multi-chain } \\
\text { optimization }\end{array}$ & $\begin{array}{l}\text { Sunflower seed produced in Spain when there is } \\
\text { LUC from Chaco in } \mathrm{Ar} \text {, rainforest in } \mathrm{Br} \text { and } \\
\text { rainforest in My_in }\end{array}$ \\
\hline 32 & Sunflower & Section 3.4 & Scenario 3.2 & $\begin{array}{l}\text { Multi-chain } \\
\text { optimization }\end{array}$ & $\begin{array}{l}\text { Sunflower seed produced in Spain when there is } \\
\text { LUC from Yungas in } \mathrm{Ar} \text {, Cerrado in } \mathrm{Br} \text { and } \\
\text { peatland in My_in }\end{array}$ \\
\hline 33 & Sunflower & Section 3.4 & Scenario 3.3 & $\begin{array}{l}\text { Multi-chain } \\
\text { optimization }\end{array}$ & $\begin{array}{l}\text { Sunflower seed produced in Spain when there is } \\
\text { LUC from cropland in } \mathrm{Ar} \text { and } \mathrm{Br} \text {, and degraded } \\
\text { grassland in My_in }\end{array}$ \\
\hline 34 & Sunflower & Section 3.4 & Scenario 4.1 & $\begin{array}{l}\text { Multi-chain } \\
\text { optimization }\end{array}$ & $\begin{array}{l}\text { Sunflower seed produced in Spain when there is } \\
\text { LUC from Chaco in } \mathrm{Ar} \text {, rainforest in } \mathrm{Br} \text { and } \\
\text { rainforest in My_in }\end{array}$ \\
\hline 35 & Sunflower & Section 3.4 & Scenario 4.2 & $\begin{array}{l}\text { Multi-chain } \\
\text { optimization }\end{array}$ & $\begin{array}{l}\text { Sunflower seed produced in Spain when there is } \\
\text { LUC from Yungas in } \mathrm{Ar} \text {, Cerrado in } \mathrm{Br} \text { and } \\
\text { peatland in My_in }\end{array}$ \\
\hline 36 & Sunflower & Section 3.4 & Scenario 4.3 & $\begin{array}{l}\text { Multi-chain } \\
\text { optimization }\end{array}$ & $\begin{array}{l}\text { Sunflower seed produced in Spain when there is } \\
\text { LUC from cropland in } \mathrm{Ar} \text { and } \mathrm{Br} \text {, and degraded } \\
\text { grassland in My_in }\end{array}$ \\
\hline 37 & Rapeseed & & & Attributional LCA & $\begin{array}{l}\text { Default emission factor in the RED and COM } \\
595\end{array}$ \\
\hline 38 & Sunflower & & & Attributional LCA & $\begin{array}{l}\text { Default emission factor in the RED and COM } \\
595\end{array}$ \\
\hline 39 & Soybean & & & Attributional LCA & $\begin{array}{l}\text { Default emission factor in the RED and COM } \\
595\end{array}$ \\
\hline 40 & Palm & & & Attributional LCA & $\begin{array}{l}\text { Default emission factor in the RED and COM } \\
595\end{array}$ \\
\hline 41 & $\begin{array}{l}\text { Oilseed } \\
\text { mix }\end{array}$ & Section 3.5 & $\begin{array}{l}\text { Experiment } \\
1\end{array}$ & $\begin{array}{l}\text { CGE model } \\
\text { GTAP }\end{array}$ & $\begin{array}{l}\text { Shock in biodiesel consumption in the EU, } \\
\text { without anti-dumping duties }\end{array}$ \\
\hline 42 & $\begin{array}{l}\text { Oilseed } \\
\text { mix }\end{array}$ & Section 3.5 & $\begin{array}{l}\text { Experiment } \\
2\end{array}$ & $\begin{array}{l}\text { CGE model } \\
\text { GTAP }\end{array}$ & $\begin{array}{l}\text { Shock in biodiesel consumption in the EU, with } \\
\text { anti-dumping duties }\end{array}$ \\
\hline 43 & Soybean & Section 3.4 & soyo.ar & $\begin{array}{l}\text { Multi-chain } \\
\text { optimization }\end{array}$ & $\begin{array}{l}\text { Soybeans produced in Ar, causing LUC from } \\
\text { Chaco }\end{array}$ \\
\hline 44 & Soybean & Section 3.4 & soyo.ar & $\begin{array}{l}\text { Multi-chain } \\
\text { optimization }\end{array}$ & $\begin{array}{l}\text { Soybeans produced in Ar, causing LUC from } \\
\text { Yungas }\end{array}$ \\
\hline 45 & Soybean & Section 3.4 & soyo.ar & $\begin{array}{l}\text { Multi-chain } \\
\text { optimization }\end{array}$ & $\begin{array}{l}\text { Soybeans produced in Ar, causing LUC from } \\
\text { cropland }\end{array}$ \\
\hline 46 & Soybean & Section 3.4 & soyo.br & $\begin{array}{l}\text { Multi-chain } \\
\text { optimization }\end{array}$ & $\begin{array}{l}\text { Soybeans produced in } \mathrm{Br} \text {, causing LUC from } \\
\text { tropical rainforest }\end{array}$ \\
\hline 47 & Soybean & Section 3.4 & soyo.br & $\begin{array}{l}\text { Multi-chain } \\
\text { optimization }\end{array}$ & $\begin{array}{l}\text { Soybeans produced in } \mathrm{Br} \text {, causing LUC from } \\
\text { Cerrado }\end{array}$ \\
\hline 48 & Soybean & Section 3.4 & soyo.br & $\begin{array}{l}\text { Multi-chain } \\
\text { optimization }\end{array}$ & $\begin{array}{l}\text { Soybeans produced in } \mathrm{Br} \text {, causing LUC from } \\
\text { cropland }\end{array}$ \\
\hline
\end{tabular}




\begin{tabular}{|c|c|c|c|c|c|}
\hline $\begin{array}{c}\text { FGB } \\
\text { pathways } \\
\text { (Figure } \\
4.2 \text { ) }\end{array}$ & $\begin{array}{c}\text { Raw } \\
\text { material }\end{array}$ & Section & $\begin{array}{l}\text { Scenario } \\
\text { formulation }\end{array}$ & Approach & Description \\
\hline 49 & Palm & Section 3.4 & palmo.my_in & $\begin{array}{l}\text { Multi-chain } \\
\text { optimization }\end{array}$ & $\begin{array}{l}\text { Palm produced in My_in, causing LUC from } \\
\text { tropical rainforest }\end{array}$ \\
\hline 50 & Palm & Section 3.4 & palmo.my_in & $\begin{array}{l}\text { Multi-chain } \\
\text { optimization }\end{array}$ & $\begin{array}{l}\text { Palm produced in My_in, causing LUC from } \\
\text { peatland }\end{array}$ \\
\hline 51 & Palm & Section 3.4 & palmo.my_in & $\begin{array}{l}\text { Multi-chain } \\
\text { optimization }\end{array}$ & $\begin{array}{l}\text { Palm produced in My_in, causing LUC from } \\
\text { degraded grassland }\end{array}$ \\
\hline 52 & Soybean & Section 3.3 & Scenario 1 & $\begin{array}{l}\text { Consequential } \\
\text { LCA }\end{array}$ & $\begin{array}{l}\text { Soybean biodiesel imported from Argentina into } \\
\text { Spain, system expansion }\end{array}$ \\
\hline 52 & Soybean & Section 3.3 & Scenario 1 & $\begin{array}{l}\text { Consequential } \\
\text { LCA }\end{array}$ & $\begin{array}{l}\text { Soybean biodiesel imported from Argentina into } \\
\text { Spain, system expansion }\end{array}$ \\
\hline
\end{tabular}

Both the RED and FQD include identical sustainability criteria to promote only the use of biofuels that deliver substantial GHG savings, calculated as the difference in emission intensity $\left(\mathrm{g} \mathrm{CO}_{2} / \mathrm{MJ}\right)$ relative to a reference fossil fuel. It is mandatory that the entire biofuel consumption in the EU transport sector by 2020 will cause a $60 \%$ reduction in the GHG emissions. Although a value of $83.8 \mathrm{~g} \mathrm{CO}_{2} / \mathrm{MJ}$ is suggested as the fossil fuel comparator, it is also said that more recent estimates for the EU case should be used instead. Hence, the same value as that used by Laborde (2011) in the estimation of ILUC emission factors has been taken into account for the emission intensity of the reference fossil fuel; that is $90.3 \mathrm{~g} \mathrm{CO}_{2} / \mathrm{MJ}$, displayed in Figures 4.1 and 4.2 as a threshold (in black). However, further debate has emerged about the fossil fuel comparator to be used. Van den Bos and Hamelinck (2014) argue that biofuels are not likely to replace the reference fossil fuel in the energy mix, but the marginal fossil fuel. Thus, they recommend adjusting the fossil fuel comparator to reflect the continuous shift in the fossil fuel market towards unconventional fuels. They propose an average emission factor of $115 \mathrm{~g} \mathrm{CO}_{2} / \mathrm{MJ}$ for unconventional oils, such as extra heavy oil and bitumen (tar sands), kerogen oil, or light tight oil (shale oil). This would definitely alleviate pressure on domestic feedstock in the EU in order to meet the sustainability criteria. Hence, a higher threshold has been plotted in the figures in light blue, indicating the suggested carbon intensity for the marginal fuel. 


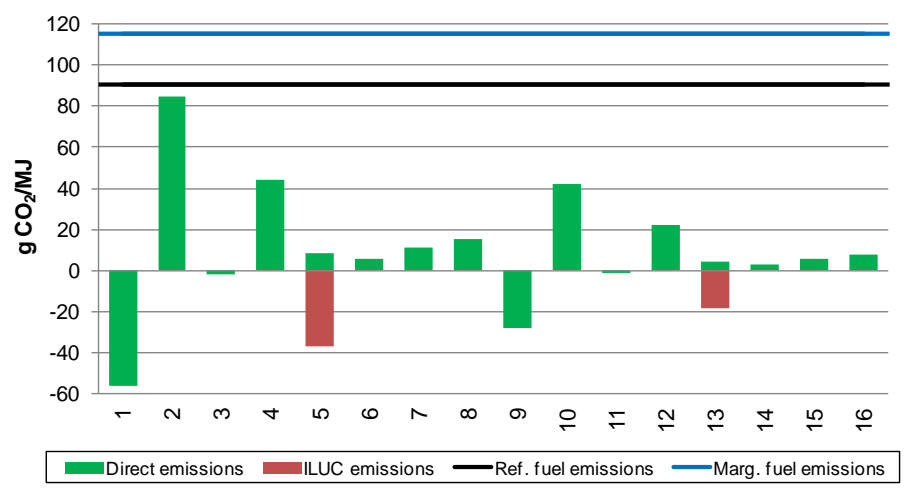

Figure 4.1. GHG emission factors for those scenarios consisting of biodiesel pathways based on UCO, with and without considering double-counting. Ref. fuel: reference fossil fuel; marg. fuel: marginal fossil fuel.

As can be seen in Figure 4.1, all the biodiesel pathways from used cooking oil (UCO) deliver huge GHG savings in general, especially when a double-counting scheme is considered (scenarios 9-16), since the same emissions are allocated to twice the amount of biodiesel; hence, emission factors are divided by two. This is only detrimental to the emission intensity when the pathway yields carbon uptake, since negative emissions are equally divided by two (scenarios 9 and 13). In any event, all the UCO biodiesel life cycles imply a GHG saving greater than $60 \%$, with the only exception of those in 2 (6\%), 4 (51\%) and 10 (53\%). These pathways refer to the Integral-b system, when it is considered that the electricity produced replaces the marginal source of electricity in the grid (that is, from wind), which generates smaller avoided burdens. In addition, it must be borne in mind that the Integral-b system is multi-functional; besides producing biodiesel, it allows organic waste to be treated by means of anaerobic digestion. $\mathrm{CO}_{2}$ emissions generated through the fulfillment of this function are allocated to the Functional Unit as well, and to $1 \mathrm{MJ}$ of biodiesel in the calculation of these GHG emission factors. This is why scenarios 3 and 4 yield lower emission factors in absolute terms than scenarios 1 and 2, respectively. A readier availability of UCO in Spain translates into greater amounts of biodiesel, the denominator dividing overall GHG emission from the multi-functional process. The higher the amount of UCO processed, the lower the GW impact of the Integral-b process, unless it is assumed that electricity from the average Spanish mix is displaced, since avoided burdens decrease as well. Under this assumption on cogeneration electricity credits, scenarios 1 and 3 generate a reduction of $162 \%$ and $102 \%$ in GHG emissions (that is, carbon uptake) relative to the reference fossil fuel, respectively. Similarly, scenarios 9 and 11 save $131 \%$ and $101 \%$ GHG. Nevertheless, due to the multi-functionality of the Integral-b 
system, emission factors obtained from section 3.1 should not be compared with the rest, since production systems are not equivalent from a life cycle perspective.

Life cycle GHG emissions from scenarios 5 and 13 are also negative thanks to the indirect emissions calculated in section 3.3 by means of system expansion in consequential Life Cycle Assessment (LCA). Under this approach, diverting UCO to produce biodiesel in Spain reduces the need to import oil from the marginal supplier in the international market, ultimately causing reforestation in Malaysia. Specifically, in scenario 5, indirect emissions amount to $-36.8 \mathrm{~g} \mathrm{CO}_{2} / \mathrm{MJ}$, which leads to an improvement of the GHG balance relative to the reference fossil fuel of $132 \%$. UCO biodiesel pathways in section 3.4 (6-8 and 14-16) are assumed to have no indirect effects, since residual oils and virgin oils belong to two distinct product markets; thus, UCO availability in Spain does not affect the supply of vegetable oils in major producing regions. Direct emissions arise from the industrial manufacture, including appropriation of the raw material and subsequent distribution. As specified in the RED/FQD, emissions up to the collection stage are zero for waste-based biodiesel. As a result, GHG savings range between $83 \%$ and $94 \%$ when no double-counting is considered and between $92 \%$ and $97 \%$, depending on the origin of the oil. These values are consistent with default values in the RED/FQD for biodiesel made from waste vegetable or animal oil (83\%). However, employing UCO originated in Spain or in a nearby third country yields higher GHG savings. Taking unconventional fuels into account as the emission comparator brings even greater environmental gains; e.g. between $87 \%$ and $95 \%$ in scenarios 6 to 8 and between $93 \%$ and $98 \%$ in scenarios 14 to 16 . However, this is not always true; specifically, when GHG savings are greater than $100 \%$ (in scenarios $1,3,5,9,11$ and 13), the greater the emission factor of the fuel comparator, the smaller the reduction, since it is more difficult to cause a $100 \%$ decrease in the emission intensity.

In Figure 4.2, scenarios 17 to 36 display emission factors for bioenergy crops in Spain, obtained by means of the multi-chain optimization model built in section 3.4. As can be seen, direct emissions are in the same range of magnitude for every scenario, around $52 \mathrm{~g} \mathrm{CO}_{2} / \mathrm{MJ}$ for rapeseed biodiesel and $43 \mathrm{~g} \mathrm{CO}_{2} / \mathrm{MJ}$ for sunflower biodiesel. These results are consistent with default values in the RED/FQD (52 and $41 \mathrm{~g} \mathrm{CO}_{2} / \mathrm{MJ}$, respectively), depicted in scenarios 37 and 38 . Calculated values yield GHG savings of around $41 \%$ for rapeseed biodiesel and $51 \%$ for sunflower biodiesel. These outcomes can also be compared with those from Lechón et al. (2009) estimated in the Spanish context. Their GHG emission factors for sunflower and rapeseed biodiesel are, however, slightly lower than our figures (30 and $35 \mathrm{~g} \mathrm{CO}_{2} / \mathrm{MJ}$, respectively), since only $\mathrm{N}_{2} \mathrm{O}$ emissions from fertilizer application were taken into account. The authors did not consider further emissions from DLUC for the purposes of simplification, on the grounds that these 
oilseeds in Spain are produced on set-aside land. Similarly, DLUC emissions are zero in the domestic biodiesel pathways in section 3.4, since it was assumed that, in Spain, there is no margin for deforestation and land conversion occurs entirely at the expense of cropland. Note that default values provided by the RED/FQD for direct emission estimation do not include DLUC either.

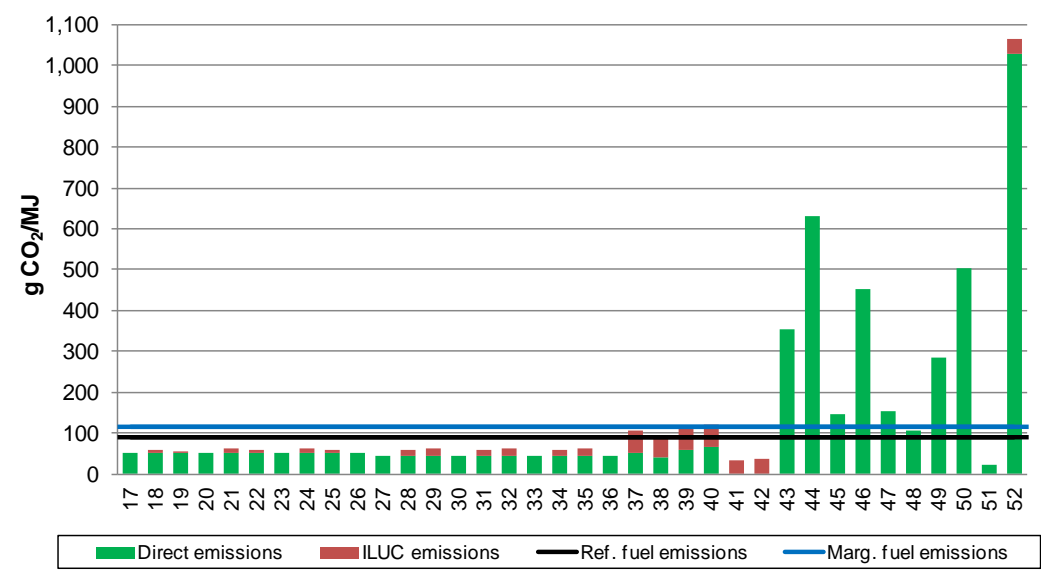

Figure 4.2. GHG emission factors for those scenarios consisting of FGB pathways. Ref. fuel: reference fossil fuel; marg. fuel: marginal fossil fuel.

When including ILUC emissions, GHG saving coefficients decrease to $32 \%$ (rapeseed) and 30\% (sunflower) in the worst case scenarios. Recall that these emissions arise from crop relocation in the Spanish agricultural sector in order to keep up with the food supply; therefore, the larger the share of domestic oilseeds in the mix, the more marked the ILUC. As could be expected, ILUC emissions associated with sunflower biodiesel are larger, since this crop is widely cultivated in Spain, mainly for food purposes, while rapeseed is produced in smaller quantities, and has rarely been used in the food industry after the crisis of $1981^{4}$. Hence, the expansion of sunflower for biodiesel production in Spain causes greater interactions in the food and feed markets, although in this case ILUC is limited to the provinces considered in the model. Specifically, the greatest ILUC emissions of all the scenarios considered are $18.8 \mathrm{~g} \mathrm{CO}_{2} / \mathrm{MJ}$ for sunflower pathways, and $11.7 \mathrm{~g}$ $\mathrm{CO}_{2} / \mathrm{MJ}$ for rapeseed ones. These are much smaller than the emission factors determined by Laborde (2011) (around $55 \mathrm{~g} \mathrm{CO}_{2} / \mathrm{MJ}$ ), also represented in scenarios 37 and 38 . These emission factors were estimated by means of a computable general equilibrium (CGE) model, capturing market-mediated responses on a global scale, while the model proposed in section 3.4 assumes that

\footnotetext{
${ }^{4}$ Around 350 people died in Spain in 1981, with more than 20,000 people affected, as a consequence of the massive sale in street markets of adulterated rapeseed oil for cooking.
} 
all the indirect effects occur within the Spanish territory. In fact, the ILUC emission factor proposed in the COM 595 would not even meet the 50\% reduction threshold by itself, which means that biodiesel from oilseeds would not be eligible in the EU market from 2017 onwards simply because of the indirect emissions. In addition, it must be taken into account that Laborde's (2011) outcomes encompass DLUC and ILUC emissions, since CGE models do not allow for the traceability of each phenomenon to be maintained separately. In this sense, if GHG emission factors are finally used in compliance with the sustainability criteria in the RED/FQD, ILUC emission factors in the COM 595 may lead to a double-counting of emissions from DLUC in biofuel life cycles, if these are properly included. Although DLUC emissions are usually much smaller than those from ILUC, this can make the difference when biodiesel comes from carbon-rich ecosystems, as is discussed below.

Results from scenarios 41 and 42 have been obtained by means of the CGE model, GTAP-BIO. In spite of sharing modeling features with the MIRAGE model, these emission factors are much lower (around $35.7 \mathrm{~g} \mathrm{CO}_{2} / \mathrm{MJ}$ ) than the one obtained by Laborde (2011). As highlighted in section 3.5, this is due to the greater market penetration of second-generation biodiesel that has been assumed in the experiment, in accordance with the new trends in limiting the consumption of FGBs in the EU.

Scenarios 43 to 51 in Figure 4.2 correspond to those pathways based on imported virgin oils analyzed in section 3.4, namely biodiesel from Southeast Asian palm, and from Argentinian and Brazilian soybeans. Since it is considered that different ecosystems may be transformed in the source countries, GHG savings vary substantially. Only palm biodiesel allows the $60 \%$ reduction target to be met when DLUC affects low-carbon ecosystems; specifically, this pathway can generate a $74 \%$ emission reduction if it comes from the conversion of degraded grassland (scenario 51), which is widely available in Indonesia, West Africa and in parts of tropical America, according to Germer and Sauerborn (2008). The rehabilitation of anthropogenic grassland, created by the human clearance of natural forest biomes a long time ago, is an interesting, optional means of providing land for oil palm planting without threatening the future of tropical rainforests, although it implies additional restoration practices.

The rest of the pathways in Figure 4.2 yield a substantial increase relative to the reference fossil fuel. For instance, at the expense of tropical rainforest, palm biodiesel causes a $216 \%$ increase (scenario 49 ), while soybean biodiesel from the Cerrado savannah in Brazil generates a 69\% increase (scenario 47). These results are consistent with those reported by Reijnders and Huijbregts (2008) and Wicke et al. (2008) for biodiesel from the same ecosystems, calculated from literature and by means of the IPCC guidelines (2006), respectively. The worst performance is 
that of scenario 44, considering that soybean expands at the expense of Yungas forest in Argentina. According to Gasparri et al. (2008), this ecosystem contains the largest carbon pools in the country, only surpassed by subtropical forests in the province of Misiones. Despite the fact that palm plantations yield approximately 8 times more oil per hectare than soybean fields, the drainage of peatlands also has a very discouraging carbon balance. Peatland oxidation occurs through the entire soil profile, releasing substantial amounts of $\mathrm{CH}_{4}$, a GHG that makes a greater contribution to $\mathrm{GW}$ than $\mathrm{CO}_{2}$. Those soybean biodiesel pathways in scenarios 45 and 48 do not meet the sustainability criteria even if they consider conversion from cropland in both Argentina and Brazil, due to high fertilization needs combined with long transport distances. It must be taken into account that all these values include only direct, annualized emissions. Default values provided in the RED/FQD for soybean (scenario 39) and palm biodiesel (scenario 40) are much lower, since emissions from DLUC are not included. This effect is indeed the greatest contributor to the life cycle emissions from most of the pathways based on imported virgin oil. The model built in section 3.4 does not allow for indirect emission in oil-exporting countries to be calculated since it is limited to the Spanish supply chain.

Finally, the emission factor in scenario 52 almost doubles that in scenario 44 , and is around three times greater than that in scenario 43 , despite the fact that all these pathways represent imported soybean biodiesel from Argentina. This is because it was assumed in section 3.3 that soybeans are not produced in rotation with any crop, as suggested by Panichelli et al. (2009). Authors state that soybeans in Argentina are grown in monoculture as well as in rotation with corn or sunflower, but there are no available data either on the proportion in monoculture or in rotation. Thus, all the land use change (LUC) emissions, direct and indirect, are allocated to the amount of biodiesel produced. On the contrary, they are divided by two in all the soybean biodiesel scenarios in section 3.4 (43-48), meaning that seeds are produced in rotation with some other crop, such as corn (Reijnders and Huijbregts, 2008). This highlights the importance of considering crop rotations when estimating LUC emissions, which leads us to recommend that the European Commission (EC) should make an additional effort to define regionalized ILUC emission factors, either for reporting or for compliance with the RED/FQD's sustainability criteria.

In scenario 52, soybean biodiesel production in Argentina also generates indirect effects, yielding an ILUC emission factor of $35.1 \mathrm{~g} \mathrm{CO}_{2} / \mathrm{MJ}$, which is very close to that determined in section 3.5. This is the result of co-product displacement in the international market on a global scale, causing deforestation in Malaysia but reforestation in Brazil. In this case, emissions in Malaysia are partially compensated by carbon uptake in Brazil. Although the approach in section 3.3 is a 
rough simplification of the economy, the underlying idea is similar to that in CGE models: indirect effects can be either positive or negative, since the expansion of bioenergy causes re-adjustment of demand and supply in many markets, mainly those of food, feed, timber and energy. ILUC impacts are likely to have a global dimension, especially if they arise from large blending mandates with collateral effects all across the world. However, these effects can lead to carbon sequestration or release depending on the country and land use that are involved.

\subsection{Emission factors for other critical impact categories}

GW is a central issue of biofuel sustainability, as has been emphasized throughout the entire dissertation, since biofuels are meant to mitigate climate change, while reducing energy dependence. In addition, GHG emissions from ILUC are deemed to be even more important than those from DLUC when talking about FGBs (Searchinger et al., 2008). Not surprisingly, GW has been the first and only impact category to be incorporated into public policies regulating biofuel consumption, and much research work has been conducted to estimate the $\mathrm{CO}_{2}$-eq. emission factors and GHG savings associated with biofuel life cycles. However, indirect effects not only imply GHG emissions but also those of other compounds which contribute greatly to other impact categories, usually associated with agricultural production. Emission factors for those impact categories proven to be critical should be progressively introduced into public policies as well. Results from chapter III have been used to calculate preliminary emission factors for acidification, eutrophication, and freshwater aquatic ecotoxicity (FAE), plotted in Figures 4.3, 4.4 and 4.5, respectively. These impact categories are also very important in analyzing the sustainability of agricultural systems worldwide (Börjesson and Tufvesson 2011; Brentrup et al. 2004). In this case, UCO scenarios that consider double-counting (9-16) have not been included for simplification purposes; neither have those scenarios representing default policy values (37-40), nor those from section 3.5 (41-42), since the results only address GW. It must be pointed out that the outcomes from section 3.4 for these three categories do not depend on the ecosystem combination in the case of biodiesel from imported virgin oils. In other words, all the scenarios defined for the same feedstock in section 3.4 share the same emission factor, since the ecosystem undergoing LUC leads only to differences in terms of $\mathrm{CO}_{2}$ emissions.

Most of the first-generation biodiesel pathways show similar $\mathrm{SO}_{2}$ emission factors, which indicates that the sub-stage with the highest contribution to acidification is agricultural production. This is mainly due to the ammonia emissions to the air from nitrogen fertilizer application. The worst acidification performance is that of soybean cultivation in Argentina, since it is particularly intensive, as has been mentioned in sections 3.3 and 3.4. In scenario 52, direct emissions (1.13 g 
$\left.\mathrm{SO}_{2} / \mathrm{MJ}\right)$ are almost twice those in scenarios 43,44 and $45\left(0.59 \mathrm{~g} \mathrm{SO}_{2} / \mathrm{MJ}\right)$, since, instead of considering crop rotation, all the agricultural emissions are allocated to the bioenergy crop. Indirect emissions arise from area expansion in Malaysia and area contraction in Brazil. When land transformation implies deforestation, forest clearing has been considered, and emissions arise from the fuel input. Rapeseed biodiesel (scenarios 17 to 26) shows the second highest emission factor in terms of direct emissions (around $0.52 \mathrm{~g} \mathrm{SO}_{2} / \mathrm{MJ}$ ), since this crop requires high fertilization rates compared to sunflower and palm. According to Spanish statistics, $45 \mathrm{~kg}$ of nitrogen are needed per ton of rapeseed, while only 35 are demanded by sunflower in the same conditions. As a result, the emission factor of sunflowerbased biodiesel is around $0.39 \mathrm{~g} \mathrm{SO}_{2} / \mathrm{MJ}$, while it is 0.44 and $0.34 \mathrm{~g} \mathrm{SO}_{2} / \mathrm{MJ}$ for biodiesel from Brazilian soybeans and Southeast Asian palms, respectively. However, and as happens for GW, the indirect effects caused by sunflower expansion in Spanish agriculture are greater than those from rapeseed, since sunflower seeds are in great demand for other uses. When taking these emissions into account, sunflower biodiesel pathways (scenarios 27 to 36) approach the acidification performance of rapeseed (in scenarios 17 to 26) and soybean-based pathways (only when crop rotations are considered in Argentina, in scenarios 43, 44 and 45).

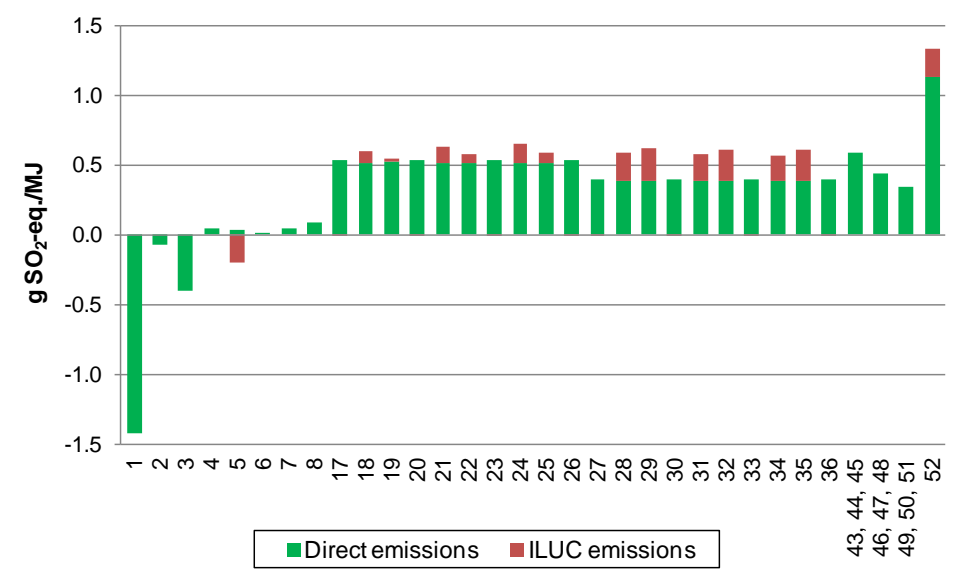

Figure 4.3. Emission factors for acidification ( $\mathrm{g} \mathrm{SO}_{2}$-eq./MJ).

Acidification impacts from UCO biodiesel scenarios are negligible, mostly caused by energy consumption, especially transport in the case of scenario 8 . Emission factors are negative in scenarios 1, 2 and 3 (due to electricity substitution) and in scenario 5 as well (due to indirect effects in Malaysia and Brazil). Specifically, the lowest value is found for scenario $1\left(-1.43 \mathrm{~g} \mathrm{SO}_{2} / \mathrm{MJ}\right)$, in which the electricity generated by the Integral-b system replaces electricity from the Spanish grid mix 
(with much greater acidification impacts); this is combined with a lower output of biodiesel than scenario 3 , due to UCO being less readily available. Hence overall negative $\mathrm{SO}_{2}$-eq. emissions are allocated to a smaller amount of $\mathrm{MJ}$. The highest value is found for scenario $8\left(0.09 \mathrm{~g} \mathrm{SO}_{2} / \mathrm{MJ}\right)$, due to the transport distance from the US to Spain. Similar outcomes are observed in terms of eutrophication and FAE impacts associated with UCO pathways, as shown in Figures 4.4 and 4.5. In these cases, life cycle emissions lead to negative emission factors in scenarios 1 to 5 , when performing system expansion under the substitution approach.

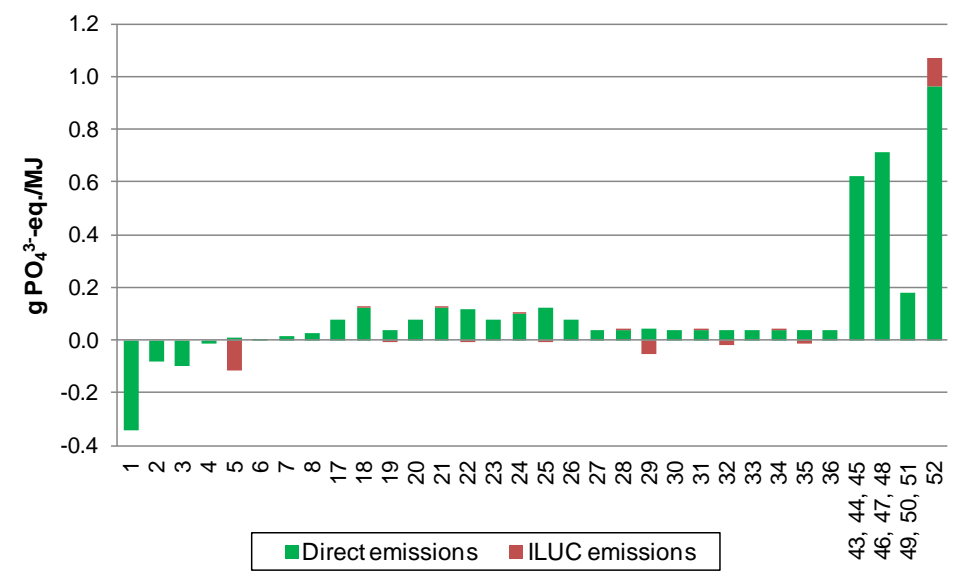

Figure 4.4. Emission factors for eutrophication ( $\left.\mathrm{g} \mathrm{PO}_{4}{ }^{3-}-\mathrm{eq} . / \mathrm{MJ}\right)$.

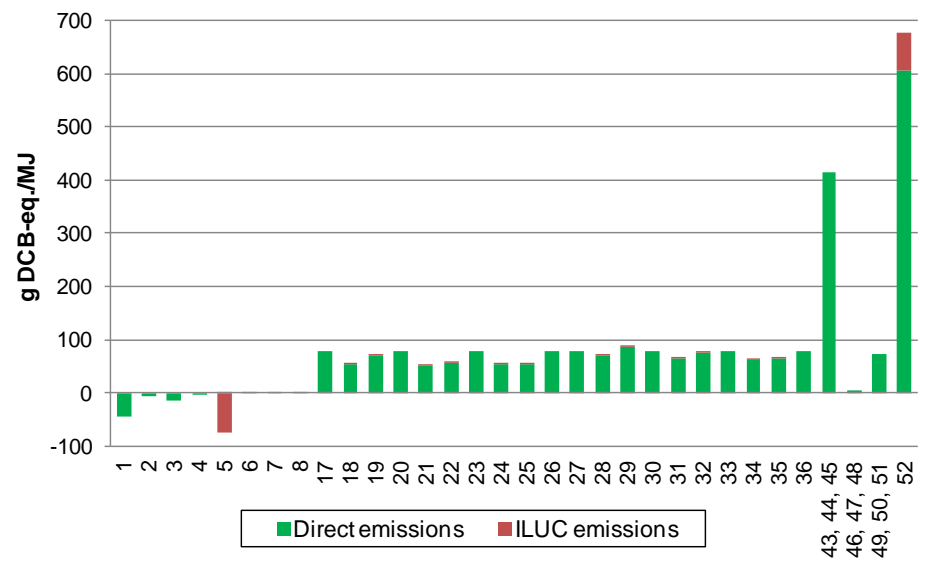

Figure 4.5. Emission factors for freshwater aquatic ecotoxicity (g DCB-eq./MJ).

As for eutrophication, emission factors for biodiesel pathways based on domestic rapeseed (scenarios from 17 to 26) vary substantially (between 0.034 and $0.123 \mathrm{~g}$ $\mathrm{PO}_{4}{ }^{3-} / \mathrm{MJ}$ ). These arise mainly from fertilizer application (and the subsequent 
nitrate lixiviation), which, in turn, depends on the yields, according to the optimization model built in section 3.4. Rapeseed yields in Spain are highly variable and depend on the province. On the contrary, emission factors for the sunflower scenarios (from 27 to 36) are more homogenous (around $0.035 \mathrm{~g} \mathrm{PO}_{4}{ }^{3-} / \mathrm{MJ}$ ). This is because sunflower has long been produced as an industrial crop in Spain and yields are stabilized in leading producing regions, which translates into similar fertilization rates and nitrate emissions. Indirect emissions causing eutrophication are negligible; however, it is worth highlighting that they may be negative in some sunflower scenarios $(29,32$ and 35$)$ as a consequence of crop relocation on a national level, which reduces overall $\mathrm{PO}_{4}{ }^{3-}$-eq. emissions from the production and subsequent application of fertilizers. Brazilian and Argentinian soybean pathways (scenarios 43 to 48) exhibit the worst eutrophication performance, showing emission factors between 8 and 27 times higher than those for domestic oilseed biodiesel pathways, when considering direct impacts only. It must be noted, however, that agricultural inventories were much more detailed for imported oils, including emissions from fertilizer application. In this sense, considering only nitrate runoff may lead to the underestimation of the eutrophication impacts from those scenarios based on domestic rapeseed and sunflower. This highlights the need to use consistent data sources when comparing biofuel alternatives, which can be difficult if regionalized emission factors are increasingly required for the definition of climate policies.

A similar figure is obtained when analyzing FAE outcomes. In this case, emissions are mainly caused by pesticide application and energy consumption across all the sub-stages. According to Panichelli et al. (2009), the production of biodiesel from Argentinian soybeans requires the use of heavy doses of cypermethrin and deltamethrin, substances with high toxicity in terms of DCB-eq. The direct emission factor in scenario $52(606.4 \mathrm{~g} \mathrm{DCB} / \mathrm{MJ})$ is not exactly twice that of scenarios 43,44 and 45 (414.6 $\mathrm{g} \mathrm{DCB} / \mathrm{MJ}$ ) since not all the LUC implies deforestation, as assumed in the second case. This yields further differences in the intensity of biomass burning, a process that consumes fuel, influencing all the analyzed impact categories to a different extent. The production of biodiesel from Brazilian soybeans leads to much lower emissions ( $4.5 \mathrm{~g} \mathrm{DCB} / \mathrm{MJ})$ because it does not require the use of these two compounds, according to the Ecoinvent v2.2 database (Hischier et al., 2010). Somewhere in between these two soybean biodiesel pathways we find the palm biodiesel one (causing $74.3 \mathrm{~g} \mathrm{DCB} / \mathrm{MJ}$ ) and the domestic oilseed ones (causing between 51.3 and $88.3 \mathrm{~g}$ DCB/MJ), which use cypermethrin and deltamethrin to a similar extent. Indirect effects from the expansion of domestic oilseeds in Spain are again negligible; they arise from differential inputs after crop relocation, but regional differences in pesticide requirements are not captured by the model in section 3.4. 
As can be inferred from this, FAE emissions are highly variable when assessing the performance of FGB pathways, since different substances may yield very different impacts, depending not only on their toxicity and diffusion properties through the environmental compartments, but on the characterization method as well. Despite the fact that the USEtox method (Rosenbaum et al., 2008; 2011) is currently considered the most robust and updated characterization model, the CML 2001 one (Guinée et al., 2002) has been used in sections 3.1, 3.3 and 3.4 for the purposes of consistency. The USEtox model tries to set a comprehensive and standardized framework to quantify FAE and human toxicity impacts (on the basis of a relatively straightforward chemical fate model). It must be pointed out that it does not consider the fate of the pesticide just after its application. This is why the same approach as Berthoud et al. (2011) has been chosen for the definition of the fate factors of each pesticide in the emission module of the supply chain model in section 3.4. In spite of difficulties, toxicity impacts should not be neglected when analyzing agricultural systems and, thus, biofuel ones.

The use of agricultural inputs is necessary in order to enhance food selfsufficiency. However, while the most important effects from fertilizers (such as eutrophication and acidification, apart from GW) have frequently been addressed in the LCA literature (e.g. Fu et al., 2003; Kim and Dale, 2005), the effects of pesticides on the ecosystems are still too often omitted, as Berthoud et al. (2011) state, even though they are one of the major environmental issues linked to agriculture. Further work is needed in order to estimate toxicity impacts associated with the consumption of FGBs; ideally, this also needs to be carried out on a regional level since these impacts are significantly influenced by agricultural practices. Impacts such as acidification, eutrophication and FAE have a regional scope and their study should require the use of site-specific factors. It is also recommended that the DLUC and ILUC emission factors for these impact categories be defined, since these indirect emissions may be responsible for greater impacts than bioenergy systems usually have when compared to fossil reference systems (Cherubini and Strømman, 2011). This may serve as a means of further promoting the use of biofuels based on alternative feedstocks over those based on arable crops, with their potential incorporation into the sustainability criteria of the RED/FQD.

\subsection{Pros and cons of life cycle methodologies}

The present dissertation is based on different life cycle methodologies aimed at evaluating the environmental effects of biodiesel consumption in Spain, while, at the same time, highlighting how the methodological approaches influence the results. Pros and cons of each approach are summarized in Table 4.3, together with their limitations and further recommendations. 
Table 4.3. Pros and cons of the methodologies used in the dissertation for the estimation of the environmental impacts of biofuel systems.

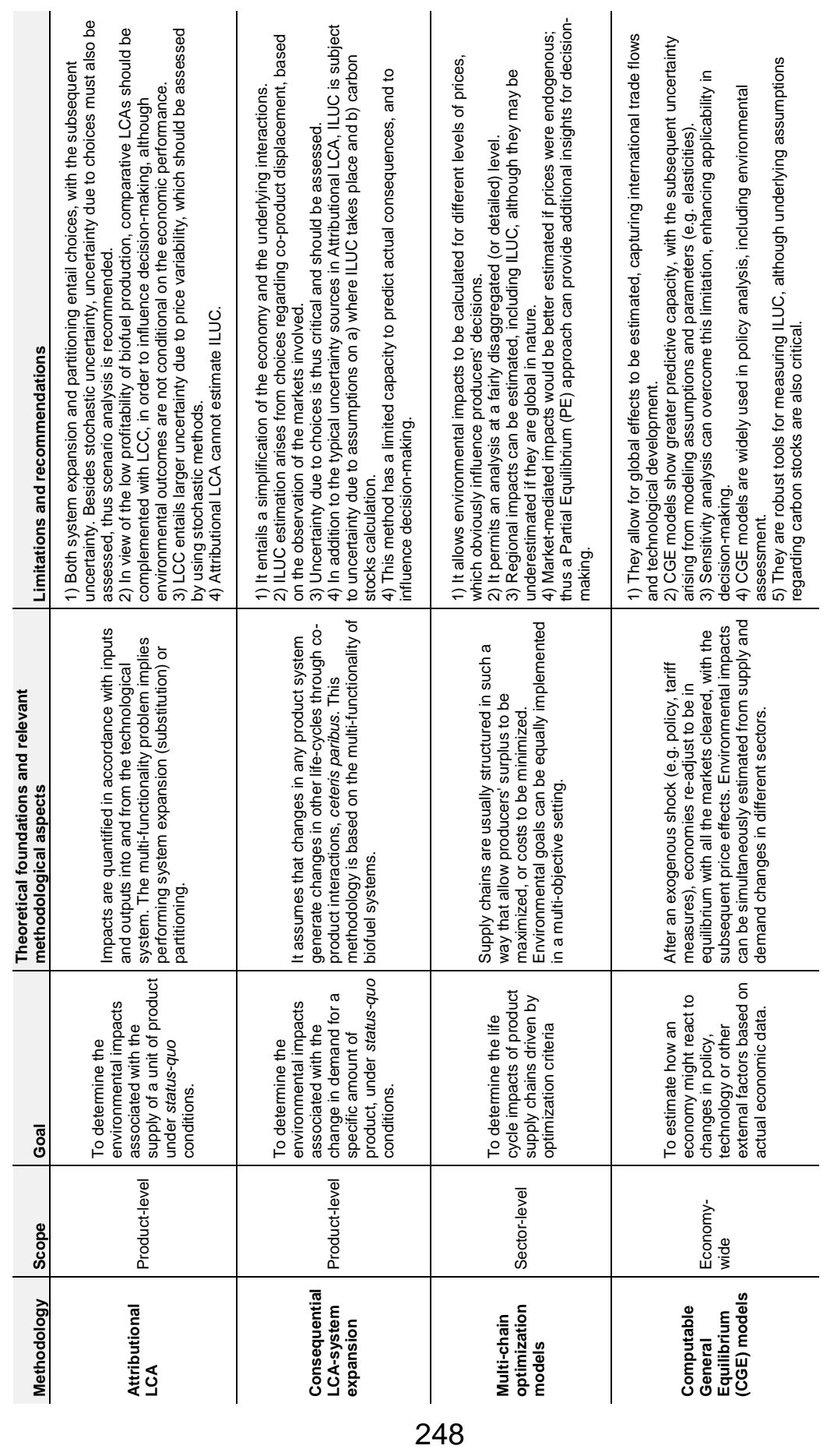


At the product-oriented level, attributional LCA proves very useful when comparing production systems based on their environmental performance. The preferred option would be that causing the lowest impact. This approach helps to identify those critical sub-stages with the highest contribution to different environmental impacts, thus assisting in technical decisions. However, in order to enhance applicability in design projects, LCA results should be complemented with results analyzing the economic viability of any decision. Life Cycle Costing (LCC) may be an appropriate methodology for decision-making, since it is based on a holistic perspective as well. However, attributional LCA, even combined with LCC analysis, fails in addressing indirect effects such as ILUC. Economic results do not influence environmental outcomes, since they are estimated in parallel.

ILUC is indeed one of the most controversial effects of biodiesel consumption, and requires the application of economic concepts since it is mediated by market forces. Despite the fact that there is no consensus on the methodology to apply for its calculation, it seems that the definition proposed by Laborde (2011) is generally accepted; this is represented graphically in Figure 4.6. According to this, the ILUC area should be the result of the observed increase in total area minus:

1) The area saved by co-products due to the substitution of animal feed (e.g. protein meals).

2) The land freed up by additional yield gains as a consequence of technological developments.

3) The reduction in cropland area due to the reduction in crop consumption for competing uses, such as food.

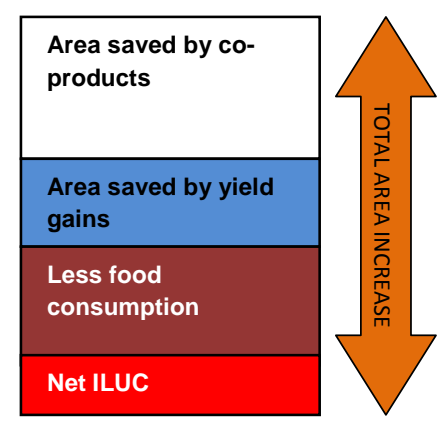

Figure 4.6. Market-mediated mechanisms driving total cropland increase as a consequence of increased demand for biofuels. Source: Laborde (2011).

The approach which is purely based on the LCA methodology (consequential LCA) only takes the first mechanism into account. ILUC arises only from co-product substitution in the international market, calculated by means of basic economic models aimed at identifying and capturing possible interactions between life cycles 
(usually related to agricultural, feed and energy markets). Most of these consequential LCAs are conducted on small systems affected by marginal variations, and are of limited applicability when analyzing greater shocks in the demand for the main production system since these may lead to non-linear environmental impacts (Dandres et al., 2011). One of the main limitations of the system expansion approach is that inter-sectorial effects are totally determined by methodological assumptions regarding marginal suppliers. Börjesson and Tufvesson (2011) thus recommend considering different scenarios when coproduct replacements are not clear, in order to enhance applicability in decisionmaking.

Multi-chain optimization models are increasingly used to look for biomass sources with the most favorable environmental profile. They allow for life cycle impacts from biofuel supply chains to be estimated, including agricultural production, which is a critical sub-stage. The more disaggregated (ideally at farm level), the greater their ability to address technological and structural change and the greater their predictive capacity, also in terms of environmental impacts, although this comes at the cost of higher computational efforts. Aimed at representing farmers' decisions, these models can incorporate detailed information on fertilizer use (with a great influence on GW, mainly due to $\mathrm{N}_{2} \mathrm{O}$ emissions), agricultural practices and cropping plans. Required crop operations and their frequency, as well as the management of crop residues, can play a significant role in both the environmental and financial profile of bioenergy crops (Glithero et al. 2012). Thus, considering the variability of farming practices leads to more reliable environmental results (Aoun et al., 2014), while allowing for the regional differentiation of GHG emissions. This feature can be used for the estimation of ILUC impacts, assuming that they occur within the area of study. These impacts may even be related to water consumption, which is expected to become a crucial issue in the medium term. Yield changes can also be modeled, capturing technology development and contributing to reductions in ILUC, as shown in Figure 4.4. In this way, ILUC can be understood as bounded ILUC, according to the definition of Vázquez-Rowe et al. (2013), since crop relocation is governed by farmers' decisions to improve their economic revenue based on current costs and harvest yields. One of the strengths of this procedure is that it allows the traceability of the GHG emissions from LUC to be maintained, discerning whether they arise from direct or indirect effects, which is useful for policy analysis. Alternatively, extended ILUC implies expanding the system boundaries to account for the different consequences in terms of new import and export flows of agricultural products; thus, it requires further modeling and data gathering.

CGE models are the only methodology to capture all the mechanisms in Figure 4.4, including the third, since price changes are endogenous. Most CGE models 
consider two market-driven effects. Firstly, increased oilseed demand results in farmers switching from other crops (e.g. cereals, vegetables) to oilseeds. Secondly, when oil and grain prices increase, families redistribute spending to cheaper sources of calories (cereals) and away from more expensive goods, such as oils, vegetables and meat. In other words, when biofuel expansion increases the demand for crops, CGE models consider that there is, on the one hand, an increase in crop supply and, on the other hand, a reduction in demand by other sectors (e.g. food and feed), driven by the same increases in crop prices. Under this approach, reduced food consumption will save the ILUC area and GHG. However, Padella et al. (2012) argue that these emission reductions should not be considered as a credit of biofuels, as they are due to the contraction of other agricultural sectors rather than the expansion of biofuels. Authors propose an alternative closure to prevent starvation, which may have inspired ILUC calculations in the multi-sector model of section 3.4. CGE models also include yield increase projections, which proved to be very influential in the estimation of ILUC emissions from European biofuel mandates, as illustrated by Laborde et al. (2014). As a result of all these factors, CGE models are, without doubt, the tools with the widest applicability in biofuel policy analysis, especially when assessing medium and long term changes, and are usually coupled with sensitivity analyses. It must be pointed out, however, that CGE models have various drawbacks; they fail in providing detailed information at sector, and even at country level; they do not address a broad set of environmental concerns; and they do not succeed in differentiating between DLUC and ILUC impacts.

Under all the aforementioned approaches for consequential LCA, indirect emissions mainly depend on two factors: the magnitude and location of ILUC (Broch et al., 2013). Firstly, all the models employed aim at predicting market responses caused by a change in demand for biodiesel. This yields the expected cropland extension in different countries and ecosystems. Secondly, each land transformation leads to changes in carbon stocks, depending on the soil and biomass characteristics in each specific location. While differences in the amount and location of ILUC arise from the models used, the methodologies for determining carbon stocks are also subject to great uncertainty. Usually, agroeconomic models are linked with databases including carbon stocks, which vary according to location and land type. In addition, different amortization times (e.g. $20,25,30$ years) will yield different ILUC emission factors. All these issues are, however, beyond the scope of the present dissertation.

Finally, it must be highlighted that ILUC effects may not be only environmental, since the expansion of biofuels is expected to affect social structures in many ways (Janssen and Rutz, 2011). Social LCA is a very promising methodological means of analyzing these consequences. Additionally, Life Cycle Costing (LCC) can be 
used to include externalities of biofuel expansion. For instance, Silalertruksa et al. (2012) applied a method based on willingness-to-pay in order to calculate the influence of externalities on the cost performance of various palm oil biodiesel blends when internalized into their respective production cost in the case of Thailand. Internalizing LUC costs could be an effective means of promoting the use of biofuels requiring low land input; however, once again, consensus on LUC calculations should be reached in advance. 


\section{Chapter V. Conclusions}



In the transport sector of many countries, there has been an increase in demand for biofuels, fostered by public policies on the promotion of renewable energy. The political motivation to support these alternative fuel sources arises from two main drivers: climate change and energy security. However, concerns have recently risen as to the impacts from the expanded production of dedicated energy crops worldwide, coinciding with the boom in biofuels. As a result, sustainability criteria have more frequently been incorporated into recent biofuel policies, following the example of the European Union (EU) and the United States. The aim of the present thesis has been to analyze the environmental impacts from different pathways for producing biodiesel for the Spanish transport market by applying different methodologies under a life cycle perspective. The main conclusions derived from this are presented below, organized into different sections according to the main methodological aspects that have been addressed. Recommendations for further research work are also set out throughout these sections, while general conclusions and recommendations for biofuel policy analysis are drawn at the end of the chapter.

\subsection{Conclusions about the Integral-b project assessment}

The system proposed by the Integral-b project is, by definition, multi-functional; which is, its life cycle delivers other functions besides that of producing biodiesel. In attributional Life Cycle Assessment (LCA), the issue of multi-functionality can be addressed through two approaches: system expansion (or substitution), and allocation (or partitioning). The Integral-b process works in an integrated way and co-products do not necessarily leave the system but are re-used in other substages. Hence, system expansion has been preferred. This approach is also recommended in order to combine the environmental results with those from the economic assessment by means of Life Cycle Costing (LCC), since co-products translate into revenues for the plant, influencing its profitability.

- From the environmental assessment (section 3.1):

- When performing system expansion for the purposes of analyzing the environmental implications of the process proposed by the Integral-b project, the fate of the glycerin and electricity from cogeneration proved decisive for the comparative assessment. Selling the electricity to the power grid generates avoided burdens, although these depend on the source of electricity assumed to be replaced (marginal or average). In this study, replacing wind-generated electricity induces smaller environmental gains in many impact categories. The assumptions on glycerin replacement appear to be much more influential, though. According to the scenarios defined, glycerol is a by-product of potential use in the food and 
chemical industry, generating substantial environmental credits in the reference scenario. Under these assumptions, glycerin recovery in the Integral-b process is detrimental to its environmental performance.

- Considering potential industrial uses for crude glycerol from biodiesel production may not be a realistic scenario if the biodiesel sector in Spain grows faster than the capacity of the chemical and pharmaceutical sectors to accommodate this by-product. This has already been observed in leading biodiesel-producing countries. Under this other perspective, glycerol would become a waste to be treated instead of a by-product, and the Integral-b process would cause greater environmental benefits than those obtained in section 3.1, since it avoids glycerin disposal or valorization. In this way, the Integral-b process constitutes an optional means of fulfilling the requirements of Directive 2008/98/EC, according to which the producer of the waste must be responsible for its proper treatment.

- Scenario analysis is recommended in order to understand the influence of choices regarding co-product credits on the results when performing system expansion. This should yield a number of discrete results generated by choice-related variations in order to help decision-makers.

- Although uncertainty due to data variability is less important than uncertainty due to choices in the environmental analysis of the Integral-b process, assessing the first reinforces confidence in the results.

- From the economic assessment (section 3.2):

- Life Cycle Costing (LCC) is a suitable tool with which to address the economic viability of the Integral-b process. Under the system expansion approach, co-products do not cause avoided costs but provide additional revenues to biodiesel plants. LCC adds further uncertainty since outcomes are greatly influenced by variability of prices, apart from that of technical parameters.

- The uncertainty analysis showed that those co-products influencing the economic performance of the Integral-b to the greatest extent are the electricity from cogeneration and the digester sludge from anaerobic digestion, which can be sold as a fertilizer for agronomic uses. The price of glycerin appeared not to be influential in the context of an integrated waste management treatment for restaurant and catering waste (including used cooking oil, UCO) generated in a given region. The amount of glycerin produced is minimal compared to the amount of waste treated. However, 
at plant level, the market price of glycerin may be decisive in reaching the breakeven point.

- The Integral-b scenario generates negative profits, lower than those of the reference system under consideration, for treating the same kind and amount of waste. The cost of solid organic waste collection is critical; however, this is dependent on the scope (e.g. smaller municipalities, biodiesel plants) and may not be true. In addition, it must be taken into account that waste management activities incur costs for society, since they require investment from the public sector.

- $\quad$ By analyzing possible trade-offs between the LCA and LCC results (from sections 3.1 and 3.2, respectively), it can be concluded that implementing the Integral-b system may help to reduce most of the impacts substantially, although this implies a decrease in profits when all the collection costs are included. This means that part of the costs of the activity should be borne by the stakeholders.

- Implementing the Integral-b system in UCO biodiesel plants, which are not responsible for organic waste collection costs, can improve their viability since this system generates revenues from the sale of electricity, while avoiding disposal costs of glycerol surplus.

Improving the logistics for an efficient collection of oil from restaurants, catering and also households, either door-to-door or with a multicontainer system, would enhance energy independence while reducing environmental impacts.

\subsection{Conclusions about the consequential LCA}

Consequential LCA is usually applied to estimate impacts arising from indirect land use change (ILUC), which cannot be addressed by means of attributional LCA. According to the new biofuel proposal of the European Commission (EC), global greenhouse gas (GHG) emissions arising from ILUC due to biofuel consumption in the EU should be estimated and reported by economic operators. However, ILUC is difficult to predict, since it is the result of global shifts in land cover and crop patterns in response to price changes and thus is subject to market forces. There are different approaches to a consequential LCA, and all of them require the application of economic concepts. The methodologies included in the dissertation differ in their ability to capture market-mediated responses. 
- From the application of the system expansion approach (section 3.3):

- The system expansion approach for consequential LCA is based on the multi-functionality of biofuel systems. It can be concluded that choices regarding the marginal suppliers play an important role; for this reason, they must be based on reliable statistical data sources, and it is advisable to carry out a scenario analysis to deal with the uncertainty due to choices regarding marginal suppliers.

- Despite the fact that the system expansion approach constitutes a simplification of the overall economy, it captures the global dimension of the bioenergy expansion. It can give a clear view of the countries most directly affected by a change in demand for the product under study, with the subsequent environmental effects.

- Imported soybean biodiesel from Argentina generates much greater environmental impacts than biodiesel from UCO collected in Spain, especially in regard to global warming (GW). One of the greatest contributors to this impact category is the land use change (LUC) occurring in Argentina.

- The quantification of the associated GHG emissions from carbon changes in soil and biomass is, however, subject to great uncertainty. Applying the IPCC guidelines allows for this uncertainty to be addressed by means of stochastic methods (e.g. Monte Carlo simulation), since they include the variability of those parameters used for the calculation of carbon stocks.

- From the model of the Spanish biodiesel supply chain (section 3.4):

- Optimization models of biodiesel supply chains, such as the one developed in section 3.4, allow both economic and environmental goals to be combined in order to tackle the environmental consequences of EU regulations affecting biodiesel markets. At the sector level, they can be used to determine optimal industry configurations. This is especially useful in the Spanish context, given the sector's idle capacity.

- Multi-chain optimization models rely on the life cycle perspective so as to estimate impacts across the entire supply chain. In order to analyze the effects of the Renewable Energy Directive (RED) goals, allocation must be based on the energy content of the co-products. In this way, more than $85 \%$ of the total impacts are allocated to the biodiesel obtained, except in the case of soybean biodiesel pathways, in which the overall allocation factor, applied to the agricultural impacts, is estimated at around $70 \%$. 
- The model of the Spanish biodiesel supply chain that has been presented couples an industry module to a detailed model of the arable sector. Since prices are set exogenously in the model, a sensitivity analysis is recommended as a means of analyzing the influence of the feedstock price and the subsequent freight costs on the consumption mix, given the share of the raw material costs relative to overall production costs (more than $90 \%$ in the case of first-generation plants).

- Optimization models can be used to analyze the effects of the RED's sustainability criteria in the feedstock mix underlying domestic biodiesel production in the Member States (MSs). In this case, a scenario analysis has been performed by taking different ecosystems into account: those most likely undergoing LUC in major oil-exporting countries. Assumptions regarding carbon stocks are crucial in determining both the optimal consumption mix and the subsequent environmental impacts.

- The multi-chain optimization model presented in section 3.4 can also be used to determine ILUC emissions from domestic oilseeds. These emissions arise from crop relocation in the Spanish agricultural sector in order to keep up with the food supply. Although ILUC is, by definition, a global effect, this approach may be a useful way to understand indirect effects on a regional level. ILUC emissions in Spain ultimately arise from regional differences in emissions from fertilizer application (mainly $\mathrm{N}_{2} \mathrm{O}$ ), which, in turn, depend on the yield (in the model).

- All the UCO pathways assessed cause a reduction in GHG emissions relative to the reference fossil fuel. Palm biodiesel produced on degraded grassland is the only food-based biodiesel to meet the sustainability requirements, leading to a $74 \%$ saving in emissions when considering only direct emissions. This result reinforces the suitability of converting degraded land for biodiesel production. Soybean pathways cause an increase in GHG emissions, even considering conversion from cropland.

- Biodiesel pathways based on domestic rapeseed cause a GHG saving of around $42 \%$ when only direct emissions are considered, while around $51 \%$ is saved by sunflower biodiesel. These values may vary slightly depending on which province the seeds originate from.

- When considering indirect emissions, GHG savings from rapeseed biodiesel in the worst-case scenarios (considering the greatest crop displacement) are reduced to $29 \%$, while those from sunflower in the same scenarios are reduced to $30 \%$. Sunflower expansion in Spain generates greater ILUC, since this crop competes for food use to a larger extent than rapeseed. According to this, domestic oilseeds would not meet the 
sustainability requirements in the RED/FQD, despite the fact that LUC in Spain is likely to take place in land that is already under crop production or fallow.

- Rapeseed biodiesel would not even meet the 35\% requirement when only direct emissions are taken into account, although this crop is mostly produced in fallow land, thus causing small LUC impacts. This may encourage policy-makers to review sustainability thresholds. In their current form, these hinder energy security and place existing investment at risk, since most of the sector's capacity in the EU is based on firstgeneration technologies.

- As the RED/FQD allows consignments of raw material or biodiesel with differing sustainability characteristics to be mixed, we encourage policymakers to maintain ineligible land categories. The results from section 3.4 show that sustainability criteria encourage the substitution of previous cropland and prevent the conversion of large forested areas; but they are not enough in themselves to prevent the consumption of soybean oil from the Cerrado savannah in Brazil under the scenarios defined.

- The calculation of ILUC in section 3.4 is based on cropping plans, understood as the set of activities selected in each province. Although ILUC is limited to the Spanish territory, this approach allows detailed information on agricultural practices to be implemented as a means of refining the estimation of emission factors. This feature may be of interest if other ILUC impacts from crop relocation are to be taken into account, such as water consumption, which may be very important in Spain. Improving agricultural practices should be a pivotal focus for the cleaner production of biodiesel.

- As regards indirect effects, the multi-chain optimization model assumes that UCO biodiesel pathways have no indirect effects, while the system expansion approach (section 3.3) assumes that UCO pathways may even have positive effects, leading to a contraction in the cropland area in some regions.

- From the application of an economy-wide model (section 3.5):

The Computable General Equilibrium (CGE) model, the Global Trade Analysis Project (GTAP), has been used in section 3.5 to estimate the global effects, in terms of LUC and GHG, of the increased demand for biodiesel in the EU from a consequential perspective. Specifically, both the cap on first-generation biofuel (FGBs) consumption and anti-dumping duties on biodiesel imports have been simulated using a comparative-static approach, representing 2004-2020 shocks. 
- The results show that limiting the consumption of first-generation biodiesel reduces the ILUC emission factor of the overall biodiesel mix by $35 \%$ relative to that in the new ILUC proposal $\left(55 \mathrm{~g} \mathrm{CO}_{2} / \mathrm{MJ}\right)$.

- The effect of the anti-dumping duties on the environmental outcomes is negligible in comparison with the huge increase in biodiesel consumption expected for 2020. In fact, the anti-dumping duties slightly increase the global emissions since they generate a greater growth in oilseed and vegetable oil exports to the $\mathrm{EU}$, and also an increase in palm biodiesel exports from Southeast Asia.

In spite of the cap on FGBs, LUC still seriously affects South-Saharan Africa, while only $7.5 \%$ of the overall cropland expansion takes place within the EU borders. The greatest GHG emissions are generated in Southeast Asia mainly due to LUC from peatland, which will continue providing the EU with palm oil and palm biodiesel. This suggests that the EC's commitment to ILUC be reconsidered.

\subsection{General conclusions and policy recommendations}

- The LCA methodology constitutes a suitable, operational tool for evaluating the GHG emissions and GHG savings generated by the biodiesel consumed in the $\mathrm{EU}$, in compliance with the sustainability criteria in the RED and the Fuel Quality Directive (FQD). It can be used to determine other environmental burdens associated with alternative biodiesel pathways, based on different feedstocks.

- Performing LCC in combination with attributional LCA is a recommended means of helping in technical decisions. In order to improve the robustness of the cost-effectiveness analysis of different design options, the Functional Unit must be exactly the same. To this end, particular attention must be paid to the system boundaries of both the economic and environmental systems, which should be consistent with the maximum possible extent.

- In spite of the rather divergent practices for consequential LCA, the results show that first-generation biodiesel pathways lead to greater life cycle emissions than UCO biodiesel pathways. As for GW, direct and indirect LUC emissions from agriculture are critical, while waste-based pathways are assumed to have zero emissions up to the collection stage, according to the RED/FQD.

- Indirect effects are only an issue of concern for FGBs. The results confirm that using waste is preferable since they do not involve displacing the production of other commodities, mainly food. In addition, feedstocks such as UCO are meant to have positive welfare effects, since they avoid waste 
treatment activities. Therefore, advanced biofuels should be clearly promoted and receive policy support. A future biofuel Directive should provide rigorous estimations of the ILUC emissions associated with each type of biodiesel and biodiesel feedstock which are of potential use in the European transport sector. CGE models, such as GTAP, are a robust tool with which to do this, due to the complexity of the global system being modeled. It must be taken into account, however, that they do not allow direct and indirect LUC to be tackled separately, which may lead to overestimating ILUC emission factors.

- The RED/FQD and the new ILUC proposal launched by the EC urge MSs to report direct and indirect LUC emissions separately. It can thus be expected that both CGE and attributional LCA will continue playing a very important role in policy definition and analysis. Uncertainty assessment is equally necessary in order to define accurate biofuel policies.

- In light of the fact that the GTAP model is of very little use in a regionalized study of the ILUC from biofuels in the EU context, partial equilibrium (PE) models are identified as the appropriate tool with which to determine ILUC emission factors at regional level. Supply chain optimization models constitute the first step towards this goal.

- Reliable economic information is necessary for constructing robust supply chain optimization models (and thus, PE models), taking the historical variability of costs and prices into account. However, this is not always possible, especially in regard to the biodiesel sector, due to the high-level competitiveness in the market. The crisis in the Spanish sector has led biodiesel companies to apply confidentiality procedures. Similarly, technical and environmental information, including uncertainty, must be gathered from representative data sources and reliable databases.

- Given the diversity of methodologies, it can be difficult to achieve total harmonization, although greater consistency of certain modeling approaches and data sets is certainly desirable, especially in regard to ILUC estimation. Greater robustness is demanded by biofuel producers and traders for ILUC emission factors.

- Once a methodological consensus is reached on the methodology to apply when defining ILUC emission factors, we recommend other impact categories that are typically critical for the sustainability of agricultural systems be taken into account, such as acidification, eutrophication, freshwater ecotoxicity or water use. 
- An explicit policy agreement on the need to increase advanced biofuel consumption in the EU could be extremely beneficial in order to encourage the investment in the biodiesel (and ethanol) sector to move towards more sustainable technologies. The implementation of a double-counting scheme in Spain is required to ensure the sector's subsistence, while also protecting current investments. In combination with a certification scheme, this can enhance the share of domestic oilseeds and UCO in the consumption mix, contributing to energy independence while reducing climate change.

- Rural development is, theoretically, another driver for FGB expansion. However, the suitability of biofuels to fulfill social goals has to be addressed in connection with economic and environmental drivers, too. For example, policies aimed at ensuring rural development and/or energy security may yield increased GHG emissions. Applying the Social LCA methodology to biofuel systems is strongly recommended, since it provides a normative framework to estimate social impacts.

- Biodiversity is another key issue for biofuel sustainability. Efforts should be made to provide standard analytical tools for the estimation of biodiversity impacts, associated with the ecosystems undergoing LUC. Finally, it must be taken into account that the new EC proposal on biofuels may raise debate into the appropriateness of defining ILUC factors for other sectors. For instance, increasing meat consumption demands more feed-crops, with the subsequent LUC. The same methodologies applied in the present dissertation could be used for this purpose. 



\section{Chapter VI. References}



Ackrill, R., \& Kay, A. (2011). EU biofuels sustainability standards and certification systems. How to seek WTO compatibility. Journal of Agricultural Economics, 62(3): 551-564.

Adler, P.R., Grosso, S.J.D., \& Parton, W.J. (2007). Life-cycle assessment of net greenhouse-gas flux for bioenergy cropping systems. Ecological Applications, 17(3): 675-691.

AFDC (2014). Alternative Fuels Data Center. Global ethanol production by country and region. US Department of Energy. Accessed at: http://www.afdc.energy.gov (19 ${ }^{\text {th }}$ November 2014).

Ahammad, H., \& Mi, R. (2005). Land use change modeling in GTEM: accounting for forest sinks. Australian Bureau of Agricultural and Resource Economics. In the 22nd EMF "Climate Change Control Scenarios", $25^{\text {th }}-27^{\text {th }}$ May 2005, Stanford University, California (US).

Albarelli, J.Q., Santos, D.T. \& Holanda, M.R. (2011). Energetic and economic evaluation of waste glicerol evaluation in Brazil. Brazilian Journal of Chemical Engineering, 28(4): 691-698.

Al-Riffai, P., Dimaranan, B., \& Laborde, D. (2010).Global trade and environmental impact study of the EU biofuels mandate. Vol. 125. International Food Policy Research Institute (IFPRI). Washington, DC (US).

Álvarez de la Puente, J.M. (2007). Estudio de mercado de los compost urbanos en España. Universidad de Huelva, Huelva (Spain). Accessed at: http://www.juntadeandalucia.es (23 ${ }^{\text {th }}$ January 2015).

Amaral, P.F.F., Ferreira, T.F., Fontes, G.C., Coelho M.A.Z. (2009). Glycerol valorization: new biotechnological routes. Food and Bioproducts Processing 87(3): 179-186.

AMCRSPP (2013). Associació de Municipis Catalans per a la Recollida Selectiva Porta a Porta. Balance económico de la recogida de residuos puerta a puerta y en contenedores para los entes locales y propuestas de optimización. Accessed at: http://www.portaaporta.cat/ (21 ${ }^{\text {st }}$ March 2015).

Aoun, W.B., Akkari, M.E., Gabrielle, B., \& Flénet, F. (2014). Considering the variability of farming practices improves the LCA of biodiesel from oilseed rape. In the $9^{\text {th }}$ International Conference on Life Cycle Assessment in the Agri-Food Sector, LCA Foods, $8^{\text {th }}-10^{\text {th }}$ October 2014, San Francisco (US). ISBN: 978-0-9882145-7-6

APPA (2013). Asociación de Productores de Energías Renovables. Las importaciones desleales copan ya el $76 \%$ del mercado del biodiesel, agravando la agonía del sector. Accessed at: http://www.appa.es ( ${ }^{\text {st }}$ December 2014). 
APPA (2014). Asociación de Productores de Energías Renovables. El objetivo de biocarburantes en España para 2014 es uno de los más bajos de toda la Unión Europea. Accessed at: http://www.appa.es (24 ${ }^{\text {th }}$ October 2014).

Ardente, F., Beccali, G., Cellura, M., \& Lo Brano, V. (2005). Life cycle assessment of a solar thermal collector. Renewable Energy, 30(7): 1031-1054.

Arena, U., Mastellone, M.L., \& Perugini, F. (2003). The environmental performance of alternative solid waste management options: a life cycle assessment study. Chemical Engineering Journal 96: 207-222.

Arriaza, M., \& Gómez-Limón, J.A. (2003). Comparative performance of selected mathematical programming models. Agricultural Systems, 77(2): 155-171.

Bachmaier, J., \& Gronauer, A. (2007). Klimabilanz von biogasstrom. Klimabilanz der energetischen nutzung von biogas aus wirtschaftsdüngern und nachwachsenden rohstoffen. Bayerische Landesanstalt für Landwirtschaft (LfL), Freising (Germany).

Balmer, R.T. (2011). Modern Engineering Thermodynamics. Ed.: Elsevier; Oxford (UK). ISBN 978-0-12-374996-3

Banse, M., Van Meijl, H., Tabeau, A., \& Woltjer, G. (2008). Will EU biofuel policies affect global agricultural markets? European Review of Agricultural Economics, 35(2): 117-141.

Banse, M., Van Meijl, H., Tabeau, A., Woltjer, G., Hellmann, F., \& Verburg, P.H. (2011). Impact of EU biofuel policies on world agricultural production and land use. Biomass Bioenergy, 35(6): 2385-2390.

Bao-guo, T., Ji-tao, S., Yan, Z., Hong-tao, W., \& Ji-ming, H. (2007). Approach of technical decision-making by element flow analysis and Monte-Carlo simulation of municipal solid waste stream. Journal of Environmental Sciences, 19: 633-640.

Barros, S. (2013). Brazil Biofuels Annual Report. . USDA-FAS. Global Agricultural Information Network (GAIN). Sao Paulo (Brazil).

Beccali, G., Cellura, M., \& Mistretta, M. (2001) Managing municipal solid waste. Energetic and environmental comparison among different management options. International Journal of Life Cycle Assessment, 6(4): 243-249.

Bernesson, S. (2004). Life cycle assessment of rapeseed oil, rape methyl ester and ethanol as fuels. A comparison between large and small scale production. Miljö, teknik och lantbruk. Rapport 2004:01, SLU Department of Biometry and Engineering. Institutionen för biometri och teknik, Swedish University of Agricultural Sciences, Uppsala (Sweden). 
Bernesson, S., Nilsson, D., \& Hansson, P.A. (2006). A limited LCA comparing large-and small-scale production of ethanol for heavy engines under Swedish conditions. Biomass and Bioenergy, 30(1): 46-57.

Berthoud, A., Maupu, P., Huet, C., \& Poupart A. (2011). Assessing freshwater ecotoxicity of agricultural products in life cycle assessment (LCA): a case study of wheat using French agricultural practices databases and USEtox model. International Journal of Life Cycle Assessment, 16(8): 841-847.

Birur, D., Hertel, T.W., \& Tyner, W.E. (2008). Impact of biofuel production on world agricultural markets: a computable general equilibrium analysis. GTAP Working Papers No. 53. Center for Global Trade Analysis, Purdue University, West Lafayette (US).

Birur, DK., Hertel, T.W., \& Tyner, W.E. (2009). The biofuels boom: implications for world food markets. The Food Economy Global Issues and Challenges. Wageningen Academic Publishers, 61-75. Wageningen (The Netherlands).

Björklund, A.E. (2002). Survey of approaches to improve reliability in LCA. International Journal of Life Cycle Assessment, 7(2):64-72.

Blanco-Fonseca, M., Burrell, A., Gay, S.H., Henseler, M., Kavallari, A., PérezDomínguez, I., \& Tonini, A. (2010). Impacts of the EU biofuel target on agricultural markets and land use. A comparative modelling assessment. Institute for Prospective Technological Studies (IPTS) of the JRC. Publications of the EU, Luxembourg (Luxembourg).

BOE (2007). Real Decreto 661/2007, de 25 de mayo, por el que se regula la actividad de producción de energía eléctrica en régimen especial. Ministerio de la Presidencia, Gobierno de España, Madrid (Spain). Accessed at: http://www.boe.es (15 ${ }^{\text {th }}$ March 2015).

BOE (2011). Orden IET/3586/2011, de 30 de diciembre, por la que se establecen los peajes de acceso a partir de 1 de enero de 2012 y las tarifas y primas de las instalaciones del régimen especial. Ministerio de la Presidencia, Gobierno de España, Madrid (Spain). Accessed at: http://www.boe.es (15 ${ }^{\text {th }}$ March 2015).

BOE (2014a). Orden IET/1045/2014, de 16 de junio, por la que se aprueban los parámetros retributivos de las instalaciones tipo aplicables a determinadas instalaciones de producción de energía eléctrica a partir de fuentes de energía renovables, cogeneración y residuos. Ministerio de la Presidencia, Gobierno de España, Madrid (Spain). Accessed at: http://www.boe.es (15 ${ }^{\text {th }}$ March 2015).

BOE (2014b). Real Decreto 413/2014, de 6 de junio, por el que se regula la actividad de producción de energía eléctrica a partir de fuentes de energía 
renovables, cogeneración y residuos. Ministerio de la Presidencia, Gobierno de España, Madrid (Spain). Accessed at: http://www.boe.es (14th March 2015).

Böhringer, C. (1998). The synthesis of bottom-up and top-down in energy policy modeling. Energy economics, 20(3): 233-248.

Börjesson, P., \& Tufvesson, L.M. (2011). Agricultural crop-based biofuels-resource efficiency and environmental performance including direct land use changes. Journal of Cleaner Production, 19(2): 108-120.

Bot, P., Van Donk, D.P., Pennink, B., \& Simatupang, T.M. (2015). Uncertainties in the Bidirectional Biodiesel Supply Chain. Journal of Cleaner Production, 95: 174183.

Bovea, M.D., Ibáñez-Forés, V., Gallardo, A., \& Colomer-Mendoza, F.J. (2010). Environmental assessment of alternative municipal solid waste management strategies. A Spanish case study. Waste Management, 30(11): 2383-2395.

Brander, M., Tipper, R., Hutchison, C., \& Davis, G. (2009). Consequential and attributional approaches to LCA: a guide to policy makers with specific reference to greenhouse gas LCA of biofuels. Econometrica Press, Technical Paper TP090403-A.

Brander, M., \& Wylie, C. (2011). The use of substitution in attributional life cycle assessment. Greenhouse Gas Measurement and Management, 1(3-4): 161-166.

Brentrup, F., Küsters, J., Kuhlmann, H., \& Lammel, J. (2004). Environmental impact assessment of agricultural production systems using the life cycle assessment methodology: I. Theoretical concept of a LCA method tailored to crop production. European Journal of Agronomy, 20(3): 247-264.

Britz, W., \& Heckelei, T. (2008). Recent developments in EU policies-challenges for partial equilibrium models. In $107^{\text {th }}$ EAAE Seminar Modeling of Agricultural and Rural Development Policies, January $29^{\text {th }}$-February $1^{\text {st }} 2008$, Sevilla (Spain).

Broch, A., Hoekman, S. K., \& Unnasch, S. (2013). A review of variability in indirect land use change assessment and modeling in biofuel policy. Environmental Science and Policy, 29: 147-157.

Brooke, A., Kendrick, D., Meeraus, A., \& Raman, R. (1998). General Algebraic Modeling System. A user's guide. GAMS Development Corporation. Washington, DC (US).

Brown, L.R. (2012). Full Planet, Empty Plates: The New Geopolitics of Food Scarcity. Ed.: W.W. Norton \& Company, New York (US). 
BSI (2011). British Standards Institution. PAS:2050. Specification for the assessment of the life cycle greenhouse gas emissions of goods and services. London (United Kingdom).

Burfisher, M.E. (2011). Introduction to Computable General Equilibrium models. Ed.: Cambridge University Press, New York (US). ISBN 978-0-521-76696-8

Burgess, A.A., \& Brennan, D.J. (2001). Application of life cycle assessment to chemical processes. Chemical Engineering Science, 56(8): 2589-2604.

Burniaux, J.M., \& Truong, T.P. (2002). GTAP-E: an energy-environmental version of the GTAP model. GTAP Technical Papers No. 18. Center for Global Trade Analysis, Purdue University, West Lafayette (US).

Campbell, P.K., Beer, T., \& Batten, D. (2011). Life cycle assessment of biodiesel production from microalgae in ponds. Bioresource Technology, 102(1): 50-56.

CARB (2009). Proposed Regulation to Implement the Low Carbon Fuel Standard, Volume I. CARB, Sacramento (US). Accessed at: www.arb.ca.gov (11 ${ }^{\text {th }}$ December 2014).

Carlsson Reich, M. (2005). Economic assessment of municipal waste management systems. Case studies using a combination of life cycle assessment (LCA) and life cycle costing (LCC). Journal of Cleaner Production, 13: 253-263.

Carré, F., Hiederer, R., Blujdea, V., \& Koeble, R. (2010). Background guide for the calculation of land carbon stocks in the biofuels sustainability scheme. Institute for Environment and Sustainability (IES) of the JRC. Publications of the EU, Luxembourg (Luxembourg).

Carter, C., Finley, W., Fry, J., Jackson, D., \& Willis, L. (2007). Palm oil markets and future supply. European Journal of Lipid Science and Technology, 109(4): 307314.

Cederberg, C., \& Mattsson, B. (2000). Life cycle assessment of milk production. A comparison of conventional and organic farming. Journal of Cleaner Production, 8(1): 49-60.

CEPA (2008). California Environmental Protection Agency. Detailed CaliforniaGREET pathway for biodiesel (esterified soyoil) from Midwest soybeans. California Air Resources Board. Sacramento (US).

Charles, C., Zamudio, A.N., \& Moerenhout, T. (2013). Biofuels at what cost? A review of costs and benefits of Spain's biofuel policies. The International Institute for Sustainable Development (IISD). Geneva (Switzerland). 


\section{Chapter VI. References}

Cherubini, F. (2010). GHG balances of bioenergy systems-Overview of key steps in the production chain and methodological concerns. Renewable Energy, 35(7): 1565-1573.

Cherubini. F., Bargigli. S., \& Ulgiati. S. (2009). Life cycle assessment (LCA) of waste management strategies: landfilling, sorting plant and incineration. Energy, 34(12): 2116-2123.

Cherubini, F., \& Strømman, A.H. (2011). Life cycle assessment of bioenergy systems: state of the art and future challenges. Bioresource Technology, 102(2): 437-451.

Choudhury, R., Wurster, R., Weber, T., Schindler, J., Weindorf, W., Miller, M., \& Dautrebande, O. (2002) General Motors Well-to-wheel analysis of energy use and greenhouse gas emissions of advanced fuel/vehicle systems. A European study. Ottobrunn (Germany).

Chouychai, W., Thongkukiatkul, A., Upatham, S., Lee, H., Pokethitiyook, P., \& Kruatrachue, M. (2009). Plant-enhanced phenanthrene and pyrene biodegradation in acidic soil. Journal of Environmental Biology, 30(1): 139-144.

Ciaian, P., Espinosa, M., Gomez y Paloma, S., Heckelei, T., Langrell, S., Louhichi, K., Sckokai, P., Thomas, A., \& Vard, T. (2013). Farm level modelling of the CAP: a methodological overview. Institute for Prospective Technological Studies (IPTS) of the JRC. Publications of the EU, Luxembourg (Luxembourg).

Ciroth, A. (2009). Cost data quality considerations for eco-efficiency measures. Ecological Economics, 68: 1583-1590.

Ciroth, A., Fleischer, G., \& Steinbach, J. (2004). Uncertainty calculation in life cycle assessments. A combined model of simulation and approximation. International Journal of Life Cycle Assessment, 9(4):216-226

Clavreul, J., Guyonnet, D., \& Christensen, T.H. (2012). Quantifying uncertainty in LCA. Modelling of waste management systems. Waste Management, 32: 24822495.

Cleary, J. (2009). Life cycle assessments of municipal solid waste management systems: A comparative analysis of selected peer-reviewed literature. Environment International, 35(8): 1256-1266.

Clift, R., Doig, A., \& Finnveden, G. (2000). The application of life cycle assessment to integrated solid waste management: Part 1-Methodology. Process Safety and Environmental Protection, 78(4): 279-287.

CNE (2013). Informe anual sobre el uso de biocarburantes correspondiente al ejercicio 2011. Accessed at: http://www.cne.es (24 ${ }^{\text {th }}$ October 2013) 
CNMC (2013). Comisión Nacional de los Mercados y la Competencia. Informe mensual de supervisión del mercado de bioarburantes. Madrid (Spain). Accessed at: http://www.cnmc.es (26 $6^{\text {th }}$ January 2015).

CNMC (2014). Estadística de Biocarburantes. Comisión Nacional de los Mercados y la Competencia. Accessed at: http://www.cnmc.es (23 ${ }^{\text {rd }}$ October 2014).

Coelli, T.J., Prasada Rao, D.S., O'Donnell, C.J., \& Battese, G.S. (2005). An introduction to efficiency and productivity analysis. In: Springer, 2nd edn. Ed.: Springer-Verlag US, New York (US). eBook ISBN: 978-0-387-25895-9

COPA-COGECA (2012). Copa-Cogeca's position on the EU's biofuels policy. Accessed at: http://www.copa-cogeca.be/Menu.aspx (10 April 2014).

Corbiere-Nicollier, T., Gfeller Laban, B., Lundquist, L., Leterrier, Y., Månson, J. A., \& Jolliet, O. (2001). Life cycle assessment of biofibres replacing glass fibres as reinforcement in plastics. Resources, Conservation and Recycling, 33(4): 267-287.

Čuček, L., Varbanov, P.S., Klemeš, J.J., \& Kravanja, Z. (2012). Total footprintsbased multi-criteria optimisation of regional biomass energy supply chains. Energy, 44(1): 135-145.

Cuniberti, M., Herrero, R., Mir, L., Berra, O., \& Macagno, S. (2012). Rendimiento y calidad comercial e industrial de la soja en la Región Núcleo-Sojera. Cosecha 2011-12. Instituto Nacional de Tecnología Agropecuaria INTA. Estación Experimental Marcos Juárez. Córdoba (Argentina). Accessed at: http://inta.gob.ar/ (24 $4^{\text {th }}$ June 2013).

Curran, M.A. (2007). Co-product and input allocation approaches for creating life cycle inventory data: a literature review. International Journal of Life Cycle Assessment 12(Special Issue 1):65-78

Dalgaard, R., Schmidt, J., Halberg, N., Christensen, P., Thrane, M., \& Pengue, W.A. (2008). LCA of soybean meal. International Journal of Life Cycle Assessment, 13(3): 240-254.

Dal-Mas M, Giarola S, Zamboni A, \& Bezzo F. (2011). Strategic design and investment capacity planning of the ethanol supply chain under price uncertainty. Biomass and Bioenergy, 35(5): 2059-2071.

Dandres, T., Gaudreault, C., Tirado-Seco, P., \& Samson, R. (2011). Assessing non-marginal variations with consequential LCA: Application to European energy sector. Renewable and Sustainable Energy Reviews, 15(6): 3121-3132.

Darlington, T.L., Heuss, J.M., \& Kahlbaaum, D.F. (2009). Review of EPA's RFS2 Lifecycle Emissions-Analysis for Corn Ethanol. Renewable Fuels Association (RFA), Washington DC (US). 
Da Silva, G.P., Mack, M., \& Contiero, J. (2009). Glycerol: a promising and abundant carbon source for industrial microbiology. Biotechnology advances, 27(1): 30-39.

D'Avino, L., Dainelli, R., Lazzeri, L., \& Spugnoli, P. (2015). The role of co-products in biorefinery sustainability: energy allocation versus substitution method in rapeseed and carinata biodiesel chains. Journal of Cleaner Production, 94: 108115.

Davis, S.C., Anderson-Teixeira, K.J., \& DeLucia, E.H. (2009). Life-cycle analysis and the ecology of biofuels. Trends in Plant Science, 14(3):140-146.

De Haes, H.A.U., Jolliet, O., Finnveden, G., Hauschild, M., Krewitt, W., \& MüllerWenk, R. (1999). Best available practice regarding impact categories and category indicators in life cycle impact assessment. International Journal of Life Cycle Assessment, 4(2): 66-74.

DGPT Valdemingómez (2012). Memoria de actividades. Dirección General del Parque Tecnológico de Valdemingómez. Madrid (Spain).

Dimaranan, B.V. (2006). The GTAP 6 data base. Center for Global Trade Analysis, Purdue University, West Lafayette (US).

Donato, L.B., Huerga I.R., \& Hilbert, J.A. (2008). Balance Energético de la producción de biodiesel a partir de soja en la República Argentina. Instituto Nacional de Tecnología Agropecuaria INTA. Buenos Aires (Argentina). Accessed at: http://inta.gob.ar/ (25 June 2013).

Duncan, J. (2003). Costs of biodiesel production. Energy Efficiency and Conservation Authority, 25: 1-26.

Earles, J.M., \& Halog, A. (2011). Consequential life cycle assessment: a review. International Journal of Life Cycle Assessment, 16(5): 445-453.

EBB (2013a). European Biodiesel Board. The EU biofuels supply chain rejects ILUC political compromise. Accessed at: http://www.ebb-eu.org/EBBpress.php (25 $5^{\text {th }}$ April 2014).

EBB (2013b). European Biodiesel Board. European biodiesel industry worried that immature and doubtful ILUC science remains central in EU policy making. Accessed at: http://www.ebb-eu.org/EBBpress.php (25th April 2014).

EC (2010a). EU energy trends to 2030 (update 2009). Directorate-General for Energy in collaboration with Climate Action DG and Mobility and Transport DG. Publications Office of the European Union, Luxembourg (Luxembourg). ISBN 97892-79-16191-9. Doi:10.2833/21664 
EC (2010b). International Reference Life Cycle Data System (ILCD) Handbookgeneral guide for life cycle assessment-detailed guidance. IPTS of the JRC. Publications of the EU, Luxembourg (Luxembourg). ISBN 978-92-79-19092-6, ISSN 1018-5593

EC (2011). Report from the Commission to the European Parliament, the Council, the European Economic and Social Committee and the Committee of the Regions on the Thematic Strategy on the Prevention and Recycling of Waste. Brussels (Belgium).

EC (2012a). COM 595. Directive of the European Parliament and of the Council, amending Directive 98/70/EC relating to the quality of petrol and diesel fuels and amending Directive 2009/28/EC on the promotion of the use of energy from renewable sources. Brussels (Belgium).

EC (2012b). EU Oilseeds trade 2011/12. AGRICommittee for the Common Organisation of Agricultural Markets, 20 December 2012. DG Agriculture and Rural Development European Commission, Brussels (Belgium). Accessed at: http://ec.europa.eu/agriculture/cereals (24 ${ }^{\text {th }}$ October 2014).

EC (2013). Trade statistics. Market access database. Accessed at: http http://madb.europa.eu/madb/indexPubli.htm ( $5^{\text {th }}$ May 2014).

EC (2014). Balance sheets for cereals, oilseeds and rice. Agriculture and Rural Development. Accessed at: http://ec.europa.eu/agriculture/cereals $\left(21^{\text {st }}\right.$ November 2014).

Ecofys, Fraunhofer, BBH, Energy Economics Group, Winrock Int. (2013). Renewable energy progress and biofuels sustainability. Report for the European Commission. London (UK).

Edwards, R., Larivé, J.F., Mahieu, V., \& Rouveirolles, P. (2008). Well-to-wheels analysis of future automotive fuels and powertrains in the European context. Tankto-wheels report, Version 3. Accessed at: http://iet.jrc.ec.europa.eu/aboutjec/downloads (22 ${ }^{\text {nd }}$ October 2014).

EIA (2014). Energy Information Administration. International Energy Statistics. Biofuels production. Accessed at: http://www.eia.gov (18 ${ }^{\text {th }}$ November 2014).

Ekvall, T. (1999). Key methodological issues for life cycle inventory analysis of paper recycling. Journal of Cleaner Production, 7(4): 281-294.

Ekvall, T. (2000). A market-based approach to allocation at open-loop recycling. Resource, Conservation and Recycling, 29(1): 91-109.

Ekvall, T., \& Finnveden, G. (2001). Allocation in ISO 14041-a critical review. Journal of Cleaner Production, 9(3): 197-208. 
Ekvall, T., \& Weidema, B.P. (2004). System boundaries and input data in consequential life cycle inventory analysis. International Journal of Life Cycle Assessment, 9: 161-171.

EMEP/EEA (2013). European Environment Agency. Air pollutant emission inventory guidebook 2013. Technical report No 12/2013. Luxembourg (Luxembourg). ISBN 978-92-9213-403-7, ISSN 1725-2237.

Engström, R., \& Carlsson-Kanyama, A. (2004) Food losses in food service institutions. Examples from Sweden. Food Policy, 29(3): 203-213.

EPI (2012). Earth Policy Institute. Statistics on Climate, Energy, and Transportation. Accessed at: http://www.earthpolicy.org/data_center/C23 $\left(18^{\text {th }}\right.$ November 2014).

Eriksson, O., Carlsson Reich, M., Frostell, B., Björklund, A., Assefa, G., Sundqvist, J.O., \& Thyselius, L. (2005). Municipal solid waste management from a systems perspective. Journal of Cleaner Production, 13(3): 241-252.

Escobar, N., Ribal, F.J., Clemente, G., \& Sanjuán, N. (2014). Consequential LCA of two alternative systems for biodiesel consumption in Spain, considering uncertainty. Journal of Cleaner Production, 79: 61-73.

Escobar, N., Ribal, F.J., Rodrigo, A., Clemente, G., Pascual, A., \& Sanjuán, N. (2015). Uncertainty analysis in the environmental assessment of an integrated management system for restaurant and catering waste in Spain. International Journal of Life Cycle Assessment, 20: 244-262.

Esteban, B., Baquero, G., Puig, R., Riba, J.R., \& Rius, A. (2011). Is it environmentally advantageous to use vegetable oil directly as biofuel instead of converting it to biodiesel? Biomass and Bioenergy, 35(3): 1317-1328.

Eurobserver (2013). Biofuels barometer. L'observatoire des Energies Renouvelables. Accessed at: http://www.eurobserv-er.org/downloads.asp (18 ${ }^{\text {th }}$ November 2014).

Eurobserver (2014). Biofuels barometer. L'observatoire des Energies Renouvelables. Accessed at: http://www.eurobserv-er.org/downloads.asp (18 ${ }^{\text {th }}$ November 2014).

Eurostat (2012). Landfill still accounted for nearly $40 \%$ of municipal waste treated in the EU27 in 2010. Accessed at: http://epp.eurostat.ec.europa.eu/ $\left(28^{\text {th }}\right.$ January 2014).

Eurostat (2013a). In 2011, 40\% of treated municipal waste was recycled or composted, up from $27 \%$ in 2001 . Accessed at: http://epp.eurostat.ec.europa.eu/ (28 ${ }^{\text {th }}$ January 2014). 
Eurostat (2013b). Climate Change and Energy Statistics Accessed at: http://epp.eurostat.ec.europa.eu (13 ${ }^{\text {th }}$ November 2013).

Eurostat (2013c). Energy statistics, primary production of renewable energy. European Commission. Accessed at: http://epp.eurostat.ec.europa.eu (20 ${ }^{\text {th }}$ December 2013).

Eurostat (2014). Energy statistics, primary production of renewable energy. European Commission. Accessed at: http://epp.eurostat.ec.europa.eu $\left(20^{\text {th }}\right.$ November 2014).

Evans, B. (2013). Canada Biofuels Annual Report. USDA-FAS. Global Agricultural Information Network (GAIN), Ottawa (Canada).

FAO (2002). Food and Agriculture Organization of the United Nations. Small-scale palm oil processing in Africa. FAO Agricultural Services Bulletin 148. ISSN 10101365. Accessed at: http://www.fao.org/DOCrEP/005/Y4355E/y4355e00.htm $\left(16^{\text {th }}\right.$ January 2014).

FAO (2013). Food wastage footprint-impacts on natural resources. Food and Agriculture Organization, Rome (Italy). ISBN 978-92-5-107752-8

Faostat (2014). FAO Statistics Division. Accessed at: http://www.faostat.fao.org (18 ${ }^{\text {th }}$ November 2014).

FAPRI (2013). Food and Agriculture Policy Research Institute. World Agricultural Outlook Database. Accessed at: http://www.fapri.iastate.edu $\left(22^{\text {nd }}\right.$ December 2013).

Fargione, J., Hill, J., Tilman, D., Polasky, S., \& Hawthorne, P. (2008). Land clearing and the biofuel carbon debt. Science, 319(5867): 1235-1238.

Finnveden, G., Björklund, A., Moberg, A., \& Ekvall, T. (2007). Environmental and economic assessment methods for waste management decision-support: possibilities and limitations. Waste Management and Research, 25(3): 263-269.

Finnveden, G., Hauschild, M.Z., Ekvall, T., Guinée, J., Heijungs, R., Hellweg, S., Koehler, A., Pennington, D., \& Suh, S. (2009). Recent developments in life cycle assessment. Journal of Environmental Management 91(1): 1-21.

Finnveden, G., Johansson, J., Lind, P., \& Moberg, A. (2000). Life Cycle Assessments of energy from solid waste. Stockholms Universitet, Systemekologi Och Foa, Stockholm (Sweden). ISBN 91-7056-103-6

Finnveden, G., Johansson, J., Lind, P., \& Moberg, A. (2005). Life cycle assessment of energy from solid waste-part 1: general methodology and results. Journal of Cleaner Production, 13(3): 213-229. 
Flach, B., Lieberz, S., Bendz, K., \& Dahlbacka, B. (2011). EU-27 Biofuels Annual Report. USDA-FAS. Global Agricultural Information Network (GAIN), The Hague (Netherlands).

Flach, B., Bendz, K., \& Lieberz, S. (2012). EU-27 Biofuels Annual Report. USDAFAS. Global Agricultural Information Network (GAIN), The Hague (Netherlands).

Flach, B., Bendz, K., Krautgartner, R., \& Lieberz, S. (2013). EU-27 Biofuels Annual Report. USDA-FAS. Global Agricultural Information Network (GAIN), The Hague (Netherlands).

Flach, B., Bendz, K., \& Lieberz, S. (2014). EU-27 Biofuels Annual Report. USDAFAS. Global Agricultural Information Network (GAIN), The Hague (Netherlands).

Forster, P., Ramaswamy, V., Artaxo, P., Berntsen, T., Betts, R., Fahey, D.W., Haywood, J., Lean, J., Lowe, D.C., Myhre, G., Nganga, J., Prinn, R., Raga, G., Schulz, M., \& van Dorland, R. (2007). Changes in atmospheric constituents and in radiative forcing. In: Climate Change 2007, The Physical Science Basis. Contribution of Working Group I to the Fourth Assessment Report of the IPCC. Ed.: Solomon, S., Qin, D., Manning, M., Chen, Z., Marquis, M., Averyt, K.B., Tignor M., \& Miller, H.L., Cambridge University Press, Cambridge, New York (US).

Freire, F., Malça, J., \& Rozakis, S. (2004). Integrated economic and environmental life cycle optimization: an application to biofuel production in France. In: Multiple Criteria Decision Aiding. Ed.: Henggeler Antunes, C., Figueira, J., \& Clímaco, J. For the $56^{\text {th }}$ Meeting of the European Working Group Multiple Criteria Decision, $p p$ 247-271. $3^{\text {th }}-5^{\text {th }}$ October 2002, Coimbra (Portugal). ISBN 972-569-140-7

Frischknecht, R., Althaus, H. J., Bauer, C., Doka, G., Heck, T., Jungbluth, N., Kellenberger, D., \& Nemecek, T. (2007). The environmental relevance of capital goods in life cycle assessments of products and services. International Journal of Life Cycle Assessment, 12(1): 7-17.

Fu, G.Z., Chan, A.W., \& Minns, D.E. (2003). Life cycle assessment of bio-ethanol derived from cellulose. International Journal of Life Cycle Assessment, 8(3): 137141.

Fullana, P., \& Samitier, S. (1996). Iniciació a l'avaluació del cicle de vida. Ed.: Dpt. de Medi Ambient de la Generalitat de Catalunya, Barcelona (Spain).

Fullana, P., \& Puig, R. (1997). Análisis del ciclo de vida. Ed.: Rubes, Barcelona (Spain).

Gasparri, N.I., Grau, H.R., \& Manghi, E. (2008). Carbon pools and emissions from deforestation in extra-tropical forests of northern Argentina between 1900 and 2005. Ecosystems, 11(8): 1247-1261. 
Geisler, G., Hellweg, S., \& Hungerbühler, K. (2005). Uncertainty analysis in life cycle assessment (LCA): Case study on plant-protection products and implications for decision making. International Journal of Life Cycle Assessment, 10(3): 184192.

Gerasimchuk, I. (2013). Biofuel policies and feedstock in the EU. Global Subsidies Initiative of the International Institute for Sustainable Development. Chatam House, London (UK).

Gerasimchuk, I., \& Yam Koh, P. (2013). The EU biofuel policy and palm oil: cutting subsidies or cutting rainforest? IISD, Geneva (Switzerland).

Germer, J., \& Sauerborn, J. (2008). Estimation of the impact of oil palm plantation establishment on greenhouse gas balance. Environment, Development and Sustainability, 10(6): 697-716.

Gholami, Z., Abdullah, A.Z., \& Lee, K.T. (2014). Dealing with the surplus of glycerol production from biodiesel industry through catalytic upgrading to polyglycerols and other value-added products. Renewable and Sustainable Energy Reviews, 39: 327-341.

Gibbs, H.K., Johnston, M., Foley, J.A., Holloway, T., Monfreda, C., Ramankutty, N., Zaks, D. (2008). Carbon payback times for crop-based biofuel expansion in the tropics: the effects of changing yield and technology. Environmental Research Letters, 3(3): 034001.

Gibbs, H.K. \& Yui, S. (2011). New spatially-explicit estimates of soil and biomass carbon stocks by GTAP region and AEZ. University of Wisconsin-Madison and University of California-Davis.

Giugliano, M., Cernuschi, S., Grosso, M., \& Rigamonti, L. (2011). Material and energy recovery in integrated waste management systems. An evaluation based on life cycle assessment. Waste Management, 31(9): 2092-2101.

Glithero, N.J., Ramsden, S.J., \& Wilson, P. (2012). Farm systems assessment of bioenergy feedstock production: integrating bio-economic models and life cycle analysis approaches. Agricultural Systems, 109: 53-64.

Gluch, P., \& Baumann, H. (2004). The life cycle costing (LCC) approach: a conceptual discussion of its usefulness for environmental decision-making. Building and environment, 39(5): 571-580.

Gnansounou, E., Dauriat, A., Villegas, J., \& Panichelli, L. (2009). Life cycle assessment of biofuels: energy and greenhouse gas balances. Bioresource technology, 100(21): 4919-4930. 
Goedkoop, M. (1995). The eco-indicator 95. Final Report. PRé Consultants, Amersfoort (The Netherlands).

Goldemberg, J., Coelho, S.T., \& Guardabassi, P. (2008). The sustainability of ethanol production from sugarcane. Energy Policy, 36(6): 2086-2097.

Goldemberg, J., Mello, F.F., Cerri, C.E., Davies, C.A., \& Cerri, C.C. (2014). Meeting the global demand for biofuels in 2021 through sustainable land use change policy. Energy Policy, 69: 14-18.

Golub, A.A., \& Hertel, T.W. (2012). Modeling land-use change impacts of biofuels in the GTAP-BIO framework. Climate Change Economics, 3(03), 1250015.

Gocht, A. \& Britz, W. (2011). EU-wide farm type supply models in CAPRI - How to consistently disaggregate sector models into farm type models. Journal of Policy Modelling, 33: 146-167.

Greenpeace (2010). La incineración de residuos en cifras. Análisis socioeconómico de la incineración de residuos municipales en España Julio 2010. Accessed at: http://www.greenpeace.org/espana (23 ${ }^{\text {rd }}$ March 2015).

GREET (2010). The Greenhouse Gases, Regulated Emissions, and Energy Use in Transportation Model v1.8d.1. Argonne National Laboratory, Illinois (US). Accessed at: http://greet.es.anl.gov/ (24 ${ }^{\text {th }}$ December 2013).

Güereca, L.P., Gassó, S., Baldasano, J.M., \& Jiménez-Guerrero, P. (2006). Life cycle assessment of two biowaste management systems for Barcelona, Spain. Resources, Conservation and Recycling, 49(1): 32-48.

Guerrero, M. (2013). Spain Biodiesel Standing Report. USDA-FAS. Global Agricultural Information Network (GAIN). Madrid (Spain).

Guinée, J., Gorrée, M., Heijungs, R., Huppes, G., Kleijn, R., De Koning, A., Van Oers, L., Wegener Sleeswijk, A., Suh, S., Udo de Haes, H.A., Briujn, H. de, Van Duin, R., \& Huigbregts, M.A.J. (2002). Life cycle assessment: an operational guide to ISO standards. I: LCA in perspective. Ila: Guide. IIb: Operational annex. III: Scientific background. Kluwer Academic Publishers, Dordrecht (The Netherlands).

Guinée, J.B., Heijungs, R., \& Huppes, G. (2004). Economic allocation: examples and derived decision tree. International Journal of Life Cycle Assessment, 9(1): 2333.

Guinée, J.B., Heijungs, R., Huppes, G., Zamagni, A., Masoni, P., Buonamici, R., Ekvall, T., \& Rydberg, T. (2011). Life cycle assessment: past, present, and future. Environmental Science and Technology, 45(1): 90-96. 
Gustavsson, J., Cederberg, C., \& Sonesson, U. (2011). Global food losses and food waste. Extent, causes and prevention. Food and Agriculture Organization (FAO), Rome (Italy).

Haas, M.J., McAloon, A.J., Yee, W.C., \& Foglia, T.A. (2006). A process model to estimate biodiesel production costs. Bioresource technology, 97(4): 671-678.

Halleux, H., Lassaux, S., Renzoni, R., \& Germain, A. (2008). Comparative life cycle assessment of two biofuels ethanol from sugar beet and rapeseed methyl ester. International Journal of Life Cycle Assessment, 13(3): 184-190.

Haque, I., Rozakis, S., Ganko, E., \& Kallivroussis, L. (2009). Bio-energy production in the sugar industry: an integrated modeling approach. In the 113th EAAE Seminar "A resilient European food industry and food chain in a challenging world", $3^{\text {th }}-6^{\text {th }}$ September 2009, Chania (Greece).

Havlík, P., Schneider, U.A., Schmid, E., Bottcher, H., Fritz, S., Skalský, R., Aoki, K., De Cara, S., Kindermann, G., Kraxner, F., Leduc, S., McCallum, I., Mosnier, A., Sauer, T., \& Obersteiner, M. (2011). Global land-use implications of first and second generation biofuel targets. Energ Policy 39: 5690-5702.

Heijungs, R. (1996). Identification of key issues for further investigation in improving the reliability of life-cycle assessments. Journal of Cleaner Production, 4(3-4): 159-166

Heijungs, R., \& Frischknecht, R. (2005). Representing Statistical Distributions for Uncertain Parameters in LCA. Relationships between mathematical forms, their representation in EcoSpold, and their representation in CMLCA. International Journal of Life Cycle Assessment, 10(4): 248-254.

Heijungs, R., \& Guinée, J.B. (2007). Allocation and "what-if" scenarios in life cycle assessment of waste management systems. Waste Management, 27(8): 997-1005.

Heijungs, R., Guinèe, J., Lankreijer, R.M., Udo de Haes, H.A., \& Wegener Sleeswijk, A. (1992). Environmental life cycle assessment of products - Guide and background (part 2). Centre of Environmental Science (CML), Leiden (The Netherlands).

Heijungs, R., \& Huijbregts, M. (2004). A review of approaches to treat uncertainty in LCA. In: iEMSs 2004 International Congress: Complexity and Integrated Resources Management. Ed.: Pahl, C., Schmidt, S., \& Jakeman, T. International Environmental Modeling and Software Society, Osnabrueck (Germany).

Heijungs, R., \& Kleijn, R. (2001). Numerical approaches towards life cycle interpretation. Five examples. International Journal of Life Cycle Assessment, 6(3): 141-148. 
Heijungs, R., Settanni, E., \& Guinée, J. (2013). Toward a computational structure for life cycle sustainability analysis: unifying LCA and LCC. International Journal of Life Cycle Assessment, 18(9):1722-1733.

Hélaine, S., M'barek, R., Gay, H. (2013). Impacts of the EU biofuel policy on agricultural markets and land use. Modelling assessment with AGLINK-COSIMO. Institute for Prospective Technological Studies (IPTS) of the JRC. Publications of the EU, Luxembourg (Luxembourg).

Hekkert, M.P., Hendriks, F.H., Faaij, A.P., \& Neelis, M.L. (2005). Natural gas as an alternative to crude oil in automotive fuel chains well-to-wheel analysis and transition strategy development. Energy Policy, 33(5): 579-594.

Hertel, T.W. (1997). Global Trade Analysis, modeling and applications. Ed.: Cambridge University Press, Cambridge (US).

Hertel, T.W., Golub, A.A., Jones, A.D., O'Hare, M., Plevin, R.J., \& Kammen, D.M. (2010). Effects of US maize ethanol on global land use and greenhouse gas emissions: estimating market-mediated responses. Bioscience, 60(3): 223-231.

Hertel, T.W., \& Tyner, W.E. (2013). Market-mediated environmental impacts of biofuels. Global Food Security, 2(2): 131-137.

Hertel, T.W., Tyner, W.E., \& Birur, D.K. (2008). Biofuels for all? Understanding the global impacts of multinational mandates. GTAP Working Paper No. 51. Center for Global Trade Analysis, Purdue University, West Lafayette (US).

Hertel, T.W., \& Walmsley, T.L. (2008). GTAP 7 Data Base Documentation Chapter 1: Introduction. Center for Global Trade Analysis, Purdue University, West Lafayette (US). Accessed at: https://www.gtap.agecon.purdue.edu $\left(12^{\text {th }}\right.$ December 2014).

Hertel, T.W., \& Winters, L.A. (2006). Poverty and the WTO: Impacts of the Doha development agenda. Ed.: Hertel \& Winters, Palgrave McMillan and World Bank Publications, New York and Washington DC (US). ISBN 978-0-8213-6314-0

Hill, J., Nelson, E., Tilman, D., Polasky, S., \& Tiffany, D. (2006). Environmental, economic, and energetic costs and benefits of biodiesel and ethanol biofuels. Proceedings of the National Academy of Sciences, 103(30): 11206-11210.

Hischier, R., Weidema, B.P., Althaus, H.J., Bauer, C., Doka, G., Dones, R., Frischknecht, R., Hellweg, S., Humbert, S., Jungbluth, N., Köllner, T., Loerincik, Y., IDAE (2011). Instituto para la Diversificación y el Ahorro de Energía. Plan de Energías Renovables 2011-2020. Ministerio de Industria, Energía y Turismo, Madrid (Spain). Accessed at: http://www.idae.es (23 ${ }^{\text {rd }}$ September 2014). 
Hoefnagels, R., Smeets, E., \& Faaij, A. (2010). Greenhouse gas footprints of different biofuel production systems. Renewable and Sustainable Energy Reviews, 14(7): 1661-1694.

Huijbregts, M.A.J. (1998a). Application of uncertainty and variability in LCA. Part 1: a general framework for the analysis of uncertainty and variability in life cycle assessment. International Journal of Life Cycle Assessment, 3(5): 273-280.

Huijbregts, M.A.J. (1998b) Application of uncertainty and variability in LCA. Part 2: dealing with parameter uncertainty and uncertainty due to choices in life cycle assessment. International Journal of Life Cycle Assessment, 3(6):343-351.

Huijbregts, M.A.J., Gilijamse, W., Ragas, A. M., \& Reijnders, L. (2003). Evaluating uncertainty in environmental life-cycle assessment. A case study comparing two insulation options for a Dutch one-family dwelling. Environmental science and technology, 37(11): 2600-2608.

Huijbregts, M.A.J., Norris, G., Bretz, R., Ciroth, A., Maurice, B., von Bahr, B., Weidema, B., \& de Beaufort, A.S. (2001). Framework for modelling data uncertainty in life cycle inventories. International Journal of Life Cycle Assessment, 6(3): 127-132.

Huo, H., Wang, M., Bloyd, C., \& Putsche, V. (2008). Life-cycle assessment of energy use and greenhouse gas emissions of soybean-derived biodiesel and renewable fuels. Environmental Science and Technology, 43(3): 750-756.

Huppes, G., \& Ishikawa, M. (2009). Eco-efficiency guiding micro-level actions towards sustainability: Ten basic steps for analysis. Ecological Economics, 68(6): 1687-1700.

Ianchovichina, E., \& Martin, W. (2003). Economic impacts of China's accession to the World Trade Organization (Vol. 3053). World Bank Publications, Washington $D C$ (US).

IDAE (2005). Instituto para la Diversificación y el Ahorro de Energía. Resumen del Plan de Energías Renovables de España 2005-2010 para El Consejo de Ministros. Ministerio de Industria, Energía y Turismo. Madrid (Spain).

IDAE (2011a). Instituto para la Diversificación y el Ahorro de Energía. Plan de Energías Renovables 2011-2020. Ministerio de Industria, Energía y Turismo. Madrid (Spain).

IDAE (2011b). Instituto para la Diversificación y el Ahorro de Energía. Evaluación del balance de gases de efecto invernadero en la producción de biocarburantes. Estudio Técnico 2011-2020. Ministerio de Industria, Energía y Turismo. Madrid (Spain). 
Ignaciuk, A., Vöhringer, F., Ruijs, A., \& Van lerland, E. C. (2006). Competition between biomass and food production in the presence of energy policies: a partial equilibrium analysis. Energy policy, 34(10): 1127-1138.

Iliopoulos, C., \& Rozakis, S. (2010). Environmental cost-effectiveness of bio diesel production in Greece: current policies and alternative scenarios. Energy Policy, 38(2): 1067-1078.

INE (2011). Instituto Nacional de Estadística. Accessed at: http://www.ine.es (13 ${ }^{\text {th }}$ December 2011).

INE (2015). Salarios y costes laborales. Instituto Nacional de Estadística, Madrid (Spain). Accessed at: http://www.ine.es (17 ${ }^{\text {th }}$ March 2015).

IPCC (2006). IPCC guidelines for national Greenhouse Gas inventories. Agriculture, forestry and other land use vol. 4. Accessed at. http://www.ipccnggip.iges.or.jp/public/2006gl/vol4.html (28th November 2014).

Iriarte, A., Gabarrell, X., \& Rieradevall, J. (2009). LCA of selective waste collection systems in dense urban areas. Waste Management, 29(2): 903-914.

ISO (2006a). International Organization for Standardization. ISO 14040 International Standard in Environmental Management. Life Cycle Assessment: Principles and Framework. ISO, Geneva (Switzerland).

ISO (2006b). International Organization for Standardization. ISO 14044 International Standard in Environmental Management. Life Cycle Assessment: Requirements and Guidelines. ISO, Geneva (Switzerland).

Janssen, R., \& Rutz, D.D. (2011). Sustainability of biofuels in Latin America: Risks and opportunities. Energy Policy, 39(10): 5717-5725.

Johansson, D.J., \& Azar, C. (2007). A scenario based analysis of land competition between food and bioenergy production in the US. Climatic Change, 82(3-4): 267291.

Johnson, D.T., \& Taconi, K.A. (2007). The glycerin glut: Options for the value-added conversion of crude glycerol resulting from biodiesel production. Environmental Progress, 26(4): 338-348.

Jolliet, O., Müller-Wenk, R., Bare, J., Brent, A., Goedkoop, M., Heijungs, R., Itsubo, N., Peña, C., Pennington, D., Potting, J., Rebitzer, G., Stewart, M., de Haes, H.A.U., \& Weidema, B. (2004). The LCIA midpoint-damage framework of the UNEPISETAC life cycle initiative. International Journal of Life Cycle Assessment, 9(6): 394-404. 
Joseph, K. (2014). Argentina Biofuels Annual Report. USDA-FAS. Global Agricultural Information Network (GAIN), Buenos Aires (Argentina).

JRC (2010). International Reference Life Cycle Data System (ILCD) Handbook. General Guide for Life Cycle Assessment-Detailed Guidance. Institute for Environment and Sustainability. Publications Office of the UE, Luxembourg (Luxembourg).

Jung, J., von der Assen, N., \& Bardow, A. (2014). Sensitivity coefficient-based uncertainty analysis for multi-functionality in LCA. International Journal of Life Cycle Assessment, 19(3): 661-676.

Kaltschmitt, M., Reinhardt, G.A., \& Stelzer, T. (1997). Life cycle analysis of biofuels under different environmental aspects. Biomass and Bioenergy, 12(2): 121-134.

Kamahara, H., Hasanudin, U., Widiyanto, A., Tachibana, R., Atsuta, Y., Goto, N., Daimon, H., \& Fujie, K. (2010). Improvement potential for net energy balance of biodiesel derived from palm oil: a case study from Indonesian practice. Biomass and Bioenergy, 34(12): 1818-1824

Kaplan, P.O., Barlaz, M.A., \& Ranjithan, S.R. (2004). A procedure for Life-CycleBased solid waste management with consideration of uncertainty. Journal of Industrial Ecology, 8(4):155-172.

Kim, S., \& Dale, B.E. (2002). Allocation procedure in ethanol production system from corn grain: I. System expansion. International Journal of Life Cycle Assessment, 7(4): 237-243.

Kim, S., \& Dale, B.E. (2005). Life cycle assessment of various cropping systems utilized for producing biofuels: bioethanol and biodiesel. Biomass Bioenergy, 29(6): 426-439.

Kim, S., \& Dale, B.E. (2011). Indirect land use change for biofuels: testing predictions and improving analytical methodologies. Biomass and Bioenergy, 35(7): 3235-3240.

Kim, H., Kim, S., \& Dale, B.E. (2009). Biofuels, land use change, and greenhouse gas emissions: some unexplored variables. Environmental Science and Technology, 43(3): 961-967.

Kim, J., Realff, M.J., \& Lee, J.H. (2011). Optimal design and global sensitivity analysis of biomass supply chain networks for biofuels under uncertainty. Computers and Chemical Engineering, 35(9): 1738-1751.

Kim, M.H., Song, Y.E., Song, H.B., Kim, J.W., \& Hwang, S.J. (2011). Evaluation of food waste disposal options by LCC analysis from the perspective of global warming: Jungnang case, South Korea. Waste Management, 31(9): 2112-2120. 
Kleyner, A., \& Sandborn, P. (2008). Minimizing life cycle cost by managing product reliability via validation plan and warranty return cost. International Journal of Production Economics, 112(2): 796-807.

Kløverpris, J., Wenzel, H., \& Nielsen, P.H. (2008). Life cycle inventory modelling of land use induced by crop consumption. International Journal of Life Cycle Assessment, 13(1): 13-21.

Koizumi, T., \& Ohga, K. (2007). Impacts of the Chinese Fuel-Ethanol Program on the world corn market: an econometric simulation approach. In the Farm Foundation and ERS Workshop "Global Biofuel Developments: Modeling the Effects on Agriculture", February $27-28^{\text {th }} 2007$, Washington DC (US).

Krautgartner, R., Audran, X., Rehder, L.E., Boshnakova, M., Dobrescu, M., Flach, B., Wilson, J., Bettini, O., Guerrero, M., \& Bendz, K. (2014). EU-28 Oilseeds and Products Annual Report. Record Rapeseed Production but Sunflower Production Down. USDA-FAS. Global Agricultural Information Network (GAIN), Vienna (Austria).

Kretschmer, B., \& Peterson, S. (2010). Integrating bioenergy into computable general equilibrium models: a survey. Energy Economics, 32(3): 673-686.

Kretschmer, B., Bowyer, C., \& Buckwell, A. (2012). EU biofuel use and agricultural commodity prices. A review of the evidence base. Institute for European Environmental Policy, London (UK)-Brussels (Belgium).

Kuosmanen, T., \& Kortelainen, M. (2005). Measuring Eco-efficiency of Production with Data Envelopment Analysis. Journal of Industrial Ecology, 9(4): 59-72.

Laborde, D. (2011). Assessing the land use change consequences of European biofuel policies. IFPRI, Washington DC (US).

Laborde, D., Padella, M., Edwards, R., \& Marelli, L. (2014). Progress in estimates of ILUC with MIRAGE model. Scientific and Policy Report by the Joint Research Centre of the EC. Publications Office of the EU, Luxembourg (Luxembourg).

Lam, M.K., Lee, K.T., \& Mohamed, A.R. (2009). Life cycle assessment for the production of biodiesel: a case study in Malaysia for palm oil versus jatropha oil. Biofuels, Bioproducts and Biorefining, 3(6): 601-612.

Lamers, P. (2011a). International biodiesel markets. Developments in production and trade. Ecofys/UFOP, Berlin (Germany).

Lamers, P., Hamelinck, C., Junginger, M., \& Faaij, A. (2011b). International bioenergy trade. A review of past developments in the liquid biofuel market. Renewable and Sustainable Energy Reviews, 15(6): 2655-2676. 
Lapola, D.M., Schaldach, R., Alcamo, J., Bondeau, A., Koch, J., Koelking, C., \& Priess, J.A. (2010). Indirect land-use changes can overcome carbon savings from biofuels in Brazil. Proceedings of the National Academy of Sciences, 107(8): 33883393.

Lange, M. (2011). The GHG balance of biofuels taking into account land use change. Energy Policy, 39(5): 2373-2385.

Larson, E.D. (2006). A review of life-cycle analysis studies on liquid biofuel systems for the transport sector. Energy for Sustainable Development, 10(2): 109126.

Leão, R.R.D.C.C., Hamacher, S., \& Oliveira, F. (2011). Optimization of biodiesel supply chains based on small farmers: A case study in Brazil. Bioresource Technology, 102(19): 8958-8963.

Lechón, Y., Cabal, H., Lago, C., De la Rúa, C., Sáez, R.M., \& Fernández, M. (2005). Análisis de Ciclo de Vida de combustibles alternativos para el transporte. Fase I. Análisis de Ciclo de Vida comparativo del etanol de cereales y de la gasolina. CIEMAT, Ministerio de Medio Ambiente. CIEMAT/ESYME/04-45201/12, Madrid (Spain). ISBN 84-8320-312-X

Lechón, Y., Cabal, H., De la Rúa, C., Lago, C., Izquierdo, L., Sáez, R.M., \& San Miguel, M.F. (2006). Análisis de Ciclo de Vida de combustibles alternativos para el transporte. Fase II. Análisis de Ciclo de Vida Comparativo de Biodiesel y Diesel. CIEMAT, Ministerio de Medio Ambiente. CIEMAT/ASE/05-E0221/2, Madrid (Spain). ISBN 84-8320-376-6

Lechón, Y., Cabal, H., De la Rüa, C., Caldés, N., Santamaría, M., \& Sáez, R. (2009). Energy and greenhouse gas emission saving of biofuels in Spain's transport fuel. The adoption of the EU policy on biofuels. Biomass and Bioenergy, 33(6-7): 920-932.

Lechon, Y., Cabal, H., \& Sáez, R. (2011). Life cycle greenhouse gas emissions impacts of the adoption of the EU Directive on biofuels in Spain. Effect of the import of raw materials and land use changes. Biomass and Bioenergy, 35(6): 2374-2384.

Lee, H.C., McCarl, B.A., \& Gillig, D. (2005). The dynamic competitiveness of US agricultural and forest carbon sequestration. Canadian Journal of Agricultural Economics/Revue canadienne d'agroeconomie, 53(4): 343-357.

Lendle, A., \& Schaus, M. (2010). Sustainability criteria in the EU Renewable Energy Directive: consistent with WTO Rules? ICTSD information note No. 2. ICTSD Project on WTO Jurisprudence and Sustainable Development. Geneva (Switzerland). 
Leoneti, A.B., Aragao-Leoneti, V., \& De Oliveira, S.V.W.B. (2012). Glycerol as a by-product of biodiesel production in Brazil: Alternatives for the use of unrefined glycerol. Renewable Eenergy, 45: 138-145.

Limpert, E., Stahel, W.A., \& Abbt, M. (2001). Log-normal distributions across the sciences: keys and clues. On the charms of statistics, and how mechanical models resembling gambling machines offer a link to a handy way to characterize lognormal distributions, which can provide deeper insight into variability and probability—normal or log-normal: that is the question. Bioscience, 51(5): 341-352.

Link, P.M., Ramos, C.I., Schneider, U.A., Schmid, E., Balkovic, J., \& Skalsky, R. (2008). The Interdependencies between food and biofuel production in European Agriculture-An application of EUFASOM. FNU-165, Hamburg University and Centre for Marine and Atmospheric Science, Hamburg (Germany). Accessed at: http://www.mi.uni-hamburg.de/ (11 ${ }^{\text {th }}$ December 2014).

Lloyd, S.M., \& Ries, R. (2007). Characterizing, Propagating, and Analyzing Uncertainty in Life-Cycle Assessment: A Survey of Quantitative Approaches. Journal of Industrial Ecology, 11(1): 161-179.

Luo, L., Van Der Voet, E., \& Huppes, G. (2009). Life cycle assessment and life cycle costing of bioethanol from sugarcane in Brazil. Renewable and Sustainable Energy Reviews, 13(6): 1613-1619.

MAGRAMA (2010a). Anuario de estadística 2010. Ministerio de Medio Ambiente y Medio Rural y Marino Madrid (Spain).

MAGRAMA (2010b). Guía práctica de la fertilización racional de los cultivos en España. Parte II. Abonado de los principales cultivos en España. Ministerio de Medio Ambiente y Medio Rural y Marino, Madrid (Spain).

MAGRAMA (2011c). Resultados técnico-económicos de explotaciones agrícolas de Andalucía en 2009. Análisis de la economía de los sistemas de producción. Ministerio de Medio Ambiente y Medio Rural y Marino, Madrid (Spain).

MAGRAMA (2010d). Resultados técnico-económicos de explotaciones agrícolas de Aragón en 2009. Análisis de la economía de los sistemas de producción. Ministerio de Medio Ambiente y Medio Rural y Marino, Madrid (Spain).

MAGRAMA (2011). Balance de Nitrógeno en la agricultura española. Año 2009. Resumen de resultados a nivel autonómico y regional. Ministerio de Medio Ambiente y Medio Rural y Marino., Madrid (Spain). Accessed at: http://www.ruena.csic.es/balances.html ( $4^{\text {th }}$ November 2014).

MAGRAMA (2012). Ministerio de Agricultura, Alimentación y Medio Ambiente. Análisis cualitativo de las tendencias de la restauración en 2012 en base a la 
percepción de los operadores del sector. Accessed at: http://www.magrama.gob.es/es/alimentacion/publicaciones/ (31 ${ }^{\text {st }}$ January 2014).

MAGRAMA (2013a). Spanish Strategy "More food, less waste". Program to reduce food loss and waste and maximize the value of discarded food. Ministerio de Agricultura, Alimentación y Medio Ambiente, Madrid (Spain).

MAGRAMA (2013b). Gestión de biorresiduos de competencia municipal. Guía para la implantación de la recogida separada y tratamiento de la fracción orgánica. Ministerio de Agricultura, Alimentación y Medio Ambiente, Madrid (Spain).

Malcolm, G. (1998). Adjusting tax rates in the GTAP data base. GTAP Technical Paper No. 15. Center for Global Trade Analysis, Purdue University, West Lafayette (US).

Malça, J., \& Freire, F. (2010). Uncertainty analysis in biofuel systems. An application to the life cycle of rapeseed oil. Journal of Industrial Ecology, 14(2): 322-334.

Malça, J., \& Freire, F. (2011). Life-cycle studies of biodiesel in Europe: A review addressing the variability of results and modeling issues. Renewable and Sustainable Energy Reviews, 15(1): 338-351.

Margni, M., \& Nemeck, T. (2010). Implementation of Life Cycle Impact Assessment Methods. Data v2.2. Ecoinvent report No 3. Swiss Centre for Life Cycle Inventories. Zurich/Laussane (Switzerland).

Martínez-Blanco, J., Colón, J., Gabarrell, X., Font, X., Sánchez, A., Artola, A., \& Rieradevall, J. (2010). The use of life cycle assessment for the comparison of biowaste composting at home and full scale. Waste Management, 30(6): 983-994.

Martínez-Blanco, J., Muñoz, P., Antón, A., \& Rieradevall, J. (2009). Life cycle assessment of the use of compost from municipal organic waste for fertilization of tomato crops. Resources, Conservation and Recycling, 53(6): 340-351.

Marvuglia, A., Benetto, E., Rege, S., \& Jury, C. (2013). Modelling approaches in consequential life cycle assessment (C-LCA) of bioenergy: critical review and proposed framework for biogas production. Renewable and Sustainable Energy Reviews, 25(1): 768-781.

Mattsson, B., Cederberg, C., \& Blix, L. (2000). Agricultural land use in life cycle assessment (LCA): case studies of three vegetable oil crops. Journal of Cleaner Production, 8(4):283-292.

McDaniel, C.A., \& Balistreri, E.J. (2003). A review of Armington trade substitution elasticities. Économie Internationale, 94(2): 301-313. 
McDougall, R., \& Golub, A.A. (2007). GTAP-E: a revised energy-environmental version of the GTAP model. GTAP Research Memorandum No. 15. Center for Global Trade Analysis, Purdue University, West Lafayette (US).

McDougall, F.R., White, P.R., Franke, M., \& Hindle, P. (2008). Integrated solid waste management: a life cycle inventory. Ed.: John Wiley \& Sons, Hoboken (US).

MECON (2011a). Ministerio de Economía y Finanzas Públicas de la Nación Argentina. Secretaría de Política Económica. Direcciones de Información y Análisis Regional y Sectorial. Accessed at: http://www.mecon.gov.ar (26 ${ }^{\text {th }}$ February 2013).

MECON (2011b). Ministerio de Economía y Finanzas Públicas de la Nación Argentina. Secretaría de Energía. Informe estadístico del sector eléctrico 2011. Accessed at: http://energia3.mecon.gov.ar (28 ${ }^{\text {th }}$ February 2013).

Mehta, P.S., \& Anand, K. (2009). Estimation of a lower heating value of vegetable oil and biodiesel fuel. Energy Fuels, 23(8): 3893-3898.

Mekonnen, M.M., \& Hoekstra, A.Y. (2010). The green, blue and grey water footprint of crops and derived crop products. Volume 1: Main report. Research Report Series No. 47. UNESCO-IHE Institute for Water Education, Delft (The Netherlands).

Mele, F.D., Guillén-Gosálbez, G., \& Jiménez, L. (2009). Optimal planning of supply chains for bioethanol and sugar production with economic and environmental concerns. Computer Aided Chemical Engineering, 26: 997-1002.

Mele, F.D., Kostin, A.M., Guillén-Gosálbez, G., \& Jiménez, L. (2011). Multiobjective model for more sustainable fuel supply chains. A case study of the sugar cane industry in Argentina. Industrial and Engineering Chemistry Research, 50(9): 49394958.

Milà i Canals, L., Burnip, G.M., \& Cowell, S.J. (2006). Evaluation of the environmental impacts of apple production using life cycle assessment (LCA): case study in New Zealand. Agriculture, Ecosystems and Environment, 114(2): 226-238.

MINETUR (2012). Precios de carburantes y combustibles. Datos de diciembre 2012. Ministerio de Industria, Energía y Turismo, Madrid (Spain). Accessed at: http://www.minetur.gob.es/ (11 $1^{\text {th }}$ February 2015).

Moberg, A., Finnveden, G., Johansson, J., \& Lind, P. (2005). Life cycle assessment of energy from solid waste-part 2: landfilling compared to other treatment methods. Journal of Cleaner Production, 13(3): 231-240.

Morgan, M.G., \& Small, M. (1992). Uncertainty: a guide to dealing with uncertainty in quantitative risk and policy analysis. Ed.: Cambridge University Press, Cambridge (US). 
MPOB (2012). Malaysian Palm Oil Board. Accessed at: http://www.palmoilworld.org (16 ${ }^{\text {th }}$ January 2014).

Mullins, K.A., Griffin, W.M., \& Matthews, H.S. (2011). Policy implications of uncertainty in modeled life-cycle greenhouse gas emissions of biofuels. Environmental Science and Technology, 45(1): 132-138.

Muñoz-Cidad, C., \& Sosvilla, S. (2012). Informe económico 2011. Federación Española de Industrias de la Alimentación y Bebidas (FIAB). Universidad Complutense de Madrid, Madrid (Spain). ISBN 978-84-695-3508-0

Muñoz Colomina, C.I., Cano Montero, E.I., \& Chamizo González, J. (2011) Una propuesta integradora de costes, indicadores y medioambiente. El caso de los residuos sólidos urbanos en Madrid. Presupuesto y Gasto Público, 65: 159-176.

Narayanan, B., \& Walmsley, T.L. (2008). Global Trade, Assistance, and Production: The GTAP 7 Data Base. Center for Global Trade Analysis, Purdue University, West Lafayette (US).

Nemecek, T., Heil, A., Huguenin, O., Meier, S., Erzinger, S., Blaser, S., Dux, D., \& Zimmermann, A. (2007). Life cycle inventories of agricultural production systems. Ecoinvent report No 15a. Swiss Centre for Life Cycle Inventories. Zurich/Laussane (Switzerland).

Niederl, A., \& Narodoslawsky, M. (2006). Ecological evaluation of processes based on by-products or waste from agriculture: life cycle assessment of biodiesel from tallow and used vegetable oil. In: "Feedstocks for the future". ACS Symposium Series, vol. 921, chapter 18 pp 239-25. Ed.: Oxford University Press, Oxford (UK).

Nielsen, P.H., Nielsen, A.M., Weidema, B.P., Dalgaard, R. \& Halberg, N. (2003). LCA food data base. 2.-0 LCA Consultants and Faculty of Agricultural Sciences, Aarhus (Denmark). Accessed at: www.lcafood.dk (30 ${ }^{\text {th }}$ October 2014).

Nijkamp, P., Wang, S., \& Kremers, H. (2005). Modeling the impacts of international climate change policies in a CGE context: The use of the GTAP-E model. Economic Modelling, 22(6): 955-974.

Norris, G.A. (2001). Integrating life cycle cost analysis and LCA. International journal of life cycle assessment, 6(2): 118-120.

NRDC (2012). Wasted: how America is losing Up to 40 percent of its food from farm to fork to landfill. Natural Resources Defense Council (NRDC), NY City (US).

OECD-FAO (2011). Organisation for Economic Co-operation and DevelopmentFood and Agriculture Organization. Agricultural outlook 2011-2020. Chapter 3. Biofuels. Accessed at: http://www.oecd.org (18 ${ }^{\text {th }}$ November 2014). 
OECD-FAO (2013). Organisation for Economic Co-operation and DevelopmentFood and Agriculture Organization. Agricultural outlook 2013. Chapter 3. Biofuels. Accessed at: http://www.fao.org/publications/en/ (19 ${ }^{\text {th }}$ November 2014).

OECD (2015). Organization for Economic Co-operation and Development. Maritime Transport Costs. Accessed at: http://stats.oecd.org (26 ${ }^{\text {th }}$ January 2015).

Ou, X., Zhang, X., Chang, S., \& Guo, Q. (2009). Energy consumption and GHG emissions of six biofuel pathways by LCA in (the) People's Republic of China. Applied Energy, 86: S197-S208.

Overmars, K.P., Stehfest, E., Ros, J.P., \& Prins, A.G. (2011). Indirect land use change emissions related to EU biofuel consumption: an analysis based on historical data. Environmental Science and Policy, 14(3): 248-257.

Pachauri, N., \& He, B. (2006). Value-added utilization of crude glycerol from biodiesel production: a survey of current research activities. In the ASABE Annual International Meeting (Vol. 9), $9^{\text {th }}-12^{\text {th }}$ July 2006, Portland (US).

Padella, M., Edwards, R., Mulligan, D., Marelli, L., \& Tyner, W.E. (2012). Indirect land use change emissions from biofuels: quantifying the benefit agro-economic models derive from reduced food consumption. In the $12^{\text {th }}$ European Energy Conference of the International Association for Energy Economics, $9^{\text {th }}-12^{\text {th }}$ September 2012, Venice (Italy).

Palisade Corporation (2009). Guide to using @RISK. Risk analysis and simulation add-in for Microsoft ${ }^{\circledR}$ Excel, version 5.5. Ithaca, New York (US).

Panichelli, L., Dauriat, A., \& Gnansounou, E. (2009). Life cycle assessment of soybean-based biodiesel in Argentina for export. International Journal of Life Cycle Assessment, 14(2): 144-159.

Panichelli, L., \& Gnansounou, E. (2008). Estimating greenhouse gas emissions from indirect land-use change in biofuels production: concepts and exploratory analysis for soybean-based biodiesel production. Journal of Scientific and Industrial Research, 67: 1017-1030.

PE International (2013). Gabi software and database: contents for Life Cycle Engineering. Stuttgart (Germany).

Phalan, B. (2009). The social and environmental impacts of biofuels in Asia: an overview. Applied Energy, 86: S21-S29.

Pimentel, D., \& Patzek, T.W. (2005). Ethanol production using corn, switchgrass, and wood; biodiesel production using soybean and sunflower. Natural Resources Research, 14(1):65-76. 
Pleanjai, S., \& Gheewala, S.H. (2009). Full chain energy analysis of biodiesel production from palm oil in Thailand. Applied Energy, 86:S209-S214.

Plevin, R.J., Jones, A.D., Torn, M.S., \& Gibbs, H.K. (2010). Greenhouse gas emissions from biofuels' indirect land use change are uncertain but may be much greater than previously estimated. Environmental science and technology, 44(21): 8015-8021.

Posada, J.A., Rincón, L.E., \& Cardona, C.A. (2012). Design and analysis of biorefineries based on raw glycerol: addressing the glycerol problem. Bioresource Technology, 111: 282-293.

Pradhan, A., Shrestha, D.S., Gerpen, J.V., \& Duffield, J. (2008). The energy balance of soybean oil biodiesel production: a review of past studies. Transactions of the ASABE, 51(1):185-194. ISSN 0001-2351

Preechajarn, S., \& Prasertsri, P. (2014). Thailand Biofuels Annual Report. USDAFAS. Global Agricultural Information Network (GAIN), Bangkok (Thailand).

Prudêncio da Silva, V., Van der Werf, H.M., Spies, A., \& Soares, S.R. (2010). Variability in environmental impacts of Brazilian soybean according to crop production and transport scenarios. Journal of Environmental Management, 91(9): 1831-1839.

Reijnders, L., \& Huijbregts, M.A.J. (2008). Biogenic greenhouse gas emissions linked to the life cycles of biodiesel derived from European rapeseed and Brazilian soybeans. Journal of Cleaner Production, 16(18): 1943-1948.

Reinhard, J., \& Zah, R. (2009). Global environmental consequences of increased biodiesel consumption in Switzerland: consequential life cycle assessment. Journal of Cleaner Production, 17: S46-S56.

Reinhard, J., \& Zah, R. (2011). Consequential life cycle assessment of the environmental impacts of an increased rapemethylester (RME) production in Switzerland. Biomass and Bioenergy, 35: 2361-2373.

RFA (2014). Renewable Fuels Association. Statistics. Accessed at: http://www.ethanolrfa.org/ (19 ${ }^{\text {th }}$ November 2014).

Richardson, C., Bernard, F., Boreux, S., Nissing, C., Soleille, S., \& Girault, N. (2013). LCA in biofuel regulations: comparing the US and the EU approaches. In the 6th International Conference on Life Cycle Management in Gothenburg (LCM), $25^{\text {th }}-28^{\text {th }}$ August 2013, Gothenburg (Sweden).

Robinson, S. (2014). Simulation models in economics: issues, design and implementation. IFPRI, Washington DC (US). Accessed at: http://globalfutures.cgiar.org (11 $1^{\text {th }}$ December 2014). 
Rodrigo, A., Martínez, L., Hag-Omer, N., \& Miguel, E. (2011). Proyecto Integral-b: sistema de producción conjunta y sostenible de biodiesel y biogás a partir de residuos orgánicos del canal HORECA e industria alimentaria. Revista Técnica de Medio Ambiente Retema, 149: 26-31.

Röös, E., Sundberg, C., \& Hansson, P.A. (2010). Uncertainties in the carbon footprint of food products: a case study on table potatoes. International Journal of Life Cycle Assessment, 15(5): 478-488.

Rosegrant, M.W. (2008). Biofuels and grain prices: impacts and policy responses. Ed.: IFPRI, Washington DC (US).

Rosenbaum, R.K., Bachmann, T.M., Swirsky Gold, L., Huijbregts, M.A.J., Jolliet, O., Juraske, R., Koehler, A., Larsen, H.F., MacLeod, M., Margni, M., McKone, T.E., Payet, J., Schuhmacher, M., Van de Meent, D., \& Hauschild, M.Z. (2008). USEtox - the UNEP-SETAC toxicity model: recommended characterisation factors for human toxicity and freshwater ecotoxicity in life cycle assessment. International Journal of Life Cycle Assessment, 13: 532-546.

Rosenbaum, R.K., Huijbregts, M. A.J., Henderson, A.D., Margni, M., McKone, T. E., Van de Meent, D., Hauschild, M.Z., Shaked, S., Sheng Li, D., Gold, L.S., \& Jolliet, O. (2011). USEtox human exposure and toxicity factors for comparative assessment of toxic emissions in life cycle analysis: sensitivity to key chemical properties. International Journal of Life Cycle Assessment, 16(8): 710-727.

Rozakis, S., Haque, M.I., Natsis, A., Borzecka-Walker, M., Mizak, K. (2013). Costeffectiveness of bioethanol policies to reduce carbon dioxide emissions in Greece. International Journal of Life Cycle Assessment, 18(2): 306-318.

Rozakis, S., \& Sourie, J.C. (2005). Micro-economic modelling of biofuel system in France to determine tax exemption policy under uncertainty. Energy Policy, 33(2): 171-182.

Rozakis, S., Tsiboukas, K., \& Korasidis, M. (2008). CAP reform impacts to Greek cotton farmers: a mathematical programming approach. Journal of Agricultural and Food Economics, 3(1-2): 85-106.

Sánchez, S.T., Woods, J., Akhurst, M., Brander, M., O'Hare, M., Dawson, T.P., Edwards, R., Liska, A.J., Malpas, R. (2012). Accounting for indirect land-use change in the life cycle assessment of biofuel supply chains. Journal of the Royal Society Interface, 9: 1105-1119.

Sanjuán, N., Ribal, J., Clemente, G., \& Fenollosa, M.L. (2011). Measuring and improving eco-efficiency using Data Envelopment Analysis. Journal of Industrial Ecology, 15(4): 614-628. 
Schmidt, J.H. (2010). Comparative life cycle assessment of rapeseed oil and palm oil. International Journal of Life Cycle Assessment, 15(2): 183-197.

Schmidt, W.P. (2003). Life cycle costing as part of design for environment environmental business cases. International Journal of Life Cycle Assessment, 8(3): 167-174.

Schmidt, J., \& Weidema, B.P. (2008). Shift in the marginal supply of vegetable oil. International Journal of Life Cycle Assessment, 13(3):235-239.

Searchinger, T., Heimlich, R., Houghton, R.A., Dong, F., Elobeid, A., Fabiosa, J., Tokgoz, S., Hayes, D., \& Yu, T.H. (2008). Use of US croplands for biofuels increases greenhouse gases through emissions from land-use change. Science, 319(5867): 1238-1240.

Shapiro, K.G. (2001). Incorporating costs in LCA. International Journal of Life Cycle Assessment, 6(2): 121-123.

Shapouri, H., Duffield, J.A., \& Graboski, M.S. (1995). Estimating the net energy balance of corn ethanol. Agricultural Economic Report No. 721. USDA, Washington $D C$ (US).

Shapouri, H., Duffield, J., \& Wang, M. (2002). The energy balance of corn ethanol: an update. Agricultural Economic Report No. 813. United States Department of Agriculture (USDA), Washington DC (US).

Silalertruksa, T., Bonnet, S., \& Gheewala, S.H. (2012). Life cycle costing and externalities of palm oil biodiesel in Thailand. Journal of Cleaner Production, 28: 225-232.

Siles López, J.Á., Martín Santos, M.Á., Chica Pérez, A.F., \& Martín Martín, A. (2009). Anaerobic digestion of glycerol derived from biodiesel manufacturing. Bioresource technology, 100(23): 5609-5615.

Slette, J. \& Wiyono, I.E. (2013). Indonesia Biofuels Annual Report. USDA-FAS. Global Agricultural Information Network (GAIN), Jakarta (Indonesia).

Solomon, B.D., Barnes, J.R., \& Halvorsen, K.E. (2007). Grain and cellulosic ethanol: History, economics, and energy policy. Biomass and Bioenergy, 31(6): 416-425.

Sonnemann, G.W., Schuhmacher, M., \& Castells, F. (2003). Uncertainty assessment by Monte Carlo simulation in a life cycle inventory of electricity produced by a waste incinerator. Journal of Cleaner Production, 11(3): 279-292.

Sorda, G., Banse, M., \& Kemfert, C. (2010). An overview of biofuel policies across the world. Energy policy, 38(11): 6977-6988. 
Spatari, S., Bagley, D.M., \& MacLean, H.L. (2010). Life cycle evaluation of emerging lignocellulosic ethanol conversion technologies. Bioresource technology, 101(2): 654-667.

Spatari, S., Zhang, Y., \& MacLean, H.L. (2005). Life cycle assessment of switchgrass-and corn stover-derived ethanol-fueled automobiles. Environmental Science and Technology, 39(24):9750-9758.

Suh, S., Weidema, B., Schmidt, J.H., \& Heijungs, R. (2010). Generalized make and use framework for allocation in life cycle assessment. Journal of Industrial Ecology 14(2): 335-353.

Swarr, T.E., Hunkeler, D., Klöpffer, W., Pesonen, H.L., Ciroth, A., Brent, A.C., \& Pagan, R. (2011). Environmental life-cycle costing: a code of practice. Society of Environmental Toxicology and Chemistry (SETAC), 98p. Pensacola (US).

Szulczyk, K.R., \& McCarl, B.A. (2010). Market penetration of biodiesel. Renewable and Sustainable Energy Reviews, 14(8): 2426-2433.

Taheripour, F., Birur, D.K., Hertel, T.W., \& Tyner, W.E. (2007). Introducing liquid biofuels into the GTAP database. GTAP Research Memorandum No. 11. Center for Global Trade Analysis, Purdue University, West Lafayette (US).

Taheripour, F., Hertel, T.W., Tyner, W.E., Beckman, J.F., \& Birur, D.K. (2010). Biofuels and their by-products: global economic and environmental implications. Biomass and Bioenery, 34(3): 278-289.

Taheripour, F., \& Tyner, W.E. (2011). Introducing first and second generation biofuels into GTAP Data Base version 7. GTAP Research Memorandum No. 21. Center for Global Trade Analysis, Purdue University, West Lafayette (US).

Taheripour, F., \& Tyner, W.E. (2013a). Induced land use emissions due to first and second generation biofuels and uncertainty in land use emission factors. Economics Research International, Vol. 2013, Article ID 315787.

Taheripour, F., \& Tyner, W.E. (2013b). Biofuels and land use change: applying recent evidence to model estimates. Applied Sciences, 3(1): 14-38.

Talens, L., Villalba, G., \& Gabarrell, X. (2007). Exergy analysis applied to biodiesel production. Resources, Conservation and Recycling, 51(2): 397-407.

Talens, L., Villalba, G., \& Gabarrell, X. (2008). Exergy analysis of integrated waste management in the recovery and recycling of used cooking oils. Environmental Science and Technology, 42(13): 4977-4981. 
Talens, L., Lombardi, L., Villalba, G., \& Gabarrell, X. (2010). Life cycle assessment (LCA) and exergetic life cycle assessment (ELCA) of the production of biodiesel from used cooking oil (UCO). Energy, 35(2): 889-893.

Tang, S., Boehme, L., Lam, H., \& Zhang, Z. (2009). Pichia pastoris fermentation for phytase production using crude glycerol from biodiesel production as the sole carbon source. Biochemical Engineering Journal, 43(2): 157-162.

Thompson, J.C., \& He, B.B. (2006). Characterization of crude glycerol from biodiesel production from multiple feedstocks. Applied Engineering in Agriculture, 22(2): 261-265.

Thompson, W., Whistance, J., \& Meyer, S. (2011). Effects of US biofuel policies on US and world petroleum product markets with consequences for greenhouse gas emissions. Energy Policy, 39(9): 5509-5518.

Tyner, W.E. (2008). The US ethanol and biofuels boom: Its origins, current status, and future prospects. BioScience, 58(7): 646-653.

United Nations (2006). The emerging biofuels market: regulatory, trade and development implications. UNCTAD Biofuels Initiative. United Nations, New York (US)-Geneva (Switzerland).

UN-REDD (2009). The United Nations Collaborative Programme on Reducing Emissions from Deforestation and Forest Degradation in Developing Countries. An options assessment approach. Meridian Institute, Washington DC (US). ISBN: 9780-615-28518-4

Urbano, P., \& Moro, R. (1992). Sistemas agrícolas con rotaciones y alternativas de cultivos. 1st ed. Ed.: Mundiprensa, Madrid (Spain). ISBN 978-84-71-14376-1.

Van den Bos, A., \& Hamelinck, C. (2014). Greenhouse gas impact of marginal fossil fuel use. Ecofys, Utrecht (The Netherlands).

Van Meijl, H., Van Rheenen, T., Tabeau, A., \& Eickhout, B. (2006). The impact of different policy environments on agricultural land use in Europe. Agriculture, Ecosystems and Environment, 114(1): 21-38.

Van Tongeren, F., Van Meijl, H., \& Surry, Y. (2001). Global models applied to agricultural and trade policies: a review and assessment. Agricultural Economics, 26(2): 149-172.

Vázquez-Rowe, I., Rege, S., Marvuglia, A., Thénie, J., Haurie, A., \& Benetto, E. (2013). Application of three independent consequential LCA approaches to the agricultural sector in Luxembourg. International Journal of Life Cycle Assessment, 18(8): 1593-1604. 
Vázquez-Rowe, I., Marvuglia, A., Rege, S., \& Benetto, E. (2014). Applying consequential LCA to support energy policy: land use change effects of bioenergy production. Science of the Total Environment, 472: 78-89.

Vinyes, E, Oliver-Solà, J., Ugaya, C., Rieradevall, J., \& Gasol, C.M. (2013). Application of LCSA to used cooking oil waste management. International Journal of Life Cycle Assessment, 18(2): 445-455.

Von Blottnitz, H., \& Curran, M.A. (2007). A review of assessments conducted on bio-ethanol as a transportation fuel from a net energy, greenhouse gas, and environmental life cycle perspective. Journal of Cleaner Production, 15(7): 607619.

Wahab, A.G. (2013). Malaysia Biofuels Annual Report. USDA-FAS. Global Agricultural Information Network (GAIN), Kuala Lumpur (Malaysia).

Wang, M. (1999). GREET 1.5-transportation fuel-cycle model, vol. 1: methodology, development, use, and results. Argonne National Laboratory, Chicago (US).

Wang, M., Huo, H., \& Arora, S. (2011). Methods of dealing with co-products of biofuels in life-cycle analysis and consequent results within the US context. Energy Policy, 39(10): 5726-5736.

Wang, M., Saricks, C., \& Santini, D. (1999). Effects of fuel ethanol use on fuelcycle energy and greenhouse gas emissions. ANL/ESD-38, Argonne National Laboratory, Chicago (US), pp 39.

WCED (1987). World Commission on Environment and Development. Our common future. Ed.: Oxford University Press, Oxford (UK).

Weidema, B.P. (2003). Market information in life cycle assessment. Environmental Project vol. 863. Danish Environmental Protection Agency, Copenhagen (Denmark).

Weidema, B.P. (2004). Geographical, technological and temporal delimitations in LCA. Environmental News No. 74. Danish Environmental Protection Agency, Copenhagen (Denmark).

Weidema, B.P., Frees, N., \& Nielsen, A.M. (1999). Marginal production technologies for life cycle inventories. International Journal of Life Cycle Assessment, 4(1): 48-56.

Wicke, B., Dornburg, V., Junginger, M., \& Faaij, A. (2008). Different palm oil production systems for energy purposes and their greenhouse gas implications. Biomass and Bioenergy, 32(12): 1322-1337. 
Williamson, S.S., \& Emadi, A. (2005). Comparative assessment of hybrid electric and fuel cell vehicles based on comprehensive Well-to-Wheels efficiency analysis. IEEE Transactions on Vehicular Technology, 54(3): 856-862.

Winkler, J., \& Bilitewski, B. (2007). Comparative evaluation of life cycle assessment models for solid waste management. Waste Management, 27(8): 10211031.Woodward, D.G. (1997). Life cycle costing-theory, information acquisition and application. International Journal of Project Management, 15(6): 335-344.

World Bank (2013). Commodity markets outlook October 2013. Development Prospects Group. The World Bank, Washington DC (US).

World Bank (2014). International Road Federation. World Road Statistics and electronic files from IEA statistics. Accessed at: http://data.worldbank.org/ (19 November 2014).

WRAP (2015). Strategies to achieve economic and environmental gains by reducing food waste. Waste \& Resources Action Programme, Banbury (UK). ISBN: 978-1-84405-473-2

Wright, R.T., \& Wiyono, E. (2014). Indonesia Biofuels Annual Report. USDA-FAS. Global Agricultural Information Network (GAIN), Jakarta (Indonesia).

Wright Tech Systems (2007). Converting organic waste to energy. Biological dryers vs. anaerobic digestion. Accessed at: http://www.wrighttech.ca (17 ${ }^{\text {th }}$ February 2014).

Yazdani, S.S., \& Gonzalez, R. (2007). Anaerobic fermentation of glycerol: a path to economic viability for the biofuels industry. Current Opinion in Biotechnology, 18(3): 213-219.

Yazdani, S.S., \& Gonzalez, R. (2008). Engineering Escherichia coli for the efficient conversion of glycerol to ethanol and co-products. Metabolic Engineering, 10(6): 340-351.

Yee, K.F., Tan, K.T., Abdullah, A.Z., \& Lee, K.T. (2009). Life cycle assessment of palm biodiesel: revealing facts and benefits for sustainability. Applied Energy, 86: S189-S196.

Zah, R., Faist, M., Reinhard, J., \& Birchmeier, D. (2009). Standardized and simplified life-cycle assessment (LCA) as a driver for more sustainable biofuels. Journal of Cleaner Production, 17: S102-S105.

Zamagni, A., Guinée, J., Heijungs, R., Masoni, P., \& Raggi, A. (2012). Lights and shadows in consequential LCA. International Journal of Life Cycle Assessment, 17(7): 904-918. 
Zamboni, A., Shah, N., \& Bezzo, F. (2009a). Spatially explicit static model for the strategic design of future bioethanol production systems. 1. Cost minimization. Energy and Fuels, 23(10): 5121-5133.

Zamboni, A., Bezzo, F., \& Shah, N. (2009b). Spatially explicit static model for the strategic design of future bioethanol production systems. 2. Multi-objective environmental optimization. Energy and Fuels, 23(10): 5134-5143.

Zamboni, A., Murphy, R.J., Woods, J., Bezzo, F., \& Shah, N. (2011). Biofuels carbon footprints: Whole-systems optimisation for GHG emissions reduction. Bioresource Technology, 102(16): 7457-7465.

Zhang, Y., White, M.A., \& Colosi, L.M. (2013). Environmental and economic assessment of integrated systems for dairy manure treatment coupled with algae bioenergy production. Bioresource Technology, 130: 486-494. 



\section{Annex A. Supplementary material for section 3.1}

\section{A1. Life Cycle Inventory}

The following table shows all the inputs and outputs considered in each of the constituent processes of both scenarios, gathered from primary and secondary data sources. Inputs of capital goods are included. Note that scenarios A and B correspond to the Functional Unit (FU) of $1.70 \mathrm{~kg}$ of $\mathrm{UCO}+35.50 \mathrm{~kg}$ of organic waste per inhabitant and year, whereas scenarios $A^{\prime}$ y $B^{\prime}$ correspond to the $F U$ of $6.38 \mathrm{~kg}$ of UCO $+35.50 \mathrm{~kg}$ of organic waste per inhabitant and year. Differences between scenarios concerning co-product displacement are drawn.

Table A1. LCl of the processes included in the scenarios under study, referred to the FU.

\begin{tabular}{|c|c|c|c|c|c|c|c|c|c|}
\hline INPUTS & $\begin{array}{c}\text { Scenario } \\
\text { A }\end{array}$ & $\begin{array}{c}\text { Scenario } \\
\text { B }\end{array}$ & $\begin{array}{c}\text { Scenario } \\
A^{\prime}\end{array}$ & $\begin{array}{c}\text { Scenario } \\
B^{\prime}\end{array}$ & OUTPUTS & $\begin{array}{c}\text { Scenario } \\
\text { A }\end{array}$ & $\begin{array}{c}\text { Scenario } \\
\mathrm{B}\end{array}$ & $\begin{array}{c}\text { Scenario } \\
A^{\prime}\end{array}$ & $\begin{array}{c}\text { Scenario } \\
\mathrm{B}^{\prime}\end{array}$ \\
\hline UCO collection: & & & & & UCO collection: & & & & \\
\hline UCO collected $(\mathrm{kg})$ & 1.53 & 1.53 & 5.74 & 5.74 & UCO collected $(\mathrm{kg})$ & 1.53 & 1.53 & 5.74 & 5.74 \\
\hline $\begin{array}{l}\text { Collection transport by } \\
\text { lorry } 20-28 t(\mathrm{tkm})\end{array}$ & 0.23 & 0.23 & 0.87 & 0.87 & & & & & \\
\hline Electricity (kWh) & $2.85 \mathrm{E}-02$ & $2.85 \mathrm{E}-02$ & 0.11 & 0.11 & & & & & \\
\hline $\begin{array}{l}\text { Polyethylene HDPE, } \\
\text { granulate, collection } \\
\text { containers }(\mathrm{kg})\end{array}$ & $8.37 \mathrm{E}-02$ & $8.37 \mathrm{E}-02$ & 0.31 & 0.31 & & & & & \\
\hline $\begin{array}{r}\text { Polyethylene HDPE, } \\
\text { granulate, storage } \\
\text { containers }(\mathrm{kg})\end{array}$ & 0.26 & 0.26 & 0.96 & 0.96 & & & & & \\
\hline Soap $(\mathrm{kg})$ & $2.30 \mathrm{E}-03$ & $2.30 \mathrm{E}-03$ & $8.62 \mathrm{E}-03$ & 8.62E-03 & & & & & \\
\hline Water $(\mathrm{kg})$ & 0.54 & 0.54 & 2.03 & 2.03 & & & & & \\
\hline Steel, dishwasher $(\mathrm{kg})$ & 2.70E-04 & $2.70 \mathrm{E}-04$ & $1.01 \mathrm{E}-03$ & $1.01 \mathrm{E}-03$ & & & & & \\
\hline Biodiesel production: & & & & & Biodiesel production: & & & & \\
\hline UCO collected $(\mathrm{kg})$ & 1.53 & 1.53 & 5.74 & 5.74 & Biodiesel (kg) & 1.45 & 1.45 & 5.42 & 5.42 \\
\hline Electricity (kWh) & 0.14 & 0.14 & 0.52 & 0.52 & Crude glycerin (kg) & 0.29 & & 1.08 & \\
\hline $\begin{array}{l}\text { Thermal energy from } \begin{array}{r}\mathrm{CHP} \\
(\mathrm{MJ})\end{array}\end{array}$ & 1.01 & & 3.78 & & Filtration residue $(\mathrm{kg})$ & $1.88 \mathrm{E}-02$ & $1.88 \mathrm{E}-02$ & 0.07 & 0.07 \\
\hline $\begin{array}{l}\text { Thermal energy from light } \\
\text { fuel oil (MJ) }\end{array}$ & & 1.01 & & 3.78 & Wastewater treatment $(\mathrm{m} 3)$ & $1.53 E-04$ & $1.53 \mathrm{E}-04$ & $5.75 \mathrm{E}-04$ & $5.75 \mathrm{E}-04$ \\
\hline Methanol $(\mathrm{kg})$ & 0.22 & 0.22 & 0.82 & 0.82 & $\begin{array}{r}\text { Avoided glycerin, from } \\
\text { epichlorohydrin (kg) }\end{array}$ & & $0.29(\mathrm{~B} 1)$ & & 1.08 (B1) \\
\hline Catalyst (kg) & $1.30 \mathrm{E}-02$ & $1.30 \mathrm{E}-02$ & $4.88 \mathrm{E}-02$ & $4.88 \mathrm{E}-02$ & $\begin{array}{l}\text { Avoided propylene glycol } \\
\qquad(\mathrm{kg})\end{array}$ & & 0.26 (B2) & & 0.97 (B2) \\
\hline Water $(\mathrm{kg})$ & 0.15 & 0.15 & 0.54 & 0.54 & & & & & \\
\hline $\begin{array}{r}\text { Methanol transport by lorry } \\
20-28 \mathrm{t}(\mathrm{kmm})\end{array}$ & 0.08 & 0.08 & 0.31 & 0.31 & & & & & \\
\hline $\begin{array}{r}\text { Catalyst transport by lorry } \\
20-28 \mathrm{t}(\mathrm{kmm})\end{array}$ & $1.38 \mathrm{E}-02$ & $1.38 \mathrm{E}-02$ & 0.05 & 0.05 & & & & & \\
\hline $\begin{array}{r}\text { Catalyst transport by } \\
\text { tanker (tkm) }\end{array}$ & 0.12 & 0.12 & 0.45 & 0.45 & & & & & \\
\hline Steel $(\mathrm{kg})$ & $7.98 \mathrm{E}-04$ & $7.98 \mathrm{E}-04$ & $2.99 \mathrm{E}-03$ & $2.99 \mathrm{E}-03$ & & & & & \\
\hline Concrete (m3) & $1.74 \mathrm{E}-06$ & $1.74 \mathrm{E}-06$ & $6.51 \mathrm{E}-06$ & $6.51 \mathrm{E}-06$ & & & & & \\
\hline Cement $(\mathrm{kg})$ & $1.17 \mathrm{E}-04$ & $1.17 \mathrm{E}-04$ & 4.37E-04 & 4.37E-04 & & & & & \\
\hline Brick $(\mathrm{kg})$ & $5.95 E-04$ & $5.95 \mathrm{E}-04$ & $2.23 \mathrm{E}-03$ & $2.23 \mathrm{E}-03$ & & & & & \\
\hline Aluminum $(\mathrm{kg})$ & 1.72E-05 & $1.72 \mathrm{E}-05$ & $6.45 \mathrm{E}-05$ & $6.45 \mathrm{E}-05$ & & & & & \\
\hline Organic waste collection: & & & & & Organic waste collection: & & & & \\
\hline Waste collected $(\mathrm{kg})$ & 37.37 & 57.26 & 37.37 & 57.26 & Waste collected $(\mathrm{kg})$ & 37.37 & 57.26 & 37.37 & 57.26 \\
\hline $\begin{array}{l}\text { Collection transport by } \\
\text { lorry } 20-28 t(\mathrm{tkm})\end{array}$ & 3.42E-04 & 7.54E-04 & 3.42E-04 & $7.54 \mathrm{E}-04$ & & & & & \\
\hline $\begin{array}{r}\text { Polyethylene HDPE, } \\
\text { granulate }(\mathrm{kg})\end{array}$ & 4.00E-04 & 2.23E-04 & 4.00E-04 & $2.23 \mathrm{E}-04$ & & & & & \\
\hline Water (kg) & $2.22 \mathrm{E}-02$ & $1.89 \mathrm{E}-02$ & $2.22 \mathrm{E}-02$ & $1.89 \mathrm{E}-02$ & & & & & \\
\hline
\end{tabular}


Annex A: supplementary material for section 3.1

\begin{tabular}{|c|c|c|c|c|c|c|c|c|c|}
\hline INPUTS & $\begin{array}{c}\text { Scenario } \\
\mathrm{A}\end{array}$ & $\begin{array}{c}\text { Scenario } \\
\text { B }\end{array}$ & $\begin{array}{c}\text { Scenario } \\
\mathrm{A}^{\prime}\end{array}$ & $\begin{array}{c}\text { Scenario } \\
\mathrm{B}^{\prime}\end{array}$ & OUTPUTS & $\begin{array}{c}\text { Scenario } \\
\text { A }\end{array}$ & $\begin{array}{c}\text { Scenario } \\
\text { B }\end{array}$ & $\begin{array}{c}\text { Scenario } \\
A^{\prime}\end{array}$ & $\begin{array}{c}\text { Scenario } \\
\text { B' }^{\prime}\end{array}$ \\
\hline Sorting: & & & & & Sorting: & & & & \\
\hline Waste collected $(\mathrm{kg})$ & 37.37 & 57.26 & 37.37 & 57.26 & Organic waste (kg) & 35.5 & 35.5 & 35.5 & 35.5 \\
\hline Electricity (kWh) & 0.53 & 0.81 & 0.53 & 0.81 & Non-organic fraction $(\mathrm{kg})$ & 1.87 & 21.76 & 1.87 & 21.76 \\
\hline Filtration residue $(\mathrm{kg})$ & 0 & 0.02 & 0 & 0.07 & & & & & \\
\hline $\begin{array}{l}\text { Organic waste } \\
\text { pasteurization: }\end{array}$ & & & & & $\begin{array}{l}\text { Organic waste } \\
\text { pasteurization: }\end{array}$ & & & & \\
\hline Organic waste $(\mathrm{kg})$ & 35.5 & & 35.5 & & Organic waste $(\mathrm{kg})$ & 35.5 & & 35.5 & \\
\hline Thermal energy $90^{\circ} \mathrm{C}(\mathrm{MJ})$ & 6.58 & & 6.58 & & & & & & \\
\hline Anaerobic digestion: & & & & & Anaerobic digestion: & & & & \\
\hline Organic waste $(\mathrm{kg})$ & 35.5 & & 35.5 & & Biogas (Nm3) & 6.64 & & 6.64 & \\
\hline Filtration residue $(\mathrm{kg})$ & $1.88 \mathrm{E}-02$ & & 0.07 & & Digester sludge (kg) & 66.23 & & 66.96 & \\
\hline $\begin{array}{r}\text { Glycerin purification } \\
\text { residue }(\mathrm{kg})\end{array}$ & 0.25 & & 0.92 & & Methane losses (kg) & 0.24 & & 0.24 & \\
\hline $\begin{array}{r}\text { Re-circulated liquid } \\
\text { fraction }(\mathrm{kg})\end{array}$ & 38.76 & & 38.76 & & & & & & \\
\hline Electricity (kWh) & 0.75 & & 0.76 & & & & & & \\
\hline Thermal energy $90^{\circ} \mathrm{C}(\mathrm{MJ})$ & 3.07 & & 3.12 & & & & & & \\
\hline Steel $(\mathrm{kg})$ & 4.80E-04 & & $4.80 \mathrm{E}-04$ & & & & & & \\
\hline Concrete (m3) & 7.42E-06 & & 7.42E-06 & & & & & & \\
\hline Aluminium $(\mathrm{kg})$ & 4.00E-06 & & 4.00E-06 & & & & & & \\
\hline Bitumen $(\mathrm{kg})$ & 4.46E-05 & & 4.46E-05 & & & & & & \\
\hline Gravel (kg) & 7.89E-03 & & 7.89E-03 & & & & & & \\
\hline Cast iron $(\mathrm{kg})$ & $7.52 \mathrm{E}-04$ & & $7.52 \mathrm{E}-04$ & & & & & & \\
\hline Polystyrene (kg) & 1.57E-05 & & 1.57E-05 & & & & & & \\
\hline Copper (kg) & $1.20 \mathrm{E}-05$ & & $1.20 \mathrm{E}-05$ & & & & & & \\
\hline Sand $(\mathrm{kg})$ & 4.26E-04 & & 4.26E-04 & & & & & & \\
\hline $\begin{array}{r}\text { Polyvinylchloride, PVC } \\
(\mathrm{kg})\end{array}$ & $1.40 \mathrm{E}-05$ & & $1.40 \mathrm{E}-05$ & & & & & & \\
\hline $\begin{array}{l}\text { Liquid-solid separation: } \\
\text { Digester sludge }(\mathrm{kg})\end{array}$ & 66.23 & & 66.96 & & $\begin{array}{r}\text { Liquid-solid separation: } \\
\text { Solid fraction to } \\
\text { agricultural use }(\mathrm{kg})\end{array}$ & 27.48 & & 28.25 & \\
\hline \multirow[t]{3}{*}{ Electricity (kWh) } & 0.16 & & 0.28 & & Liquid fraction $(\mathrm{kg})$ & 38.76 & & 38.76 & \\
\hline & & & & & $\begin{array}{r}\text { Transport to farm by lorry } \\
20-28 t(\mathrm{tkm})\end{array}$ & 1.66 & & 1.68 & \\
\hline & & & & & $\begin{array}{r}\text { Waste water, treatment } \\
\text { (m3) }\end{array}$ & $2.78 \mathrm{E}-02$ & & $2.85 \mathrm{E}-02$ & \\
\hline $\begin{array}{l}\text { Avoided fertilizers } \\
\text { production: }\end{array}$ & & & & & $\begin{array}{l}\text { Avoided fertilizers } \\
\text { production: }\end{array}$ & & & & \\
\hline $\begin{array}{l}\text { Nitrogen in digester sludge } \\
\qquad(\mathrm{kg})\end{array}$ & 0.44 & & 0.44 & & $\begin{array}{r}\text { Ammonium nitrate as N } \\
(\mathrm{kg})\end{array}$ & 0.44 & & 0.44 & \\
\hline $\begin{array}{r}\text { Phosphorus in digester } \\
\text { sludge }(\mathrm{kg})\end{array}$ & 0.06 & & 0.06 & & $\begin{array}{r}\text { Single superphosphate } \\
\text { as P2O5 }(\mathrm{kg})\end{array}$ & 0.13 & & 0.13 & \\
\hline Glycerin purification: & & & & & Glycerin purification: & & & & \\
\hline Crude glycerin $(\mathrm{kg})$ & 0.29 & & 1.08 & & Purified glycerin (kg) & 0.04 & & 0.16 & \\
\hline $\begin{array}{r}\text { Thermal energy } 400^{\circ} \mathrm{C} \\
(\mathrm{MJ})\end{array}$ & 7.3 & & 27.39 & & $\begin{array}{r}\text { Glycerin purification } \\
\text { residue }(\mathrm{kg})\end{array}$ & 0.25 & & 0.92 & \\
\hline $\begin{array}{l}\text { CHP engine } \\
\text { (cogeneration): }\end{array}$ & & & & & $\begin{array}{l}\text { CHP engine } \\
\text { (cogeneration): }\end{array}$ & & & & \\
\hline $\begin{array}{r}\text { Biogas from anaerobic } \\
\text { digestion }(\mathrm{Nm} 3)\end{array}$ & 6.64 & & 6.64 & & Thermal energy (MJ) & 39.35 & & 40.86 & \\
\hline Purified glycerin $(\mathrm{kg})$ & 0.04 & & 0.16 & & Methane emissions $(\mathrm{kg})$ & $3.55 E-02$ & & 3.56E-02 & \\
\hline Copper (kg) & 4.17E-04 & & 4.17E-04 & & $\begin{array}{r}\text { Avoided electricity from } \\
\text { the Spanish production } \\
\text { mix (kWh) }\end{array}$ & $\begin{array}{c}14.93 \\
(\mathrm{~A} 1)\end{array}$ & & $\begin{array}{l}15.15 \\
(\mathrm{~A} 1)\end{array}$ & \\
\hline Steel $(\mathrm{kg})$ & $1.52 \mathrm{E}-03$ & & $1.55 \mathrm{E}-03$ & & $\begin{array}{r}\text { Avoided wind-generated } \\
\text { electricity (kWh) }\end{array}$ & $\begin{array}{c}14.93 \\
(\mathrm{~A} 2)\end{array}$ & & $\begin{array}{c}15.15 \\
(\mathrm{~A} 2)\end{array}$ & \\
\hline $\begin{array}{r}\text { Polyvinylchloride, PVC } \\
(\mathrm{kg})\end{array}$ & 1.97E-05 & & $2.00 \mathrm{E}-05$ & & & & & & \\
\hline Aluminum $(\mathrm{kg})$ & $1.58 \mathrm{E}-04$ & & $1.60 \mathrm{E}-04$ & & & & & & \\
\hline $\begin{array}{l}\text { Landfill with biogas } \\
\text { recovery: }\end{array}$ & & & & & $\begin{array}{l}\text { Landfill with biogas } \\
\text { recovery: }\end{array}$ & & & & \\
\hline $\begin{array}{l}\text { Organic waste to landfill } \\
\qquad(\mathrm{kg})\end{array}$ & & 24.22 & & 24.26 & Electricity (kWh) & & 4.17 & & 4.18 \\
\hline Electricity (kWh) & & 1.33E-0.2 & & 1.33E-02 & $\begin{array}{l}\text { Sewage treatment, } \\
\text { leachate }(\mathrm{m} 3)\end{array}$ & & $3.76 \mathrm{E}-03$ & & 3.76E-03 \\
\hline Diesel $(\mathrm{kg})$ & & $1.56 \mathrm{E}-0.2$ & & 1.57E-02 & $\begin{array}{r}1,1,1-\text { Trichloroethane to } \\
\text { air }(\mathrm{kg})\end{array}$ & & 3.39E-06 & & 3.39E-06 \\
\hline Clay (kg) & & 1.12 & & 1.12 & $\begin{array}{r}\text { 1,1-Dichloroethylene to } \\
\text { air }(\mathrm{kg})\end{array}$ & & $8.31 \mathrm{E}-07$ & & 8.33E-07 \\
\hline
\end{tabular}


Annex A: supplementary material for section 3.1

\begin{tabular}{|c|c|c|c|c|c|c|c|c|c|}
\hline INPUTS & $\begin{array}{c}\text { Scenario } \\
\mathrm{A}\end{array}$ & $\begin{array}{c}\text { Scenario } \\
\text { B }\end{array}$ & $\begin{array}{c}\text { Scenario } \\
\mathrm{A}^{\prime}\end{array}$ & $\begin{array}{c}\text { Scenario } \\
\text { B' }^{\prime}\end{array}$ & OUTPUTS & $\begin{array}{c}\text { Scenario } \\
\text { A }\end{array}$ & $\begin{array}{c}\text { Scenario } \\
\text { B }\end{array}$ & $\begin{array}{c}\text { Scenario } \\
\mathrm{A}^{\prime}\end{array}$ & $\begin{array}{c}\text { Scenario } \\
\text { B' }\end{array}$ \\
\hline $\begin{array}{r}\text { Polyvinylchloride, PVC } \\
(\mathrm{kg})\end{array}$ & & $3.64 \mathrm{E}-07$ & & $3.64 \mathrm{E}-07$ & $\begin{array}{r}\text { Acetone (dimethylcetone) } \\
\text { to air }(\mathrm{kg})\end{array}$ & & $2.34 \mathrm{E}-05$ & & 2.34E-05 \\
\hline Iron $(\mathrm{kg})$ & & 1.23E-05 & & 1.23E-05 & Acrylonitrile to air $(\mathrm{kg})$ & & 1.35E-06 & & 1.35E-06 \\
\hline Steel (kg) & & 1.05E-05 & & $1.05 E-05$ & Benzene to air $(\mathrm{kg})$ & & $1.36 \mathrm{E}-05$ & & $1.36 \mathrm{E}-05$ \\
\hline $\begin{array}{r}\text { Polyethylene HDPE, } \\
\text { granulate }(\mathrm{kg})\end{array}$ & & 4.65E-03 & & 4.66E-03 & Butane to air $(\mathrm{kg})$ & & 1.77E-05 & & 1.77E-05 \\
\hline \multirow[t]{32}{*}{$\begin{array}{r}\text { Bottom ashes from } \\
\text { incinerator }(\mathrm{kg})\end{array}$} & & 0.83 & & 0.83 & $\begin{array}{r}\text { Butanone (methyl ethyl } \\
\text { ketone) to air }(\mathrm{kg})\end{array}$ & & 4.05E-05 & & 4.06E-05 \\
\hline & & & & & $\begin{array}{r}\text { Carbon dioxide (biogenic) } \\
\text { to air }(\mathrm{kg})\end{array}$ & & $1.23 E+00$ & & 1.23E+00 \\
\hline & & & & & $\begin{array}{r}\text { Carbon monoxide } \\
\text { (biogenic) to air (kg) }\end{array}$ & & $1.60 \mathrm{E}-03$ & & $1.60 \mathrm{E}-03$ \\
\hline & & & & & Chlorobenzene to air $(\mathrm{kg})$ & & 6.47E-06 & & $6.48 \mathrm{E}-06$ \\
\hline & & & & & $\begin{array}{r}\text { Chlorodifluoromethane } \\
\text { (R22) to air (kg) }\end{array}$ & & $1.62 \mathrm{E}-05$ & & $1.62 \mathrm{E}-05$ \\
\hline & & & & & $\begin{array}{l}\text { Chloromethane (methyl } \\
\text { chloride) to air (kg) }\end{array}$ & & 4.16E-06 & & 4.16E-06 \\
\hline & & & & & $\begin{array}{r}\text { Dichloroethane (ethylene } \\
\text { dichloride) to air }(\mathrm{kg})\end{array}$ & & $2.89 \mathrm{E}-05$ & & 2.89E-05 \\
\hline & & & & & $\begin{array}{r}\text { Dichloromethane } \\
\text { (methylene chloride) to } \\
\text { air }(\mathrm{kg})\end{array}$ & & $1.11 \mathrm{E}-04$ & & 1.11E-04 \\
\hline & & & & & Dioxins to air $(\mathrm{kg})$ & & $3.75 \mathrm{E}-11$ & & 3.76E-11 \\
\hline & & & & & PM10 particles to air $(\mathrm{kg})$ & & $8.10 \mathrm{E}-06$ & & 8.11E-06 \\
\hline & & & & & Ethane to air $(\mathrm{kg})$ & & $1.58 \mathrm{E}-03$ & & $1.58 \mathrm{E}-03$ \\
\hline & & & & & Ethyl benzene to air $(\mathrm{kg})$ & & 5.36E-05 & & 5.36E-05 \\
\hline & & & & & $\begin{array}{r}\text { Hexane (isomers) to air } \\
\qquad(\mathrm{kg})\end{array}$ & & $1.38 \mathrm{E}-07$ & & $1.38 \mathrm{E}-07$ \\
\hline & & & & & $\begin{array}{l}\text { Hydrogen chloride to air } \\
\qquad(\mathrm{kg})\end{array}$ & & $1.28 \mathrm{E}-04$ & & $1.29 \mathrm{E}-04$ \\
\hline & & & & & $\begin{array}{r}\text { Hydrogen fluoride to air } \\
\qquad(\mathrm{kg})\end{array}$ & & $2.27 \mathrm{E}-05$ & & 2.27E-05 \\
\hline & & & & & $\begin{array}{l}\text { Hydrogen sulphide to air } \\
\qquad(\mathrm{kg})\end{array}$ & & 4.58E-05 & & 4.59E-05 \\
\hline & & & & & Methane to air (kg) & & 5.96E-01 & & 5.97E-01 \\
\hline & & & & & $\begin{array}{r}\text { Methyl isobutyl ketone to } \\
\text { air }(\mathrm{kg})\end{array}$ & & 8.86E-06 & & 8.87E-06 \\
\hline & & & & & $\begin{array}{r}\text { Nitrogen dioxide to air } \\
(\mathrm{kg})\end{array}$ & & $1.51 \mathrm{E}-04$ & & $1.51 \mathrm{E}-04$ \\
\hline & & & & & $\begin{array}{r}\text { Nitrogen oxides to air } \\
(\mathrm{kg})\end{array}$ & & $1.06 \mathrm{E}-03$ & & $1.06 \mathrm{E}-03$ \\
\hline & & & & & $\begin{array}{r}\text { Pentane (n-pentane) to } \\
\text { air (kg) }\end{array}$ & & $2.56 \mathrm{E}-05$ & & $2.56 \mathrm{E}-05$ \\
\hline & & & & & Propane to air (kg) & & $6.59 \mathrm{E}-05$ & & $6.60 \mathrm{E}-05$ \\
\hline & & & & & $\begin{array}{r}\mathrm{R} 11 \\
\text { (trichlorofluoromethane) } \\
\text { to air }(\mathrm{kg})\end{array}$ & & $1.03 E-05$ & & 1.03E-05 \\
\hline & & & & & $\begin{array}{r}\mathrm{R} 12 \\
\text { (dichlorodifluoromethane) } \\
\text { to air }(\mathrm{kg})\end{array}$ & & $1.13 E-04$ & & 1.13E-04 \\
\hline & & & & & $\begin{array}{r}\mathrm{R} 21 \\
\text { (Dichlorofluoromethane) } \\
\text { to air }(\mathrm{kg})\end{array}$ & & $2.69 \mathrm{E}-05$ & & 2.69E-05 \\
\hline & & & & & $\begin{array}{r}\text { Sulphur dioxide to air] } \\
(\mathrm{kg})\end{array}$ & & 2.07E-05 & & 2.07E-05 \\
\hline & & & & & $\begin{array}{r}\text { Tetrachloroethene } \\
\text { (perchloroethylene) to air } \\
(\mathrm{kg})\end{array}$ & & 7.36E-05 & & 7.37E-05 \\
\hline & & & & & $\begin{array}{r}\text { Toluene (methyl } \\
\text { benzene) to air ( } \mathrm{kg})\end{array}$ & & $2.94 \mathrm{E}-04$ & & 2.95E-04 \\
\hline & & & & & $\begin{array}{r}\text { trans-Dichloroethene to } \\
\text { air }(\mathrm{kg})\end{array}$ & & $2.28 \mathrm{E}-05$ & & 2.29E-05 \\
\hline & & & & & $\begin{array}{r}\text { Trichloroethene (isomers) } \\
\text { to air }(\mathrm{kg})\end{array}$ & & 2.96E-05 & & 2.97E-05 \\
\hline & & & & & $\begin{array}{r}\text { Vinyl chloride } \\
\text { (chloroethene) to air (kg) }\end{array}$ & & $2.61 \mathrm{E}-05$ & & 2.61E-05 \\
\hline & & & & & $\begin{array}{r}\text { Xylene (dimethyl } \\
\text { benzene) to air (kg) }\end{array}$ & & 1.12E-04 & & 1.12E-04 \\
\hline Incineration: & & & & & Incineration: & & & & \\
\hline Electricity (kWh) & & 0.25 & & 0.25 & Electricity (kWh) & & 1.37 & & 1.37 \\
\hline $\begin{array}{l}\text { Organic waste to } \\
\text { incineration }(\mathrm{kg})\end{array}$ & & 3.76 & & 3.77 & $\begin{array}{l}\text { Disposal filter dust to } \\
\text { residual material landfill } \\
(\mathrm{kg})\end{array}$ & & 7.53E-02 & & 7.54E-02 \\
\hline Diesel (kg) & & 5.91E-04 & & 5.92E-04 & $\begin{array}{r}\text { Disposal limestone } \\
\text { residue to inert material } \\
\text { landfill }(\mathrm{kg})\end{array}$ & & 4.52E-02 & & 4.52E-02 \\
\hline Natural gas (MJ & & 1.19E-02 & & 1.19E-02 & $\begin{array}{r}\text { Bottom ashes from } \\
\text { incinerator to sanitary } \\
\text { landfill }(\mathrm{kg})\end{array}$ & & 0.83 & & 0.83 \\
\hline
\end{tabular}




\begin{tabular}{|c|c|c|c|c|c|c|c|c|c|}
\hline INPUTS & $\begin{array}{c}\text { Scenario } \\
\text { A }\end{array}$ & $\begin{array}{c}\text { Scenario } \\
\text { B }\end{array}$ & $\begin{array}{c}\text { Scenario } \\
\mathrm{A}^{\prime}\end{array}$ & $\begin{array}{c}\text { Scenario } \\
\text { B' }\end{array}$ & OUTPUTS & $\begin{array}{c}\text { Scenario } \\
\mathrm{A}\end{array}$ & $\begin{array}{c}\text { Scenario } \\
\text { B }\end{array}$ & $\begin{array}{c}\text { Scenario } \\
\mathrm{A}^{\prime}\end{array}$ & $\begin{array}{c}\text { Scenario } \\
\text { B' }\end{array}$ \\
\hline Cement (kg) & & $5.08 \mathrm{E}-02$ & & $5.09 \mathrm{E}-02$ & $\begin{array}{r}\text { Carbon monoxide } \\
\text { (biogenic) to air (kg) }\end{array}$ & & $9.41 \mathrm{E}-04$ & & $9.43 \mathrm{E}-04$ \\
\hline Concrete block (kg) & & 2.59E-03 & & $2.59 \mathrm{E}-03$ & Dioxins to air $(\mathrm{kg})$ & & $1.88 \mathrm{E}-12$ & & $1.89 \mathrm{E}-12$ \\
\hline Clay (kg) & & 3.69E-02 & & $3.70 \mathrm{E}-02$ & $\begin{array}{l}\text { Hydrogen chloride to air } \\
\qquad(\mathrm{kg})\end{array}$ & & $1.88 \mathrm{E}-04$ & & $1.89 \mathrm{E}-04$ \\
\hline Water (kg) & & 0.6 & & 0.6 & $\begin{array}{r}\text { Hydrogen fluoride to air } \\
(\mathrm{kg})\end{array}$ & & $1.88 \mathrm{E}-05$ & & $1.89 \mathrm{E}-05$ \\
\hline $\begin{array}{r}\text { Polyethylene HDPE, } \\
\text { granulate }(\mathrm{kg})\end{array}$ & & 5.01E-05 & & 5.01E-05 & $\begin{array}{l}\text { Nitrogen dioxide to air } \\
\qquad(\mathrm{kg})\end{array}$ & & 3.76E-03 & & 3.77E-03 \\
\hline Steel $(\mathrm{kg})$ & & $2.12 \mathrm{E}-03$ & & $2.12 \mathrm{E}-03$ & $\begin{array}{l}\text { Nitrogen monoxide to air } \\
\qquad(\mathrm{kg})\end{array}$ & & 3.76E-03 & & 3.77E-03 \\
\hline Urea $(\mathrm{kg})$ & & $1.13 \mathrm{E}-02$ & & $1.13 \mathrm{E}-02$ & Sulphur dioxide to air $(\mathrm{kg})$ & & $9.41 \mathrm{E}-04$ & & $9.43 E-04$ \\
\hline Activated carbon $(\mathrm{kg})$ & & $9.41 E-03$ & & $9.43 \mathrm{E}-03$ & & & & & \\
\hline $\mathrm{Ca}(\mathrm{OH}) 2(\mathrm{~kg})$ & & 1.20E-02 & & $1.21 \mathrm{E}-02$ & & & & & \\
\hline $\mathrm{CaO}(\mathrm{kg})$ & & $9.41 \mathrm{E}-02$ & & 9.43E-02 & & & & & \\
\hline Sodium silicate $(\mathrm{kg})$ & & $5.65 \mathrm{E}-03$ & & $5.66 \mathrm{E}-03$ & & & & & \\
\hline Composting & & & & & Composting & & & & \\
\hline $\begin{array}{r}\text { Organic waste to } \\
\text { composting }(\mathrm{kg})\end{array}$ & & 7.53 & & 7.54 & Compost (kg) & & 1.05 & & 1.05 \\
\hline Pruning waste $(\mathrm{kg})$ & & 0.75 & & 0.75 & $\begin{array}{r}\text { Transport to farm by lorry } \\
20-28 \mathrm{t}(\mathrm{tkm})\end{array}$ & & 2.70E-02 & & 2.71E-02 \\
\hline Electricity (kWh) & & 0.38 & & 0.38 & Ammonium to air $(\mathrm{kg})$ & & $8.28 \mathrm{E}-04$ & & 8.30E-04 \\
\hline Diesel (kg) & & 3.57E-02 & & 3.58E-02 & Methane to air $(\mathrm{kg})$ & & $2.56 \mathrm{E}-04$ & & $2.56 \mathrm{E}-04$ \\
\hline Water $(\mathrm{kg})$ & & 2.6 & & 2.6 & Nitrous oxide to air $(\mathrm{kg})$ & & $6.93 \mathrm{E}-04$ & & $6.94 \mathrm{E}-04$ \\
\hline Gravel (kg) & & $1.68 \mathrm{E}-01$ & & $1.68 \mathrm{E}-01$ & VOC emissions to air ( $\mathrm{kg})$ & & $9.11 \mathrm{E}-03$ & & $9.12 \mathrm{E}-03$ \\
\hline Sand $(\mathrm{kg})$ & & $9.11 \mathrm{E}-03$ & & $9.13 \mathrm{E}-03$ & $\begin{array}{r}\text { Carbon dioxide (biogenic) } \\
\text { to air }(\mathrm{kg})\end{array}$ & & 7.53E-03 & & 7.54E-03 \\
\hline Steel (kg) & & 4.57E-04 & & $4.58 \mathrm{E}-04$ & & & & & \\
\hline Bitumen (kg) & & $9.50 \mathrm{E}-04$ & & $9.52 \mathrm{E}-04$ & & & & & \\
\hline Concrete (m3) & & 2.86E-06 & & $2.86 \mathrm{E}-06$ & & & & & \\
\hline
\end{tabular}

\section{A2. Description of the sensitivity analysis}

This supplementary section aims to provide information on how the sensitivity analysis was conducted in order to identify those parameters contributing the most to the uncertainty of the output results. All the parameters taking part in the differential scenarios (scenario B-scenario A) were changed \pm coefficient of variation $(\mathrm{CV})$, relative to the basis value. For the estimation of the $\mathrm{CVs}$, the same criteria followed by Sonnemann et al. (2003) to determine the probability distributions were used, but with some modifications:

1. For site-specific inputs and outputs in processes from both, primary and secondary sources, a CV of $10 \%$ was assumed.

2. Transport distances were assigned a CV of $20 \%$.

3. The CV of the parameters related to process assumptions (e.g. fraction of waste diverted to landfill, fraction of biogas used for electricity production in a sanitary landfill, etc) was calculated according to plausible values. For example, the $C V$ of the parameter fraction to landfill was $26 \%$, which would result in a minimum value of $50 \%$, a realistic goal for the Spanish situation.

4. The CV of the parameters from Ecoinvent v2.2 (Hischier et al., 2010) was gathered from the corresponding flows in the same database. This only concerns inputs of capital goods in some processes of both scenarios for which no primary information from the Integral-b partners or information 
from other studies was available (e.g. "vegetable oil esterification plant" to produce biodiesel).

For emissions, Sonnemann et al. (2003) used guidelines from Meier (1997), assuming:

5. A CV of $2 \%$ for data obtained by stochimetric determination.

6. A CV of $10 \%$ for actual emission measurements or data computable in a well-known process simulation.

7. A CV of $20 \%$ for well-defined substances or sum-parameters.

8. A CV of $30 \%$ for data acquired of specific compounds by an elaborated analytical method.

Since both systems (A and B) cause avoided burdens, the impact categories are broken down into input and output effects, depending on the contribution of the sub-processes in each system. For further interpretation, input means avoided emissions, whereas output means net emissions, except for abiotic depletion (where input means avoided resource consumption).

Histograms were built with the outputs from the sensitivity analysis on GaBi 6 software (PE International, 2013), for each scenario formulation and for each impact category. These histograms show the relative change of the impact values when one single process parameter is changed at a time; this helps to determine the relative contribution of each parameter to the overall impact, in order to discern which parameters are critical. Only the results of the first scenario formulation (scenario B1-scenario A1) are shown in Figures A1-A12. Specifically, this formulation considers the UCO reference flow of $1.70 \mathrm{~kg} / \mathrm{inh}$ abitant and year, electricity displacing electricity from the Spanish mix (in scenario A) and glycerin displacing synthetic glycerin (in scenario B). Note that some parameters increased the impact, whereas others decreased it. However, in order to discern which parameters have a greater influence on each impact category, the absolute values of the percentage change were taken, showing the magnitude of change. 


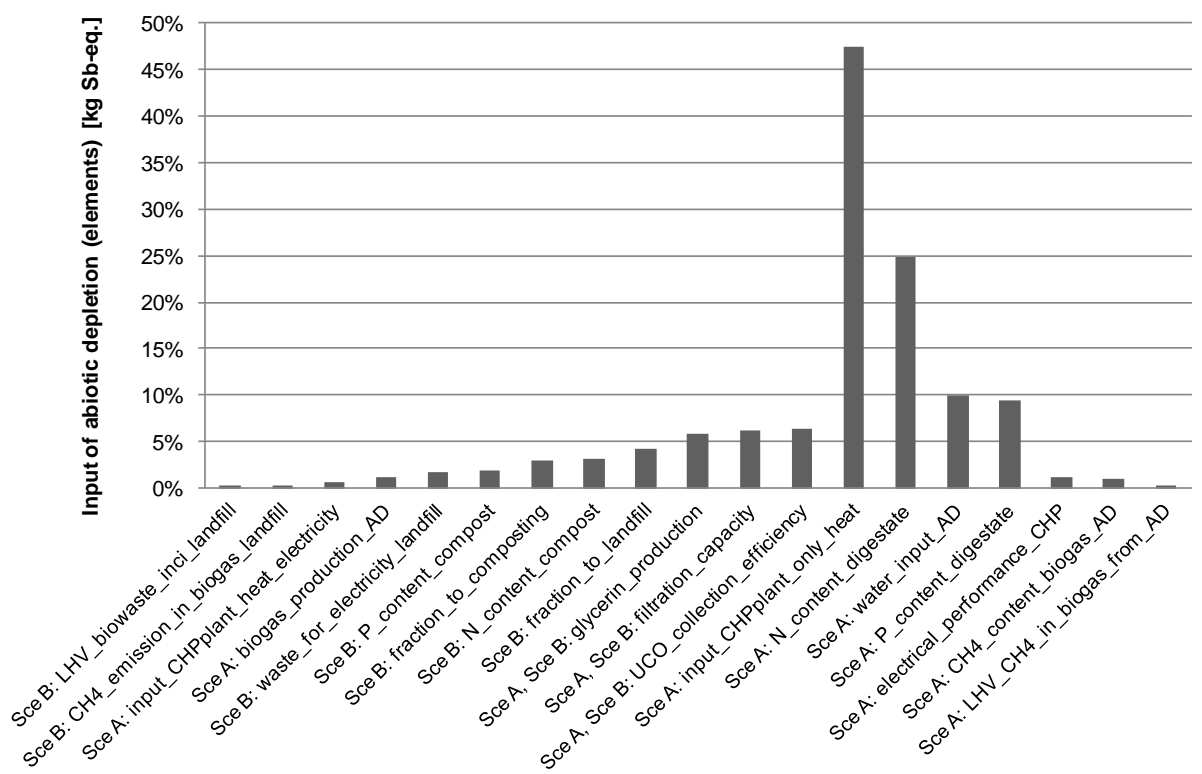

Figure A1. Histogram showing the parameters with the highest contribution (in absolute value) to the overall input of abiotic depletion in the differential assessment of scenario B1scenario A1.

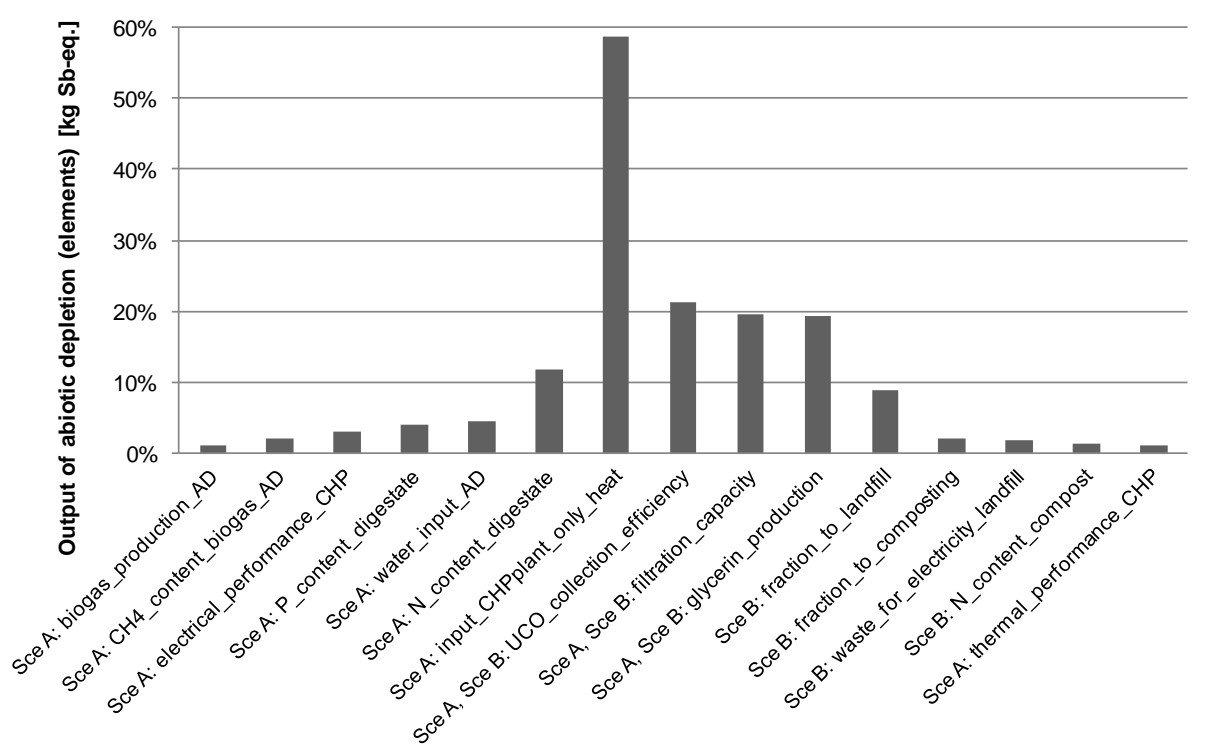

Figure A2. Histogram showing the parameters with the highest contribution (in absolute value) to the overall output of abiotic depletion in the differential assessment of scenario B1scenario A1. 


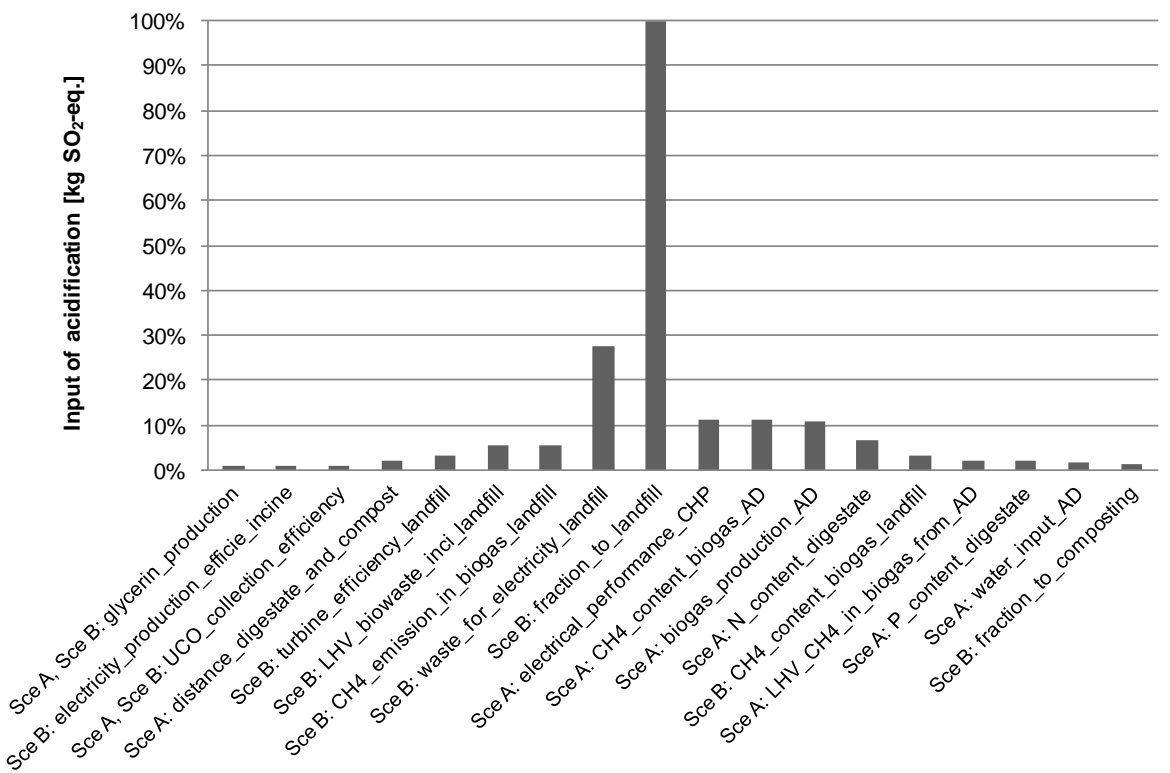

Figure A3. Histogram showing the parameters with the highest contribution (in absolute value) to the overall input of acidification in the differential assessment of scenario B1scenario A1.

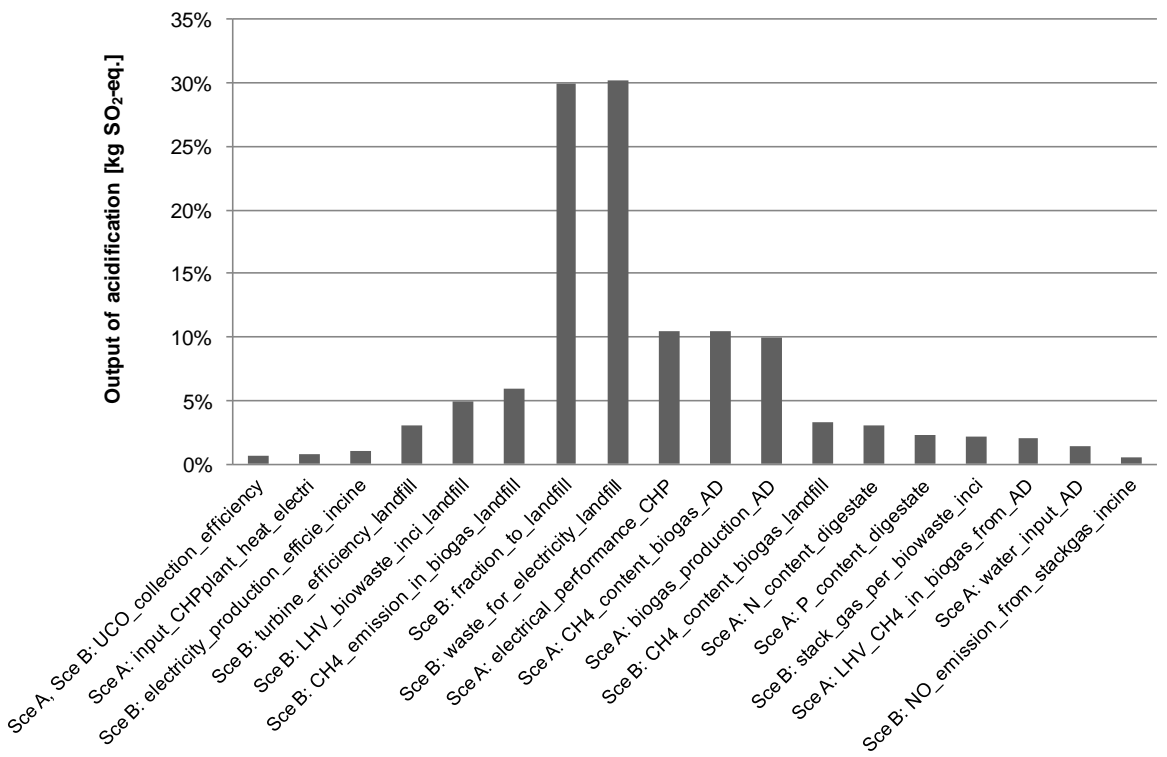

Figure A4. Histogram showing the parameters with the highest contribution (in absolute value) to the overall output of acidification in the differential assessment of scenario B1scenario A1. 


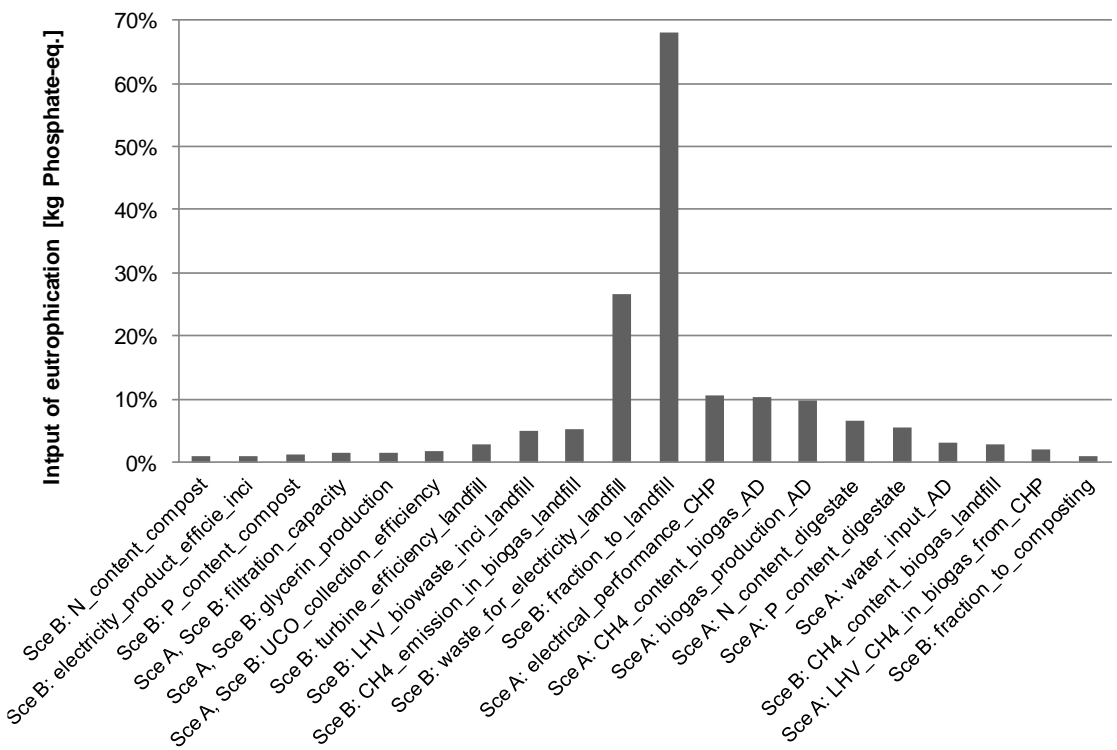

Figure A5. Histogram showing the parameters with the highest contribution (in absolute value) to the overall input of eutrophication in the differential assessment of scenario B1scenario A1.

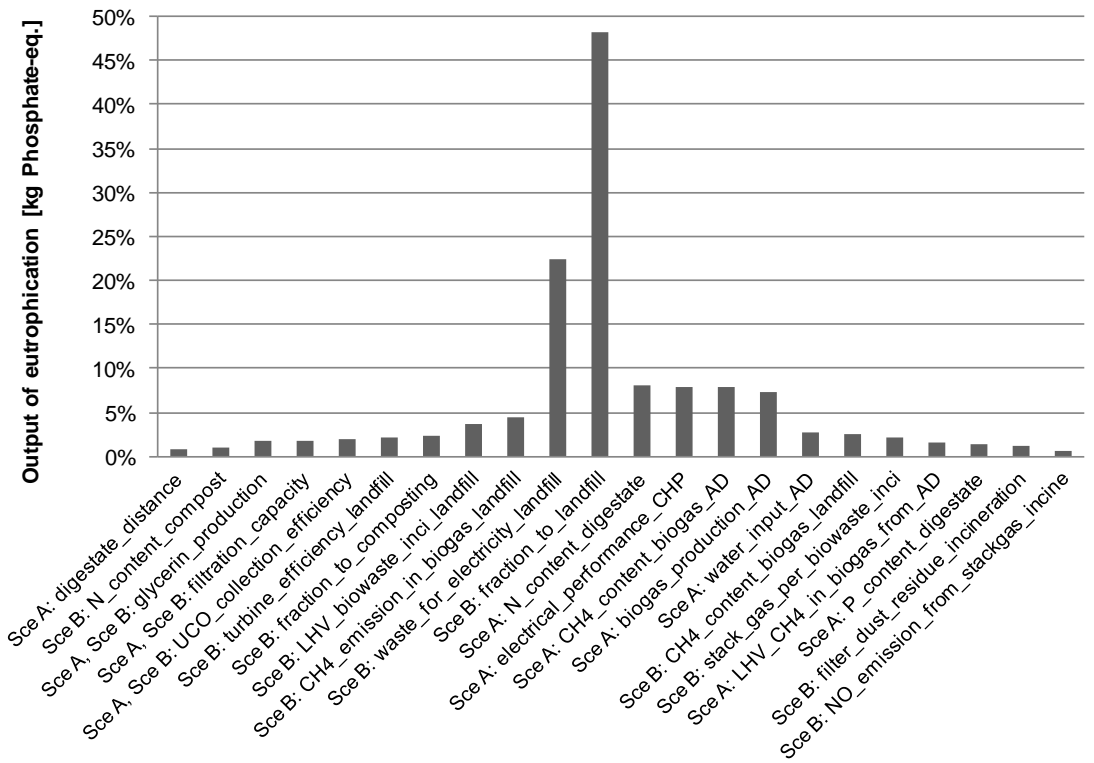

Figure A6. Histogram showing the parameters with the highest contribution (in absolute value) to the overall output of eutrophication in the differential assessment of scenario B1scenario A1. 


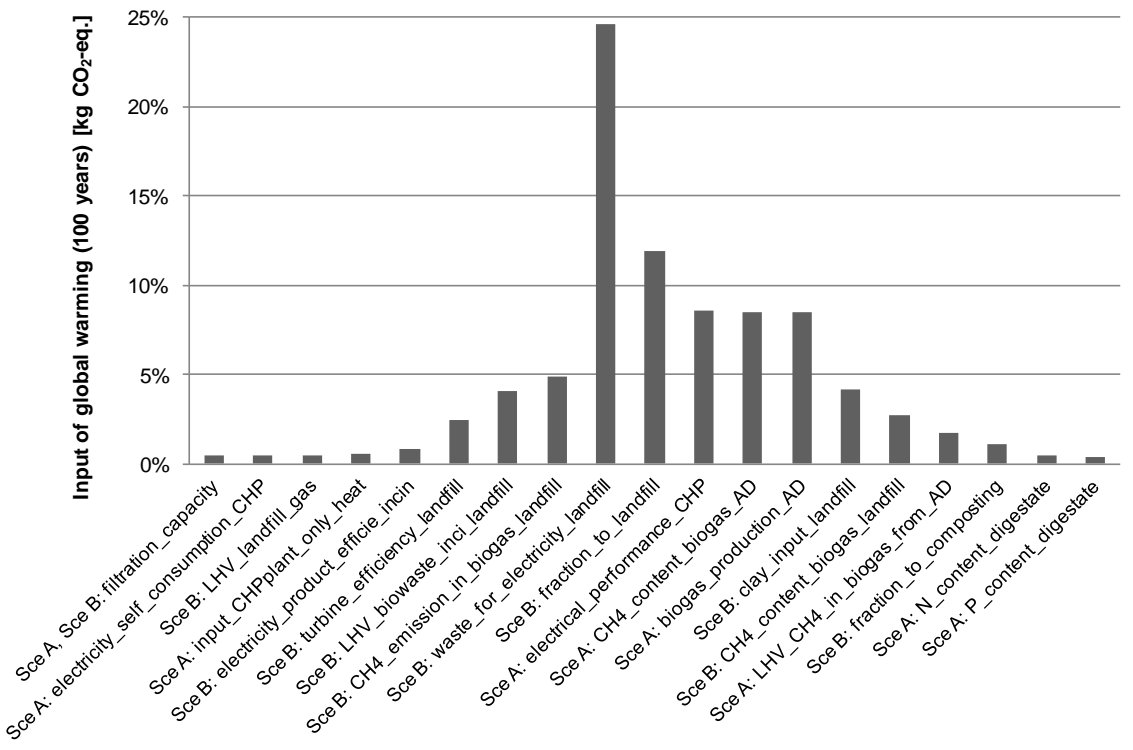

Figure A7. Histogram showing the parameters with the highest contribution (in absolute value) to the overall input of global warming in the differential assessment of scenario B1scenario A1.

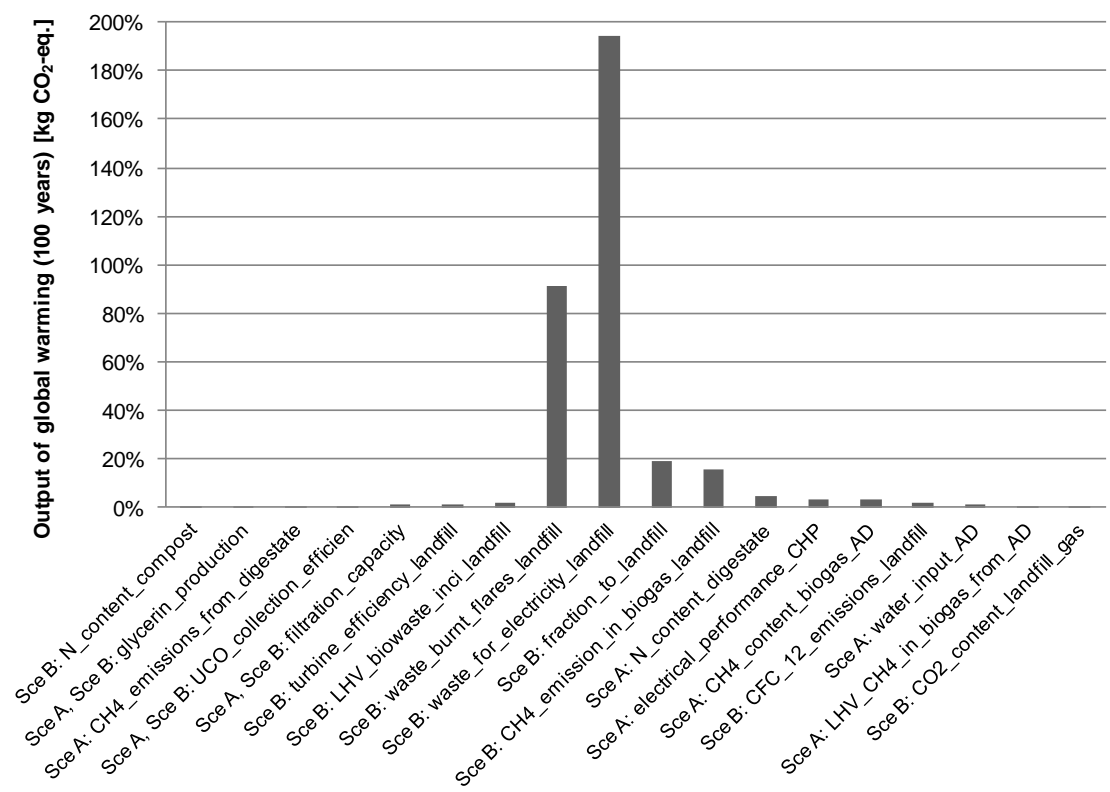

Figure A8. Histogram showing the parameters with the highest contribution (in absolute value) to the overall output of global warming in the differential assessment of scenario B1scenario A1. 


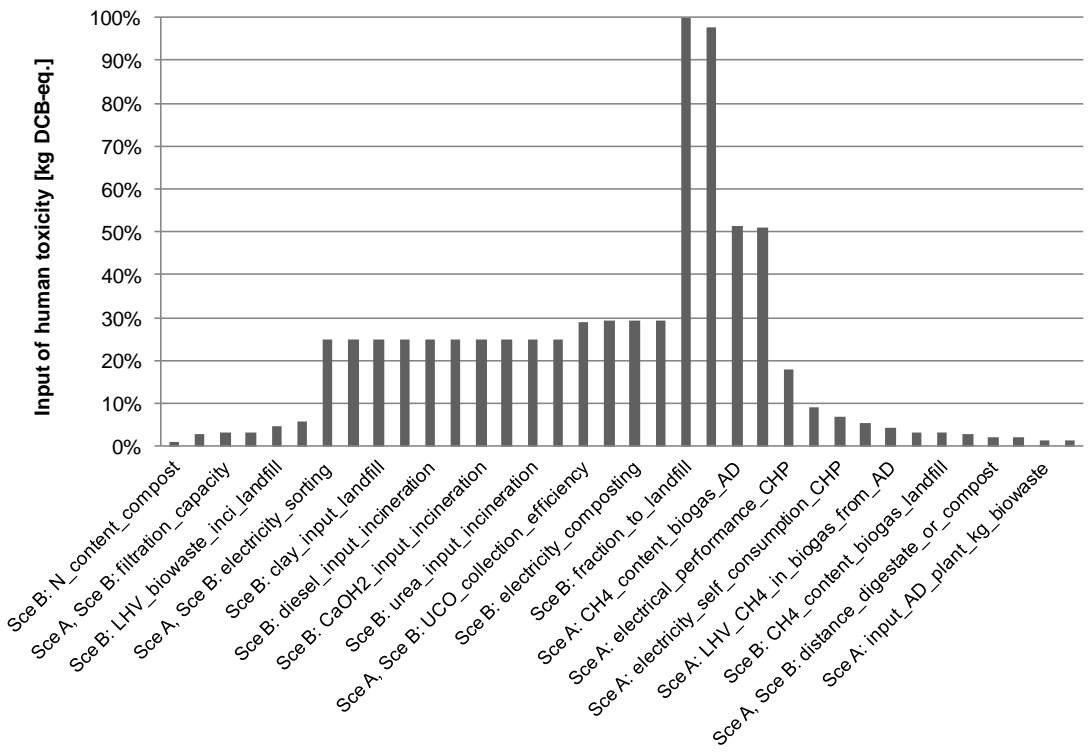

Figure A9. Histogram showing the parameters with the highest contribution (in absolute value) to the overall input of human toxicity in the differential assessment of scenario B1scenario A1.

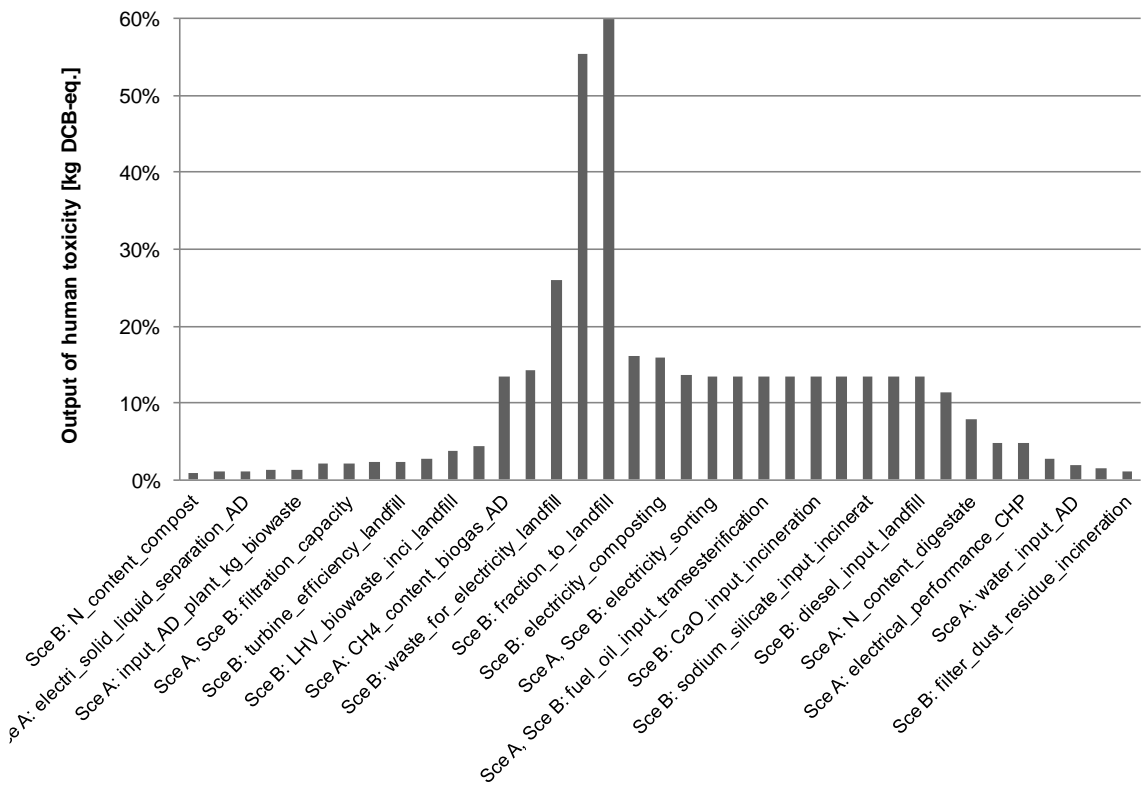

Figure A10. Histogram showing the parameters with the highest contribution (in absolute value) to the overall output of human toxicity in the differential assessment of scenario B1scenario A1. 


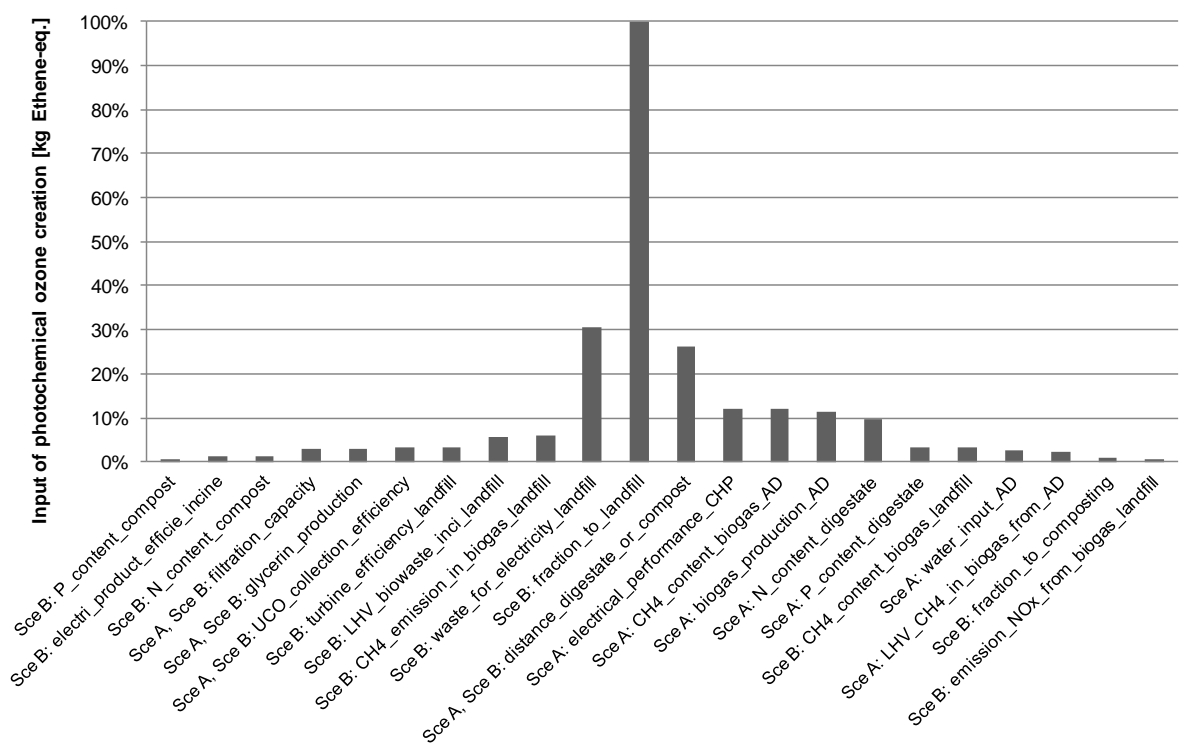

Figure A11. Histogram showing the parameters with the highest contribution (in absolute value) to the overall input of photochemical ozone creation in the differential assessment of scenario B1-scenario A1.

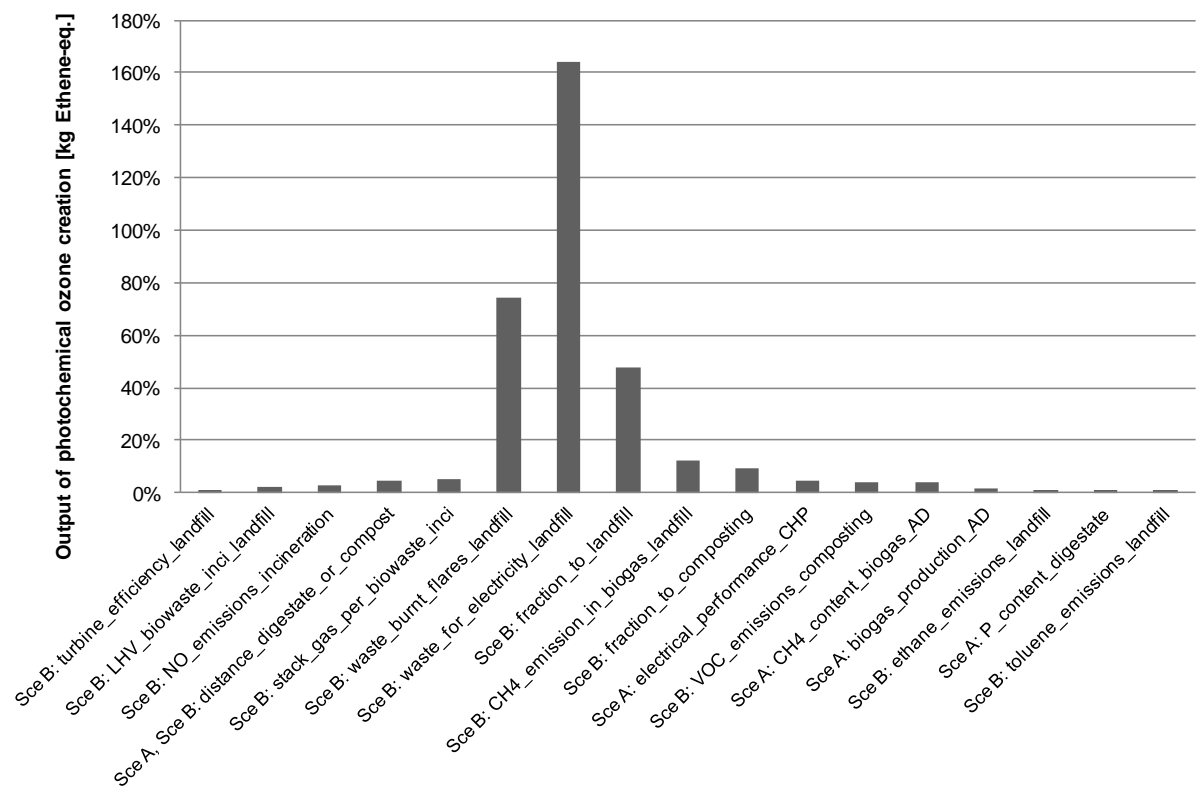

Figure A12. Histogram showing the parameters with the highest contribution (in absolute value) to the overall output of photochemical ozone creation in the differential assessment of scenario B1-Scenario A1. 
As can be seen, but for some small variations, the risk parameters are practically the same in all the categories, except in human toxicity $(\mathrm{HT})$, where the results are sensitive to more parameters. In general, the parameters with the highest contribution to the input in all the categories are those determining the amount of electricity produced by both scenarios, since it generates avoided burdens. That is particularly the case of parameters such as the fraction of waste going to landfill or the proportion of the waste used to produce electricity in scenario $B$, and the biogas production, glycerin used in the combined heat and power (CHP) or its electrical performance in scenario A. Parameters related to the $\mathrm{N}$ and $\mathrm{P}$ content of both the compost and digester sludge also appear to be relevant because the avoided fertilizer production in scenario A depends on them. This is the reason why fraction of waste going to composting has an influence in some impact categories.

These parameters are also responsible for the main emissions in all the sub-stages of both scenarios. In addition, parameters such as the efficiency of the collection of used cooking oil (UCO) are important because they deliver the overall amount of UCO to be processed, and all the inputs and outputs depend on this. The water input in the anaerobic digestion determines the amount of water to waste-water treatment (WWT), which is the difference between the total liquid fraction in the digester sludge minus the water re-circulated into the digester. This has a remarkable effect in some categories such as abiotic depletion, since all the capital goods in the WWT plant were included, with the subsequent inputs and outputs. In global warming (GW) output, apart from the fraction of waste used for electricity production, the contribution of the emissions of compounds with high characterization factors (e.g. CFC-12, $\mathrm{CO}_{2}, \mathrm{CH}_{4}$ ) is also remarkable. For the same reason, emissions of toluene or ethane during landfilling appear to be important in photochemical ozone creation (POC).

The situation of the impact category HT is slightly different, as there are more parameters causing relevant variability in the results. Since the production processes of all the inputs are included, with the subsequent resource depletion and emissions, all the parameters determining the amount of resources consumed are important in both cases, input and output. Similarly, parameters such as urea, clay or diesel inputs in landfilling, or sodium silicate and $\mathrm{CaOH}_{2}$ in incineration contribute significantly to the impact. This happens again because the different production processes are included, which take capital goods into consideration as well. Industrial production involves the consumption of chemicals (inputs) and the direct release of pollutants (outputs) into the environment, both of which cause toxicity in humans. Both histograms are symmetrical, with parameters showing a similar incidence in input and output, although in opposite directions. 
Only the parameters causing the highest change were selected, based on the histograms. Table A2 summarizes the number of risk parameters to be selected in each impact category, depending on the different cut-off criteria. Finally, only parameters causing more than $\pm 2 \%$ change of the impact were identified as risk parameters. Using this cut-off criterion, the number of parameters is enough to ensure the robustness of the forecast distributions (since the parameters to which the model is most sensitive are included), whilst not being very large; this avoids unwanted interactions between parameters and the slowing of the simulation process. In addition to these parameters taken from the sensitivity analysis, the percentage of food losses considered in order to calculate the FU was also included, since all the impact results directly depend on it.

The same analysis was carried out for all the scenario formulations and the same cut-off criterion was used to determine the risk parameters for respective Monte Carlo simulations.

Table A2. Different cut-off criteria for the identification of the risk parameters in each impact category, and the number that should be selected in each case.

\begin{tabular}{|c|c|c|c|c|c|c|c|c|}
\hline & & $\begin{array}{l}\text { Range > } \\
\pm 0,5 \% \\
\end{array}$ & $\begin{array}{c}\text { Range }> \\
\pm 1 \% \\
\end{array}$ & $\begin{array}{c}\text { Range }> \\
\pm 2 \% \\
\end{array}$ & $\begin{array}{c}\text { Range }> \\
\pm 5 \%\end{array}$ & $\begin{array}{c}\text { Range > } \\
\pm 10 \% \\
\end{array}$ & $\begin{array}{c}\text { Range > } \\
\pm 25 \%\end{array}$ & $\begin{array}{c}\text { Range > } \\
\pm 50 \% \\
\end{array}$ \\
\hline \multirow{2}{*}{$\begin{array}{l}\text { Abiotic } \\
\text { Depletion }\end{array}$} & INPUT & 16 & 15 & 10 & 7 & 3 & 1 & 0 \\
\hline & OUTPUT & 17 & 15 & 11 & 6 & 5 & 1 & 0 \\
\hline Acidification & INPUT & 23 & 17 & 12 & 8 & 5 & 2 & 1 \\
\hline \multirow{2}{*}{ Eutrophication } & INPUT & 24 & 17 & 13 & 8 & 4 & 2 & 1 \\
\hline & OUTPUT & 23 & 20 & 13 & 6 & 2 & 1 & 0 \\
\hline Global Warming & INPUT & 15 & 12 & 10 & 5 & 2 & 0 & 0 \\
\hline Human Toxicity & OUTPUT & 43 & 36 & 29 & 19 & 18 & 3 & 2 \\
\hline \multirow{2}{*}{$\begin{array}{l}\text { Photochemical } \\
\text { Ozone Creation }\end{array}$} & INPUT & 24 & 20 & 17 & 9 & 6 & 3 & 1 \\
\hline & OUTPUT & 22 & 17 & 12 & 6 & 4 & 3 & 2 \\
\hline \multicolumn{2}{|c|}{$\begin{array}{l}\text { TOTAL, without repeating } \\
\text { parameters }\end{array}$} & 57 & 47 & 35 & 28 & 26 & 17 & 6 \\
\hline
\end{tabular}

\section{A3. Impact assessment results}

In this section, the results from the impact assessment of those categories not shown in the main body of the text are presented. Scenarios A and B correspond again to the FU of $1.70 \mathrm{~kg}$ of $\mathrm{UCO}+35.50 \mathrm{~kg}$ of organic waste per inhabitant and year, whereas scenarios $A^{\prime} y B^{\prime}$ are for the $\mathrm{FU}$ of $6.38 \mathrm{~kg}$ of $\mathrm{UCO}+35.50 \mathrm{~kg}$ of organic waste per inhabitant and year. 


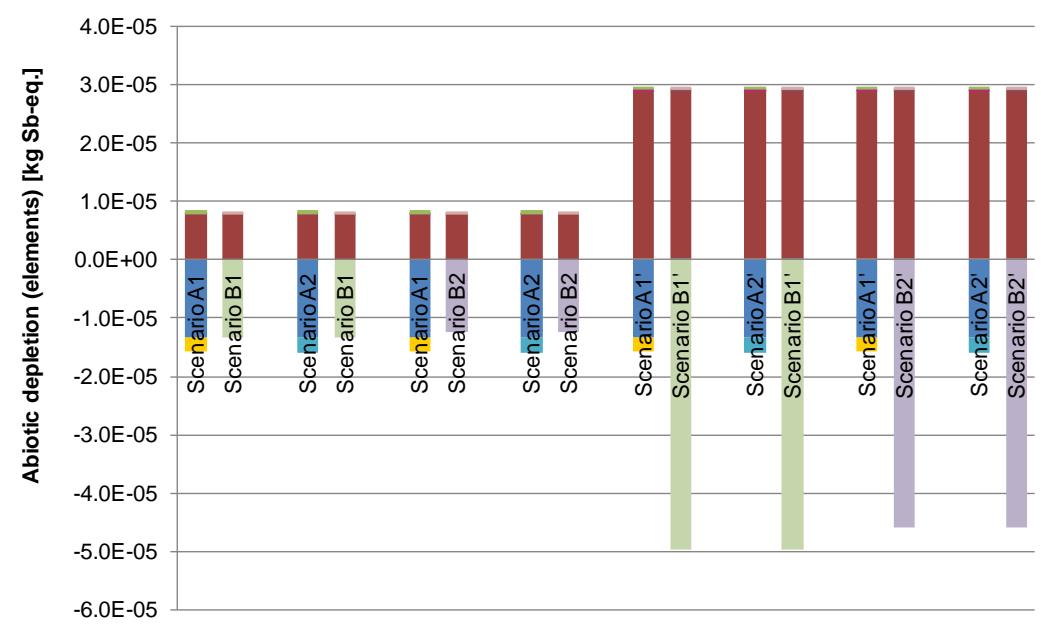

Figure A13. Contribution of the constitutive processes of each scenario to abiotic depletion, according to the deterministic results of the impact per inhabitant and year.

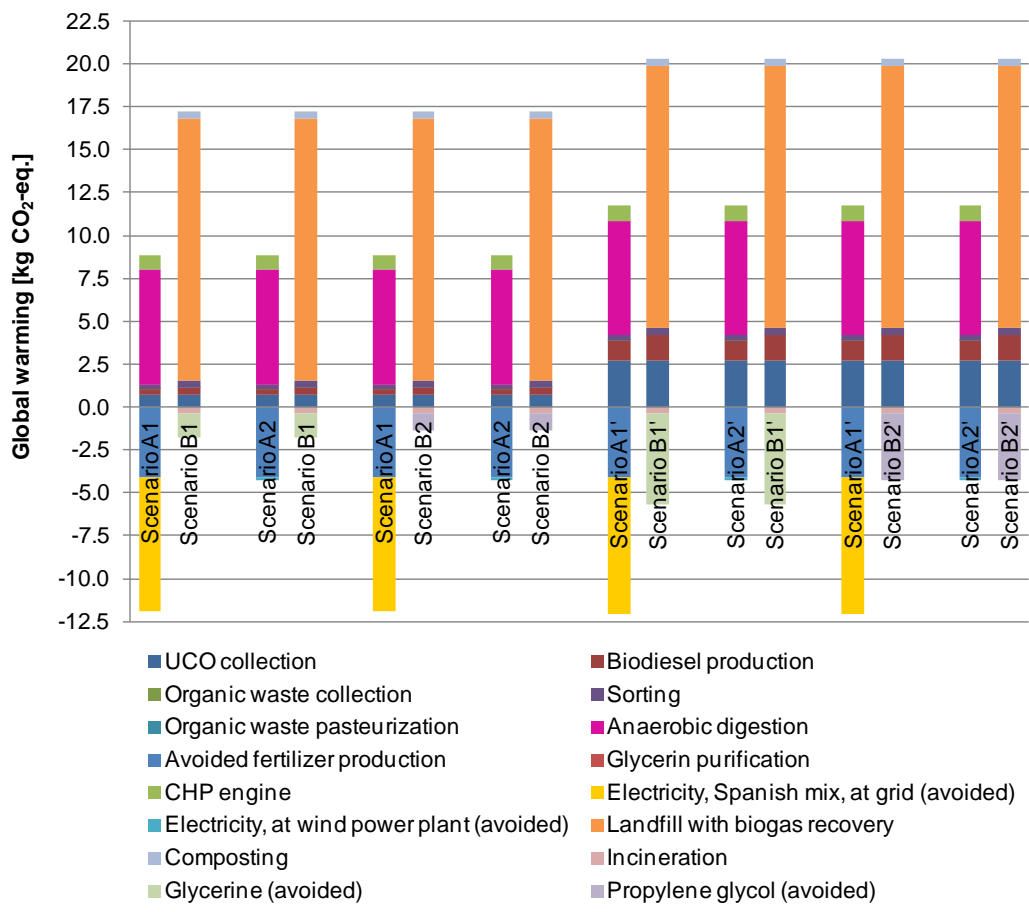

Figure A14. Contribution of the constitutive processes of each scenario to global warming, according to the deterministic results of the impact per inhabitant and year. 
Annex A: supplementary material for section 3.1

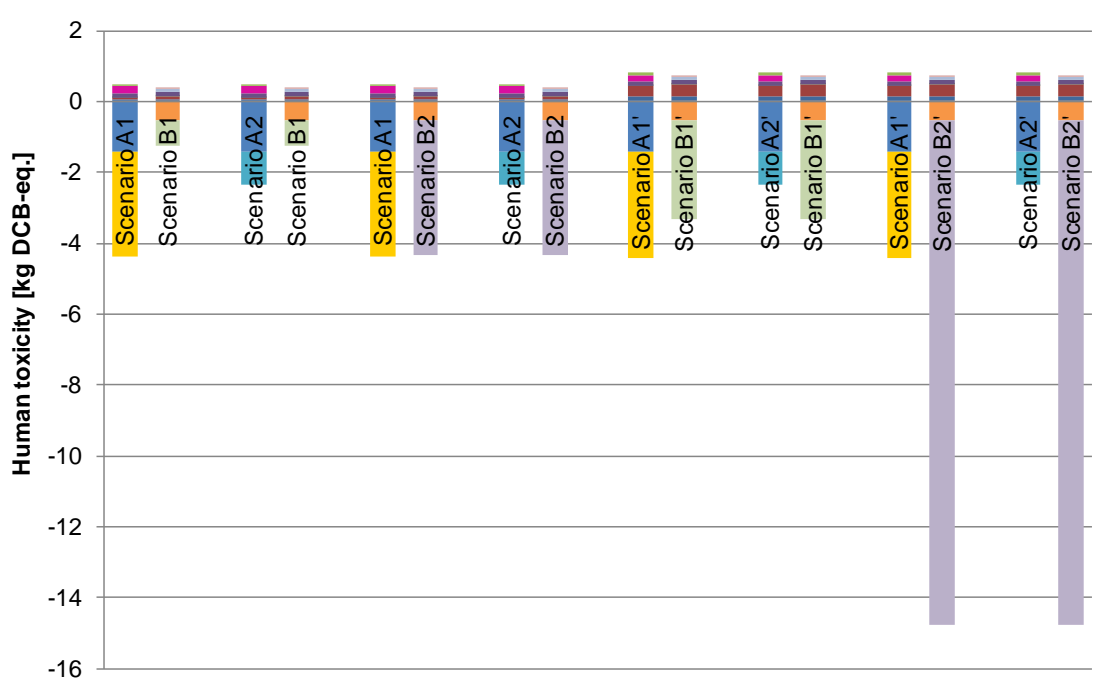

Figure A15. Contribution of the constitutive processes of each scenario to human toxicity, according to the deterministic results of the impact per inhabitant and year.

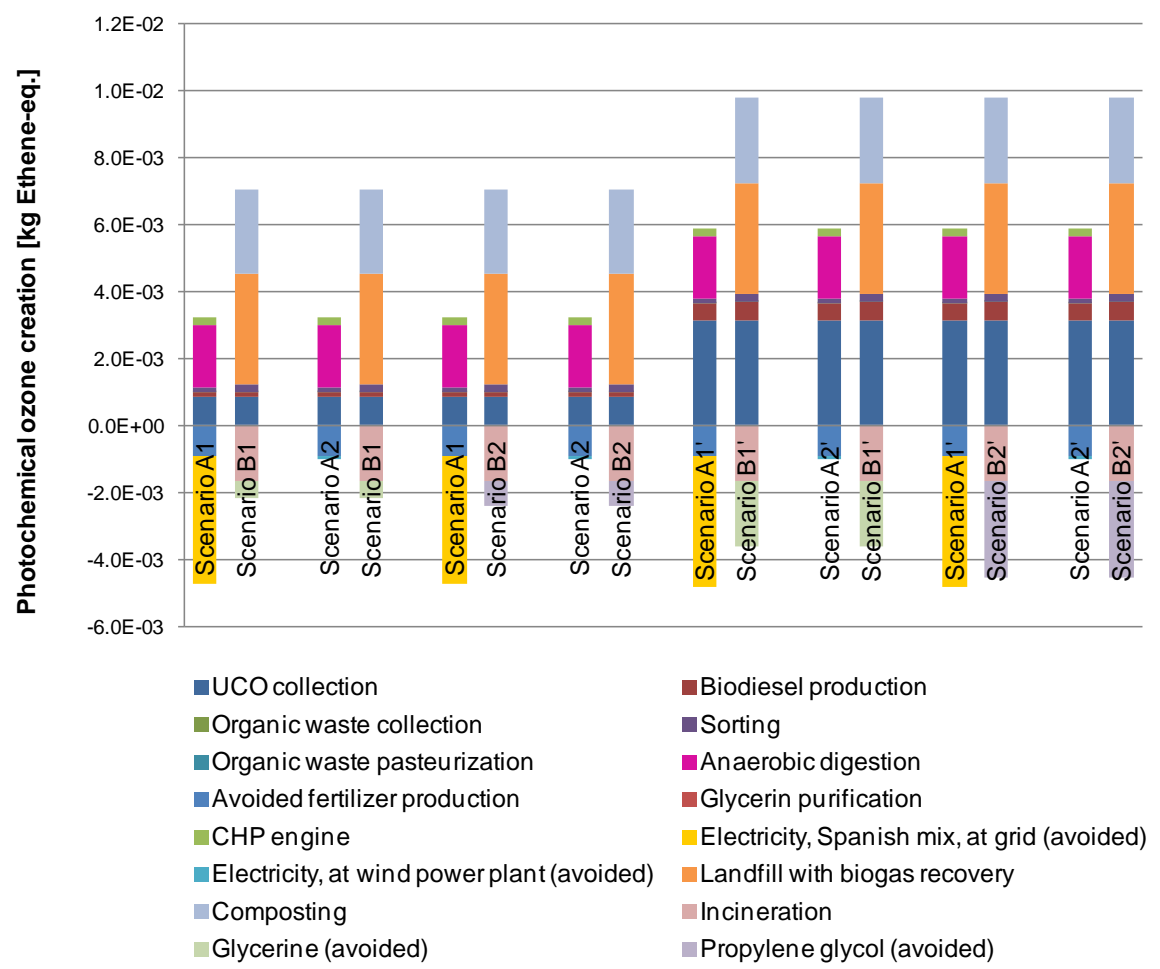

Figure A16. Contribution of the constitutive processes of each scenario to photochemical ozone creation, according to the deterministic results of the impact per inhabitant and year. 
Annex A: supplementary material for section 3.1

\section{A4. Probability distributions and Monte Carlo simulation results}

Table A3. Summary of mean and uncertainty distributions of risk parameters in all the scenario formulations considered. Key parameters selected by sensitivity analysis appear in gray.

\begin{tabular}{|c|c|c|c|c|c|c|c|c|c|c|c|c|c|c|c|c|c|c|c|c|c|c|}
\hline 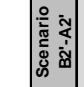 & 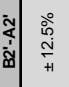 & $\mid$ & $\begin{array}{l}\text { ذे } \\
\text { +1 } \\
+1\end{array}$ & $\underset{+1}{\stackrel{0}{0}}$ & & & 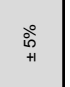 & & & $\mid \begin{array}{c}\text { s̀ } \\
+1 \\
+1\end{array}$ & & & $\mid \begin{array}{l}\stackrel{\circ}{\circ} \\
+1 \\
+1\end{array}$ & $\underset{+1}{\stackrel{\circ}{\circ}}$ & $\begin{array}{l}\text { Nे } \\
\text { +1 }\end{array}$ & 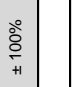 & 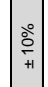 & & $\underset{+1}{\stackrel{\circ}{\circ}}$ & 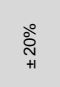 & 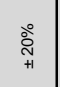 & $\underset{+}{\stackrel{े}{\circ}}$ \\
\hline 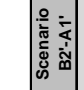 & 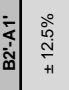 & $\mid$ & 总 & 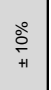 & & & 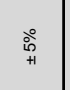 & 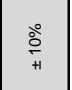 & & 离 & & & $\begin{array}{l}\mid \\
\vdots \\
+1 \\
+1\end{array}$ & $\begin{array}{l}\text { ذे } \\
\stackrel{0}{\circ} \\
+1\end{array}$ & \begin{tabular}{l|l} 
Nे \\
+1
\end{tabular} & $\begin{array}{l}\text { sें } \\
\text { +1 } \\
+1\end{array}$ & | & & 今ે & 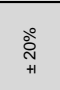 & 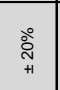 & ড̀ \\
\hline 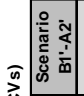 & 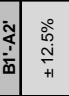 & 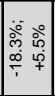 & 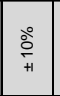 & $\underset{+1}{\stackrel{0}{0}}$ & & 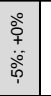 & & & & 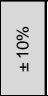 & & & $\mid \begin{array}{c}\stackrel{\circ}{0} \\
\stackrel{+}{+1}\end{array}$ & $\begin{array}{l}\stackrel{\circ}{0} \\
+1\end{array}$ & \begin{tabular}{l|l} 
& \\
\multirow{2}{*}{+} & \\
+1 & \\
\end{tabular} & $\begin{array}{l}0 \\
\\
\\
+1 \\
+1\end{array}$ & $\mid$ & & $\underset{+1}{\stackrel{\circ}{\circ}}$ & $\underset{\substack{0 \\
+1}}{\stackrel{\circ}{\circ}}$ & $\begin{array}{c}\stackrel{0}{0} \\
+1\end{array}$ & $\begin{array}{c}\text { Dे } \\
+1\end{array}$ \\
\hline 总 & 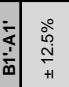 & $\mid$ & 害 & 离 & 竞 & 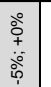 & & $\underset{+1}{\stackrel{\circ}{\circ}}$ & & 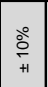 & 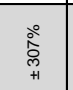 & $\mid$ & $\mid \begin{array}{l}0 \\
\vdots \\
+1 \\
+1\end{array}$ & 离 & $\begin{array}{c}\text { Nิ } \\
+1\end{array}$ & 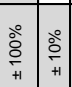 & 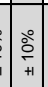 & $\mid$ & 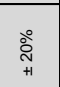 & $\underset{+1}{\stackrel{\text { Oे }}{+1}}$ & 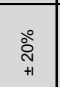 & $\underset{\substack{0 \\
+1}}{\stackrel{\circ}{0}}$ \\
\hline 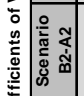 & 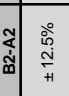 & $\mid$ & 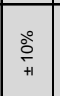 & 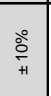 & & & 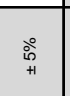 & $\underset{+1}{\stackrel{\circ}{\circ}}$ & 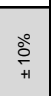 & $\begin{array}{l}\stackrel{\circ}{\circ} \\
+1 \\
+1\end{array}$ & & & 离 & $\begin{array}{l}\text { 总 } \\
+1\end{array}$ & $\underset{+}{\stackrel{े}{~}}$ & 突 & | & & 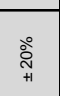 & $\underset{\substack{\text { Dे } \\
+1}}{\circ}$ & & \\
\hline 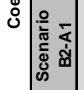 & 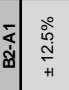 & $\mid$ & 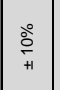 & 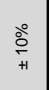 & & & $\begin{array}{c}\text { ì } \\
\text { t+ }\end{array}$ & $\stackrel{\substack{\circ \\
+1}}{\circ}$ & $\begin{array}{l}\stackrel{8}{\circ} \\
+1 \\
+1\end{array}$ & $\begin{array}{l}\stackrel{\circ}{\circ} \\
+1 \\
+1\end{array}$ & & \begin{tabular}{|l|} 
के̀े \\
+1 \\
+1
\end{tabular} & $\begin{array}{l}\stackrel{\circ}{\circ} \\
+1 \\
+1\end{array}$ & $\begin{array}{l}\stackrel{\circ}{\circ} \\
+1\end{array}$ & సે & 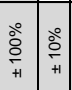 & \begin{tabular}{|c|c|c}
0 \\
$\vdots$ \\
\hdashline \\
+1
\end{tabular} & & 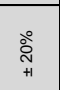 & $\underset{+1}{\stackrel{\text { Dे }}{+1}}$ & & \\
\hline 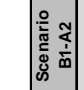 & 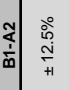 & $\mid$ & 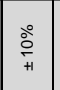 & $\begin{array}{l}\stackrel{\circ}{\circ} \\
+1\end{array}$ & & 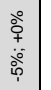 & & 害 & 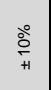 & \begin{tabular}{|l|}
$\stackrel{\circ}{0}$ \\
+ \\
+1
\end{tabular} & $\begin{array}{c}\text { 产 } \\
\text { Dे } \\
\text { +1 }\end{array}$ & & 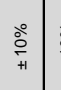 & $\begin{array}{c}\stackrel{8}{0} \\
\substack{+1 \\
+1}\end{array}$ & \begin{tabular}{l|l} 
& \\
\multirow{2}{*}{} & \\
+1 & \\
+1
\end{tabular} & 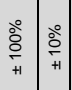 & \begin{tabular}{|l}
0 \\
$\vdots$ \\
\hdashline \\
+1
\end{tabular} & 竞 & $\underset{+1}{\stackrel{\circ}{\circ}}$ & $\underset{+1}{\stackrel{9}{0}}$ & $\underset{\substack{0 \\
+1}}{\stackrel{0}{0}}$ & \\
\hline 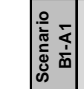 & 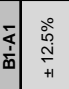 & $\mid$ & ذ্خ & $\underset{+1}{\stackrel{0}{+}}$ & 票 & 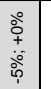 & & 究 & $\begin{array}{l}\stackrel{8}{\circ} \\
+1 \\
+1\end{array}$ & $\begin{array}{l}\stackrel{8}{\circ} \\
+1 \\
+1\end{array}$ & & | & 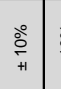 & 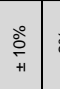 & \begin{tabular}{l|l} 
\\
Nì \\
+1
\end{tabular} & 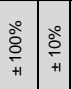 & \begin{tabular}{l}
1 \\
$\vdots$ \\
\hdashline \\
+1 \\
+1
\end{tabular} & & $\underset{\substack{++1}}{\stackrel{0}{0}}$ & $\underset{+1}{\stackrel{\circ}{\circ}}$ & & \\
\hline$\frac{n}{5}$ & $\therefore$ & $\therefore$ & 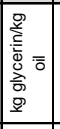 & 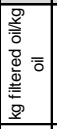 & 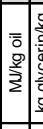 & 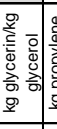 & 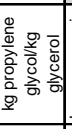 & 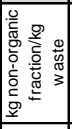 & 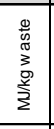 & 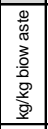 & 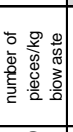 & & $\therefore$ 产 & 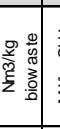 & 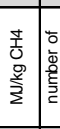 & 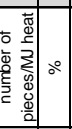 & $\therefore$ & $\circ$ & 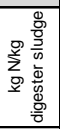 & 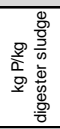 & 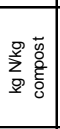 & 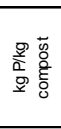 \\
\hline $\begin{array}{l}\text { ॠू } \\
\Sigma\end{array}$ & ণ & \& & ?ํㅇ & $\stackrel{\circ}{\circ}$ & $\mid \begin{array}{l}: \\
\vdots \\
\vdots\end{array}$ & $\rightarrow$ & $\stackrel{\circ}{\circ}$ & 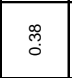 & $\begin{array}{l}\text { L } \\
0 \\
0\end{array}$ & 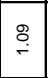 & 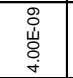 & م & $\stackrel{\leftrightarrow}{\stackrel{0}{0}}$ & $\stackrel{\text { ఎ }}{\sim}$ & \begin{tabular}{l|l}
\multirow{2}{*}{} \\
$\dot{p}$ \\
\end{tabular} & 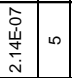 & 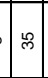 & q & 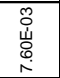 & 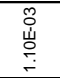 & 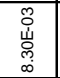 & 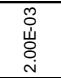 \\
\hline 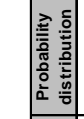 & 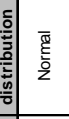 & 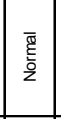 & \begin{tabular}{|l}
$\overline{\underline{\xi}}$ \\
$\underline{\underline{\underline{z}}}$
\end{tabular} & 产 & 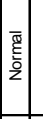 & $\begin{array}{l}\overline{\underline{\xi}} \\
\underline{\underline{\underline{s}}}\end{array}$ & $\begin{array}{l}\overline{\underline{\xi}} \\
\underline{\underline{\underline{s}}}\end{array}$ & 縍 & $\begin{array}{l}\overline{\underline{\xi}} \\
\overline{\underline{z}}\end{array}$ & \begin{tabular}{|l|}
$\overline{\underline{\underline{m}}}$ \\
$\underline{\underline{\underline{z}}}$
\end{tabular} & $\begin{array}{l}\text { 縍 } \\
\frac{\underline{q}}{2}\end{array}$ & 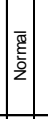 & \begin{tabular}{|l|}
$\overline{\underline{\underline{m}}}$ \\
$\underline{\underline{\underline{z}}}$ \\
\end{tabular} & 产 & $\begin{array}{l}\overline{\underline{m}} \\
\bar{z}\end{array}$ & 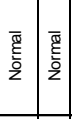 & $\left|\overline{\frac{m}{5}}\right|$ & $\mid$\begin{tabular}{|}
$\overline{\underline{\underline{m}}}$ \\
$\frac{\bar{z}}{2}$
\end{tabular} & & $\begin{array}{l}\overline{\underline{\underline{m}}} \\
\frac{\underline{\underline{q}}}{2}\end{array}$ & 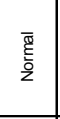 & $\begin{array}{l}\overline{\underline{\underline{w}}} \\
\frac{\underline{\underline{s}}}{2}\end{array}$ \\
\hline 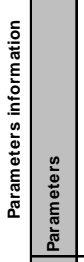 & 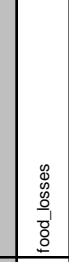 & 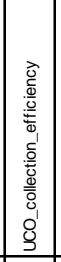 & 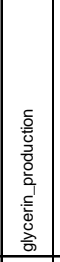 & 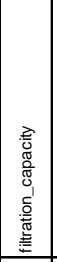 & 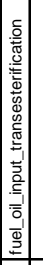 & 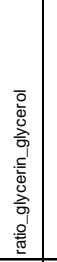 & 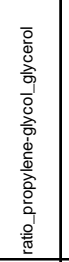 & 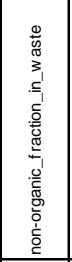 & 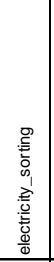 & 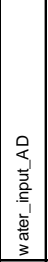 & 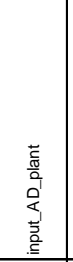 & 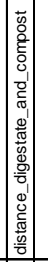 & 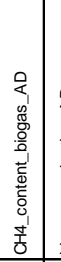 & 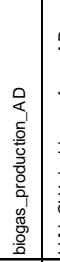 & 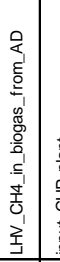 & 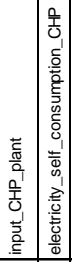 & 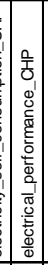 & 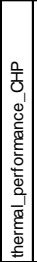 & 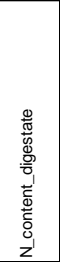 & 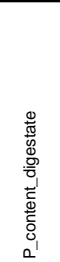 & 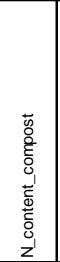 & 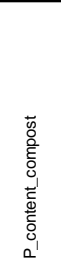 \\
\hline 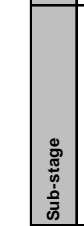 & 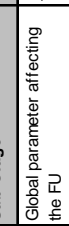 & 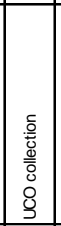 & 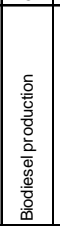 & 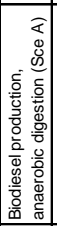 & & $<5$ & 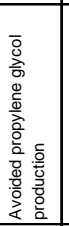 & 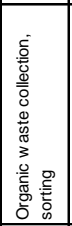 & 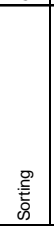 & 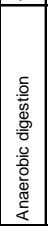 & 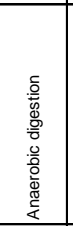 & 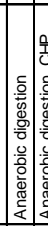 & 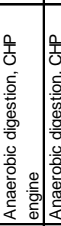 & 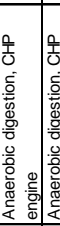 & 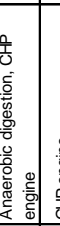 & 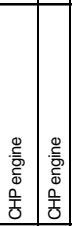 & 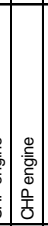 & 兽 & 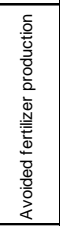 & 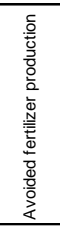 & 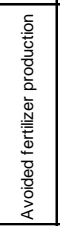 & 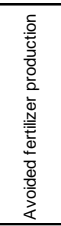 \\
\hline ֻ & 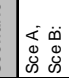 & & 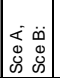 & 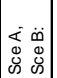 & & $\begin{array}{l}\infty \\
\vdots \\
\dot{n} \\
0\end{array}$ & $\begin{array}{l}\dot{0} \\
0 \\
\ddot{\Lambda}\end{array}$ & $\begin{array}{l}\infty \\
\stackrel{\infty}{\infty} \\
心 \\
心\end{array}$ & 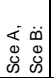 & $\begin{array}{l}\dot{\Xi} \\
\check{c}\end{array}$ & 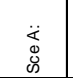 & \begin{tabular}{|l|} 
\\
$\vdots$ \\
$u$ \\
\end{tabular} & 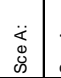 & 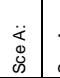 & \begin{tabular}{l|l}
$\dot{1}$ \\
$\dot{8}$ \\
$\dot{n}$
\end{tabular} & 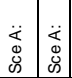 & 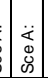 & & 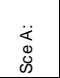 & 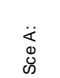 & 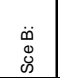 & $\begin{array}{l}\infty \\
\stackrel{\infty}{0} \\
心 \\
心\end{array}$ \\
\hline
\end{tabular}




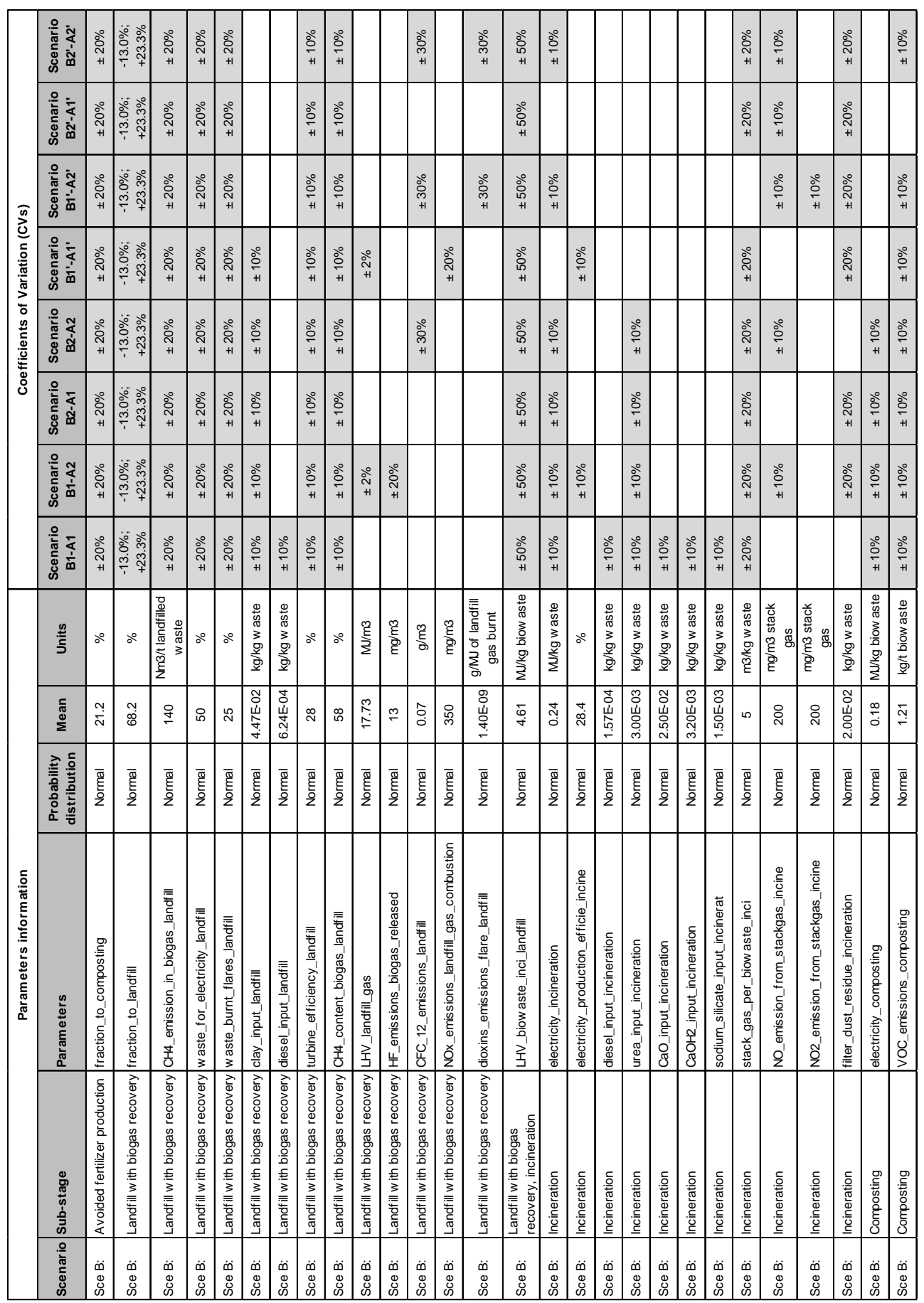


The box and whiskers plots from the uncertainty analysis for those impact categories not shown in section 12.3.2 are presented below.
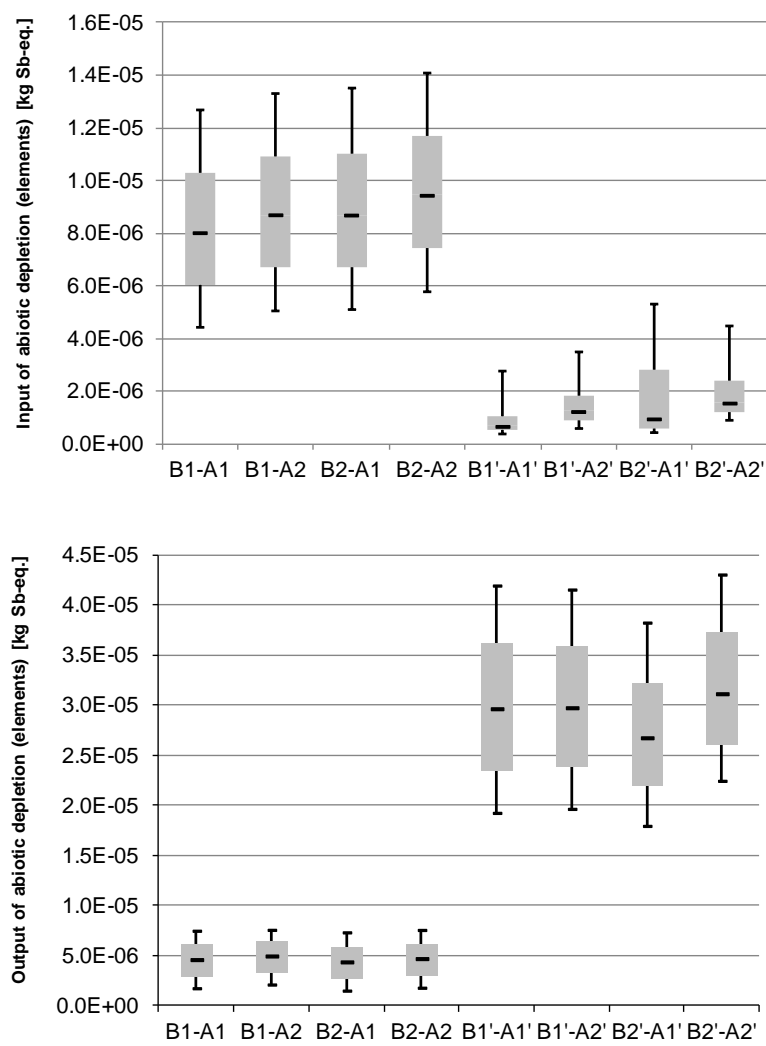

Figure A17. Box-and-whiskers plots from the differential Monte Carlo simulations of scenario B-scenario A for the impact category abiotic depletion, as input and output.

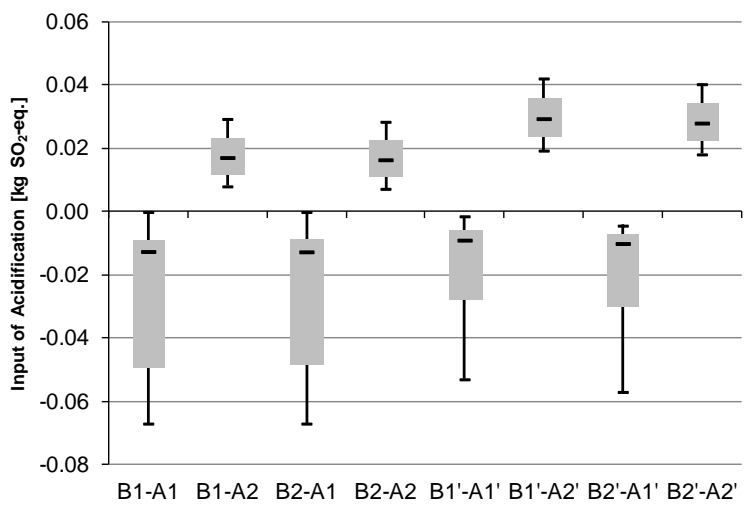




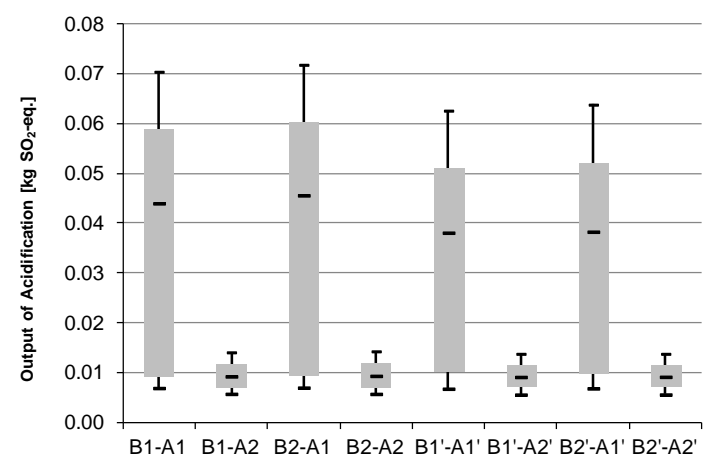

Figure A18. Box-and-whiskers plots from the differential Monte Carlo simulations of scenario B-scenario A for the impact category acidification, as input and output.

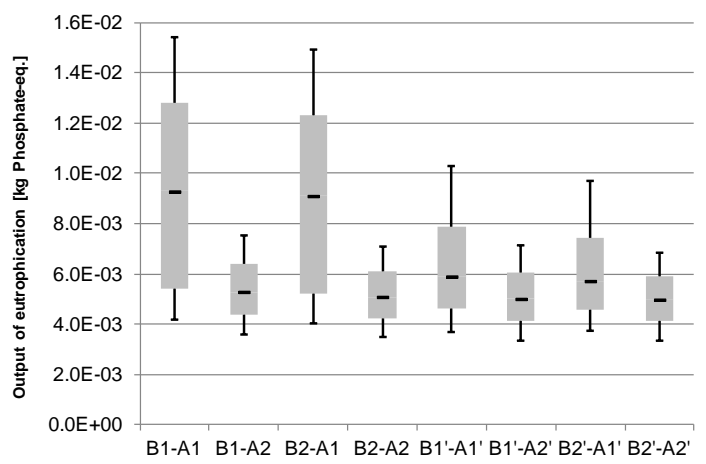

Figure A19. Box-and-whiskers plots from the differential Monte Carlo simulations of scenario B-scenario A for the impact category eutrophication (output).

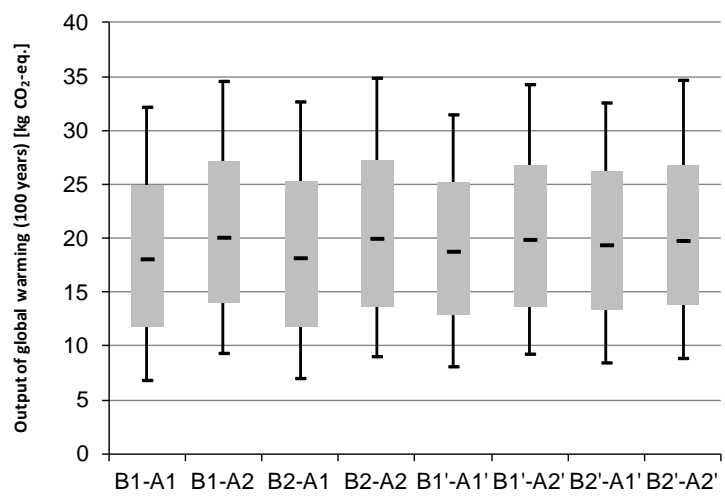

Figure A20. Box-and-whiskers plots from the differential Monte Carlo simulations of scenario B-scenario A for the impact category global warming (output). 


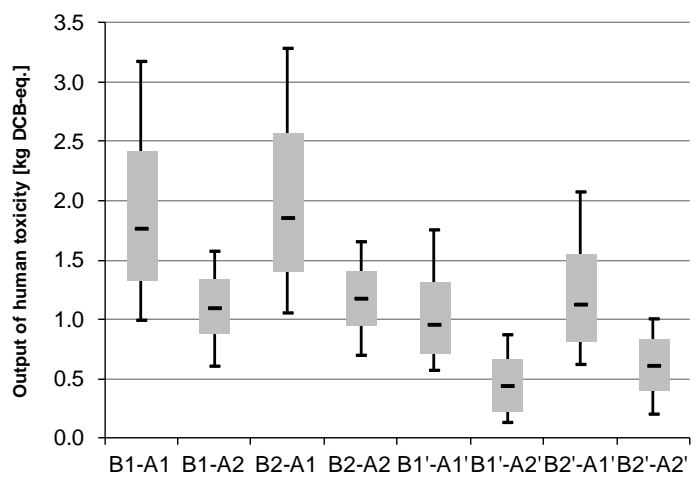

Figure A21. Box-and-whiskers plots from the differential Monte Carlo simulations of scenario B-scenario A for the impact category human toxicity (output).

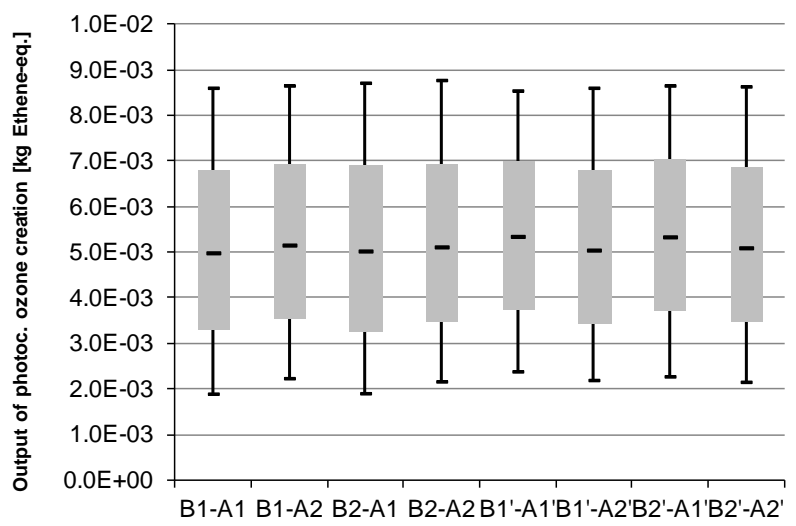

Figure A22. Box-and-whiskers plots from the differential Monte Carlo simulations of scenario B-scenario A for the impact category photochemical ozone creation (output). 
The histograms obtained by means of the Risk 5.5 software (Palisade Corporation, 2009) from the uncertainty analysis are presented below, only for those scenario formulations not shown in section 12.4 for which the impact result can change its sign within the forecast distribution.

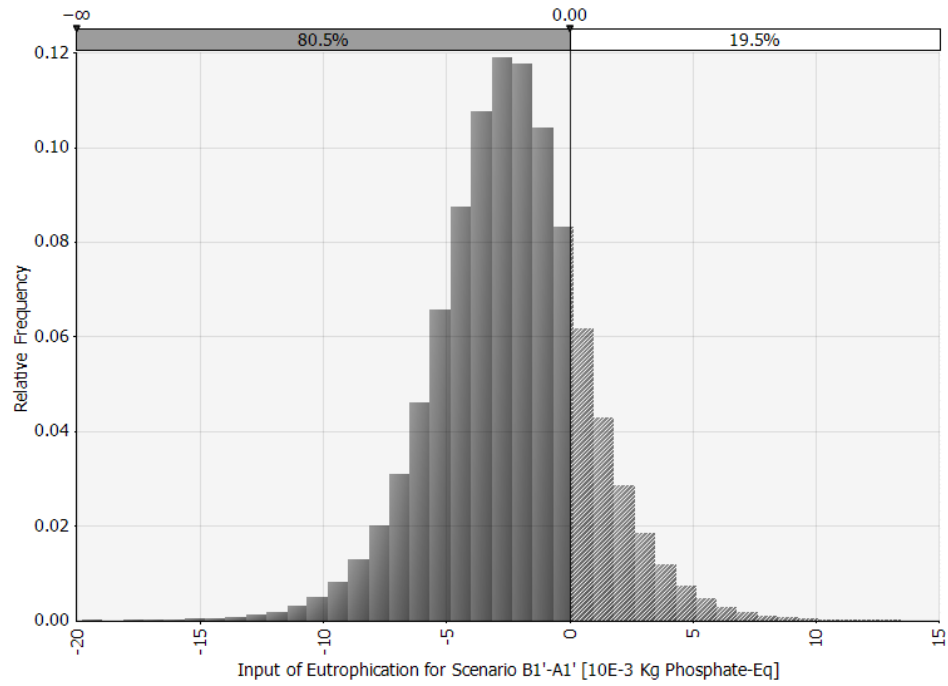

Figure A23. Histograms from the differential Monte Carlo simulation of scenario B1'-A1' for eutrophication (input).

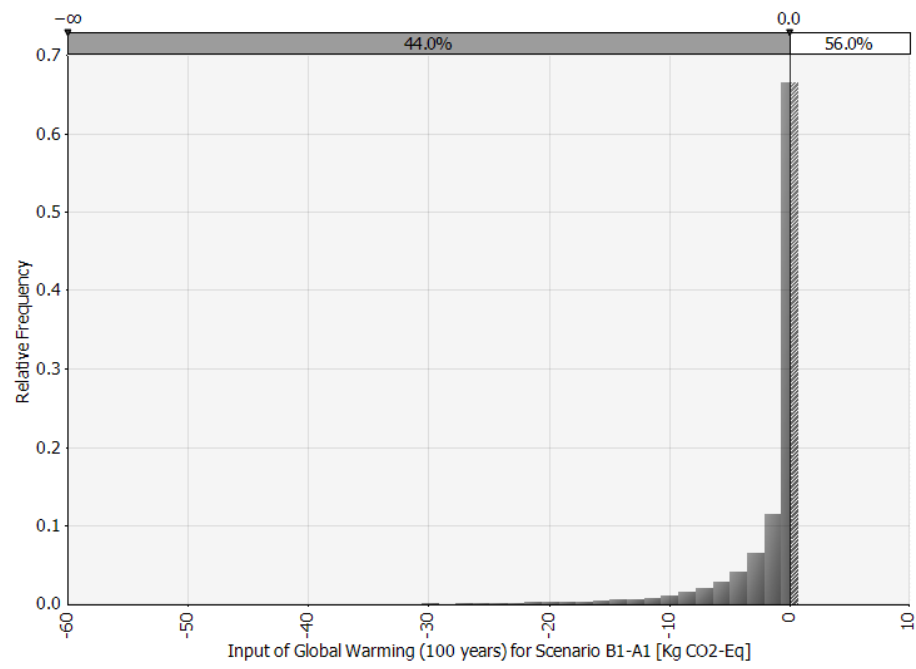

Figure A24. Histograms from the differential Monte Carlo simulation of scenario B1-A1 for global warming (input). 


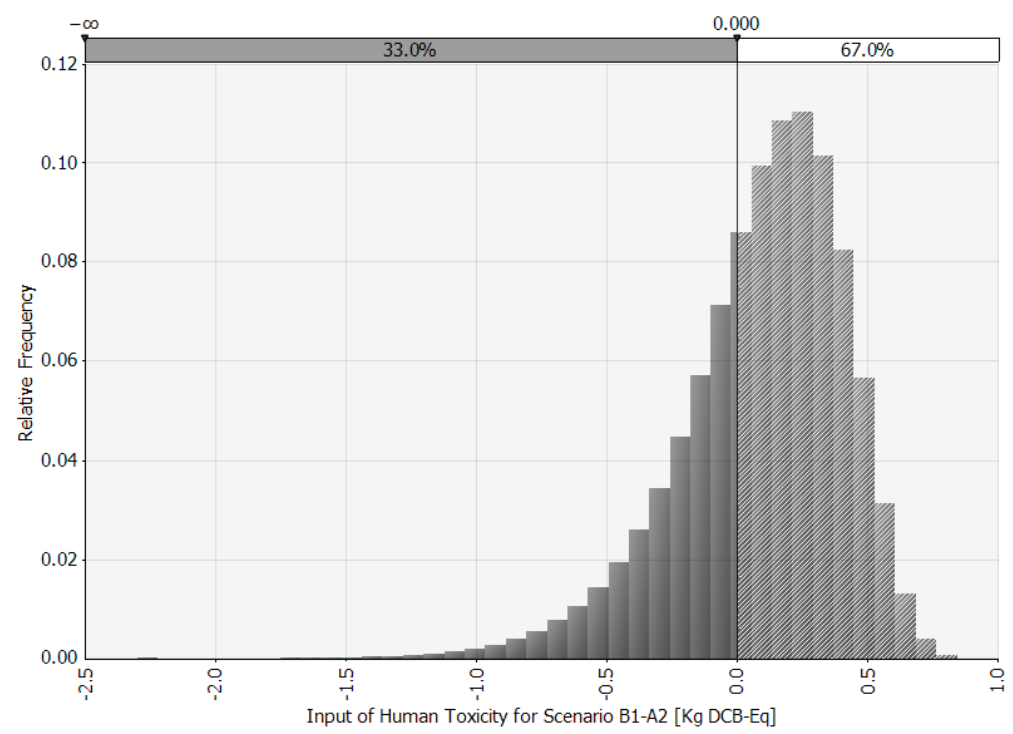

Figure A25. Histograms from the differential Monte Carlo simulation of scenario B1-A2 for human toxicity (input).

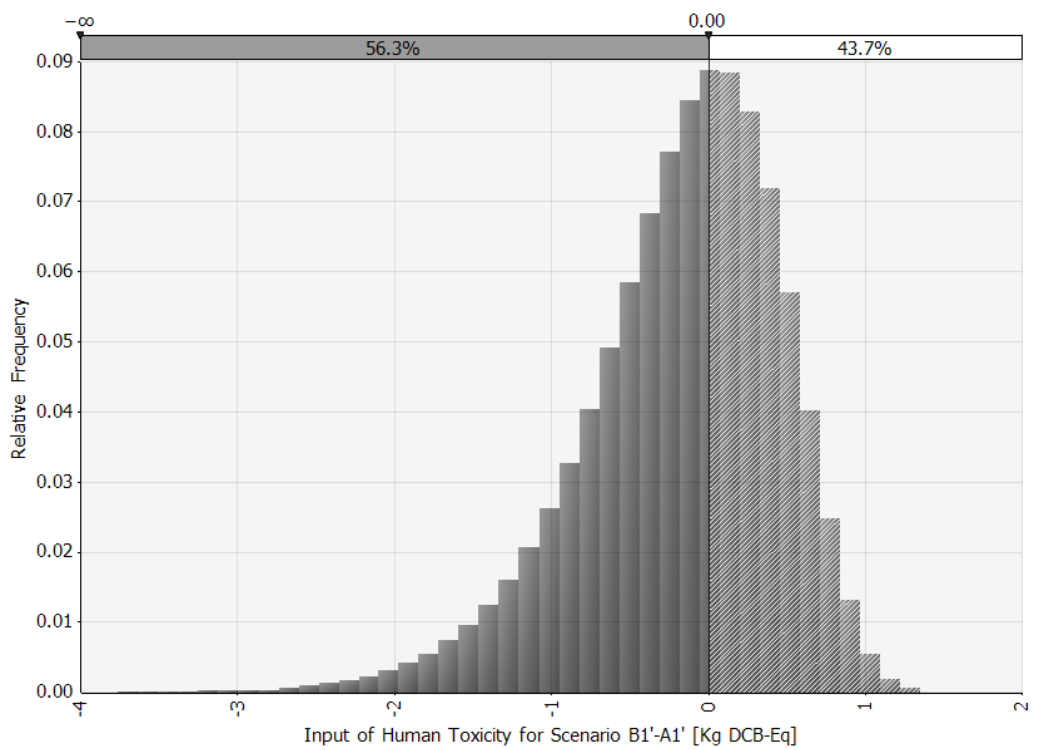

Figure A26. Histograms from the differential Monte Carlo simulation of scenario B1'-A1' for human toxicity (input). 
Annex A: supplementary material for section 3.1

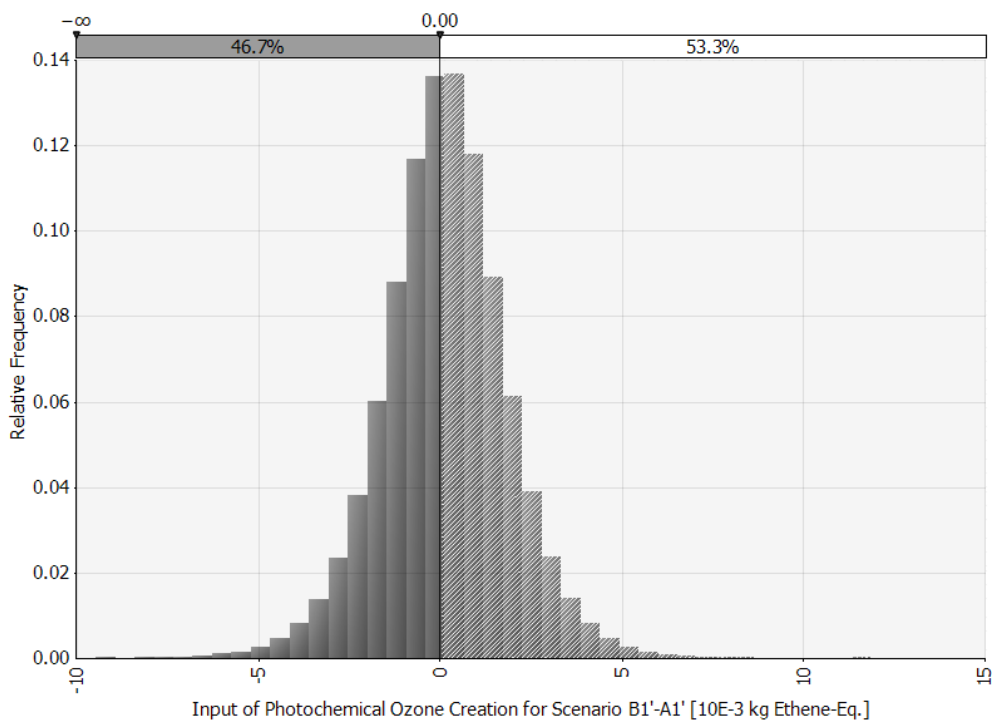

Figure A27. Histograms from the differential Monte Carlo simulation of scenario B1'-A1' for photochemical ozone creation (input).

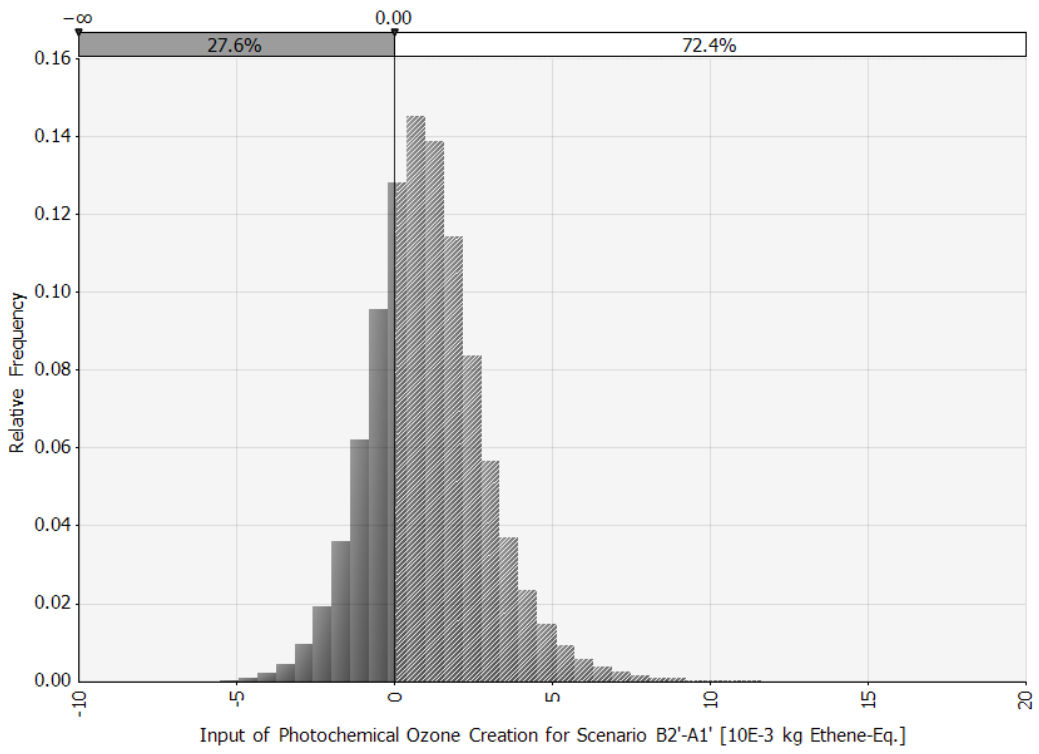

Figure A28. Histograms from the differential Monte Carlo simulation of scenario B2'-A1' for photochemical ozone creation (input). 


\section{A5. References}

Hischier, R., Weidema, B.P., Althaus, H.J., Bauer, C., Doka, G., Dones, R., Frischknecht, R., Hellweg, S., Humbert, S., Jungbluth, N., Köllner, T., Loerincik, Y., Margni, M., \& Nemeck, T. (2010). Implementation of Life Cycle Impact Assessment Methods. Data v2.2. Ecoinvent report No 3. Swiss Centre for Life Cycle Inventories. Zurich/Laussane (Switzerland).

Meier, M.A. (1997). Eco-efficiency evaluation of waste gas purification systems in the chemical industry. LCA Documents, vol 2. Ecom Publishers. Landsberg (Germany).

Palisade Corporation (2009). Guide to using @RISK. Risk analysis and simulation add-in for Microsoft ${ }^{\circledR}$ Excel, version 5.5. Ithaca, New York (US).

PE International (2013). Gabi software and database: contents for Life Cycle Engineering. Stuttgart (Germany).

Sonnemann, G.W., Schuhmacher, M., \& Castells, F. (2003). Uncertainty assessment by Monte Carlo simulation in a life cycle inventory of electricity produced by a waste incinerator. Journal of Cleaner Production, 11(3): 279-292. 


\section{Annex B. Supplementary material for section $\mathbf{3 . 4}$}

\section{B1. Model validation and calibration}

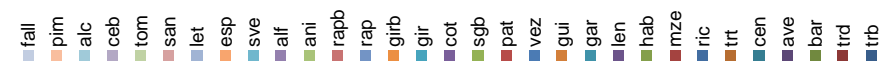

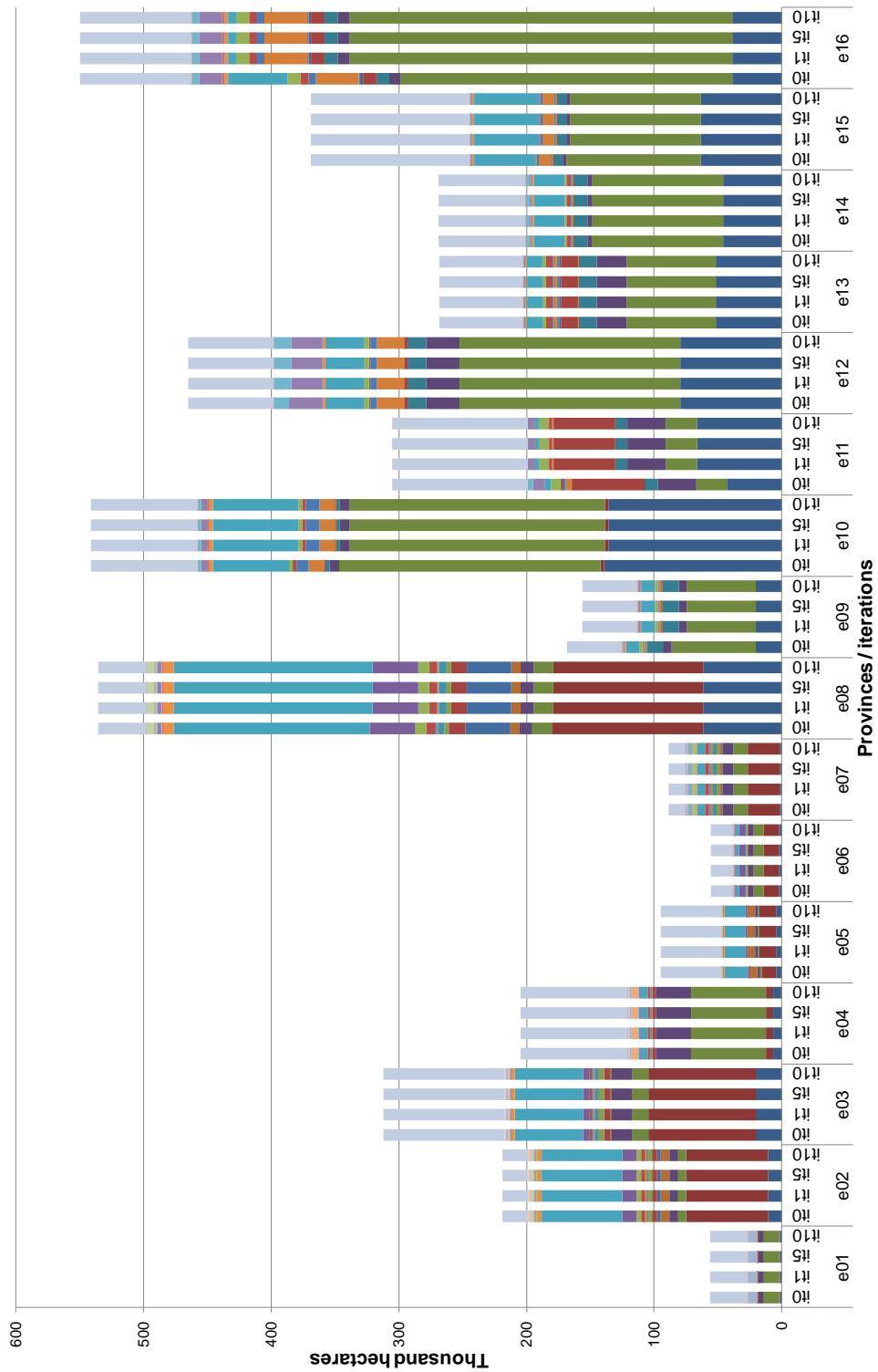

Figure B1. Calibration results from the agricultural module optimization through the subsequent iterations in provinces e01-e16. Iteration 0 (it0) refers to the observed situation. 


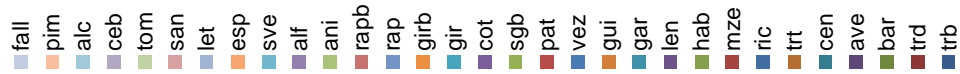

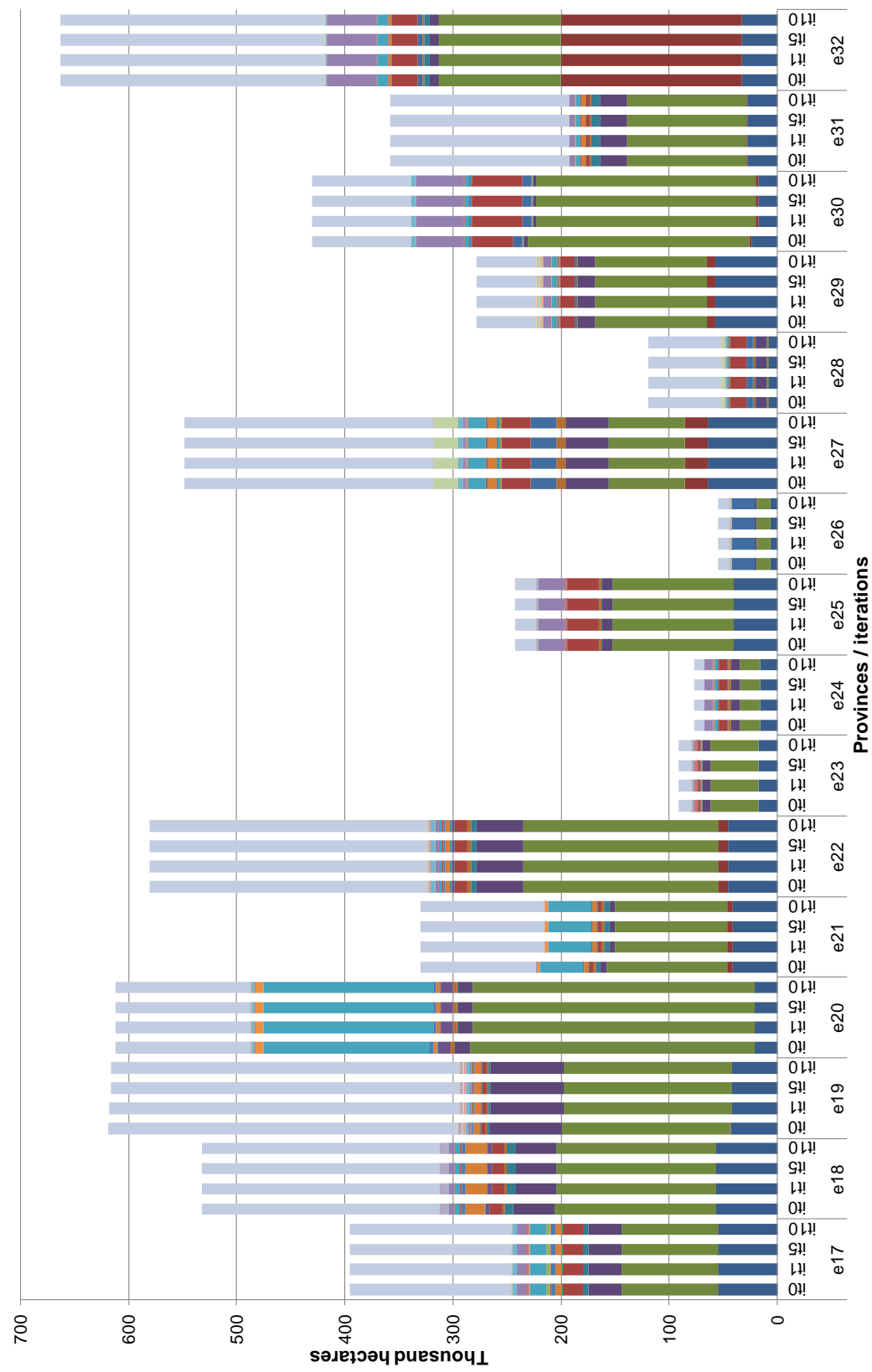

Figure B2. Calibration results from the agricultural module optimization through the subsequent iterations in provinces e17-e32. Iteration 0 (it0) refers to the observed situation. 
As can be seen, divergences between the model output (after calibration) and the observed values affect rainfed cereals, mainly in the central regions of Spain, which are also the leading cereal-producing regions (Castilla y León, Castilla-La Mancha and Aragón). Major differences are found for barley alone or in combination with a second crop. Barley is a major crop in Spain, but it appears to have negative margins essentially in some provinces of these regions. One reason for this is probably that we have used variable costs from Catalunya for most of the crops, which makes a particular difference in the case of non-irrigated cereals. Hence, the model tends to reduce areas of barley in those regions where the margins are negative, driven by optimization principles. Besides, it must be borne in mind that farmers also try to diversify production by following risk-aversion behavior.

The most significant differences are discussed in this section. Specifically, the most significant contraction in barley extension relative to the initial situation is observed in e09, e15, e20 and e21. In the first case, this decrease translates into a more reduced extension of the total agricultural land available in Ávila (e09). In the rest of these provinces (Soria e15, Cuenca e20 and Guadalajara e21), changes in barley extension lead to an expansion in the area diverted to other activities: sunflower and fallow land. The area diverted to barley only increases in Valladolid (e16), at the expense of sunflower; this is because its margin is positive, while the margin of sunflower is negative. Other crops for which area re-adjustments occur are soft wheat and corn. In the province of Burgos (e10), there is a decrease in the extension of both barley and soft wheat, entailing an increase in the area diverted to non-biodiesel sunflower, which has a positive margin in that very region due to a much higher price. In León (e11), soft wheat expands at the expense of corn, alfalfa, fodder vetch and fallow land. In Albacete (e18), the extension of barley decreases slightly because that of peas expands; this is due to the fact that this crop is highly profitable in the region. As was said, these divergences mostly concern rainfed agriculture, despite the fact that Figures B1 and B2 do not make any distinction between techniques (t0 and $\mathrm{t} 1$ ) in order to avoid the need for a larger graph. However, in Huesca (e30), changes affect irrigated crops: corn, which is highly profitable, expands at the expense of barley and soft wheat. 


\section{B2. Mathematical specification of the agro-industrial model}

\section{Indices:}

$r$

e

C

$t$

K

fk

0

y

i

Subsets:

$$
\begin{array}{ll}
\text { andal }(e) & \text { Andalucía: }\{\text { e01-e08\} } \\
\text { castle }(e) & \text { Castilla León: }\{\mathrm{e} 09-\mathrm{e} 17\} \\
\operatorname{castm}(e) & \text { Castilla la Mancha: }\{\mathrm{e} 18-\mathrm{e} 22\} \\
\operatorname{cat}(e) & \text { Catalunya: }\{\mathrm{e} 23-\mathrm{e} 26\} \\
\operatorname{extre}(e) & \text { Extremadura: }\{\mathrm{e} 27, \mathrm{e} 28\} \\
\operatorname{nava}(e) & \text { Navarra: }\{\mathrm{e} 29\} \\
\operatorname{arag}(e) & \text { Aragón: }\{\mathrm{e} 30-\mathrm{e} 32\} \\
\operatorname{bioc}(c) & \text { Bioenergy crops: }\{\text { girb, rapb }\}
\end{array}
$$$$
\text { nonbio(c) Non-bioenergy crops: }\{\text { trb, trd, bar, ave, cen, trt, ric, mze, trb, trd, bar, ave, }
$$
cen, trt, hab, len, gar, gui, vez, pat, sgb, cot, gir, rap, alf, sve, esp, let, san, tom, ceb, alc, pim\}

cere(c) Cereals: $\{t r b, \operatorname{trd}$, bar, ave, cen, trt, ric, mze $\}$

$\operatorname{rot}(c) \quad$ Cereals in rotation: $\{t r b$, trd, bar, ave, cen, trt $\}$

legu(c) Legumes $\{$ hab, len, gar, gui, vez $\}$

tub(c) Tubers: $\{$ pat $\}$ 


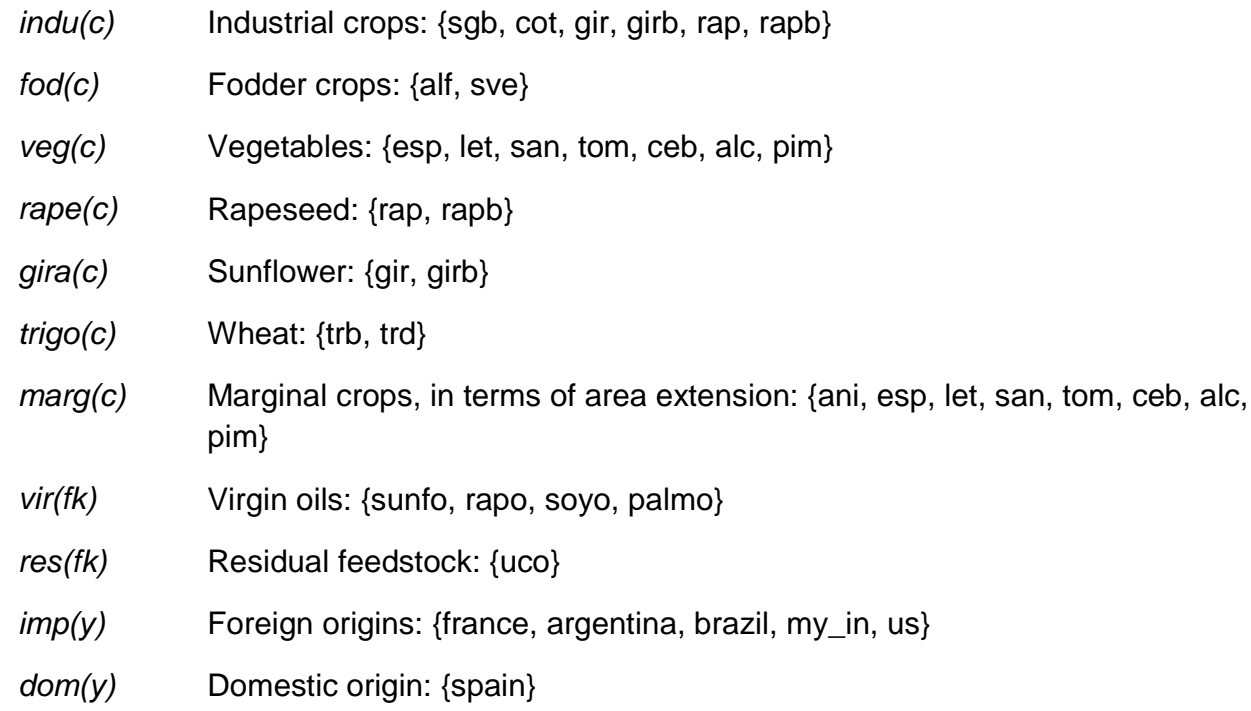


Annex B: supplementary material for section 3.4

\begin{tabular}{|c|c|}
\hline ucosp & Maximum UCO availability in Spain \\
\hline ucofr & Maximum UCO to be imported from France \\
\hline Ihv & Low heating value of biodiesel \\
\hline ghgf & Greenhouse gas (GHG) emission factor of the reference fuel \\
\hline wght & Weight of the second attribute in the objective function \\
\hline bioe & Emissions of $\mathrm{CO}_{2}$ from biodiesel transesterification \\
\hline$p_{c}$ & Price of crop c \\
\hline$z_{r, e, c, t}$ & Yield of crop c, in province e of region $r$, under irrigation $t$ \\
\hline$S_{r, e, c, t}$ & Observed area of crop c, in province e of region r, under irrigation t in 2009 \\
\hline$v_{r, e, c, t}$ & Variable cost of crop c, in province e of region r, under irrigation t in 2009 \\
\hline$W_{r, e, c, t}$ & Water consumption by crop $c$, in province e of region $r$, under irrigation $t$ \\
\hline $\operatorname{rain}_{r, e}$ & Total agricultural land without irrigation in province e of region $r$ \\
\hline irrig $_{r, e}$ & Total agricultural land under irrigation in province e of region $r$ \\
\hline$w_{a t} t_{r, e}$ & Water availability in province e of region $r$ \\
\hline yield $_{r, c}$ & Technological improvement in yields of crop $\mathrm{c}$ in region $r$ \\
\hline subs $_{c}$ & Direct payment to some specific crops c \\
\hline$t r d s_{r, e}$ & $\begin{array}{l}\text { Direct aid for durum wheat in some specific provinces e of regions } r \text {, with low } \\
\text { yields }\end{array}$ \\
\hline$s g b s_{c}$ & Subsidy for crop c sugarbeet \\
\hline $\operatorname{reg}_{c}$ & Subsidy for some crops $\mathrm{c}\left(\right.$ cere $_{\mathrm{c}}$ and legu $\mathrm{u}_{\mathrm{c}}$ ) under the CAP regionalization plan \\
\hline coeff $_{c}$ & Coefficient for area constraint on marginal crop c $\left(\right.$ marg $\left._{c}\right)$ \\
\hline coeff $2_{r, c, t}$ & $\begin{array}{l}\text { Coefficient for area constraint on fodder crop c in region } r \text {, under irrigation t } \\
\left(\text { fod }_{c}\right)\end{array}$ \\
\hline$c h_{k}$ & Characterization factor of pollutant $\mathrm{k}$ \\
\hline $\operatorname{cap}_{i}$ & Production capacity of biodiesel plant i \\
\hline oil $_{c}$ & Oil content of the seeds of crop c \\
\hline mealx ${ }_{c}$ & Meal obtained by the extraction of the seeds of crop c \\
\hline pbio $_{o}$ & Price of the biodiesel obtained by technology o \\
\hline pmeal $_{c}$ & Price of the meal obtained from crop $c$ \\
\hline $\operatorname{poil}_{f k}$ & Price of the oil feedstock fk \\
\hline pglyo & Price of the glycerin obtained by technology o \\
\hline
\end{tabular}




\begin{tabular}{|c|c|}
\hline$u c_{o, f k, y}$ & $\begin{array}{l}\text { Unit cost of the biodiesel produced by technology o, from feedstock fk from } \\
\text { country } y\end{array}$ \\
\hline$i n c_{o}$ & Increase in operational costs when technology o is used \\
\hline$i n v_{i}$ & Investment cost of plant i \\
\hline $\operatorname{ainv}_{i, 0}$ & Annualized investment cost of the plant $\mathrm{i}$, operating with technology o \\
\hline binvc $_{o}$ & Base investment cost for plants operating with technology o \\
\hline freigh $_{y}$ & Transportation freight costs of the oils from origin y to Spain \\
\hline age $_{r, e, c, t}$ & $\begin{array}{l}\text { Emissions of } \mathrm{CO}_{2} \text { from } 1 \text { ha in province e of region } r \text {, with crop } c \text {, under } \\
\text { irrigation } t\end{array}$ \\
\hline oile $_{f k, y}$ & Emissions of $\mathrm{CO}_{2}$ from the production of oil fk in country $\mathrm{y}$ \\
\hline
\end{tabular}

Model variables:

$P S_{o, i} \quad$ Producer surplus of biodiesel plant i using technology o

$E S_{f k} \quad$ Extraction surplus when using feedstock $f k$

AS Agricultural surplus

Qbio $_{o, i} \quad$ Biodiesel production in plant i by means of technology o

$Q b_{o, i, f k, y} \quad$ Biodiesel production from feedstock fk from country $y$, in plant $\mathrm{i}$, using technology o

Qmix $_{o, i} \quad$ Oil mix for biodiesel production in plant i for technology o

Qoil $_{o, i, f k, y} \quad$ Oil input of feedstock fk from country y, in plant i, for technology o

Qme $_{c, f k, y} \quad$ Meal supply from crop c when producing feedstock fk in country y Spain

$\operatorname{Qcrp}_{c, f k, y} \quad$ Demand for crop c for the feedstock fk in country y Spain

cult $_{r, e, c, t} \quad$ Agricultural area for crop c, under irrigation $t$, in province e of region $r$

$n z_{r, e, c, t} \quad$ Negative deviation between the observed cropland area and the model outcome

$p z_{r, e, c, t} \quad$ Positive deviation between the observed cropland area and the model outcome 
Objective function: maximization of the agro-industry system welfare, and minimization of the relative deviation between the initially observed areas in 2009 and the ones obtained by the model in absolute terms.

$$
\operatorname{Max} \sum_{o, i} P S_{o, i}+\sum_{f k} E S_{f k}+A S-w g h t \sum_{r, e, c, t}\left(n z_{r, e, c, t}+p z_{r, e, c, t}\right)
$$

In which,

$$
\begin{gathered}
P S_{o, i}=\operatorname{ainv}_{i, o}+\sum_{f k, y}\left(\left(\text { pbio }_{o, i}-u c_{o, f k, y}\right) Q b_{o, i, f k, y}-\text { Qoil }_{o, i, f k, y}\left(\text { poil }_{f k}+\text { freigh }_{y}\right)\right) \\
E S_{f k}=\sum_{c, y}\left(\text { pmeal }_{c} Q m e_{c, f k, y}-p_{c} Q c r p_{c, f k, y}\right)+\sum_{o, i, y} \text { Qoil }_{o, i, f k, y}\left(\text { poil }_{f k}-\text { extc }\right) \\
A S=\sum_{r, e, c, t}\left(\text { cult }_{r, e, c, t}\left(p_{c} z_{r, e, c, t}-v_{r, e, c, t}\right)\right)+\operatorname{subs}_{c}+\operatorname{trds}_{r, e}+\left(\operatorname{reg}_{c}+s g b s_{c}\right) z_{r, e, c, t}(1 \\
\left.\quad+\operatorname{yield}_{r, c}\right)
\end{gathered}
$$

Being,

$$
\begin{gathered}
\text { ainv }=\frac{\operatorname{inv}_{i} \operatorname{binv}_{o}}{\frac{1-(1+0.06)^{-15}}{0.06}} \\
i n v_{i}=3.41\left(\log c a p_{i}-\log \text { basec }\right)^{\text {scal }}
\end{gathered}
$$

Driven by the exogenous demand for biodiesel:

Biodiesel supply in Spain must meet the 2020 demand according to the Renewable Energy Directive.

$$
\sum_{o, i} \text { bbio }_{o, i} \geq \text { Dbio }
$$




\section{Subject to the GHG emissions constraint:}

The GHG emissions saving from the use of biodiesel due to the 2020 target must be at least $35 \%$ relative to the life-cycle emissions associated with the reference fossil fuel (expressed in terms of $\mathrm{g} \mathrm{CO}_{2} / \mathrm{MJ}$ ).

$$
\begin{aligned}
& \sum_{o, i}\left({\text { bioe } \text { Qbio }_{o, i}}+\sum_{f k, y} \text { oile }_{f k, y} \text { Qoil }_{o, i, f k, y}\right)+\sum_{r, e, b i o c, t} \text { age }_{r, e, c, t} \text { cult }_{r, e, c, t} \\
& \leq \operatorname{ghgf} \sum_{o, i} \text { Qbio }_{o, i} l h v
\end{aligned}
$$

Subject to capacity constraints of the plants:

Biodiesel production in each plant cannot exceed its nameplate capacity.

$$
\sum_{o} \text { bio }_{o, i} \leq \operatorname{cap}_{i}
$$

Subject to technical constraints in the industrial module:

Biodiesel mix: the biodiesel output manufactured from different oils yields the overall biodiesel production of each plant, given the technology.

$$
\sum_{f k, y} Q b_{o, i, f k, y}=Q b i o_{o, i}
$$

Transesterification: biodiesel is obtained from the transesterification of the oils, given the reaction yield.

$$
\text { Qoil }_{o, i, f k, y} \text { transy }=Q b_{o, i, f k, y}
$$

Oil mix: the oil mix of each biodiesel plant is the sum of different feedstocks.

$$
\operatorname{Qmix}_{o, i}=\sum_{f k, y} \text { Qoil }_{o, i, f k, y}
$$

Domestic oils: sunflower and rapeseed oil are obtained from domestically crushed oilseeds.

$$
\operatorname{Qcrp}_{b i o c, f k, s p} \text { oilx }_{b i o c}=\sum_{o, i} Q o i l_{o, i, f k, s p}
$$


Oil extraction co-product: crushing of domestic oilseeds yields the co-production of protein meals.

$$
Q_{c r p} p_{b i o c, f k, s p} \text { mealx }_{\text {bioc }}=Q m e_{b i o c, f k, s p}
$$

Subject to oil availability constraints:

UCO in Spain: industrial input of Spanish UCO may not exceed the national availability.

$$
\sum_{o, i, u c o, s p} \text { Qoil }_{o, i, f k, y} \leq 300,000
$$

UCO imports from France: industrial input of French UCO may not exceed the country's export capacity.

$$
\sum_{o, i, u c o, f r} Q_{o i l}, i, f k, y \leq 11,000
$$

Generating the expansion of domestic bioenergy crops:

The agricultural sector in Spain must provide the industry with the oilseeds needed for biodiesel production.

$$
\left.\sum_{f k, y} Q_{c r p} p_{b i o c, f k, y}=\sum_{r, e, t} c u l t_{r, e, b i o c, t} z_{r, e, b i o c, t}\left(1+\text { yield }_{r, b i o c}\right)\right)
$$

Subject to food demand constraints:

The supply of food crops in Spain cannot be reduced as a consequence of the expansion in bioenergy crops.

$$
\sum_{r, e, t}\left(\text { cult }_{r, e, \text { nonbio }, t} z_{r, e, \text { nonbio }, t}\left(1+\text { yield }_{r, \text { nonbio }}\right)\right) \geq \sum_{r, e, t} s_{r, e, \text { nonbio }, t} z_{r, e, \text { nonbio }, t}
$$

Subject to resource constraints in the agricultural module:

Irrigated land area: area devoted to irrigated crops may not exceed total land under irrigation in the province in 2009.

$$
\sum_{c} \text { cult }_{r, e, c, t 1} \leq \text { irrig }_{r, e}
$$


Non-irrigated area: area devoted to rainfed crops may not exceed total land without irrigation in the province in 2009.

$$
\sum_{c} \text { cult }_{r, e, c, t 0} \leq \operatorname{rain}_{r, e}
$$

Water consumption: water demand by crops may not exceed the total availability of irrigation water in the province.

$$
\sum_{c, t}\left(\text { cult }_{r, e, c, t} w_{r, e, c, t} z_{r, e, c, t}\left(1+\text { yield }_{r, c}\right)\right) \leq w a t_{r, e}
$$

\section{Subject to quota constraints:}

Quota constraints: area devoted in each region to sugarbeet may not exceed the area cultivated with sugarbeet in 2009 .

$$
\text { cult }_{r, e, s g b, t} \leq s_{r, e, s g b, t}
$$

Subject to rotation constraints:

Rapeseed rotation without irrigation: rapeseed is produced in rotation with fallow and cereals.

$$
\sum_{\text {rape }} \text { cult }_{r, e, c, t 0}+\frac{1}{3} \text { cult }_{r, e, f a l l, t 0} \leq \sum_{\text {rot }} \text { cult }_{r, e, c, t 0}
$$

Sunflower rotation in Castilla León, without irrigation: sunflower is produced in rotation with fallow and cereals.

$$
\sum_{\text {gira }} \text { cult }_{\text {castleon,e,c,to }}+\text { cult }_{\text {castleon,e,fall,to }} \leq \sum_{\text {rot }} \text { cult }_{\text {castleon,e,c,to }}
$$

Vetch rotation in Castilla León, without irrigation: vetch is produced in rotation with cereals.

$$
\text { cult }_{\text {castleon,e,vez,t0 }} \leq \sum_{\text {rot }} \text { cult }_{\text {castleon,e,c,to }}
$$


Sunflower rotation in Andalucía and Castilla León, without irrigation: sunflower is produced in rotation with broad beans, wheat and sugarbeet.

$$
\begin{aligned}
& \sum_{\text {gira }} \text { cult }_{\text {castleon,e,c,to }}+\text { cult }_{\text {castleon,e,hab,to }} \leq \text { cult }_{\text {castleon,e,sgb,to }}+\sum_{\text {trigo }} \text { cult }_{\text {castleon,e,c,to }} \\
& \sum_{\text {gira }} \text { cult }_{\text {andalucia,e,c,t0 }}+\text { cult }_{\text {andalucia,e,hab,to }} \leq \text { cult }_{\text {andalucia,e,sgb,t0 }} \\
& +\sum_{\text {trigo }} \text { cult }_{\text {andalucia }, e, c, t 0}
\end{aligned}
$$

Subject to agronomic constraints:

Maximum cropland area with fodder crops: area devoted to fodder crops may not exceed initially observed areas in 2009 on a provincial level.

$$
\sum_{\text {fod }, t} \text { cult }_{r, e, c, t} \leq \sum_{f o d, t} \operatorname{coeff} 2_{r, e, c} s_{r, e, c, t}
$$

Maximum cropland area with marginal crops: area devoted to those crops observed in small proportions (in terms of area) in 2009 may not exceed initially observed areas in 2009 on a province level.

$$
\text { cult }_{r, e, \text { marg }, t} \leq \operatorname{coeff} 2_{r, e, \operatorname{marg}} s_{r, e, \operatorname{marg}, t}
$$

Minimum fallow land: fallow land area in each province must be at least $50 \%$ of the initially observed area in 2009. This is to ensure that bioenergy expansion does not occur at the expense of fallow land; there is a minimum requirement for agronomic reasons.

$$
\sum_{t} \text { cult }_{r, e, f a l l, t} \geq \frac{1}{2} \operatorname{coeff} 2_{r, e, f a l l}+\sum_{t} s_{r, e, f a l l, t}
$$

Subject to a consistency requirement for agricultural land distribution:

Calculating the relative deviation between the initially observed areas in 2009 and the ones obtained by the model in absolute terms for the objective function:

$$
\text { cult }_{r, e, c, t}-s_{r, e, c, t}+s_{r, e, c, t}\left(n z_{r, e, c, t}-p z_{r, e, c, t}\right)=0
$$




\section{Annex C. Supplementary material for section 3.5}

\section{C1. Regions, industries and commodities in the GTAP-BIO model}

Table C1. Regions, industries and commodities included in the GTAP-BIO version employed to analyze biofuel policies in depth.

\begin{tabular}{|c|c|c|c|c|c|}
\hline \multicolumn{2}{|r|}{ Regions: } & \multicolumn{2}{|r|}{ Industries: } & \multicolumn{2}{|r|}{ Commodities: } \\
\hline 1 & USA & 1 & Paddy_Rice & 1 & Paddy_Rice \\
\hline 2 & EU27 & 2 & Wheat & 2 & Wheat \\
\hline 3 & Brazil & 3 & Sorghum & 3 & Sorghum \\
\hline 4 & Canada & 4 & Oth_CoarseGrains & 4 & Oth_CoarseGrains \\
\hline 5 & Japan & 5 & Soybeans & 5 & Soybeans \\
\hline 6 & China_HongKong & 6 & Palm & 6 & Palm \\
\hline 7 & India & 7 & Rapeseed & 7 & Rapeseed \\
\hline 8 & Central_Amer & 8 & Oth_Oilseeds & 8 & Oth_Oilseeds \\
\hline 9 & S_Amer & 9 & Sugar_Crop & 9 & Sugar_Crop \\
\hline 10 & E_Asia & 10 & Oth_Crops & 10 & Oth_Crops \\
\hline 11 & Mala_Indo & 11 & Forestry & 11 & Forestry \\
\hline 12 & SE_Asia & 12 & Dairy_Farms & 12 & Dairy_Farms \\
\hline 13 & S_Asia & 13 & Ruminant & 13 & Ruminant \\
\hline 14 & Russia & 14 & NonRuminant & 14 & NonRuminant \\
\hline 15 & Oth_CEE_CIS & 15 & Proc_Dairy & 15 & Proc_Dairy \\
\hline 16 & Oth_Europe & 16 & Proc_Rumiants & 16 & Proc_Rumiants \\
\hline 17 & ME_Asia_N_Africa & 17 & Proc_NonRumiants & 17 & Proc_NonRumiants \\
\hline 18 & SS_Africa & 18 & Vol_Soy & 18 & Bev_Sug \\
\hline 19 & Oceania & 19 & Vol_Palm & 19 & Proc_Rice \\
\hline & & 20 & Vol_Rape & 20 & Proc_Food \\
\hline & & 21 & Vol_Oth & 21 & Proc_Feed \\
\hline & & 22 & Bev_Sug & 22 & Oth_PrimarySectors \\
\hline & & 23 & Proc_Rice & 23 & Ethanol_sugarcane \\
\hline & & 24 & Proc_Food & 24 & Biod_Soy \\
\hline & & 25 & Proc_Feed & 25 & Biod_Palm \\
\hline & & 26 & Oth_PrimarySectors & 26 & Biod_Rape \\
\hline & & 27 & Ethanol_grains & 27 & Biod_Oth \\
\hline & & 28 & Ethanol_sugarcane & 28 & Coal \\
\hline & & 29 & Ethanol_Oth & 29 & Oil \\
\hline & & 30 & Biod_Soy & 30 & Gas \\
\hline & & 31 & Biod_Palm & 31 & Oil_Products \\
\hline & & 32 & Biod_Rape & 32 & Electricity \\
\hline & & 33 & Biod_Oth & 33 & Energy_Int_Ind \\
\hline & & 34 & Coal & 34 & Oth_Ind_Services \\
\hline & & 35 & Oil & 35 & NTrdServices \\
\hline & & 36 & Gas & 36 & Pasturecrop \\
\hline & & 37 & Oil_Products & 37 & Ethanol_grains \\
\hline & & 38 & Electricity & 38 & DDGS \\
\hline & & 39 & Energy_Int_Ind & 39 & Vol_Soy \\
\hline & & 40 & Oth_Ind_Services & 40 & VOBPS \\
\hline & & 41 & NTrdServices & 41 & Vol_Palm \\
\hline & & 42 & Pasturecrop & 42 & VOBPP \\
\hline & & & & 43 & Vol_Rape \\
\hline & & & & 44 & OBPR \\
\hline & & & & 45 & Vol_Oth \\
\hline & & & & 46 & VOBPO \\
\hline & & & & 47 & Ethanol_Oth \\
\hline & & & & 48 & DDGSS \\
\hline
\end{tabular}




\section{C2. Market responses}

Table C2. Main market responses as a consequence of a blending mandate in line with the new COM 595 (exp 1), as combined with import tariffs on biodiesel imports from Mala_Indo, S_Amer and the US (exp 2). Outcomes from the linearized equations in the model represent percentage changes of the variables, relative to the baseline.

\begin{tabular}{|c|c|c|c|c|}
\hline \multirow[b]{2}{*}{ Price effects: } & \multicolumn{4}{|c|}{ Exp $1 /$ Exp 2} \\
\hline & Soybean & Palm & Rapeseed & Others \\
\hline Biodiesel market price in the EU & $8.49 / 8.51$ & $4.02 / 4.03$ & $11.43 / 11.46$ & $12.30 / 12.33$ \\
\hline $\begin{array}{l}\text { Vegetable oil market price in the } \\
\text { EU }\end{array}$ & $11.00 / 10.99$ & $8.94 / 8.94$ & $14.80 / 14.83$ & $17.02 / 17.07$ \\
\hline Seeds market price in the EU & $3.07 / 3.05$ & $1.87 / 1.85$ & $14.97 / 14.96$ & $15.46 / 15.45$ \\
\hline \multicolumn{5}{|l|}{ Effects on demand: } \\
\hline $\begin{array}{l}\text { Private households demand for } \\
\text { imported biodiesel in the EU }\end{array}$ & 45.02 / 48.59 & $32.79 / 34.19$ & & \\
\hline $\begin{array}{l}\text { Private households demand for } \\
\text { domestic biodiesel in the EU }\end{array}$ & $45.70 / 36.37$ & 867.59 / 852.94 & $685.00 / 685.00$ & $\begin{array}{c}16,313.87 / \\
16,313.78 \\
\end{array}$ \\
\hline $\begin{array}{l}\text { Demand for imported vegetable } \\
\text { oils by biodiesel firms in the EU }\end{array}$ & $48.17 / 38.50$ & 867.59 / 852.94 & $703.11 / 703.08$ & $\begin{array}{c}17,234.96 / \\
17,234.12\end{array}$ \\
\hline $\begin{array}{l}\text { Demand for domestic vegetable } \\
\text { oils by biodiesel firms in the EU }\end{array}$ & 43.22 / 34.22 & & $756.60 / 743.40$ & $\begin{array}{l}15,422.42 / \\
15.423 .05 \\
\end{array}$ \\
\hline $\begin{array}{l}\text { Demand for domestic oilseeds by } \\
\text { crushing firms in the EU }\end{array}$ & $0.95 / 0.04$ & & 150.82 / 150.87 & $158.55 / 158.57$ \\
\hline $\begin{array}{l}\text { Demand for domestic oilseeds by } \\
\text { crushing firms in S_Amer }\end{array}$ & $1.70 / 1.68$ & & & \\
\hline $\begin{array}{l}\text { Demand for domestic oilseeds by } \\
\text { crushing firms in the US }\end{array}$ & $-7.50 /-5.72$ & & & \\
\hline $\begin{array}{l}\text { Demand for domestic oilseeds by } \\
\text { crushing firms in Mala_Indo }\end{array}$ & & $18.76 / 18.80$ & & \\
\hline $\begin{array}{l}\text { Demand for imported oilseeds by } \\
\text { crushing firms in the EU }\end{array}$ & $7.04 / 6.04$ & & 172.58 / 172.64 & $193.92 / 193.95$ \\
\hline $\begin{array}{l}\text { Demand for imported oilseeds by } \\
\text { crushing firms in S_Amer }\end{array}$ & $2.75 / 2.69$ & & & \\
\hline $\begin{array}{l}\text { Demand for imported oilseeds by } \\
\text { crushing firms in the US }\end{array}$ & $-8.49 /-6.44$ & & & \\
\hline $\begin{array}{l}\text { Demand for imported oilseeds by } \\
\text { crushing firms in Mala_Indo }\end{array}$ & & $22.76 / 22.84$ & & \\
\hline \multicolumn{5}{|l|}{ International trade effects: } \\
\hline $\begin{array}{l}\text { Exports of biodiesel from S_Amer } \\
\text { to the EU }\end{array}$ & $67.29 / 24.91$ & & & \\
\hline $\begin{array}{l}\text { Exports of biodiesel from the US } \\
\text { to the EU }\end{array}$ & $2.70 / 93.20$ & & & \\
\hline $\begin{array}{l}\text { Exports of biodiesel from } \\
\text { Mala_Indo to the EU }\end{array}$ & & $32.79 / 34.19$ & & \\
\hline $\begin{array}{l}\text { Aggregate imports of vegetable } \\
\text { oils into the EU, CIF weights }\end{array}$ & $91.71 / 90.79$ & $9.51 / 8.29$ & $248.29 / 248.29$ & $258.87 / 258.81$ \\
\hline $\begin{array}{l}\text { Export sales of vegetable oils } \\
\text { from US to the EU }\end{array}$ & $-3.08 /-12.10$ & & & \\
\hline $\begin{array}{l}\text { Export sales of vegetable oils } \\
\text { from other regions than the US to } \\
\text { the EU }\end{array}$ & $\begin{array}{c}{[3.78-68.71] /} \\
{[1.48-67.69]}\end{array}$ & & & \\
\hline $\begin{array}{l}\text { Export sales of vegetable oils } \\
\text { from Mala_Indo to the EU }\end{array}$ & & $85.35 / 84.39$ & & \\
\hline
\end{tabular}


Annex C: supplementary material for section 3.5

\begin{tabular}{|c|c|c|c|c|}
\hline \multirow[b]{2}{*}{ International trade effects: } & \multicolumn{4}{|c|}{ Exp $1 /$ Exp 2} \\
\hline & Soybean & Palm & Rapeseed & Others \\
\hline $\begin{array}{l}\text { Export sales of vegetable oils } \\
\text { from other regions than } \\
\text { Mala_Indo to the EU }\end{array}$ & & $\begin{array}{c}{[98.20-144.46] /} \\
{[97.68-143.53]}\end{array}$ & & \\
\hline $\begin{array}{l}\text { Export sales of vegetable oils } \\
\text { from the rest of regions to the EU }\end{array}$ & & & $\begin{array}{c}{[317.67-606.83] /} \\
{[313.18-608.15]} \\
\end{array}$ & $\begin{array}{c}{[244.66-531.72] /} \\
{[244.88-531.51]}\end{array}$ \\
\hline $\begin{array}{l}\text { Aggregate imports of oilseeds } \\
\text { into the EU, CIF weights }\end{array}$ & $-0.41 / 0.82$ & $8.56 / 8.65$ & $79.57 / 79.59$ & $92.03 / 92.04$ \\
\hline $\begin{array}{l}\text { Export sales of soybeans from } \\
\text { the US to the EU }\end{array}$ & $3.41 / 2.59$ & & & \\
\hline $\begin{array}{l}\text { Export sales of soybeans from } \\
\text { S_Amer to the EU }\end{array}$ & $-1.54 /-1.81$ & & & \\
\hline \multicolumn{5}{|l|}{ Effects on supply: } \\
\hline $\begin{array}{l}\text { Industry output of biodiesel in the } \\
\text { EU }\end{array}$ & $45.70 / 36.37$ & 867.59 / 852.94 & $685.00 / 685.00$ & $\begin{array}{c}16,313.85 / \\
16,313,78 \\
\end{array}$ \\
\hline $\begin{array}{l}\text { Industry output of vegetable oils } \\
\text { in the EU }\end{array}$ & $6.89 / 5.89$ & $18.49 / 18.63$ & $158.71 / 158.77$ & $173.75 / 173.78$ \\
\hline $\begin{array}{l}\text { Industry output of oilseeds in the } \\
\text { EU }\end{array}$ & $-7.60 /-7.76$ & & $61.09 / 61.10$ & 61.49 / 61.48 \\
\hline $\begin{array}{l}\text { Overall oilseeds supply in } \\
\text { S_Amer }\end{array}$ & $67.29 / 24.91$ & & & \\
\hline Overall oilseeds supply in the US & $2.70 / 93.2$ & & & \\
\hline $\begin{array}{l}\text { Overall oilseeds supply in } \\
\text { Mala_Indo }\end{array}$ & 32.49 / 33.88 & & & \\
\hline
\end{tabular}




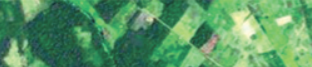

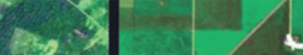

$5 x^{-1}+x^{2}+x^{2}$

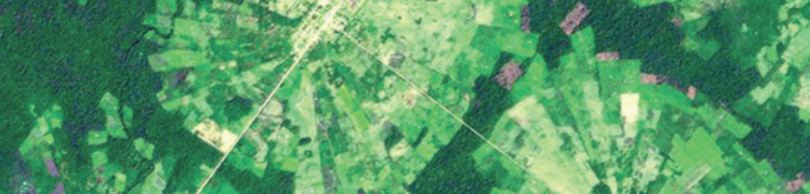

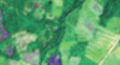

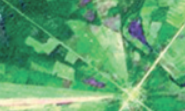

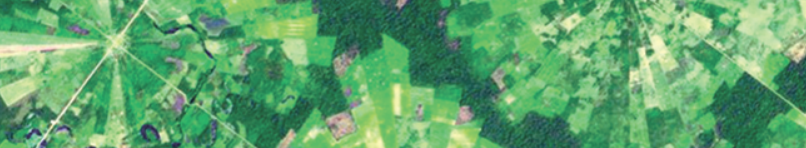

$\left.-x^{2}\right)^{2}$

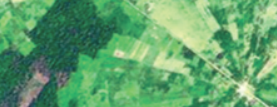

10. 20,3 is

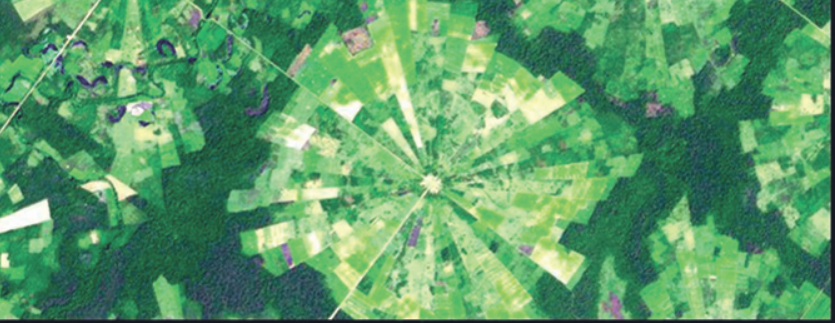

$114=$

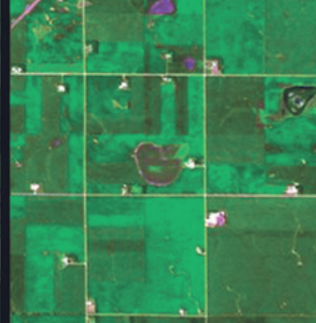

In
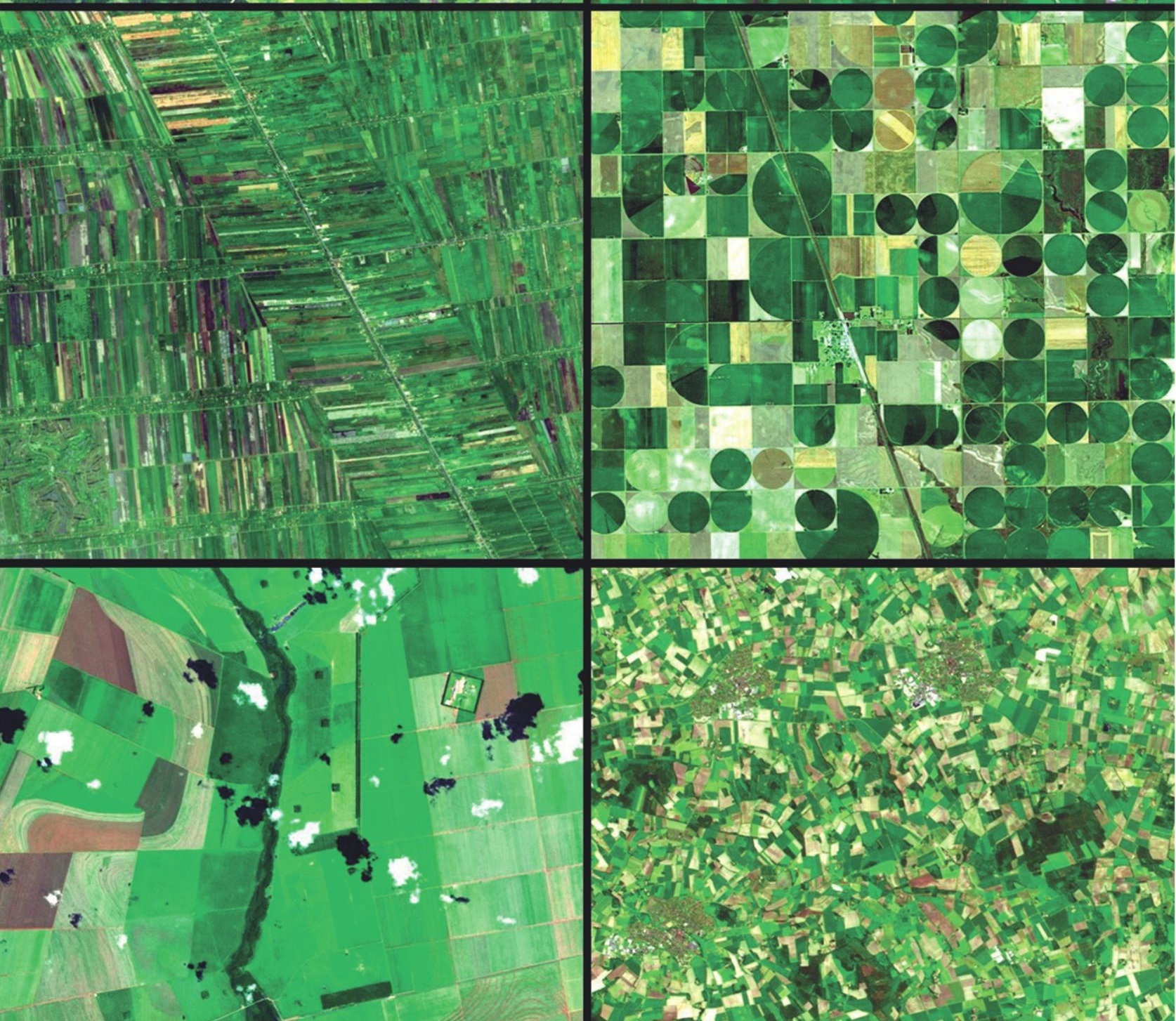

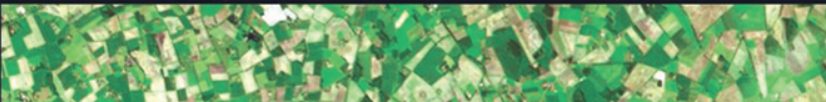

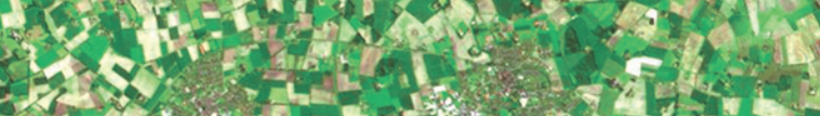

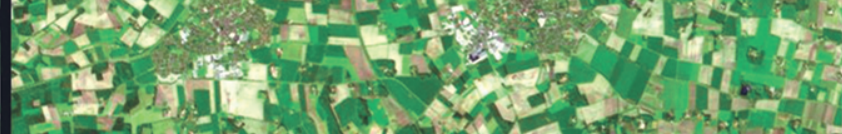

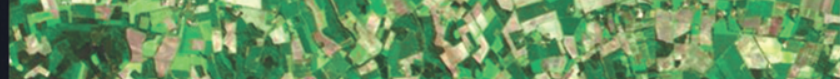

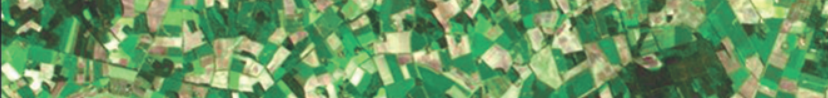

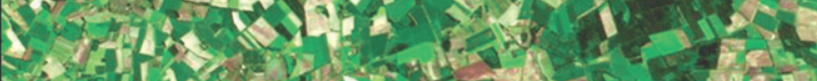

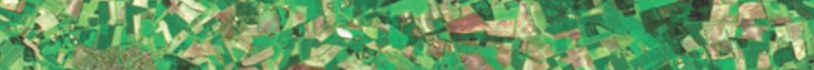

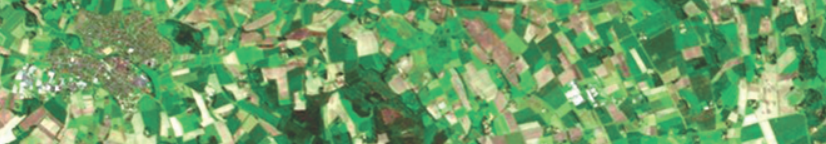

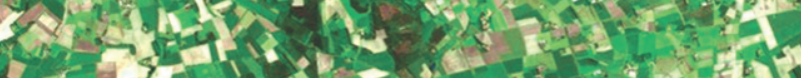

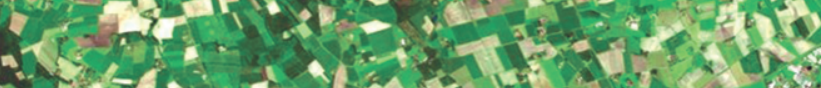

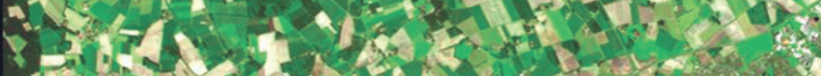

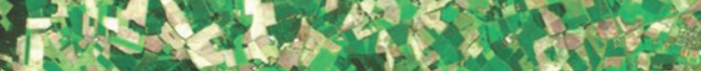

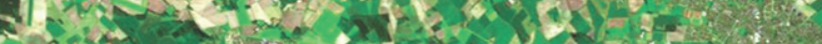

